UNIVERSIDADE DE SÃO PAULO I INSTTTUTO DE ARQUTTEIURA E URBANISMO

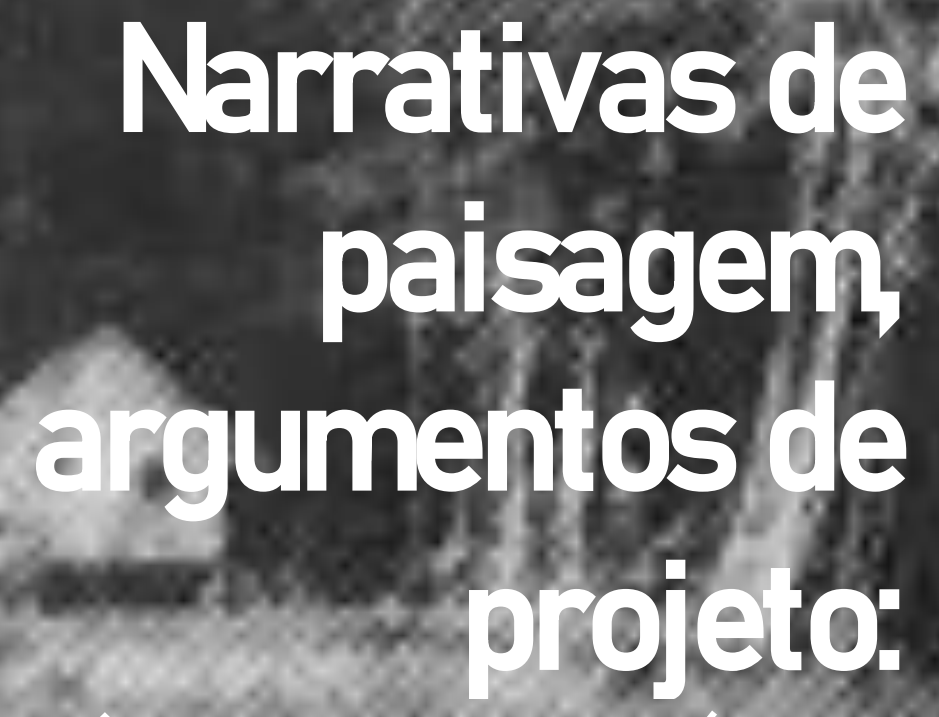

centralidade da Amazônia em textos e na prática da Arquitetura e Urbanismo no Brasil, de 1934 a 1989. 


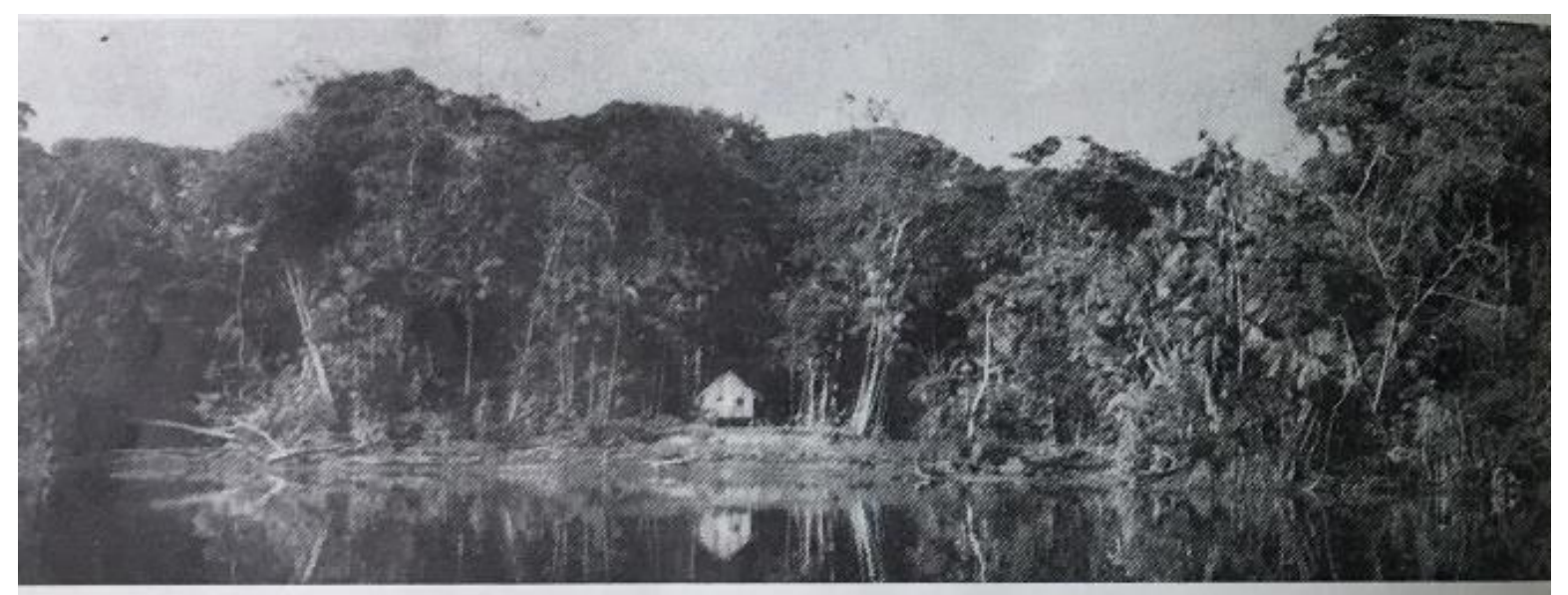

Imagem da capa: Fragmento de uma das imagens presentes no artigo de Luiz de Miranda Corrêa intitulado Problemas habitacionais no trópico brasileiro, publicado na revista ARQUITETURA-IAB n.30, em dezembro de 1964, p. 32. 


\section{Narrativas de paisagem, argumentos de projeto: centralidade da Amazônia em textos e na prática da Arquitetura e Urbanismo no Brasil, de 1934 a 1989.}

\section{Versão Corrigida}

(Versão original encontra-se na unidade do Programa de Pós-Graduação)

Tese apresentada ao Programa de Pós-Graduação em Arquitetura e Urbanismo do Instituto de Arquitetura e Urbanismo da Universidade de São Paulo, Campus de São Carlos, como requisito à obtenção do título de Doutora em Arquitetura e Urbanismo, Área de concentração Teoria e História da Arquitetura e Urbanismo.

Orientador:

Professor Titular Dr. Renato Luiz Sobral Anelli 


\section{AUTORIZO A REPRODUÇÃO TOTAL OU PARCIAL DESTE TRABALHO, POR QUALQUER MEIO CONVENCIONAL OU ELETRONICO, PARA FINS DE ESTUDO E PESQUISA, DESDE QUE CITADA A FONTE}

Ficha catalográfica elaborada pela Biblioteca do Instituto de Arquitetura e Urbanismo com os dados fornecidos pelo(a) autor(a)

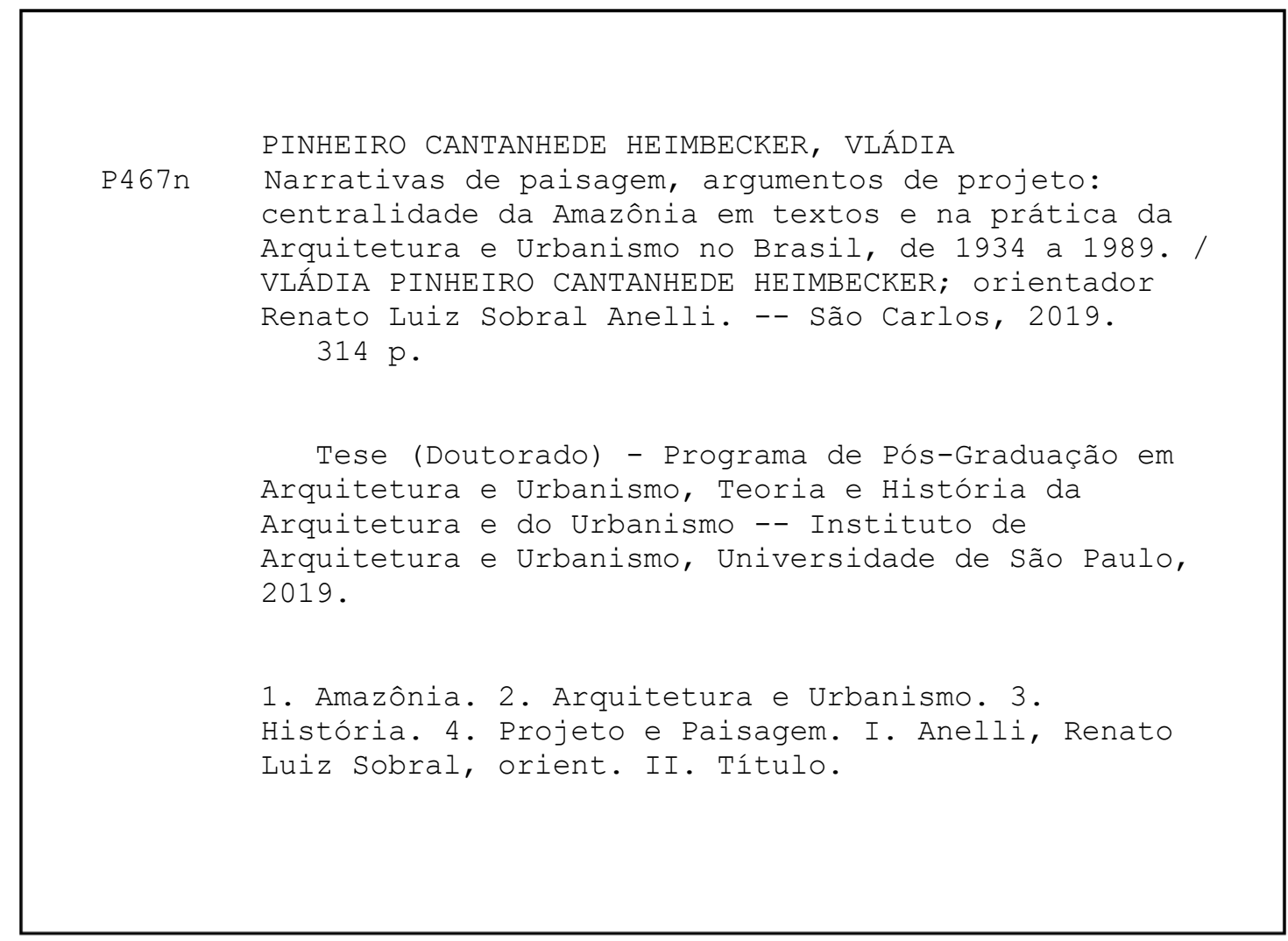

Bibliotecária responsável pela estrutura de catalogação da publicação de acordo com a AACR2: Brianda de Oliveira Ordonho Sígolo - CRB - 8/8229 


\section{FOLHA DE JULGAMENTO}

Candidato(a): Vládia Pinheiro Cantanhede Heimbecker

Título da tese: "Narrativas de paisagem, argumentos de projeto: Centralidade da Amazônia em textos e prática da Arquitetura e Urbanismo no Brasil, de 1938 a $1989^{\prime \prime}$

Data da defesa: 01/11/2019

Orientador: Prof. Dr. Renato Luiz Sobral Anelli

Comissão Julgadora:

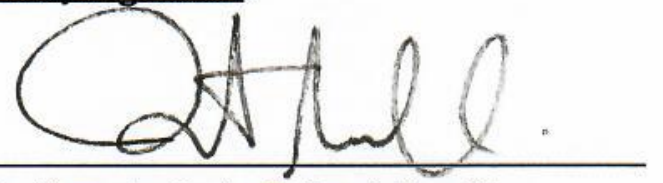

Prof. Dr. Renato Luiz Sobral Anelli (IAU/USP)

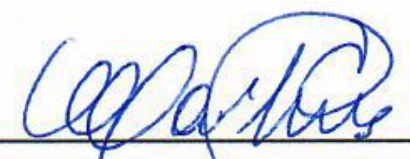

Prof. Dr. Carlos Alberto Ferreira Martins (IAU/USP)

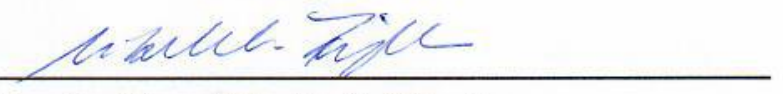

Profa. Dar. Cibele S. Rizek

(IAU/USP)

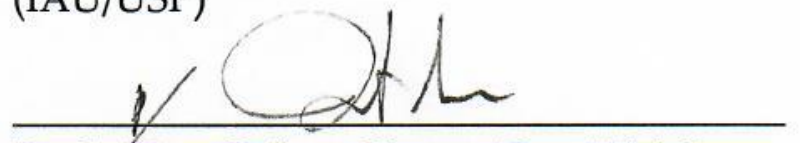

Profa. Dra. Celma Chaves Pont Vidal

(UFPA)

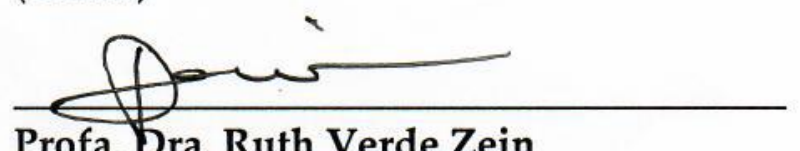

Profa. Dra. Ruth Verde Zein

(UP Mackenzie)

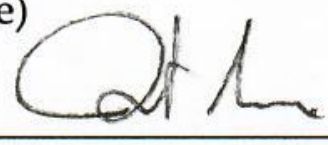

Prof. Dr, Aldrin Moura de Figueiredo (UFPA)
Resultado:

Não votante

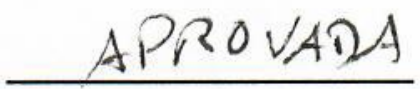

APROUADA

APROVADA

ARTOVAPA

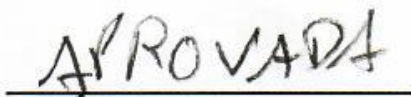

Coordenador e Presidente da Comissão de Pós-Graduação do Programa de PósGraduação em Arquitetura e Urbanismo: Prof. Dr. Tomás Antonio Moreira. 



\section{Agradecimentos}

Esta tese não revela uma totalidade da pesquisa, senão o produto do que foi organizado durante sua realização, diante de oscilações e do contentamento em especular sobre meu lugar de origem e ao reconhecê-lo, a Amazônia, contribuir para a História da Arquitetura no Brasil. Diante da complexidade apresentada pelo objeto, prevaleceu o anseio pelo trabalho, frutificado, ao fim, do esforço atenuado pelas inúmeras contribuições que o cercaram neste caminho e que o tornaram possível. A todos que de algum modo participaram deste processo, sou profundamente grata.

Agradeço especialmente ao Professor Renato Luiz Sobral Anelli, pelo incentivo e por toda atenção despendida nos anos de pesquisa e escrita, pela amizade, apoio, ensinamentos, pelo estímulo ao diálogo nas orientações, sou muito grata.

Aos professores do IAU - Instituto de Arquitetura e Urbanismo/ USP - São Carlos com os quais tive contato, especialmente ao Professor Carlos Alberto Ferreira Martins, pelas fundamentais contribuições na banca de qualificação, por partilhar generosamente de seu conhecimento na disciplina da Pós-Graduação e em várias outras oportunidades. À Professora Cibele Rizek, pelos ensinamento na disciplina da Pós-Graduação e contribuições no Seminário de Acompanhamento da Pós-Graduação. Às Professoras Aline Sanches, Eulália Negrelos e ao Professor Carlos Martins, pela oportunidade da experiência junto ao Programa de Apoio ao Ensino - PAE.

À Professora Celma Chaves de Souza Pont Vidal pelas significativas observações na banca de qualificacão, pela usual gentileza e pelos ensinamentos, diante do vasto conhecimento que possui acerca da Arquitetura na Amazônia.

Aos funcionários da biblioteca da EESC - USP São Carlos, especialmente à Brianda de Oliveira, Cleverci Malaman, Vilma Coutinho, da Biblioteca do IAU, pelo apoio durante o levantamento das revistas e extensivamente aos demais funcionários.

Aos colegas do ArqBras - IAU, especialmente Adriana Leal, Fúlvio Teixeira, Maryá Aldrique, pela recepção e por dividirem comigo tão amistosamente sua experiência no grupo de pesquisa. 
Ao Cláudio Muniz Viana, do Centro de Documentação da Faculdade de Arquitetura e Urbanismo da UFRJ, pela contribuição com a documentação a respeito dos projetos do Hotel de Silves - AM e do CPA - Balbina - AM.

À Ana Guerreiro, pela amizade ao longo deste processo e pelas informações cedidas, especialmente relativas às revistas de seu acervo.

Ao Wolfgang Schuster e à Luzia Schuster, pela gentileza em expor suas informações e narrar suas experiências na casa do Tarumã, em Manaus-AM.

A todos os professores do Departamento de Arquitetura e Urbanismo da Universidade Federal do Amazonas.

Aos amigos, Professores Roger Pamponet da Fonseca e Taís Pontes Furtado, por terem participado de momentos tão importantes deste processo.

À Ana Beatriz Marcondes Marra, Araceli Hackbarth, Fernanda Anibal e Marina Stamato, pela alegria do convívio nos quatro anos de estada em São Carlos e pela valiosa amizade.

Muito especialmente, agradeço ao fundamental apoio de Regina Célia Pinheiro Cantanhede, pelo carinho incondicional e disponibilidade. Agradeço ao Silvio Heimbecker Neto, pelo estímulo e paciência frente minhas ausências, pelo amor e afeto, à Ana Luisa e Beatriz Cantanhede Heimbecker, por serem tão especiais, uma motivação à tudo. À Erika Pinheiro Cantanhede e Bruno Pinheiro Cantanhede, pela torcida, amor e estímulo de sempre. À Rebeca Teixeira Lobato Rodrigues e Igor Araújo Ferreira da Silva pelo carinho e apoio emocional, pelos momentos partilhados em São Carlos. A todos eles, pela presença constante neste percurso, tornando possível a finalização deste trabalho.

A realização da pesquisa e resultante tese foi possível graças ao apoio da FAPEAM - Fundação de Apoio à Pesquisa do Estado do Amazonas, com a concessão de uma bolsa de Doutorado. Por isso e por fomentar a pesquisa no Amazonas em uma conjuntura tornada desfavorável à tão fundamental atividade, a de pesquisador, sou agradecida.

Para a presente versão corrigida da tese, foram consideradas as observações da banca examinadora formada pelos Professores Aldrin Moura de Figueiredo, Carlos Alberto Ferreira Martins, Celma Chaves Pont Vidal, Cibele S. Rizek, Renato Luiz Sobral Anelli e Ruth Verde Zein, pelos quais nutro grande admiração e agradeço imensamente. 
À Regina Máxima do Nascimento Pinheiro (in memorian). 





\section{Resumo}

Em perspectiva histórica, este trabalho examina a arquitetura na Amazônia brasileira entre 1934 e 1989, a partir de como foi dada a ver nas fontes documentais onde circulou como temática nesses anos, revistas especializadas e historiografia da Arquitetura e Urbanismo no Brasil. A Amazônia foi avistada pelo entrelaçamento destas fontes às bibliográficas, quando aportada pelos recortes da modernização, urbanização e como paisagem. Acompanhando o fluxo da intervenção estatal sobre a região, a atividade de arquitetos foi intensificada e remetida a contextos nos quais o território foi sendo modificado. Dos sentidos capturados das fontes, uma Amazônia como paisagem, depurada e prospectiva, atravessou a prática de projeto, produzindo diálogos distintos com a disciplina, absorvida pelas construções culturais que em longa duração formularam a região em síntese. Os projetos de arquitetura foram demarcatórios de estágios da transformação do espaço regional, revivificando a memória sobre a Amazônia, sem estabelecer filiação a uma tradição construtiva em particular, ressignificando o território e o reelaborando como paisagem.

Palavras chave: Amazônia, Arquitetura e Urbanismo, História, Paisagem. 


\section{Abstract}

This work examines architecture in the Brazilian Amazon between 1934 and 1989 in a historical perspective, from how it was seen in the documentary sources where it circulated as a theme in those years, specialized magazines and historiography of Architecture and Urbanism in Brazil. The Amazon was seen by the intertwining of these sources with the bibliographic ones, contributed by the cuts of modernization, urbanization and as landscape. During the flow of state intervention in the region, the activity of architects was intensified and referenced in contexts in which the territory was being modified. From the senses captured from the sources, an Amazon, as a purified and prospective landscape, crossed the practice of project, whose dialogued distinctly with the discipline, although absorbed by the cultural constructions that in a long time has been formulated the region in synthesis. Resignifying the territory, the architectural projects were demarcated as stages of the transformation of the regional space, reviving the memory, without establishing affiliation to a particular constructive tradition, re-elaborating it as a landscape.

Palavras chave: Amazon, Architecture and Urbanism, History, Landscape. 


\section{Índice de ilustrações}

Figura 1 - Reprodução de pintura de Moacir Andrade, 1982, sem título. Fonte: LOPES, 2018, p.71. .77

Figura 2 - Capa da revista Acrópole e imagens do artigo Estrada de Ferro Madeira-Mamoré. Esplendor e decadência da estrada da borracha, de Adhemar Chaves. Fonte: ACRÓPOLE n.268, 1961, p. 154-158.

Figura 3 - Seleção de capas de revistas de Arquitetura entre as décadas de 1960 e 1980, enfatizadas pela mediação visual presente em narrativas sobre a Amazônia. Revistas (1) Acrópole (ACRÓPOLE n.326, 1966), (2) Arquitetura Brasileira do Ano (ABA n.1, 1967-68), (3) CJ Arquitetura (CJ ARQUITETURA n.20, 1978), (4) Projeto (PROJETO n.38, 1982), (5) Projeto (PROJETO n.40, 1982), (6) Arquitetura e Urbanismo (AU n10, 1987).

Figura 4 - Capas do Livro-catálogo Brazil Builds, de Philip Goodwin (1943), do livro Modern Architecture in Brazil de Henrique Mindlin (1956) e Arquitetura contemporânea no Brasil, de Yves Bruand (1981).

Figura 5 - Livro 10 Arquitectos Latinoamericanos com publicação de sete obras e projetos de Severiano Mário Porto junto as de outros arquitetos da América Latina. Fonte: WAISMAN \& NASELLI, 1989, p. 186201.

Figura 6 - Artigo (1) Por uma arte brasileira de Theodoro Braga, publicado no primeiro número da revista Acrópole. Fonte: ACRÓPOLE n.1, 1938, p. 19-20. Cerâmica referenciada na arte marajoara (2). Fonte: ACRÓPOLE n.6, 1938, p. 23-24.

Figura 7 - Localização do arquipélago do Marajó e corte de teso indígena com detalhe típico de urnas funerárias. Fonte: REV. MUN. DE ENG. n.6, 1942, vol. IX, p. 24-25.

Figura 8 - Desenhos de passeios públicos com motivos referenciados na arte marajoara. Fonte: REV. MUN.

DE ENG. n.3, vol. X, 1943; REV. MUN. DE ENG. n.6, vol. IX, 1942.

Figura 9 - Projeto de Arnaldo de Macedo Baena. Fonte: ACRÓPOLE n. 48, 1942, p. 448.

Figura 10 - Projeto da pç Pedro Teixeira, sob o encargo da Prefeitura Municipal de Belém, de autoria dos

Engenheiros Alcy Meira Filho e David Lopes. Fonte: ACRÓPOLE n.52, 1942, p. 138-139. 167

Figura 11 - Mapa do Brasil veiculado no livro catálogo de Philip Goodwin (1943) e mapa do Brasil de 1940 (IBGE, 1940).....

Figura 12 - Abrigos para o Serviço de Transporte de Trabalhadores para a Amazônia - SEMTA. Fonte: CONDURU, 2004, p. 68-69.

Figura 13 - Estação aeroviária de passageiros em Belém do Pará, projeto do arquiteto engenheiro Vital Brazil.

Fonte: REV. MUN. DE ENG. n.1, 1945, Vol.XII, p. 18.

Figura 14 - Projeto de Jorge Wilheim em Campo Grande -MT (1). Fonte: ACRÓPOLE n.195, 1954, p. 125127); (2) Exposição de projetos em Cuiabá-MT. Fonte: ACRÓPOLE n.201, 1955, p. 412.

Figura 15 - Projeto residencial para lote urbano em Belém - PA, arquiteto A.P.de Albuquerque. Fonte: ACRÓPOLE n.182, 1953, p. 69.

Figura 16 - Projeto de Carlos Lemos para casa de fazenda no Mato Grosso. Fonte: ACRÓPOLE n.193, 1954, ano 17, p. 28. 
Figura 17 - Gráfico com a posição de Brasília no planalto central e as distâncias das capitais dos estados e territórios e a desconsideração do espaço do território nacional (1). Fonte: BRASÍLIA, n.2, 1957. Mapa da configuração do território e a mesma lógica das distâncias em linha reta (2). 188

Figura 18 - Projeto do Banco de Crédito da Amazônia, de Francisco Bolonha em Belém-PA. Fonte: HABITAT n.55, 1959, p. 2-4.

Figura 19 - Projeto de Paulo Antunes Ribeiro para o Banco do Brasil em Belém-PA. Fonte: ARQUITETURA E ENGENHARIA n.28, 1953, ano V, p. 44-47.

Figura 20 - Hotel Amazonas. Projeto de Paulo Antunes Ribeiro. Manaus - AM. Fonte: ARQUITETURA E ENGENHARIA, n.16, 1951. 195

Figura 21 - Hotel Amazonas em páginas da revista O Cruzeiro - RJ. O edifício, como agente da modernização local é representado em contexto de figurações remetidas à paisagem amazônica como "Inferno Verde", referenciada em Alberto Rangel e "Selva”, em Ferreira de Castro. Fonte: O CRUZEIRO ed. 51, 1950, p.67; O CRUZEIRO, ed.13, 1951, p.21.

Figura 22 - Imagens selecionadas de matéria em que foi veiculado o projeto do Hotel Amazonas. Fonte: HABITAT, n.4, 1951.

Figura 23 - Imagens da Amazônia na primeira Habitat. Nas legendas, os "navios gaiola que navegam os rios do norte do país" (1); o "interior de uma casa de seringueiro no Acre" (2); em sequência da esquerda para a direita, casas no rio Negro, casa de seringueiro no rio Purús, "casa de operário em Espírito Santo", um igarapé em Manaus- AM (3). Fonte: HABITAT n.1, 1951, p.54; 68-71..................................206

Figura 24 - As casas sobre palafitas no Amazonas. Fonte: MÓDULO n.1, 1955, p. 42-43.....................208 Figura 25 - (1) A cidade flutuante desde seu interior (SCHULTZ, 1964) e (2) em panorama (ANDRADE, 1984). 210

Figura 26 - Projeto do Estádio Vivaldo Lima, de Severiano Mário Porto e Paulo Emílio Ribeiro, III Premiação Anual do IAB-GB. Fonte: ARQUITETURA-IAB n.44, 1966, p. 24.

Figura 27 - Projeto de Severiano Mario Porto para o Estádio Vivaldo Lima em três publicações da década de 1960. Fonte: (1) ARQUITETURA-IAB n.42, 1965, p. 55; (2) ARQUITETURA - IAB n.44, 1966, p.24; (3) AMAZÔNIA É BRASIL, 1967, s/p.

Figura 28 - Projeto de Severiano Mario Porto para restaurante premiado na categoria de "edifícios para fins recreativos”, na V Premiação Anual do IAB - GB, de 1967. Fonte: ARQUITETURA-IAB n.68, 1968. 222

Figura 29 - Projeto de Edson Musa para residência em Santana - AP. Fonte: ARQUITETURA-IAB n.46, 1966, p. 27.

Figura 30 - Imagens publicadas no artigo Arquitetura contemporânea de Manaus. Dentre os edifícios publicados, figurou o de Paulo Antunes Ribeiro. Fonte: ARQUITETURA-IAB n.42, 1965. 229

Figura 31 - Imagens veiculadas no artigo Casa ecológica da Amazônia consagrada na Bienal de São Paulo. Fonte: ARQUITETURA-IAB n.41, 1965, p. 35-38.

Figura 32 - Habitações projetadas pelo arquiteto Oswaldo Bratke e capa da revista em que foram publicadas, em artigo intitulado Núcleos Habitacionais no Amapá. Fonte: ACRÓPOLE n.326, 1966, p. 17-38. 237 Figura 33 - Arquitetura e Paisagismo na Amazônia, de Leandro Tocantins (TOCANTINS, 1966)........239 Figura 34 - Imagens localizadas antes da publicação dos projetos na revista Arquitetura Brasileira do Ano. Fonte: ABA n.1, 1967-68.

Figura 35 - Três projetos de edifícios publicados isolados de contextualidade urbana, na revista ABA-1, em Manaus-AM. Departamento de Estradas de Rodagem-DRM, de Luiz Antony e Pereira da Cunha (1), primeira casa do arquiteto Severiano Porto (2) e Projeto de Sérgio Bernardes para hotel (3). Fonte: ABA n.1, 1967-68, p. 70, 125, 133. 244 
Figura 36 - Capa da revista CJ n.7 e projeto do edifício sede do Ministério da Fazenda em Belém - PA, de autoria de Maria Laura Pinheiro, Eurico Calvente, Luiz Augusto dos Santos Braga, Arima Diehl Pereira Travassos. Fonte: CJ ARQUITETURA n.7, 1975, p. 24-27.

Figura 37 - Projeto tipo para os reservatórios de água de Manaus de autoria de Severiano Mário Porto. Fonte:

CJ ARQUITETURA n.7, 1975, p. 54-56.

Figura 38 - Projeto da sede do departamento nacional de portos e vias navegáveis de autoria de Severiano

Mário Porto em Manaus - AM. Fonte: CJ ARQUITETURA n.7, 1975, p. 88-92. .251

Figura 39 - (1) Capa da exposição de 1969, Amazônia brasileira (AMAZÔNIA BRASILEIRA, 1969); (2)

Capa da revista CJ Arquitetura (CJ ARQUITETURA n.20, 1978). ..............................................257

Figura 40 - Matéria A descoberta da Amazônia. Fonte: MANCHETE ed. 1102, 1973............................261

Figura 41 - Edição Especial Amazônia um novo Brasil. Fonte: MANCHETE ed. Especial, 1973. ...........261

Figura 42 - Projetos na estrutura de novas paisagens e espacialidades urbanas em Manaus-AM. Fonte: CJ

ARQUITETURA n.20, 1978. .264

Figura 43 - Projeto de Severiano Porto para residência de Robert Schuster. Fonte: MÓDULO n.53, 1979, p.

$60-67$.

Figura 44 - Casa de Severiano Mário Porto, Manaus - AM. Fonte: PROJETO n.40, 1982, p. 22-25 .......268

Figura 45 - Usina hidrelétrica de Tucuruí. Fonte: PROJETO n.44, 1982, p. 59-69................................271

Figura 46 - Vila permanente da Usina de Tucuruí. Fonte: PROJETO n.56, 1983 .................................272

Figura 47 - Projetos desenvolvidos por Sérgio Teperman para o setor de telecomunicações, dentre os quais a

sede no Amapá, Mato Grosso, Pará, Acre e Maranhão. Fonte: PROJETO n.45, 1982, p. 57-67........273

Figura 48 - Projeto de terminal rodoviário de Cuiabá-MT, de autoria de Moacir Freitas, Ercílio G. de Souza,

Paulo A. Mendes da Rocha, Newton Arakawa. Fonte: PROJETO n.26, 1981, p. 16-18 ..................275

Figura 49 - Projeto de pousada na ilha de Silves-AM, de Severiano Mário Porto, Mário Emílio Ribeiro e equipe. Fonte: MÓDULO, n. 75, 1983, p.58-61. .277

Figura 50 - Projeto de pousada na ilha de Silves-AM, de Severiano Mário Porto, Mário Emílio Ribeiro e equipe. Fonte: PROJETO n.49, 1983, p. 36-46. 278

Figura 51 - Capa da revista; Universidade do Amazonas em Manaus (1;2); Clube do Trabalhador - SESI em

Manaus (3); Assembleia Legislativa do Estado em Porto Velho - RO (4); Banco da Amazônia em Manaus - AM (5). Fonte: (PROJETO N.83, janeiro de 1986). .281

Figura 52 - Revistas com denúncia e crítica à devastação ambiental na Amazônia, com capas de Paulo Caruso.

Fonte: PROJETO n.38, 1982; PROJETO n.40, 1982. .282

Figura 53 - Projeto de urbanização da Amazônia, de Spencer de Morais Pupo Nogueira. Fonte: PROJETO n.38, 1982, p. 30-34. 283

Figura 54 - Implantação geral do conjunto habitacional Cidade Nova em Manaus-AM, de autoria de Ricardo Julião, Edson Musa e Edith de Oliveira. Fonte: PROJETO n.38, 1982, p. 40-48. .284

Figura 55 - Artigo Amazônia: ocupação irracional do espaço. Fonte: A CONSTRUÇÃO SÃO PAULO n. 1852,1983 , p. $10-11$

Figura 56 - Imagens dos projetos publicados no artigo Arquitetura Brasileira Atual, no segmento da revista

Projeto Os anos 70/Tendências. Fonte: PROJETO n.42, 1982, p. 133;154;155. .290

Figura 57 - Imagens de projetos em páginas dedicadas à Arquitetura no Norte do país no livro Arquitetura Moderna Brasileira. Em sequência, Sede da Portobrás (1), Superintendência da Zona Franca de Manaus (2), Residência do Arquiteto Severiano Porto (3) e Residência de Robert Schuster (4), todas as obras em Manaus - AM. Fonte: FICHER \& ACAYABA, 1982, p.106-111. .294

Figura 58 - Capa do catálogo da exposição Arquitetura Brasileira Atual e projetos publicados, de Sergio Teperman, Paulo Lepage, Severiano Porto e Mário Emílio Ribeiro, atuantes na Amazônia. Fonte: MOSTRA DA ARQUITETURA BRASILEIRA ATUAL, catálogo, 1983, p.107-108. .296 
Figura 59 - Projetos expostos na primeira mostra de arquitetos de Manaus. Capa do catálogo (1); conjunto parque Ayapuá de Mario Alvise Tedesco de 1981 (2); projeto do banco da Amazônia de Severiano Mário porto e Mário Emílio Ribeiro, 1974 (3); projeto para sede da Justiça Federal do Amazonas de 1978, de Agesilau Souza de Araújo (4); projeto do auditório do Campus do INPA, 1983, de David Rodney Lionel Pennington (5); projeto para o Banco do Estado do Amazonas, 1984, de José Henriques Bento Rodrigues (6). Fonte: MOSTRA DE ARQUITETOS DE MANAUS, catálogo, 1984. 299

Figura 60 - Dissertação Estudo sobre exemplos de arquitetura tropical, erudita e suas adequaçóes a Amazônia Brasileira no último decênio defendida na Escola de Engenharia de São Carlos, Universidade de São Paulo. Capa e mapa das viagens. Fonte: FILHO, 1984. 302 Figura 61 - Capa e imagens do projeto de João Castro Filho para o Retiro Tagaste, em Ananindeua - PA (1) e projeto para o Parque Anauá, de Otacílio Teixeira Lima Neto, em Boa Visa - RR (2). Fonte: PROJETO n.120, 1989. 303

Figura 62 - Matéria da revista A Construção São Paulo sobre a obra de Severiano Mário Porto. Fonte: A

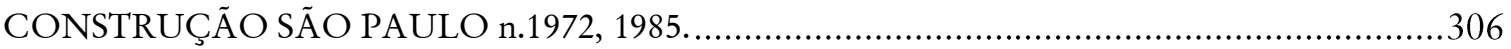

Figura 63 - Arquiteturas no Brasil: Anos 80. Fonte: SEGAWA (org.), 1988; PROJETO n. 114, 1988.....308

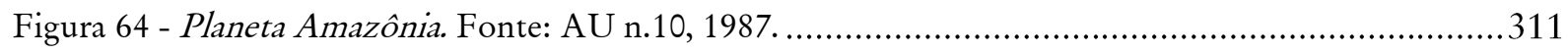
Figura 65 - Leitura territorial de Fleury de Oliveira, para proposta em adequação ao território, de uma ecoarquitetura para a Amazônia (OLIVEIRA, 1989)..... 313

Figura 66 - Realidade amazônica. Fonte: AU n.10, 1987, p. 3. 320

Figura 67- Uma síntese da paisagem, em ilustração do artigo de Luiz de Miranda Corrêa, "Problemas habitacionais no trópico brasileiro". Fonte: ARQUITETURA-IAB n.30, 1964, p. 32. 321

Figura 68 - Imagens de moradias típicas presentes no artigo de Luiz de Miranda Corrêa. Fonte: ArquiteturaIAB n.17, 1963, p. 3-5. 329

Figura 69 - Exemplo de uma arquitetura "extremamente funcional e muito estética" no artigo "Amazônas: o povo arquiteto". Fonte: HABITAT n.1, 1951, p.54; 68-71.

Figura 70 - Imagem da moradia com a legenda fachada da finíssima casa do Sr. José da Silva e Matto, numa localidade do Amazonas. Fonte: HABITAT n.7, 1952, p. 3-9.

Figura 71 - Imagem do tapiri. Fonte: ABA n.1, 1967-68, p. 23.

Figura 72 - Artigo do engenheiro Joaquim Cardozo, diretor da revista Módulo. Fonte: MÓDULO n.5, 1956, ano 2 , p. 20-23. 334

Figura 73 - Desenho mais publicado da casa projetada para Robert Schuster, por Severiano Porto. ..........338 Figura 74 - (1) Universidade do Amazonas, Manaus - AM. Fonte: Revista PROJETO n.83, janeiro de 1986; (2) Pousada, Silves - AM. Fonte: Revista PROJETO n. 114, setembro de 1988; (3) Sede do Departamento Nacional de Portos e Vias Navegáveis, Manaus - AM. Fonte: Revista CJ ARQUITETURA n.7, 1975; (4) Residência Schuster, Manaus - AM. Fonte: Revista MÓDULO n. 53, março-abril de 1979; (5) Centro de Proteção Ambiental, Balbina - AM. Fonte: Revista PROJETO n.125, 1989. 340

Figura 75 - Imagens referenciais à escolha dos locais de implantação das Vilas no Amapá, comentadas pelas “condições físicas e socioeconômicas locais existentes na região". Fonte: ACRÓPOLE, n.326, 1966, p. 18-19. 343

Figura 76 - Síntese da Evolução de habitação típica de Vila Serra do Navio (RIBEIRO, 1992, p. 4)..........347 Figura 77 - Espacialidade moderna, construção racionalizada e desenho da paisagem civilizatória na Amazônia, numa tríade sintética do projeto de Bratke em imagens veiculadas na Revista Acrópole. Fonte: ACRÓPOLE n.326, 1966.

Figura 78 - (1) Perspectiva da implantação do Distrito Industrial em Manaus-AM (SUFRAMA, 1971); (2) Paisagem da recente industrialização em uma perspectiva da sede da Suframa (CJ ARQUITETURA n.8, 1975). 
Figura 79 - (1) Suframa, de Severiano Mário Porto, na XII premiação anual do IAB - GB. Fonte: CJ ARQUITETURA n.8, 1975, p. 6-7,18-23); (2) Publicação da mesma obra na revista Projeto. Fonte: PROJETO n.83, 1986, p. 46 . .

Figura 80 - Suframa e implantação por malha expansiva. Fonte: PROJETO n.40, 1982 .........................357

Figura 81 - Sede da Suframa em registros que evidenciam a malha regular do projeto e a ênfase conferida pelo

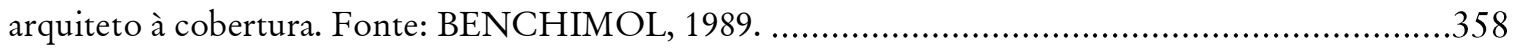

Figura 82 - Vila e vista geral do canteiro de Balbina - AM. Fonte: ELETRONORTE, 1982....................362

Figura 83 - Publicação do CPA de Balbina. Fonte: PROJETO n.125, 1989...........................................363

Figura 84 - (1) Centro de Proteção Ambiental de Balbina em imagem do conjunto edificado, enfatizado pela cobertura dominante. (2) Registro em desenho do projeto compondo a paisagem. ..........................364

Figura 85 - Projeto com implantação completa do CPA - Balbina, de Severiano Porto. Fonte: AU n.11, 1987.

Figura 86 - Projeto de Milton Monte para o clube Interpass. Mosqueiro - PA. Fonte: PROJETO n.148, 1991.

Figura 87 - Projeto de Milton Monte para o clube Interpass. Mosqueiro - PA. Fonte: PROJETO n.156, 1992.

Figura 88 - Fotografia do conjunto e corte do "barracão" do clube Interpass. Mosqueiro - PA. Fonte: PROJETO n.156, 1992. 371 



\section{Sumário}

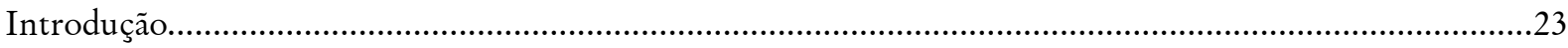

1. Amazônia brasileira, o urbano e a paisagem …………..........................................................................

1.1 Amazônia como objeto em interpretações convergentes ..................................................35

1.2 Aproximação a um aporte cronológico do urbano na Amazônia.......................................49

1.3 Amazônia como paisagem, uma construção cultural ......................................................69

2. Fontes documentais e a Amazônia na Arquitetura e Urbanismo no Brasil .............................................99

2.1 Mediações da Arquitetura e as fontes documentais da pesquisa ....................................101

2.2 Fontes documentais e sincronicidade nos textos ........................................................112

2.3 Amazônia em recortes historiográficos de Arquitetura e Urbanismo no Brasil...........117

3. Dentro e fora da História: centralidade da Amazônia brasileira nos textos e prática de Arquitetura e

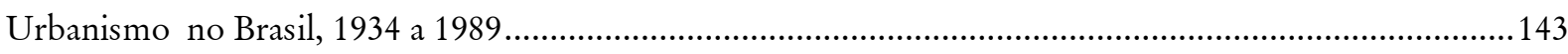

3.1 Indo aos textos: Arquitetura e Urbanismo e a Amazônia, de 1934 a 1942 ....................145

3.2 Expectativas de modernização, de 1943 a 1967 ...........................................................168

3.3 Amazônia, a questão ambiental e a alternativa à Arquitetura brasileira, 1968 a 1989 ...247

4. Narrativas de Paisagem, argumentos de Projeto..................................................................................

4.1 O projeto como um fato de paisagem na Amazônia..........................................................319

4.2 A paisagem tipificada pela habitação..................................................................................327

4.3 A paisagem civilizatória, arquitetura das Vilas Serra do Navio e Amazonas, no Amapá

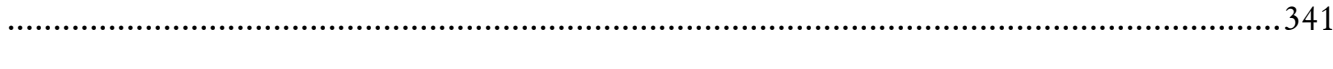

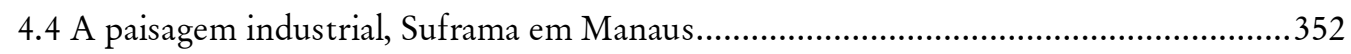

4.5 A paisagem da memorialização da perda, Centro de Proteção Ambiental em Balbina -

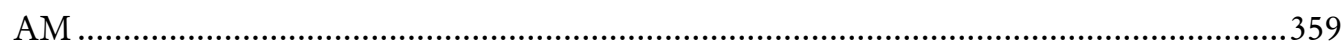

4.6 A paisagem identitária, Interpass Clube de Milton Monte em Mosqueiro - PA............366

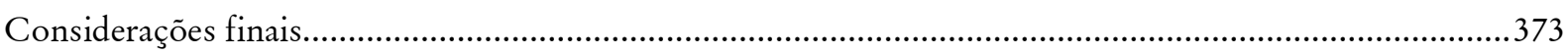

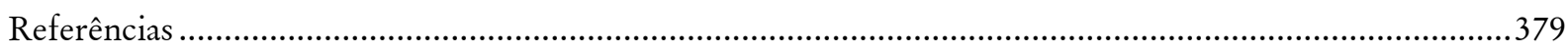

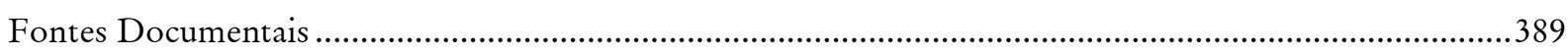





\section{Introdução}

Como realizar um estudo de História desde um recorte geográfico de monta como o delimitado pela Amazônia brasileira? Que enfoques dele partidos e entrelaçados às realizações da Arquitetura e Urbanismo sustentariam tal pretensão? Que questões e temas tornariam a investigação uma realização possível e significativa ao tempo presente, sob que olhar inédito? Como não incorrer em mitificações, à defesa de alguma unidade, ou à naturalização daquele território, pouco explicativas de dinâmicas sobre a Amazônia brasileira no âmbito da Arquitetura e Urbanismo? Ao objetificá-la em inteireza - a Amazônia - seria possível que fosse produzido conhecimento plausível, alinhado ao nosso interesse de pesquisa sobre a História da Arquitetura? Em acréscimo, como abordar criticamente a obra, o projeto, sobretudo na Amazônia, desde quais fronteiras disciplinares?

A identificação de trabalhos, especialmente advindos das Ciências Sociais, trouxe complexidade a tais questões, já que sobre a Amazônia uma tradição a tem constituído como objeto privilegiado de observação e pesquisa e produzido intenso intercâmbio de saberes a respeito dos inúmeros sistemas que o território abrange, a exemplo dos sociais, ambientais, políticos, culturais. Isto torna fragilizada a adoção de posturas neutras diante da possibilidade de compreensão de fenômeno a ele associado, já que seu respeito tem sido desenvolvidas investigações desde diversos recortes, além de incorporados enredamentos inevitáveis à Amazônia, na admissão de sua imprecisão e de sua complexidade. Assim, justificá-la como objeto, ainda que observado desde a perspectiva da Arquitetura e Urbanismo, implicou depreendê-lo como fenômeno atado à sua própria historicidade.

As fontes foram tornadas centrais no percurso da tese, tendo em vista apontarem para questões até então não tratadas pelos estudos de Arquitetura e Urbanismo no Brasil. A ausência de compilações ampliadas ou estudos constituídos do corpus documental aqui apresentado, prevalentemente revistas especializadas e escritos referenciais de Arquitetura e Urbanismo, bem como o limitado acesso a registros de documentação técnica, enquadraram a pesquisa, alinhada intencionalmente à localização da Amazônia na História da Arquitetura e Urbanismo no Brasil. Por isso a importância conferida aos registros da Amazônia em publicações, que no recorte temporal proposto, de 1934 a 1989, fizeram 
circular um painel da atividade projetual e intelectual em vigor, conformado por escritos de teoria crítica, história e de cunho jornalístico. Para a tese, em recorte, interessaram prioritariamente, além das obras e arquitetos presentes nas fontes, os significados propagados acerca da Amazônia, o modo como foi veiculada nos textos, tanto nas falas que a problematizaram em unidade e generalização ou em pormenor, até as enunciações explicativas de obras referenciais pelos vínculos culturais suscitados pela Amazônia.

A produção presente em revistas especializadas e em textos referenciais da Arquitetura e Urbanismo no Brasil compôs um quadro de exemplares icônicos que incluiu de algum modo aqueles relacionados à Amazônia. Junto aos nexos estabelecidos com o processo da modernização nacional e o transcurso da disciplina no país desde o primeiro quartel do século XX, o lugar ocupado pela arquitetura alusiva à Amazônia, revelou o interesse dos arquitetos em absorvê-la como tema, mobilizados a decifrá-la e transpô-la a seus projetos em síntese, na prospecção de novas paisagens. Textos e prática, atuaram na construção dos sentidos conferidos à Amazônia e a seu delineamento em narrativas de uma paisagem. Junto aos textos especializados e ao pensamento intelectual acerca da Amazônia, que constitui campo próprio de saber, a atividade projetual quando de encontro ao tema em pauta, exigiu dos arquitetos leituras territoriais, mas recorrentemente incorporou outras, da ordem do simbólico e do memorial. $\mathrm{Na}$ atividade projetual, arquitetos vislumbraram uma Amazônia em ideações do território, constitutivas da valoração de suas obras.

Os projetos que compõem o último capítulo adensam a presente tese, como arquétipos da conformação do espaço da Amazônia brasileira no século XX, objetos elaborados como fatos de uma paisagem em aprimoramento e principalmente, referenciada em um espaço, o amazônico, na temporalidade de sua efetiva e mais expressiva transformação. Esta paisagem tem sido construída culturalmente desde a geografia moderna do século XIX e a cada momento da Amazônia histórica e de seu delineamento como território, foi nuançada, adquiriu novos matizes de designação e foi figurada junto a reelaborações intelectuais. Certo grau de continuidade narrativa prevalece nos textos acerca da Amazônia, dado o caráter memorial com que tem sido representada e o juízo ético que tem permeado as formas de interação entre o artifício da arquitetura e a natureza neste lugar. No campo da Arquitetura e Urbanismo, os projetos e os textos dialogaram direta e indiretamente com o conteúdo memorial ao contactarem este acervo da Amazônia, uma 
construção cultural e materialmente difusa. Deste modo que lidos em conjunto, os dados presentes nas revistas e demais fontes, revelaram concepções de paisagem e sua reelaboração em continuidade, em demarcações temporais interpretadas no terceiro capítulo da tese, quando as fontes são lidas em mais detalhe. Certas arquiteturas, como fatos de paisagem, selecionadas da presente interpretação, materializaram novos e ressignificaram velhos sentidos conferidos à Amazônia, foram e são representativas da conformação de novos lugares, mas principalmente a prospecção de paisagens depuradas.

$\mathrm{O}$ argumento que conduz à tal assertiva, percorre os capítulos da tese a partir de três camadas de interpretação: uma primeira, estabelece o discernimento entre a concretude da transformação do território da Amazônia brasileira por um lado e deste como paisagem ideada, memorial, por outro, frutificada da construção do pensamento intelectual que incorporou concepções de certa amazonicidade, uma unidade cultural, como categoria operativa. Os projetos interpretados transitam entre a materialidade, posto que arquiteturas, e o simbólico, dada sua inscrição junto às representações da Amazônia; a segunda é conduzida pela identificação de marcos históricos determinantes às temporalidades da Amazônia no século XX, sua modernização e transformação espacial, como condição de possibilidade da atuação de arquitetos e urbanistas no recorte em pauta. Neste caso é estabelecida a ponte entre os encargos e a conjuntura de transformação do território, em sua potencial urbanicidade. A Amazônia concebida e representada em paisagem, conforme narrada nos textos e transposta ao projeto, produziu ocultamentos sobre o caráter controverso com que foi dada sua modernização. Sobretudo a experiência com a modernização no âmbito da arquitetura, centrou a tensão de estar localizada entre a inevitável transformação do espaço para abarcar o novo e em complementaridade, a perda. Desta tensão, foram enriquecidas as formas de contato com a memória, evocativas da história do território; uma terceira camada, condicionada pelas fontes documentais, caracterizou o regime de visibilidade da Amazônia nos escritos de Arquitetura e Urbanismo no Brasil e as representações do território, como ideias em circulação junto aos projetos, entre os anos de 1934 e 1989. Nas representações textuais que percorreram este intervalo, a Amazônia oscilou entre centro e periferia da Arquitetura e Urbanismo no Brasil, contudo, no câmbio entre essas representações e a prática projetual, foi sobretudo, espaço possível às experimentações de intelectuais e arquitetos na modernidade. 
Um paralelo possível que subjaz esta linha interpretativa diz respeito à localização da Amazônia para a crítica brasileira, assim como o Brasil esteve para a crítica internacional. Quando a Arquitetura moderna europeia foi esvaziada de sentido, frente ao desencanto do pós-guerra, os críticos recorreram às excepcionalidades ao seu julgo periféricas, dentre elas, as brasileiras. Quando a Arquitetura Moderna Brasileira foi esvaziada do mesmo modo pela atividade crítica, recorreu às "regionalidades" para fins de afirmação da nação. A busca por outros caminhos alicerçados pelo recorte das distinções e particularismos, produziram argumentos e leituras que a própria modernidade estava a revelar, trazidos de longa duração, mas com novas roupagens, a exemplo das relativas ao caráter sustentável e ecológico das obras que ao longo do tempo tem sido associado a distintas significações. Deste modo, as fontes não revelam a completude do fenômeno, Arquitetura e Urbanismo e Amazônia, mas um panorama das ideias em circulação ao tempo da análise ora proposta.

Deste modo, a importância conferida às mediações realizadas pelos textos, é dada sob duas justificativas centrais. Primeiro, os textos são ao presente, os registros das ideias em circulação no recorte temporal em estudo, portanto são fontes elementares para o resgate da prática disciplinar da Arquitetura e Urbanismo no Brasil entre 1934 e 1989. Junto à mediação das obras de Arquitetura e Urbanismo, nas fontes, prevalentemente revistas especializadas, circularam no período em estudo, agentes, ideias, objetos e textos referenciais à prática disciplinar. Particularmente, a abertura do campo editorial no Brasil mais expressivamente nos anos de 1980, consolidou a importância dessas mediações, e no que tange ao objeto desta tese, o caráter excepcional de uma Arquitetura revelada não apenas em excentricidade, mas em associações simbólicas e memoriais ao território historicamente constituído como a Amazônia. Esta linha interpretativa conduziu o rastreamento da Arquitetura e Urbanismo ali desenvolvidos para revelar, em centralidade, as formulações que the dotaram de sentido e ao seu lugar de inscrição, bem como pontes com a prática e crítica da Arquitetura no Brasil. Nas fontes foi possível identificar distintas temporalidades da Amazônia junto à história do país e às dinâmicas do campo disciplinar, seus referenciais e questões latentes, sob a mediação dos textos.

Além desta premissa, noutro curso, os textos revelaram pontes entre o campo da Arquitetura e uma produção intelectual interessada na Amazônia, que tem comportado um acervo de conhecimento específico, detentor de sua própria historicidade, que é 
reconhecido dentre distintos aportes, como o pensamento social sobre a Amazônia. Foi possível identificar algumas pontes entre ambos. Estes contatos, particularmente expressos na tese pelas vias discursivas com que foram identificados, aparecem mais expressivamente desde a década de 1960, quando da intervenção decisiva do Estado sobre o espaço da Amazônia brasileira. As mediações da produção de Arquitetura e Urbanismo nos textos, pela crítica e imprensa especializadas, deram a ver estas trocas culturais, revelando ideias acerca da Amazônia, como uma paisagem em prospecção. Significados propagados sobre uma Arquitetura e Urbanismo na Amazônia conferiam certo imobilismo à interpretação das obras, reproduzindo determinada forma de observá-las, material e discursivamente, a partir de um dado de condicional perenidade, uma constância que enfatizou as representações da Amazônia como paisagem.

Com a trilha deixada pelo conjunto de registros textuais foi possível observar em panorama, o repertório a Arquitetura e Urbanismo na Amazônia em vigor, em recorte próximo à cronologia prevalente na historiografia brasileira. Este recorte foi condicionado a alguns eventos relacionados ao próprio campo, como o processo de consolidação e esvaziamento discursivo de uma Arquitetura Moderna Brasileira, entre os anos de 1920 e 1960 e depois, os registros de obras icônicas e sobre a Amazônia, desde os anos de 1930, no curso da modernização nacional. Por outro lado, entre 1960 e 1980 a Amazônia apareceu nas revistas em um ambiente já crítico à vertente consagrada da Arquitetura Moderna Brasileira, de modo que quando foi identificada nos textos, neste segundo intervalo, o foi no ambiente de revisão historiográfica, não coincidentemente quando esteve mais frequente nas publicações especializadas.

De modo oscilante, a produção de Arquitetura e Urbanismo na Amazônia teve um lugar junto aos ecos de uma arquitetura brasileira ou noutra condição, a de uma arquitetura regionalizada, demarcada pelos particularismos "amazônicos", ainda que referenciada ao nacional. A Amazônia vislumbrada como paisagem fundamentou a elaboração material e sua relação com a crítica e a atividade projetual, conforme a (in)visibilidade do lugar nos escritos de Arquitetura e Urbanismo no Brasil, especialmente revistas especializadas. Sobretudo como uma paisagem reelaborada no tempo, a Amazônia pautou discussões éticas e estéticas quando da elaboração de artifícios da Arquitetura e Urbanismo em formas de diálogo com a natureza, os saberes tradicionais, as memórias. Como campo de 
experimentos com a modernização, o território da Amazônia foi vislumbrado como ideação pela atividade projetual, quando objetos foram concebidos sob a condicional antevisão de novas paisagens, em um espaço em transformação, especialmente em frentes de expansão urbanas, como a maior parte dos que foram selecionados e apresentados ao fim, na tese. A única exceção foi o tema da habitação, apresentado no primeiro tópico do último capítulo. A habitação se apresenta na Amazônia como o objeto síntese, que concentra em suas formas materiais distintas, as especulações acerca dos saberes, dos modos de vida, a domesticidade, o imaginário do próprio homem amazônico em sua relação com o meio. O tema é apresentado, ao fim, como uma especulação ideada acerca do ambiente amazônico, explicativa e propositiva do espaço e da paisagem na Amazônia.

A tese percorre um emaranhado de questões, mas traz a tona algumas pautas centrais, a partir das quais os capítulos foram desenrolados e alcançam, ao fim, as obras de referência à Arquitetura e Urbanismo na Amazônia em acordo com a interpretação ora proposta. Em síntese, pautam a tese: a problematização do objeto Amazônia, a partir do seu duplo enquadramento, como paisagem e como território; a compreensão dos meios de interpretação das fontes, como suportes decisivos da mediação e representação da Arquitetura e Urbanismo na Amazônia e desta mesma, como paisagem; o panorama historiográfico junto à teoria crítica da Arquitetura e Urbanismo no país para a localização da Arquitetura e Urbanismo na Amazônia nos textos do século XX; a construção de periodização particular desde as fontes, na determinação de novas demarcações temporais da Arquitetura e Urbanismo na Amazônia, sobretudo junto à centralidade com que foi campo de experimentação às ideias de modernização, de projetistas e intelectuais, deslocados de uma unidade recorrentemente conferida à produção nacional; dentre as obras icônicas, a identificação de projetos que endossam a tese de que a atividade projetual, em diálogo com os textos, quando do encontro com o tema Amazônia, a apreendeu como paisagem em variações interpretativas e propositivas, produzindo construções prospectivas transpostas à materialidade de objetos.

Deste modo, no primeiro capítulo, a Amazônia é apresentada desde duas acepções, entre a paisagem e o urbano, abarcando o campo simbólico e a concretude espacial, a partir de suportes bibliográficos, quais sejam, relativos a estudos do pensamento social sobre a Amazônia e a estudos geográficos. Ambos foram incorporados desde leituras abrangentes 
originárias de outros campos do conhecimento e junto aos quais, algumas narrativas da paisagem da Amazônia produzidas desde leituras partidas de seu interior, ilustram o capítulo, enfatizada a hinterlândia como imagem memorial construída em equivalência à paisagem cultural tipificada pela ideação moderna. Relações entre espaço e temporalidade são demarcadas em representações produzidas na trajetória histórica da Amazônia brasileira que desde o século XIX foi sendo delineada em condição de unidade, como uma paisagem. De modo relacionado, são comentadas as implicações desta perspectiva sobre as lacunas no conhecimento mais aproximado aos fenômenos transcorridos e determinantes do território, sobre os ocultamentos condicionados pelas elaborações discursivas que tem cercado a Amazônia. Frente a este panorama são apresentadas perspectivas que se utilizam dos textos como base documental à investigação da Amazônia pelo viés da cultura, que ainda assim apontam para a condicional paisagem com que foi prevalentemente narrada no fluxo da modernidade. Em acréscimo, a partir de aportes transdisciplinares, é abordada a particularidade com que o espaço na Amazônia foi e vem sendo transformado, em velocidade fugidia à sua completa compreensão. São relacionados fenômenos que, encadeados, devem levar a indícios do urbano na Amazônia, desde alguns enfoques específicos e pertinentes à tese. Com esta discussão, da Amazônia entre o urbano e a paisagem, é problematizada a Hinterlândia amazônica, apresentada como síntese de um projeto intelectual, de um lugar presente na modernidade, ausente na modernização regional, almejado idealmente, como uma paisagem prospectada.

No segundo capítulo são problematizadas as fontes documentais, escritos de história e teoria prevalentes nos anos em estudo a partir dos quais foi composto um panorama historiográfico. Para a localização da produção de Arquitetura e Urbanismo na Amazônia brasileira nos textos, foram pontuados os cortes estabelecidos pela historiografia com base em uma moderna arquitetura brasileira entre as décadas de 1930 e 1980, quando da redefinição dos rumos interpretativos da produção realizada no país. São pontuadas algumas questões perpassadas por delimitações geográficas, pelo campo editorial, pelos marcos referenciais de uma produção tornada referencial à Arquitetura e Urbanismo no Brasil. O corte interpretativo apresentado neste tópico é sustentado pelos entrelaçamentos da Amazônia aos escritos prevalentes e em circulação até o final do recorte temporal. $\mathrm{O}$ intervalo de aproximados cinquenta anos foi delineado pelo redirecionamento crítico e pela 
renovação das linhas de análise sobre a Arquitetura no país, de ampliação da atividade jornalística e dos estudos de História da Arquitetura no Brasil e de abertura à revisão das narrativas em vigor até então.

No terceiro capítulo é apresentada uma compilação a partir da costura das fontes pesquisadas. Nela estão situados obras e arquitetos em entrelaçamentos à trajetória histórica da Amazônia entre os anos de 1934 e 1989. Foram propostos três cortes temporais, interpretados desde a centralização da Arquitetura e Urbanismo na Amazônia, inclusos seus textos e a prática projetual como identificados nas revistas, relacionados a recursos bibliográficos referentes à da Amazônia. As representações da Amazônia, conforme dados nos enfoques presentes nas mediações das obras, foram revolvidas em aportes da prevalente história da Arquitetura no Brasil. O material coletado das revistas e então apresentado é atravessado por algumas perspectivas críticas do presente e por outras, datadas, que constam como parte do conteúdo da narrativa. Já as obras identificadas nas fontes, percorrem todo o capítulo, em registros visuais reproduzidos das revistas. A precisão das datas de projeto e obra não foi fator determinante para a inclusão dos objetos arquitetônicos na narrativa, já que esta refletiu o conteúdo reportado pelas revistas ao tempo de sua veiculação. Os recortes temporais resultaram da demarcação estabelecida nas fontes documentais, em três intervalos, sobretudo pela correspondência das revistas aos eventos que reportaram. Somente com a varredura dos documentos foi possível determinar os três recortes, também conferir evidência ao final, que praticamente condicionou a seleção dos projetos presentes no último capítulo da tese.

O primeiro intervalo de 1934 a 1942 ambientou os debates em torno da identidade nacional, que em relação à Amazônia foram rebatidos na dualidade representada pelos movimentos de defesa dos referenciais marajoaras como aqueles originários da cultura nacional e os intentos da engenharia sintetizados na modernização de Belém-PA, na conjuntura de decaimento econômico regional. O segundo intervalo, de 1943 a 1968, extensivamente à atividade planejadora e interventora do Estado Nacional sobre a Amazônia, foi sistematizado no pensamento primordial em torno da adequabilidade da arquitetura ao contexto amazônico, junto a transformações espaciais transcorridas em contextos urbanizados, ou não. O particularismo cultural e a adaptação ecológica orbitaram o pensamento social sobre a Amazônia, bem como pesquisas de cunho etnográfico que 
viriam a sustentar uma série de formulações discursivas e de projeto, quanto à sua adaptabilidade, ao seu caráter, à sua inscrição contextual, à sua refletividade cultural.

O terceiro intervalo, de 1969 a 1989, revelou a articulação de autores e arquitetos em novo ambiente político. Nele, a prática do projeto e o aprofundamento da técnica foram associados a estudos socioambientais sobre a Amazônia, em teses inovadoras e novos esforços discursivos e materiais, representativos da formulação de uma faceta regional da modernidade brasileira. $\mathrm{O}$ marco final do capítulo foi dado pelos novos aportes elaborados sob o discurso ambientalista, preservacionista, que conferiram a projetos referenciais, projeção nacional e internacional, também quando referidos a uma Amazônia paisagem. A centralidade exercida por Severiano Mário Porto nas revistas, especialmente a partir de determinadas obras, frente aos demais arquitetos atuantes no período na Amazônia, foi indicativa do ocultamento da atividade profissional, de sua vibilização nesses anos.

As alterações gradativamente mais profundas do território afetaram escritas reativas às transformações sob a pauta da modernização. Também sobre a prática da própria Arquitetura, ajustada nos anos estudados, a novas formas de representá-la, tendo incorporado o discurso ambientalista moldado aos novos conhecimentos, mais aproximados da Amazônia. O recorte é finalizado pelas distintas frentes nas quais a Arquitetura e Urbanismo na Amazônia foi destacada no âmbito disciplinar: como alternativa à arquitetura brasileira, pela trilha da regionalidade cultural, pelo ingresso no circuito latino-americano de Arquitetura, pela centralidade da Amazônia na temática transdisciplinar do ambientalismo.

No quarto capítulo da tese, são apresentadas interpretações conferidas aos projetos considerados referenciais à tese, a partir do conjunto das representações que os veicularam à Amazônia, neste capítulo, condicionada à paisagem projetada. Junto às representações reverberadas nos textos igualmente presentes neste capítulo, são tratados aspectos relativos aos projetos, pensados do mesmo modo, desde a perspectiva de que quando formulados, o foram a partir de determinadas concepções dos arquitetos acerca da paisagem na Amazônia. Os objetos projetados são considerados como fatos de paisagem, contributos à construção de novos significados ao espaço amazônico em transformação, a partir do artifício da Arquitetura. As narrativas de paisagem, textualizadas, seriam, em tese, argumentos dos projetos. 



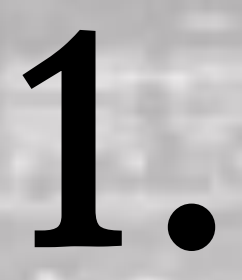

\section{Amazônia brasileira, o urbano e a paisagem}


Neste capítulo a Amazônia é apresentada desde duas acepçôes, entre a paisagem e o urbano, localizada entre uma categoria que abarca o campo do simbólico e outra que concebe as concentraçóes humanas numa dada concretude espacial. Relaçôes entre espaço e temporalidade são demarcadas em representaçôes produzidas na trajetória histórica da Amazônia brasileira que desde o século XIX é delineado em condição de unidade, como paisagem. De modo relacionado, são comentadas as implicaçôes desta perspectiva sobre as lacunas no conhecimento mais aproximado aos fenômenos transcorridos e determinantes do território, sobre os ocultamentos condicionados pelas elaboraçóes discursivas que tem cercado a Amazônia a partir de suporte textual. Frente a este panorama são apresentadas perspectivas que se utilizam dos textos como base documental à investigação da Amazônia pelo viés da cultura, que ainda assim apontam para a condicional paisagem com que foi prevalentemente narrada, no fluxo da modernidade. Em acréscimo é comentada a particularidade com que o espaço na Amazônia foi e vem sendo transformado, em velocidade fugidia à sua completa compreensão. São relacionados fenômenos que, encadeados, devem levar a indícios do urbano na Amazônia, desde alguns enfoques específicos e pertinentes à tese. Com esta discussão, da Amazônia entre o urbano e a paisagem, é problematizada a hinterlândia amazônica, apresentada como síntese, como um projeto intelectual, de um lugar presente na modernidade, fora do alcance da modernização regional, almejado recorrentemente como paisagem prospectada.

Imagem: Reprodução de pintura de Moacir Andrade, 1982, sem título. Fonte: LOPES, 2018, p.71. 


\subsection{Amazônia como objeto em interpretações convergentes}

A obra de Fernand Braudel ${ }^{1}$ contribuiu com gerações de historiadores, destacadamente pela proposição das durações de temporalidades históricas ${ }^{2}$ e pelo intento de dissolução de fronteiras disciplinares nas Ciências Sociais. Em seu trabalho referencial construiu uma história pautada pela análise de base econômica, que com a Nova História francesa e suas abordagens revigoradas - como a micro História e aquela sob influência da Antropologia na década de 1970 - foi de certo modo ressignificado ${ }^{3}$. Ainda assim o autor permanece influente (LOPES, 2003) pelo trabalho de compreensão de uma dada espacialidade, de uma geografia conformada pelas temporalidades históricas, para a leitura dos fenômenos sob a perspectiva de suas múltiplas durações ${ }^{4}$, mesmo que atreladas a dinâmicas estruturantes, como as de base econômica.

Fábio Duarte Joly fez um questionamento ${ }^{5}$ sobre a interpretação de Braudel acerca do Mediterrâneo antigo: “A partir de que momento é possível falar que esse mar cercado por três continentes e por populações heterogêneas tornou-se unificado”? Para o autor, foi justamente a experiência humana junto ao Mediterrâneo que o deslocou de uma "realidade

\footnotetext{
${ }^{1}$ Sua tese publicada em 1949 intitulada La Méditerranée et le monde méditerranéen à l'époque de Philippe II, é sua obra de referência no pós-guerra. Nela estabeleceu um objeto geográfico na construção histórica, "mar e terra do mundo mediterrâneo", propondo uma unidade entre espaço-temporalidade e os estudos históricos (AYMARD, 2003).

${ }^{2}$ Posição frente a disputa pela hegemonia nas Ciências Sociais, onde Lévi-Strauss era um dos mais atuantes, pela "força de um programa estruturalista". Ele retomou em fins de 1940 o debate entre história e sociologia e defendeu a impossibilidade do historiador de criar modelos por não acessar as "estruturas profundas da sociedade", seria, portanto, "condenado a viver na opacidade de um descritivo informe, ao caos da contingência". Braudel defendeu a "identidade historiadora da parte de alguém que está persuadido de ter a seu favor a duração" para superar a forma tradicional do "acontecimento/ data". Propôs a "longa duração que condiciona até mesmo as estruturas mais imutáveis para os valores antropológicos” (DOSSE, 2003, p. 75-81). ${ }^{3}$ A Nova História francesa dos anos de 1970 é compreendida com a referida na produção da terceira geração de historiadores vinculados à Escola dos Annales, periódico francês fundado na década de 1920, do qual Fernand Braudel pertenceu à segunda geração. Foi a geração subsequente que revisou suas noções de temporalidade histórica, trilhando o caminho da subjetividade das temporalidades históricas e da admissão de uma diversificação de objetos de análise histórica (LE GOFF e NORA, 1995).

${ }^{4}$ As categorias de longa, média e curta duração, compunham a "dialética da duração". A primeira equivaleria à quase imobilidade, à "história lenta", dada "quase fora do tempo", sem exercer interferência mais perceptível sobre os sujeitos. Em sequência, haveria uma "história social, a do grupo e dos agrupamentos", a das "economias e os Estados, as sociedades, as civilizações". Por fim, a temporalidade "ao tempo do indivíduo" seria demarcatória de uma "história tradicional" ou de "oscilações breves, rápidas, nervosas". Assim Braudel chegou à "distinção, no tempo da história, de um tempo geográfico, de um tempo social, de um tempo individual" e da mais curta duração, o evento (BRAUDEL, 2013, 2 ed., p. 13-16; 41-70).

${ }^{5}$ Maurice Aymard explica a construção do "personagem central" para Braudel, o Mediterrâneo no século XVI, "na mais ampla estrutura de uma longa corrida cronológica e de todos os mundos que o Mediterrâneo e suas pessoas descobriram, colonizaram, criaram e organizaram à sua própria imagem e por suas próprias necessidades, isto é, a própria Europa, América Latina, costas da África e até mesmo uma porção do Sudoeste da Ásia” (AYMARD, 2003, p. 15).
} 
geográfica" a uma "entidade histórica", desde quando “começa a ser navegado pelos homens, que com seus barcos realizam trocas comerciais e intercâmbios culturais” (JOLY, 2003, p. 142). É aludida a obra de Fernand Braudel pelo fato de que o objeto de análise da presente tese é delineado por um recorte geográfico, para um estudo em História, a Amazônia brasileira.

Todavia, buscar a presença humana na conformação da Amazônia desde tempos remotos equivale, em termos objetivos, a exemplo da temporalidade envolvida pelas recentes pesquisas arqueológicas, percorrer cerca de onze mil anos passados. ${ }^{6}$ Implica também tratar de um meio físico referenciado pela maior bacia fluvial do mundo, que ocupa mais de $40 \%$ do território nacional, abrange 6 estados brasileiros e 6 países vizinhos, em $5.846 .100 \mathrm{~km}^{2}$, a Bacia Amazônica. Assim, para esta tese, a longa duração remete à impossível recuperação da relação humana com esse espaço em origem, bem como à impossibilidade de sua revelação, por questões óbvias, em temporalidades arqueológicas ou mesmo encerradas na modernidade. Mesmo por se tratar de uma pesquisa em História, esses superlativos por si já evidenciam a complexidade do objeto ora estudado, observado em pretensa unidade, como território historicamente construído. Este tópico preambular deve basear o encaminhamento das interpretações focalizadas na tese, quando a prática e a reflexão sobre a disciplina da Arquitetura e Urbanismo foram referenciadas no espaço geográfico da Amazônia brasileira e o representaram em estreito diálogo com as obras ${ }^{7}$. Em atenção ao território, foram evocados desde esse campo, significados historicamente adensados sobre a Amazônia, alguns dos que tem acompanhado sua trajetória histórica, conformando-a como construção simbólica e material.

A longa duração, ainda que tenha sido o ponto de partida deste tópico, para sustentar a ideia de um território amazônico capturado em inteireza, não serve de base objetiva ao estudo de sua materialidade, já que são múltiplas as temporalidades com que especialmente no âmbito da cultura, foram e são dadas as dinâmicas na Amazônia, do mesmo modo, na Arquitetura nela referenciada. Assim, a temporalidade não é tratada como ferramenta

\footnotetext{
${ }^{6}$ Eduardo Góes Neves faz referência à vestígios humanos no Pará, datados em torno de 9.200 a.C. e no Mato Grosso, de 12.000 a.C. (NEVES, 2006).

${ }^{7}$ Não se trata de explicar a produção e a teoria crítica de Arquitetura e Urbanismo na Amazônia e ao território em completude, mas centralizá-lo junto ao registro do produto da atuação de agentes mais diretos, fossem projetistas, críticos, historiadores.
} 
operativa de uma pesquisa histórica na determinação do território ou do processo de conformação da espacialidade amazônica em uniformidade. Ela sim, constata um fluxo intelectual que elaborou a Amazônia, a formulando em formas de idealização ${ }^{8}$ que foram evocadas de tempos não necessariamente assinalados pela pesquisa, contaminando e possibilitando o diálogo e a interação entre os agentes mais diretamente relacionados ao campo da Arquitetura e Urbanismo e um conjunto de saberes exógenos a ele, elaborados por intelectuais e estudiosos de outras procedências.

Para uma discussão inicial são aqui apresentados alguns olhares interpretativos sobre a Amazônia, seja em observação a fenômenos transcorridos na longa duração, desenvolvidos a partir da concepção de uma Amazônia em unidade, de leituras sistêmicas, ou pela familiarização a questões que envolvem a espaço-temporalidade amazônica. Eles apontam para temas reveladores de questões latentes, sobre as quais estão assentadas pesquisas recentes a respeito do objeto Amazônia. São concatenados desde a perspectiva de que problematizam, frente o condicional processo urbanizador da Amazônia no fluxo da modernidade, algumas questões que tornam efetiva a interação entre eles e a compreensão da Amazônia para uma leitura da Arquitetura e Urbanismo, quais sejam, o território, o imaginário, a paisagem, em textos demarcatórios do pensamento social e da cultura, a partir de como têm sido centrais à Amazônia, sobretudo quando observada desde a conjugação da materialidade às ideias, entre a concretude, a subjetivação e o ficcional.

Yara Vicentini, referenciada em Fernand Braudel, enfocou em longa duração, a formação de cidades na Amazônia, avaliando em continuidade a relação entre artifício urbanizador e significados atribuídos à natureza, na leitura sobre os processos de urbanização quando confrontados a um recorte geográfico particular, a Bacia Amazônica. As cidades levantadas pela autora foram então interpretadas pelas suas características específicas e traçados, explicadas a partir de sua inscrição em relações econômicas mundializadas, pelo enfoque dado a uma modernização controversa do território. Adotando a premissa de uma Amazônia como um espaço de fronteira ${ }^{9}$, elaborou uma trajetória partida das primeiras apropriações nômades à diversidade do meio urbano

\footnotetext{
${ }^{8}$ Conforme a proposta de Renan Freitas Pinto, de identificar a partir dos textos de viajantes que circularam pela Amazônia e de seu olhar desde o exterior, o fluxo de uma "viagem das ideias" (PINTO, 2006).

${ }^{9}$ Em referência a conceituação elaborada nos trabalhos de Bertha Becker sobre a Amazônia como espaço de fronteira.
} 
amazônico no presente, perpassando variados temas e centralizando na cidade e em elaborações intelectuais sobre a natureza, seu interesse de análise (VICENTINI, 2004).

Aproximada de uma interpretação geo-histórica, Vicentini analisou a constituição de cidades na Amazônia desde sua base formativa, morfologia e inscrição geofísica, considerando as disputas por domínio do território, perpassadas pelos efeitos da modernidade sobre a urbanização regional. Encadeou as cidades como eventos, sem contêlas em modelos interpretativos prévios. Sobre a estratégia da longa duração em referência ao instrumental da pesquisa em História, delineou o estudo desde a relação entre "espaço e tempo" referida no objeto geográfico que buscou compreender. Para a autora, “a Bacia Amazônica, além de exprimir um conceito espacial, distingue uma temporalidade diferenciada em sua concretização histórica, que não se restringe à possibilidade de uma temporalidade estritamente vinculada a ciclos econômicos gerais, conforme expõe a bibliografia clássica sobre a área” (VICENTINI, 2004, p. 14).

A compreensão das cidades em rede de relações, do processo de urbanização com a inclusão de particularismos regionais, como de cidades pequenas e médias, desde o enfrentamento do território, marcado pela presença de vasta rede hídrica e pelos grandes projetos estatais, tem sido uma questão presente em estudos geográficos sobre a Amazônia. $\mathrm{Na}$ busca de dados associados à concretude da urbanização em suas distintas formas, têm sido desenvolvidas ferramentas de análise mais aproximadas à decodificação do real. A compreensão de que a especificidade da periodização de sua rede urbana, em temporalidades e espacialidades desiguais, regional e globalmente, são fatores que endossam a defesa de que a Amazônia envolve uma realidade na qual "espaço-tempo, lugar e ambiente não podem ser separados nem tratados como meras abstrações fora das condições concretas da história e da geografia” (SCHOR, COSTA e OLIVEIRA, 2009, p. 46).

O território amazônico comporta processos sociais desiguais situados em meio aos condicionais rios e florestas, desde os quais tem sido produzidas distâncias físicas e sociais não necessariamente conexas, numa rede dinâmica e reconhecidamente plural. A compreensão desse espaço, sua urbanização, depende sobretudo, da análise da experiência sobre o espaço vivido, do "local geográfico da ação", não podendo este ser reduzido a dualidades que o têm construído por “entendimentos miniaturizados dos indivíduos". Como exemplo, a associação discursiva da Amazônia à carência, frente o universal 
paradigma do desenvolvimento, tem servido de fundamento para o avanço da circulação de mercadorias e do capital, às custas, em geral, de restrições decisórias aos locais, sobre os processos urbanos que eles próprios têm experimentado (SCHOR, COSTA e OLIVEIRA, 2009, p. 37-47).

A compreensão dos particularismos do urbano na Amazônia é perseguida pelos estudos geográficos, mobilizados, junto às Ciências Sociais, a preencher as "lacunas na formulação de balanços teóricos mais abrangentes que busquem entender as regularidades, as continuidades, as estruturas e as singularidades do fenômeno urbano" neste lugar. Leituras baseadas exclusivamente em índices ou na utilização de estruturas modelares de interpretação do urbano, como o europeu, que o referencia em processos tipificados de industrialização, não se ajustam como "fundamento de esquemas analíticos aplicáveis à Amazônia” já que sua urbanização "expressa outras interfaces históricas nem sempre contempladas nas pesquisas", como as práticas informais do trabalho, a composição étnicoracial múltipla ou a sua condição de fronteira (CASTRO, 2008, p. 15-24).

Vários autores afirmam que o ocultamento dos processos relativos ao fenômeno da urbanização na Amazônia, não unicamente, mas os da ordem de seu ambiente, os quais eles têm se dedicado a revelar, é fato devido em especial, à perpetuação e contínua elaboração de formulações ficcionais. A mitificação da Amazônia fundida à própria dimensão do real, afeta práticas sociais locais e serve à apropriação discursiva para finalidades outras, como as relacionadas à afirmação de formas de poder e controle, especialmente quando da atuação do Estado e de estruturas empresariais sobre o território. Neste curso, a interferência literária - ou no caso da tese, textual - sobre as formas de compreensão do que seja a Amazônia em seus traços comuns, e de sua transformação no tempo, se inscrevem também no campo discursivo. Milton Santos revelou que a Amazônia corporificou uma série de construções discursivas sobre a natureza, como formas de "apresentação sobre a significação, ainda que reclamando uma ancoragem", dentre as quais enumerou o "buraco de ozônio, efeito-estufa, chuva ácida", componentes de uma ideologia formada pela linguagem unilateral, simplificadora e eloquente da comunicação produzida pela mídia, que tem como consequências mais efetivas, o distanciamento humano e ocultamento dos fenômenos em sua escala real, contribuído para impossibilitar interferências em seu curso (SANTOS, 1994). A este respeito, Marilene Corrêa explica que (SILVA, 1997, p. 11): 
Uma dimensão exposta nas relações da Amazônia com o mundo é a que se afigura nas divergências mais explícitas entre as 'identidades' e as 'homogeneidades'. As concepções antagônicas sobre os impactos e tensões entre as culturas tradicionais e as formas de interferência da civilização ocidental na região constituem dificuldades de abordagem e de diálogo. Se a complexidade dessa esfera pudesse ser resumida, dir-se-ia que grande parte das discordâncias entre campos interpretativos dos fenômenos e processos culturais se dá na fronteira da ciência com a ficção, das ideologias com o pensamento científico.

As Ciências Sociais tem abordado o complexo de representações sobre a Amazônia, que assim como afirma Marilene Corrêa, tem servido ao que o geógrafo Carlos Walter Porto Gonçalves nomeou de “embate simbólico-material”. Para ele, os fenômenos urbanos na Amazônia têm sido envolvidos num “jogo de verdades”, contribuindo para seu ocultamento e da participação mais efetiva de formas sociais nativas. Imagens de homogenização nas quais a Amazônia aparece unificada, sujeita a "desígnios outros que não aos dos seus próprios habitantes", uma "natureza imaginária”, uma "região periférica”, uma “questão nacional”, um "vazio demográfico", uma "reserva de recursos”, a “última fronteira”, têm restringido perspectivas explicativas ancoradas em dinâmicas sociais e geohistóricas concretas, bem como perspectivas para o próprio desenvolvimento regional (GONÇALVES, 2008, p. 12-25; 93):

[...] quando se fala de Amazônia é preciso estar atento para sabermos de que Amazônia estamos falando, tendo em conta que os diferentes agentes que atuam na região, ou por ela se interessam, tentam propor/ impor a sua visão do que seja a verdade na região como sendo a verdade da região.

Para os de fora, a imagem que se tem da Amazônia é mais homogênea [...] Para os habitantes da própria região, a "Amazônia” é um termo vago, que adquire múltiplos significados correspondentes aos mais diferentes contextos socioecológicos-culturais específicos que são os espaços do seu cotidiano.

[...] a Amazônia nunca é o presente, mas sempre o futuro que será redimido pelos seus recursos imensos reais e imaginários. Assim a Amazônia nunca é; é sempre o vir-a-ser. E esse vir-a-ser nunca é o vir-a-ser das populações que, na região, constroem no seu dia-a-dia suas vidas, suas histórias, seus espaços, suas culturas. Ao contrário, é o vir-a-ser daqueles que veem a região pelo seu potencial de exploração futura.

Carlos Walter Porto Gonçalves enfatiza o campo de disputas em torno da determinação do território amazônico, destacando a conjugação de práticas de domínio à formulação discursiva, especialmente nos anos de 1960, desde quando o padrão espacial riovárzea-floresta tem sido transformado na estrutura estrada - terra firme - subsolo, como 
sintetiza. Os discursos estatais contundentes, junto à sua prática intervencionista efetiva, conduziram a reestruturação espacial e influíram na política desenvolvimentista que se sucedeu na Amazônia, demonstrando o quanto as elaborações ficcionais a seu respeito, têm estado inscritas em campos discursivos e o quanto têm adquirido eficácia, como base justificativa às estratégias de desenvolvimento regidas pela perspectiva políticoeconômico-empresarial, de estruturas de poder dominantes e atuantes na organização do espaço amazônico em integralidade (GONÇALVES, 2008).

O projeto geopolítico estatal que incorporou efetivamente a Amazônia, já estava em curso desde a Primeira República. Antes mesmo da intervenção que viria a transformar mais substancialmente a espacialidade amazônica, a partir da reestruturação produzida pela implantação de redes de comunicação a partir da década de 1960, a exemplo da BelémBrasília. As expedições exploratórias e científicas para reconhecimento da interioridade do país e o estabelecimento de fronteiras já eram práticas em curso no começo do século XX. Nos anos de 1940, o Estado Nacional esteve empenhado em ampliar seus alcances e, colonizar o território brasileiro desde seu interior. Designações como a "marcha para o oeste", formaram bases discursivas associadas desse intento, junto ao repertório cultural e em linguagens que produziram representações da espacialidade geográfica, constituindo a história do pensamento social brasileiro (MAIA, 2011).

Para Marilene Corrêa, o processo de ingresso da Amazônia à Nação, no desenvolvimento de formas sociais locais e a redefinição do território, demandou um tratamento excepcional por parte da Coroa e Estado Português. ${ }^{10}$ Esta condição, com origem em 1823, quando da incorporação da Amazônia ao Brasil, alimentou o descompasso

\footnotetext{
${ }^{10}$ Nas disputas sociais relacionadas ao domínio e poder político sobre o território, na formação do país, Marilene Corrêa pontua o particular tratamento do Estado português despendido à Amazônia, os "procedimentos excepcionais" adotados, fosse na militarização e catequese na determinação de fronteiras físicas no século XVII, fundantes do confronto entre "poder lusitano" e "povos amazônicos", fosse pela ação do Diretório Pombalino e Companhias de Comércio no século XVIII que implicaram a "formação da sociedade colonial regional" e suas castas, "a minoria branca colonizadora e a maioria indígena e mestiça representada nas populações amazônicas”, ou fosse entre os séculos XVIII e XIX, com a criação do ViceReino do Grão-Pará e do Rio Negro como "saída para o poder metropolitano", no enfrentamento de riscos externos e internos da crise colonial. Para Corrêa, "a imposição do Estado nacional sobre a Amazônia concebida pelo poder tem todos os temas justificadores da ação interventiva. A construção da Amazônia brasileira, após a revolução Cabana, resgata do espírito colonial a feição da região bárbara e inóspita, a condição de fronteira da Nação soberana, a situação de atraso econômico e cultural, fundamentado, neste parâmetro, as diretrizes para a ocupação, para a civilização, para a conformação da Região à unidade dita nacional" (SILVA, 1997, p. 215-216).
} 
crescente entre o centro do poder nacional e a Região Norte. A manutenção da ordem nacional foi justificativa para o impedimento de "direitos de autodeterminação dos povos amazônicos”, frente interesses econômicos atuantes junto ao posterior Estado Nacional, que forjaram uma "vocação extrativista”, ou uma genérica "indianidade", deslocada mais tarde para uma "laboriosidade”. Este discurso foi transferido à indústria extrativa junto aos agentes com “interesse da região” e aos nacionais, aspectos estes de uma (SILVA, 1997, p. 216):

[...] tutela nacional, que criou a tradição de dependência, reafirmou ao mesmo tempo, a necessidade da intervenção do Estado forte sobre o espaço e sobre as populações amazônicas. Criou, por outro lado, o imobilismo político das representações regionais dominantes e recriou, sobre a herança indígena deixada à população regional, todos os estereótipos reafirmadores da qualidade inferior de uma gente não afeita ao processo exigido pela Nação brasileira.

A Amazônia esboçada nas lutas pela Independência não existe mais. Existe a Amazônia do Brasil, a Amazônia Brasileira submetida pelo Império e absorvida pela República, segundo os interesses dos setores dominantes no âmbito do Estado Nacional. Este é o sentido em que a questão da Amazônia torna-se um problema nacional permanente.

Assim, o impasse da inscrição da Amazônia na formação do país, também teve raiz nos significados atribuídos à Independência pelo poder Imperial no enfrentamento de forças nativas regionais, pela uniformização das regionalidades que não reconheceram, na organização social nacional, os movimentos contrários à colonização. A Nação emergente foi assim uma "soma de partes desiguais, diluindo as diversidades em nome da segurança, da civilidade, do patriotismo, que o Estado Nacional assegurou, com a manutenção da desigualdade”. Tal condição implicou o controle da Amazônia pelo Estado brasileiro, sob o discurso de soberania e integridade nacionais e com a atuação de formas de organização social como evidências da tensão entre Nação e Região perdurada no século XX, quando a região ingressou mais efetivamente em processos econômicos mundializados ${ }^{11}$ (SILVA, 1997, p. 214).

\footnotetext{
${ }^{11} \mathrm{O}$ imperativo controle estatal da Amazônia brasileira no século XX, foi base ao monitoramento e exploração por sucessivos governos nacionais. À defesa dessas práticas seguiram enunciações de necessária ocupação, segurança nacional, preservação ambiental. Do centro das ingerências estatais, onde próprio Estado construiu espaços partilhados de ação com a participação empresarial. Os movimentos sociais dos anos de 1980, como o Conselho Nacional dos Seringueiros, símbolo de um "movimento de resistência das populações locais autóctones e migrantes - à expropriação da terra", eclodiram junto ao esgotamento do modelo inaugurado por Getúlio Vargas, de um nacional desenvolvimentismo (BECKER, 2009, p. 27-31). Também se inscrevem
} 
Noutra escala de apreensão do território, para além da nacional, a mundialização da Amazônia tem sido requerida discursivamente, em enunciações de políticos e representantes estrangeiros que a questionam como território pertencido estritamente a seus respectivos Estados. O reclame tem sido feito desde diversas formulações, em forma de crítica à soberania de determinados países sobre a Amazônia, sob o argumento de ser sua posse estrita, circunstancial, em razão da função que exerce a região para o equilíbrio ambiental planetário. Assim que a Amazônia, tida como patrimônio da humanidade, tem sua autonomia questionada, como aborda Luis Aragón. De sua parte, como pesquisador locado no NAEA $^{12}$, avalia sobre a necessidade de uma definição regional da Amazônia, especialmente para fins do planejamento e destinação de recursos públicos. $O$ autor a inscreve em problemática do presente, atestando que se trata de um território ainda impreciso $^{13}$ (ARAGÓN, 2007):

A Amazônia tornou-se, queira-se ou não, uma questão nacional e global, mas que ainda hoje, como outrora, e apesar dos múltiplos avanços, falta muito por conhecer. Quem se atreve, por exemplo, a defini-la fisicamente com precisão; isto é, responder a aparentemente simples questão de afinal até onde vai a Amazônia? (ou as Amazônias?).

Além da soberania nacional, gestores de políticas públicas e investimentos na Amazônia necessitam saber com clareza onde localizar tais investimentos; mas tal definição se faz necessária, também, para quantificar com precisão sua população, o capital humano, os estoques naturais disponíveis na região e analisar as mudanças espaciais ocorridas dentro dela.

Diversos esforços têm sido realizados para definir regionalmente a Amazônia, mas ainda não existe consenso. De certa forma tal definição passou a depender do que se quer fazer com uma determinada definição; isto é, a definição passou a depender de sua utilidade, e talvez nunca se chegue a uma definição única.

neste espectro, formas de organização social financiadas por bancos estrangeiros sob o incentivo estatal aos projetos de colonização a partir do "desenvolvimento de baixo" (KOHLHEPP 2002, p.41).

${ }^{12}$ Núcleo de Altos Estudos Amazônicos.

${ }^{13}$ A Revista Brasileira de Geografia publicou o artigo de Lúcio de Castro Soares, "Delimitação da Amazônia para fins de planejamento econômico", no qual o geógrafo desenvolveu um estudo, em resposta à solicitação da Comissão Especial do Plano de Valorização Econômica da Amazônia, da Câmara dos Deputados, de base à escolha do "critério mais racional a ser adotado na delimitação da região que deve ser considerada como sendo amazônica, exclusivamente para fins de planejamento econômico", numa fase de atuação do Estado pautada pelo planejamento do desenvolvimento da região. Apresentou os seguintes critérios que o antecederam: Limites naturais, da "Hiléia", da Bacia Hidrográfica, dos paralelos, meridianos e divisas administrativas. Defendeu a incorporação de fatores sociais, geohistóricos, econômicos, frente sua vastidão e isolamento, além da particular forma de desenvolvimento da agricultura, predominantemente nômade. Afirmou que "os contingentes colonizadores terão de ser, pois, amparados e de perto, na sua luta, dura, lena e heroica, de desbravamento do chamado "deserto verde". Seus estudos estavam voltados à "conquista" ou "colonização" da Amazônia (SOARES, 1948). 
Dentre os enfoques com que estudos recentes têm encaminhado a delimitação da Amazônia, como "fatores biológicos, culturais, históricos, econômicos e até geopolíticos", Luis Aragón discorre sobre as "controvérsias" dos pautados em seus atributos físicos, a floresta tropical ou a bacia hidrográfica, constituída pela "bacia do rio Amazonas e todos seus mais de 1000 rios que compõem o sistema fluvial da região" e ainda, sobre a artificialidade dos critérios administrativos e legais, que no caso brasileiro foram estabelecidos pela lei 1806 de 1953, a mesma que criou a "Superintendência do Plano de Valorização Econômica da Amazônia (SPVEA), antecessora da Sudam, criada em 1966”14. Também expõe a proposta de definição geográfica da Amazônia pelo IMAS - Instituto do Meio Ambiente e Sustentabilidade da Comissão Europeia ${ }^{15}$, partida de critérios estabelecidos por outros parâmetros, hidrográficos, ecológicos, biogeográficos.

Diante desta imprecisão, junto a inadequação dos instrumentos e parâmetros de análise geográfica e ao "embate simbólico-material” instaurado na Amazônia, os abrangentes Estudos Culturais têm revelado os rastros das manifestações incrustradas no próprio território, como meio, inclusive, de produzir conhecimento mais aproximado de suas dinâmicas em contraste às enunciações ficcionais ainda ligadas à Amazônia. O termo é considerado na perspectiva da relação da História com outras áreas das Ciências Sociais, frente à cronologia que apresenta Peter Burke sobre a História Cultural e as vinculações desta com a Antropologia e a Sociologia (BURKE, 2005). Os “Estudos Culturais” são assim autodesignados ainda que articulem as temporalidades em suas investigações.

Em amplitude, os objetos dos Estudos Culturais na Amazônia podem ser definidos a exemplo dos que se interessam pelo "mundo amazônico em suas variadas fronteiras", sejam sociais, culturais, espaciais, temporais, as variadas tradições e suas interações, o patrimônio, os saberes, bem como "o lugar, as práticas e os modos de viver de povos da floresta, do campo, das águas, das beiras de estradas, de aldeias, de quilombos e mocambos,

\footnotetext{
${ }^{14}$ A SPVEA foi criada sob a influência direta do Tennessee Valley Authority (TVA), que também serviu como referência aos planos da Comissão do Vale do São Francisco, como uma modalidade de "planejamento integral" de "espírito pioneiro e missionário", com bases técnico científicas (D'ARAÚJO, 1992).

${ }^{15}$ Sob solicitação à Comissão Europeia, da Organização do Tratado de Cooperação Amazônica (OTCA) criada em 2002 a partir do Tratado de Cooperação Amazônica, assinado em 1978 pelos representantes dos governos dos países amazônicos. A proposta incorporou os resultados de pesquisas anteriormente realizadas, como as do NAEA - Núcleo de Altos Estudos da Amazônia, que mapeou uma "grande Amazônia", dividida em municípios, com projeções de densidade e identificação de áreas de povoamento antes consideradas de fronteira (ARAGÓN, 2007, p. 158-160).
} 
de centros, de periferias urbanas ou de ambiente de margens silenciadas" (PACHECO, NASCIMENTO, et al., 2015, p. 13-23) em uma variedade de formas culturais. Em contraposição ao ocultamento dos fenômenos sociais no território, ou de sua compreensão ampliada e sintética, os estudos culturais têm se dedicado aos diversos modos de vida junto ao meio amazônico. Campos distintos do conhecimento, ainda que sejam prevalentes a História, Geografia, Antropologia, também têm se dedicado à identificação de ideias matrizes na trajetória do pensamento moderno sobre a Amazônia, sua amplitude e formas de alcance (PINTO, 2006).

Neide Gondim analisou textos literários emergentes do ingresso da Amazônia na modernidade, na conjuntura de contato do europeu com o Novo Mundo. Numa interpretação do imaginário a partir dos escritos, o território não foi lido morfologicamente, mas desde uma espacialidade culturalmente construída, fundida a imagens já conhecidas pelo colonizador, em narrativas, relatos e literatura de viagens. Utilizando-se dessas fontes documentais, Gondim abordou uma Amazônia inventada pelo artifício do texto e limites da linguagem, como uma construção dada a partir de preconcepções sobre o território desconhecido, portanto de dados da cultura. A análise que realizou sobre o produto da construção das ideias sobre o espaço amazônico, reelaborado pelas vias dos escritos desde o século XVI, possibilitou uma (re)exploração da Amazônia e de seus entrelaçamentos históricos transfronteiriços, a partir dos registros textuais.

A autora não condicionou a Amazônia brasileira à espacialidade, compreendida como um complexo que ao longo do tempo foi delineado, adquirindo seus contornos fronteiriços e a territorialidade mais aproximadamente de como é conhecida no presente. Partiu do imaginário ocidental a respeito de lugares míticos cujas aproximações ao espaço contatado desde o século XV pelos europeus lhe possibilitou, desde associações evocativas, formas de elaboração e enunciação perpetuadas, especialmente, como condição utópica.

$\mathrm{Na}$ trilha de Neide Gondim, articulando formas literárias à escrita da história, Brigitte Thierion explorou o diálogo entre ficção e realidade a partir da produção literária na avaliação que realizou da continuidade de imagens de representação da Amazônia. A interpretou como um "espaço ficcional", moldado pela interação de sua concretude histórica aos limites delineados pela história e a literatura. Thierion narrou os ecos da fabulação, dos atributos conferidos à natureza, à terra, aos amazônidas, como produto de 
significação do outro, da própria colonização ${ }^{16}$, também das tensões que produziram escritores radicados na Amazônia, frente a tais representações. Para a autora, a Amazônia envolve um imaginário costurado pelas adjetivações contidas nos escritos e em reconstruções literárias, dadas em longa duração (THIERION, 2014):

Nos seus escritos, os cronistas Pero Vaz de Caminha (1500; 1773), Gabriel Soares de Souza (1587), Fernão Cardim (1583 e 1601), Magalhães de Gandavo (1576) moldaram uma sensibilidade que tende ao exagero. O próprio Lévi-Strauss (2001: 433) destaca o fato de que a "linguagem amazônica gosta de superlativos". Com efeito, essa tendência pode ser observada nos estilos de escritores do século XIX como Euclides da Cunha ou Alberto Rangel, e de forma paródica em Galvez Imperador do Acre (1976), do escritor contemporâneo Márcio Souza.

Magali Bueno também reforça a abordagem de Neide Gondim, reafirmando a presença da Amazônia nas narrativas de La Condamine, Spix e Martius, Euclides da Cunha a Alberto Rangel, como uma paisagem uniforme. Para a autora, as imagens propagadas da Amazônia foram reformuladas pela fotografia e pelo cinema no século XX, contaminadas pelas concepções pregressas, especialmente as de uma paisagem unitária de predominantes fauna e flora. Concepções de paisagem em equivalência ao Éden, como uma natureza primordial, ao Eldorado, lugar mítico de fonte de riquezas e tesouros, à ideia do vazio inexplorado, por vezes inóspito, foram inclusive absorvidas pelo discurso ambientalista (BUENO, 2002).

As representações da Amazônia adquiriram novos contornos quando relocadas na trajetória composta pelos textos. Na escrita literária, autores como Márcio Souza, Darcy Ribeiro e Milton Hatoum acresceram componentes às imagens sobre a Amazônia, manejando na longa duração, a escrita ficcional desde pontes com o real, escrevendo e inscrevendo sua "perspectiva paródica e crítica" no fluxo chamado por Brigitte Thierion de um “imaginário em construção". Os textos denotaram a passagem de uma "visão eufórica” a partir dos primeiros contatos do colonizador com a Amazônia, para uma "visão disfórica", tendida ao estudo "do homem", ou de uma "floresta da fábula" para a "realidade de exploração econômica”. As representações do homem nativo foram dadas em decorrência

\footnotetext{
${ }^{16}$ Brigitte Thierion defendeu que se "esses escritos têm um valor científico e documental incontornável, não deixam de ser um espaço narrativo em que transparece a subjetividade do narrador, assim como o espírito do tempo, e as ideologias em voga na altura da escrita" (THIERION, 2014).
} 
de sua “diferença radical” que "induziu uma lógica de eliminação, sustentada pela ideologia do progresso”, muito própria da modernidade (THIERION, 2014).

Os juízos sobre os nativos estão também destacados nos textos, a princípio em sua "familiaridade com a natureza” o que levava o europeu a transferir a ele a sua "amargura”, sua "incapacidade de sobrevivência em local tão exótico sem a ajuda do homem da terra". A formulação de "traços diferenciadores" foi o ponto de partida para esta "construção da imagem diferenciada do outro". Forjados oportunamente como "agentes perturbadores da ordem natural”, dada a impossibilidade de domínio do colonizador sobre o meio, os nativos foram sobretudo empecilho, obstaculizando a própria atividade colonizadora, que a medida em que se confirmava, se desligava de um imaginário pautado no fantástico ${ }^{17}$ frente a concretude do conhecimento propiciado pelo empreendimento expansionista (GONDIM, 2007, p. 39-41).

Além do entendimento da Amazônia como formulação textual e construção cultural ecoada no presente, Neide Gondim realizou a leitura das fontes documentais escritas, inscrevendo-as em temporalidade que as entrelaçou em nova narrativa, ao processo de invenção de uma Geografia, no caminho do ingresso da Amazônia na modernidade. Neste fluxo, o paraíso perdido, a partir da visão bíblica, foi transposto idealmente à Amazônia percorrida pelo seu “mar de águas doces” 18 , formulada e difundida do encontro do europeu com o desconhecido, também de outros brasileiros não tão ambientados e do mesmo modo surpreendidos. Este imaginário produzido pelo confronto dos referenciais de herança europeia com um novo mundo, de feições humanas e paisagens exóticas nunca vistas, mas já imaginadas e narradas, compôs formulações explicativas que adensaram não unicamente a escrita literária, mas sobretudo a científica. As representações tiveram impacto direto sobre o diálogo entre os significados miticamente moldados para a Amazônia e os científicos, já que "quase a totalidade dos viajantes que percorreu a Amazônia incluiu nos

\footnotetext{
${ }^{17}$ Embora as paisagens fossem estonteantes ao olhar estrangeiro, densas populações pré-coloniais as habitavam, adaptando-se àquele ambiente, seletivas quanto ao lugar de sua fixação, como evidenciam pesquisas arqueológicas que abordam a apropriação humana de recursos ambientais que tem cercado a história précolonial na Amazônia. Demonstram o interesse de sociedades indígenas pela fixação em proximidade a cursos d'água, por serem simbolicamente referenciais e dada sua fertilidade (MORAES, 2015).

${ }^{18}$ Em referência ao segundo capítulo do livro de Neide Gondim, no qual ela apresenta as várias significações atribuídas ao Rio Amazonas pelos cronistas viajantes, como um rio humanizado (GONDIM, 2007, p. 77111). Interessante notar a correspondência com a figura da "voragem gulosa e sempre insatisfeita do rio" descrita por Maria Portugal Milward referenciada no terceiro capítulo da tese (REV. MUN. DE ENG. N.6, novembro de 1942, vol.IX, p. 25).
} 
seus relatos minudências históricas e geográfica como provas insofismáveis de verdades científicas” (GONDIM, 2007, p. 38-39; 209):

A similitude ou a semelhança significarão a placidez da permanência do mundo familiar. O novo é filtrado pelo antigo, assegurando a este, sua supremacia. A prática de comparar as novidades vistas pela primeira vez com algo pretensamente conhecido, sendo domesticado, fortalecerá e documentará a estabilidade do antigo [...] utilizar a analogia é familiarizar o exótico.

Por outro lado, a constatação da diferença franqueia o avanço ao desconhecido e o conhecimento se alarga com o leque de possibilidades que o contato com o novo pode oferecer.

O trecho em destaque é uma explicação da autora ao processo de assimilação do novo mundo pelo europeu, se refere diretamente à "ignorância” atestada na passagem do pensamento escolástico ao humanista universalista, que mobilizou a formação das consciências nacionais em torno dos descobrimentos, constatada a "existência do antimundo revelada pelas viagens ultramarinas" (GONDIM, 2007, p. 77). Assim, o delineamento da Amazônia pelos escritos, também a tem moldado aos paradigmas científicos, em diálogo e como contributo à Geografia, Cartografia, Etnologia, Biologia sobre a Amazônia ${ }^{19}$. Esta concatenação está muito presente, como atestou Renan Freitas Pinto, nas definições em retorno, das formas sociais locais marcadas pelo condicionamento da geografia e do clima para a vida social, especialmente como limitadores de sua evolução ou explicativas das sociabilidades ali situadas ${ }^{20}$ (PINTO, 2006).

A Amazônia não é um objeto neutro. Sob o paradigma do desenvolvimento se apresenta em complexidade, quando encontra no campo das ideias que recaem sobre sua

\footnotetext{
${ }^{19}$ Incluindo autores centrais no desenvolvimento do pensamento moderno, como Montaigne e Rousseau. É possível considerar que o pensamento social sobre a Amazônia se deu de partida em relação ao fluxo do pensamento ocidental, direta ou indiretamente pautado por ideias que tem servido de base à sua interpretação, contribuindo de algum modo com a "história das ideias sociais no Brasil". Neste fluxo, os naturalistas viajantes no século XVIII foram movidos pelo desejo se com certa dose de objetividade, avaliar a realidade com a qual se deparavam. Em suas expedições, buscavam explicações à experiência e aos fenômenos então contactados, produzindo representações baseadas na cientificidade com que operaram a escrita, de modo inaugural (PINTO, 2006), já que como apontado por Neide Gondim, a escrita era moldada também pelos signos pregressos, memórias e pela própria concepção de mundo do estrangeiro no Novo Mundo.

${ }^{20} \mathrm{Em}$ análise genealógica das ideias, exemplo ressaltado por Renan Freitas Pinto foi o de Georges-Louis Buffon, que "caracteriza a Amazônia como um experimento da natureza, ainda em formação, mas apresentando condições desfavoráveis ao pleno desenvolvimento das formas de vida naturais e humanas", narrando negativamente o Novo Mundo, ideia influente no pensamento ilustrado do século XVIII. Ideia também presente em Hegel, para quem a geografia e a civilização seriam explicadas pelo "espírito da história", ou seja, pelo estágio civilizacional, que no caso das populações indígenas, seriam identificadas em sua condição de atraso. Outro autor foi Alexandre Rodrigues Ferreira, fundamental ao "pensamento científico tal como se desenvolveu em relação aos povos e ao meio natural dessa parte da América” (PINTO, 2005, p. 100-101).
} 
compreensão espacial, uma dualidade explicativa. Aspecto determinante desta condição perene de dualidade é refletido em interpretações que cercam as temáticas da modernização e da preservação, pensadas junto à concretude do território amazônico e das formas ideais que o moldariam em adequação. Em consideração às múltiplas temporalidades que na Amazônia convivem, no presente, expressas em modos de vida e formas culturais diversificadas, a paisagem, como construção cultural, e o urbano, em materialidade, delineiam a Amazônia como objeto, interpretada junto a explicações que transitam entre experiência, a memória e razão objetiva.

\subsection{Aproximação a um aporte cronológico do urbano na Amazônia}

No desenvolvimento de seus estudos geográficos sobre a Amazônia, iniciados na década de 1960, Bertha Becker foi contundente ao definir a Amazônia como uma "floresta urbanizada”. Este conceito utilizado pela geógrafa em contraponto ao discurso que definiu a Amazônia como espaço vazio e eminentemente natural. Também em relação à leitura efetiva dos fenômenos urbanos transcorridos no território, desfocada dos regidos pela pauta do ambiente natural, ainda que profundamente reveladores de sua alteração. Com isso a geógrafa incluiu uma gama complexa de componentes, dentre os quais as formas sociais de resistência, as disputas territoriais, os fluxos, os eixos de desenvolvimento, os particularismos sociais e culturais, como categorias de análise do espaço geográfico da Amazônia. A leitura dos processos de urbanização desde os anos de 1960, que passaram a envolver necessariamente aspectos relativos às disputas sociais e ao papel central do Estado e sua ação interventora, a levou à síntese da Amazônia como um espaço político e social de fronteira, ao qual se relacionava o referido conceito. Sua interpretação foi sendo ajustada às transformações territoriais, em razão de fenômenos históricos e processos espaciais ali transcorridos. De fronteira de recursos minerais na primeira metade do século XX, para fronteira móvel a partir dos anos de 1960, e desde os 1980, fronteira ambiental, esta, uma "fronteira do capital natural” (BECKER, 2009). Como categoria de análise, Bertha Becker definiu tal estágio da espaço-temporalidade da Amazônia como de "Fronteira Socioambiental".

A condição de fronteira socioambiental situa a Amazônia no presente, pela "imensa reserva de capital natural” reconhecida pela "consciência coletiva sobre os limites naturais 
do planeta”. A valoração de recursos tornados mundialmente escassos, como a água doce planetária, os tem convertido em mercadorias. De outro lado, o movimento ambientalista demarcado a partir de 1992 com a Conferência Mundial das Nações Unidas sobre o Meio Ambiente e Desenvolvimento, têm-nos pleiteado como bens comuns. Todavia, se a mercantilização dos recursos naturais esgotáveis conduz sua exploração ao limite, carece de formas de regulação e gestão, à admissão de sua sujeição comercial, reforçando a concretização de mercados, como do ar e da biodiversidade. São as políticas públicas, apoiadas numa geopolítica, o que contradiz serem tais recursos universais, e que tem desmistificado o território amazônico, como afirma Luis Aragón (ARAGÓN, 2007, p. 168):

\begin{abstract}
A visão mítica da Amazônia, como vazio demográfico, inferno verde, pulmão do mundo, foi superada, gerando um lento processo de construção duma nova visão da região. Reconhece-se, pelo menos no discurso, que a riqueza maior da região é sua biodiversidade, sua floresta, enfim, seu capital natural, e que as atenções devem ser voltadas para o desenvolvimento sustentável de tal forma que atenda às necessidades das populações que ali vivem. Nesse sentido os jargões de "terra sem homens para homens sem-terra", e de "integrar para não entregar" são substituídos por "desenvolver sem destruir"; esboçam-se agendas de desenvolvimento seguindo o ideário do desenvolvimento sustentável e formulam-se programas de cooperação.
\end{abstract}

Nos termos como expôs Luis Aragón, a perspectiva de Becker foi sobretudo, a partir de uma Amazônia condicionada à fronteira, a de produzir bases interpretativas que possibilitassem construir formas específicas de análise do desenvolvimento do território regional, em alinhamento aos interesses emergidos das sociedades locais e de seus ambientes de vida. Assim, à Amazônia como um espaço de fronteira, mais do que numa relação imediata à indeterminação territorial que o termo poderia sugerir, foram incorporadas escalas de interpretação, para além da econômica e quantitativa. Estas novas escalas, foram partidas desde seu interior, ou analisaram o interior a partir do impacto de intervenções expressivas, especialmente as decorrentes da expansão do capital. Assim que a ingerência do Estado, as dinâmicas da força de trabalho, as organizações sociais, os comparativos de desenvolvimento frente o território foram componentes determinantes à leitura do fenômeno urbano na Amazônia, para a referida geógrafa.

Numa cronologia que estabeleceu em leitura de finais do século XX, Bertha Becker sintetizou a ocupação regional da Amazônia em "três grandes períodos de formação da região": um primeiro estágio de formação territorial (1616-1930), outro de planejamento 
regional (1930-1985) e ao fim, a fase de "Fronteira Socioambiental" (1985-1996), marcados por surtos econômicos, como os "extrativos de exportação", pela aplicação de estratégias de controle territorial, por buscas por modelos de ocupação, mesmo até o presente. No primeiro período foi dada a "aproximação lenta e gradativa do território", com base em uma economia exportadora de drogas do sertão, que antecedeu a configuração da Amazônia mais aproximada ao tempo presente, entre 1850 e 1899, sob a atenção do Império à “internacionalização da navegação do grande rio, e o boom da borracha”. Por meio de uma geopolítica e acordos internacionais, foram então estabelecidos os limites regionais, entre 1899 e 1930 (BECKER, 2009, p. 23-25). A rede urbana da Amazônia aqui considerada, foi a formada de princípio, pela circulação e organização de produtos, especialmente no sistema de exportação da borracha desde a qual foram formadas vilas de cidades, com a projeção de algumas, em razão de serem locais de portos de exportação, ainda que praticamente as cidades fossem todas portuárias, como afirma Edna Castro (CASTRO, 2008, p. 18):

Belém e Manaus - aquela por ser próxima ao Atlântico e na porta de entrada da Amazônia e esta pela sua posição privilegiada no escoamento da produção do médio Amazonas e seus afluentes - tiveram crescimento mais expressivo. Os seringais eram os lugares de produção, e a cidade, o lugar de comércio. A borracha representa o momento mais importante da formação da rede urbana, ainda que incipiente, com o povoamento e a formação de cidades em função dos fluxos econômicos.

A ocupação colonizadora da Amazônia teve marco inicial em 1540. Vilas e fortificações formavam nucleações humanas junto às organizações e assentamentos indígenas predominantes em quantidade, em meio a disputas entre ingleses, franceses, portugueses, holandeses, espanhóis, pela sua posse. O interesse do colonizador português sempre foi grande sobre aquele espaço ao norte da América que viria a ser conhecido posteriormente como Amazônia. Durante o período da União Ibérica, marcadamente, foi intensificada a penetração daquele espaço, e a partir de rearticulações de posse e arranjos entre nativos e donatários, o movimento de crescente domínio luso ampliou as fronteiras portuguesas durante o século XVII, de modo que soberania portuguesa sobre a Amazônia em relação a outras nações europeias era efetiva no século XVIII, ainda que não o fosse em 
relação às populações indígenas locais participantes ativas, até o presente, da dinâmica daquele espaço social ${ }^{21}$ (JÚNIOR, jan/jun de 2015).

As temporalidades, as durações, as formas e as escalas espaciais na Amazônia não são dados homogêneos, como esclarece Roberto Lobato Corrêa, ao desenvolver uma periodização, alertando para o fato de tratar-se de uma “operação intelectual”, mais do que uma apreensão de uma totalidade social regional, já que a desigualdade dos tempos sociais é uma das marcas da rede urbana na Amazônia (CORRÊA, 1987, p. 39-41). Assim, em sua abordagem, demarcou as primeiras nucleações urbanas, a partir de cidade de Belém, que comandava uma rede a partir de 1616 , de vilas situadas prevalentemente às margens do rio Amazonas e em muitos casos na confluência de algum de seus afluentes, mobilizadas economicamente pela atividade extrativa de drogas do sertão para o comércio ao estrangeiro, conformando um padrão específico de ocupação organizada pelas ordens religiosas e comerciais, desde então reforçando uma forma espacial típica de ocupação, um “mesmo padrão de localização relativa e absoluta: localização ribeirinha consubstanciando um padrão espacial dentrítico, e um Sítio sobre um terraço fluvial, a salvo das cheias periódicas” (CORRÊA, 1987, p. 44-45).

A política colonial portuguesa expandida no território não precisado como Amazônia, fortalecida pela administração de Marques de Pombal, fundou em 1755 a Companhia Geral do Grão-Pará e Maranhão (1755-1778), para inserir a região no mercado europeu de "produtos tropicais", como meio de alcance ao capitalismo de base industrial. Este foi o motivo pelo qual diversas medidas foram adotadas, implicando o desenvolvimento desigual das práticas comerciais e a prevalência de Belém na condição de capital do Grão Pará e Maranhão, no controle econômico regional (CORRÊA, 1987, p. 47). Núcleos urbanos seriam configurados a partir de então, com vistas a "implementar a

\footnotetext{
${ }^{21}$ Uma produção no campo da História tem revelado o protagonismo de populações indígenas na Amazônia frente uma tradicional historiografia que os representa predominantemente na condição de vencidos. Esta produção visa "romper com verdades que teimam em considerar essas populações como fragmentos ancestrais, como imunes ao dinamismo, como vazias de história", sob a ideologia do progresso, como afirma Almir Diniz de Carvalho Júnior. Diante do esforço de conquista pelo colonizador, nativos indígenas são relatados a partir de suas estratégias de resistência e formas de rebeldia (JÚNIOR, 2015, p.23). Também cabe mencionar o fato de que uma das características apontadas por diversos autores dos estudos urbanos na Amazônia, é a marca de distintas etnias, línguas e saberes que impregnaram as dinâmicas urbanas, nas quais estão fundidos mundo rural e urbano, ainda que sob a interferência de um mercado internacional que implicou a alteração mais expressiva do território desde a década de 1960, a exemplo do recorte que faz José Carlos Matos Pereira ao analisar o caso de Belterra, no Pará (PEREIRA, 2012).
} 
economia e nacionalizar a estrutura comercial da colônia para fortalecer o Estado português”, com restrição do poder de missionários que atuavam no comércio, promoção da miscigenação com indígenas, intensificação do comércio pela atividade da Companhia e criação de vilas, com o propósito de articulação das práticas de "urbanizar, colonizar e civilizar”. É possível que com a "expansão agroextrativista” desse século, como observa Bertha Becker, cidades como Belém e Manaus, além de Santarém e Parintins tenham experimentado surtos de crescimento econômico, junto à obtenção de privilégios políticos de determinados segmentos sociais locais (BECKER, 2013, p. 28-29;43).

Bertha Becker trata criticamente das particularidades do processo histórico de conformação das cidades na Amazônia. Ela destaca a especificidade do período de vigência do estado do Grão-Pará e Maranhão, quando a região esteve sujeita ao contexto internacional e à metrópole, passando por fluxos descontínuos de crescimento e estagnação. Outro aspecto é o "modelo caribenho de povoamento, marcado pela pirataria e disputa de poder”, caracterizando a diversidade de modelos empreendidos no sistema capitalista colonial. A Amazônia seria deste modo, uma "fronteira múndi”, "espaço de grande valor estratégico na economia-mundo” (BECKER, 2013, p. 24). No fim desse século, a prevalência de um livre comércio, frente o fechamento da Companhia, levou à diminuição de transações realizadas com "produtos tropicais" bem como a baixa de preços nas transações internacionais, com certa estagnação econômica e urbana. A primeira exportação de borracha aconteceu em 1825 e o produto ficou até 1848 , em "4º lugar entre os produtos exportados, abaixo do fumo, cacau e couros”. Quanto à rede urbana na Amazônia (CORRÊA, 1987, p. 47):

Ao final da primeira metade do século XIX, em um momento que antecede à grande expansão econômica e urbana apoiada na valorização da borracha, a rede urbana na Amazônia caracteriza-se pela proeminência de Belém, e por um padrão espacial predominantemente ribeirinho, centrado no eixo do rio Amazonas. No litoral havia alguns poucos núcleos urbanos, outros poucos na zona guajarina e na ilha de Marajó. Nos afluentes do Amazonas a presença de núcleos urbanos limitava-se aos baixos cursos do Tocantins, Xingu, Tapajós e Madeira, sobressaindo em importância o vale do Rio Negro, com uma rede relativamente densa, porém em profunda decadência.

Entre 1850 e 1920, essa estrutura foi transformada na econômica e no espaço, pela demanda comercial externa por borracha. Com o ajustamento da produção ao sistema de 
transporte para a navegação no rio Amazonas, ${ }^{22}$ a existência de recursos materiais e trabalhadores aptos aos seringais, a produção chegou a atingir $90 \%$ do consumo mundial do produto em 1890. A movimentação comercial regional foi intensificada com a introdução de expressivos capitais mercantis, estrangeiros e nacionais, a revigoração de antigos núcleos, a exemplo de Manaus emancipada do Pará em 1852, a constituição de novos, a maior parte deles vinculados à produção da borracha, como sedes de seringais, em grande parte ribeirinhos ${ }^{23}$. As disputas comerciais entre Belém e Manaus, os dois principais núcleos de concentração dos lucros com a borracha, de "atividades e população urbana”, e do poder político, mobilizavam administrações locais e empresas. Eram priorizados interesses mercantis de segmentos sociais economicamente dominantes, na centralização dos investimentos de modernização, nos subsídios à navegação e o centralismo conferido aos portos de Manaus e Belém para realização das exportações regionais (CORRÊA, 1987, p. 48-52). Essa hierarquia decorreu das práticas relacionadas à “economia da borracha”. $\mathrm{Na}$ segunda metade do século XIX, ${ }^{24}$ a intensificação da produção e comércio acarretou novas aglomerações condicionadas pela geografia do território (AMARAL, CÂMARA e MONTEIRO, 2001, p. 4-5):

A forma dentrítica desta rede urbana relacionava-se à área de ocorrência da borracha: regiões de produtividade nas várzeas e circulação fluvial. A rede englobava aglomerações em pontos de transbordo, nos portos das grandes unidades produtoras ou na confluência de rios que drenavam a produção das sub-bacias. A evolução da economia da borracha conduziu ao aparecimento da estrutura Urbana Primaz onde se evidenciaram as diferenças entre as cidades maiores e o conjunto das menores.

Roberto Lobato Corrêa identificou neste estágio a "intensificação das relações entre os núcleos de povoamento", pela circulação de produtos na rede fluvial regional, tanto destinados à exportação como para consumo interno, a partir do sistema de "aviamento".

\footnotetext{
${ }^{22}$ Em 1853, Barão de Mauá criou a Companhia de Navegação e Comércio do Amazonas a qual introduziu a "navegação a vapor no rio Amazonas e, em breve, nos seus afluentes, possibilitando um escoamento mais rápido da produção regional", o que viria a atrair "capitais estrangeiros vinculados ao comércio e à navegação no Amazonas", como os ingleses, tendo sido a navegação liberada em 1867 à embarcações estrangeiras (CORRÊA, 1987, p. 48). Para a atividade nos seringais, um contingente de trabalhadores atuava, principalmente de migrados do Pará e Nordeste, o que aumentou sobremaneira a população regional.

${ }^{23}$ A exemplo de Óbidos, que em 1873 tinha teatro para cerca de 200 lugares, clube literário, biblioteca e uma Sociedade Filarmônica (CORRÊA, 1987, p. 50).

${ }^{24} \mathrm{~A}$ anexação definitiva da Amazônia à nação brasileira ocorreu no século XIX, mais precisamente em 1835, com a expulsão por parte do Império, da resistência cabana de Belém, com a "imposição das decisões políticas em nome da soberania e da unidade nacional” (SILVA, 1997, p. 210).
} 
Uma empresa dominante exportadora, a "casa aviadora" com sede em Belém ou Manaus, financiava, abastecia e intermediava bens materiais aos seringais e a aviadores menores, podendo ter posto comercial nos seringais, que "aviava o seringalista, que por sua vez, através do regime de barracão", "aviava o coletor”, e em fluxo de retorno, era dada a passagem pelos mesmos atravessadores da borracha extraída, garantindo assim o abastecimento do comércio internacional, desde os seringais até as casas aviadoras em Belém e Manaus com a borracha excedente. Deste modo, as duas cidades, a partir dos "excedentes oriundos do sistema de aviamento", iriam concentrar investimentos materiais de modernização urbana, dentre os implantados por empresas estrangeiras, como bondes, saneamento, iluminação (CORRÊA, 1987, p. 52).

A concorrência com outros centros produtores apresentada a partir da primeira década do século XX, em especial a volumosa produção asiática, acarretou o decaimento expressivo dos preços da borracha no mercado internacional. Mais precisamente entre 1915 a 1919, a produção representou 12\% e de 1925 a 1929, 2\% do consumo mundial (CORRÊA, 1987, p. 54). Belém e Manaus foram as cidades que evidenciavam a concentração de riquezas e a presença de instituições administrativas. Na primeira, pela centralização de recursos financeiros e na segunda, pela sua localização geográfica favorecida pela internalização das atividades de exploração da borracha. $\mathrm{O}$ decaimento econômico comprometeu desde os anos de 1920, tanto sua participação no incipiente sistema produtivo e comercial da borracha, quanto no fluxo de modernização que vinham experimentando, pois havia em Belém e Manaus, a urbanização havia conformado uma "forma cidade". Os benefícios modernizadores eram socialmente excludentes nas duas cidades ${ }^{25}$, um fenômeno acentuado com a decadência dos seringais nas primeiras décadas do século XX. Deste então, a presença de migrantes foi acentuada em virtude do êxodo proveniente das unidades produtoras de borracha (AMARAL, CÂMARA e MONTEIRO, 2001). Nas pequenas cidades, tiveram decréscimo populacional, e nos seringais, foi desenvolvida uma agricultura de subsistência. A partir da década de 1920, algumas cidades também apresentaram relativo dinamismo,

\footnotetext{
${ }^{25}$ As contradições e tensões desse processo de modernização, em origem, principalmente sociais, são explicitadas por Edinea Mascarenhas quando afirma que não somente "substitui a madeira pelo ferro, o barro pela alvenaria, a palha pela telha, o igarapé pela avenida, a carroça pelos bondes elétricos, a iluminação a gás pela luz elétrica, mas também transforma a paisagem natural, destrói antigos costumes e tradições, civiliza índios transformando-os em trabalhadores urbanos, dinamiza o comércio, expande a navegação, desenvolve a imigração" (DIAS, 1999, p.32).
} 
como centros de comércio interno ou de produção agrícola, bem como pela presença de imigrantes e novos produtos, como a cultura da juta realizada pelos japoneses entre Manaus e Santarém a partir da década de 1930 (CORRÊA, 1987, p. 55). ${ }^{26}$

Foram portanto as cidades de Belém e Manaus, as mais afetadas pela decadência das atividades dos seringais, até a década de 1960, ressaltando que na década de 1940, as taxas de urbanização na Amazônia seguiam a média do Brasil, a primeira com 27,7\% e a média nacional com 31,2\%, cuja disparidade só viria a acontecer em 1970, com o incentivo estatal à industrialização regional e o processo migratório dela decorrente (CASTRO, 2008, p. 19). Esta leitura confere de antemão uma temporalidade linear aos acontecimentos históricos que tem implicado a configuração espacial amazônica, sobretudo demarcatórios para a tese, frente ao recorte de 1934 a 1989. Ainda que esta delimitação advenha precisamente de eventos mais relacionados ao objeto estudado, qual seja, a centralidade da Amazônia nos textos e prática da Arquitetura no Brasil, há uma nítida sincronia entre ambos, os eventos demarcatórios da transformação do espaço amazônico em sentido lato, os eventos transcorridos no âmbito mais estrito do campo da Arquitetura e Urbanismo no Brasil. Este esforço de conciliação de ambos, de compreensão da consonância entre os eventos relativos ao espaço amazônico e as formas de representação nos textos de Arquitetura ${ }^{27}$, a partir das quais esse espaço foi sendo delineado pela escrita, bem como a Arquitetura ali desenvolvida, justifica este primeiro aporte bibliográfico, uma aproximação ao urbano na Amazônia.

Ainda que seja este um estudo de História da Arquitetura e Urbanismo, portanto condicionado à identificação da temporalidade na qual são pautados os acontecimentos, a “natureza do urbano na Amazônia”, cabe mencionar o que aponta Edna Castro, como “fenômeno mais geral”. Isto a levar-se em conta que o espaço amazônico é "diverso e interligado por redes socioeconômicas e culturais complexas”. Nele, a cidade vinculada ao rural e ao contexto regional, onde grupos sociais, indivíduos em modos de vida particulares,

\footnotetext{
${ }^{26}$ Lobato Corrêa ressalta que tanto a cultura da castanha como da juta, estavam "submetidas ao sistema de aviamento, sistema este que, regionalmente, culminava em Belém” e que o segundo estabelecia um elo com a economia nacional, já que "centros de comércio e beneficiamento de juta" destinavam o produto "sobretudo às fábricas paulistas de sacaria” (CORRÊA, 1987, p. 55).

${ }^{27}$ Nesta categoria arbitrada preambularmente, estão situados os textos pertencentes à cultura escrita da Arquitetura, sejam os oriundos da história, da teoria, da crítica, da imprensa especializada, bem como dos textos visuais a elas associados. Além destes, foram considerados outros textos, fossem escritos ou visuais, que estabeleceram pontes com as representações da Arquitetura na Amazônia, e da própria Amazônia, aqueles identificados em revistas populares, jornais, publicações oficiais, anúncios, dentre os levantados.
} 
atuam na produção do espaço, é tão presente quanto referencial aos estudos interpretativos do "fenômeno urbano na Amazônia", e de suas distintas formas de cidade. Estas, por não seguirem as estruturas modelares usuais de análise pautadas pela relação entre a urbanização e a industrialização, não têm correspondente explicativo, justamente pelo fato de que a urbanização na Amazônia, “expressa outras interfaces históricas” que escapam dos aportes teóricos usuais (CASTRO, 2008, p. 16-17).

Foi justamente entre 1930 e 1985, portanto no recorte aproximado ao considerado para a tese, que o Estado empreendeu uma atividade inicial do planejamento espacial da Amazônia $^{28}$, tendo sido desde o início até 1966 , realizado um claro aparelhamento estatal ${ }^{29}$ para o encaminhamento de tal tarefa. É necessário que seja conferido destaque à participação do Estado nas decisões que viriam a transformar substancialmente o território da Amazônia. A partir de 1966, em particular, neste fluxo, foi iniciado um "novo e ordenado ciclo e devassamento amazônico, num projeto geopolítico para a modernização acelerada da sociedade e do território nacionais” (B. K. BECKER, 2009, p. 25-26). Este processo foi marcado inicialmente pelo primeiro governo de Getúlio Vargas, e mais tarde pelo decaimento do ideário nacional desenvolvimentista por ele principiado, já em meados dos anos de 1980.

Um processo não uniforme, demarcado pela presença do Estado na região, pelo "planejamento governamental, com a formação do moderno aparelho de Estado e sua crescente intervenção na economia e no território", foi estabelecido a partir da década de 1930, junto à implantação do Estado Novo getulista no país. Mas, de fato, somente com Juscelino Kubitschek que ações mais profundas a afetariam, com a "implantação das rodovias Belém-Brasília e Brasília-Acre, duas pinças contornando a fímbria da floresta”,

\footnotetext{
${ }^{28}$ Ariovaldo Umbelino de Oliveira destaca a realização do Congresso Internacional de Geologia em Estocolmo em 1910, a partir do qual grupos econômicos internacionais, além de ingleses, tomaram ciência das reservas minerais brasileiras. Daí o interesse estadunidense desde a primeira década do século XX, em mapear os recursos naturais norte americanos e inventariar fontes de matérias primas mundiais. Após a Primeira Guerra Mundial, grupos ingleses associaram-se a americanos, na fundação da Itabira frui Ore Co. para exploração de minério de ferro no Brasil. Em 1920 Epitácio Pessoa admitiria não só a exploração de minério por tal empresa, mas a construção de siderurgias, estradas de ferro, portos, isentando-a de impostos par 60 anos. Este teria sido o episódio "Itabira Iron", processo cuja legalização ocorreria em 1928 (OLIVEIRA, 1988, p. 13-14).

${ }^{29}$ Bertha K. Becker ressalta o caráter discursivo da atuação do Estado nesse período, mencionando a "Marcha para Oeste", a criação da Fundação Brasil Central em 1944 e do Programa de Desenvolvimento para a Amazônia, inserido na Constituição de 1946, a delimitação do território regional, a criação da Superintendência de Valorização Econômica da Amazônia — SPVEA.
} 
acentuando o fenômeno da migração (BECKER, 2009, p. 25). Este segundo recorte foi enfatizado na tese no terceiro capítulo, dada a oportunidade, no período, de intensificação da atuação de arquitetos na região. Mas também pelas representações de paisagem intelectualmente elaboradas, que viriam a ser veiculadas em textos presentes nas revistas especializadas e absorvidas para a concepção do projeto na Amazônia, o que fez com que os objetos analisados ao fim, no quarto capítulo, fossem recortados deste intervalo de vinte anos.

Foi após a Segunda Guerra, que a internalização das ocupações na Amazônia ocorreu em "pequenos núcleos, originalmente de natureza eminentemente rural, localizados longe dos rios, fugindo do padrão ribeirinho da 'beira', e estabelecendo o padrão de 'centro', em plena mata e servido por uma picada ou uma estrada carroçável”, em virtude da frente de expansão de agricultores vindos do nordeste, com uma prática itinerante de agricultura, de ocupação da terra firme (CORRÊA, 1987, p. 56). Roberto Lobato Corrêa não faz menção aos acordos de Washington, mas há de se supor que essa ocupação internalizada se desse como efeito à tentativa frustrada de reativação dos seringais no momento anterior ao término da Segunda Guerra. A questão é que esta teria sido uma primeira mobilização, ainda que nada comparável à intervenção do Estado, na alteração de uma lógica de circulação regional dada eminentemente, até então, por vias fluviais.

As regiões Norte e Nordeste, frente a industrialização do Sudeste brasileiro, foram constituídas como "fronteiras do capital” e a Amazônia foi incorporada à expansão capitalista nacional, em função, de seus recursos e "dada a dimensão dos capitais disponíveis", a partir da qual a Amazônia foi vislumbrada como "fronteira ampla e extremamente diversificada" para exploração, não uma incorporação “cívica” ou possivelmente, cultural e social. Este processo, que em prática processou uma colonização interna, comportou um conflito estrutural já que (CORRÊA, 1987, p. 57):

ao falar em integração nacional, ocupação de vazios demográficos e desenvolvimento estava, no plano ideológico, justificando a incorporação capitalista da Amazônia. A integração atendia, simultaneamente, a vários propósitos da burguesia nacional e do capital estrangeiro e contou com a participação do Estado brasileiro. Dada a dimensão dos recursos a serem investidos e o tempo necessário para o seu retorno, os custos desses investimentos foram socializados: o Estado foi o responsável pelos investimentos da infra-estrutura a serem realizados, sendo o avalista e repassador dos recursos provenientes do exterior. Por outro lado, e 
complementarmente, coube ao Estado estabelecer um conjunto de políticas que concretizasse aqueles propósitos.

Deste modo, os propósitos foram de administração do excedente rural, criando com a Amazônia mercados de trabalho para locá-lo e inserir a Amazônia no mercado nacional de produtos industrializados e matérias primas ${ }^{30}$. Por fim, o controle capitalista dos recursos naturais, com a alteração da estrutura urbana pregressa, especialmente no "padrão espacial da rede de cidades” e na "paisagem urbana”, já que agora as terras no centro, prevaleceram frente as de "beira", junto a rio navegável, pois houve a "ruptura do tradicional padrão espacial dentrítico da rede urbana”, especialmente pela implantação da rede rodoviária de circulação. Ainda assim, formas pregressas de cidade permanecem presentes na Amazônia, especialmente em áreas não afetadas mais diretamente pelas transformações espaciais decorrentes deste processo (CORRÊA, 1987, p. 59).

O planejamento efetivo estatal viria a ocorrer intensamente entre os anos de $1966 \mathrm{e}$ 1985, quando o Estado "toma para si a iniciativa de um novo e ordenado ciclo de devassamento amazônico”, quando a Amazônia foi tornada central, tanto como estratégia de atenuação dos conflitos sociais frente a possibilidade de focos revolucionário, quanto manejo dos fluxos populacionais do nordeste, como já mencionado, para o controle de fronteiras, o controle territorial frente o temor difundido da internacionalização da Amazônia, motivo pelo qual foi desenvolvido um aparato institucional e a "modernização das instituições”, criado um “enclave industrial”, a Zona Franca de Manaus-AM, e implantada uma "poderosa estratégia territorial", por meio de uma malha de "controle técnico e político” da região, com a implantação de redes, fossem rodoviárias, de telecomunicações, de urbanização, até “o primeito e o segundo choques do petróleo e a súbita elevação das taxas de juros no mercado internacional (BECKER, 2009, p. 26-27).

\footnotetext{
${ }^{30}$ O primeiro teria sido as bases de criação do Plano de Integração Nacional de 1970 e o segundo, das ligações rodoviárias ao sudeste, primeiro de Belém a Brasília, depois de Porto Velho a Santarém, para o alcance da Amazônia, pela produção industrial do sudeste brasileiro e pelo envio de matéria prima desta às regiões industrializadas do país. A criação de aparato técnico para monitoramento e reconhecimento dos recursos amazônicos foi em fins dos anos 1960 e começo dos 1970, como o Projeto Radar da Amazônia - RADAM, meio para a implantação dos mega projetos estatais na região, como "hidrelétricas, mineração em grande escala, reflorestamento e fabricação de celulose - ao lado das estradas, portos e aeroportos" que deste modo representavam a inserção da região num mercado mundial, "para a engenharia, as construtoras, os fabricantes de equipamentos" (CORRÊA, 1987).
} 
Das transformações espaciais apontadas por Lobato Corrêa, são destacadas a urbanização concentrada em poucos centros urbanos, especialmente pela industrialização conduzida a Manaus, e o processo migratório dado pela mudança das atividades extrativista e agropecuárias, a centralidade de Manaus no crescimento demográfico, a revigoração de centros antigos que cresceram entre os anos de 1960 e 1980 em virtude da rede rodoviarista e um menor crescimento em cidades ribeirinhas, a criação de novos núcleos como as “company towns", "introduzindo nova paisagem e um novo estilo de vida, que muito pouco ou nada tem a ver com a paisagem e a população regionais", também os "núcleos de povoamento ligados à extração de ouro", além de núcleos novos dados mais espontaneamente, de pequenos agricultores ou posseiros (CORRÊA, 1987, p. 59-64).

A reconfiguração processada desde os anos de 1960 decorreu marcadamente da implantação do projeto geopolítico estatal voltado à modernização do território brasileiro, no qual a região foi chave para o ideal desenvolvimentista lançado pelo Estado ao território nacional, que influiu mais expressivamente no reordenamento do espaço amazônico. Criticamente, os investimentos estatais a partir de então, dirigidos às redes dos anos de 1970 para possibilitar a abertura da região ao capital, provocaram impactos ao meio natural, às populações, bem como violentos conflitos sociais (BECKER, 2009), concretizando estratégias exógenas ao espaço social regional em danosas consequências. $\mathrm{O}$ estabelecimento dos 59\% da área do Brasil para a região da Amazônia Legal, cerca de 5 milhões de $\mathrm{km}^{2}$, foi justificado também discursivamente, em concepções difundidas em variados meios como os oficiais e junto à imprensa, de uma Amazônia como vazio demográfico, como reserva de recursos, como potencial econômico e em sua vulnerabilidade, tendo em vista os riscos de perda da soberania nacional frente o interesse estrangeiro. Macro estratégias estatais foram articuladas a esse intento de homogenização territorial, materializadas em projetos de monta, dentre os quais os eixos rodoviaristas transpostos às intervenções de semelhante teor nas cidades da região amazônica, com efeitos sobre a rede urbana na Amazônia (CORRÊA, 1987, p. 65):

A partir de 1960, a rede urbana amazônica, em virtude das transformações a que foi submetida, passou a ter novos significados. Não se trata mais de uma rede urbana dendrítica, com uma funcionalidade monotônica [...]

A rede de cidades não é mais uma expressão e condição para a ação direta do capital mercantil, mas adquire novos significados derivados do fato dela ter sido alterada diretamente - através de modificações funcionais e na organização interna dos núcleos preexistentes, e da criação de novos 
núcleos - pelo capital industrial e financeiro e pelo Estado capitalista, agentes através dos quais verificou-se e viabilizou-se a introdução de novas atividades, população e relações sociais de produção na Amazônia.

[...] A complexidade dos centros urbanos e dos fluxos resumem as mudanças que se processaram na Amazônia, fundamentalmente a redefinição de sua integração na divisão nacional e internacional do trabalho, dentro da fase atual do capitalismo. Trata-se, em realidade, de uma crescente integração real, que exprime a subordinação real da Amazônia ao capital: a rede urbana é transformada, complexificada, para dar conta desta integração que assume várias facetas.

Este processo de teor desenvolvimentista, culminou na atuação do governo militar, conservador, que ao difundir um doutrinamento ideológico às fronteiras nacionais, efetivou a internacionalização do acesso aos recursos minerais nacionais e de abertura do país ao capital estrangeiro (OLIVEIRA, 1988, p. 15-26). Deste modo, o projeto de controle da Amazônia, que foi a princípio ancorado em um processo amplo de reordenamento territorial, foi articulado à implantação da nova capital Brasília, num entrelaçamento de escalas, regionais e nacionais. $\mathrm{Na}$ reconfiguração do território amazônico, concomitantemente à redefinição de centralidades político-simbólicas da nação, foi processada uma “colonização moderna” regional, desenvolvida até finais dos anos 1980 na Amazônia brasileira (TAVARES, 2013). A concretização desse ideário colonizador da Amazônia articulado pelo Estado, adquiriu força a partir dos anos de 1960, quando grandes projetos foram implantados na região, em um processo encaminhado mais precisamente até 1985, com a realização do projeto Calha Norte, o último nesses moldes. Produzindo formas de controle e possibilitando a circulação de fluxos de capitais, o Estado conduziu vultosos investimentos na construção de redes de circulação e comunicação, provocando impactos expressivos ao meio natural, às populações tradicionais, além de relações conflitivas, especialmente pela violência com que foram implantados muitos desses projetos (BECKER, 2009, p. 25-26):

O privilégio atribuído aos grandes grupos e a violência da implantação acelerada da malha terno-política, que tratou o espaço como isotrópico e homogêneo, com profundo desrespeito pelas diferenças sociais e ecológicas, tiveram efeitos extremamente perversos, destruindo, inclusive, gêneros de vida e saberes locais historicamente construídos. Tais são lições de corno não planejar uma região.

Este processo teria a feição de uma "Modernização conservadora 'de cima', exercida pelos governos militares que incorporavam o setor privado às elites regionais e nacionais 
por incentivos fiscais", nas palavras de Gerd Kohlhepp. Incluiu o empreendimento público privado, derivado de ações do Estado, especialmente com investimentos em infraestrutura predominantemente rodoviária, além da realização de projetos de colonização rural e da política de redução de impostos. Também ações privadas mediante benefícios fiscais revertidos em capitais de investimento, principalmente na pecuária, indústria e mineração, atividades desenvolvidas mais intensamente com o plano de formação de "polos de desenvolvimento" entre 1974 e 1980, o que acabou por produzir enclaves artificiais no território amazônico (KOHLHEPP, 2002, p. 37-38;40).

A década de 1970, sobretudo, foi marcada pela intensificação de políticas de ocupação da Amazônia brasileira, com a transição de projetos de desenvolvimento realizados desde os anos de 1950 para os projetos de colonização nos anos de 1970 (RABELLO, 2013). Tendo como marco a inauguração da rodovia Transamazônica em 1972, até então inacabada, desenvolvida uma fase caracterizada pelo fortalecimento da urbanização reconduzida a vetores de modernização e redes de circulação rodoviária iniciados na década anterior. ${ }^{31}$ Ainda a respeito dos anos de 1970, explica Bertha Becker que houve "um processo explicitamente dirigido por meio do urbanismo rural, que criou cidades ou fortaleceu projetos de colonização ao longo de novos eixos de circulação, para atrair o povoamento e organizar o mercado de trabalho", numa década em que a população na Amazônia aumentou em 35\% (BECKER, 2013, p. 33).

O caráter autoritário das ações nesses anos incluiu além de práticas repressivas a formas sociais de reação à atuação governamental sobre o território, a centralização do aparato institucional para realização das ações federais. ${ }^{32}$ Minimizando o papel dos estados regionais, governos incentivaram investimentos externos como já mencionados, e a partir da administração de Emílio Médici também realizaram grandes projetos, criando fontes de recursos através de órgãos públicos. Assim, nos anos 1970, a presença do Estado na região era expressiva e impactante, tanto pelos megaprojetos que realizava quanto pela facilitação

\footnotetext{
${ }^{31}$ As tensões sociais relacionadas à questão da terra no nordeste brasileiro, onde a reforma agrária era "urgente e necessária", e as consequências da seca, compuseram também, o quadro no qual nos anos de 1970, foi instaurada uma "estratégia geopolítica que combinava programas de exploração da infraestrutura e econômicos na Amazônia, com um projeto de colonização para o assentamento de nordestinos sem-terra. A região amazônica era vista como escape espacial para os conflitos sociais não solucionados" (KOHLHEPP, 2002, p. 37).

${ }^{32}$ Márcio Souza menciona os órgãos SUDAM, BASA, SUFRAMA, IBRA como aqueles que serviam para a movimentação de recursos.
} 
de crédito e incentivos fiscais, ${ }^{33}$ produzindo efeitos como os mencionados por Márcio Souza (SOUZA, 2001, p. 209):

No início da década de 1970, em plena época do chamado Milagre Econômico, a Amazônia era então não mais uma região de economia extrativa, mas basicamente uma área de agropecuária, mineração, metalurgia e siderurgia. Já no final de 1966, mais de mil investidores tinham instalados projetos de criação de gado ao longo da estrada Belém-Brasília. A agropecuária seria, no início, o principal atrativo.

Nessa nova fase de colonização pelas vias da ocupação territorial, desde finais da década de 1960 e nos anos de 1970, foi intensificada a comercialização irregular de terras da Amazônia por firmas estrangeiras, especialmente americanas, com envolvimento de órgãos e representantes do governo militar. A assinatura do “Ato Complementar n. 45”, em 1969, pelo General Costa e Silva, embora limitasse a aquisição de terras nacionais a brasileiros ou estrangeiros residentes no país e estabelecesse outros critérios de acesso à terra por estrangeiros, não teve caráter retroativo. Além disso, o Decreto Lei n.924 de 10/10/1969, que regulamentou o referido ato complementar, excluía as terras "necessárias à execução de empreendimentos industriais considerados de interesse para a economia nacional, cujos projetos tenham sido aprovados pelos órgãos competentes” (OLIVEIRA, 1988, p. 58-59).

Esta e uma série de outras regulações legais, como aponta Ariovaldo Umbelino de Oliveira, conformavam o campo para a atuação de empresas estrangeiras na região, como o caso do Projeto Jari ${ }^{34}$, um “latifúndio multinacional” (MÓDULO N.55, setembro de 1979, p. 10) de Daniel Keith Ludwig, para produção de celulose, que contava com mais de 3.500.000ha de terras na fronteira entre os estados do Pará e Amapá para sua realização, e que foi implantado dentro da legalidade que lhe serviu de suporte. Junto aos incentivos, a

\footnotetext{
${ }^{33}$ Márcio Souza aborda a atuação da empresa ICOMI, que já exportava manganês extraído do Amapá desde 1956, como precedente à concessão feita por Castelo Branco em 1967, de três milhões e meio de hectares de terras, possibilitando ao empresário norte-americano Daniel Ludwig, a realização do projeto Jari, no Pará. Também, ao caso dos incentivos fiscais à companhia King Ranch of Texas, que associada à Swift-Armcur de Brasil estabeleceu sua fazenda em 180 mil acres em Paragominas, no Pará. Esses subsidias culminariam nos anos 1980 com a atuação da Vale do Rio Doce no projeto Carajás. Márcio Souza ressalta que antes disso, em 1974, a estatal foi associada à empresa japonesa C. Itoh, para construção da Hidrelétrica de Tucuruí. A empresa japonesa foi isentada de gastos na hidrelétrica, e para a obra orçada em dois e meio bilhões de dólares, na qual foram gastos cinco bilhões e quatrocentos milhões de dólares, a empresa Camargo Correia obteve lucro líquido de quinhentos milhões de dólares (SOUZA, 2001, p. 209-210).

${ }^{34}$ Daniel Chaves de Brito analisou a negociação do governo militar do Brasil com o empresário, de modo a auxiliar e proteger o capital estrangeiro, inclusive assumindo para si, os riscos do investimento, inclusive as perdas, já que os bancos nacionais entraram em sociedade na empresa que só foi lucrativa no ano de 1994 (BRITO, 2001, p. 193-195).
} 
publicidade e a articulação a empresários, compuseram a empreitada estatal para a Amazônia. A chamada "Venha investir no Amazonas", se unia à tentativa de se construir uma imagem de progresso e de oportunidades de lucro para os que investissem e o governo divulgava mais ampla e sistematicamente os recursos potenciais naturais, a fim de atrair investimentos externos. Numa publicação de 1969, o Governo do Estado do Amazonas deixava transparecer seu intento de atingir "a grande integração" territorial. Deste livreto, são descatadas as afirmativas "Amazonas — nem inferno nem paraíso: simplesmente uma verdade que se impõe”, “o Amazonas é também um convite”, "Convite para investimento de capital", "oferecendo o Amazonas", como complementos ao argumento de total condição e permissividade para ingresso de capitais externos, como investimentos articulados a essa ideia progressista para a região, onde “a prática de uma política desenvolvimentista para o Amazonas, principalmente se levados em consideração os incentivos fiscais e as vantagens que o poder público, quer estadual, quer federal, vem oferecendo" (Venha investir no Amazonas, 1969, p. 24).

Neste ínterim, nos anos de 1960, os movimentos ambientalistas, em sua configuração não institucionalizada, compuseram “organizações sociais que incorporam a demanda ambiental como outro elemento integrante de uma crítica maior, de base civilizacional”, segundo Fernando Pinto Ribeiro, dirigida ao Estado centralizador, aos conflitos, às desigualdades, à pobreza, à degradação de ambientes naturais. $\mathrm{Na}$ década de 1970, quando as carências de direitos eram fator substancial para as mobilizações sociais, a temática ambiental ganhou força, com uma projeção desenvolvida no interior do processo de globalização econômica, junto à ideologia neoliberal, esta, adotada por governos como meio possível de desenvolvimento. O cenário do pós Segunda Guerra, junto ao envolvimento de movimentos sociais em processos políticos, foram fundamentais para o delineamento do modo como foi arranjada a temática ambiental, em uma fase de fortalecimento Neoliberal na qual o próprio discurso ambiental foi adequado "à razão econômica e reforça o viés prospectivo imbrincado à mercantilização da natureza e de elementos verdes” (RIBEIRO, 2012, p. 212-214). Os ativismos foram ponto de partida para o surgimento de movimentos ambientais, no processo da experiência humana junto à modernidade do capitalismo industrial e na Amazônia foram revelados mais diretamente a partir da década de 1970. 
Os próprios órgãos financeiros internacionais se ajustaram administra e operativamente, frente a novos paradigmas ambientais difundidos mundialmente a partir dos anos de 1970. O documento "World Bank Support for the Environment, Progress Report", neste sentido, estabeleceu metas para valorizar temas ambientais nos campos da pesquisa, formação, visando o "desenvolvimento econômico sustentado". Visou aumentar financiamentos para projetos ambientais, com o envolvimento de esforços internacionais na questão do meio ambiente. Outro documento, denominado "The World Bank and the Environment: First Annual Report, Fiscal 1990" explicitou cinco problemas ambientais prioritários do Banco aos países membros, como apontado por Carlyle Vilarinho, a destruição de habitats naturais, a degradação dos solos, dos recursos hídricos, poluição e degradação do meio ambiente comum. O Banco e os países tomadores de empréstimos deveriam entrar em consonância com estas prioridades (VILARINHO, 1992, p. 38-39).

Fernando Pinto Ribeiro enumera os contributos ao fortalecimento de um pensamento ambiental nos anos de 1970, em paralelo às investidas mercadológicas. Dentre os que o autor enumera estão o aprofundamento da crise ecológica, o ingresso da "crítica ambiental na esfera política”, ${ }^{35}$ as novas formas de concepção de desenvolvimento, ancoradas em pressupostos ambientais, humanitários, mas também numéricos, o que encaminhou de certo modo discussões mais recentes a respeito dos parâmetros de sustentabilidade não apenas da natureza, mas do próprio desenvolvimento. Este passou a ser pensado também a partir dos parâmetros e meios de inteligência que tornariam viáveis sua perpetuação. Assim que o próprio mercado incorporou o pensamento ambiental, como “interpretação dominante focada no crescimento econômico sustentável” e a crise ambiental foi tornada argumento para as ações mercadológicas, que incluem "expropriar pessoas e comunidades de seus territórios, explorar agricultores tradicionais e financeirizar a natureza no mercado” (RIBEIRO, 2012, p. 219-221).

Na mesma década, no Segundo Plano de Desenvolvimento Nacional, entre os anos de 1975 e 1979, vigorou a estratégia estatal de criação de polos de crescimento setoriais, a partir dos quais a implantação de determinadas atividades econômicas acarretou além de expressivos danos ambientais, processos especulativos de terra, violência e conflitos entre

\footnotetext{
${ }^{35}$ Com a Conferência sobre o Meio Ambiente de 1972, realizada em Estocolmo, Suécia, pela Organização das Nações Unidas, produziu um Manifesto Ambiental, com "princípios comuns que ofereçam aos povos do mundo inspiração e guia para preservar e melhorar o meio ambiente humano" (ONU 1972).
} 
populações tradicionais e posseiros, efeitos do processo no qual, de acordo com Gerd Kohlhepp (KOHLHEPP, 2002, p. 39-40):

Investidores de capital nacional e internacional foram atraídos por reduções consideráveis de taxas tributárias e também por outros benefícios. Tornou-se vantajoso para bancos, companhias de seguro, mineradoras e empresas estatais, de transportes ou de construção de estradas, investir na devastação da floresta tropical para introduzir grandes projetos de criação de gado, com subsídios oficiais, realizando a exploração das terras a preços baixos. Os tradicionais fazendeiros de gado no Brasil trabalharam como subcontratados em grande escala. As fazendas de gado - a área máxima oficial era de 60 mil hectares, mas na realidade havia ainda as fazendas da Volkswagen do Brasil, com 140 mil hectares, ou a da multinacional Liquigas Group, com 566 mil hectares, e muitas outras mais - foram responsáveis pela enorme destruição das florestas tropicais, principalmente nas regiões do sudeste e do leste do estado do Pará e na parte norte do Mato Grosso. Em meados dos anos 1980, os projetos oficiais de fazendas de criação de gado ocupavam quase que 9 milhões de hectares. De um total de 350 mil $\mathrm{km} 2$ de terra adquiridos pelas fazendas de gado, uma área florestal de cerca de 140 mil km2 foi destruída.

Ariovaldo Umbelino de Oliveira demarcou as mudanças da "política de ocupação" do Estado nos anos de 1970, materializando-a na viagem coordenada por três ministros (Planejamento, Interior e Agricultura) e 20 grandes empresários sulistas à Amazônia. A viagem resultou na compra de dois milhões de hectares "no entroncamento das rodovias Cuiabá-Santarém e Transamazônica" para implantação de projetos, enunciando "tendência à formação de grandes consórcios empresariais na Amazônia, aceita e estimulada pelo governo”. Em tese, a finalidade desse estímulo seria garantir a preservação de áreas verdes e produzir a "autossustentação, em termos econômicos, de uma estrada até agora de valor reduzido como a Transamazônica” pois segundo o referido jornal, os projetos seriam justificados para o Ministro do Planejamento, em detrimento de outros menores, por serem “essenciais para evitar desmatamentos indiscriminados e assegurar o equilíbrio ecológico da região” (OLIVEIRA, 1988, p. 87).

Assim o discurso estatal incorporou o argumento preservacionista, pelas vias da articulação do controle territorial junto ao incentivo à colonização e a práticas empresariais estimuladas à região Amazônica a partir dos anos de 1970. Um componente somado à atuação prevalente de práticas empresariais foi o ingresso de capital por vias especulativas, como as ações de incentivo à migração para a Amazônia brasileira, já em curso nos anos de 1970, como forma de aliviar tensões sociais da “expulsão de pequenos produtores do 
Nordeste e do Sudeste pela modernização da agricultura” e frente às preocupações com possíveis ocupações do território (BECKER, 2009, p. 26).

Junto ao interesse em promover programas de aproveitamento dos recursos naturais da região, estratégias de uma geopolítica regional articularam o plano de ocupação e integração nacional a formas de controle social. Assim, programas governamentais financiados pelo Banco Mundial no início dos anos de 1980, impulsionaram a colonização por pequenos agricultores, como o Polonoroeste em Rondônia ou no noroeste do Mato Grosso, criando "novo conceito para um desenvolvimento orientado para a pobreza nas áreas rurais”, como estratégias para satisfazer necessidades básicas sociais a partir de “métodos participativos”, o que Gerd Kohlhepp nomeou de “desenvolvimento de baixo”. Concomitantemente aos "megaprojetos”, especialmente os realizados a leste da Amazônia legal, nos moldes do "desenvolvimento de cima”, estas ações produziram impacto em variadas intensidades, destruição da floresta tropical, degradação ecológica e social, conflitos e a desintegração regional (KOHLHEPP, 2002, p. 40-41).

Como síntese dos processos empreendidos a partir dos anos de 1970 na Amazônia com impactos profundos sobre a região, Carlyle R. O. Vilarinho menciona a instalação de hidrelétricas, pastagens, lagos, as atividades de mineração, as derrubadas de áreas de floresta, a poluição de rios por mercúrio, o crescimento populacional e a favelização, além de megaprojetos, como o "Programa Grande Carajás, financiado pelo Banco Mundial - que utiliza a floresta para produzir carvão vegetal e assim viabilizar a produção de ferro-gusa”, bem como a (VILARINHO, 1992, p. 44):

[...] abertura de novas rodovias, a modernização da agricultura na região Centro-Sul e a expansão da fronteira agrícola; a política de incentivos fiscais, creditícios e os subsídios do governo federal a grandes grupos industriais, bancários e outros do Centro-Sul; junto com uma débil política de colonização, foram fatores que se somaram para que ocorresse, nos últimos anos, um processo de ocupação bastante intenso e predatório, onde sobressai a destruição da floresta em ritmo crescente.

Além dos efeitos sobre o meio natural e a afetação da biodiversidade, os conflitos violentos de terra são comumente enfatizados pelos danos a posseiros, líderes sociais ou trabalhadores. Bertha Becker explica o desenvolvimento dos projetos alternativos, de baixo, como a transfiguração dos conflitos sociais das décadas de 1970-1980, de teor conservacionista, articulados em "redes transnacionais", das quais participam "ONGs, 
organizações religiosas, agencias de desenvolvimento, partidos políticos, governos”, produzindo "novas territorialidades", com diversas formas de parceria (BECKER, 2009, p. 28). Assim, os anos de 1980 seriam a marca, tanto do esgotamento da política nacional desenvolvimentista iniciada com Getúlio Vargas, quanto pelo surgimento de formas de organização social reativas às práticas estatais prevalentes para a região Amazônica nos últimos trinta anos ao menos. Bertha Becker aponta junto a esses dois fenômenos, a atuação de um "vetor tecnoecológico na dinâmica regional”, predominante entre os anos de 1985 e 1996, configurando a Amazônia como uma "fronteira socioambiental", justamente pela convergência de múltiplos projetos dirigidos à região, elaborados com esse teor (BECKER, 2009).

Quando se refere a esses projetos e às modalidades de ingerência sobre a Amazônia deslocadas das ações centradas no Estado e fortalecidas a partir dos anos de 1980, Bertha Becker ressalta o fato de que os projetos desenvolvidos não foram restritos aos coletivos, mas sob a politização global da questão ambiental, refletiram o interesse mais generalizado na preservação da natureza, como na atuação do G7, Banco Mundial e governo brasileiro. Nesta linha, o "Programa Piloto para Proteção de Florestas Brasileiras (PP-G7)", ${ }^{36}$ a “criação do Ministério do Meio Ambiente, dos recursos Hídricos e da Amazônia Legal e sua Secretaria de Coordenação dos Assuntos da Amazônia Legal”, produziram avanços no campo da preservação, como na demarcação de terras indígenas, na gestão ambiental integrada entre os estados, na criação de novas unidades de conservação, mesmo que nessa “fronteira socioambiental” venham sendo reproduzidos modelos endógenos de desenvolvimento. Para a geógrafa, a proteção da biodiversidade é colocada em plano global, de modo que a Amazônia centra esta discussão. A autora aponta como impedimento à expansão de tal "positividade social e ambiental”, a "dificuldade de inserção nos mercados, em virtude de carências gerenciais, de acessibilidade, de competitividade, e a sua

\footnotetext{
${ }^{36}$ Esta foi uma iniciativa alemã, na reunião de cúpula dos países do G-7 em Houston, em 1990. A proposta era de "apoiar financeiramente a reorganização dos modelos de desenvolvimento regional para a Amazônia", com doações e prestação de assistência técnica, aceitas pelas autoridades brasileiras. A proposta foi aprovada "às vésperas da cúpula da LJNCED, no Rio de Janeiro, em 1992 (ECO 92)". O Banco Mundial coordenou o programa e foi criado um "Rein Forest Trust Fund' de 60 milhões de dólares, administrado pelo mesmo banco. Este empreendimento consistiu em um conjunto de projetos voltados ao "uso sustentável dos recursos naturais e para uma substancial redução da taxa de desflorestamento" (KOHLHEPP 2002, p.42).
} 
característica pontual, que não alcança escala significativa de atuação em tão vasta região”. (BECKER, 2009, p. 27-29).

Na década de 1990 foram retomadas, ao contrário desse fluxo "alternativo", práticas de planejamento territorial, com o desenvolvimento de muitos projetos voltados à mobilização de recursos naturais, aos negócios e às empresas. Programas como "Brasil em Ação” e “Avança Brasil” foram, “pautados nos Eixos Nacionais de Integração”, produziram conflitos com a Amazônia como "fronteira socioambiental” (BECKER, 2009).

Este é justamente o momento no qual se dá o marco final do recorte da tese, quando uma série de eventos convergem para a centralização da Amazônia numa geopolítica mundializada não mais explicada unicamente pelas vias da ação estatal e sua ingerência sobre o território, mas em múltiplas formas de organização social, e de práticas, como as advindas dos movimentos sociais, de organizações não governamentais, articulados a estruturas governamentais, na conjuntura da redemocratização do país. Nos textos da arquitetura, tem-se a consagração da obra dos arquitetos atuantes na Amazônia sob distintos aportes, como regionalistas, como idealizadores de uma arquitetura brasileira, como arquitetos latino-americanos, ou seja, arquitetos produzindo uma arquitetura reportada nas revistas sob diversos recortes geográficos e narrativos, ainda que possa ser aquela arquitetura, relacionada discursivamente a concepções de uma paisagem amazônica, como construção.

\subsection{Amazônia como paisagem, uma construção cultural}

A trajetória histórica da Amazônia foi marcada por associações do território a concepções utópicas e à sua ideação que a partir do século XIX passou a ser explicado pela Geografia Moderna em prevalentes referências junto ao “mundo natural” (FIGUEIREDO, CHAMBOULEYRON e ALONSO, 2017). Foi justamente quando a Geografia moderna adquiriu um caráter científico e uma sistematização, com Humboldt e Ritter, e que esteve voltada à identificação e compreensão do meio e seus elementos naturais, que "viagens, descrições complexas de paisagens, levantamentos de dados, fizeram da Geografia uma ciência única, que se preocupava não apenas com o 'onde', a localização”, mas em "descrever minunciosamente os lugares, as paisagens, o modo de vida das civilizações”(JÚNIOR, 2015, p. 572-573). 
Neste contexto, Alexander von Humboldt delineou o termo Hileia, forjando um conceito de Amazônia como paisagem, principal categoria com a qual a Geografia interpretou o ambiente, até o século XX. Outras designações, como "região do Amazonas" ou o "país das Amazonas” reproduziram elaborações da Amazônia como conceito, variando no tempo e conforme o ponto de vista com que foi explorada e projetada, fosse "fisiográfico, geomorfológico, biogeográfico, político e histórico", como explicam Aldrin Moura de Figueiredo, Rafael Chambouleyron e José Liz-Peinado Alonso (2017), para quem a Amazônia absorveu as marcas de um "espaço de fronteiras, de políticas transnacionais e de relações sociais, intelectuais e econômicas em escala mundial”, sobretudo sob a perspectiva $\mathrm{da}$ centralidade representativa da floresta (FIGUEIREDO, CHAMBOULEYRON e ALONSO, 2017).

No século XX uma corrente da escola possibilista ${ }^{37}$, no interior da Geografia, a despertou à interpretação das relações entre o meio e a intervenção humana, conforme transcorridas numa dada região geográfica que constituiria a relação entre homem e ambiente. No Brasil, os anos 1950 demarcaram a associação entre os ideais e práticas de planejamento, quando interpretar, conhecer e delimitar as fronteiras regionais dependeram diretamente de "objetivos do instrumento de intervenção" e não de condições estritamente naturais e físicas dos ambientes geográficos. Deste modo, a busca pelo estabelecimento das fronteiras da região amazônica pautou intensas discussões acerca dos critérios para sua delimitação, numa fase de planejamento do território nacional advinda dos nos de 1940, diante do interesse estatal de ocupar, explorar, dominar e desenvolver o território (JÚNIOR, 2015).

A Amazônia Legal foi instituída em $1953^{38}$, por meio de medida político administrativa, sem que, no entanto, tenha sido substituído a Hileia Amazônica como um

\footnotetext{
${ }^{37}$ Criada por Paul Vidal de La Blache, defendeu a interação entre homem e meio natural, em distinção ao determinismo ambiental alemão. A natureza, para a escola possibilista, foi compreendida como meio para a evolução humana e suporte de suas práticas.

${ }^{38}$ Estabelecida em 1953 pela Lei 1.806, com a definição dos limites territoriais que seriam geridos pela SPVEA - Superintendência do Plano de Valorização Econômica da Amazônia, criada no governo de Getúlio Vargas. Abrangeu os "Estados do Pará e do Amazonas, territórios federais do Acre, Amapá, Guaporé e Rio Branco, e ainda, a parte do Estado de Mato Grosso a norte do paralelo $16^{\circ}$, a do Estado de Goiás a norte do paralelo $13^{\circ}$ e do Maranhão a oeste do meridiano de 44", conforme disposto no art. $2^{\circ}$ da referida lei. Em 1966 foi alterada com a criação da SUDAM, pela lei 5.173 e reformulada pela lei complementar n.31 de 1977, quando seus limites foram ampliados com a .
} 
conceito correspondente à Amazônia como paisagem. Eidorfe Moreira ${ }^{39}$ (MOREIRA, 1960), intelectual identificado com a Geografia, escreveu sobre a Amazônia num momento em que esta ciência atingiu um "alto nível de complexidade teórico-metodológica”, quando as categorias de região e paisagem adquiram importância para a Geografia Tradicional, impactada pelas velozes transformações possibilitadas pela combinação de "técnica-ciênciainformação”, no século XX. Neste momento, a Amazônia, deslocada dos centros produtivos nacionais, já não conformava unicamente uma paisagem, mas constituía uma região “de planejamento ou para o planejamento" (JÚNIOR, 2015).

Eidorfe Moreira, em uma fase de transição da Geografia, centrou uma análise da Amazônia como paisagem, em texto no qual prevaleceram os componentes constitutivos do meio físico, natural, do "espaço tropical por excelência”, uma "paisagem como que permanece igual a si mesma”, uma “fantástica paisagem”. Elaborado desde sua experiência, tanto de vivência em Belém-PA quanto junto à SPVEA, seu escrito registrou também suas expectativas ao desenvolvimento humano na região, numa leitura da Amazônia em perspectiva. Descrições físicas e atributos valorativos compuseram seu texto, no qual apresenta as dualidades temporais e espaciais, categorias com que construiu sua interpretação da Amazônia, a situando entre o selvagem e o civilizado, o local e o universal. Sua “impressão” do "caráter selvagem e majestoso" da natureza, passou pela identificação da "pujança” daquele lugar revelador das "reservas da primitividade" do planeta, como um contraponto (MOREIRA, 1960).

Aspectos do relevo distinguido em "várzea, terra firme e planalto", da estrutura hidrográfica de "lagos, paranás, furos, igarapés e rios”, em “confusão”, caracterizou em o produto sistematizado de sua interpretação geográfica, a partir da qual descreveu o relevo, as águas, os locais propícios ao cultivo, numa tentativa de síntese de uma paisagem potencial e universal, ainda que dada pelos tantos particularismos e excepcionalidades que expôs (MOREIRA, 1960, p. 51-58). Na Amazônia "tudo parece viver e definir-se em função das águas: a terra, o homem, a história”, e ainda, "o rio condiciona e dirige a vida”, um "ímã líquido”, atraente da vida. O ritmo da vida regional seria estabelecido pelo rio, com suas “enchentes e inundações periódicas”, que fertilizavam as terras e a floresta, um "conjunto

\footnotetext{
${ }^{39}$ Eidorfe Moreira (1912-1989) foi um intelectual fixado em Belém - PA, interessado nas questões da Geografia, atuou na SPVEA, quando o Estado operou diretamente no planejamento regional da Amazônia.
} 
fluvial" tanto adjetivado quanto hierárquica e objetivamente descrito. A "poderosa dinâmica do rio", o "imenso conjunto fluvial”, o "portentoso Amazonas", a "imensidão do conjunto", em seu "aspecto de força e amplidão" foram atributos das águas determinantes à vida regional, sendo o rio, o "condensador demográfico por excelência da Amazônia" (MOREIRA, 1960, p. 63-68; 84).

A cobertura vegetal, por sua vez, foi "o fato geograficamente mais expressivo e que por isso mesmo mais avulta na paisagem amazônica", na designação do que conceituou como "a floresta". Este seria seu componente mais representativo, o que "define e simboliza a Amazônia", o "background" na formação da paisagem amazônica, em suas múltiplas formas de apreensão. Desde o rio, de cima, a Hileia Amazônica foi caracterizada pela "densidade, estratificação, heterogeneidade". Do mesmo modo, com a descrição e distinção de elementos vegetais em famílias, locações típicas, especialmente "a floresta de várzea", contígua ao rio em sujeição às "inundações periódicas", e a da "terra firme", em "terrenos elevados e apartados dos cursos d'água", as coberturas vegetais, foi acrescido ao quadro de reconhecimento da Amazônia em uma paisagem. Logicamente não apreendida de todo, mas referenciada na realidade experimentada pelo olhar sensível, às variações e frequências do meio natural. Além destes componentes, o clima, e o homem formariam essa composição de paisagem de Eidorfe Moreira (MOREIRA, 1960, p. 69-75).

Desde a viagem de Francisco de Orellana ${ }^{40}$, quando foram registradas paisagens nas crônicas de acento ficcional, a Amazônia é explorada e vivida no trânsito pelas águas dos rios. Já nos primeiros contatos, exploradores se apropriavam de meios típicos de locomoção e de visualidades desde há tempos pregressos e imprecisos experimentados por populações autóctones (UGARTE, 2004). As águas tem sido componente da paisagem amazônica, principais vias de locomoção intraregional. Tem servido de recurso a formas de vida ainda filiadas mais intimamente ao ambiente geográfico, como em cidades que sobreviveram "com fortes ligações com as dinâmicas da natureza" (TRINDADE, 2013). Os rios são também componentes das memórias continuamente reconstruídas pelas experiências na Amazônia, constitutivos de um conjunto de referências do modo de vida ribeirinho marcado pela relação com as águas, de onde fluem variadas sociabilidades (SOUZA, 2010).

\footnotetext{
${ }^{40}$ A expedição de Francisco de Orellana entre 1541 e 1542 foi a primeira a percorrer o rio Amazonas desde sua nascente até o Atlântico, sob a chefia de Gonzalo Pizarro (BUENO, 2002, p. 40).
} 
Para Leandro Tocantins, uma cultura amazônica foi enraizada com o tempo e aprimorada no ambiente geográfico amazônico, desde o contato dessas populações com o colonizador, o português. Tendo experimentado a vida na Amazônia, imerso nos debates sobre o desenvolvimento nacional nos anos de 1960, afirmou que "homem e rio são os dois mais ativos agentes da Geografia humana da Amazônia. O rio enchendo a vida do homem de motivações psicológicas, o rio imprimindo à sociedade rumos e tendências, criando tipos característicos na vida regional” (TOCANTINS, 1973, p. 280). Além de vias de acesso ao explorador, componentes de uma visualidade tipificada e condicionantes de modos de vida, as águas constituíram uma rede de caminhos e fronteiras estruturais às dinâmicas na Amazônia e da paisagem. Nas bordas e beiras, as primeiras cidades foram formadas, junto ao regime de oscilação das águas, numa dinâmica apenas modificada no século XX, quando foi implantada uma rede terrestre de circulação e estabelecidas novas fronteiras e intensificado o controle territorial com os projetos de grande porte, com a introdução de novas dinâmicas agroindustriais e territoriais (DROULERS, 2017).

O homem, para Eidorfe Moreira, diante do gigantismo da natureza amazônica, se apresentava minimizado diante da "vasta Hinterlândia amazônica" e condicionado à sua “desoladora insuficiência”. A "rarefeita população" e a "insuficiência demográfica" na Amazônia, conformavam “antes um mal do que um bem”. Sua visão de paisagem em projeção o fazia crer que a ocupação efetiva da Amazônia, conferiria conteúdo humano à paisagem, ampliando “a expressão paisagística da cultura”. A respeito das habitações nos núcleos ribeirinhos, afirmou que aquela "população vive em função dos cursos d'água, adstrita aos caprichos de seu traçado" e ao longo do Rio Amazonas, "a civilização não ultrapassou as suas barrancas, permanecendo por assim dizer entre o rio e o igapó”, leitura a partir da qual projetou condição ideal de desenvolvimento regional, pelas vias da ocupação do território (MOREIRA, 1960, p. 83).

A inscrição da Amazônia na modernidade, com base na síntese da paisagem apresentada por Eidorfe Moreira, dificulta uma interpretação naturalizada da modernização como visão aspirada de futuro, já que particularidades deste processo estão relacionadas à diversificação do urbano, sobretudo em função de a Amazônia ser um “estoque estratégico de recursos naturais que podem ser transformados em matéria-prima bem como enquanto fornecedora de mão de obra barata”(PEREIRA, 2012). Neste sentido, a paisagem 
amazônica, mesmo que constitutiva de um imaginário que a associou ao selvagem, ao primitivo e ao vernáculo, tem sido transformada como lugar de experiências concretas junto à modernidade. Na relação que estabelece Paulo Tavares, Fordlândia (1927) e Belterra (1934) foram exemplos de experiências "inscritas numa geografia global”, extendidas para a região, em "espaços de vanguarda no terceiro mundo", exemplares da expressão do “projeto de ocupação e modernização do interior”, como forma de sustentação do empreendimento industrial capitalista. Do ponto de vista da arquitetura, elas foram experiências em extrema contradição com os projetos modernistas, tornados referenciais à Arquitetura Moderna no Brasil (TAVARES, 2013).

A modernidade é um tema referencial à Arquitetura e Urbanismo. Período iniciado no século XVI e perdurado no presente, ao que interessa à presente tese tem como marca uma tendência à unificação dos modos de vida e de experiências partilhadas espaçotemporalmente entre os homens, como definiu Marshall Berman. Em termos concretos, é um fenômeno de longa duração, da ordem do paradoxal e da incompletude, um movimento de transformação contínua localizado entre a "anulação de fronteiras” de toda ordem, tanto as geográficas quanto sociais, e a "desintegração e mudança”, a "agitação”, a "luta”, a “ambiguidade”, advindas desta tendência à uniformização das vidas e de indivíduos afetados diretamente pela expansão do mercado mundializado, capitalista. Assim que a modernidade tem produzido efeitos sobre as percepções, mentalidades e sobre o mundo material que cerca a existência humana, conformando um "perpétuo estado de vir-a-ser”, chamado de “modernização” (BERMAN, 1982, p. 15-35).

A modernização foi moldada à racionalidade iluminista francesa do século XVIII, momento em que industrialização, urbanização, social democracia, convergiram na alteração mais substancial dos modos de vida até então existentes (COHEN, 2013). Diante da transitoriedade dos mercados carecidos de infraestruturas que lhes possibilitassem expandir e das consciências afetadas diretamente pela instabilidade vindas das transformações mais profundas nas sociabilidades, a melhor das expectativas diante da modernidade foi a que a vislumbrou em sua tradução objetiva e racional, em meios materiais, técnicos ou infraestruturais, como aspirações de futuro, junto às transformações em curso, tendidas ao progresso humano. 
Artistas e arquitetos apreenderam da modernidade, em uma atitude de autoconscientização e recolocação de suas práticas, as virtudes potenciais, fossem as subjetivas, perceptuais, ou mais diretamente relacionadas aos meios produtivos, técnicos e tecnológicos. Essa visão positiva diante do campo de possibilidades que a modernidade abriu à vista, na transição dos séculos XIX ao XX, refletiu mais precisamente sobre o projeto - do edifício ou da cidade, qual fosse - definindo um caminho que seria trilhado desde então, no aperfeiçoamento continuado da arquitetura, pela clareza de sua inevitável imersão na modernidade, pensada assim para ser universal. A ela, foi dedicada a destinação de intromissão no mundo material de novas ideias construtivas, formas visíveis ajustadas aos recursos da modernidade, as mais atualizadas, em esforços para viabilizar o avanço universal das sociedades.

Todavia, para o espaço, a modernização, como efeito da modernidade, não é revelada homogeneamente. E os lugares da modernização manifesta estão sujeitos a formas variadas de sua expressão. Integrados, revelam mais que identidades locais, indicam formas de relação implicadas pela expansão mercadológica, nas quais são empreendidas ações de sujeitos concretos e em temporalidades precisas (BOURDIN, 2001). Então, distinguir os efeitos da modernidade sobre a modernização em dualidades, “atraso" frente ao "progresso", são inócuas à análise das suas distintas formas, pois ainda que díspares pertencem a uma mesma complexidade, processual e histórica, que lhes sustenta em interdependência funcional, já que estão ligadas pela mesma economia produtiva. As temporalidades partilhadas, que geram múltiplas formas de expressão da modernidade, resultam, assim, de relações orgânicas e complexas, de modo que (OLIVEIRA, 2003, p. 3233):

[...] o conceito do subdesenvolvimento como uma formação históricoeconômica singular, constituída polarmente em torno da oposição formal de um setor "atrasado" e um setor "moderno", não se sustenta como singularidade: esse tipo de dualidade é encontrável não apenas em quase todos os sistemas, como em quase todos os períodos. Por outro lado, a oposição na maioria dos casos é tão-somente formal: de fato, o processo real mostra uma simbiose e uma organicidade, uma unidade de contrários, em que o chamado "moderno" cresce e se alimenta da existência do "atrasado", se se quer manter a terminologia.

Essa dualidade, no âmbito da percepção das temporalidades, é ainda mais absorvida na experiência, pela “sensação de viver em dois mundos”, percepção da transitoriedade 
frente a dissolução das formas sociais tradicionais, que produz o desencanto e apego às memórias. O distanciamento da natureza nas metrópoles, junto à construção da ciência sociológica em finais do século XIX, singularmente, foram os locais da individualização e anonimato dos sujeitos na nova organização social ritmada pelas relações mercadológicas, ambiente no qual aquela percepção da transformação de valores tradicionais foi um marco. Em substituição aos sistemas valorativos partilhados comunitariamente, passaram a prevalecer outros, subordinados às trocas comerciais monetizadas e atreladas a um sistema produtivo global. No plano mental, a consciência da modernidade e seus efeitos sobre a ruptura com o que parecia ser um dado perene da existência, no entorno, também é

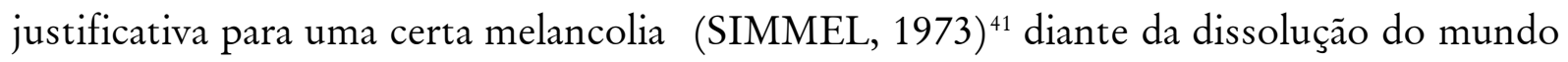
como estruturado. Esta condição que beira uma explicação genérica, de um estado emocional socialmente partilhado, parece estar latente, quando se trata da modernização na Amazônia, mesmo no presente. Moacir Andrade relatou desde sua própria percepção que (ANDRADE, 1981, p. 125):

Quem navega as centenas de rios dessa monumental Amazônia poderá sentir o desolamento, a tristeza, o silêncio e a devastação do que foi, um dia, um verdadeiro santuário dessas avezinhas que mais pareciam ninfas encantadas bailando suavemente no espaço que margeia as bordas dos inúmeros rios, paranás e lagos da região. As garças sumiram para sempre de alguns lagos amazônicos. O lago do Janauary, a uma hora da cidade de Manaus, em 1935 era chamado de o lago das garças, tal a quantidade dessas brancas aves que se concentravam aos milhares naquele recanto paradisíaco.

O pintor narrou sua memória, revigorou a infância e a paisagem de rios e garças, figurando o lugar da experiência, prosseguindo em escrita crítica às transformações que experimentou em seu ambiente familiar. Dois fatos ocorridos na década de 1980 esboçam o contexto da fala do artista e fazem contraponto a ele próprio. Um ano antes da publicação do referido livro, Moacir Andrade expôs seus quadros em diversos países, na Grécia, Suíça, Austrália, em pelo menos sete cidades. No mesmo ano da publicação, expôs na Irlanda e Escócia. Em 1982, expôs na Noruega, numa fase vinda de finais da década de 1970, na qual o artista privilegiou as pinturas de "paisagens amazônicas" (LOPES, 2018, p. 65-66). Em acréscimo, na década de 1980, a Amazônia ingressa em redes de ativismo transnacional, sob a “pressão ambientalista internacional e nacional” (BECKER, 2009, p. 27).

\footnotetext{
${ }^{41}$ Publicado originalmente em 1902.
} 
A Amazônia estava nos textos, mas principalmente nas inúmeras paisagens que pintou Moacir Andrade. Na representação de Manaus [figura 1], desde um ponto de vista da margem de um igarapé urbano, o pintor apresenta em confronto as indústrias, casario, palafitas. A temática da pintura inspirada na modernidade está articulada à figuratividade remetida aos componentes tipificados da paisagem do espaço urbanizado na Amazônia. $\mathrm{Na}$ imagem, os galpões e as edificações ecléticas completam a composição do quadro. Os efeitos das transformações da Amazônia das memórias de Moacir Andrade transpareceram em seus escritos, ao tempo em que a visibilidade da Amazônia foi ampliada, pela ascensão ambientalista e da participação direta de organizações não governamentais e organismos financeiros na moldagem de estratégias baseadas discursivamente no desenvolvimento sustentável. A articulação do crescimento econômico à proteção ambiental moldou um processo de interação com a Amazônia no qual atores locais foram "projetados na arena global”, em circunstâncias muito diferentes das que enfrentavam domesticamente. Ao serem "lançados no espaço global", assumiram posições distintas dos conflitos locais, tornando-se representantes ambientalistas, como informa Andréa Zhouri (ZHOURI, 2006, p. 144-145).

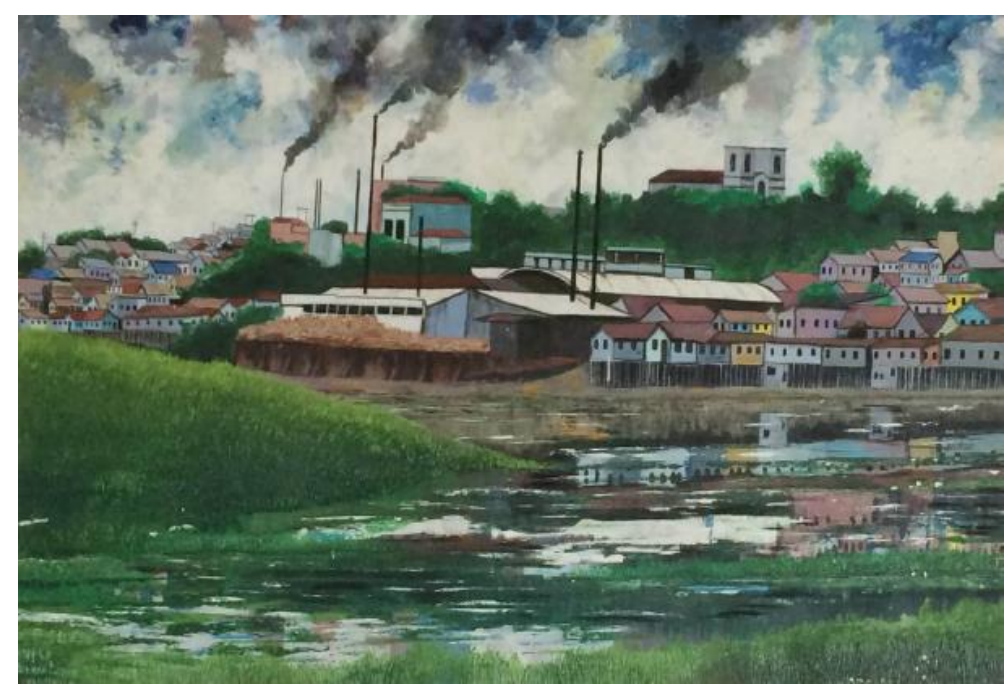

Figura 1 - Reprodução de pintura de Moacir Andrade, 1982, sem título. Fonte: LOPES, 2018, p.71.

Outra experiência com a modernidade, narrada por Adhemar Chaves ${ }^{42}$ ao tempo da publicação de Eidorfe Moreira de 1960, deixou explícita uma particularidade da Amazônia no contexto da modernidade. O autor discorreu sobre a construção da estrada de ferro

\footnotetext{
${ }^{42} \mathrm{Na}$ revista há indicação de que o autor pertenceu à Sociedade Brasileira de Geografia.
} 
Madeira-Mamorée ${ }^{43}$ no início do século XX, em leitura retrospectiva. Sua narrativa sobre o evento, publicada na revista Acrópole [figura 2], expôs a dualidade entre a natureza e a civilização na Amazônia, ilustrada com uma série de imagens textuais de referência. Para o autor, não se tratou de um feito de "valor técnico extraordinário", mas sim de difícil realização. Adhemar Chaves mencionou o entrosamento entre empresas estrangeiras e o governo brasileiro para a finalização da obra, já que várias haviam atuado no encargo, enfrentando a falência e mesmo a morte de trabalhadores por acidentes e epidemias. A região, “inóspita e selvagem”, foi o ambiente de uma “verdadeira tragédia amazônica!”, um “sorvedouro de vidas", numa sequência de tragédias, num processo "possivelmente agravado pela maldição dos pajés ameaçados em suas malocas pelos ‘caraíbas' invasores”, um completo "fatalismo" (ACRÓPOLE N.268, fevereiro de 1961).

Construída para o escoamento de produtos bolivianos ao Atlântico, a estrada de ferro foi implantada na divisa de dois estados, ao sul do Amazonas e norte do Mato Grosso, no fluxo do Rio Madeira, "artéria principal do caminho líquido amazônico", afluente da margem direita do rio Amazonas, tendo por ascendentes o "Mamoré e a seguir o Guaporé”, ${ }^{44}$ com mais de $3000 \mathrm{Km}$ antes de desaguar no Rio Negro. Para Adhemar de Barros a obra expôs o confronto entre a natureza e a técnica, numa frente de expansão na Amazônia. Foi uma obra de gastos incontrolados, um verdadeiro "caos de dezenas ou centenas de infernos verdes”, (ACRÓPOLE N.268, fevereiro de 1961), termos estes, remetidos à alegoria de Alberto Rangel presente em seu escrito ficcional de 1908 (RANGEL, 2008), na qual minimiza da presença humana diante do gigantismo e do caráter desafiador do sertão amazônico. Uma observação de Eduardo Yázigi ${ }^{45}$ foi extensiva a esta perspectiva, quando afirmou que "a transamazônica, por exemplo, mais parece ser um desafio do que uma necessidade; mais um ato de heroísmo do que uma estrada” (CJ ARQUITETURA N.20, 1978, p. 62).

\footnotetext{
${ }^{43}$ Segundo Roberto Lobato Corrêa, a estrada constituiu "a superação dos obstáculos fluviais", pela "Madeira and Mamoré Railway Company". Esta ferrovia foi responsável pela criação de núcleos de povoamento no atual Estado de Rondônia, as cidades de Guajará-Mirim e Porto Velho, "pontas de trilhos" à época da construção (CORRÊA, 1987, p. 49-50).

${ }^{44}$ Em proximidade ao Acre, na divisa entre o Brasil e a Bolívia, em Rondônia, equivalente ao território Guaporé estabelecido em 1943, tornado Território de Rondônia em 1956 e Estado de Rondônia em 1982.

${ }^{45} \mathrm{Um}$ dos primeiros pesquisadores a desenvolverem trabalhos acadêmicos sobre a Amazônia, no âmbito da Arquitetura e Urbanismo. Publicou a tese desenvolvida na Universite de Paris, Études preliminaires en vue d'un urbanisme tropical pour l'Amazonie brésilienne, orientado por Pierre Mombeig, em 1972.
} 

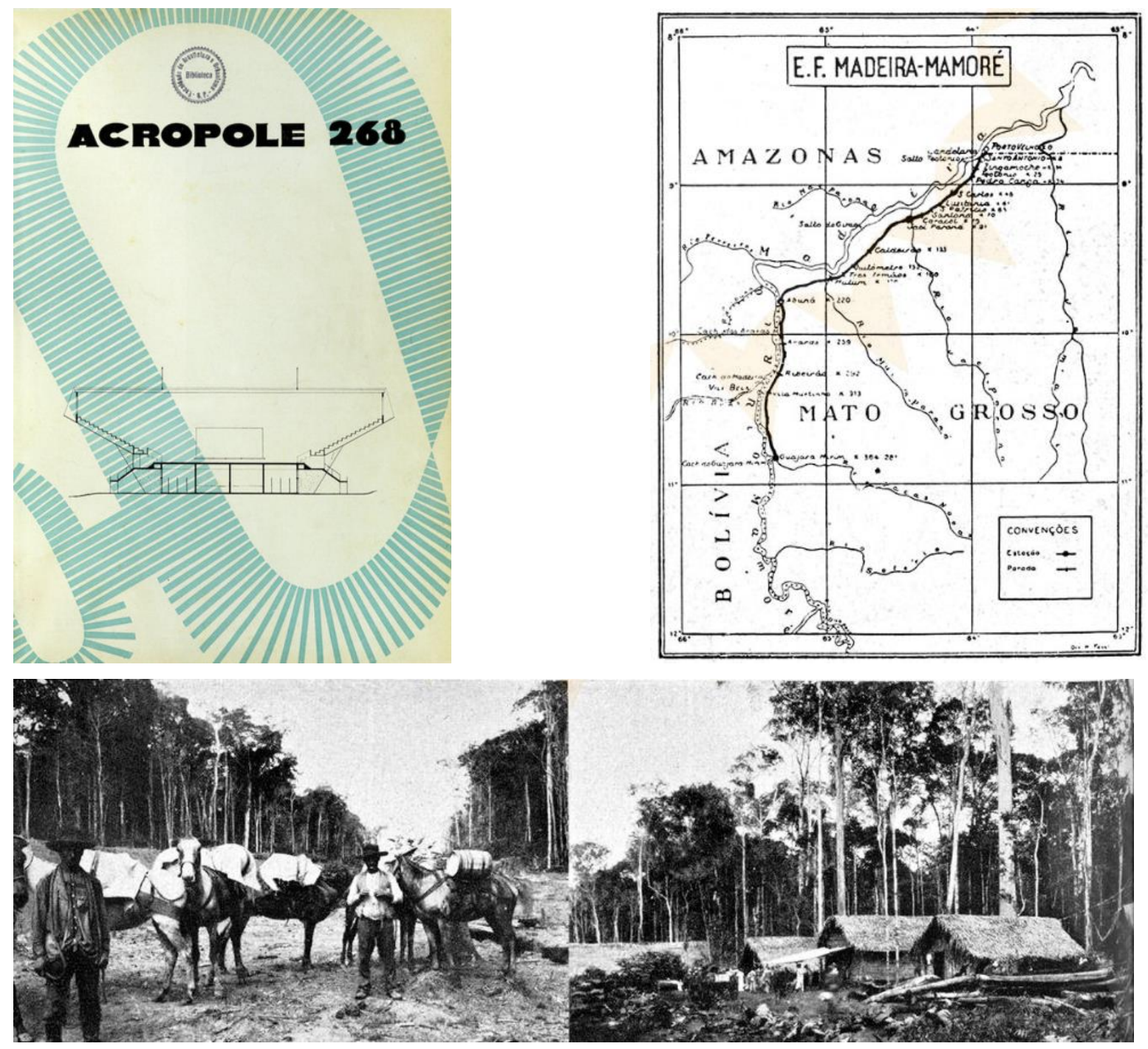

Figura 2 - Capa da revista Acrópole e imagens do artigo Estrada de Ferro Madeira-Mamoré. Esplendor e decadência da estrada da borracha, de Adhemar Chaves. Fonte: ACRÓPOLE n.268, 1961, p. 154-158.

Em entrevista publicada em 1918, o engenheiro civil de minas do Ministerio da Viação, José Pires do Rio ${ }^{46}$, em “excursão scientifica pelo desconhecido Norte do Paiz” com a finalidade de fiscalizar a obra da Madeira-Mamoré, teceu comentários sobre a modernização regional com o comércio da borracha, o teatro comparável ao de Belém, as ruas bem calçadas no centro urbano, os serviços de bonde e energia elétrica, e também o que viu "fora de Manáos". A navegação a vapor, com navios "muito superiores aos navios do Mississipi", onde "uma grande conquista em favor da civilização dessas terras virgens”,

${ }^{46}$ A entrevista foi publicada sob o título de "Excursão scientifica - Viaja pelo Norte competente engenheiro do Ministério da Viação. A capital entrevista-o á véspera de seu regresso". Como prefeito de São Paulo, contratou Francisco Prestes Maia para elaboração do Plano Urbanístico da cidade. No ano seguinte à entrevista, quando exercia o cargo de "inspetor federal das estradas de ferro Madeira-Mamoré e BelémBragança”, passou a ser ministro da viação e obras públicas do governo de Epitácio Pessoa entre 1919 e 1922. 
formou a paisagem apreendida de sua viagem pelas águas, onde identificou canoeiros e barracas de seringueiros e "habitantes ribeirinhos" nos afluentes do rio Amazonas. A respeito dos $364 \mathrm{Km}$ da "Madeira Mamoré”, aquele “centro civilizador de grande significação", ressaltou a incompatibilidade das medidas governamentais, "sem perfeita informação das ciscunstancias locaes”, para contestar o encaminhamento de sua execução (A CAPITAL N.305, 23 de maio de 1918 Anno II).

Observou que o "alto curso da mão de obra devido á insalubridade da região" era o motivo do "custo extraordinário da estrada", sem contar os valores de indenização, como em troca da incorporação do Acre ao território nacional quando da assinatura do Tratado de Petrópolis ${ }^{47}$. Na viagem “as casas teladas, á prova de mosquito” foram percebidas pelo engenheiro, como medida efetiva contra o impaludismo, para favorecimento do povoamento a seu ver, inevitável (A CAPITAL N.305, 23 de maio de 1918 Anno II). Alguns pontos da entrevista cedida ao repórter local, são pontes aos componentes explicativos de uma condição de projetos modernizadores na Amazônia brasileira. Assim como na epopeia extremada de Fitzcarraldo, ${ }^{48}$ a modernidade na região tem sido relacionada a processos de colonização cultural e exploração, a disputas e formas de resistência, a benefícios reais, também utópicos constituindo um quadro de controversa modernização. José Pires do Rio experimentava as temporalidades que na Amazônia eram perceptíveis a ele, sintetizadas na visualidade marcada pelas canoas e navios a vapor, das habitações ribeirinhas e da estrada de ferro.

No século XX, a delimitação da Amazônia junto ao Estado Nacional, como região, serviu ao planejamento econômico e territorial do país, em decorrência de interesses e articulações locais e nacionais. Para Daniel Chaves de Brito, no âmbito da colonização representada pela integração nacional e o planejamento estatal, a Amazônia se inseriu como um espaço suscetível ao sistema de mercado, frente seu expressivo potencial econômico (BRITO, 2001, p. 116). Do ponto de vista de uma política de desenvolvimento voltada à modernização conduzida, a Amazônia foi reduzida aos ideais de crescimento econômico governamentais e empresariais. Esta faceta da modernização também foi constitutiva da dualidade experimentada regionalmente, do "choque" entre modernidade e tradição,

\footnotetext{
${ }^{47}$ Assinado em 1903 entre os governos brasileiro e boliviano, na demarcação da fronteira entre ambos os países.

${ }^{48}$ Werner Herzog, 1981.
} 
justamente pela coexistência de distintas temporalidades em desarmonia. Assim, os enclaves modernos centraram todo o “instrumental de domínio da natureza” produzindo, cada vez mais, mecanismos de exclusão a populações locais. Deste modo, a "visão de um mundo em transformação” tem sido uma marca paradoxal e superficial da modernidade na Amazônia. A falta de lógica com que o Estado produziu mais contradições do que efetivamente empreendeu a modernização, provocou prejuízos sociais, ambientais e financeiros. Os impactos ao ambiente e à vida local resultaram justamente de incentivos do próprio Estado a empresas não lucrativas, arcando com os riscos das empreitadas de exploração regional no período em que atuou mais incisivamente no território amazônico, desde a década de 1960 (BRITO, 2001, p. 187-188).

O processo de urbanização na região, desta "difusão não homogênea da modernidade", tem sido reelaborado a partir da admissão de particulares e múltiplas temporalidades existentes na Amazônia, a exemplo da distinção estabelecida por Saint-Clair Cordeiro da Trindade Júnior. O geógrafo interpretou o espaço urbano na Amazônia demarcando a presença de núcleos desassociados das "atividades mais modernas e voltadas ao mercado externo". Admitindo sua condição cultural, as conferiu alteridade, distinguiu das "cidades na floresta”, formas de cidades em atendimento às demandas prioritariamente externas, "fazendo o ecossistema florestal um elemento de pouca integração aos novos valores da vida urbana”, como fruto de um processo de exploração econômica ou de negação do ecossistema florestal. Aqui incluiu as cidades-empresa como "bases logísticas" controladas por "corporações" e voltadas às demandas mercadológicas, absorvendo seus efeitos, nas formas de consumo, de comunicação, da expansão, da espacialidade, de cultura.

Neste grupo também estão situadas as cidades rodoviárias das frentes de expansão, relacionadas a processos migratórios induzidos pelo Estado. Fosse por meio dos projetos privados ou públicos de urbanismo para colonização rural ou como efeito da ação estatal, as cidades concentraram atividades exploratórias ou agrárias comunicadas à lógica de mercado externa. As “cidades da floresta” por outro lado foram dominantes até a década de 1960 se mantém no presente. São as cidades “pioneiras”, relacionadas à formação primal do território, núcleos presididos "por um tempo lento e dinamizados por atividades econômicas tradicionais", abarcando dimensões do rural e do urbano. Traço particular nesses núcleos é a predominância de habitantes de origem local culturalmente enraizados. 
As cidades ribeirinhas são o tipo mais representativo da absorção nos modos de vida nativos, dos elementos ambientais de várzea/rio/floresta além de relacionadas às práticas da agricultura não recentes, mesmo com a presença de migração do início do século XX. Mesmo que estejam "inseridas a lógicas globais, tendem a negar a exclusividade dessa mesma lógica”, seja nas práticas ou nos saberes (TRINDADE, 2013, p. 16-17). Saint-Clair Trindade as apresenta como "tipo ideais" de cidades que "contém o passado", como um produto de sua reflexão sobre a complexidade e multiplicidade de formas de vida urbana na Amazônia, tornando nítida a sincronia de diversas temporalidades naquela espacialidade e de distintas formas de produção, desde as quais é dinamizada uma "sociedade diversamente territorializada”. Justamente, ele as abarca pela leitura não unicamente de viés econômico, mas também da ordem do cultural, do social, que explica a Amazônia por sua “urbanodiversidade” (TRINDADE, 2013, p. 7-9).

Noutra linha de raciocínio, o lugar da Hinterlândia ${ }^{49}$ foi a imagem construída entre a mitificação e a realidade, delineado por aproximações, todavia não equivalente aos conceitos geográficos. Análogo ao "sertão", é lugar não afetado pela modernização, em proximidade a modos de vida relacionados à ruralidade ou àqueles enraizados e estreitamente vinculados à floresta e águas como nas cidades da floresta, conforme explicação de Saint-Clair Cordeiro da Trindade Júnior. Descolado da condição urbana afetada pela modernização, ${ }^{50}$ é aqui compreendido como uma construção cultural, um ideal, absorvido como premissa às novas formas de ocupação ideais, considerado o território amazônico e sua historicidade e as fronteiras de expansão, em suma, o espaço em vias de transformação. Mais do que nos termos apontados pela Geografia quando considera a Hinterlândia em interdependência econômica a outras centralidades, ou mesmo como espaço de iminente transformação, quando observado desde a perspectiva desenvolvimentista, como “sertão" (LIMA, 2014), a Hinterlândia, como aqui considerada, é uma imagem, uma paisagem imanente amazônica, tornada objeto de observação e ideação.

\footnotetext{
${ }^{49}$ Em livre interpretação, é considerada a Hinterlândia o lugar entre a mitificação e a realidade, estabelecido por aproximações, todavia não equivalente aos conceitos usuais da geografia. Pode se tratar da aproximação ao "sertão", ou ao lugar não afetado pela modernização, em aproximação também aos modos de vida relacionados à ruralidade, em sua condição histórica, de espaço pré-industrial, pode também estar aproximado aos modos de vida enraizados e estreitamente vinculados à floresta, como nas cidades da floresta, também em sentido aproximado.

${ }^{50}$ É possível que seja estabelecida uma relação com a definição já apresentada de Saint-Clair Trindade, para as "cidades da floresta".
} 
Seria portanto a expressão visual, representativa da oposição latente à modernidade e por isso forma de resistência em sua expressão limite, frente às condições das mais paradoxais decorrentes da modernidade na Amazônia, de acordo com a definição de Marta Gutman quando designa a modernidade como uma “unidade em desunião” (GUTMAN, 2015).

Para Danilo Araújo Fernandes, o "regional”, como forma valorativa de processos modernizadores na Amazônia, junto a modos de vida tipificados e à natureza, esteve atrelado diretamente ao discurso nacional-desenvolvimentista. De um lado, pela referência no âmbito local, a autores como Gilberto Freyre e sua conceituação de desenvolvimento regional, acrescida uma “tradição nacional-desenvolvimentista que terá na década de 50 seu período de auge com o aprofundamento do processo de substituição de importações e com a implantação do Plano de Metas por Juscelino Kubitstchek”. Foi então enraizada uma geração de intelectuais amazônidas, interessados em estudos regulares e sistemáticos a respeito do "ajuste do homem ao meio ecológico amazônico, assim como as possibilidades de seu processo de desenvolvimento”. Estes teriam sido “construtores e ideólogos” de uma “identidade regional” e de uma noção de "homem amazônico" ${ }^{51}$ tornados símbolos referenciais da região (FERNANDES, 2011, p. 53).

A perspectiva da Hinterlândia compreendida como um lugar mítico não alcançado pela modernização, também como uma expressão da paisagem elaborada em síntese para a Amazônia, pode ser identificada em distintos recortes, sobretudo como uma imagem em projeção, um lugar ideado e imprecisamente situado. $\mathrm{O}$ conceito aparece nos textos de intelectuais analisados por Danilo Araújo Fernandes, em curtos comentários proferidos por Arthur César Ferreira Reis ${ }^{52}$ e Djalma Batista ${ }^{53}$, "um dos grandes intelectuais amazonólogos

\footnotetext{
${ }^{51}$ Cabe a observação de Carlos Walter Porto Gonçalves a respeito dessas sociedades, já que "diversos povos que já habitavam há milhares de anos essa vasta porção territorial que se convencionou chamar de Amazônia, plasmaram ao longo do tempo diferentes territórios onde desenvolveram múltiplas culturas. Não tinham, em virtude disso, uma identidade única. Para os colonizadores, sim, eram nativos, eram índios, eram aborígenes expressões que, desse modo, os integrava numa única categoria. Eles eram, na verdade, não-brancos, uma primeira maneira de não-ser. Mais uma vez uma identidade atribuída por outrem e com a qual, quase sempre contra a qual, terão que se haver, reinventando suas identidades culturais/ territoriais nesse novo contexto" (GONÇALVES, 2008, p. 19)

${ }^{52}$ Historiador e político, ocupou cargos administrativos durante o governo militar, quando foi governador do estado do Amazonas, entre 1964 e 1967. Antes disso, teve trânsito nas estruturas de poder, tendo sido o primeiro presidente da SPVEA, em 1954, quando foi elaborado o primeiro programa de desenvolvimento regional.

${ }^{53}$ Médico interessado em saúde pública, foi diretor do INPA - Instituto Nacional de Pesquisas da Amazônia entre 1958 e 1959 e autor interessado no estudo de instituições científicas na Amazônia.
} 
do período desenvolvimentista das décadas de 50 e 60”. Tendo concebido a Amazônia como uma "unidade cultural”, foi atento às relações entre o regional e o nacional e contrário à uma posição determinista da Amazônia, a interpretou frente as razões de um subdesenvolvimento, avistando sua superação. Djalma Batista, se referia à Euclides da Cunha e a outros intelectuais como "homens de letras que haviam revelado a Amazônia aos brasileiros”. Para Danilo Araújo Fernandes esses escritores, políticos, médicos, foram atuantes desde a década de 1930, e mais fortemente nas décadas de 40 e 50 formaram uma “nova tradição de pensamento" sobreposta à trajetória "ecológica” de Euclides da Cunha (FERNANDES, 2011, p. 211;228).

Djalma Batista é situado por Danilo Araújo Fernandes na lista dos intelectuais que atuaram na formulação do pensamento "desenvolvimentista-regionalista amazônico". Em seu escrito "Da habitabilidade da Amazônia”, Djalma Batista mencionou a Hinterlândia. No texto, considerou em unidade a própria Amazônia como uma Hinterlândia, em seu estado de isolamento, em condição provavelmente periférica, caracterizada profundamente pelo traço de região subdesenvolvida. Uma Hinterlândia, à espera da modernização, uma Hinterlândia "sertão", para a qual vislumbrou um futuro de desenvolvimento. Aventava a dominação da terra, "pela técnica e pela ciência”, para que o homem aprimorasse sua cultura, “pela educação e pela higiene", numa sociedade de novas "diretrizes econômicas”. Ao responder à pergunta que fazia na publicação, "possui a Hinterlândia amazônica satisfatórias condições de habitabilidade?”, deu resposta afirmativa e otimista diante da possibilidade de seu aspirado desenvolvimento (BATISTA, 1965).

Para o historiador Arthur Cezar Reis, que ocupou o cargo de governador do Amazonas, a Hinterlândia foi caracterizada também como a totalidade amazônica, mas esta, como os confins, o lugar afastado, ao qual estava ainda assim, em sua análise. Condicionado aos seus domínios, como extensão do Estado nacional, aquele lugar era também o foco de sua atuação, "facilitando, coordenando, investindo, cooperando de modo a tornar certas áreas políticas e suas populações mais dinamizadas na sua ascenção”, se assim era o Nordeste, assim devia ser a Amazônia, como em suas palavras. A presença do Estado no Amazonas, deste modo, se daria para inclusive o controle de suas fronteiras e da Hinterlândia, como espaço de dispersão de habitantes (ARTHUR REIS, 1964, p. 219-222). 
Para Renan Freitas Pinto, um conjunto relativamente limitado de ideias formuladas na modernidade tem atravessado o tempo, constituindo o cerne do pensamento social sobre a Amazônia e influindo em explicações desta região como um "espaço natural e cultural", em acréscimo às suas transformações materiais. Ele atribui a este processo a construção de noções duais, a exemplo de "civilizado e primitivo", "modernidade e tradição", como atributos explicativos da Amazônia. As formulações de Euclides da Cunha, como exemplo, pertencentes a uma genealogia do pensamento da qual também fazem parte Leandro Tocantins e Gilberto Freyre, refletiu a busca pela "face primitiva” do Brasil, as desigualdades regionais e as condições de atraso, explicadas em razão de estágios distintos com que cada região, dada sua natureza, alcançou o desenvolvimento. A Amazônia estaria à margem da história justamente pelo seu estágio primitivo, em inadequação ao desenvolvimento e ao alcance civilizacional. Com esta análise, defendeu a atuação central do Estado para a modernização e desenvolvimento regional, medida que a tiraria de seu estado de natureza. $\mathrm{Na}$ literatura e nas representações culturais, este pensamento social foi abordado por autores como Alberto Rangel, para quem a natureza da Amazônia foi retratada em grandiosidade e mistério (PINTO, 2006).

Tais ideias mesclam-se aos processos de autodesignação dos próprios amazônidas, em que se pesem as concepções em circulação, impregnadas de alusões aos sentidos de um “imobilismo social” ou "conservadorismo romântico", como as reverberadas em designações a exemplo dos "povos da floresta" e "populações ribeirinhas”. Também as afetadas pela noção de condicionais implicações do meio geográfico ou climático ao desenvolvimento humano, tornado recurso explicativo desse lugar e das formas sociais ali ambientadas. Tais recursos fazem parte do pensamento social moderno, que sobretudo representam a Amazônia como lugar de natureza, também do selvagem e do primitivo (PINTO, 2005). Para Renan Freitas Pinto, no fluxo de uma tradição de ideias sobre o espaço referenciado na Amazônia, os escritos do Padre João Daniel ${ }^{54}$ foram propositivo de ideias para a colonização regional que viriam a ser repercutidas no século XX, travestidas de noções atreladas ao "luso tropicalismo", defendido no contexto de formulações intelectuais acerca da modernização regional, por autores como Gilberto Freyre, Arthur Cézar Ferreira

\footnotetext{
${ }^{54}$ Tesouro descoberto do rio das Amazonas foi um escrito produzido nos anos de cárcere, a partir da rememoração de seus anos de vivência missionária na Amazônia entre 1741 e 1757. Foi preso em Belém, após o banimento dos jesuítas do Brasil em 1759. Sua obra foi publicada integralmente em 1976.
} 
Reis, Leandro Tocantins, ou à “amazonotropicologia”, elaborada por este último na década de 1960 (PINTO, 2006).

Nesta trilha, a tese de Odenei de Souza Ribeiro aborda a perspectiva de Leandro Tocantins para a complexidade cultural da Amazônia a partir de referências do regionalismo de Recife e do movimento modernista prevalente no eixo Rio-São Paulo. Se por um lado o escritor explicou a fusão entre portugueses e índios na determinação formativa de uma identidade regional possibilitada pela atividade econômica do extrativismo e pelo ambiente tropical, sua instabilidade econômica seria motriz a um desenvolvimento de base industrial, sob o incentivo estatal, que viabilizasse a modernização e a perduração da economia regional (RIBEIRO, 2012).

Para Danilo Araújo Fernandes, as obras de Leandro Tocantins e Arthur Reis foram aquelas que fundamentaram o pensamento de adaptação ecológica do "homem amazônico", assim tipificado, ao meio, sob a influência direta dos escritos de Euclides da Cunha e Gilberto Freyre (FERNANDES, 2011, p. 245-246):

No total, o conjunto das obras destes dois autores - escritas em sua maioria nas décadas de 50 e 60 - representa de certa forma o espírito da intelectualidade mais sofisticada da época, responsável pela elaboração de um discurso culturalista e ecológico em íntima ligação com o tratamento da questão regional brasileira. Em comum, a influência marcante de Euclides da Cunha e Gilberto Freyre, além de um forte apreço pela necessidade de valorização da cultura regional enquanto ingrediente de um projeto de valorização econômica da Amazônia. Um projeto que busca, ao mesmo tempo, uma estratégia de conciliação entre o projeto nacionalista e de industrialização do país; e um projeto intelectual de matriz tropicológica (a chamada Amazontropicologia), que visa compreender o papel da cultura regional como ingrediente ecológico de sustentação do bioma amazônico, em uma linha de pensamento muito próxima à lusotropicologia de Gilberto Freyre.

Desta relação é possível estabelecer a ponte dos efeitos de seus textos, junto a outros, como do arquiteto Luiz de Miranda Corrêa, nas revistas de arquitetura. Seu papel como participante do corpo editorial, a partir da década de 1960 nas publicações da Revista Arquitetura- IAB RJ ${ }^{55}$, bem como o estreitamento discursivo e a sustentação que sua escrita estabeleceu com a materialidade da arquitetura a qual apareceu articulada, como na revista

\footnotetext{
${ }^{55}$ Esta revista circulava entre todos os arquitetos que exerciam a profissão, bem como escritórios técnicos e construtoras, instituições de ensino superior nacionais e estrangeiras, além de outras instituições ligadas à Arquitetura e Urbanismo, conforme afirmado no expediente da própria publicação.
} 
ABA (ABA N.1, 1967-68), foi motivo para o desenvolvimento do segundo tópico do terceiro capítulo. Deste modo, as ideias presentes nos escritos do Padre João Daniel, desenroladas na perspectiva colonizadora interpretada sob a luz do século XX, do desenvolvimento das populações nativas em seu ambiente físico, baseando-se nos questionamentos que fez ao próprio processo colonizador, o distinguiu de posturas como a de Georges-Louis Buffon, ${ }^{56}$ para quem o determinismo geográfico seria condicional à estagnação dos modos de vida locais ${ }^{57}$. Esta seria uma referência muito presente nas formulações de Leandro Tocantins.

A obra adveio de sua "experiência ecológica” (TOCANTINS, 1976, p. 22), tornada um "grande projeto para a Amazônia”, inclusos o ambiente, os meios técnicos, as formas de organização social, em defesa do que seria "terra onde os homens poderiam desfrutar de abundância e riqueza”. Pensando no ordenamento daquele mundo natural, revelou o apego às paisagens delineadas nos dois séculos anteriores ao de sua escrita, à prática da distinção e julgo dos modos de vida nativos, para os quais previu um condicionamento às novas formas produtivas (COSTA, 2002). As ideias do religioso sobre a cidade, espaço de um novo modelo de ocupação no século XVIII, para a dinamização econômica e inserção das comunidades nativas em "novos padrões de sociabilidade", e numa economia revigorada, foi assim tornada uma construção aproximada à projetiva (PINTO, 2005, p. 107-108):

[...] 1) a arquitetura deve ser concebida levando-se em conta, em primeiro lugar, que a região é equatorial e tropical e tem como topografia dominante áreas de extensas planícies cortadas por inúmeros rios. Além disso, a região dispõe de uma grande quantidade e variedade de materiais que devem ser combinados para a construção [...];2) o traçado das cidades, vilas e demais aglomerações deveria considerar como primeira regra um tamanho limitado para balizar o crescimento urbano e assim evitar o excesso de aglomeração populacional que comprometeria uma distribuição humana equilibrada pelo território. [...]

\footnotetext{
${ }^{56}$ Se referia à "imaturidade do continente americano, à debilidade dos autóctones, à degeneração das espécies animais americanas em comparação às do Velho Mundo, à decadência da natureza na América”. (BUENO, 2002, p. 45)

${ }^{57}$ O Professor Renan Freitas Pinto reforçou esta relação mais direta em palestra proferida em 20 de março de 2019, no Auditório Rio Negro da Universidade Federal do Amazonas. Em sua exposição, especulou sobre uma tradição de pensamento, inaugurada pelos escritos de Padre João Daniel, o qual enunciou como "provavelmente o primeiro lusotropicalista", um "protolusotropicalista", seguido por Gilberto Freyre, Arthur Reis, e por conseguinte Leandro Tocantins. Os levantamentos realizados durante a pesquisa, em revistas de arquitetura, nas quais figuraram os nomes de Arthur Reis e Leandro Tocantins informavam terem sido colaboradores, o segundo, a partir do número 14, de agosto de 1963, de publicações do Instituto de Arquitetos do Brasil, aspecto este, mais bem desenvolvido no capítulo 3 desta tese.
} 
Esta concepção de paisagem em projeção, repertoriada em componentes tipificados em um ambiente da Amazônia, tomada e antevista como unidade, demarcou a condição ideal para a produção material de edificações e cidades, sob a premissa da adequação, desde sua fusão às ideias ocidentais de modernização. A condição equatorial, tropical, a topografia dominante de extensas planícies, o potencial hídrico, os variados materiais disponíveis, resultariam numa síntese, formativa da "bíblia ecológica" ${ }^{58}$ do Padre João Daniel. Ele incluiu como formulação, certa arquitetura, formas de arranjo urbano, sob o argumento da consonância com o meio, com os "lugares amazontropicais". $\mathrm{Na}$ introdução que fez à publicação de 1976, portanto como leitor desse tempo, Leandro Tocantins o interpretou como um "afeiçoado ao mundo amazontropical, curioso das farsas e das realidades da Natureza”, como (TOCANTINS, 1976, p. 16-17):

Um reflexionador, o Padre João Daniel, cheio de fé no progresso tropical, um homem em quem o fenômeno da esperança [...] ergue-se em potência de ativação de vida.

Todos três portugueses tropicalistas, antecipadores de uma nova ciência a Tropicalogia - que hoje se sistematiza, se metodiza a favor de uma Ecologia adequada ao equilíbrio biótico, e assim favorecendo a presença e a criação do homem em processo de Civilização. Presença permanente, plena, integrativa, nos trópicos. Aliás, Tropicologia sugerida por um brasileiro, Gilberto Freyre, tropicólogo por direito de conquista e de apostolado. Ele mesmo sistematizador desse novo campo de estudos, a ser ciência, começo de preocupação do mundo.

$[\ldots]$

Ironia do destino (com desculpa do lugar-comum), o que fez João Daniel senão antecipar-se ou juntar-se ao afã modernizador do Marquês, escrevendo obra em que a filosofia do Iluminismo se deixa transparecer ao leitor de hoje do Tesouro com perspectiva de espaço e tempo, dentro da ordem e forma que a realidade tome para quem o examine.

$\mathrm{Na}$ interpretação de Leandro Tocantins, os comparativos estabelecidos por João Daniel às formas de organização produtiva ocidentais as quais os "naturais” já eram nesses tempos coloniais, ativos como força de trabalho, os adaptou em suas proposições às técnicas pretendidas para a “modernização dos ofícios”. Para tanto aplicou uma "ciência nessas áreas

\footnotetext{
${ }^{58}$ Termo utilizado na introdução à publicação de 1976, por Leandro Tocantins. Ressaltar a publicação nesse ano de 1976 de Leandro Tocantins, que fala sobre os "reveladores de nossa natureza", como se fosse uma "Nossa Senhora Ecológica" (p.10) e especuladores da Amazônia. Leandro Tocantins apela às memórias, às suas e às possíveis que elabora para o missionário, ele próprio, mitificando o espaço que partilharam em tempos distanciados, mas demarcado pela "beira", ponte ao mundo luso, fosse de uma paisagem partilhada, a da beira portuguesa, a da belenense amazônica, a beira em seu "poder telúrico" . Incluiu no rol dos amazontropicologistas, Alexandre Rodrigues Ferreira e Antonio José Landi. (TOCANTINS, 1976, p. 11).
} 
amazontropicais”, nas quais fundiu ideais modernizadores àqueles religiosos, que lhe eram caros (TOCANTINS, 1976, p. 20), preenchendo sua imaginação com a imanente paisagem de uma Amazônia como Éden, ${ }^{59}$ sintetizada em unidade natural primordial. Também lugar onde partilhou da experiência vivida com os nativos, com os quais apreendeu seu "desprezo" pelas "riquezas", sua "habilidade e aptidão" para a lida com o ambiente, pelo modo de vida em descompasso com o europeu, sob as marcas do sofrimento causado pela escravização (TOCANTINS, 1976, p. 201-202; 250), lugar dos inúmeros recursos naturais que descreveu.

A nominação motivada pelo impulso enciclopédico de catalogar, frente ao que lhe havia provocado estranhamento, foi resgatada das memórias desde a experiência com o ambiente sobre o qual João Daniel empreendeu sua escrita. Assim como ele, desde os primeiros cronistas, viajantes, artistas, cientistas, despertos ao contato com o Mundo Novo, ainda que tenham variado em sua procedência ou temporalidade, "diante do rio e da mata amazônicos, quase genericamente, nenhum se isentou de externalizar sentimentos que variavam do primitivismo pré-edênico ao infernismo primordial”. Mesmo familiarizados na região, registraram a afetação aos "olhos renascidos na contemplação extasiada da grandiloquência natural” (GONDIM, 2007, p. 77).

A paisagem sintetizada na imagem da "floresta" foi deste modo, um produto exógeno e dominante como representação da Amazônia, diante das tentativas de explicação de uma totalidade inapreensível unicamente pela experiência, conforme explica Magali Bueno $^{60}$. Desde o interior, a Amazônia, como paisagem, é pouco nomeada como tal, já que tem sido o espaço de quem a experimenta e aos lugares nela situados, raramente percebidos em panorama, dada a imersão e o olhar naturalizado de quem os habita. A paisagem, portanto, como forma de compreensão unitária da Amazônia, tem consistido, sobretudo, na representação de um lugar “almejado” e “pretendido” (BUENO, 2002, p. 167-168):

A visão exógena de Amazônia atribui, através do conceito de região, uma feição característica para a Amazônia. Essa atribuição ou caracterização

\footnotetext{
${ }^{59}$ Aqui é referencial o atributo proferido por Euclides da Cunha, para quem João Daniel fora um "imaginoso", frente sua capacidade potencial de antevisão da modernização amazônica. Sua capacidade de antecipação e ligação do passado e futuro. Tratou-se de uma "imaginação sociológica", como afirmou Leandro Tocantins (TOCANTINS, 1976, p. 21).

${ }^{60}$ A autora evidencia em seu trabalho o quanto a visão exógena se sobrepõe às experiências locais, ao tratar do imaginário nacional sobre a Amazônia em distintos meios, como os proferidos por viajantes, pelo Estado, presentes na mídia e nos livros didáticos.
} 
acontece em determinados momentos como instituição política, em outros como qualificação, inserida num determinado momento histórico. A qualificação e mesmo a delimitação da área, criando a região $-\mathrm{e}$, concomitantemente, definindo a paisagem —, está inserida num determinado momento histórico, portanto inserida nas condições da sociedade que a produziu. Exploradores, jornalistas, escritores, planejadores, professores, políticos, enfim, todos que veem a Amazônia a partir de um distanciamento, criam dela uma imagem que terá características diferenciadas de acordo com o momento histórico que a produziu.

Esta acepção faz equivalência entre paisagem e imagem, produto da apreensão pelos sentidos e da percepção direta, mas sobretudo de sua fusão ao próprio imaginário, o que conferiria à paisagem, um sentido da ordem do simbólico. Esta paisagem narrada tanto seria adensada pelos conteúdos naturalizados de tempos pregressos, quanto reelaborada no tempo corrente, como formulação transposta a elementos com os quais se daria a tentativa de representação de uma Amazônia em extrapolação ao lugar geográfico. Esta perspectiva também emergiu da Geografia cultural dos anos de 1970, que considerou o componente cultural para o redirecionamento da leitura de seus próprios objetos de trabalho, assim como a História (CORRÊA, 2007). Se por um lado essas formas simbólicas representaram o lugar em síntese, por outro, proferiram sentidos propositados, socialmente construídos e articulados à dominação e conformação territorial pelo estabelecimento de fronteiras. ${ }^{61}$

A categoria da "paisagem” é oportuna à compreensão da Amazônia como elaboração da cultura, em particular, por ter sido refletida na prática da Arquitetura e em suas representações textuais. Neste caso, a paisagem comporta uma dimensão eminentemente cultural. Num primeiro viés, a paisagem é compreendida em construções narrativas, portanto elaborada por meio da linguagem escrita ou visual. Referenciadas no lugar, tais representações não se isentam por completo do lugar, o adensam em síntese. Interessa à tese a dimensão textualizada da narrativa, seja em evocações históricas ou em elaborações sintéticas do território, em aproximação a este, em menor ou maior grau. Por definição, as “figurações paisagísticas” ou a "retórica da paisagem”, são dados circunstanciais aos contínuos ajustes de conhecimento sobre o “real”, mas também, são produzidos pelo juízo

\footnotetext{
${ }^{61}$ Embora não tenha sido desenvolvido o aporte nessa linha de análise, cabe mencionar a produção de Rogério Haesbaert, no que tange a discussão a respeito de processos interpretados desde a Geografia, pautados pela relação entre a construção política da imagem culturalmente geografada e as dinâmicas espaciais de territorialização.
} 
seletivo pautado na realidade geográfica, entre sua subjetividade e sua concretude, já que (MACIEL, 2009, p. 32-33):

[...] é a partir de uma carga simbólica narrativamente referenciada nos espaços de vida que se constrói uma compreensão das conexões e recortes históricos, sociais e biográficos envolvidos em representações espaciais mais abrangentes. É possível, portanto, sublinhar o papel das simbologias paisagísticas, uma vez que estas permitiriam ao sujeito um salto abstrato e não aleatório desde os espaços imediatos da existência até o alhures.

Graciela Silvestri explica a paisagem ao localizá-la entre o imaterial e o material, para além de uma condição física estável, pelo quanto é capaz de abarcar o simbólico, condensar significados e constituir, pelos testemunhos com que foram relacionados objetos naturais e artificiais, representações significativas, ainda que não totalizantes (SILVESTRI, 2003). E os textos difundidos sobre a Amazônia em sua condição de paisagem, alimentaram um imaginário que a fez circular em recorte geográfico, sobretudo em distanciamento e aproximação ao espaço da experiência e do cotidiano. Da separação entre homem e mundo que emerge outro significado da paisagem pelo qual esta categoria também tem sido tratada em enfoques culturais, como os apresentados por Fernando Aliata e Graciela Silvestri. Para eles, a paisagem fornece a chance de compreensão e interpretação dos vínculos e das formas de relação entre artefatos humanos e natureza, mantidos neste ínterim, os valores e os resultantes estéticos que pautam este arranjo entre cultura e natureza. A paisagem é compreendida como unidade apreensível, mas detentora de propriedades propícias à decodificação e à projeção. Ela não é um dado passivo, mas uma construção da própria cultura e das formas construídas pela e para a apreensão (ALIATA e SILVESTRI, 2008, p. 12-13):

Para que exista uma paisagem não basta que exista "natureza”; é necessário um ponto de vista e um espectador; é necessário, também um relato que dê sentido ao que se vê e experimenta; é consubstancial à paisagem, portanto, à separação entre o homem e o mundo. Não se trata de uma separação total, entretanto, mas de uma ambígua forma de relação, onde o que se olha se reconstrói a partir de recordações, perdas, nostalgias próprias e alheias, que remetem às vezes aos larguíssimos períodos da sensibilidade humana, outras a modas efêmeras. O olhar paisagístico é o olhar do exilado, daquele que conhece sua estranheza radical com as coisas, mas recorda ou, melhor, constrói um passado, uma memória, um sentido.

$[\ldots]$

O olhar paisagístico, em efeito, é sempre um olhar estético, no sentido amplo da palavra, que indica uma conexão inseparável entre forma percebida e sentida. 
Nicolau Sevcenko, desde uma perspectiva das sensibilidades, discorre sobre a paisagem brasileira no contexto da colonização, como uma construção cultural, produto de um "jogo de olhares" entre europeus e brasileiros e destes ao seu território. A colonização conformou a exploração e, neste sentido, para o europeu o Brasil era o "sertão bravio", impulsionando o desbravamento e o rompimento daquela "virgindade nativa", o controle e a imposição sobre a natureza, já que desprendido da Europa o que vê o colonizador é unicamente o desejo de conquista e não a "paisagem como projeção desejante". Era mais simplesmente a exploração predatória. Mas a "visibilidade da paisagem" na colonização do Brasil, foi também objeto de desejo, "o desejo pelo desconhecido, a vontade de conquistar", da parte dos que veem a paisagem como "ato de adoração", a "percepção sensual da paisagem", produto de sua interpretação da natureza como objeto de desejo (SEVCENKO, 1996).

Uma "forma vaga e melancólica de nostalgia" (SEVCENKO, 1996) pode ser identificada em relação à modernização na Amazônia, à sua radicalidade e a seus particularismos, produzida pela intrincada prospecção da paisagem e de seus artifícios, neste processo. A Hinterlândia formulada pelo intelecto, constituiu o imaginário desde a memória, compondo uma certa visualidade com a qual novas paisagens viriam a ser prospectadas, especialmente pelo projeto. Com a tese são debatidos os textos e as obras, quando resgatada a dualidade imanente à trajetória do urbano na Amazônia, como território e representação cultural. Esta dualidade, com certa liberdade interpretativa, nos textos e prospeç̧ões da paisagem na Amazônia pela prática de Arquitetura e Urbanismo, transitou nos anos em análise, entre o instintivo desbravamento, a romântica possibilidade de perpetuação da condição de natureza, a irremediável perda, a tentativa conciliação, raro em desconsideração ao contexto amazônico.

A paisagem unifica as nuances do território e o adensa, como síntese. Por isso ela está latente nos projetos que compõem o último capítulo deste trabalho. Neles, a paisagem foi o fio condutor do projeto. São exemplares da tese de que na relação entre a prática de projeto e suas formulações discursivas, quando a Amazônia foi absorvida em condição de paisagem, foi também convertida a um tema determinante e central da reflexão na prática do projeto. A paisagem, como forma de incorporação da Amazônia ao projeto, seu 
problema central, não é considerada unicamente uma categoria geográfica fisicamente estrita ou passível à apreciação estética, mas sobretudo "um valor, uma dimensão do discurso e da vida humana”, fruto da relação experienciada entre homem e a terra e de imagens pregressas conformadoras de uma “cultura do olhar” (BESSE, 2019).

A paisagem prospectada pelos arquitetos para a Amazônia é revelada em suas obras e extensivamente ao que representaram os textos, ideadas a partir da evocação de imagens produzidas pelo olhar cultivado acerca do território da Amazônia, em longa duração. Ainda que polissêmica, ancora uma questão fundamental da prática de Arquitetura e Urbanismo quando de encontro com a temática da Amazônia. Esta formulação transparece da forma com que a produção foi dada a ver nas fontes amplamente levantadas, em como nos textos foram operados a seleção e o argumento acerca dos projetos tornados referenciais àquele lugar. Nas fontes é muito presente, ainda que não seja a única mediação identificada, uma Amazônia paisagem, absorvida como problema central ao projeto de Arquitetura, e como argumento explicativo deste.

É elementar que a atividade de projeto não prescinda da paisagem e exemplos já clássicos têm marcado, na disciplina, o condicionamento estrito entre a formulação de objetos da Arquitetura e a reestruturação de paisagens, ou sua incorporação ao projeto, como na relação entre ambiente e projeto moderno reivindicada pela vanguarda $\mathrm{da}$ Arquitetura e Urbanismo no Brasil. Em obras de Gregori Warchavchik ou Lúcio Costa para quem a natureza é constitutiva dos ideais culturais de modernidade, ou mesmo no caso da "segunda natureza tropical" de Burle Marx, extensiva à arquitetura, a natureza compreendida como paisagem é componente da cultura e do projeto, como explicam Fernando Aliata e Graciela Silvestri ${ }^{62}$. Também, Le Corbusier considera a formulação de paisagem em suas utopias urbanas para cidades na América Latina, carregadas de estratégias de visualidade, quando "a borda entre o ambiente natural e o território urbano ocupado por uma lamina contínua ou grupos de arranha-céus constitui-se em ditas cidades como a demonstração didática das possibilidades da civilização maquinista”. Também o confronto

\footnotetext{
${ }^{62}$ Para os autores, a indistinção entre o "primitivismo" e o "naturalismo exótico", contribuiu para centrar a arte vanguardista no Brasil na construção dos particularismos fundantes da "condição nacional", o que por outro lado guiou "impulsos" de a "periferia reconhecer-se como tal", homogeneizando a cultura, inclusa a "natureza tropical", para a elaboração de uma concepção de nacionalidade brasileira, desde a década de 1920 (ALIATA e SILVESTRI, 2008).
} 
entre a natureza como paisagem em relação às formas de desenvolvimento modernizadoras, foi importante pauta de discussão na América Latina, nos anos de 1960 e 1970, desde quando (ALIATA e SILVESTRI, 2008, p. 208-213):

as considerações sobre a relação entre arquitetura e ambiente natural aparecem tingidas por concepções bastante diferentes ao otimismo intervencionista dos anos anteriores, quando a natureza era vista ainda como um sujeito neutro, cuja característica essencial se resumia na resistência à transformação civilizadora. Os principais fatores que contribuem à mudança geral na concepção do problema radicam na crise energética dos anos 1973 e no amadurecimento da ciência ecológica que converte imagem de uma natureza hostil e imutável em uma frágil estrutura cuja modificação é permanente e problemática.

Josep Maria Montaner trata da ideia de como a leitura exógena sobre a América Latina, a partir da Europa, a concebeu como reserva de natureza e o quanto a paisagem, categoria relacionada ao meio ambiente e à conformação territorial, que esteve presente na construção de cidades e da arquitetura, quando "a paisagem foi determinante para uma boa parte da arquitetura e urbanismo americanos”, mantida como elemento importante, já que “representa a sobrevivência de uma natureza, que do outro lado do oceano, a Europa acabou sacrificando motivada pela Revolução Industrial”. Em sua fala transparece a correlação entre a paisagem prospectada e a paisagem como referenciada em uma geografia da natureza, quando a relaciona à “sobrevivência de uma natureza” atestada na América (MONTANER, 2014, p. 21-24). Na conjuntura da América Latina, esta leitura sintética acerca da ruptura dos paradigmas sobre a paisagem na década de 1970, frente a novas concepções sobre a natureza, é extensiva à Amazônia.

Os juízos acerca da natureza, nos anos de 1960, foram atravessados pelo ecologismo em associação a imagens da presença do Estado Nacional e à modernização do território da Amazônia brasileira, como já mencionado. Interpretações de paisagem passaram tanto a integrar imagens de urbanidade prospectadas para a Amazônia nos anos de 1970, como articular junto à paisagem mais próxima do conhecimento do território em transformação, valores preservacionistas. A Amazônia como paisagem, sob diversos matizes, foi convertida em problema e consequentemente argumento de projeto, suscitando interpretações por parte dos arquitetos que não prescindiram de adotar miradas abrangentes do território, tendo sido resgatadas para tanto, imagens simbólicas e evocações históricas. A concepção da Amazônia como paisagem, do ponto de vista da captura sintética do território para 
construção de uma certa materialidade, dadas as reformulações materiais propiciadas pelo projeto, antevê a paisagem conformada pelos objetos em sua articulação inevitável ao meio natural.

Pelas vias da elaboração da paisagem, a Amazônia adquiriu unidade de sentido também em confronto com sua complexidade sócio espacial. De modo oscilante, as significações associadas à Amazônia como uma paisagem, foram atravessadas pelo ocultamento de processos internos ao território e conformaram visadas abrangentes e homogeneizadoras deste. Na própria trajetória histórica da Amazônia brasileira, essas formulações transcorreram consonantes a disputas, sendo por vezes apropriadas para fins outros, como ao controle e à exploração econômica. Foram formulações que emergiram de processos conjunturais complexos e contribuíram para o estabelecimento dos cortes histórico temporais e dos objetos arquitetônicos referenciais desta tese, especialmente os situados no terceiro e no quarto capítulos.

Mudanças nos paradigmas de compreensão da natureza no século XX conferiram à paisagem enfoques bastante distintos, especialmente os refletidos na interpretação no campo da Arquitetura e Urbanismo que determinaram o encerramento do recorte da tese. A década de 1980 é identificada como um período divisor para a Arquitetura e Urbanismo na Amazônia, como refletido nas publicações pesquisadas e nas práticas da disciplina nelas registradas. A projeção da natureza como recurso limitado, o fortalecimento de vertentes do pensamento ligadas ao ecologismo dos anos de 1960 e aos movimentos sociais reativos à presença intervencionista do Estado, foram pano de fundo à absorção de uma arquitetura representativa do paradigma ético da preservação ambiental. Sua estética, ancorada na valoração da memória sintetizada no saber vernáculo, posto que textualmente significada pelo estreitamento com os componentes visuais da Amazônia paisagem, foi fruto de uma "ligação intelectual, não natural, com a tradição". Esta definição estabelece pontes conceituais com a leitura de Claudia Costa Cabral e Helena Bender, que atestam o agenciamento do primitivo pela arquitetura e arte moderna na América Latina, quando pensadas "para uma modernidade universal", numa interpretação intelectual do vernáculo que conforma o que denominam de "primitivismo" (CABRAL e BENDER, 2017), que no caso da Amazônia, como aqui defendido, possui a particularidade de ajustamento à condição de uma Amazônia paisagem. 
Esta paisagem guarda relação com o imaginário, naturalizado e reproduzido, com os modos de vida não modificados diretamente pela modernidade - práticas e saberes em dependência ao entorno natural - e com o plano da formulação, quando a Amazônia, nos textos e na materialidade, é objetificada em síntese pela Arquitetura. Esta composição da Amazônia como paisagem foi identificada nos textos que lhe fizeram referência, presentes em revistas e publicações de teor histórico entre 1934 e 1989. O período, marcado pelo planejamento e produção do espaço estatal na Amazônia, equivaleu para a Arquitetura, em aproximação temporal, à formulação e dissolução do movimento voltado à unidade disciplinar e a afirmação profissional no país, seu relativo alcance e dissolução, até a absorção pelo próprio campo, das pluralidades e regionalidades, na conjuntura da redemocratização do país. Neste curso, como a Amazônia compareceu nas revistas e textos referenciais e como as representações a respeito desse lugar acresceram à explicação da materialidade das obras que estavam sendo reportadas nas publicações? A principal hipótese que pautou o trabalho foi a de que as mediações textuais da Arquitetura desenvolvida na Amazônia foram extensivas às representações da Amazônia como paisagem. Essas representações foram postas em relação às práticas de projeto, que em crescente as absorveu, conformando um fenômeno passível à apreciação em leitura histórica.

A leitura da centralidade da Amazônia no campo disciplinar da Arquitetura e Urbanismo, incluindo a eleição de seus objetos referenciais, adveio do regime de (in)visibilidade com que ela foi dada a ver nas fontes, com suas obras referenciais legitimadas pelo trato do juízo crítico que as mediou nas revistas. Nos dois casos, como construção simbólica ou material, em um período bastante particular de modernização controversa do território, a Amazônia foi tema central ao projeto, absorvida como paisagem simbólica, mítica e memorial, complementarmente, como paisagem prospectada de um espaço em plena transformação. Uma paisagem imaginada por projetistas foi sendo ressignificada, construída sobre o passado memorial, tendo no projeto de Arquitetura, em recorte, sua possibilidade de concretização.

Dessa forma, a paisagem é elaboração, fruto da invenção e da intervenção material em espaços recém transformados e afetados pelo artifício, em aportes cada vez mais aproximados de leituras do lugar. Nos anos em pauta, aos projetos, foi gradativamente sendo transposto um conhecimento cada vez mais aproximado da Amazônia brasileira que 
centrou no Brasil a discussão acerca dos ideais de uma Arquitetura em adequação ao meio socioambiental, sob a pauta preservacionista da década de 1980, também balizada pelos lampejos de um regionalismo frequentemente referenciado na Amazônia. No entanto, aspecto que tem acompanhado a ocupação humana da Amazônia tem sido a presença de "imensa biodiversidade", grande "variabilidade geográfica" e consequente "variabilidade de formas de vida" e de culturas, o que torna equivocado considerar a existência de um único padrão sociopolítico e de modos de vida das populações pré-coloniais (NEVES, 2006), denotando variadas tradições que vem à tona quando observada a Amazônia em retrospecto. Diante da variabilidade socioambiental, geográfica, que condição inteligível, abarcado o território, poderia ser vislumbrada e servir de base à interpretação histórica desde a Arquitetura e Urbanismo na Amazônia, senão o de síntese, evocada das memórias construídas? Na prática e teoria da Arquitetura, a Paisagem aparece nos textos como essa possibilidade de síntese, no fluxo da modernidade. 



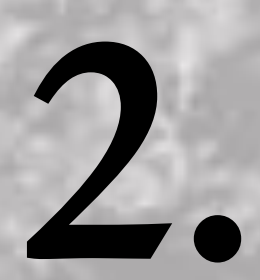

Fontes documentais e a Amazônia na Arquitetura e Urbanismo no Brasil 
Neste capítulo são abordadas as mediações textuais da arquitetura na condição de recursos para a compreensão histórica desta prática disciplinar. Nele deve ser justificada a escolha das fontes utilizadas na pesquisa que teve como objeto a Amazônia, bem como situá-la no curso da escrita de teor histórico sobre a Arquitetura e Urbanismo nos anos em análise, considerando que as representações presentes nas fontes textuais proferiram significados a ambas, Arquitetura e Amazônia. Foram consideradas, em específico, os registros textuais, prioritariamente publicados em revistas especializadas, além de outras fontes escritas e visuais quando relacionadas ao conteúdo das primeiras. Esta modalidade de leitura histórica leva a duas reflexóes de partida: uma mais restrita à análise da Arquitetura, por se tratar de objeto material, outra do âmbito da História, abrange a categoria das representações. Neste tópico, são feitas aproximações às duas reflexóes, para apresentação das fontes documentais utilizadas em resposta aos objetivos delineados para a realização da pesquisa sobre a qual se assenta a presente tese, de leitura histórica de textos e obras com foco na Amazônia brasileira, entre 1934 e 1989, bem como é localizada a Amazônia no curso da historiografia prevalente sobre a arquitetura no Brasil nesses anos.

Imagem: Reprodução de capa da revista CJ Arquitetura. Fonte: CJ ARQUITETURA n.20, 1978. 


\subsection{Mediações da Arquitetura e as fontes documentais da pesquisa}

Os textos têm servido de suporte a conteúdos próprios da Arquitetura, no interior da prática ou na exterioridade da atividade interpretativa que a inscreve no âmbito disciplinar. Neste segundo caso, os textos incidem sobre a prática de projeto, especialmente quando formulados em Teoria, Crítica ou como história. Eles estão situados na base constitutiva da cultura da disciplina, em origem, como recurso primeiro ao registro de seus fundamentos. Desde então, possibilitaram o intercâmbio da prática com a escrita, e mesmo numa moderna arquitetura, a “analogia linguística resistirá na infraestrutura do pensamento projetual”, ainda que essa mesma arquitetura tenha sido fomulada como um texto, com seus códigos próprios disponíveis à leitura. Para Guilherme Lassance, Gustavo Rocha-Peixoto, Laís Bronstein e Beatriz Santos de Oliveira, a arquitetura, na cotemporaneidade (LASSANCE, ROCHA-PEIXOTO, et al., 2010, p. 21-22):

Sem precedentes, ela dependerá da própria ação literária do meio profissional para comunicar seus propósitos. Apesar da severa crítica ao estatuto da interpretação, os escritos sobre a arquitetura virão, em escala inédita, responder às funções que sempre lhe couberam do juízo, da mediação e da legitimação. Tudo indica que nunca, como agora, estiveram tão atados os nós da arquitetura e do texto.

A complementaridade do texto à arquitetura, ainda que seja uma noção que remeta a certa objetividade ${ }^{63}$, posto que o texto é ferramental à atividade prática mesma, do projeto, e não unicamente a mediações fora do próprio ato projetual ou teórico que lhe confere o caráter disciplinar, constitui questão distintamente qualificada no âmbito da teoria, esta mesma, em sua inevitável condição de sujeição aos textos. Quando transposto à atividade crítica, como aponta Helio Piñon, o texto é mediador e revelador, considerado uma “instituição mediadora”, que tem um "papel esclarecedor”, uma finalidade eminentemente informativa e auxiliar às sensibilidades sem no entanto ofuscá-las (PIÑ́N, 2006, p. 190191):

O papel genuíno da crítica é revelar as categorias e os princípios sobre os quais se estabelece uma ou outra forma de arte, com o fim de que o público defina seus próprios juízos. Desse modo, o crítico ajuda que a resposta de agrado ou desagrado do usuário vá além da mera reação visceral, baseada em critérios estritamente sensitivos. A crítica - em sentido estrito - tem por missão, portanto ajudar o público sem chegar a suplantá-lo; revelar as

\footnotetext{
${ }^{63}$ No sentido como é tratado na tese, o texto também detém em sua materialidade, as ideias, propiciam sua circulação quando em acréscimo às obras, mas sobretudo o texto é compreendido em retorno ao ato projetual, como força argumentativa de projeto.
} 
categorias da obra para facilitar o reconhecimento da sua formalidade específica e seu sentido histórico.

A missão do crítico é aproximar a arte do público, tratando de desvendar as chaves das tendências ou obras concretas, para facilitar o seu acesso a uma autêntica experiência estética que - por definição - é subjetiva e de caráter pessoal. Com efeito, a apreciação da arte se baseia no reconhecimento da formalidade e do sentido da obra, o que não se pode transferir, como a paternidade ou a dor de dentes.

Como mediação, esta mesma linha de análise está presente na abordagem que faz Renato Anelli sobre a atividade curatorial, como extrapolação do texto escrito e visual, em acréscimo às produções bibliográficas mediadoras da fruição e compreensão da obra de Arquitetura. O impacto propiciado pela exposição de arquitetura, similarmente a um texto narrativo que possibilita leituras múltiplas, a partir do suporte tridimensional do espaço, é também forma de mediação da obra de Arquitetura. A exposição, em sua finalidade pedagógica, é um estímulo à interpretação enriquecida de obras de Arquitetura, considerando ser a compreensão da obra e a experiência junto a mesma, fruto de um processo intelectual a ser continuamente apurado (ANELLI, 2017). As próprias revistas, fontes documentais consultadas na tese, são forma escrita de mediação de projetos e obras, definidas como um conjunto de (SEGAWA, CREMA e GAVA, 2003):

periodismo multifacetado que se consolidou ao longo do século XX em uma cultura literária e visual que foi também responsável pela veiculação de ideias e imagens que ajudaram a transformar o ideário e a prática profissional, circunscrito naquilo que se convencionou chamar de arte, arquitetura e urbanismo modernos.

As revistas, além de constituírem formas de mediação, difundiram esses ideais modernos, sendo importantes fontes documentais para a compreensão histórica de fenômenos relacionados à propagação de determinadas vertentes do pensamento de arquitetura, lidos especialmente pela interpretação das obras selecionadas e publicadas em seriação. ${ }^{64}$ Textualmente, as revistas compunham a trama, do ponto de vista da propagação de valores e ideais de arquitetura modernos, conformada pela criação e desenvolvimento do movimento moderno no mundo (CAPPELLO, 2007). Além dos textos, as imagens também produzem enunciações acerca da arquitetura, como as que levantou Nelci Tinem, ao identificar determinadas características quando da difusão da arquitetura moderna no

\footnotetext{
${ }^{64}$ A própria consagração da arquitetura moderna no Brasil no estrangeiro, como aponta Nelci Tinem, foi indicador de seu êxito, para além de serem as revistas, instrumentos de formação de opinião (TINEM, 2006).
} 
Brasil em revistas e manuais em circulação entre os anos de 1940 e 1955, recorte que arbitrou em função de ter sido o período de consagração crítica da arquitetura brasileira. $\mathrm{Na}$ análise a respeito de um conjunto de textos e imagens do período, identificou a oposição afirmada nestes, entre tradição e modernidade, uma das bases discursivas da arquitetura propagada, também a presença de elementos de arquitetura voltados ao "controle climático e as novas soluções plástico-formais", na demarcação de exemplos nos quais foi presente a comunicação entre interior e exterior das edificações, e sua relação com a paisagem natural, a proposta formal daquela arquitetura como novidade, todos esses, componentes constantes nas publicações, como conteúdos enunciados de valoração da arquitetura brasileira que contribuíram para sua absorção internacional (TINEM, 2006).

Interpretações transpostas a novos textos, para além dos autorreferentes da parte de arquitetos, sejam os escritos, visuais ou ainda espaciais, e da obra de Arquitetura, em distintas inserções no campo, produzem dos próprios objetos. A obra de arquitetura é continuamente atravessada pelas mediações, procedimentos detentores de uma "dimensão ativa", ou "elementos que se agregam à obra, reconstituindo-a por sua inserção em uma trama que recoloca e reconverte o objeto de análise" (MARTINS, 2010, p. 135):

A análise das relações entre experiência artística e experiência verbal, superadas as visões de sua mútua irredutibilidade, leva a uma transformação da percepção do trabalho crítico e/ou histórico que reconhece "a crítica como uma participação ativa e fundamental não só na propagação, mas também na geração da cultura arquitetônica” ${ }^{35}$.

A utilização de fontes textuais para realização da pesquisa em História que deu origem à presente tese, teve como intuito a captura das mediações da Arquitetura para identificação das formas de representação da Arquitetura e Urbanismo na Amazônia e desta mesma, quando presentes nestes registros. $\mathrm{Na}$ identificação e cruzamento de significados nelas proferidos, extensivos dos objetos de Arquitetura à Amazônia, a pesquisa comportou um paralelo à noção de "representação". Deste modo, uma explicação aproximada ao conceito é cabível, especialmente frente a dualidade que apresenta, de estar situado entre a simulação do ausente, pois tende a substituir aquele que é representado e constituir a

\footnotetext{
${ }^{65}$ Cf. BONTA, Juan Pablo. Arquitetctura hablada. In WAISSMAN, Marina (org.). Arquitetctura y crítica.
} Buenos Aires, Summarios, fev/mar. 1977. 
própria realidade, e a evocação de uma presença, determinando as práticas sociais futuras e constituindo também os fenômenos históricos.

No âmbito da História Cultural, a "representação" é relacionada à "virada linguística" dos anos de 1960 e 1970, quando do "encontro de diversas correntes teóricas baseadas num pressuposto comum acerca da filosofia da linguagem, isto é, da linguagem como instância constituinte da realidade”. Francisco J. Calazans Falcon apresenta esta definição como uma tendência a qual filiaram-se historiadores aproximados a ideias tidas por ele como pós-modernas. Isto por terem concebido de modo distinto o discurso histórico e a própria História, rompendo com a possibilidade de ser a "representação" uma "categoria inerente ao conhecimento histórico", ou com a ideia de História compreendida "como realidade e como conhecimento dessa realidade", em defesa da "representação" "como negação da possibilidade mesma desse conhecimento". O texto histórico passaria então a ser um "artefato linguístico" autorreferenciado e remetido a "estruturas da narrativa" (FALCON, 2000, p. 41-44).

Para um deslocamento de embates deste tipo, envolvidos na temática das representações à prática da História, cabe senão localizar o termo como aqui compreendido. E mais especificamente, para a afirmação da hipótese de que as mediações da Arquitetura desenvolvida na Amazônia foram extensivas às representações da Amazônia como paisagem, sobretudo nos anos em estudo, entre 1934 e 1989. Essas representações teriam permeado a atividade projetual da arquitetura ali desenvolvida, influído na prática, portanto. Isto leva a crer que com os textos em sua condição de existência, especialmente linguagem, suporte e assimilação, foi ativada a construção dos sentidos que levaram à compreensão, ainda que não completamente, dos objetos aos quais foram eles referentes, a Arquitetura e seu contexto espacial de inscrição, a Amazônia Brasileira.

Deste modo, as "representações" são adequadas à tese, como categoria de análise das fontes documentais, por fornecerem base à compreensão do lugar central que ocupam os textos junto às práticas sociais, em detrimento de seu caráter literário. Neste caso, os textos de Arquitetura, em sua capacidade de ingerência sobre as práticas deste campo, influem e compõe referenciais disciplinares. Roger Chartier, a partir da apresentação de seu próprio objeto de interesse, diante das transformações dadas no âmbito das Ciências Sociais a partir dos anos 1980, esclarece quanto a inevitabilidade da conjugação das representações às 
práticas, "que, diversamente, se apreendem dos bens simbólicos, produzindo assim usos e significações diferençadas”, na construção das sociabilidades. $\mathrm{Na}$ etapa de coleta documental das fontes de pesquisa que sustentam esta tese, foi selecionada uma "classe particular de objetos impressos” para a investigação, além de outros textos complementares, condicionados às abordagens trazidas nas revistas especializadas, ainda que não consideradas em totalidade suas "significações múltiplas e móveis", ou de como foram recebidas pelos leitores, como defendido pelo autor (CHARTIER, 1991, p. 178).

Inscrito na tradição francesa dos Analles, Roger Chartier ${ }^{66}$ foi um dos protagonistas em finais dos anos de 1980, do processo de reavaliação da prática da História no âmbito do ambiente acadêmico francês. Ele delineou novos caminhos frente a vertente de uma história das mentalidades, cujo método era apoiado em abordagens próprias da antecessora história econômica social, especialmente no sentido quantitativo das análises das fontes. Sustentando uma história cultural do social, passou a ser incluso no movimento da "Nova História Cultural”, da qual emergiu a ideia de que aspectos relativos à cultura, dentre os quais as práticas e representações, são condutores explicativos do mundo social e de sua própria conformação e dinâmica. Para uma localização dos princípios fundamentais dos conceitos que desenvolveu e aplicou, Gisele Venancio explica que (VENANCIO, 2014, p. 298):

Ao pensar o consumo cultural criativo - e a leitura como sua metáfora -, Chartier elabora uma proposta original que desvia o olhar dos dispositivos de poder dos produtores dos objetos culturais para as práticas dos usuários, propondo que as apropriações devam ser pensadas como um objeto de análise que resulta de uma negociação entre produtores e consumidores. Em oposição às interpretações que sugerem a leitura - ou o consumo cultural - como passiva, Chartier propõe que se observem as liberdades dos leitores e, em lugar de se atentar apenas para as dependências e os processos de alienação, que se verifiquem os procedimentos de invenção e consciência.

Neste sentido, as representações não equivalem aos fenômenos, mas operam sobre eles, como elaborações de indivíduos que produzem interferências objetivas em sua

\footnotetext{
${ }^{66}$ A ressalva que fez Chartier ao sentido extritamente semântico do texto na leitura histórica, o coloca junto às práticas sociais, reguladas nos mais diversos contrastes e similitudes com que os textos são lidos, pelos modos de ler, pelos leitores em si, pelas formas de interpretação, pelos usos e formas materiais do livro, a partir da inclusão da apropriação como parte dos processos sociais relacionados à leitura. Sua compreensão se desloca da análise discursiva, pois é inclusiva das formas de interpretação e ressignificação e oferece espaço ao leitor (CHARTIER, 1991), diferentemente dos postulados de Michel Foucault, que "nega qualquer possibilidade de liberdade, quer dentro, quer fora” das instituições sociais (BERMAN, 1982, p. 33).
} 
construção quando a eles se referem, participando diretamente do mundo social. Deste modo, ainda que a "representação" possa ser compreendida em substituição de um dada realidade, ela é constitutiva desta mesma relaidade, com seu “poder de modificar a realidade que parece refletir” (BURKE, 2005, p. 84). Os documentos não seriam portadores de uma única realidade dos eventos, mas revelariam sua capacidade inerente de representá-los (SILVA, 2000, p. 83). Os textos, deste modo, não são compreendidos como suportes de representações de uma falsa realidade, nem tampouco autônomos, mas elementos ativos e influentes na construção da realidade, mais especificamente, da Arquitetura, como prática social, onde são absorvidos em linguagem e conteúdo, já que "história é sempre texto, ou mais amplamente, discurso, seja ele escrito, iconográfico, gestual, etc, de sorte que somente através da decifração dos discursos que exprimem ou contêm a história poderá o historiador realizar seu trabalho" (CARDOSO e VAINFAS, 1997, p. 378).

Assim, as representações sociais afetam diretamente as sociabilidades, produzindo significações que lhe são atribuídas, partilhadas e difundidas. Todavia, embora não seja reduzida a uma mera consequência das significações, a concretude desses mundos é afetada e portanto constituída das próprias representações, podendo ser também transpostas às elaborações culturais. As representações sociais são ajustadas à presente tese justamente pelo modo como, por meio das significações atribuídas aos objetos centrais à Arquitetura e Urbanismo nos textos, a Amazônia é inscrita na trajetória da Arquitetura no Brasil prevalentemente como paisagem. As representações revelam, desde as fontes, os atributos com que a Amazônia foi “construída”, reproduzindo a terminologia de Neide Gondim, no campo da Arquitetura e Urbanismo, extrapolando a ficcionalidade dos textos, o imaginário, mas em transposição à prática do projeto e a novos textos.

Logicamente que a totalidade dos acontecimentos sobre a Arquitetura na Amazônia no intervalo recortado na tese não foi revelada nas revistas, mas estas, como fontes documentais, portam registros dos vestígios sobre os quais fala Marc Bloch, que podem ser rastreados pois são dados a ver aos nossos sentidos do presente, mesmo que não revelem completamente os eventos passados perseguidos. Afinal, como afirma o historiador, "o que entendemos efetivamente por documentos senão um 'vestígio', quer dizer, a marca, perceptível aos sentidos, deixada por um fenômeno em si mesmo impossível de captar?” (BLOCH, 2001, p. 73). 
As fontes em pauta são mediadoras de representações sobre a Amazônia e compõem um conjunto mais ampliado de referências da Arquitetura no Brasil. O estudo, ainda assim, foi deslocado de uma revisão historiográfica e não foi pautado pela compreensão de filiações, processos evolutivos ou da linearidade dos acontecimentos consagrados no país, detidos ao campo. Ele foi dirigido sim, à interpretação de uma ideia de Amazônia construída pela mediação dos textos ao longo dos anos, como um fenômeno histórico, o que centralizou a Amazônia como objeto da análise. As representações, como recurso à identificação da Amazônia nos textos, foram postas em dependência ao objeto, dado seu caráter impreciso e complexo, na defesa de que os textos influíram em processos projetuais, quando pensados desde e para a Amazônia, capturada como uma paisagem particular.

A esta paisagem está entrelaçado um conjunto de formulações, oriundas da literatura e do pensamento social sobre a Amazônia. Estas formulações são identificadas nas revistas, bem como alguns de seus autores significativos. Por outro lado, o estudo também percebe a imersão da Amazônia em um universo mais ampliado de questões relativas à História da Arquitetura no Brasil junto à própria modernização do país, a contar eventos demarcatórios e textos fundantes, sobretudo a extensividade da Amazônia a debates mais ampliados no campo, como nos recortes da Arquitetura na América Latina e à adequabilidade do projeto ao ambiente.

O desvio de uma possível narrativa baseada no êxito de uma modernização regional ou de uma história positivista sobre a Arquitetura no Brasil levada à Amazônia, transcorre das evidentes tensões provocadas pela modernização regional e de sua desnaturalização, como fenômeno abordado no primeiro capítulo, compreendido em seu paradoxismo e superficialidade (BRITO, 1983) como concretizada nesse espaço de fronteira socioambiental. Em aproximação à História da Arquitetura no Brasil, por outro lado, não foi pretendido confinar a Amazônia em enfoque regionalizado ou detido ao contexto pormenorizado dos acontecimentos. Um certo diálogo com a cultura disciplinar presente na História da Arquitetura no Brasil moldou o segmento narrativo da tese, especialmente nos dois últimos capítulos. Ainda que enfatizadas as representações e as designações conferidas à Arquitetura na Amazônia e a este lugar nos textos, sua presença foi incoporada 
à escrita ora proposta, entremeada dos eventos demarcatórios e problemáticos da historiografia da Arquitetura no Brasil. ${ }^{67}$

O recorte do processo no qual a tese está assentada, para dar a ler os encontros e desencontros nas formas textuais, dos eventos, objetos e significados constitutivos da Arquitetura na Amazônia, não deve desconsiderar "a realidade sobre a qual se construíram as representações, mas sim, a entender que a realidade do passado só chega ao historiador por meio de representações" (PESAVENTO, 2003, p. 42-43). Assim, as revistas foram as fontes documentais que tornaram possível essa dupla identificação - dos eventos transcorridos e de suas significações - portanto, das práticas e das representações. A observação do fenômeno dado em recorte, Arquitetura na Amazônia entre os anos de 1934 e 1989, possibilitado pela leitura das fontes, serviu à elaboração de nova narrativa, pelo adensamento e conjugação dos dados delas abstraídos. Com o intuito de acrescer à história escrita da Arquitetura no Brasil, como cultura continuada, as revistas foram consideradas fontes documentais, aos moldes de pesquisas já consolidadas como de Maria Beatriz Camargo Capello (CAPPELLO, 2005) e Nelci Tinem (TINEM, 2006). Primeiramente por terem reportado os eventos ao tempo dos acontecimentos. Depois, pelas impossibilidades apresentadas diante do caráter disperso e profuso da documentação sobre a Arquitetura na Amazônia. As revistas foram a síntese mais fiel para a leitura do fenômeno em recorte histórico, da Arquitetura na Amazônia entre os anos pesquisados.

Uma infinitude de imagens de significação tem constituído um imaginário acerca da Amazônia e do qual a pesquisa não poderia desviar. A respeito desta categoria, o imaginário, é considerada como um conjunto de "ideias e imagens de representação coletiva que os homens, em todas as épocas, construíram para si, dando sentido ao mundo”, em condições de existência de certa "coerência” e “organização". O imaginário, desde várias acepções que o termo pode comportar, detém certa temporalidade, como produto construído de representações "para conferir sentido ao real”, em uma construção ampla que envolve

\footnotetext{
${ }^{67}$ A proposta para o último tópico deste mesmo capítulo e para os dois últimos capítulo da tese foi justamente esta, considerar as representações como meios para elucidação das significações proferidas sobre o objeto perseguido na pesquisa. Por outro lado, considerar essas mesmas representações em sua realidade histórica, já que em fluxo, os sentidos conferidos a tal produção e ao lugar de sua inscrição compuseram também a sua realidade. Por isso mesmo, a escrita foi materializada em narrativa linear, especialmente no Capítulo 3.
} 
“palavras/discursos/sons”, “imagens, coisas, materialidades”, "práticas, ritos, performances” (PESAVENTO, 2003, p. 43).

Para não o tornar conceito impalpável à realização das análises pretendidas, dadas tantas possibilidades de sentido que ele detém, o imaginário em questão é considerado pelos componentes visuais em articulação aos textuais, representações escritas e visuais acerca da Amazônia. Para a pesquisa em História, ao serem utilizadas imagens não somente como documentos visuais, mas pela sua natureza discursiva, a partir de meios que cerquem a visualidade em sua historicidade, são tornadas possíveis interpretações ampliadas, com base em fontes deste tipo. Ulpiano Bezerra de Menezes esclarece quanto à extensão de um estudo da visualidade, imerso numa possível História Visual. Quanto à abrangência destas investigações, para além da abordagem já corrente a respeito da recepção das imagens, como ocorre na História da Arte, defende a inclusão da "materialidade das representações visuais no horizonte dessas preocupações", a compreensão das imagens "como coisas que participam das relações sociais, e mais que isso, como práticas materiais” (MENEZES, 2003).

Ao percorrer as imagens para compreensão dos fenômenos sociais, o historiador pontua a contribuição significativa de antropólogos e sociólogos, "quer ressaltando o potencial cognitivo do documento visual, quer valorizando a dimensão visual da vida social", defendendo que a cultura material poderia ser estudada como "a dimensão física, empírica, sensorial, corporal, da produção/reprodução social”. O autor se refere à História Visual como um "campo operacional em que se elege um ângulo estratégico de observação da sociedade - de toda a sociedade", não que a fonte seja o foco da leitura histórica em si, nem que o historiador deva priorizar a fonte frente o problema histórico enfrentado, ou como afirma, para ser História, precisa ser "história da sociedade", sendo a cultura material, uma possível “plataforma de observação”. A visualidade, portanto, diria respeito à sociedade e não às fontes em caráter estrito, tendo preponderância, fontes "de caráter visual” que deste modo, não possuem sentido imanente. Frente à possibilidade de compreensão mais ampliada dos textos, escritos ou visuais, foram incorporadas as imagens presentes nas revistas no fluxo das análises utilizadas na tese, a partir de sua disposição em relação aos escritos, como sugerido por Ulpiano Bezerra, para que pudesse assim ser o estudo, levado a decifrar o "regime de visualidade" desde as fontes (MENEZES, 2003, p. 26-28). 
As revistas têm registrado, veiculado e propagado as atividades práticas e teórico críticas de Arquitetura, noutro fluxo, sido fontes para o desenvolvimento de leituras lançadas à disciplina em sua trajetória histórica e a outras relacionadas em geral, a debates acerca da cultura construtiva e à constituição do espaço habitado. Internacionalmente, foram cruciais para a articulação de ideias vanguardistas desde os anos de 1920 à mídia, em seu caráter modernizado, como recurso para que arquitetos dessem a ver imagens moldadas de si e de suas obras. Ideias em circulação articuladas a recursos gráficos novos, nas revistas, influíram em inovações na prática da Arquitetura e Urbanismo e em discussões a ela centrais, sintetizando trabalhos coletivos, bem como propostas revolucionárias ${ }^{68}$ (COLOMINA, 2010).

As revistas de Arquitetura, Paisagismo ou o Design possuem caráter heterogêneo e constituem modalidade profusa de "periodismo multifacetado" consolidado no século XX como "cultura literária e visual”, meio influente para a transformação de ideias e práticas de Arquitetura e Urbanismo, como avaliam Hugo Segawa, Adriana Crema, Maristela Gava. O conjunto de publicações deste tipo tem oscilado quanto ao rigor e frequência com que tem sido produzido, distanciado gradativamente da atividade crítica reflexiva, mesmo que seja esta uma finalidade essencial desse tipo de publicação especializada (SEGAWA, CREMA e GAVA, 2003). Ainda que as revistas tenham sido um conjunto documental oportuno à pesquisa como fontes, também condicionaram os resultados obtidos com o levantamento dos dados e sua interpretação. Isto em razão de sua própria historicidade (SEGAWA, 1998, p. 130), seu período de duração, peridiocidade, linha editorial e outros fatores restritivos à leitura abrangente e totalizante da Arquitetura na Amazônia, nos anos estudados. Todavia, as revistas que circularam ao tempo dos eventos que aqui serão apresentados, constituíram, junto a outros referenciais da prática de Arquitetura, material referencial disponível a profissionais, fossem arquitetos ou engenheiros. Portanto, o que é apresentado nesta tese resulta do conteúdo capturado das mediações que portavam as revistas e que estavam em circulação.

\footnotetext{
${ }^{68}$ Beatriz Colomina, ainda que enfatiza as revistas de circulação limitada e independentes, as "pequenas revistas", como fontes da pesquisa histórica pelo caráter em parte relacionado a eventos extrínsecos, como atividades coletivas intelectuais, em parte pela condição de eventual efemeridade. Também como possibilidade de produto experimental da atividade acadêmica realizada em coletivo.
} 

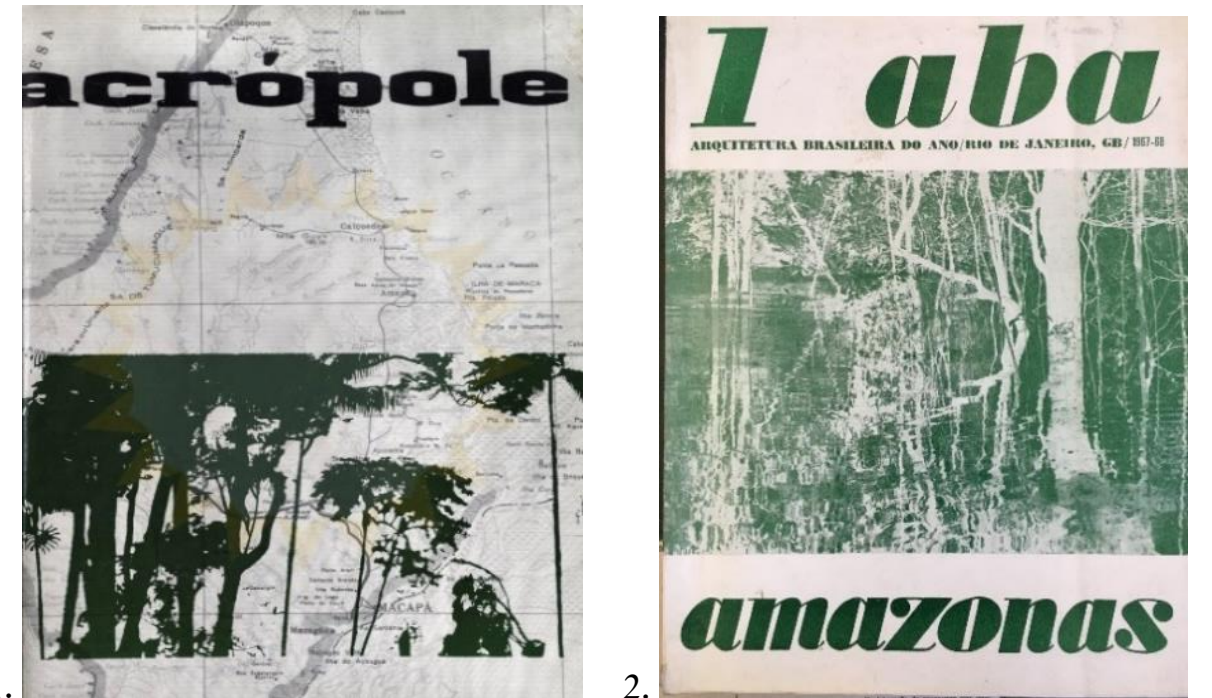

1.

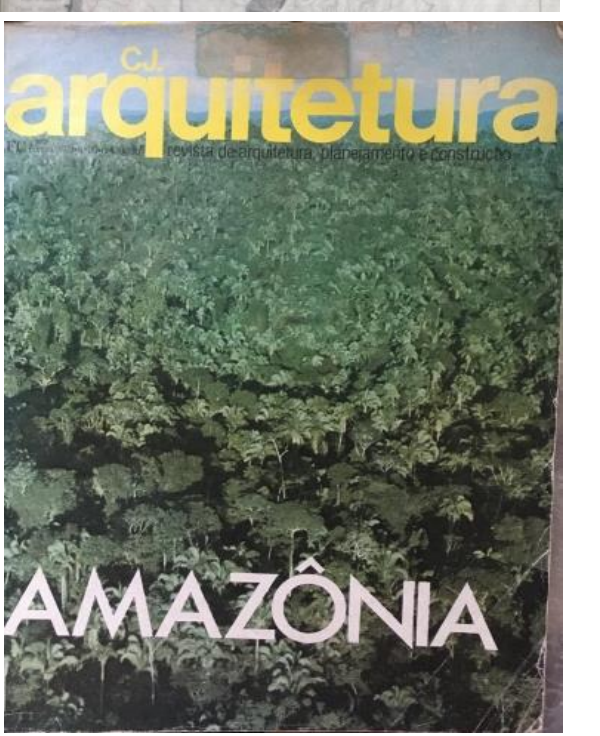

\section{ainaronas}

2.
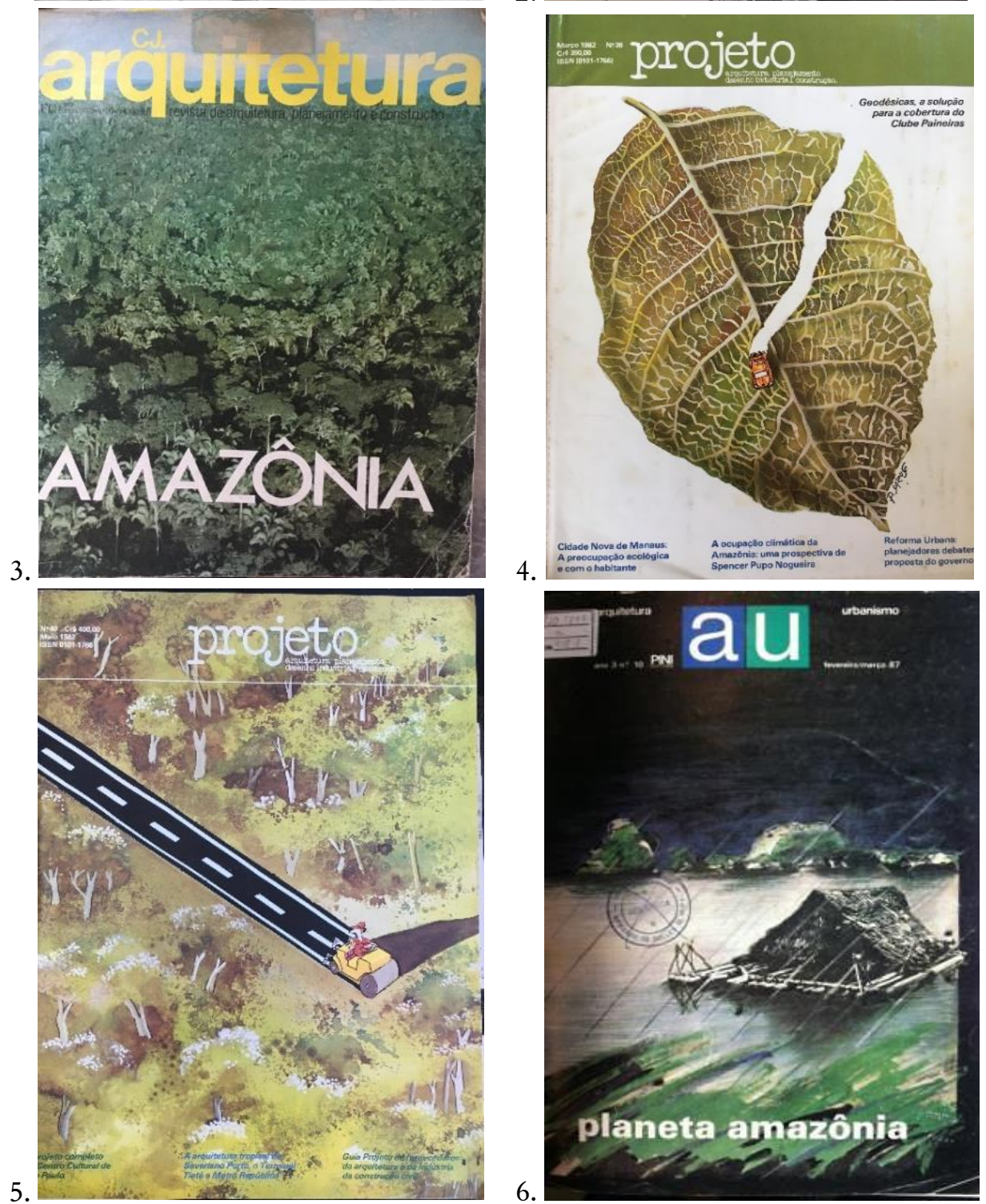

4.
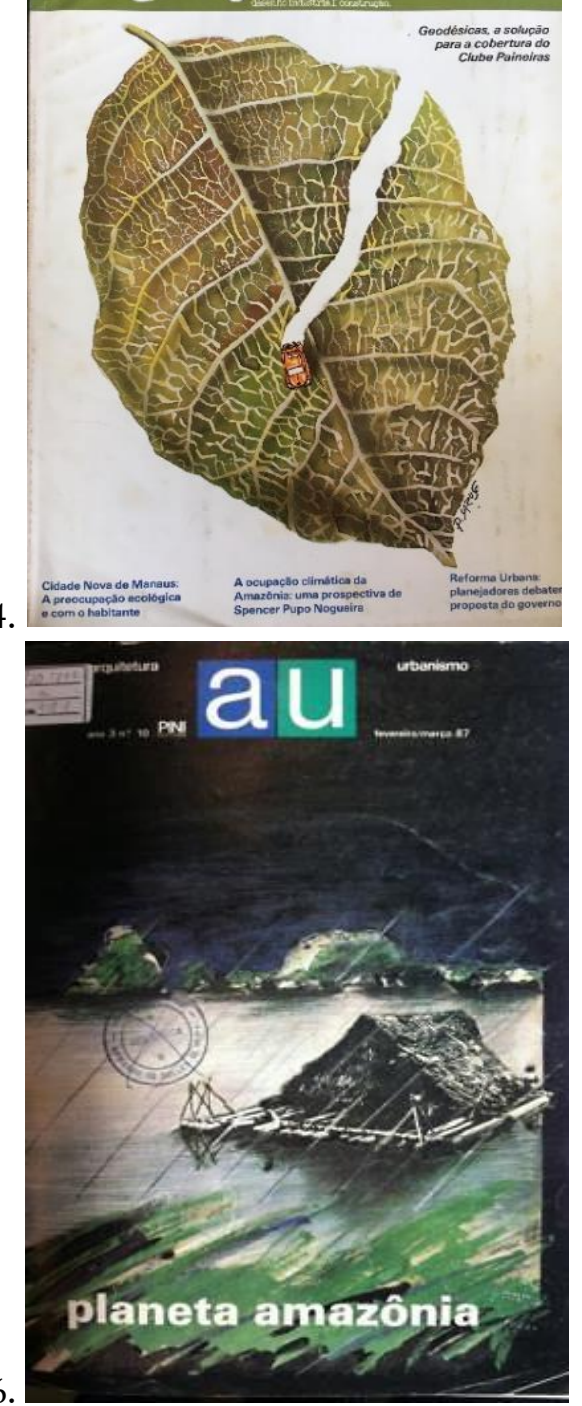

Figura 3 - Seleção de capas de revistas de Arquitetura entre as décadas de 1960 e 1980, enfatizadas pela mediação visual presente em narrativas sobre a Amazônia. Revistas (1) Acrópole (ACRÓPOLE n.326, 1966), (2) Arquitetura Brasileira do Ano (ABA n.1, 1967-68), (3) CJ Arquitetura (CJ ARQuitetura n.20, 1978), (4) Projeto (PROJETO n.38, 1982), (5) Projeto (PROJETO n.40, 1982), (6) Arquitetura e Urbanismo (AU n10, 1987). 
$\mathrm{Na}$ cultura arquitetônica, tornada objeto de investigação histórica, as revistas compõem um acervo do qual fazem parte outras formas textuais justapostas às obras construídas em si, numa complexa e "fluida rede de signos" (COHEN, 2013). A investigação dos objetos centrais na Arquitetura e Urbanismo, obras construídas e projetos, articulada às fontes textuais diversificadas, viabiliza a elucidação da inscrição, julgo e circulação das ideias, ${ }^{69}$ também, a análise de condicionais entrelaçamentos da obra a outros fatores a ela extrínsecos. Estes, lidos a partir de rastros de documentos desta espécie, aludem à imersão social dos objetos, dos encargos e do produto das táticas profissionais, revelando aspectos da imersão da prática da arquitetura em sociabilidades.

Para esta tese, em específico, foram consideradas prioritariamente as revistas que tematizaram a Amazônia, publicando projetos, obras, textos críticos, escritos de outras procedências disciplinares, ${ }^{70}$ além de propagandas, de modo que as formas de menção as mais diversificadas foram levantadas. As fontes documentais trabalhadas foram além das revistas, as que, por outro lado, estabeleceram pontes de contato com a Arquitetura, especialmente por publicarem obras e projetos, de modo que foram acrescidos ao conjunto das fontes documentais, as revistas populares, os jornais, as revistas institucionais, os documentos oficiais, que também comparecem nos dois capítulos a seguir, como suporte das leituras apresentadas.

\subsection{Fontes documentais e sincronicidade nos textos}

Da primeira leitura panorâmica das fontes consultadas, foi identificado que um conjunto de projetos em circulação nas revistas especializadas, para além daqueles presentes na aparente trivialidade de anúncios e propagandas de revistas populares e classificados de jornais, foram publicados durante longos intervalos de tempo, em uma condição de atualidade, no curso de aproximadamente vinte anos, entre as décadas de 1960 e 1980 . O Hotel para pescadores em Silves, como exemplo, foi publicado inicialmente como projeto,

\footnotetext{
${ }^{69}$ Considerando-se a Arquitetura desde um campo ampliado de interpretação. Não é só a questão estrita à arte, mas sua ampliação em termos de entendimento de como a Arquitetura transforma a vida social.

${ }^{70}$ Algumas das revistas especializadas levantadas, forneceram perspectivas transdisciplinares, ampliadas sobre a Amazônia. Esta temática, nas publicações, não foi esgotada no próprio campo disciplinar da Arquitetura e Urbanismo, tendo sido incorporadas pontes com a Geografia, Antropologia, Artes, História, para enumerar alguns dos casos identificados nas fontes documentais.
} 
em 1967 (ABA N.1, 1967-68) e desde então veiculado em revistas especializadas mais de uma dezena de vezes, sob atributos proferidos tanto pela crítica especializada, quanto por agentes governamentais e imprensa, com o suporte visual das mesmas imagens, tanto do projeto quanto da obra pronta (ABA, 1967-68, n.1, p112-115), (MÓDULO, 1983, n.75, p.58- 61), (PROJETO, 1983, n.49, p.30-35; 1983, n.49, p.36-46; 1983, n.52, p.22; 1983, n.53, p.83; 1983, n.53, p.116;1983, n.57, p.80; 1985, n.75, p. 50; 1985, n.77, capa, p. 50-52; 1987, n.95, p.32-37; 1988, n.114, p.112; 1990, n. 129, p.119; 1990, n. 129, p.156), (AU, 1999, n.81, p.24; 2005, n.130, p.55).

Esse levantamento preliminar junto às fontes apontou para uma série de projetos referenciados na Amazônia, que assim como o Hotel de Silves, haviam sido publicados em arcos ampliados de tempo. Das explicações que os cercaram, foram recorrentes as pautadas em interpretações partidas de sua circunscrição, quando enfatizadas as fronteiras político administrativas do espaço de sua implantação, os situando em delimitação espacial e pondo em perspectiva, além da região amazônica, o Estado Nação, mesmo a América Latina, a depender do enfoque das enunciações. Explicados em relação a esta circunscrição, ou considerando a preponderância desta sobre os projetos, emergiram justificativas que os explicou em articulação à uma dada cultura construtiva, especialmente como repertório abstraído da modernidade na Arquitetura, com sotaque localizado. Mesmo pela fusão de ambos, universalização e regionalidade.

E justamente falas em defesa da modernização da Amazônia, incorporaram a Arquitetura como agente de transformação do espaço regional, especialmente a partir dos anos de 1960, desde quando o Estado Nacional intervencionista no Brasil, sob o mote de uma modernização conservadora, empreendeu grandes projetos econômicos, de exploração e integração econômica no território. Manifestações de Arquitetura, enunciadas pelo enraizamento cultural, foram representadas desde a especificidade da manipulação da técnica e da estética construtiva, que se apropriaram, docilizaram e propagaram imagens memoriais de um vernáculo e popular, por um lado, absorvendo e reformulando um conhecimento cultivado de condicional adaptação humana ao meio natural, socialmente experimentado na Amazônia ao longo de sua história, por outro.

Imersas no processo contraditório de modernização, como discorrido no primeiro capítulo, essas falas, extensivamente, se valeram da excentricidade com que foram expostos 
determinados projetos nas revistas, bem como seu condicionamento à uma perene atualidade, para uma intencional, ou não, reprodução de imagens de mitificação do território e singularização de obras ali implantadas. Contribuíram para esta condição, o desconhecimento do próprio território, seu atrativo ineditismo nas publicações e o caráter incomum das obras e das paisagens, as nuances de exotismo em muitas das enunciações proferidas acerca da Arquitetura na Amazônia, decorrentes de uma posição observadora de controle e distanciamento, que a considerou desde a exterioridade. A Amazônia, bem como uma Arquitetura desenvolvida no território, sua presença nas revistas, também foi a mediação afirmativa da pluralidade da produção nacional entre os anos de 1960 e 1980. Neste período, obras referenciais foram projetadas como manifestações regionalizadas, fosse em representação ao nacional, ou transnacional, a exemplo de cultura arquitetônica latino-americana, delineada em alteridade.

Esta interpretação inspirou a condução da pesquisa ao levantamento sistemático das revistas, que viriam a ser analisadas em seriação, de modo a servir de base à reconstituição histórica mais aproximada ao fluxo com que a Amazônia e a Arquitetura ali realizada haviam sido publicadas, já que revistas foram veículo de sua mediação, possibilitando a visibilização da própria Amazônia ao público nacional, também estrangeiro, a contar as edições bilíngues. Além do levantamento bibliográfico, o trabalho prosseguiu com o amplo levantamento das revistas que por si só conformaram um conjunto variado de informações e por isso foram priorizadas, frente a possibilidade de contato com outras fontes, relativas mais estritamente à documentação dos projetos. $\mathrm{O}$ volume de dados presente nas revistas foi representativo e potencial à análise subsequente.

Em termos quantitativos foi levantado o volume de projetos realizados na Amazônia presentes nas revistas, cerca de 110, além da temática, a Amazônia e seus termos correlatos em todo tipo de menção. O conjunto de fontes consultadas foi composto pela Revista de Arquitetura $^{71}$ (1934-1950), todos os números da Revista Acrópole ${ }^{72}$ (1938-1971), 129

\footnotetext{
${ }^{71} \mathrm{O}$ primeiro número deste periódico vinculado à Escola Nacional de Belas Artes, desde quando foram publicados vários artigos acerca da Arte Marajoara, demarcou o início do recorte do terceiro capítulo da tese. ${ }^{72}$ Segundo Hugo Segawa, a Acrópole foi uma revista peculiar pelo fato de que foi a mais duradoura dos periódicos no Brasil. De início, a revista apresentava projetos ecléticos, nos anos de 1950, acompanhou a tendência da arquitetura moderna no país, e na última década, "transformava-se na publicação que se prestou para a divulgação e o diálogo entre arquitetos paulistas, na realização de uma arquitetura que sucedia a arquitetura carioca em novos termos e propostas". Com o encerramento de suas atividades, acabava o "último remanescente histórico", sucedida de publicações intermitentes
} 
números da Revista A Casa (1924-1952), todos os números da revista Habitat ${ }^{73}$ (19501965), 58 números da revista Arquitetura - IAB (1961-1968), 5 da revista $A B A-C A B$ (1967-); 16 da CJ Arquitetura (1973-1980); todos os números da Módulo (1955-1986); 110 números da revista Projeto (1977-); 40 números da revista AU - Arquitetura e Urbanismo (1985-), perpassando um total aproximado de 550 exemplares. Além destes, três trabalhos acadêmicos voltados à Amazônia foram referenciados nas revistas e identificados no acervo do banco de teses da USP, pertencentes ao recorte temporal estudado. A tese de Eduardo Yázigi, de 1972, a dissertação de João Castro Filho, de 1984 e tese de Fleury de Oliveira, de 1989 foram os trabalhos acadêmicos percursores e denotativos de uma mudança de compreensão da Amazônia em curso, nos anos de 1970 e 1980, desde quando as pesquisas passaram a apreendê-la de modo mais aproximado e recortado.

O levantamento das mediações da Arquitetura na Amazônia nas revistas, trabalhos acadêmicos e fontes correlatas foi localizado em uma tabela geral de referência, na qual foram lançados os dados descritivos das publicações e demais dados de autoria, conteúdo de textos, seguindo uma classificação criada para este fim e gerativa das fichas de catalogação de obras e das fichas de organização de artigos publicados. Deste modo, foi confeccionada uma tabela matriz ${ }^{74}$ a partir da qual foram geradas fichas padronizadas de projeto para cada obra de referência presente nas publicações e fichas padronizadas de matéria, para cada um dos artigos que interessaram à tese. Cada ficha projeto concentrou as publicações nas quais cada uma das obras foi registrada, para fins de cruzamento dos conteúdos dos artigos. Para cada artigo referente à Amazônia ou de temática a ela relacionada, também foram feitas fichas individuais de registro, somando aproximadamente 275 fichas de matérias e 110 fichas de projetos.

De início os dados seriam cruzados em análise à seriação, pela identificação de frequências discursivas, de veiculação de imagens e textos. Este trabalho ficou em grande parte resolvido ao tempo do doutorado e constituiu grande parte do terceiro capítulo da tese. Porém este levantamento deverá ser continuado na construção de um banco de dados, possivelmente associado a pesquisas futuras que darão vazão às informações já coletadas

\footnotetext{
${ }^{73}$ Hugo Segawa menciona que foi a primeira revista moderna de editora estabelecida no Brasil, lançada em 1950 e dirigida pla recém-chegada Lina Bo Bardi. Tratava-se de uma revista e arte e arquitetura, "naqueles anos de Guerra Fria" (PROJETO N.42, maio de 1982, p. 42).

${ }^{74}$ Esta base servirá à construção de um banco de dados futuro.
} 
não contempladas na tese e outras que possam ser agregadas ao conjunto já organizado. Uma outra planilha matriz foi produzida concomitantemente ao preenchimento das fichas, a de arquitetos e obras. Esta matriz gerou uma tabela a parte, na qual foram identificados os arquitetos, suas obras publicadas, o ano de publicação, as revistas nas quais foram publicadas as obras e uma linha temporal com o cruzamento desta com as fichas individuais de projeto e com as fichas individuais de matérias. A classificação das fichas seguiu a numérica simples, P01, P02, P03 ... para cada projeto, e M01, M02, M03... para cada matéria. Na tabela matriz de arquitetos, foram então identificados os projetos e as matérias a partir desta classificação.

Com o lançamento destas informações em planilhas, além do banco de dados foram produzidos alguns gráficos para compreensão das frequências das publicações, especialmente volume de publicações por ano, de obras por arquiteto, de obras por localização geográfica. Foram identificados os momentos nos quais a Amazônia apareceu nas revistas, bem como as obras mais publicadas, sendo estabelecidos comparativos entre estes e os escritos de História sincrônicos às revistas. Concatenadas as publicações em uma nova narrativa mais geral, ancorada principalmente dos textos publicados, foi tornada visível a Amazônia desde as publicações, em síntese. Outros juízos, que não cabem pormenorizar, como a frequência de publicação de determinadas obras e arquitetos referenciais, também podem ser identificados no conjunto de dados e servir a publicações futuras.

Das publicações, especialmente a partir da década de 1960, frente o recorte ampliado de 1934 a 1989, foi possível identificar a recorrente presença da obra de Severiano Mário Porto, no volume das que foram publicadas, em relação aos demais arquitetos presentes nas revistas e atuantes no recorte da Amazônia brasileira. Em análise quantitativa, este período comportou a fase de maior intensidade da produção daquele arquiteto, convergente ao processo de reabertura de discussões no campo da Arquitetura e Urbanismo no país. Este foi o período revelado pelos escritos como pós-Brasília, especialmente nos debates registrados pela revista Projeto. Ainda a leitura das frequências de publicação das obras indicou os dois momentos de maior intensidade de publicações que cercaram a Amazônia, a década de 1960 e a passagem 1970 aos 1980.

A primeira decorreu da participação de intelectuais, escritores locais, nas revistas Arquitetura-IAB e ABA-CAB, em uma análise mais pormenorizada das fontes. A segunda, pela intensificação das publicações periódicas e de recondução de temas e debates à época, 
mais bem observada pela leitura dos textos referenciais da própria disciplina quando de encontro às publicações das revistas. Em virtude do caráter vestigial das fontes documentais selecionadas para a presente tese, que foram rastreadas como vias elucidativas das práticas e representações da Arquitetura e Urbanismo na Amazônia. Cabe a ponderação dos limites da interpretação quantitativa desses dados, aos quais devem ser acrescidos outros de base qualitativa, o que inclui a sua sincronização aos escritos de História. Ambos, sob a pretensão de abarcar a Amazônia, pelo caminho da temática de sua Arquitetura, foram reveladores tanto das próprias limitações do empreendimento, quando da posição exteriorizada de sua observação.

\subsection{Amazônia em recortes historiográficos de Arquitetura e Urbanismo no Brasil}

Os anos de $1920^{75}$ balizaram um processo desenrolado desde o século anterior no Brasil, ao qual se engajaram arquitetos atuantes na prática, teoria e ensino da Arquitetura e Urbanismo, partilhando com outros segmentos sociais, ideais de modernidade. Como fenômeno memorial, um "período heroico" da Arquitetura, entre 1920 e $1930^{76}$ e seus encaminhamentos posteriores, produziram efeitos mais efetivos sobre prática projetual no país até a década de $1960 .{ }^{77}$ Fruto da articulação e desenvoltura de agentes, fossem arquitetos, intelectuais, políticos, que avistaram uma cultura moderna em Arquitetura e Urbanismo para o país, foi urdida pela inventividade material discursiva, do intercâmbio direto com fontes europeias. ${ }^{78}$

Certa produção foi relevada pela escrita de teor histórico crítico e amplamente reconhecida, tornada tão dominante entre especialistas brasileiros e estrangeiros, quanto

\footnotetext{
${ }^{75}$ Desde os anos de 1910, debates no âmbito da Arquitetura opunham posições favoráveis e desfavoráveis à "ideia de um estilo nacional" e diversas tendências disputavam o lugar de uma arquitetura nacional no Brasil, em debates complexificados pelas primeiras obras de Warchavchik (FILHO, 2010).

${ }^{76} \mathrm{O}$ intervalo apresenta a dupla referência, de conjuntura demarcada pelas atenções dadas dos movimentos de discussão no campo da arte, literatura e ciências sociais acerca da cultura nacional, por outro lado, seu rebatimento sobre a disputa discursiva e material entre os representantes do Neocolonialismo e da Arquitetura Moderna como representações legítimas da cultura construtiva nacional.

${ }^{77}$ Este recorte é dado a partir do campo da Arquitetura e Urbanismo, já que nos anos de 1960 a arquitetura referenciada numa escola carioca teve sua unanimidade amplamente questionada. O estabelecimento de Brasília como marco temporal dialoga diretamente com a historiografia da Arquitetura Moderna Brasileira (CAVALCANTI, 2006).

${ }^{78}$ As vanguardas no Brasil se apoiaram nos significados de brasilidade e nacionalidade em sua participação na construção da ideia de modernidade nacional. A arte moderna brasileira foi construtiva, ao ser referenciada em elementos de significação da cultura nacional (BRITO, 1983).
} 
socialmente assente, ${ }^{79}$ a partir de um marco inaugural tomado como referência pela história escrita (GORELIK, 2005, p. 161-162):

o Ministério da Educação supõe um divisor de águas porque fecha um período de intensa experimentação vanguardista, conformando o modo canônico capaz de acolher e homogeneizar qualquer outro tipo de busca. Há uma série de elementos que o tornam um selo nacional: a colaboração entre arquitetos e artistas; a apropriação levemente distorcida (folclorizante, classicizante, em outra escala) de motivos da figuração modernista internacional; a relação dos arquitetos com o Estado como promotor de programas novos e de sua nova figuração.

Esta síntese de Gorelik recorta criticamente o marco inicial do que viria a ser o fenômeno da Arquitetura Moderna Brasileira. Os anos 1930 traziam a possibilidade, frente o decaimento do Estado Liberal, do incentivo estatal à modernização do país, conjuntura na qual o edifício do Ministério da Educação e Saúde, amplamente difundido como marco da moderna arquitetura brasileira, foi projetado e construído na capital, entre os anos de 1937 e 1943. A equipe brasileira coordenada por Lúcio Costa, composta por Affonso Eduardo Reidy, Carlos Leão, Jorge Moreira, Ernani Vasconcelos e Oscar Niemeyer, foi encarregada do projeto e ao contatar Le Corbusier em 1936, demarcou o caminho trilhado pela arquitetura racionalista, desde a "nova monumentalidade" e a "síntese das artes" ${ }^{80} \mathrm{Se}$ seus exemplares edifícios ambientados na capital do país passaram a transformar aquela paisagem urbana desde então, a República Varguista teria, com esse evento demarcatório, o início da materialização de um ideário de nação, viabilizado pelo vislumbre do futuro partilhado pela cultura construtiva e pelo Estado Nacional surgentes. ${ }^{81}$

\footnotetext{
${ }^{79}$ Fernando Luiz Lara trata da absorção da Arquitetura moderna no Brasil, que a tornou expressão significativa no ambiente construído das cidades entre os anos de 1940 e 1960. Para o autor, as construções afetadas pelos exemplos paradigmáticos da arquitetura, foram "signos das apropriações populares do vocabulário do movimento moderno", constitutivas do fenômeno do movimento moderno no Brasil e mundo (LARA, 2005). ${ }^{80}$ A "nova monumentalidade" foi a categoria debatida por Lúcio Costa que defendeu a inerente e necessária capacidade de "emocionar" da Arquitetura, pela "expressão plástica", e sua "complexidade lírica". Além da dimensão "utilitária" das edificações, elas seriam continentes das demais artes, de modo que a nova monumentalidade possibilitou que o arquiteto dialogasse esteticamente sobre a arquitetura desenvolvida nacional e internacionalmente, já que Le Corbusier, "desde a época do Pavilhão do Espírito Novo da Exposição das Artes Decorativas em Paris, 1925”, vinha defendendo a síntese das artes e que Giedion desde os anos 1930, falava sobre a evolução que a nova monumentalidade traria à arquitetura moderna. Assim, o monumental desliza do eminentemente memorial e evocativo do passado para tornar-se condição valorativa da arquitetura do presente (CAPPELLO, 2005, p. 185-187).

${ }^{81} \mathrm{O}$ fortalecimento gradativo do Estado Nacional, desde o investimento no crescimento das instituições políticas como meio de unificar administrativamente o país e da indústria, em substituição aos "argumentos históricos do setor de exportação sobre o papel natural do Brasil como exportador de produtos primários". Deste modo, "se o Brasil queria deixar de ser uma economia agrícola de exportação, e passar a ser um país
} 
Numa apreensão abrangente de modernidade, demarcada por eventos historicamente relacionados à rearticulação econômica capitalista junto a ampliada atividade industrial e seus desdobramentos urbanos desde o século XIX, obras modernas constituíram em "múltiplas e sobrepostas temporalidades” (COHEN, 2013, p. 10-17) a renovação da prática arquitetônica. Guardadas as especificidades que o recorte requer, no caso latino-americano, a articulação intensificada no período entre-guerras entre o Estado, “agente estrutural da modernização” e as vanguardas, ${ }^{82}$ na formulação de representações simbólicas nacionais, constituiu um processo ambíguo pela incorporação, mesmo que distintamente em cada país, retornando a valores da tradição pela Arquitetura e Urbanismo, para o alcance de uma sociedade moderna (GORELIK, 2005, p. 29; 49-50):

Trata-se da materialização de uma vontade ideológica sob formas arquitetônicas de grande capacidade de simbolização. Daí que, no ponto de chegada e consumação desse longo ciclo latino-americano construtivo, o desenvolvimentismo dos anos cinqüenta e sessenta, o arquiteto como figura e a planificação como tópico tenham-se convertido em núcleoschave do pensamento e do imaginário social, em cristalizações da teoria da modernização.

A concretização do que viria a ser consagrada como a moderna arquitetura brasileira dependeu muito diretamente da engenhosidade discursiva e material de Lúcio Costa, ${ }^{83}$ mas além desta, de articulações em outras frentes. A presença de alguns dos representantes mais diretos de uma vertente da arquitetura moderna em estruturas governamentais vigentes, foi crucial para a consagração de uma arquitetura moderna no Brasil, pelo protagonismo desses agentes, fosse nas frentes de seleção dos referenciais da memória nacional, ${ }^{84}$ de construção

industrializado, seria preciso destruir uma considerável barreira de sólidos costumes”, política que viria a ser mais explicitamente endossada por Vargas no pós-guerra (SKIDMORE, 2010, p. 73-79).

82 "conjunto plural de intrincadas tramas em que se cruzam produções estéticas, vidas de artistas, manifestos, programas, posições políticas, valorações críticas, apelos genealógicos ou postulados filosóficos" (GORELIK, 2005, p. 19). "vontade de construção ex novo" que no caso da América Latina significou que a "modernidade foi um caminho para se chegar ao desenvolvimento, não sua consequência", numa "constante cultural" que "dá sentido à arquitetura de vanguarda e, por outro lado, a que se explica nela". (GORELIK, 2005, p. 49)

${ }^{83}$ Como aponta Abílio Guerra "a crença (que habita textos, narrativas e falas das décadas de 1920 a 1940) em um projeto alternativo de ação moderna - onde a cultura e a natureza ocupam papeis principais -, que devido sua eficácia discursiva se metamorfoseia em características reais da arquitetura moderna brasileira. Em síntese, os artifícios intelectuais se convertem em caráter orgânico. Assim, o entendimento da montagem discursiva do moderno brasileiro é, ao mesmo tempo, o entendimento da sua eficácia na constituição de uma arte e de uma arquitetura com características próprias. A compreensão do fenômeno histórico se dá, portanto, através do discurso que o descreve, o constitui e o legitima" (GUERRA, 2017, p. 15).

${ }^{84}$ Márcia Regina Chuva aborda em profundidade a participação de intelectuais em redes sociais de relação, junto ao processo de constituição de um Patrimônio Nacional e sua institucionalização, a partir da década de 
de monumentos do Estado Nacional, ${ }^{85}$ de contribuição à constituição de políticas nacionais de habitação ${ }^{86}$ (CAVALCANTI, 2006). Ainda que não tenha sido vertente absoluta do moderno na arquitetura no Brasil, até os anos de 1960, foi esta a Arquitetura a prevalente do imaginário dentro e fora do país, ${ }^{87}$ justificada pelo diálogo com as premissas do funcionalismo de procedência europeu, engendrada da atualização material e simbólica das experiências construtivas coloniais realizadas em solo nacional e sintetizada numa visualidade proposta a partir da referência ao passado colonial brasileiro interpretado, em textos e na prática.

Entre 1940 e meados de $1950^{88}$ a produção tornada referencial para a cultura arquitetônica no Brasil foi valorada por historiadores e críticos, nacionais e estrangeiros, além de arquitetos, que extraíam e propagavam seus atributos, os que a tornariam paradigmática, num conjunto estrito de textos. Ao tempo de sua difusão pela imprensa

1920 no Brasil. O ideal nacionalista difundido pelo Estado desde então, contribuiu para que a modernidade e a tradição fossem de modo particular do país, constitutivas das práticas de preservação com a criação do SPHAN em 1937 pela lei n.378, e a discriminação do patrimônio histórico e artístico nacional, pelo Decreto Lei n.25 do mesmo ano (CHUVA, 2009).

${ }^{85}$ Neste caso está em pauta tanto o sentido fornecido por Le Corbusier e Giedion sobre a Nova Monumentalidade, ou seja, o caráter desejável à Arquitetura de poder vir a afetar às percepções ainda que destituída sua carga memorial historicista, quanto o relativo à representatividade do Estado Novo em edifícios como o Ministério da Educação e Saúde, a exemplo da posição de Gustavo Capanema que "queria um prédio que retratasse a instituição que dirigia, por ele pensada como instrumento de um projeto cultural visando preparar, compor e aperfeiçoar o homem brasileiro" (COMAS, 2010, p. 90-91).

${ }^{86}$ Foi no Estado Novo, nos anos de 1930, que a habitação foi tornada objeto de interesse estatal, tanto como política em atendimento às demandas sociais, quanto meio de "controle do uso da terra urbana, num momento em que as cidades brasileiras estavam crescendo aceleradamente e a especulação imobiliária sobrepunha-se a qualquer planejamento urbano", quando os Institutos de Aposentadorias e Pensões foram tornados os "primeiros departamentos públicos efetivamente voltados para os problemas da habitação social em massa", produzido obras referenciais com princípios modernos de "compreensão científica da habitação", "uso de critérios racionais de composição", "racionalização dos sistemas construtivos", "projeto como indutor de uma nova cultura da habitação", "produção industrial de componentes da habitação", "reconhecimento do papel indutor do planejamento do Estado" (BRUNA, 2015, p. 119-168).

${ }^{87}$ Ruth Verde Zein relata que nos anos de 1970 uma mesma abordagem, baseada no "triunfo da arquitetura moderna europeia sobre o ecletismo do início do século, sua implantação em nosso país, as obras-símbolo dessa modernidade brasileira e, por fim, Brasília - interrompendo seu relato em 1960". A arquitetura canônica era apresentada como fato histórico, em condição não suscetível a novas formas de interpretação, novos caminhos e reflexões atualizadas, exceto quando desfocados da arquitetura, como quando sob interesse dos fenômenos sociais e de sua espacialização urbana (ZEIN, 2001, p. 17).

${ }^{88}$ É considerado o intervalo de publicações entre o livro catálogo Brazil Builds escrito por Philip L. Goodwin, organizado pelo Museu de Arte Moderna de Nova York (MARTINS, 1987, p. 8) e a série de manifestações críticas à Arquitetura moderna desenvolvida no Brasil, demarcadas pela proferidas por Max Bill em 1953 (XAVIER, 1987), ainda que os anos de 1960 tenham concentrado posições divergentes em relação a essa Arquitetura (WISNIK, 2004). Maria Alice Junqueira Bastos e Ruth Verde Zein veem a posição de Max Bill teve "mais fama do que importância" e sua projeção foi devida à repercussão provocada pela revista Habitat, pela qual Lina Bo Bardi abria "novos caminhos" à Arquitetura, num contexto de valorização de leituras de cunho social (ZEIN e BASTOS, 2010, p. 43). 
especializada e popular, tal produção foi moldada à imagem simbólica do processo socialmente almejado de modernização brasileira. Discursiva e materialmente, a arquitetura personificada em Lúcio Costa e Oscar Niemeyer, foi expressa em edifícios de notabilidade e qualificada prevalentemente pelos atributos construtivos que lhes eram referenciais, dada a capacidade com que sua materialidade foi remetida à componentes da cultura construtiva luso-brasileira, em representações idealizadas da nação. Todavia, noutro curso (ZEIN e BASTOS, 2010, p. 26):

Essa arquitetura brasileira - chamada aqui, para maior clareza, de "escola carioca” - ainda não era, finda a Segunda Guerra, plenamente hegemônica no panorama cultural do país, pois seguiam concomitantemente atuando arquitetos de outras tendências, seja de tradição acadêmica, seja afinados com outras possibilidades formais "modernistas"; mas seu exemplo brilhante e sua consagração internacional impulsionam e incrementam a rapidez na aceitação de seus paradigmas - entre os quais, o desejo de representar uma "brasilidade" e de colocar-se entre os aspectos culturais relevantes da "identidade nacional".

Esses exemplos e essas vontades manifestavam a consolidação de uma escola, a já mencionada escola carioca, que precipuamente estabelece a autoridade de uma determinada doutrina projetual moderna, de corte corbusiano mas de caráter brasileiro, validando e oferecendo um conjunto de procedimentos com os quais a arquitetura moderna brasileira poderia idealmente se expandir. E que servirão, muito a propósito, para dar fé e exemplo cabal do triunfo da arquitetura moderna também no panorama internacional, a partir de meados dos anos de 1940, com influência marcante até pelo menos meados dos anos de 1960.

Assim, a articulação simbólico-material da cultura nacional, seu "nexo particularista", o que "plasmou a arquitetura brasileira, aos olhos do mundo, sob a rubrica da identidade nacional” (WISNIK, 2004), serviu de base a um projeto cultural consagrado como cânone. Ainda assim, a produção tornada prevalente sob a pauta da modernização, assim como a afirmação e consagração de seus feitos, comumente enquadrados numa vertente específica da "escola carioca", ${ }^{89}$ transcorreram ao tempo de outras experiências que responderam distintamente ao intento de atualização da Arquitetura na condição de agente da modernização urbana no país. Estas só teriam maior visibilidade nos anos de 1960, e mais decisivamente após os anos de 1980, quando foram desenvolvidos novos recortes interpretativos e críticos sobre a arquitetura no Brasil. Estes, foram os que se posicionaram conscientes de que um espectro variado e maior de realizações, dentro da própria escola

\footnotetext{
${ }^{89}$ Mário de Andrade nomeou assim a produção realizada no Rio de Janeiro (XAVIER, 1987, p. 179).
} 
carioca, e mesmo na arquitetura e artes em outras partes do país, em processos distintos geradores de respostas igualmente diferenciadas à questão da modernização da cultura construtiva nacional, nas diversas condições geográficas.

Não só na Arquitetura e Urbanismo, mas estudiosos das artes e da cultura tem desenvolvido pesquisas que atestam o quanto as mitificações de eventos demarcatórios já consagrados na História tem produzidos formas de ocultamento de processos concretos dados nesses campos. Eles têm percorrido, desde outras bases teóricas de compreensão e método de pesquisa, revelando formas orgânicas com que tem sido dadas as trocas culturais e os sincronismos das ideias no âmbito da modernidade, com a aplicação de leituras que consideram as transculturalidades, as transnacionalidades, a exemplo da constatação de Aldrin Moura de Figueiredo, estudioso das artes e literatura ao afirmar sobre a Amazônia (FIGUEIREDO, 2016, p. 131):

[...] desde o final do século XIX, com o incremento da exploração da borracha e sua exportação no mercado internacional crescente, um trânsito de artistas e literatos, de diversos matizes intelectuais, tomou conta da seara das letras e das artes. Ligações diretas com Paris, Roma, Lisboa ou Berlim, fizeram de Belém e Manaus importantes capitais culturais do Brasil na virada do século XIX. Pintores e desenhistas, brasileiros e estrangeiros, marcaram presença constante com exposições, mostras e intercâmbios com colecionistas, marchands e aficionados das artes.

O historiador desenvolve ampla pesquisa a respeito do modernismo nas artes em leituras transculturalizadas, focalizando empiricamente eventos transcorridos em Belém PA, mas lidos sob a ótica de uma História Global. Suas análises, no caso supracitado em específico, descentralizam a Semana de Arte Moderna de São Paulo, no sentido com que este evento foi situado na história das artes no país, trazendo à tona outras experiências de importância na composição da vanguarda artística nacional de início do século XX.

Todavia, a perspectiva desta tese não é a de uma crítica historiográfica, mas decorre de uma investigação que, conforme a presente compreensão, deve anteceder uma avaliação de tal porte. Uma primeira leitura da Arquitetura e Urbanismo na Amazônia desde os textos, além de necessária, para que fosse dada a ver sua inscrição no conjunto da História escrita no campo, foi motivada pela condição com que a temática foi dispersa e diversamente significada nas fontes. Em si, o rastreamento e análise de ambos, da inscrição da Arquitetura na Amazônia nos textos e das significações, dos atributos que lhe foram conferidos, 
consistiu em vasta pesquisa. Como já afirmado, no curso dos eventos referenciais à Arquitetura e Urbanismo no Brasil, os textos incidiram sobre o mundo material, produzindo distinções entre os objetos da Arquitetura no Brasil, no conjunto de sua cultura escrita. Inscrevendo a Arquitetura na Amazônia no campo disciplinar, veicularam significados aos seus objetos, como referenciais à formulação material e simbólica de edificações na Amazônia.

No Brasil, desde os anos de 1940 até a realização de Brasília, ocorreu "uma aceitação aparentemente inconteste da predominância e liderança da escola carioca, bem como de sua identificação com “a” arquitetura brasileira, sem que, aparentemente a ela se contrapusessem outras linhas ou tendências” (ZEIN e BASTOS, 2010, p. 36), mesmo que perspectivas bastante distintas já estivessem em curso sem no entanto obter a mesma projeção junto à atividade crítica. De sua própria experiência, Ruth Verde Zein se refere a uma "história interrompida em 1960" por Brasília, que teria sido o ápice do projeto da arquitetura moderna nacional, e seus efeitos sobre a academia nos anos de 1970, quando se ouvia a respeito de que "a história se interrompia em Brasília porque se havia, desde então, perdido o rumo correto: as eventuais novas realizações não teriam valor por haverem se afastado da unidade da arquitetura moderna brasileira” (ZEIN, 2001, p. 45-47).

De todo modo, as revistas já nos anos de 1950, portavam olhares distintos sobre temas que viriam a ganhar força nos anos seguintes, como no caso da revista Habitat e sua temática do popular ${ }^{90}$. No recorte temporal estabelecido por Renato Anelli para a História que reconstitui da Arquitetura Contemporânea no Brasil, o estabelecimento do ano de 1957, decorreu justamente dessa reflexão acerca dos eventos que concomitantemente estavam em curso no país, quando do concurso de projetos para a realização de Brasília (ANELLI, 2008).

A historiografia desde os anos de 1980, por outro caminho, passou a revelar o quanto a escrita de teor histórico foi extensiva às bases discursivas daquela produção desenvolvida por um grupo de arquitetos e intelectuais, destacadamente Lúcio Costa, em consonância ao Estado Nacional. O estudo de Carlos Ferreira Martins é demarcatório e já clássico. Ao voltar-se à compreensão da estreita relação entre a arquitetura moderna em contributo à

\footnotetext{
${ }^{90}$ Desde a primeira revista Habitat, a Amazônia aparece em artigos que privilegiaram o registro escrito e visual de modos de vida tipificados, em associações ao popular.
} 
ideologia do "Estado Nação", empreendeu o desnudamento discursivo nas bases textuais pelas quais a arquitetura moderna nacional foi consolidada pela posição central em uma “trama narrativa recorrente”. O caminho dessa narrativa foi iniciado com o livro catálogo de Philip Goodwin (1943), o primeiro a gerar "grande impacto de divulgação internacional da emergente arquitetura moderna brasileira", marcada pela "originalidade" e pelo elo que estabeleceu, informado por Lúcio Costa, entre modernidade e tradição (MARTINS, 1987).

Em prosseguimento, Henrique Mindlin (MINDLIN, 1956) atualizou a referida trama, chancelado por Giedion, que prefaciou sua publicação. Com ele era demarcada a projeção internacional da produção brasileira, de "assimilação generalizada de normas e procedimentos linguísticos e técnicos” que reforçavam “a identificação dessa arquitetura como brasileira", com a produção de mais de 120 arquitetos. Após nove anos depois de Mindlin, Geraldo Ferraz (1973) publicou, "Warchavchik e a introdução da nova arquitetura no Brasil: 1925 a 1940”, “disposto a resgatar o papel pioneiro da produção paulista moderna”, a partir da inscrição de Warchavchik e Flávio de Carvalho na bifurcação que traçou para a narrativa da Arquitetura no Brasil, com nova periodização e abordagem, desde a leitura do movimento moderno como "fato internacional", pautado no racionalismo construtivo europeu (MARTINS, 1987, p. 18-42).

A tese tornada livro de Yves Bruand (1977/1981), foi realizada em "um momento novo na historiografia", sob a ciência do autor de sua necessidade de "manejar a tensão entre crítica e história”. Para Carlos Martins, o rigor e a amplitude do levantamento documental por um lado, o esforço de interpretação como trajetória, do "processo de evolução da arquitetura brasileira de filiação moderna”, por outro, foram os traços fundamentais deste texto situado "entre o determinismo técnico e o psicologismo que perpassa toda a sua análise das condições históricas e políticas”. Especialmente pela periodização, foi a confirmação das primeiras publicações desse conjunto de narrativas interligadas, como na minimização do pioneirismo de Warchavchik, que embora tenha sido mencionado, o foi como que em preparação ao acontecimento de 1936, com a construção do MES, os trabalhos de Reidy e Luis Nunes (MARTINS, 1987, p. 44-56).

Carlos Martins reconheceu, ao apresentar o último escrito sob sua análise, que a “contribuição brasileira à historiografia” era "bastante pobre”. Destacou do Departamento de História da FAUUSP o trabalho de Carlos Lemos (1979), cuja atenção maior foi dada à 
romper "barreiras entre a produção culta e o modo de habitar da população", revalorizar a produção eclética de início do século, formulando com certa imprecisão o corte temporal da origem da arquitetura moderna no Brasil. Incorporou Warchavchik, Vital Brazil, Flávio de Carvalho como importantes referenciais dos anos de 1920 e 1930, mas foi convergente com Goodwin e Mindlin, no acento dado aos anos de 1940 para a "consolidação da linguagem moderna", destacadamente pela atividade de Oscar Niemeyer e pela arquitetura realizada no Brasil com projeção internacional, dentre outros fatores, pela competência técnica dos profissionais em ascensão (MARTINS, 1987, p. 64-70).

Portanto, o instrumental da História, a seletividade crítica foram recurso aos escritos que formularam discurso e imagem a arquitetura moderna nacional. $\mathrm{O}$ alinhamento desse conjunto estrito de escritos compôs com certa proximidade temporal dos acontecimentos, a base textual da cultura escrita sobre a arquitetura no Brasil até a década de 1980. De um lado o ancoramento discursivo de uma moderna arquitetura brasileira e de outro, sua objetificação e consagração naturalizada pela História. Nas vias textuais, atributos agregados à uma moderna arquitetura no Brasil, constituíram assim, um enredo em escritos específicos, que visavam narrar uma completude que estavam ainda a explorar ou que dela eram partícipes. Em fluxo, os escritos não apenas revelavam, mas consagravam à memória, eventos demarcatórios, temporalidades, arquitetos, ideias fundantes para a história da Arquitetura do país (MARTINS, 1987, p. 28).
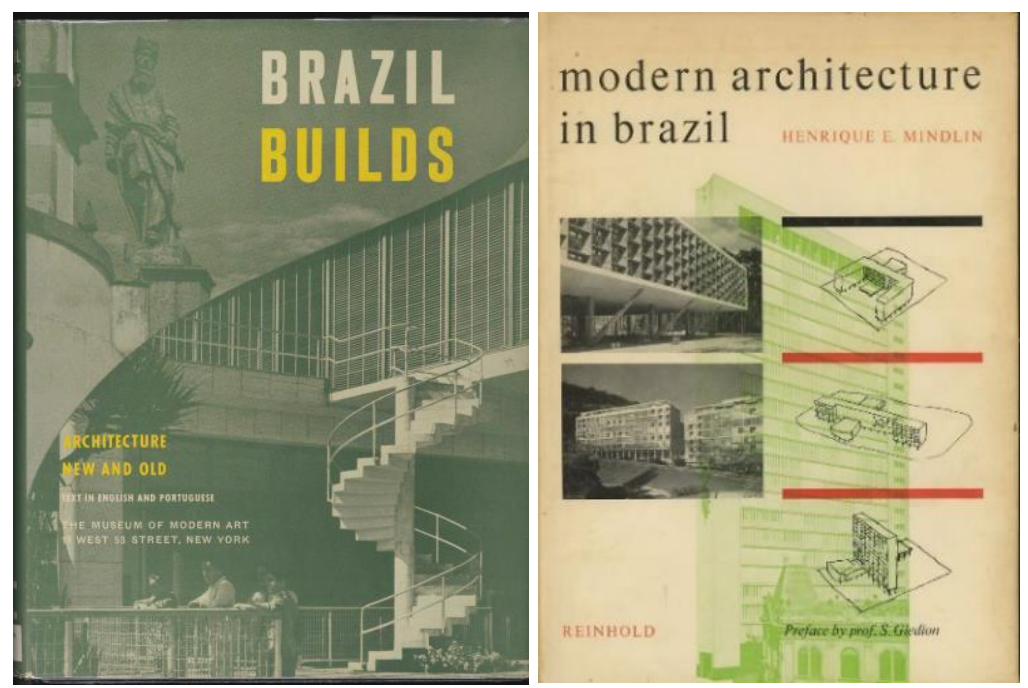

ARQUTTETURA CONTEMPORANEA NO BRASIL

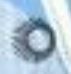

Figura 4 - Capas do Livro-catálogo Brazil Builds, de Philip Goodwin (1943), do livro Modern Architecture in Brazil de Henrique Mindlin (1956) e Arquitetura contemporânea no Brasil, de Yves Bruand (1981). 
As publicações consideradas na historiografia desenvolvida por Carlos Martins, figuram centrais no período analisado. Esta constatação parte do princípio de que os autores objetivavam historicizar os fenômenos da arquitetura, elaborar e registrar em fluxo a trajetória passada dos acontecimentos relativos à gênese da moderna Arquitetura no Brasil e seus desdobramentos. Também, desde os textos, a interpretação discursiva, capturada da lógica narrativa, identificou uma estrutura desencadeada e intensamente replicada da ordem do discurso. Não estavam sob a mesma condição, à análise historiográfica estrita, outros textos que traziam registros ${ }^{91}$ ao tempo das realizações detidas ao campo da arquitetura. Com a legitimidade de serem meios destinados prioritariamente a veicular atualidades, as revistas de arquitetura, junto a outros impressos, como os manuais de arquitetura, foram fundamentais para a consolidação da trama recorrente elucidada por Carlos Martins, bem como decisivas para a difusão da moderna arquitetura brasileira.

Nelci Tinem acresceu documentos à pesquisa historiográfica ao investigar a difusão e consolidação do ideário moderno na Arquitetura brasileira, desde o diálogo crítico capturado da leitura internacional, para a compreensão da produção sob "o olhar estrangeiro". Para a autora, componentes discursivos decisivos contribuíram para a consagração da arquitetura moderna brasileira entre 1936 e 1955. O vínculo entre a tradição cultural e a modernidade, a ênfase formal, o particularismo, foram revelados ou reforçados em variados escritos internacionais. Sua análise pode ser apreendida pelo foco à convergência nos textos, do interesse no segmento hegemônico da arquitetura realizada no Brasil. Ainda que atenta a posturas distintas aos princípios de Lúcio Costa identificadas nas fontes documentais, o estudo reiterou uma hegemonia, esmiuçando os outros caminhos pelos quais seu discurso adquiriu validação. A respeito do caráter dual das publicações, expressa Nelci Tinem, ${ }^{92}$ endossando a tese de Carlos Martins (TINEM, 2006, p. 20):

Costa (1936), Goodwin (1943), Mindlin (1954), Ferraz (1965) e Lemos (1979) constituem as tentativas de escrever uma história contempladas nesta etapa. Ainda que os três primeiros se caracterizem, à primeira vista, como documentos de divulgação, a forma como são feitos os converte em matéria prima para a construção de uma versão historiográfica. O quarto

\footnotetext{
${ }^{91}$ As revistas especializadas de Arquitetura, ainda que apresentem além de leituras atualizadas de mediação de obras, escritos perpassados pela intencionalidade de crítica, teoria, história, são compreendidas como registro de eventos de curta duração, em geral, experimentados e reportados na temporalidade do tempo presente.

${ }^{92} \mathrm{O}$ livro foi resultado da tese de doutorado da autora, defendida em fevereiro de 2001, no Programa de Doutorado História Urbana, História de la Architectura, da Escuelal Técnica Superior de Arquitectura de Barcelona, Universidade Politécnica de Cataluña, ETSAB/ UPC.
} 
se contrapõe à linha geral seguida pelos anteriores e oferece dados para uma nova versão, tentando influir nos rumos dessa construção. O último, cuja publicação é posterior, e por isso muito diferente em relação à postura metodológica, se distancia dos anteriores e sugere novos aportes para reflexão a respeito dessa construção historiográfica hegemônica.

Trabalhos como os de Maria Alice Junqueira Bastos e Ruth Verde Zein, mais próximos do presente, se voltam ao preenchimento de outras lacunas historiográficas, apontando as múltiplas temáticas implicadas pela atividade projetual, em amplo debate entre os anos de 1945 e $1955 .{ }^{93}$ Em destaque, apontam as relativas ao patrimônio cultural, aos saberes populares, à constante crítica à homogeneização dos modos de vida com a industrialização, ao transporte urbano, às limitações do projeto no pleno atendimento das complexas demandas sociais, à inviabilidade e à fragmentação do “desenho total” do ideário moderno. Findo o destaque que conferiram à Oscar Niemeyer, as autoras desfocam a arquitetura da escola carioca em sua narrativa e priorizam um caminho que leva ao momento fundacional de uma potente arquitetura em São Paulo. Os autores da consagrada arquitetura emergida do Rio de Janeiro, e seus feitos, são então inscritos num fluxo não linear e único, mas em "diálogos” sincrônicos a outros eventos do campo multifacetado apresentado no período.

Na década de 1950, a visibilidade da arquitetura no Brasil foi afirmada no campo da crítica internacional, que a reconheceu como uma referência a questões importantes para a Arquitetura como disciplina prática. Destas, a relação com o urbanismo, suas bases ideológicas, a própria ideia da monumentalidade, foram desarraigadas do contexto brasileiro e levadas a um plano global de discussão. A própria crítica internacional, centrada na atividade desenvolvida na capital do país, havia negligenciado São Paulo. Nos anos de 1950, o espaço metropolitano e sua exacerbação, junto ao fenômeno urbano implicado pela industrialização conforme experimentados em São Paulo, demarcaram mais claramente novas experiências de projeto, bem como o esgotamento da unanimidade de uma vertente da Arquitetura no Brasil.

Mais que fenômeno inscrito no tempo e no espaço, a "escola carioca” foi ao menos até os anos de 1960, referencial à prática da disciplina e da história interessada em identificar

\footnotetext{
${ }^{93}$ Não se trata de estudo restrito ao referido recorte, o período de maior destaque da Arquitetura brasileira no âmbito internacional.
} 
e propagar realizações afeitas à vertente de uma moderna arquitetura nacional. A centralidade desta vertente, pela força afirmativa de ser constituída como a produção representativa da nação teve ampliado alcance durante algumas décadas, sendo reafirmada e ocupando o lugar de referência ao trabalho de historiadores, passando a ser Brasília ${ }^{94}$ a chave explicativa de sua própria exaustão. Assim, a arquitetura moderna brasileira ainda que não fosse mais hegemônica a partir dos anos de 1960, Brasília consistiu num fenômeno de baliza aos escritos sobre a produção no país, que desde então passava a registrá-la em novos enquadramentos críticos, a partir de renovadas interpretações. Ruth Verde Zein sintetiza sobre as mentalidades nos anos de 1960 (ZEIN, 2001, p. 18-19):

Uma coisa nos intrigava: por que a história parou em Brasília, se nela se afirmava estar configurado o triunfo da arquitetura brasileira? E por que se falava tão pouco dessa Brasília, tanto a do plano-piloto, quanto a da vida real? Devido ao golpe militar de 1964, diziam-nos, o qual teria sido o responsável-mor pela "ruptura" no andamento do processo arquitetônico brasileiro. Mas não era esse mesmo poder autoritário quem promovera o definitivo crescimento de Brasília, fazendo-a cumprir de fato suas funções de capital, ali se instalando confortavelmente?

Talvez não se falasse de Brasília justamente por isso: por ser ali a sede desse poder discricionário, com suas cidades-satélites tão carentes quanto quaisquer outras periferias das demais cidades brasileiras. Pois dizer isso era admitir que o fato arquitetônico e urbano de Brasília, com suas qualidades e defeitos, era impotente para mudar a realidade social e política. Mas não tinham sido justamente estes seus pressupostos? Mas nos haviam ensinado que a arquitetura moderna era o motor que transformaria a sociedade, criando, através dos espaços livres, homens livres? Brasília, realizando essa utopia da modernidade - a ideia da construção da cidade sem barreiras como cristalização do advento da sociedade sem fronteiras econômicas -, pôs em pé um mito e ao mesmo tempo desnudou-o, trazendo à luz suas mais íntimas contradições. O golpe militar de 1964 não mudou esse fato, nem interrompeu esse processo: apena o deixou mais patente.

Obras referenciais, seus autores e o alcance do processo de elaboração e concretização de uma arquitetura representativa do Estado Nacional, o qual teve como ápice a inauguração de Brasília, tornaram-se constitutivos da história narrada a respeito da formulação e propagação de uma moderna arquitetura brasileira. Sua prevalência para a disciplina motivou especulações desde perspectivas para além das pautadas em seu engenho material e genealogia. O desnudamento discursivo dos articuladores de Brasília e a

\footnotetext{
${ }^{94}$ Como apontou Adrián Gorelik, Brasília tida como "a realização da cidade mítica na representação cultural da modernidade latino-americana” (GORELIK, 2005, p. 31).
} 
visibilidade fornecida pela pesquisa histórica, das condições sociais de possibilidade de sua realização e propagação, ocorreram pari passu à construção da própria História da arquitetura no Brasil no século XX. Em particular, os escritos até a década de 1980, recorte final da presente tese, revelaram a decisiva influência da arquitetura moderna demarcada desde os anos de 1930, como de caráter nacional.

Coincidiu com o golpe militar de 1964, um processo que no âmbito disciplinar era experimentado na década de 1960, de um período de "transição" que perdurou até os anos de 1980, marcado pela "maturação do projeto moderno", pelo "cenário internacional em mutação", pelo "quadro institucional de exceção" ${ }^{95}$ no país, além da intensificação de um mercado contraposto ao diminuído investimento estatal no segmento da Arquitetura. Neste intervalo de aproximados vinte anos, prevalecia entre os arquitetos, a "vontade de expressão" na prática do projeto. Os anos de 1980 teriam sido aqueles, que marcados pela ausência passada de atividade crítica restritiva, foram plenos de um "pluralismo" diante da hegemonia do paradigma moderno brasileiro, ainda que sempre tenha havido "defecções, sobretudo em manifestações regionais, como nos estados do Norte e Nordeste" (SPADONI, 2007, p. 243-255).

Para Francisco Spadoni, justamente a partir dos anos de 1980, ainda que sempre tenha havido "caminhos alternativos" em relação ao movimento moderno, estes passaram a ser valorados e reconhecidos a partir de novas bases de admissão, especialmente pela crítica e pela atividade editorial que então vinha sendo retomada, como atestado por Abílio Guerra (GUERRA, 2010). Perpassada por pautas revisionistas internacionais da arquitetura moderna, a prática e também a crítica absorveram alguns de seus temas principais, como os relativos à memória, à história, à valorização do cotidiano, no entanto, sem ter produzido no âmbito nacional efeitos de longo prazo sobre a disciplina. Em síntese, “ou se combatia o moderno, como um passado o qual já não tinha mais com o quê contribuir, ou se combatia a novidade, que, por não ter uma face precisa, reduzia todas as ações em um único rótulo renegado" de pós-moderno, como síntese de um ambiente de tensão, dúvida e atitude reflexiva que regia a atividade profissional nos anos de 1980 (SPADONI, 2007, p. 257).

\footnotetext{
${ }^{95}$ Francisco Spadoni faz referência, em sua análise, à relação da arquitetura nacional com o Estado, portanto presume que a dependência "do projeto oficial para sua massificação e sedimentação da linguagem" e a resistência, "para prosseguir a aventura da invenção" do projeto, em simultâneo e contraditoriamente, foram a pauta do processo de transição da Arquitetura do que teria sido em sua "matriz moderna".
} 
Para Hugo Segawa, a trajetória da arquitetura moderna atrelada ao Estado Nacional, passou a ser desnaturalizada pela crítica e história mais marcadamente a partir da década 1980. E justamente na metade da década, o pós-modernismo teria alcançado "alguma densidade" no Brasil (SEGAWA, 1998, p. 191). Noutros termos, a atividade profissional entre os anos de 1965 e 1975, de "profundas contradições e tensões" foi implicada pela conjuntura repressora contraposta a determinados arquitetos que vinham protagonizando posições políticas muito claramente influídas pelo caráter progressista que subjazia suas obras, em particular, em São Paulo. Por outro lado, este ambiente de "tensão" disciplinar não teria limitado a prática, muito intensificada pelas frentes de trabalho deslocadas dos escritórios para as contrutoras e a novos temas de projeto, como os industriais (SEGAWA, 1998, p. 163). E justamente a crítica que se constituiu após esse período, redelineando o campo discursivo e teórico, já que esteve até então separada da atividade prática, em virtude do esvaziamento do debate crítico a respeito da arquitetura, foi sendo mais permissiva às formulações plurais, não mais arraigadas necessariamente à tradição discursiva e material do moderno nacional (ZEIN e BASTOS, 2010, p. 109).

Até a década de 1960, a produção brasileira lidou com a "questão problemática de se construir uma nação moderna", a partir da qual experimentou soluções muito variadas. Desde então, o "horizonte" passou a outro patamar, como em São Paulo, onde a "metrópole" centrou a maior parte das discussões acerca da Arquitetura (WISNIK, 2004, p. 42). Miguel Alves Pereira, quando foi presidente do conselho superior do Instituto de Arquitetos do Brasil - IAB, afirmou em 1973 que "as fronteiras do país foram transpostas e a excelência da arquitetura brasileira foi decantada em todo o mundo", referindo-se à arquitetura moderna nacional. Mas que diante de tantos elogios à arquitetura brasileira, parecia que as obras deveriam ficar "a salvo de qualquer dúvida, crítica ou polêmica", se referindo muito provavelmente às posturas reativas de Lúcio Costa à crítica internacional a partir da década de 1960. Por isso, toda uma geração de arquitetos foram formados sob o "hábito da intocabilidade consentida". Os profissionais absorvidos por essa mentalidade seriam os que não incorporaram "à sua experiência o hábito do comportamento crítico, isolando em si mesmo, na sua própria fortaleza" (CJ, 1973, p. 6-7). Era portanto a defesa mais nítida da necessidade de ser retomada a atividade crítica no país, mas não só, o amplo 
debate acerca da arquitetura já vinha sendo realizada no âmbito nacional. Para Ruth Verde Zein, nos anos de 1970 (ZEIN, 2001, p. 26-27):

[...] os arquitetos brasileiros adquiriram sua maturidade profissional. Passou-se da experimentação limitada e do exercício pontual à prática em grande escala; e, se a realidade autoritária e discriminatória marcou negativamente os limites para uma atuação mais coletiva e social dos arquitetos, não é única culpada pelas deficiências que se seguiram, nas décadas seguintes: muitos dos problemas que hoje podem ser apontados na arquitetura contemporânea são também fruto da falta de consciência crítica e da pouca maleabilidade conceitual dos arquitetos, no reconhecimento e no debate de sua produção.

Este fenômeno, lido em detrimento ao campo, é compreendido em equivalência ao período que adquiriu o recorte designado de Pós-Brasília, como um período dado a partir dos anos de 1960, repercutido nas escolas de Arquitetura com o esvaziamento do discurso de uma moderna arquitetura nacional. A criação de novos cursos de Arquitetura no país também caracterizou este novo momento, bem como o declínio do campo editorial da Arquitetura, como apontado por Hugo Segawa na década de 1980 (PROJETO N.42, maio de 1982, p. 42):

Nunca o arquiteto brasileiro teve tantas publicações nacionais à disposição
como na década dos anos 50 e início dos 60. Neste período nasceram e
morreram revistas como Habitat, Brasil Arquitetura contemporânea,
Arquitetura e decoração, Forma, Módulo, Brasília, Bem estar, IAB,
Espaço, Arquitetura, além da Acrópole e Arquitetura e engenharia,
anteriores a esta fase.
Era o conhecimento local de um prestígio que começara no exterior, e
também o reconhecimento das possibilidades comerciais de publicações
sobre arquitetura, cujo mercado não se restringia apenas ao Brasil. A
maioria dessas revistas traziam versões em francês e inglês, numa
demonstração do direcionamento desejado.

A atividade projetual acompanhava a intensificação produtiva em equivalência aos anos do "milagre econômico" no país e o fluxo das publicações prosseguiu ainda que com menor intensidade no alinhamento à prática, como as revistas Arquitetura - $I A B$, que desde os anos de 1960 veicularam, com certa regularidade, a Amazônia e a Arquitetura localizada no norte do país. Foi sendo demarcada mais claramente uma interpretação condicionada à realização de Brasília, sendo este um marco final da arquitetura pretensamente nacional. Nomeadamente o Pós-Brasília, como enunciado nos Cadernos Brasileiros de Arquitetura publicados em 1976, foram tidos como um marco da transição às novas possibilidades de projeto e de assimilação pela crítica, das pluralidades. 
Em 1976 o IAB-RJ retomou os debates sobre a Arquitetura brasileira, no período após a concretização de Brasília. O ano de 1981, quando da realização do II Inquérito Nacional de Arquitetura, "foi um período de posições extremadas no cenário arquitetônico nacional” ${ }^{96}$, como aponta Maria Alice Junqueira Bastos. Mesmo anteriormente, a Arquitetura na Amazônia ou a temática da Amazônia foi publicada, mais intensamente na revista Arquitetura- $I A B$, mas também na Arquitetura Brasileira do Ano - $A B A,{ }^{97}$ havia cerca de dez anos. À primeira foram vinculados também os Cadernos de Arquitetura Brasileira - $C A B$, que publicaram, do mesmo modo, obras de Arquitetura na Amazônia, sob pauta conduzida pelo debate mais centrado em São Paulo e Rio de Janeiro. Todavia, a autora afirma ter sido uma revista mineira, Pampulha, a responsável por trazer a tona uma diversidade de posicionamentos, bem como uma clara postura reativa à "Arquitetura oficial do país” (BASTOS, 2007, p. 53-54).

Algumas questões importantes desse período são determinantes na abordagem da tese, especialmente como justificativa ao seu recorte final, o ano de 1989. Um primeiro fenômeno, conforme enunciado, foi transcorrido entre as décadas de 1960 e 1980, diz respeito às publicações que apresentaram mais correntemente obras de arquitetura na Amazônia, sendo as revistas de circulação nacional, prevalentemente situadas no sudeste do país. Estas revistas abordaram de algum modo o lugar, a Amazônia brasileira, em artigos que a objetificaram em inteireza. Outra questão diz respeito à condição propícia à pluralidade da produção no campo da Arquitetura, que até a década de 1960, esvaziava de sentido uma Arquitetura oficial constitutiva do nacional. Frente às críticas correntes à prática estritamente ancorada nesta Arquitetura foi dada vazão a outras vertentes e designações da Arquitetura.

Esta conjuntura, digamos assim, formativa de um ambiente intelectual aderente à experiências ancoradas na pluralidade, desde então, e mais expressivamente a partir da década de 1980, pôde ser abastecido com as obras que vinham sendo realizadas especialmente em Manaus-AM e Belém-PA. O primeiro curso de Arquitetura na região foi

\footnotetext{
${ }^{96}$ A autora apresenta os embates desse período, frente a defesa da Arquitetura representada em continuidade, mais marcadamente pela produção da atividade projetual de Oscar Niemeyer, e a admissão da pluralidade de manifestações ancoradas em aspectos da regionalidade.

${ }^{97}$ Hugo Segawa atestou a precariedade de sua distribuição como condição limitadora da circulação da revista (PROJETO N.42, maio de 1982, p. 47).
} 
implantado em Belém-PA, no ano de 1964, o que denotaria desde então, o favorecimento à constituição de um ambiente intelectual, de formação e atuação profissional na referida capital. No entanto, as revistas não foram fontes reveladoras dessa trajetória disciplinar em Belém, o que é denotativo de seu ocultamento no período, considerada a quantidade minimizada de projetos situados em Belém, publicados nas revistas. Em leitura seriada, cabe observar a já mencionada preponderância da publicação dos trabalhos de Severiano Mário Porto, questão relacionada a diversos fatores. Seu trânsito nacional, sua participação junto ao IAB, o grande número de encargos públicos que realizou, além da consonância de seus projetos à pauta ambientalista da segunda metade do século $\mathrm{XX}$, foram alguns destes.

As obras de arquitetura na Amazônia foram registradas nas publicações, assim como outras situadas fora dos locais consagrados, especialmente Rio de Janeiro e São Paulo, sendo que ao serem apresentadas, o foram a partir de determinadas designações de distinção. $\mathrm{O}$ que cabe abordar a esta altura é que foram inscritas no ambiente disciplinar crescentemente aberto à compreensão das pluralidades projetuais no país. Uma mentalidade pós-moderna junto ao reconhecimento de movimentos regionalistas, também viriam a atravessar a crítica, quando atenta às manifestações da arquitetura na Amazônia. As pautas que passariam a ser publicadas nas revistas acerca de uma certa arquitetura desenvolvida na Amazônia eram informadas desde o interior do fenômeno, a exemplo da produção de Severiano Porto ou de João Pinto de Castro Filho. Suas redes de sociabilidade, como arquitetos atuantes na região, sua atuação junto às instituições de classe, a exemplo do primeiro no IAB, as publicações de entrevistas, de textos assinados e de memórias, foram manifestações partidas das suas próprias práticas e lugares de ação na Amazônia.

O ambiente de discussões do Pós-Brasília foi propício ao debate a respeito da prática profissional organizada, na feição de um “debate político institucional”, que fosse avaliativo da conduta das entidades, bem como voltado ao "intercâmbio das experiências", como objetivado pelo X Congresso de Arquitetura realizado em novembro de 1979, em Brasília. Encontros regionais eram organizados e precediam a reunião geral do Congresso, como em Belém, onde arquitetos organizados participaram de discussão a respeito "do regulamento do congresso" e apresentaram aos "arquitetos paraenses a relação dos subtemas" que ali seriam discutidos (PROJETO N.16, novembro de 1979, p. 7). 
Na mesma revista que noticiou o referido Congresso, Marlene Milan Acayaba e Sylvia Ficher escreveram um artigo intitulado Arquitetura brasileira: tendências atuais. Para as autoras, o momento de busca pela redemocratização do país equivalia à "procura de caminhos" originados de uma fala recorrente, sob a assertiva de que "arquitetura está em crise”. As autoras produziram uma retrospetiva da arquitetura no país, desde os anos de 1920 até Brasília. Atestaram que se os anos de 1940 foram propícios à "superação dos impasses”, neste caso aqueles para dar vazão à consagração de uma moderna arquitetura brasileira, os de 1970 seriam centrados em Brasília, que "se concretiza no edifício e no urbanismo" (PROJETO N.16, novembro de 1979, p. 23-30).

Os “descaminhos” políticos que na década de 1960 implicaram o abandono por parte dos arquitetos, de sua atividade cultural, dos anos de 1920 até a realização de Brasília. Também implicaram sua própria autodeterminação como "profissionais da prancheta" diante de suas “conquistas alcançadas”. Naquele momento, Ficher e Acayaba expunham que as opções que tinham à época, nos anos de 1970, eram duas: a de "tecnocratas do planejamento ou bóias frias do ensino”, tamanha a dificuldade de realização de projetos, em grande parte pela desativação do incentivo estatal àquela atividade profissional. Assim, a retomada das discussões no âmbito da prática produziu campo aberto e fértil à troca de experiências e à averiguação do que foi realizado até então no país, mesmo que houvesse profissionais que admitiam, dada a conjuntura política antidemocrática, de que este teria sido o fator preponderante sobre a limitação do alcance, por meio do projeto, da modernidade no país.

Novas considerações acerca do urbano apoiavam-se no âmbito nacional e internacional, à revisão do paradigma representado por Brasília, de absoluto rompimento com a malha histórica de cidades tradicionais. Desde Brasília, a cidade como realidade urbana, social, espacial, passou à tema central no campo da arquitetura, atraindo para si, o interesse dos profissionais. Este tema ganhou espaço no Brasil sob os efeitos dos debates europeus acerca de um contextualismo cultural da arquitetura, pensado a partir de adequação da obra aos significados do lugar e à tradição, a exemplo de Ernesto Nathan Rogers e Aldo Rossi, que desde a segunda metade da década de 1970 passaram a conceber a Arquitetura desde os contextos de sua inscrição na cidade, esta, compreendida como "bem histórico e cultural” (BASTOS, 2007, p. 93-95). Uma outra faceta do urbano se fazia 
presente nos debates desse período, em especial sua relação com a "eclosão dos movimentos sociais pela democracia”. Este fator impulsionou uma das três vertentes que na arquitetura, reforçaram o processo de revisão da produção moderna canônica, bem como a relação entre Arquitetura, Estado e sociedade, numa vertente experimentalista. Junto a esta, o regionalismo e o pós-modernismo teriam influído diretamente na crítica e prática do período (ANELLI, 2008).

O experimentalismo possibilitou o encontro da prática projetual ao mundo social, especialmente junto aos "movimentos sociais por moradia e serviços públicos". O regionalismo inverteu, durante o regime militar, o sentido de uma unidade nacional moderna, já que foi afirmativo da fragmentação cultural que vinha sendo construída desde a década de 1930. O pós-modernismo, por sua vez, em seu parco enraizamento na cultura disciplinar, absorveu os referenciais provenientes da cultura de massas, além dos historicistas e contextualistas, como bases à atividade de projeto (ANELLI, 2008). Ainda que a arquitetura, a exemplo da realizada em Manaus-AM desde o regime militar (ABA N.1, 1967-68), tivesse estreita relação com o discurso e constituição de uma moderna arquitetura brasileira, foi tratada pela crítica em oscilação, como arquitetura brasileira ou como manifestação localista, de caráter regional.

Foi no curso deste processo de revisão disciplinar e de debates intencionalmente intensificados no campo, que ideias relacionadas ao pós-modernismo sustentaram as formulações estéticas e construtivas que viriam a ser gradativamente assimiladas por escritórios atuantes e pela indústria. Para Otília Arantes, a própria exacerbação da racionalidade, tendida à racionalização absoluta, com que operaram as vanguardas artísticas, inclusive a própria Arquitetura, foi além de seu impulso, o contributo ao seu declínio, no sentido de terem sido tornadas a prevalência discursiva. Este domínio teria aberto o espaço às novidades, que mesmo pertencentes ao mesmo fluxo da modernidade propiciada pela universalização do capitalismo e seus desdobramentos, incluso sobre as sociabilidades, “foram encobertas sob um véu de novas roupagens” (ARANTES, 1998, p. 34):

A estética relativamente estável do modernismo fordista teria cedido a vez à instabilidade e qualidades fugidias de uma estética pós-moderna que celebra a diferença, a efemeridade, o espetáculo, a moda, etc.

A reificação das relações sociais toma agora forma de uma irrealização do mundo convertido em imagens, da publicidade às artes eletrônicas, passando pela arquitetura simulada, cenarística, etc. 
Além dessas acepções, o pós-modernismo no Brasil, especialmente entre os anos de 1970 e 1980, também adquiriu outra conotação, que foi além da ruptura estética propalada por determinados segmentos, por ter aberto às "sensibilidades e a tolerância com a diversidade de posicionamentos, com a apreensão e compreensão de outras formas de instrumentar o raciocínio de projeto". Ele contribuiu para a validação de novos temas no debate nacional, como os relativos às formas de diálogo do projeto com os contextos urbanos e culturais de sua inserção, ao campo do patrimônio cultural, todos estes, como já observado, termas relacionados aos domínios do urbano (SEGAWA, 1998, p. 191).

Para Sophia Silva Telles, a Arquitetura requeria a recuperação de uma "específica institucionalização no campo cultural”, uma reformulação de seus referenciais apoiada na busca por outras referências. Com base na tradição ou na contextualização, era formulado um "começar de novo", como se a arquitetura racionalista estivesse desgastada naquele momento e por isso entre os chamados "pós-modernos", imperou um desejo de rompimento da relação que o racionalismo proclamou entre arte e técnica. Se a formalização $\mathrm{da}$ arquitetura do projeto racionalista almejava atender a uma universalidade e ao homem em seu cotidiano, para cada indivíduo, a dissolução dos "valores comuns, dos símbolos que haviam permitido uma antiga experiência coletiva" pelo uso da razão para o atendimento às demandas sociais, agora seriam substituídos pela "experiência privada" (AU N.4, 1986, p. 34-37).

A Bienal de Paris intitulada Arquitetura, em sua chamada, expôs uma definição de vertente revisionista, no início da década de 1980. Apresentada na revista Módulo, n.70, uma inteção de reconceituação da modernidade e da própria cultura disciplinar arquitetônica internacional foi assim explicitada (MÓDULO N.70, 1982):

A modernidade se fundamenta na consciência do mundo que se transforma. A modernidade não tem um só modelo. Ela está sempre à procura. Não existe uma forma definitica da modernidade. São os conceitos para o tema da próxima Bienal de Paris "Arquitetura"- Modernidade ou o espírito do tempo

$[\ldots]$

se propõe a reunir projetos e realizações de jovens arquitetos do mundo inteiro numa grande confrontação. Essa Bienal ambiciona romper com o sistema de cooptação que leva ao reencontro do semiternos participantes de exposições internacionais, quer seja elas em Paris, Nova Iorque ou Milão. A Bienal de Paris "Arquitetura" dará uma atenção especial aos projetos inéditos e aos arquitetos pouco conhecidos. 
O enriquecimento do debate na Arquitetura pela ampliação de suas fronteiras e de suas balizas valorativas mobilizou os organizadores do International Handbook of Contemporary Developments in Architecture a realizarem um "ensaio" sobre a Arquitetura moderna no Brasil, a partir de um roteiro dos organizadores para que arquitetos de mais de trinta países encaminhassem essa investigação, interessada na Arquitetura produzida após a década de 1960. Sylvia Ficher e Marlene Acayaba realizariam no Brasil a referida pesquisa, no momento em que a revisão da própria cultura disciplinar nacional, também era entrelaçada às novas frentes abertas à pesquisa transcorridas no âmbito acadêmico revigorado na década de 1980 (GUERRA, 2010). As autoras viajaram pelo país no ano de 1979 e após a publicação do livro, o traduziram para o português. A partir de recortes regionais, apresentaram a produção diversificada da Arquitetura do Brasil. Este teria sido uma primeira publicação de teor histórico, acerca da arquitetura brasileira, com a publicação de obras do norte do país (FICHER e ACAYABA, 1982).

Outras duas compilações referenciadas da Arquitetura no país e que publicaram obras na Amazônia, não necessariamente assim referenciadas, motivo pelo qual se aproximam do fim do recorte da tese, 1989, foram o catálogo decorrente da exposição "Arquitetura Brasileira Atual” (WISSENBACH, 1983) e o "Arquiteturas no Brasil/Anos 80” (WISSENBACH, 1988). Ambos catálogos resultaram de pesquisas e textos de Hugo Segawa, Cecília Rodrigues dos Santos e Ruth Verde Zein e estiveram vinculados à sua atividade na revista Projeto e discutiam sob distintos matizes, a questão da tradição e da regionalidade na arquitetura. Seus olhares, para além da arquitetura realizada em São Paulo e Rio de Janeiro, atestaram uma realidade advinda desde antes mesmo da década de 1970, a não unanimidade do movimento moderno na Arquitetura no Brasil e que a pluralidade das obras abarcava inclusive os recortes regionais.

Esses olhares ilustram as centralidades desde as quais foram formulados os debates de recondução da atividade editorial e crítica no período. No mínimo, diz respeito à atividade de determinados agentes mais diretamente relacionados à prática editorial, interessados na revigoração, na busca pela instauração de espaços voltados ao debate crítico ampliado à todo o país, e de modo integrado, às instituições e entidades profissionais, ou seja, à atuação política e articulada na disciplina. A observação exógena da Arquitetura na 
Amazônia, frente o desconhecimento de processos sócio espaciais no interior da Amazônia, esta mesma, em suas múltiplas realidades, favoreceu a propagação da Arquitetura mais filiada ou mais adequada à tese das vertentes regionalistas, afirmativas de uma unidade amazônica na Arquitetura.

Na Universidade Federal do Pará, um grupo de arquitetos muito se interessou em formular desde o aprofundamento da pesquisa e do projeto, uma arquitetura regional concebida em adequação às condições amazônicas, especialmente culturais e ambientais. Neste caminho, Edgar Graeff teria orientado a partir de suas lições, a formação do curso de especialização em Arquitetura nos Trópicos, entre 1986 e 1987. O arquiteto sulista relacionava esta adequação, à aplicação dos meios compositivos da Arquitetura em detrimento da "oferta de recursos naturais como materiais de construção, nas sociedades industrialmente menos desenvolvidas”. Ao invés das tentativas de reprodução da prática de países ricos, a inventividade daqueles arquitetos deveria considerar prioritariamente o clima e a vernacularidade, bem como os meios materiais locais como meio de garantir alteridade à Arquitetura local. Ronaldo Marques de Carvalho, Milton Monte, Stélio Santa Rosa seguiriam este caminho, do curso que era então coordenado por João Pinto de Castro Filho $^{98}$ (MIRANDA, CARVALHO e TUTYIA, 2015, p. 72-73).

Noutro sentido, a adaptação de códigos modernos da Arquitetura brasileira a essas mesmas condições de meios materiais e de clima, como na atividad eprática de Hélio Oliveira Veríssimo ${ }^{99}$, também ocorria, tanto quanto a experimentação construtiva desenvolvida por outros arquitetos, como Milton Monte (MIRANDA, CARVALHO e TUTYIA, 2015, p. 72-73). Mas se a vontade de adequação cultural dessa arquitetura a fez pensada a partir dos paradigmas do regional, para o clima e a paisagem com a qual na atividade profissional lidavam os arquitetos, seu vocabulário constitutivo, mesmo como defendia Luiz de Miranda Corrêa já no ano de 1963, se apoiava no agenciamento moderno desses componentes construtivos e arquitetônicos consagrados, desde sua aplicação pragmática e racional, em resposta aos encargos.

\footnotetext{
${ }^{98} \mathrm{O}$ arquiteto defendeu sua dissertação intitulada "Estudo sobre exemplos de arquitetura tropical, erudita e suas adequações a Amazônia Brasileira no último decênio", na Escola de Engenharia de São Carlos, Universidade de São Paulo, em 1984.

${ }^{99}$ Arquiteto formado no sul do país, fez parte da primeira geração de professores da Faculdade de Arquitetura e Urbanismo da UFPA (MIRANDA, CARVALHO e TUTYIA, 2015).
} 
A respeito da obra de Severiano Mário Porto e Mário Emílio Ribeiro na Amazônia, Hugo Segawa avaliou que "a atitude de Porto e Ribeiro confunde-se com alguns posicionamentos genericamente pós-modernos, mas eles são, ante o contexto de seus trabalhos e trajetória de coerência profissional, genuínos arquitetos modernos - que certa sensibilidade pós-moderna soube reconhecer e valorizar” (SEGAWA, 1998, p. 192). Também a respeito do trabalho de Severiano Porto, afirmou Ruth Verde (ZEIN, 2001, p. 192):

o trabalho de Severiano Porto nada tem de exótico, nem de folclórico, exceto para os mal-informados. Claro que a precariedade da divulgação e do debate de nossa arquitetura nos desculpa a todos de nossa ignorância; entretanto, para não repertirmos o modus operandi da consagração de ídolos à moda internacional, é preciso ir além das primeiras aparências.

Exótico, na sua acepção literal, significa estrangeiro, o que está fora, o que é alheio. Uma arquitetura que se insere harmoniosamente no meio em que é produzida, dialogando criativamente com sua realidade, não é exótica. $\mathrm{O}$ emprego desse termo, no presente caso, sugere, isso sim, parâmetros exóticos de julgamento, externos à realidade que pretendem criticar.

Ambos se referiam mais diretamente a determinadas obras do arquiteto, àquelas referenciadas em premissas ambientais ou contextuais como fundamentação dos projetos que lhes originaram e lhes consagraram. Foram estas as obras publicadas em maior frequência e em intervalos dilatados de tempo, em condição de atualidade, a exemplo da pousada de Silves-AM. A presença da obra de arquitetos atuantes em cidades da Amazônia e seu entrelaçamento às delimitações de uma produção latino-americana, para além da admissão no quadro central da arquitetura no Brasil, foi destacadamente, uma alternativa às lacunas deixadas pelo esvaziamento do movimento moderno em seu aporte discursivo, para a Arquitetura brasileira, possibilitada pela abertura à pluralidade investigações e experimentos projetuais. Hayfa Sabbag, como evidenciado no seguinte comentário selecionado de um número da revista Construção São Paulo, revelador de uma busca não findada por alguma outra brasilidade, afirmou, na década de 1970 (A CONSTRUÇÃO SÃO PAULO N.1972, novembro de 1985):

O respeito pela preservação da identidade regional, com uso de técnicas e materiais apropriados ao clima e ao ambiente locais, levou o profissional a receber várias premiações do $\mathrm{IAB}$, além do reconhecimento internacional, através da Bienal realizada, este ano, em Buenos Aires. Recentemente, por ocasião do Congresso Nacional de Arquitetos, em Belo Horizonte, o trabalho de Severiano Porto foi apontado como caminho para uma possível arquitetura genuinamente brasileira. 
Um caminho interpretativo abria à ressignificação, tanto da experiência passada quanto da perspectiva que se apresentava à prática profissional no país. A partir da década de 1980 a Arquitetura na Amazônia foi localizada em condição de referência à produção no Brasil. Primeiramente como alternativa à prática de projeto, quando fundado em premissas contextualistas, mesmo que ancorado culturalmente em referenciais da cultura construtiva nacional. Também, pela iconicidade de obras interpretadas em dependência à sua circunscrição, em um viés que as considerou pelos significados regionais, localizados. Também, como alternativa ao engajamento nacional às temáticas culturalistas e políticas apresentadas pelos Seminários de Arquitetura Latino-americana - SAL. Por fim, como alternativa à ancoragem do campo da Arquitetura e Urbanismo à uma pauta transdisciplinar, em discussão desde os anos de 1960, marcadamente desde o VI Congresso Brasileiro de Arquitetos em 1966, e que nos anos de 1970 teria sido intensificada pela projeção adquirida pelos movimentos sociais e ecologistas organizados, bem como em virtude da notoriedade junto a comunidade internacional: a pauta ambientalista.

Esses enquadramentos foram destacados dos próprios textos entrelaçados no próximo capítulo desta tese e que revelaram os temas em atenção no campo da Arquitetura nos anos de 1970 e 1980 no Brasil, quando a presença de uma Arquitetura na Amazônia foi mais frequentemente publicada nas revistas, ainda que de um ponto de vista abrangente e pouco aprofundado. Hugo Segawa designou de "conservadorismo ecológico" um dos movimentos sintomáticos dos anos de 1970, pertencente a uma "série de reavaliações dos paradigmas do passado", junto ao processo amplificado de revisão dos referenciais da Arquitetura moderna. No âmbito latino-americano, foi o período politicamente trágico, no qual as ditaduras causaram o exílio de intelectuais e arquitetos brasileiros (SEGAWA, 1998, p. 190). 

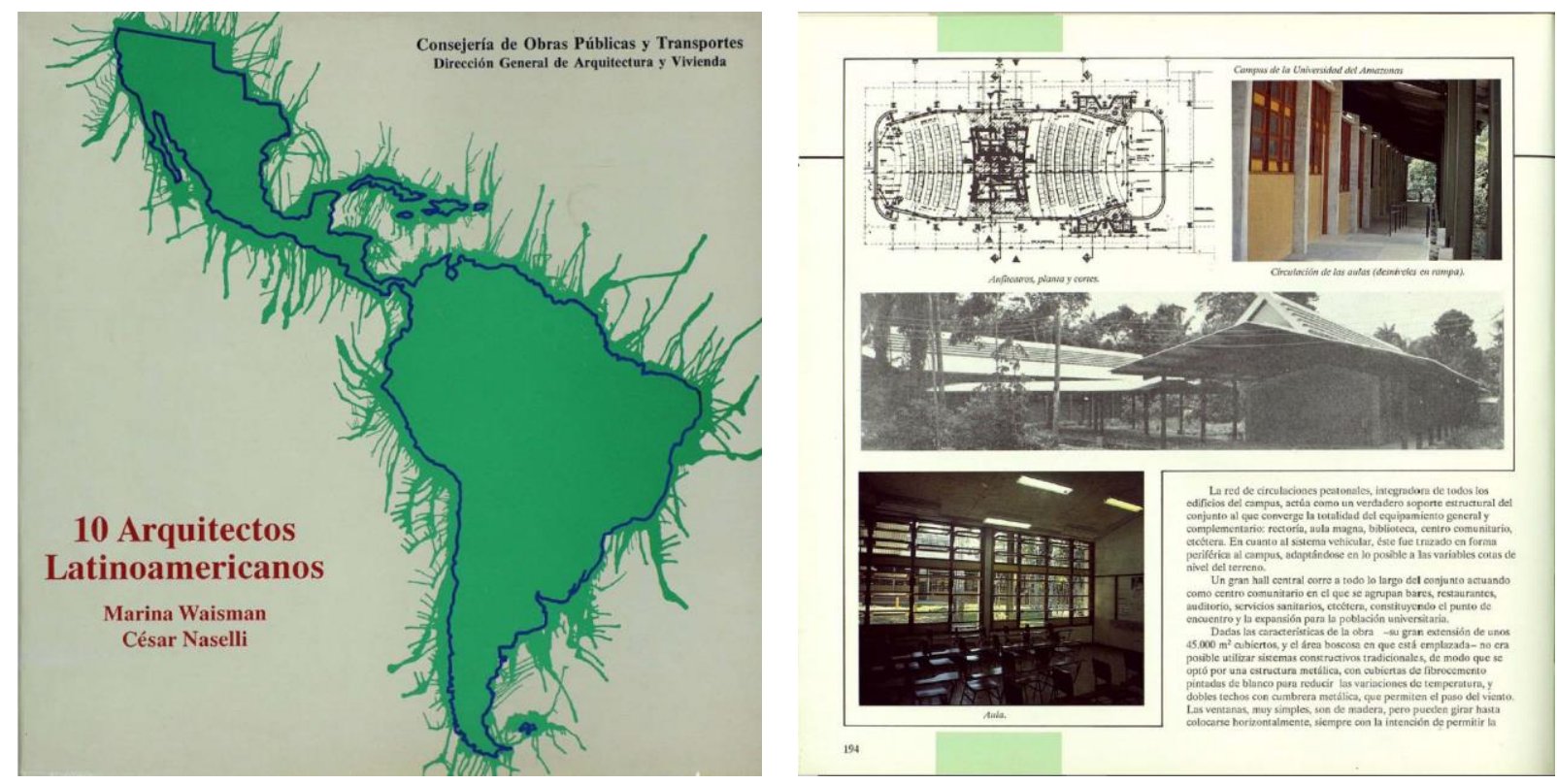

Figura 5 - Livro 10 Arquitectos Latinoamericanos com publicação de sete obras e projetos de Severiano Mário Porto junto as de outros arquitetos da América Latina. Fonte: WAISMAN \& NASELLI, 1989, p. 186-201.

Todavia, a atitude crítica que se formava nos anos de 1970 nas escolas de Arquitetura foi consonante a uma "consciência nacional em relação à natureza e à planificação do uso dos recursos naturais básicos", dedicando maior atenção ao meio ambiente, "tomado em suas variáveis paisagísticas e ecológicas”. Os grandes projetos, especialmente os estatais, que causariam impactos "irreversíveis, nas condições ecológicas de áreas de problemática preservação e manejo", como a Floresta Amazônica, passaram a ser profundamente questionadas, como afirmaram Fernando Chacel e Aziz Ab'Saber quando defenderam em 1976 a criação de currículo de Planejamento Paisagístico nas escolas de arquitetura, que fosse centrado nas "condições naturais do Mundo Tropical" (CJ ARQUITETURA N.12, 1976, p. 13-17). E é justamente este novo aporte reverberado no campo da Arquitetura, não filiado à sua configuração material estritamente, mas atento à condição territorial da Amazônia como ambiente patrimonializado e a preservar, que finaliza o recorte da tese, juntamente com a projeção da Arquitetura e da Amazônia para além de quaisquer fronteiras de sua inscrição, mas em diálogo com a produção dada no panorama da Arquitetura em geral. 

Dentro e fora da História: centralidade da Amazônia brasileira nos textos e prática de Arquitetura e Urbanismo no Brasil, 1934 a 1989 
Neste terceiro capítulo é apresentada uma narrativa costurada das fontes pesquisadas. Nela estão situados obras e arquitetos entrelaçados à trajetória histórica da Amazônia entre os anos de 1934 e 1989 como foi dada a ver no recorte. Para tanto, são propostos três períodos, interpretados a partir do regime de visibilidade da Arquitetura e Urbanismo na Amazônia nas revistas, inclusos textos e prática projetual, relacionados a recursos bibliográficos referentes à temática da Amazônia. As representaçôes da Amazônia foram revolvidas em aportes da prevalente história da Arquitetura no Brasil. O material apresentado é atravessado por algumas perspectivas críticas do presente e por outras, datadas, que constam como parte do conteúdo da narrativa. Já as obras identificadas nas fontes, percorrem todo o capítulo, em registros visuais reproduzidos das fontes e os recortes temporais propostos, três intervalos, guardam correspondência aos eventos por elas reportados. O primeiro intervalo de 1934 a 1942, ambientou os debates em torno da identidade nacional rebatidos na dualidade representada pelos movimentos de defesa dos referenciais marajoaras como aqueles originários da cultura nacional e os intentos da engenharia sintetizados na modernização de Belém-PA, na conjuntura de decaimento econômico regional e de embates em torno da formulação de uma Arquitetura brasileira. $O$ segundo intervalo, de 1943 a 1968, extensivamente à atividade planejadora e interventora do Estado Nacional sobre a Amazônia, em suas distintas fases, foi sistematizado no pensamento primordial em torno da adequabilidade da arquitetura ao contexto amazônico, junto a transformaçóes espaciais transcorridas em contextos urbanizados, ou não. O particularismo cultural e a adaptação ecológica orbitaram o pensamento social sobre a Amazônia, bem como pesquisas de cunho etnográfico que viriam a sustentar uma série de formulaçôes discursivas e de projeto, quanto à sua adaptabilidade, caráter, inscrição contextual, refletividade cultural. O terceiro intervalo, de 1969 a 1989, foi revelador da articulação de arquitetos e teóricos em novo ambiente político, no qual a prática do projeto e o aprofundamento da técnica foram associados a estudos socioambientais sobre a Amazônia, em teses inovadoras e novos esforços discursivos e materiais, representativos da formulação de uma faceta regional da modernidade brasileira. O capítulo tem como marco final novos aportes elaborados sob o discurso preservacionista, que conferiram a projetos referenciais, projeção nacional e internacional, em especial quando referidos a uma Amazônia paisagem. A centralidade exercida por determinadas obras de Severiano Mário Porto, a contar o número das que foram publicadas frente aos demais arquitetos no período, foi indicativa do ocultamento, nas revistas, de visibilidade ampliada à atividade profissional nesses anos na região. As alteraçôes gradativamente mais profundas do território produziram efeito sobre escritas reativas às transformaçôes sob a pauta da modernização. Também sobre a prática da própria Arquitetura, tendo sido incorporado o discurso ambientalista moldado a novos conhecimentos mais aproximados da Amazônia. O recorte é finalizado pelas distintas frentes nas quais a Arquitetura e Urbanismo na Amazônia foi destacada no âmbito disciplinar: como alternativa à arquitetura brasileira, pela trilha da regionalidade cultural, pelo ingresso no circuito latino-americano de Arquitetura, pela centralidade da Amazônia na temática transdisciplinar do ambientalismo.

Imagem: Capa da Dissertação Estudo sobre exemplos de arquitetura tropical, erudita e suas adequaçóes a Amazônia Brasileira no último decênio de João Castro Filho. Fonte: FILHO, 1984. 


\subsection{Indo aos textos: Arquitetura e Urbanismo e a Amazônia, de 1934 a 1942}

Nos anos de 1938 e 1939, quatro artigos ${ }^{100}$ publicados na revista Acrópole (19381971) traziam a Amazônia representada pelo ambiente de uma arte desenvolvida desde tempos pré-coloniais, no arquipélago de Marajó - PA. Os componentes da cultura que pudessem referenciar o Brasil eram perseguidos desde a década anterior, com vistas a construção de uma identidade que pudesse ser partilhada, frente à realidade concretamente complexa e distinta do país recentemente tornado República. Para as discussões em curso a respeito dos componentes da cultura com a qual o recente Estado Nacional getulista buscava se afirmar, a arte marajoara foi tomada por grupos com trânsito na Arte e Arquitetura, como representante dos mais genuínos.

Na mudança política nacional entre os anos de 1920 e 1930, as transformações sociais experimentadas no Brasil foram demarcatórias, dada a emergência de novas gerações da elite, de maior complexidade do tecido social urbano e intensificação da industrialização em determinados centros econômicos do país. Estes alimentavam a atividade de intelectuais interessados em debater a modernização, passando a responder às transformações sociais, desde suas próprias predileções políticas, com formas alternativas de organização da cultura nacional, ou pelo estabelecimento ideológico do que fosse o "caráter" da unidade nacional, como exercício de vislumbre do futuro. A questão da nacionalidade como uma construção e os modelos que nela adquiriam "consistência”, foram conteúdo social do próprio processo de modernização brasileira, como explica Luiz Guilherme Piva (PIVA, 2000). No âmbito da cultura, mais especialmente (DUTRA, 2013, p. 244):

Os tempos eram de nacionalismo e cultura, e todo esse afã de buscar um conhecimento sobre o Brasil e de pesquisar sua história coincidiu com a elaboração de ensaios de interpretação do país, que se tornariam clássicos de nosso pensamento social, pois assumiriam o desafio de compreender as especificidades da "formação social brasileira" e os dilemas e entraves para $\mathrm{o}$ acesso do país à modernidade, na chave das dicotomias tradição $\mathrm{x}$ civilização, particular x universal.

\footnotetext{
${ }^{100}$ Os artigos em destaque foram Por uma arte brasileira (ACRÓPOLE N.1, maio de 1938, p. 19-20); Motivos Marajouaras na cerâmica brasileira (ACRÓPOLE N.6, outubro de 1938, p. 22-25); Decoraçóes Marajouaras (ACRÓPOLE N.8, dezembro de 1938, p. 26-27); Por uma arte brasileira (ACRÓPOLE N.20-21, dez/jan de 1939-40, p. 25-26).
} 
Deste modo que intelectuais como Gilberto Freyre e Roger Bastide, ${ }^{101}$ nas primeiras décadas do século XX, debruçavam-se sobre a concepção de uma sociedade nacional e buscavam em manifestações culturais interiorizadas, conteúdo constitutivo de uma tradição brasileira que estavam eles próprios a encorpar, frente o projeto de modernização social do Brasil (ANDRADE, 2008). Neste contexto que Mário de Andrade ${ }^{102}$ viajou à Amazônia em 1927, nutrido desde anos anteriores a este, pelo interesse em produzir um conhecimento pessoal e cultural sobre o Brasil, fora de seu próprio contexto originário. ${ }^{103} \mathrm{~A}$ experiência do escritor em 1924 junto a modernistas paulistanos ${ }^{104}$ nas cidades históricas de Minas Gerais, marcou o início de outros contatos no Brasil em suas viagens de descoberta, sem que no entanto, tenha estabelecido pontes mais diretas com os agentes intelectuais e artísticos locais, no caso da Amazônia.

Nesse contexto, um paraense ambientado em São Paulo, cidade onde estava baseada a Revista Acrópole, publicou seus curtos textos, que seriadamente, traziam apreciações aos referenciais marajoaras, como legítimos componentes da figuratividade de uma arte brasileira. Theodoro Braga, dominando o marajoara como estilo, o defendeu com desenvoltura, mesmo porque sua atuação nas Belas Artes e seu interesse investigativo sobre a cultura amazônica o deixavam em posição de intimidade com seu código.

Theodoro Braga foi significativo representante da vanguarda artística modernista em Belém, dentre outros motivos, pela perspectiva que construiu sobre a arte pictórica a partir de ideais republicanos, nas condições em que para ele, "a história da arte na Amazônia era, toda ela, republicana", como uma "arte nacional - um conceito que será caro ao movimento intelectual que ele mesmo ajudou a construir no Pará das primeiras décadas do século XX”

\footnotetext{
${ }^{101}$ Desenvolvendo um trabalho pré-sociológico, Gilberto Freyre e Roger Bastide foram alguns dos chamados “intérpretes do Brasil” (VASCONCELLOS, 2013).

${ }^{102}$ Além de Mário de Andrade, importa destacar as experiências de Raul Bopp e Manuel Bandeira com a região amazônica nos anos de 1920, bem como frutos artísticos que produziram, especialmente no campo literário (ARAÚJO, 2008).

${ }^{103}$ José Lira aponta razões às viagens de Mário de Andrade, destacadas as motivações de pesquisa por novas fontes culturais, em especial as formas populares de expressão (LIRA, 2005, p. 145).

${ }^{104}$ Olívia Penteado, mecenas paulista, incentivou artistas modernistas, brasileiros e estrangeiros e foi próxima aos escritores e artistas paulistas desta vertente intelectual. Pela imprensa belenense, foi tratada à época da viagem como "abastada fazendeira, ilustre senhora, distinta viajante, ilustrada e opulenta fazendeira, distinta turista paulista, rica fazendeira” (ARAÚJO, 2008). Blaise Cendrars foi poeta franco suíço próximo ao grupo modernista paulista e visitou a Amazônia em 1934 e 1935. Para o poeta, o Brasil foi campo potencial às artes e fonte de inspiração. Incentivou seus interlocutores locais a olharem para o próprio país e não ao estrangeiro (WIMMER, 2013, p. 33).
} 
(FIGUEIREDO, 2016, p. 29). Sua perspectiva para o “marajoara” estrapolava a condição de objeto de seu interesse como intelectual pesquisador da arte amazônica, para ocupar parte do ideário que estava a defender, assim como outros interessados em adotá-lo como representativo de uma Arquitetura nacional.

Dentre eles, os arquitetos Archimedes Memória e Francisque Cuchet, foram autores do anteprojeto vencedor do concurso para um novo Ministério da Educação e Saúde que seria implantado na capital do país, mas que não foi ao fim construído, para frustração de seus autores e contentamento do contratante. ${ }^{105}$ Com referências ao marajoara, seu projeto foi rejeitado em detrimento de outro, ajustado à Arquitetura moderna que viria a ser consagrada como brasileira (BRUAND, 1981, p. 81) (SEGAWA, 1998, p. 61) (CAVALCANTI, 2006, p. 39-41).

No entanto, para Theodoro Braga, a adoção da decoração marajoara como arte ornamental era meio estratégico para incorporação de referencial nativo em meio aos códigos visuais exóticos em vigor no país, para o alcance de uma obra com o "caracter regional brasileiro", ou uma arte "exclusivamente brasileira na fôrma como no seu espírito". Nos artigos levantados, sua escrita demonstrou erudição, recheada da terminologia muito própria do código da arte ambientada no Marajó, característica dos artigos "Motivos Marajouaras na cerâmica brasileira" (ACRÓPOLE N.6, outubro de 1938) do qual foram extraídos estes primeiros fragmentos e "Decorações Marajouaras" (ACRÓPOLE N.8, dezembro de 1938).

Por outro lado, no primeiro artigo e no último, de conteúdos muito semelhantes, a escrita foi dirigida a público mais universal. Neles, Theodoro Braga defendeu a adoção do estilo na Arquitetura, a arte onde por excelência, seriam manifestas todas as demais. Tanto na decoração quanto nas "variadas fórmas dos relevos" aplicadas sobre "as linhas núas da architectura moderna, com seus altos planos de verticalidade”, a decoração seria a operação

\footnotetext{
${ }^{105}$ Por solicitação do ministro Gustavo Capanema, após os resultados do concurso iniciado em 1935, Lúcio Costa e equipe ficaram encarregados de desenvolver o novo projeto desde 1936, o que foi então construído. O evento é mencionado por vários autores, com acento à tramitação das decisões e os embates em torno do ajustamento do projeto de arquitetura ao que seria um palácio ministerial, entre afeitos à arquitetura moderna e de cunho memorialista, também à atualidade do projeto construído em face do vencedor do concurso, unicamente baseado, como exclamado por Yves Bruand, nos registros cerâmicos disponíveis de artefatos marajoaras, daí seu "caráter aberrante" (BRUAND, 1981, p. 81).
} 
de inscrevê-la no "meio paisagístico e de seu espírito naccional” (ACRÓPOLE N.1, maio de 1938 , p. 20) ${ }^{106}$ :

Em torno de nós, tudo nos falla de nossa personalidade, quer no meio natural dentro do nosso clima tropical, quer no meio espiritual evoluido dentro de nossa historia e dos nossos destinos.

Não é crível, pois, que não tenhamos em volta de nós, elementos característicos com os quaes possamos marcar a nossa passagem dentro da nossa época na historia da humanidade.

$[\ldots]$

Tudo em torno a nós suggere um movimento de são patriotismo: a linha coleante de um reptil, o esvoaçar alegre de uma ave, a tranquilidade hierativa de uma orchidea, tudo nos impõe as características de um estylo e nos dirão alguma cousa da alma brasileira.

A artes decorativas, como uma “expressão bem moderna” (MILWARD, 1942), era vista em tais escritos como um dos componentes inevitáveis da arquitetura compreendida como obra integral, mas também a causadora de efeitos "aos olhos" e ao "espírito", a serviço de "nos aproximar de nós mesmos, de nossas cousas e nossa pátria”. Este foi motivo central pelo qual seu autor foi crítico às importações dos estilos (ACRÓPOLE N.20-21, dez/jan de 1939-40, p. 25-26):

[...] transportados de outras paragens exóticas, sem o valor da originalidade e apezar de sua momentanea aparencia que impressiona ao grosso publico, repetem-se vulgarmente por toda parte, não se harmonisando com o meio em que se vive.

Vivendas algumas e confortaveis, em meio a jardins floridos e cuidados, despidas de estylo caracteristico definido que correspondam ao clima e a paisagem, delineadas sob a preocupação de agradar, discordantes entre umas e outras, permitem, entretanto, ampla liberdade aos seus construtores na escolha da planta e elevação, na distribuição dos detalhes e na aparencia, muitas vezes, torturada de suas fachadas.

$[\ldots]$

Porque então essa aversão aos característicos elementos de nossa fauna e nossa flóra? Porventura essas estampas inexpressivas importadas serão mais aproximadas as nossas obras? Quando iniciaremos o patriotico trabalho de nacionalizarmos a nossa Arte?

O objeto artístico teria uma capacidade de significar, por isso afetar o espírito por meio de determinados códigos visuais reconhecíveis. Para a conformação de uma arte nacional, mais do que justo seria então combater a "nociva importação de máo gosto" e

\footnotetext{
${ }^{106}$ Nesta mesma revista foi publicado o projeto de Vital Brazil, edifício Esther, em São Paulo, um edifício multifuncional, cujos princípios formais e tecnológicos eram afinados a uma vertente construtiva racionalista $\mathrm{da}$ arquitetura (CONDURU, 2000).
} 
promover a substituição dos "leões, ursos e elefantes", pela onça, pela sucurijú, pela "luxuriante flóra" encontrados no Brasil. A adoção dos códigos importados era vista por Theodoro Braga como forma de sujeição ao estrangeiro e substituí-los chegava a ser atitude patriótica, além de pedagógica ao "espírito popular”, em razão da legitimidade advinda da relação entre "ornamentação" e o "seu próprio ambiente”. O repertório de procedência amazônica, portanto, seria o referencial da cultura nacional, ainda que também muito pertencente ao universo particular do artista e intelectual. Esta relação, o que também pode ser antevista como tensão latente entre uma identidade nacional e outra regional, que viria a percorrer os escritos sobre a Arquitetura na Amazônia em algumas conotações distintas, é dada a ver nos artigos de Braga, que deslocados da realidade amazônica à brasileira, forneceram conteúdo ao debate em curso a respeito da formulação da unidade cultural do país e de sua modernização, pelas vias da Arquitetura.

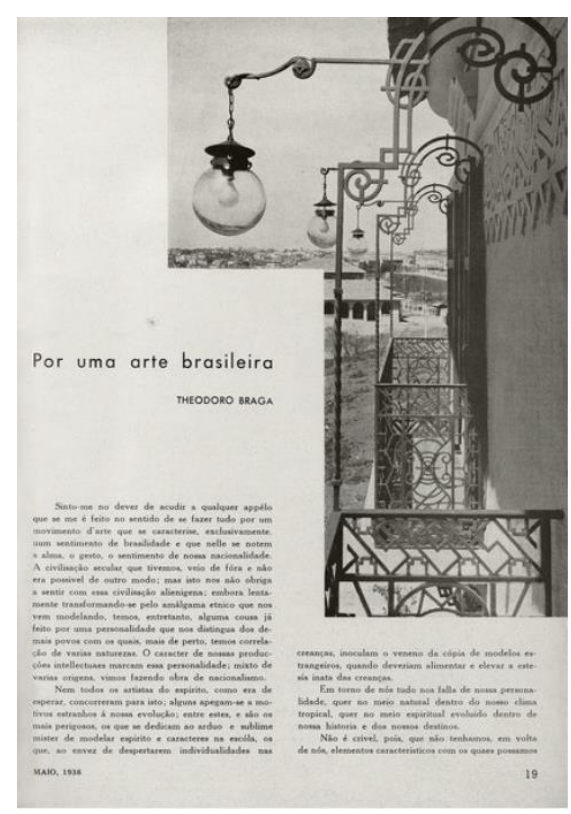

(1)

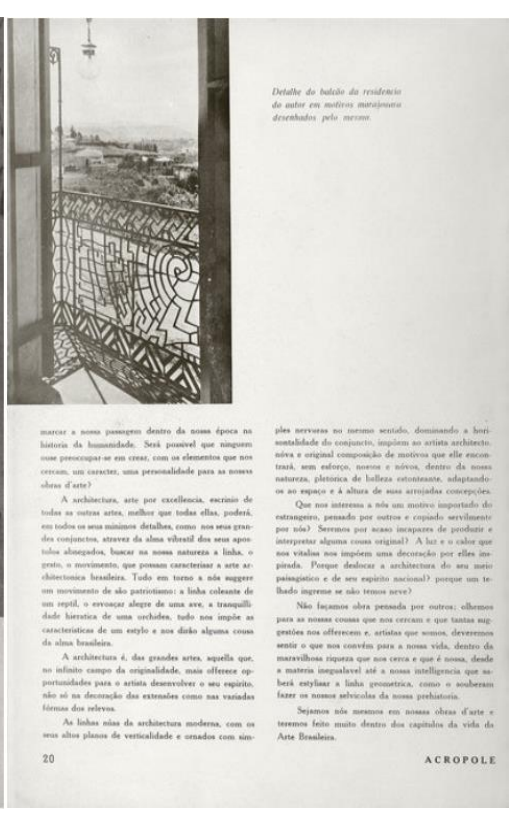

$(2)$

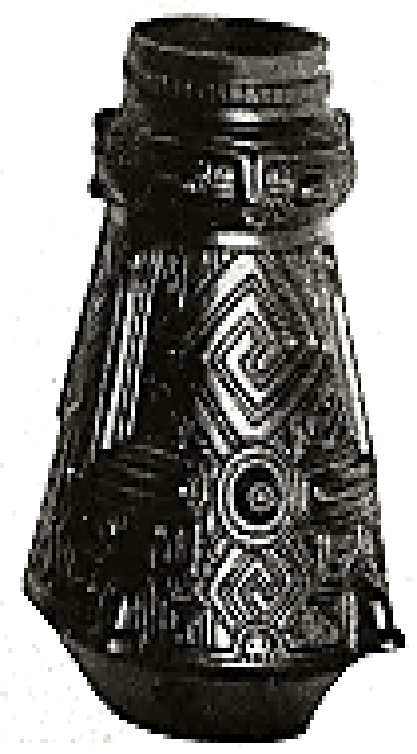

Figura 6 - Artigo (1) Por uma arte brasileira de Theodoro Braga, publicado no primeiro número da revista Acrópole. Fonte: ACRÓPOLE n.1, 1938, p. 19-20. Cerâmica referenciada na arte marajoara (2). Fonte: ACRÓPOLE n.6, 1938, p. 23-24.

Um artigo de autoria de Maria Portugal Milward, da Secretaria Geral de Viação e Obras da capital, sobre o "aparecimento das artes, da arte brasileira” e sua aplicação em 
estudos de pavimentação, foi publicado em 1942 na Revista Municipal de Engenharia ${ }^{107}$ (REV. MUN. DE ENG. N.6, novembro de 1942, vol.IX, p. 23-29) revelava que a atividade projetual na capital ainda estava impregnada de uma modernização construtiva cujo caráter figurativo estava também embasado em referenciais memoriais. Dentre eles os da arte marajoara, considerados como os de partida de uma arte decorativa brasileira. Neste artigo, Milward comenta a ausência de edifícios marajoaras para contemplação no presente, ao comparar a produção dos “magnificos artistas primitivos” a monumentos aos moldes dos mexicanos e peruanos, bem como às civilizações Astecas e Incas, o que especulou ter sido devido a falta de "material sólido, apropriado às grandes realizações da arquitetura” naquele ambiente amazônico, distinguindo geograficamente, cordilheira e vale. "Lá, toda a fortaleza do solido; aqui, toda a incerteza do liquido” (REV. MUN. DE ENG. N.6, novembro de 1942, vol.IX, p. 24).

No ano seguinte a mesma autora publicou um artigo sob o título "Pavimentação de Passeios”, no qual sugeria a padronização de passeios públicos, apresentando desenhos executivos de pavimentos para a capital (REV. MUN. DE ENG. N.3, julho de 1943, vol.X, p. 25-31). A autora desenvolve toda uma argumentação embasada em pesquisa de cunho histórico, arqueológico, conferindo destaque à análise das formas de habitação típicas de construções "primitivas", das "mais antigas épocas" no Amazonas, ${ }^{108}$ ilustradas com dois desenhos, um de localização do arquipélago, o qual também foi descrito em geografia física, e outro, contendo corte e detalhe de acomodação das urnas funerárias indígenas (REV. MUN. DE ENG. N.6, novembro de 1942, vol.IX, p. 25):

[...] o homem do Amazonas se cautelava contra o domínio das águas. As estearias, (construção sobre estacas) no Maranhão e outras localidades do norte brasileiro, revelam essa precaução defensiva, que também se reflete na feitura de "mounds" ou montículos de terra escura, que movimentam as planuras inundadas da Marajó [...]

Ainda hoje se pratica a construção sobre estacas, costume esse usado pelo caboclo do norte que vive nas margens ribeirinhas do Amazonas e de seus inúmeros afluentes.

Pela época das cheias, quando as águas em toda plenitude de volume tudo cobrem e tudo esmagam, se repetem casos dessas habitações serem

\footnotetext{
${ }^{107}$ A revista teve seu primeiro número publicado em julho de 1932 (Decreto 3.759), criada pela Prefeitura do Distrito Federal (PDF) para dar visibilidade às atividades do corpo técnico da prefeitura, a "engenharia oficial da Cidade do Rio de Janeiro", da qual participou muito diretamente Carmen Velasco Portinho. Neste primeiro número foi publicado o projeto de Warchavchik e Lúcio Costa de apartamentos para a Rua Barão da Gambôa.

${ }^{108}$ Neste ponto a geografia é tornada imprecisa, entre recursos gráficos e escritos.
} 
sorvidas conjuntamente com as "terras caídas", na voragem gulosa e sempre insatisfeita do rio. Não importa, mais acima, um pouco além do desbarranco, o caboclo firma novamente outras estacas, apruma a cabana tosca de barro e sapê, sua única riqueza naquele cenário imenso de prodigalidade panteísta de selvas e águas, continuando dessa forma a tradicional usança do autóctone brasileiro.

O recorte da paisagem amazônica focalizou um ambiente rural de moradias tipificadas onde uma certa miscigenação construtiva, entre a casa do indígena, caracterizada pela menção à terra preta, e a do seringueiro, referenciada pelas habitações palafíticas de áreas de beira (NEVES, 2007) eram apresentadas, também ressaltando uma habilidade adaptativa do homem ao meio natural frente seus condicionantes, especialmente das cheias e vazantes das águas. A geografia genérica a qual foi associada a designação do "caboclo do norte”, junto a uma caracterização psicológica, detentor de uma virtude próxima a teimosia, junto à caracterização do modo de vida na "cabana tosca”, foram arrematados pela paisagem na evasiva representação de "prodigalidade panteista de selvas e aguas”. Estas formulações foram todas constitutivas de um quadro valorado pela projetista, que forneceu um sentido ético, de arte virtuosa, aos artefatos marajoara, muito em função de sua inscrição no ambiente amazônico ao qual fazia menção.

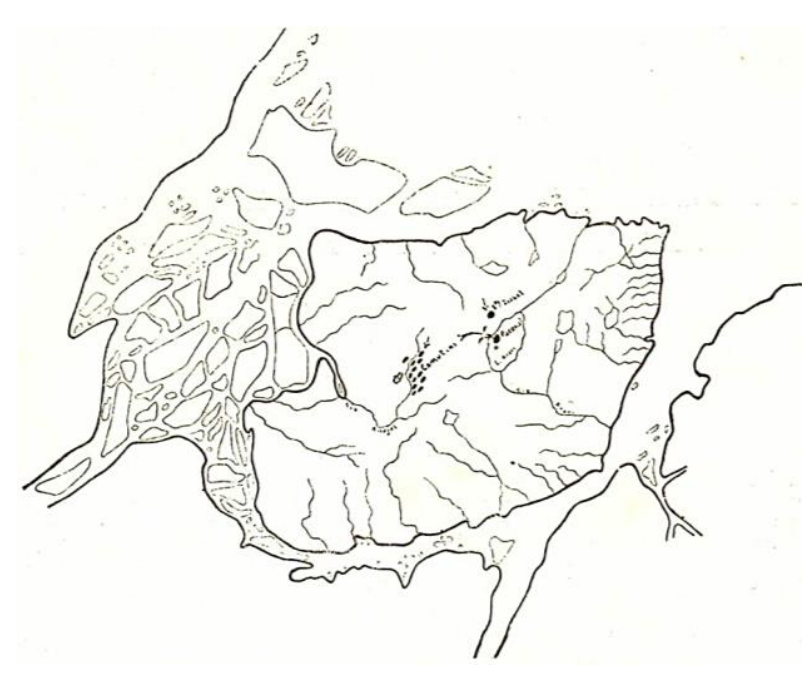

Figura 7 - Localização do arquipélago do Marajó e corte de teso indígena com detalhe típico de urnas funerárias. Fonte: REV. MUN. DE ENG. n.6, 1942, vol. IX, p. 24-25.

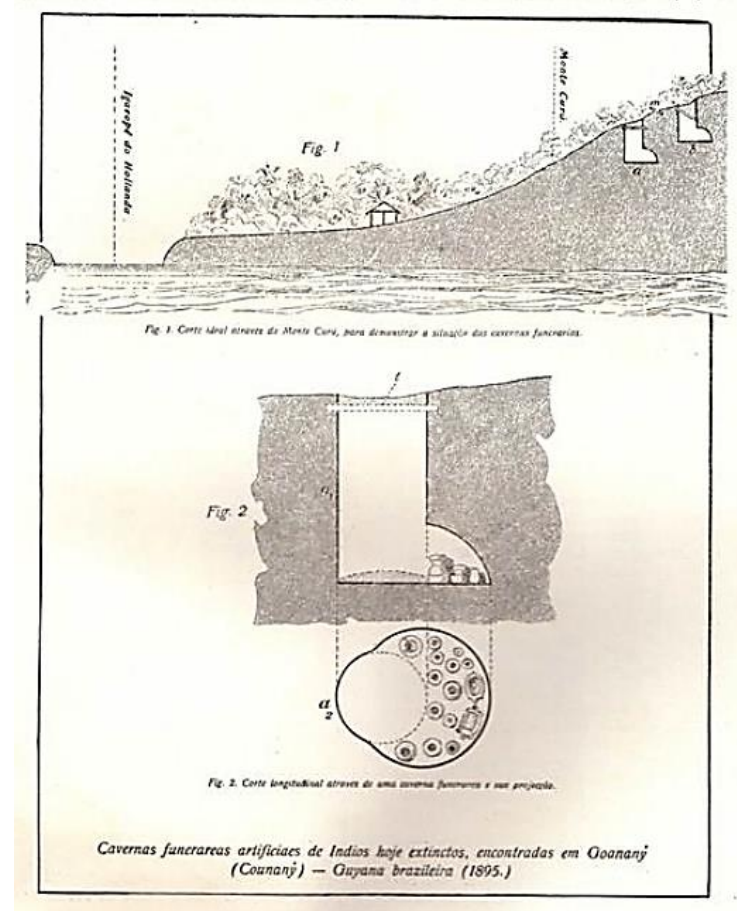




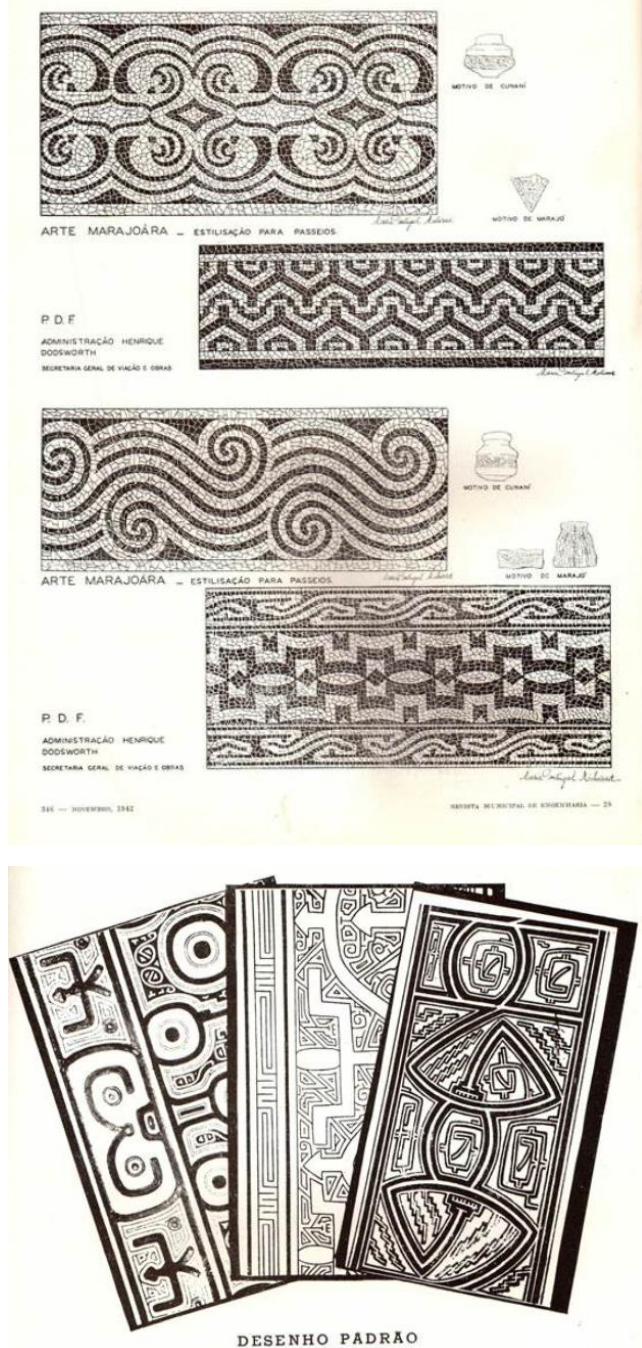

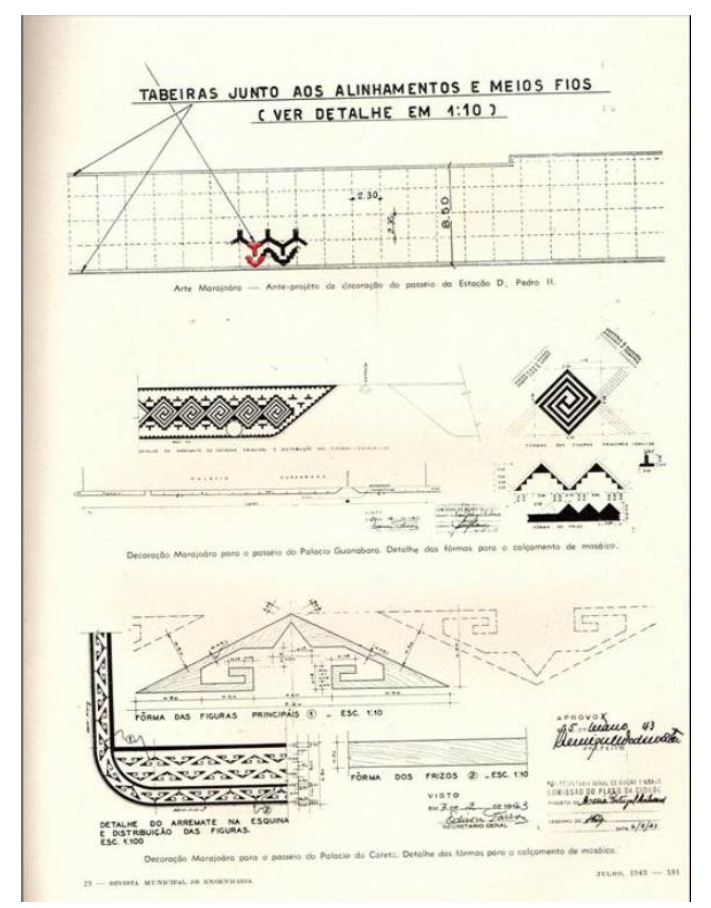

Figura 8 - Desenhos de passeios públicos com motivos referenciados na arte marajoara. Fonte: REV. MUN. DE ENG. n.3, vol. X, 1943; REV. MUN. DE ENG. n.6, vol. IX, 1942.

Esta foi a base à apresentação de suas composições para pavimentação, de linhas geometrizantes, inspiradas nos grafismos tidos como os mais primitivos que foram tomados em abstração, que se pese a grande qualidade gráfica dos mesmos. Descrito o ambiente e justificado o caráter primitivo e valorável da arte marajoara, inspiração para os "motivos exóticos e sui-generis" das paginações propostas pela projetista, destinadas também aos olhos do turista, dos padrões daquela "arte brasileira", "traço singularissimo de nosso primitivismo luminoso", produto da invenção de homens livres sem "servilismos nem traços de escravidão", Maria Portugal Milward justificou a aplicação de revestimentos nos desenhos que propôs para os passeios da capital, que seriam aplicados em ruas, praças, jardins, avenidas, que teriam sido abertas pelo "Plano Remodelador da Cidade" ${ }^{109}$ (REV. MUN. DE ENG. N.6, novembro de 1942, vol.IX, p. 26).

${ }^{109}$ O Plano ao qual se referiu foi o de Agache para o Rio de Janeiro, de 1930. 
A Revista de Arquitetura ${ }^{110}$ (1934-1950) já havia publicado alguns artigos ${ }^{111}$ sistemáticos, a respeito dos referenciais marajoara, especialmente em sua aplicabilidade às artes decorativas brasileiras, a exemplo dos Da arte marajoara como decoração (REVISTA DE ARQUITETURA N.1, maio de 1934, p. 6-10) (REVISTA DE ARQUITETURA N.2, junho de 1934, p. p.15-19) (REVISTA DE ARQUITETURA N.3, julho de 1934, p. 9-12). No entanto, no artigo As artes do desenho na época pré-cabralina, de Gerson Pompeu Pinheiro (REVISTA DE ARQUITETURA N.7, novembro de 1934, p. 36-37), foi apresentado outro acento à incorporação dos referenciais marajoaras às artes e arquitetura no país, em meados da década de 1930:

Ultimamente tem sido tentado o aproveitamento dos elementos marajóaras na decoração architectonica.

Resulta, no entretanto, inutil essa tentativa, por ser forçada, contrariando todas as leis de formação artistica.

Qual a afinidade que existe entre, nós, das cidades, e os nossos irmãos indios, marajóaras?

Talvez que delles ainda se aproximem um pouco os homens do norte. Mas nós, do centro e do sul, de que modo estamos, porventura, a eles ligados? Somos mais ligados ao estrangeiro immigrado que ao índio autochthone. Estudar a arte marajóara, com o objetivo de recompor analysando, a vida e a arte dos indígenas brasileiros, é tarefa digna dos melhores applausos.

Se quizessemos representar graphicamente, a evolução do nosso homem, encontrariamos linhas distinctas e de origens differentes; uma para o brasileiro marajóara, outra para o brasileiro post-cabraliano.

São independentes, e por isso, o melhor elogio que se pode fazer a arte marajóara, é o affirmar-se que ella não representa absolutamente, a origem de uma possivel arte brasileira. Vale por si mesma. Nasceu, viveu, e morreu com o homem marajóara.

O conteúdo do escrito de Gerson Pompeu Pinheiro não é esgotado nesta análise, especialmente quanto ao seu lugar de observação do norte, aqui apontado em sentido genérico. De todo modo é importante que seja observado quanto à crítica que fez à decoração marajoara no tocante à possibilidade de síntese de uma arte nacional, ainda que sua presença ainda tenha sido identificada nas revistas até os anos de 1940. Em meio aos embates, como os que vinham sido registrados nas revistas, ${ }^{112}$ entre a defesa de uma

\footnotetext{
${ }^{110}$ Revista vinculada à Escola Nacional de Belas Artes da Universidade do Rio de Janeiro.

${ }^{111}$ De autoria de Alberto Gallo.

${ }^{112}$ Lauro Cavalcanti abordou do processo de consagração do projeto de vertente moderna para o Ministério da Educação e Saúde, a vanguarda da arquitetura no país, especialmente desde a participação de intelectuais "com filiação moderna" nos embates em sua defesa. Desta abordagem, cabe destacar as revistas que mencionou o autor, tenha sido para apresentar uma definição para o "estilo marajoara", como em uma Revista
} 
arquitetura nacional sob princípios memorialistas e outra, ancorada em novos parâmetros figurativos, materiais e metodológicos de projeto, aquela modalidade compositiva mais própria do juízo artístico das Belas Artes passou a ser em gradativo substituída pos outros referenciais de modernização material da arquitetura, mais atrelados à abstração.

Os projetos presentes nos poucos periódicos onde a Amazônia foi identificada como tema ou lugar de sua implantação até o início da década de 1940 foram aqueles de autoria de engenheiros, justamente pela intensidade com que exerciam a atividade de projeto e construção na região, dada inclusive à ausência de escolas de Arquitetura. O contexto de Belém-PA foi referencial pela implantação do curso da Escola de Engenharia do Pará, na Universidade Federal do Pará, em 1931 (MIRANDA, CARVALHO e TUTYIA, 2015). Ele foi o único na Amazônia Legal até a década de 1960, desde quando foram criados outros cursos no Amazonas, Maranhão e Mato Grosso.

Os engenheiros civis atuantes em Belém tinham contato com a arquitetura moderna por meio de viagens aos Estados Unidos e Europa, além de revistas, fossem nacionais ou estrangeiras, como a francesa L'Architecture d'Aujourd'hui e as nacionais Acrópole e Módulo, segundo Giovanni Blanco Sarquis. A revista Acrópole despertava especial interesse dos engenheiros pelos artigos técnicos que publicava, como os voltados às soluções de conforto térmico, a exemplo da edição de número 251 de 1958, na qual foi publicada matéria acerca das soluções construtivas para o uso de venezianas e vidros. Além das revistas, também foram referenciais a estes profisionais atuantes na prática, os livros Modern Architecture in Brazil de Henrique Mindlin de 1956 e o Arquitetura social em países de clima quente, de Richard Neutra, de 1948 (SARQUIS, 2012, p. 48).

A atividade projetual de Richard Neutra, cuja experiência em países latinoamericanos e em Porto Rico o fez moldar a prática de projeto em atenção ao vínculo entre arquitetura e natureza, inspirou alguns desses engenheiros que se identificavam com suas ideias de racionalização e adoção de processos construtivos “eficientes” sob a ótica do conforto e da adaptação da arquitetura pública à sua reprodutibilidade construtiva. Além de Richard Neutra, Lúcio Costa e Oswaldo Bratke eram referenciais, especialmente os

de Arquitetura de 1934 ou para registrar as posições modernas, quando projetos que haviam sido desclassificados do concurso, foram publicados na Revista de Engenharia Municipal, da qual participava ativamente Carmem Portinho (CAVALCANTI, 2006, p. 38-40). 
projetos das Vilas da ICOMI no Amapá dos anos de 1950, além de Severiano Mário Porto (SARQUIS, 2012, p. 48). A obra de Severiano Mário Porto, por sua vez, deve ser considerada no último recorte temporal deste capítulo, frente a questões suscitadas a partir da década de 1960, quando de sua atuação na Amazônia.

Os efeitos de uma atividade editorial restrita de periódicos especializados, considerado o fato de que o "tema autônomo" da arquitetura foi levado às revistas a partir da década de 1950 (SEGAWA, 1998, p. 130), é fato relevante à quantidade reduzida de registros identificados na pesquisa neste período. Além os artigos na revista Acrópole tratados no tópico, uma série de projetos de engenheiros foram publicados na revista $A$ Casa $^{113}$ (1923- 1952), um periódico apresentado como de arte decorativa, construção, topografia, que abordava um universo ampliado e irrestrito de temas e linguagens, a exemplo de projetos situados nas cidades de Belém e Mosqueiro, no Pará. Para Juliana Cardoso Nery, ${ }^{114}$ a revista $A$ Casa demonstrava o incentivo à renovação da prática construtiva no país e a tentativa de sua popularização, com "matizes locais", para "formar um novo gosto", "qualificar a moradia dos menos abastados", alguns dos objetivos da revista, que era destinada a público mais abrangente do que o especializado (NERY, 2013, p. 294). Desde tênues pontos de contato com vertentes modernas na arquitetura, ainda que sob marcas de uma crescente racionalização construtiva, as linguagens dos projetos publicados não seguiam matriz comum, o que pode ser identificado nos exemplos a seguir [figuras 16-18].

A arquitetura de estilo, como o marajoara, norteava variados projetos publicados nesse recorte de 1934 a 1943, quando foram recorrentes os de autoria de engenheiros civis. Eles foram publicados em desenhos e fotografias, sem quaisquer explicações por escrito, além das informações descritivas que os acompanharam, de autoria e localização. Duas casas projetadas por Arnaldo Macedo Baena, um edifício de múltiplo uso de autoria de Moacyr Fraga e duas casas de autoria de A. Meira Filho enquadram, em síntese, a pluralidade de

\footnotetext{
${ }^{113} \mathrm{O}$ ano final da revista foi considerado em detrimento de sua última publicação, ainda que tenha sofrido um redirecionamento editorial no ano de 1945, quando deixou de reportar assuntos estritamente relativos à Arquitetura e à profissão (NERY, 2013, p. 308). Cabe observar um artigo, do ano de 1949, de Padre Carlos Borromeu, intitulado "Construções da Companhia de Jesus na Amazônia", no qual o autor apresentou uma série de exemplares jesuíticos construídos principalmente no Pará, até o século XX.

${ }^{114}$ A pesquisadora desenvolveu tese a respeito da difusão da Arquitetura Moderna nas revistas brasileiras $A U$ e $A$ Casa.
} 
linhas de projetos comerciais, apropriados da publicidade oferecida pela revista à época. Estes projetos retratam um contexto no qual era ausente uma cultura disseminada, enraizada, de arquitetura e do projeto e onde a atuação de profissionais engenheiros, mestres de obra, projetistas em geral era intensa e prevalente, já que grande parte das obras eram acordadas entre "projetistas e mestre de obras", e que "o trabalho do engenheiro ou do construtor resumia-se em produzir a obra acabada” no segmento da construção em Belém-PA (MIRANDA, CARVALHO e TUTYIA, 2015) ${ }^{115}$, cidade centrada nas publicações do período em recorte.

A paisagem urbana de Belém-PA era marcada pela presença de reproduções ecléticas e, como identificado por Jussara Derenji, por um "neocolonial amorfo, de raízes não definidas”, desenraizado de referências locais, inclusive. Além destas edificações, havia outras limitadas a quatro pavimentos, até a década de 1940, quando o uso do elevador e do concreto armado foram tornados correntes. Jussara Derenji, definindo um quadro da prática profissional na região, trouxe à tona uma questão que até o presente ronda as pesquisas interessadas neste objeto. Dada ausência de escolas de arquitetura até a década de 1960, se perguntou, afinal, quem teria construído na Amazônia? (DERENJI, dezembro de 1995, p. 73-78):

Poucos arquitetos ou engenheiros, de outras regiões do país ou do exterior, projetam para Belém no período da Segunda Guerra Mundial e nos anos seguintes. Além de Oswald Massler [...] Ugo Furini [...] Entre os profissionais nacionais deve ser destacada a atuação de Álvaro Vital Brazi, que projeta os aeroportos de Manaus (1944) e de Belém (1945).

[...] um grupo reduzido de engenheiros locais que dominou o panorama construtivo até fins da década de 60. Esse grupo - com destaque para Judah Levy, Laurindo Amorim, Angenor Penna de Carvalho, Milton Monte, Alcyr Meira e Camilo Porto de Oliveira - tem grande responsabilidade na imposição de um padrão arquitetônico até o surgimento, em 1964, do primeiro curso de arquitetura. Este seria, mais precisamente, uma iniciativa que alguns engenheiros que buscavam legitimar sua situação de projetistas.

\footnotetext{
115 Esta publicação, indicada pela Professora Celma Chaves de Souza Pont Vidal durante a banca de qualificação, foi fundamental para alinhavar os sentidos conferidos à arquitetura quando situada em Belém. Nela, os autores narraram o processo formativo do curso de Arquitetura e Urbanismo implantado em 1964 em Belém-PA, pioneiro na região. Sem restringi-la ao enfoque estritamente pedagógico e disciplinar, estabeleceram vinculações à cultura da Arquitetura e Urbanismo na capital e à conjuntura disciplinar, ampliando os limites interpretativos para além da própria faculdade.
} 
Capítulo 3 - Dentro e fora da História:

centralidade da Amazônia brasileira nos textos e prática de A.U. no Brasil, 1934 a 1989
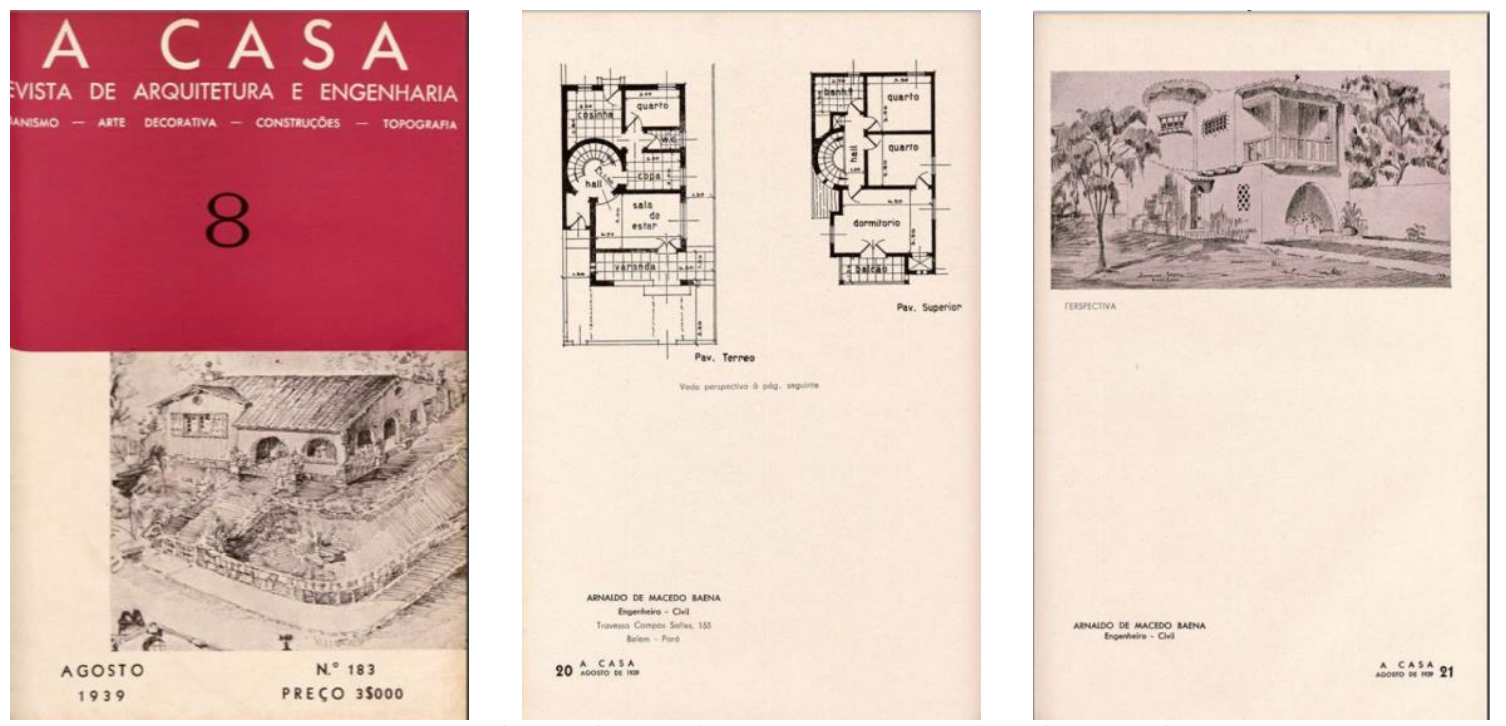

Figura 16 - Projeto de residência do engenheiro Arnaldo de Macedo Baena.

Fonte: A CASA, n.183, 1939, p. 20-21.

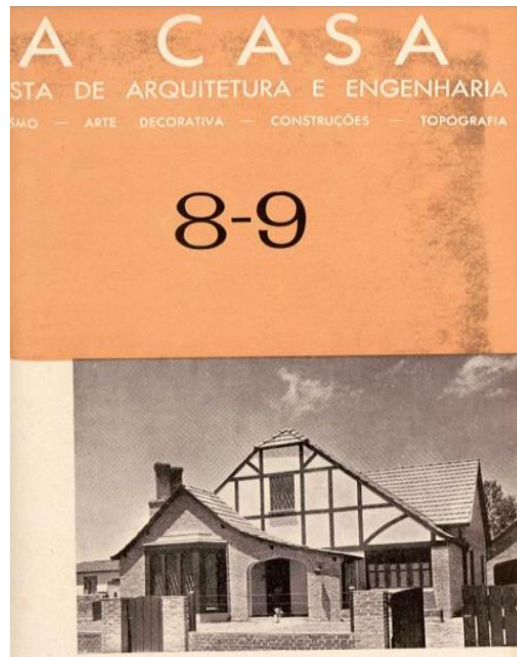

AGOSTO E SETEMBRO $1940 \quad N^{\circ} 0^{\circ} 195-196$ PREŞO $3 \$ 000$
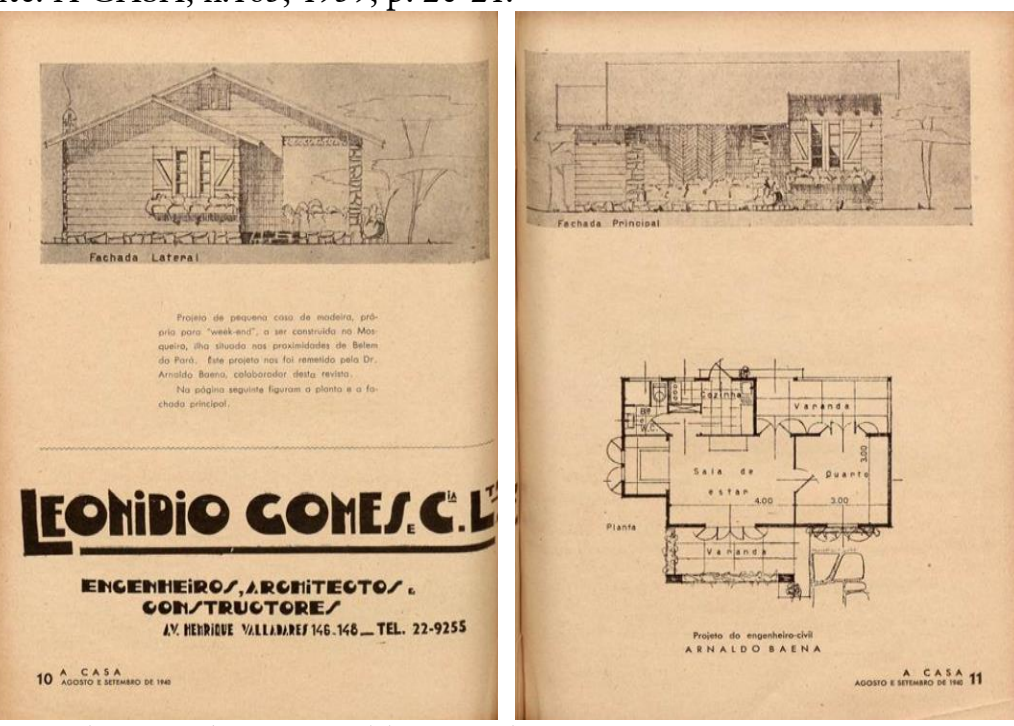

Figura 17 - Projeto de residência do engenheiro Arnaldo Macedo Baena, em Mosqueiro.

Fonte: A CASA, n.195-196, 1940, p. 10-11.
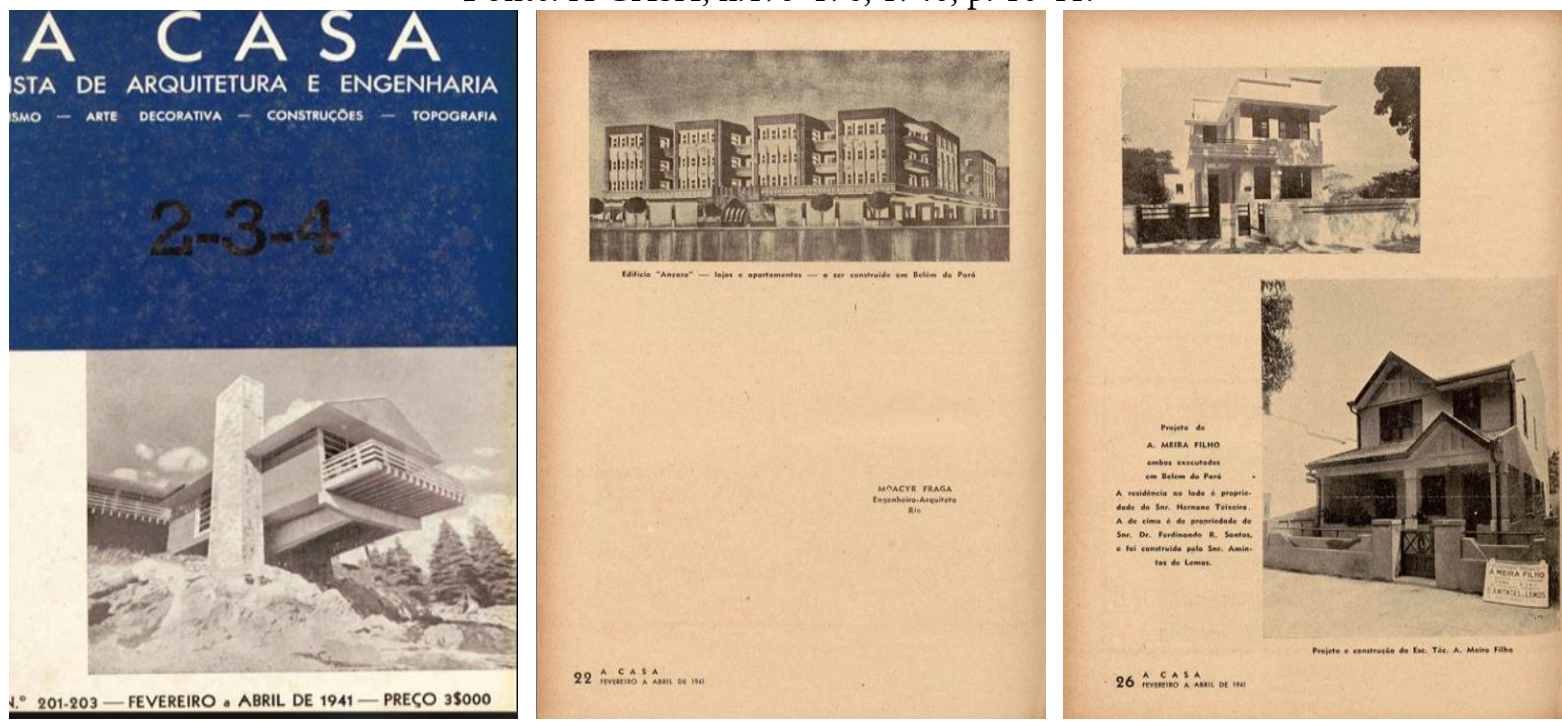

Figura 18 - Edifício de apartamentos e comércio, de Moacyr Fraga, engenheiro arquiteto baseado no Rio de Janeiro e projeto para duas residências, de A. Meira Filho. Fonte: A CASA, n. 201-203, 1941, p. $22 ; 26$. 
Os engenheiros dominantes nesse panorama, como nos casos apresentados, fizeram prevalecer a liberdade inventiva com certa dose de dispersão na linguagem que adotaram, explicada pelo caráter de suas propostas, remetido ao ambiente suburbano do século XIX (DERENJI, 1987, p. 164-165). Também produziram alinhamentos à moderna arquitetura, quanto a destituição de referenciais datados e à simplificação construtiva. A ausência de cenário urbanizado ${ }^{116}$ nos registros gráficos, que garanta uma leitura destas construções em seus locais originais de inscrição, sugere serem contextos em transformação, ou espacialmente deslocados de centralidades já demarcadas pelas feições modernizadas da capital, desde o século XIX, por construções de filiação eclética. $\mathrm{O}$ ambiente de implantação pode também ter sido desinteressante aos projetistas, não encarado como um problema nas representações dos projetos.

Noutro curso, as revistas de engenharia registravam pesquisas técnicas que incorporavam a região em análises pautadas na racionalidade construtiva do projeto, a exemplo do estudo de conforto térmico de Herminio de Andrade Silva publicado na Revista Municipal de Engenharia em artigo intitulado Contribuição ao estudo da insolação dos edifícios nas cidades do norte do Brasil. Nele, o autor avaliou elementos de proteção solar a fachadas, placas móveis e brises em exemplares da arquitetura moderna no Brasil, a Estação de Hidroaviões em Salvador, de Ricardo Antunes, o Entreposto de Pesca e Mercado de Peixe em Recife, de Luiz Nunes, o Ministério da Educação e Saúde, de Lúcio Costa e equipe e Obra do Berço, de Oscar Niemeyer, os últimos dois, no Rio de Janeiro. Este artigo foi extensivo ao publicado em número anterior da revista, a respeito da insolação dos edifícios no Rio de Janeiro. O autor acresceu ao comentário que teceu sobre as soluções adequação dos elementos arquitetônicos ao conforto nas obras já consagradas, outro texto, explicativo das condições de insolação nas cidades do norte do país. O autor analisou as cartas de Belém, Recife e Salvador, e ao fim estabeleceu bases técnicas ao projeto, especialmente para o cálculo da proteção das superfícies exteriores, com base em referenciais modernos de projeto (REV. MUN. DE ENG. N.5, setembro de 1940, p. 16-32). De fato a partir dos anos de 1930, “apareceu a consciência crítica da necessidade de adaptação dos princípios do

\footnotetext{
${ }^{116}$ Mosqueiro -PA, como exemplo, foi um local de veraneio onde no ecletismo foi predominante, especialmente na arquitetura de chalés radicalmente discordantes dos seus entornos de implantação (DERENJI, 1987, p. 164).
} 
movimento moderno em função tanto dos variados bioclimas da vasta geografia do país quanto de seus descompassos técnicos, artísticos e sociais” (CONDURU, 2004, p. 66).

Pelo que pode ser observado nas duas únicas imagens da maquete do Mercado Municipal para o bairro Umarisal em Belém-PA publicadas na revista Acrópole ${ }^{117}$ (ACRÓPOLE N.48, abril de 1942), Arnaldo Macedo Baena, engenheiro do Departamento de Engenharia da Prefeitura, que havia sido o autor de duas casas das publicadas pela revista “A Casa”, apresentou indícios do interesse tomar distância da rustificação das primeiras casas. Projetado na administração do prefeito Abelardo Condurú, o mercado estava sendo desenvolvido dois anos depois dos projetos das casas. A modularidade dos vãos e certa rigidez compositiva, como da presença de uma estrutura assemelhada à um alpendrado de acesso, não destitui, em função e na própria simulação da maquete, atenção despendida à inserção urbana do projeto tornado obra.

A participação dos engenheiros não ficou restrita à projetação de moradias unifamiliares, a exemplo do mercado público de Arnaldo Baena, ou mesmo à atividade projetual. A palestra de Augusto Meira Filho publicada na revista Acrópole em 1942 evidencia também o interesse de alguns desses engenheiros pelos desígnios da região. A matéria intitulada Acrópole em Belém do Pará registrou a Palestra realizada pelo engenheiro Augusto Meira Filho, em Reunião do Rotary Club de Belém - PA (ACRÓPOLE N.48, abril de 1942, p. 454). Na fala, o engenheiro traçou o quadro de dificuldades "do isolamento em que tem vivido essa Amazônia grandiosa”, dos problemas "gigantescos” frente à experiência nacional, dando relevo à sua postura patriótica na aspiração de um "Brasil elevado e livre”, ${ }^{118}$ explicado em síntese pela sua raiz formativa como um ambiente constituído de natureza “estonteante e sublime” e pelo imaginário de distintas geografias e climas. O autor situou a Amazônia num conjunto nacional no qual foi dada a "fusão de gentes”, o indígena, o africano, o colonizador. As ideias de Augusto Meira Filho estavam alinhadas às de Getúlio Vargas, quanto a um projeto de SANEAMENTO DA $A M A Z \hat{O} N I A$, uma verdadeira engenharia nacional. Nesses anos eram experimentados os

\footnotetext{
${ }^{117}$ Interessante notar o registro na publicação de agosto de 1941, de que a revista Acrópole n.40 passava a ser comercializada em Manaus, à Livraria Escolar, na Rua Henrique Martins, 177, teria sido este o primeiro local de venda da revista na região.

118 Muito provavelmente se referindo ao contexto do Estado Novo. Getúlio Vargas governava autoritariamente, numa administração centralizadora desde 1937 e em 1942, dava sinais de uma recondução de sua política para caminhos mais democráticos (SKIDMORE, 2010).
} 
efeitos do fim de um ciclo econômico de enriquecimento, notavelmente em Belém-PA e Manaus-AM, cidades que haviam concentrado os investimentos materiais e de riqueza advindos da comercialização exportadora da borracha, desde o século anterior até a primeira década do século XX.

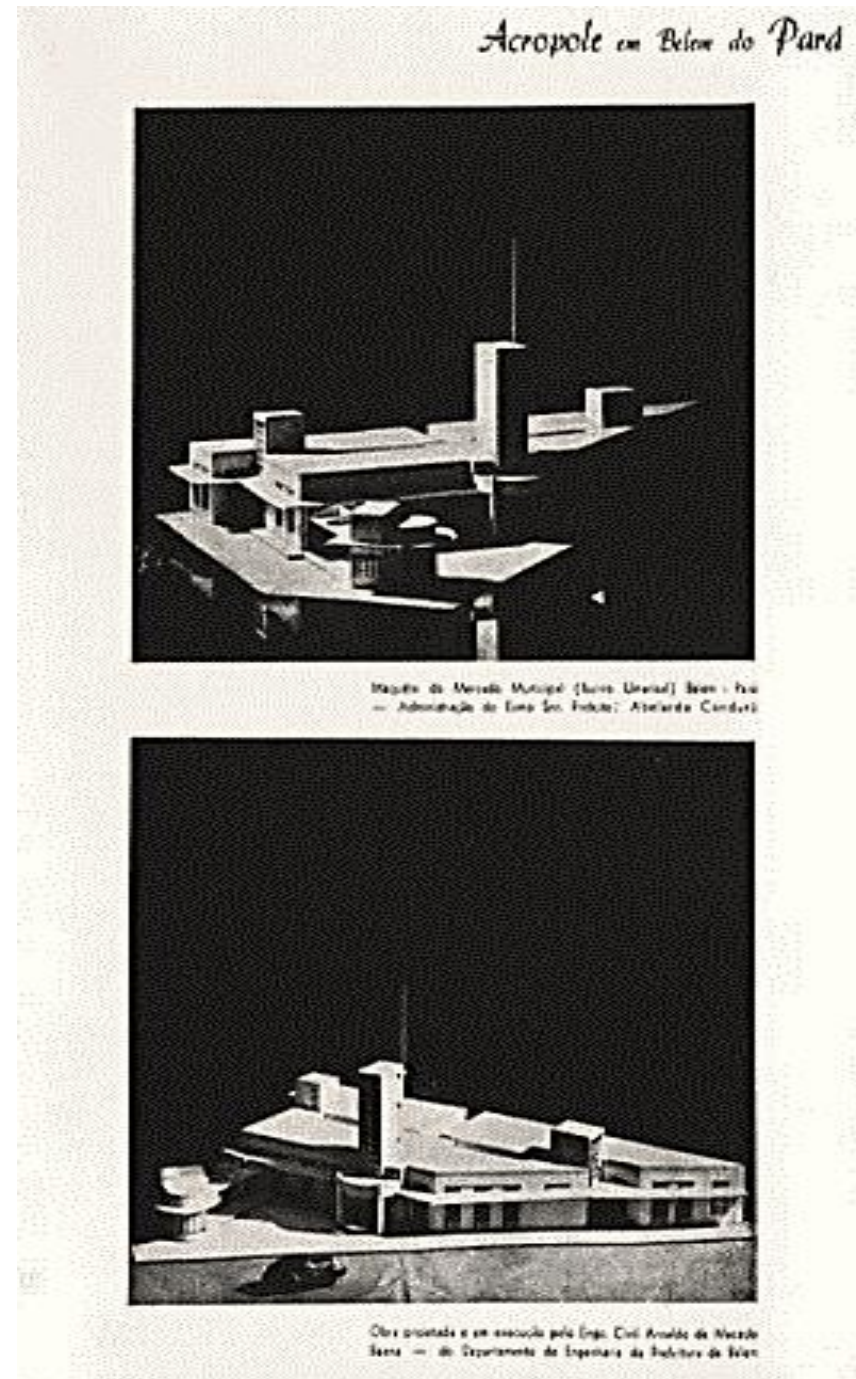

Figura 9 - Projeto de Arnaldo de Macedo Baena. Fonte: ACRÓPOLE n. 48, 1942, p. 448.

Em alinhamento às ideias de Vargas, o engenheiro utilizou como força argumentativa a necessária compensação de investimentos infraestruturais concentrados até então nos "prósperos Estados do sul", onde haviam sido construídas estradas, desobstruídos rios, construídas pontes, ligadas cidades, e no nordeste, com seus projetos de irrigação, de construção de açudes. Foram estes os exemplos a partir dos quais Meira Filho sintetizou seu anseio de que a Amazônia fosse interligada ao país, como parte da 
unidade a qual pertencia em direito mas não de fato, de modo a ser parte componente de uma "verdadeira nacionalidade" (ACRÓPOLE N. 48, abril de 1942):

É chegado o momento decisivo em que ela se vê protegida por parte do governo federal, desejando torná-la digna e merecedora dos méritos ainda por muitos desconhecidos.

Sómente agora resta-lhe a oportunidade de mostrar praticamente os vaticínios de Humboldt que a predestinou a uma grande civilização do futuro e celeiro do mundo. E ela, forçosamente, nos aparecerá, não como o inferno verde dos poetas, como miséria e abandono dos descrentes, não como paraizo de animais anti-diluvianos e "habitat" de insétos infecciosos, ao contrário, nos aparecerá completamente saneada, livre dos males que a infestam e que dominam à sua própria existência.

$[\ldots]$

E nós, principalmente nós, crentes da sua magnitude e fatôr necessário ao progresso nacional, podemos, de antemão, contar com a sua realização após o descaso e abandono sem par a que esteve sujeita por longos anos. Cabe-nos agora aguardar o futuro e, então, falar e dizer com segurança positiva o que a solução desse problema, poderá realizar por um Brasil maior, digno pelo seu valor econômico do qual em grande parte a Amazônia será colaboradora.

A construção mítica de uma Amazônia colonizada, um "celeiro do mundo", é atribuída ao naturalista alemão Alexander von Humboldt, que realizou expedição científica à região no século XIX e propagou uma paisagem formulada a partir daquele espaço elaborado em um absoluto "estado de natureza" e desde o qual foi delineado em seu desígnio produtivo e ignorado em suas dimensões culturais. A partir da concepção de Humboldt, Alfred Russel Wallace escreveria no fim do século XIX, que a "floresta primitiva pode ser convertida em ricas pastagens, em campos cultivados, hortas e pomares com todas as variedades de produtos, à custa da metade do esforço" (BRITO, 2001, p. 117).

Nesta linha, Augusto Meira Filho ilustrou sua ideia de modernização da Amazônia com as proposições de ali ser estimulada uma "agricultura magestosa", renovada uma "indústria extrativa", realizada uma "colonização" frente à baixíssima densidade, com a qual visava angariar "braços", força de trabalho ao empreendimento de saneamento a partir de técnicas modernas e atualizadas. O engenheiro fazia ecoar no âmbito regional, o interesse demonstrado discursivamente por Getúlio Vargas, de incorporação estratégica da Amazônia. Após a instauração do Estado Novo em 1937, o plano de ocupar regiões 
consideradas distantes, além de isoladas e vazias constituiu a "marcha para o oeste", ${ }^{119}$ estratégia de colonização interna que viria a ser reforçada discursivamente após 1940, quando da visita do presidente à Amazônia. Nesta oportunidade, ele afirmou o interesse de tornar efetivo o "Plano de Saneamento da Amazônia", fortalecendo o combate à malária na região, um dos entraves regionais ao desenvolvimento (ANDRADE, 2007).

Nesta fase, a administração de Getúlio Vargas foi "muito mais discursiva do que ativa”, ainda que expressando seu interesse em tornar efetivos seus planos para a Amazônia. Sua atuação foi marcada, neste sentido, por medidas que contribuiriam para o aparelhamento estatal, a exemplo da criação da Fundação Brasil Central, em 1944 (BECKER, 2009, p. 25). No mesmo ano de 1942, na segunda viagem à região, Getúlio Vargas proferiu em Manaus o "Discurso do Rio Amazonas”, que seria transformado pelo Departamento de Imprensa e Propaganda em "marco da marcha para a Amazônia”, para fins do "recrutamento dos soldados da borracha" (SECRETO, 2007). Nele, Getúlio Vargas expressou seu ímpeto civilizador quando se referiu às aspirações governamentais para a região da Amazônia brasileira, como no trecho a seguir, ao qual aderia o de Augusto Meira Filho (VARGAS abril-junho de 1942):

Nada nos deterá nesta arrancada que é, no século XX, a mais alta tarefa do homem civilizado: conquistar e dominar os vales das grandes torrentes equatoriais, transformando a sua força cega e a sua fertilidade extraordinária em energia disciplinada. O Amazonas, sob o impulso fecundo da nossa vontade e do nosso trabalho, deixará de ser, afinal, um simples capítulo da história da terra e, equiparado aos outros grandes rios, tornar-se-á um capítulo da história da civilização.

Neste fragmento da fala de Vargas, foi expresso o ânimo por uma colonização em escala regional, do território e da cultura, por um amplo disciplinamento e conquista. No ideário, predominou a representação da natureza em equivalência ao selvagem, ou como forma de aprisionamento condicionador dos homens, também, como potencial e riqueza da nação. Esta representação da região, junto às que incorporavam o caboclo e o indígena como

\footnotetext{
${ }^{119}$ Rômulo de Paula Andrade apresentou um panorama das estratégias varguistas relacionadas ao Plano de Saneamento da Amazônia, em especial a de reconduzir o intento primordial da marcha para o oeste. Pensada a princípio como uma "corrida ao ouro" para viabilizar a industrialização nacional, foi adequada aos projetos expansionistas do governo, de colonização do interior do país. A ideia da integração nacional demonstrada nos discursos de Getúlio Vargas deveria encarar o "o sertão, o isolamento e a falta de contato", defendendo que deveria demarcar sua presença nas várias partes do território, para angariar aliados regionais, diante de um período de contestações ao seu governo nos primeiros anos de Estado Novo (ANDRADE, 2007, p. 43-45).
} 
nativos condicionados ao ambiente, e mais tarde, como trabalhadores aptos, formaria o discurso oficial do Estado Novo. Tais representações haviam sido deslocadas do contexto da Primeira República, desde a produção de autores que como Euclides da Cunha, contribuíram para a construção de um imaginário sobre a Amazônia, produzindo ideias basilares para Vargas, de integrá-la espacial e economicamente ao país (ANDRADE, 2010).

Rômulo de Paula Andrade reforça a relação discursiva entre os escritos de Euclides da Cunha, Alberto Rangel e Alfredo Ladislau, e sua absorção por intelectuais como Arthur Reis e Leandro Tocantins, ainda que sejam os textos dos primeiros autores, pertencentes a categorias distintas, de literatura e relativos ao pensamento social na Amazônia. O autor inscreveu historicamente os textos: os de Euclides da Cunha (1905) e Alberto Rangel (1908), junto ao ápice da economia da borracha, foram pautados em temas relativos às fronteiras regionais e a ocupação do espaço, já o texto de Alfredo Ladislau (1924) foi escrito no período de decadência econômica regional. Todos eles teriam sido influenciados pela ciência de fins do século XIX e início do XX, especialmente do "determinismo climático e geográfico" como meio para produzir explicações sobre o caráter dos nativos, reduzidos a seguinte constante explicativa da região (ANDRADE, 2010, p. 455-461):

[...] as condições naturais da Amazônia teriam dado aos habitantes condições tão favoráveis para seu sustento que estes não enxergariam a necessidade de se desenvolver, ao passo que o clima tropical, favorável à disseminação de enfermidades (principalmente a malária) transformaria a história em uma eterna luta do homem contra a selva, quase sempre perdida pelo primeiro.

Esses autores teriam superado a síntese explicativa do “clima e ambiente” como entraves à modernização, identificando as ações estatais como os meios possíveis para a concretização do desenvolvimento regional. Para Euclides da Cunha, autor influente entre os intelectuais dos anos de 1930 e 1940, a Amazônia teria que ter sua natureza selvagem domesticada para que pudesse ser incorporada ao Brasil e então desenvolvida. Alberto Rangel, por sua vez, incorporava a mentalidade científica à ficção, em sua visão de uma natureza "edênica” e "apocalíptica”, para a qual também vislumbrou a redenção humana pelo progresso e civilização. Para ambos, a atuação do poder central seria forma pela qual a natureza, dominada, possibilitaria à Amazônia, ser incorporada ao país. Vislumbrando do mesmo modo a unidade nacional, para Alfredo Ladislau, o Estado teria a responsabilidade de evitar a decadência econômica regional. As ideias desses textos teriam profundo 
entrelaçamento aos discursos de Vargas, especialmente os absorvidos pela potente propaganda institucional de seu governo (ANDRADE, 2010, p. 455-461).

A instituição do Código de Mineração ${ }^{120}$ de 1934 foi um marco do processo de ingresso do capital internacional na Amazônia, pois foi então “iniciado o percurso que, aliando nacionalismo e estatismo, desembocaria na 'santa tríplice aliança' dos anos pós-64", especialmente com concessões do governo brasileiro às atividades de indústrias dos Estados Unidos, ligadas à área de exploração mineral. Ainda, com os "Acordos de Washington" e o alinhamento do Brasil àquele país, foram instituídas estratégias de exploração de recursos naturais da Amazônia brasileira, das quais participaram governos e grandes estruturas empresariais, como no caso do (OLIVEIRA, 1988, p. 14-16):

[...] monopólio estatal da borracha através do Banco da Amazônia, com a participação de $50 \%$ de capital norte-americano, e o monopólio estatal da exportação do minério de ferro, através da Companhia Vale do Rio Doce CVRD, constituída em 1942.

[...] $\mathrm{Na}$ mesma raiz dos "Acordos de Washington" de Vargas estava o veio em que germinaram mais tarde a SPVEA (Superintendência do Plano de Valorização Econômica da Amazônia), sua sucessora a SEUDAM (Superintendência do Desenvolvimento da Amazônia) e a ação da estatal Cia. Vale do Rio Doce na aliança com grupos multinacionais para exploração de minérios, sobretudo na Amazônia.

Para Ariovaldo Umbelino de Oliveira, ${ }^{121}$ o empreendimento varguista constituiu um "falso nacionalismo/estatismo". Mascarado pelo discurso desenvolvimentista, teria favorecido estruturas empresariais e governamentais externas, com prejuízos aos interesses sociais locais, a exemplo da Vale do Rio Doce. A empresa adquiriu empréstimos em dólares do Eximbank - Export \& Import Bank of Washington para prestação de serviço aos aliados durante a Segunda Guerra, acumulando déficits até o ano de 1952. Essa "política mineral” subordinada ${ }^{122}$ aos Estados Unidos, foi planejada em continuidade, como na

\footnotetext{
${ }^{120}$ O Código de Mineração de 1934 estabeleceu a distinção entre as propriedades do solo e subsolo nacionais, tornado dependente da concessão pública quando submetido a qualquer tipo de exploração (OLIVEIRA, 1988).

${ }^{121}$ Em sua tese, o autor explica o protagonismo da atividade das companhias de mineração dos Estados Unidos desde a República Velha até o governo militar, no processo marcado pela de sujeição do país ao capital internacional (RABELLO, 2013).

${ }^{122}$ Gerd Kohlhepp afirma que a "exploração de recursos minerais foi um dos objetivos centrais dos programas de desenvolvimento da Amazônia" e empresas nacionais e internacionais foram licenciadas para larga exploração de jazidas na região. Depois da exploração no Amapá e Rondônia entre 1950 e 1960, "novas descobertas de enormes jazidas de minério de ferro na serra dos Carajás, de bauxita no rio Trombetas e também de ouro e diamantes revelaram a riqueza de recursos minerais da Amazônia, sendo iniciados grandes projetos na região, nos anos 1980" (KOHLHEPP, 2002, p. 40).
} 
concessão até 2003 da exploração de jazidas de manganês no território do Amapá pela Bethlehem Steel Co., articulada à ICOMI — Indústria e Comércio de Minérios S/A, e com a assinatura do “Acordo Intergovernamental Brasil-Estados Unidos" em 1948, para mapeamento e difusão das reservas minerais de Minas Gerais com recursos norte$\operatorname{americanos}^{123}$ (OLIVEIRA, 1988).

Naqueles anos de decaimento da economia extrativa, o “esforço de guerra”, de 1942, havia mobilizado um contingente humano de imigrantes deslocados do Nordeste como tentativa de reativação dos seringais (SOUZA, 2001), frente a expectativa de absorção do látex que seria produzido na Amazônia novamente. O governo brasileiro, que monopolizou este comércio de exportação frente as estruturas de comércio que tradicionalmente o realizavam, esvaziou a mediação local, o que provocou críticas contundentes das “Associações Comerciais de Belém e de Manaus”, inclusive aos “Contrato-Padrão”, que em tese garantiriam ao seringueiro, 60\% do valor da borracha (GONÇALVES, 2008, p. 29-30):

Esse Contrato-Padrão era o reconhecimento tácito do extremo grau de exploração a que se achavam submetidos os seringueiros na Amazônia e é interessante observar que ele tenha sido instituído exatamente através de um acordo internacional. Ao mesmo tempo exaltavam-se aqueles que viessem servir à Pátria como Soldados da Borracha, como passaram a ser conhecidos aqueles que migraram para a região durante o período (19421945).

[...]A importância da Amazônia naquele contexto serviu também para o governo nacional barganhar a implantação da Companhia Siderúrgica Nacional, base do processo de industrialização por substituição de importações e do projeto militar nacionalista de construir uma indústria de base capaz de gerar as condições materiais e tecnológicas necessárias para que as Forças Armadas desempenhassem seu papel de defesa da integridade territorial do país.

Desfocado da amplitude territorial da Amazônia e detido ao contexto urbano belenense, A. Meira Filho, juntamente com outro engenheiro, David Lopes ${ }^{124}$ tiveram um projeto seu publicado também na revista Acrópole neste ano de 1942 (ACRÓPOLE N.52,

\footnotetext{
${ }^{123}$ Com a assinatura do "Acordo Militar Brasil-Estados Unidos", Getúlio Vargas possibilitou a ampliação da ingerência dos Estados Unidos sobre processos econômicos no Brasil, como de matérias-primas nacionais, especialmente o minério de ferro, e a CVRD foi submetida a controle contábil americano, sendo a "Cleveland Cliffs 'ror; Co., de Ohio", sua representante direta nos Estados Unidos. Desta forma, "estava implantado o controle por um monopólio privado do fornecimento do minério de ferro da estatal brasileira", fortalecendo a "aliança capital norte-americano/ Estado/ militares/ fração da burguesia nacional 'testa de ferro" (OLIVEIRA, 1988, p. 18-19).

${ }^{124}$ Interessante notar que na mesma publicação, à David Lopes foi designada a atribuição de engenheiro e noutro momento, de arquiteto, em dois lugares distintos do texto.
} 
agosto de 1942). Celma Chaves de Souza Pont Vidal e Gleyciane Viana da Silva situam este projeto no contexto de descompasso no qual as artes plásticas tendida à abstração e a arquitetura dominada pela prevalente adoção do ecletismo e do art decò nos anos de 1930 em Belém-PA, eram manifestas nos "Salões de Belas Artes”. As autoras analisaram os salões de 1936, 1940, 19421944 e 1947, e destes, a presença de projetistas, engenheiros e arquitetos estrangeiros. Neste recorte, o projeto da praça Pedro Teixeira de Alcy Meira Filho e Arquiteto David Lopes foi particularmente analisado junto aos que tinham, à época, “caráter historicista, mas modernizado”, "padrões da linguagem histórica da arquitetura como diretriz da arquitetura da cidade, embora os edifícios propostos expressassem em sua forma e partido, elementos modernos", como outros projetos desenvolvidos junto à Diretoria de Obras Públicas do Estado (CHAVES e SILVA, junho de 2011).

O memorial descritivo publicado na revista, fez revelar o interesse dos engenheiros pela "técnica moderna" voltada ao "embelezamento da cidade", em resposta ao encargo solicitado pela Prefeitura Municipal. A “estética da cidade” foi o motivo quase exclusivo, segundo escrito pelos autores, para a realização do projeto. A fonte de inspiração, deixaram claro por meio da observação e comparação, foram as outras cidades do país, desde as quais foi pautado o projeto visando o atendimento da "estética, a circulação, a locação, a função econômica e a função social” urbanas. A intervenção deveria alterar profundamente a paisagem urbana, especialmente a avenida 15 de agosto, onde seria situado na capital Belém.

De linhas classicizantes, demarcado ao centro pelo monumento de reverência ao navegador luso Pedro Teixeira, o projeto previa uma praça memorial de $2.400 \mathrm{~m}^{2}$ contornada por edifícios de arquitetura mais austera, erguidos a partir da série de desapropriações caracterizadas como eventuais, que estavam previstas no projeto e puderam ser identificadas nas legendas, somadas ao todo, de 24 prédios. As edificações confeririam limites espaciais à praça, representada em corte, junto à circulação periférica prevista, tanto para a caixa viária, quanto para o trilho de bonde e passeios arborizados. A atenção despendida ao "trânsito perturbador" verificado no contexto da avenida pelos engenheiros, fez do projeto uma estratégia para reordenação dos fluxos urbanos. Em tempos de guerra, foi prevista a inclusão de um abrigo antiaéreo, desenhado em escala 1:200, em planta, e igualmente incluso no corte. Os engenheiros projetistas previam obter, com a construção do projeto, "magnífico 
resultado estético, grandioso e admirável à principal avenida de Belém, de acordo com o prestígio que mantém entre as grandes capitais do Brasil”.

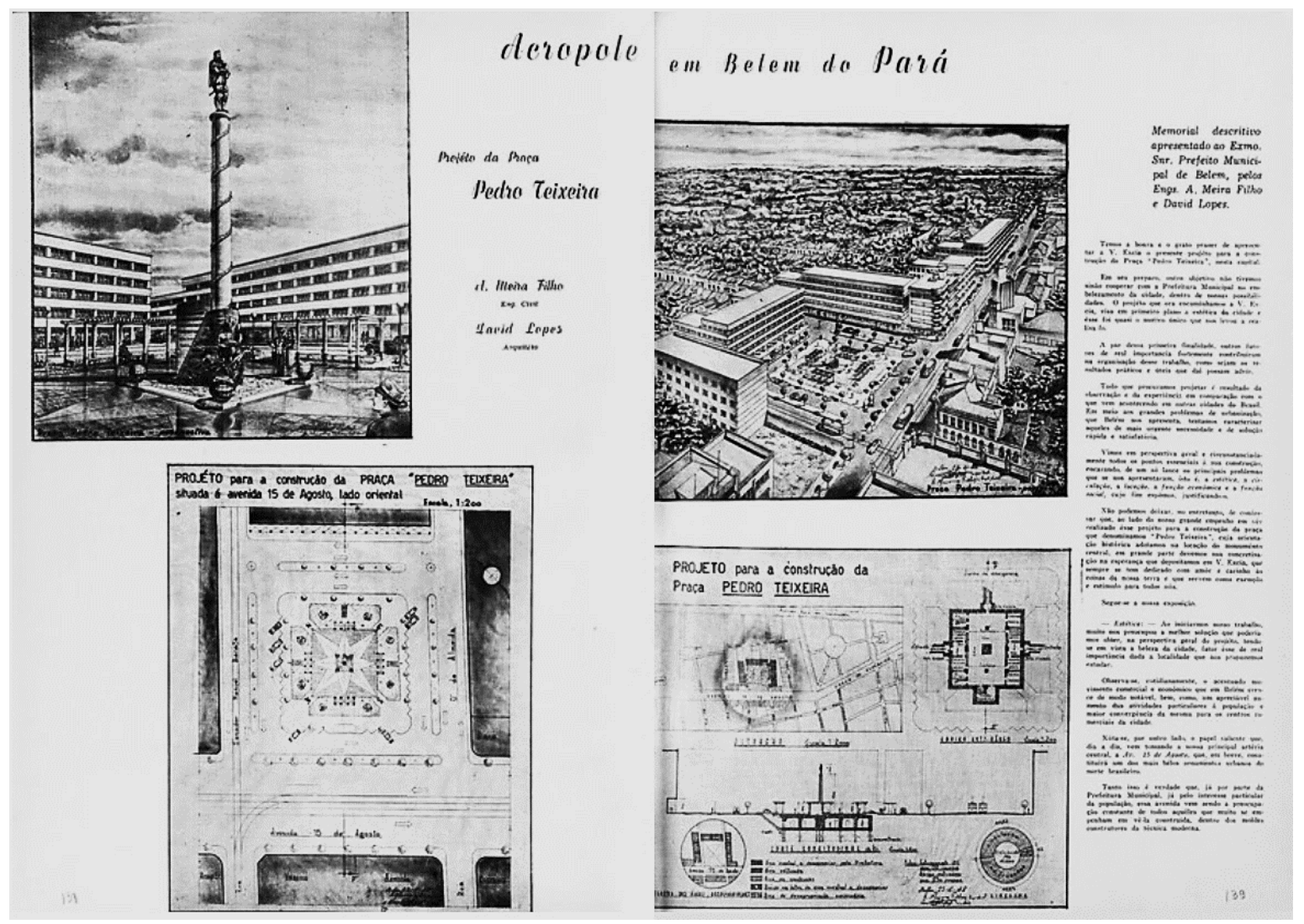

Figura 10 - Projeto da pç Pedro Teixeira, sob o encargo da Prefeitura Municipal de Belém, de autoria dos Engenheiros Alcy Meira Filho e David Lopes. Fonte: ACRÓPOLE n.52, 1942, p. 138-139.

Neste primeiro recorte, de 1934 a 1942, a parca arquitetura publicada nas revistas foi centralizada em Belém-PA, num estágio de anseio pelas poucas vozes identificadas nas revistas à modernização urbana, em uma fase de decaimento econômico a qual a capital partilhava com Manaus-AM. Na Amazônia, entre os anos de 1934 e 1942, a decadência de um sistema produtivo que havia perdurado de meados do século XIX aos anos de 1910, era sentida e alimentava a expectativa de pelas vias das intervenções federais, especialmente as de incentivo às práticas econômicas, fosse alcançado o soerguimento da economia regional, tal como os áureos anos vividos, ainda que não com alcance geral, da riqueza propiciada pela economia da borracha. 


\subsection{Expectativas de modernização, de 1943 a 1967}

Um estrangeiro interessado no valor de certa arquitetura centrada ao sul no Brasil, narrou de relance uma aproximação à Amazônia. A havia observado desde o ponto de vista singular de um rasante de avião, o que resultou em uma imagem limitada, mesmo que plausível, do que apreendeu em perspectiva geral, à distância: uma paisagem e algumas suposições. O escrito em questão, de Philip Goodwin (GOODWIN, 1943), foi inaugural de um conjunto de textos que povoam a cultura da Arquitetura e Urbanismo no Brasil. Seu apontamento sobre a Amazônia constrói um ponto de partida para o percurso narrado neste segundo tópico do capítulo, que termina com textos emergidos da interioridade da região. Contrastando no aprofundamento e nos objetivos ante a Amazônia, de início e ao fim do tópico, os autores se utilizaram de recursos distintos para sua mediação, alinhavada pelo contato que tiveram com a temática, Arquitetura e Amazônia, em menor ou maior grau de intimidade.

Philip Goodwin apresentou o Brasil em seu livro catálogo o explicando como a uma paisagem e partindo do processo colonizador que lhe constituiu historicamente. O país foi sintetizado pela sua estrutura natural e física, explicativa da ocupação e da moldagem do território por parte do colonizador, seletivo que foi às "regiões altas e a litoral, relativamente frescas e secas", em detrimento do calor e umidade das "florestas cerradas de madeiras de cerne", condicionais à penetração dos "primeiros agricultores" naquele lugar (GOODWIN, 1943, p. 19). A Amazônia, apresentada em características genéricas, mereceu sua breve atenção, ainda que tenha sido necessária ao texto como meio de afirmação do objeto sobre o qual pretendeu lançar olhar aproximado e evidenciar: a cidade sublinhada pela presença da novidade de uma moderna arquitetura no Brasil no século XX (GOODWIN, 1943, p. 17):

O enorme avião prateado atravessa velozmente o rio Amazonas. Quilômetros e quilômetros de água sinuosa serpenteando pântanos e contornando ilhas, a perder de vista. Prossegue depois através de tufos de nuvens, por sobre terras desertas, virgens do passo humano, apenas pontilhadas de colinas verdes. De repente, a cidade de Belo Horizonte, ao lado de um lago em forma de polvo. A terra parece povoar-se, de novo.

Foram poucas linhas sobre aquelas "terras desertas” que ilustraram o estado de natureza apresentado como contraponto ao que o autor relevou naquele ano de 1942. Todavia, com a geografia equivocada de contíguas Belo Horizonte e Amazônia 
(CARRANZA e LARA, 2014), a "selva intrincada" e autônoma, "impondo o transporte por água” significou o oposto à modernização. Serviu à afirmativa da produção arquitetônica resultante do processo que ele próprio estava a narrar, formativo da cultura construtiva brasileira evoluída até aquele momento. Focalizado no sudeste do país, seu texto foi fruto do esforço de dar a ver aos norte-americanos, "o encanto das velhas e a inspiração das novas construções do Brasil” e aos “muitos latino-americanos”, ainda não familiarizados com aquela produção nacional que foi explicada desde o que considerou seu ponto de partida originário ao estágio mais atualizado (GOODWIN, 1943, p. 7-19).
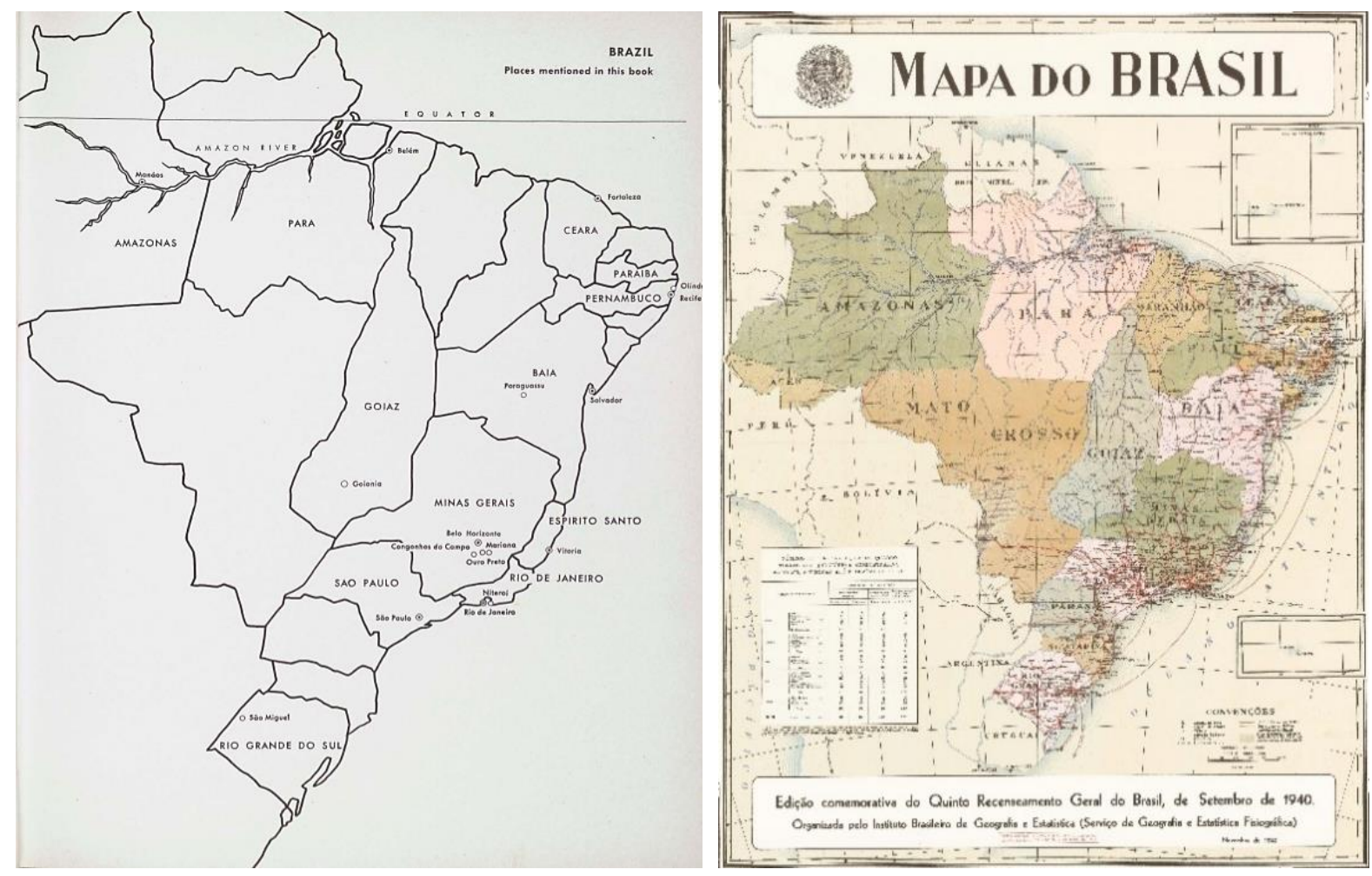

Figura 11 - Mapa do Brasil veiculado no livro catálogo de Philip Goodwin (1943) e mapa do Brasil de 1940 (IBGE, 1940).

O mapa com que representou o país trazia algumas lacunas, já que a ilustração serviu à identificação dos "lugares mencionados no livro". O próprio esquema que serviu de legenda, construiu os ocultamentos que a escrita apresentou, especialmente das fronteiras amazônicas. Das motivações, inclusive as políticas, relacionadas aos interesses estadunidenses "por travar relações com Brasil” ${ }^{125}$ (GOODWIN, 1943, p. 7), decorreu a

${ }^{125}$ País tornado seu aliado na Segunda Guerra Mundial a partir dos Acordos de Washington, de 1942. 
escrita sintética ${ }^{126}$ que narrou a mesclagem das obras à paisagem, da cultura à natureza (GUERRA, 2017, p. 15). Foi assim desenhado um quadro da arquitetura desenvolvida no país, passada e presente, concebida da fusão de uma tradição construtiva de base europeia. A ela foi acrescida uma renovada arquitetura em adequação ao tempo, ao lugar, ainda que de referenciação externa, constituída de uma produção enraizada num contexto peculiar e inscrita em trajetória histórica evolutiva. No recorte de 1652 a 1942, Philip Goodwin selecionou experiências de arquitetura moderna no país, ${ }^{127}$ realizadas desde 1938, que junto aos edifícios antigos, apontariam para uma linearidade no curso dos acontecimentos no campo da arquitetura, neste caso, alinhados à concepção de cultura arquitetônica nacional.

O fato do referido livro-catálogo ter sido demarcatório da narrativa propagada e presente na cultura arquitetônica do sec. XX no Brasil, a partir do contexto de "Política de Boa Vizinhança” (CAVALCANTI, 2006, p. 165-171) entre Brasil e EUA, e de ter veiculado imagens daquela natureza abundante, fazem da publicação, demarcatória deste segundo recorte. Isto pelo seu inevitável entrelaçamento às que dali por diante abordaram em distintos aportes, a Arquitetura e a Amazônia brasileiras. Há, todavia, outras ocorrências, além dos aspectos conjunturais que dos anos antecedentes ao término da Segunda Guerra, fazem o de 1943 singular. ${ }^{128} \mathrm{Um}$ artigo de Gilberto Freyre, dos publicados no O Jornal ${ }^{129}$ naquele ano, nomeadamente "Em torno da colonização da Amazônia", trazia alguns dos motivos desta particularidade (FREYRE, 1943, p. 4):

Falou-me o sr. Paulo Assis Ribeiro na cooperação técnica que lhe vem prestando o arquiteto Vital Brazil, no sentido do aproveitamento de elementos da vegetação amazônica para a construção de tipos de casas

\footnotetext{
${ }^{126}$ A escrita foi adequada ao formato de um livro-catálogo.

${ }^{127}$ Ressaltando o maior número de exemplares "antigos", cerca de quarenta e seis, frente os de "arquitetura moderna", trinta e nove no total. Os exemplares da moderna arquitetura estavam implantados nas cidades do Rio de Janeiro, com quinze exemplares, São Paulo, com nove, Recife, Belo Horizonte e Niterói, três em cada cidade, Salvador, com dois, e Fortaleza, Ouro Preto e Olinda, com uma edificação de feição moderna cada.

${ }^{128} \mathrm{Uma}$ das facetas desses intercâmbios culturais foi a do recobrimento de interesses político econômicos nas relações entre os dois países, a exemplo da atuação de etnógrafos americanos na América Latina na primeira metade do século XX. Eles produziam mapas da Amazônia para a identificação de mão de obra indígena e localização de recursos naturais estratégicos, especialmente a Borracha. Com a fundação em 1943, do Institute of Social Anthropology pelo Departamento de Estado dos EUA, antropólogos realizavam pesquisas em toda a América Latina, sob o interesse expansionista daquele país (TAVARES, 2013).

${ }^{129}$ Jornal de grande circulação entre 1924 e 1974, pertencente à rede dos Diários Associados, de Assis Chateaubriand. Em sua intensa atividade intelectual, Gilberto Freyre se utilizou de jornais e revistas como recursos midiáticos para difusão de suas ideias. Sua experiência nos Estados Unidos, com Franz Boas e com as ideias de determinismo ambiental sobre a vida social, além do contato com a Nova História, possibilitou sua articulação entre Ciências Sociais e História, na atenção que conferiu ao cotidiano e às práticas sociais (DALMONTE, 2009).
} 
pequenas e de grandes pavilhões ecológicos 130 e econômicos adaptados às condições regionais. É este um dos aspectos mais simpáticos e mais inteligentes no esforço de autocolonização que se realiza na Amazônia. Esse esforço correria o risco de morrer na infância se não cuidassem desde agora seus organizadores de dar-lhe firme base ecológica e seguro fundamento econômico de acordo com as condições e possibilidades regionais.

Precisamos de reagir contra a demagogia que pretende fazer da casa vegetal uma invenção invariavelmente satânica, a que se deve opor sempre a casa chamada de material. O norte-americano não ocupou o seu oeste nem povoou o seu sul, com habitações de tijolo ou de pedra, mas com casas simplesmente de madeira; e nas Filipinas, os norte-americanos, depois de estudos científicos do problema da habitação popular, reconheceram na casa vegetal condições de aeração e de insolação superiores ás dos tipos importados de vivendas chamadas econômicas. Vivendas ótimas para enriquecerem os fabricantes e importadores de material caro e, afinal, antiecológico, de construção.

Ainda que breve, este fragmento do escrito com o qual Gilberto Freyre cercou o projeto de "colonização da Amazônia" trouxe, da complexidade de suas formulações, conteúdos familiares a arquitetos e intelectuais no Brasil da primeira metade do século XX, que como ele concebiam a arquitetura como "forma de expressão" e síntese da cultura. Especialmente desde o contexto dos anos de 1930, "momento crucial da constituição do moderno discurso cultural brasileiro", quando protagonizaram ativamente da construção simbólica e projetiva do "amálgama” cultural e político do nacionalismo no qual estariam "unidos e indivisos cidadãos de origens e costumes diferentes" (SILVA, 2009, p. 32-36). Além deste entrelaçamento de ideias, outros juízos relativos à Amazônia estavam presentes em seu artigo. Mesmo porque Gilberto Freyre as articulou objetivamente, arquitetura e Amazônia, assim como outros intelectuais com os quais estabeleceu distintas formas de diálogo no país.

A acentuação de Gilberto Freyre ao atributo ecológico das habitações revelou sua posição como "grande expoente" de um movimento de "procura do regional no "tipo mais primitivo de casa popular brasileira"”, de investigação de seu correspondente mais tradicional, manifesto autêntico na arquitetura popular. ${ }^{131}$ De fato, os anos de 1920 no Brasil

${ }^{130} \mathrm{O}$ atributo "ecológico condizia com uma "ecologia" compreendida como ciência de "adaptação do homem ao meio", a partir de suas bases culturais (FERNANDES, 2011, p. 236). Significados associados à questão preservacionista, ambientalista, não anacrônicos aos significados que Gilberto Freyre apresentava ao termo. ${ }^{131}$ Emerge em Recife, uma discussão sobre a "procura de uma habitação adaptada aos trópicos" e das desvirtuações do morar dadas pelo imperativo urbano (LIRA, ano XIV, n.37, 1994). Em Recife, a "Liga social 
foram marcados pelo debate sociológico a respeito da habitação, incluída a identificação de elementos reveladores de uma "cultura regional autêntica, imediatamente ligada ao território", na qual ele inscreveu o mocambo do nordeste, ${ }^{132}$ na condição de "abrigo mais primitivo, idílico e ecológico", "investido de um forte sentido de nacionalidade" (LIRA, ano XIV, n.37, 1994). Sua formulação repercutiu junto aos agentes diretamente envolvidos com uma arquitetura de "contornos de uma identidade própria e identificável à nação", especialmente a partir dos anos de 1930.

Como aponta José Lira, o livro de Gilberto Freyre sobre os mocambos foi uma encomenda do Serviço do Patrimônio Histórico e Artístico Nacional em 1937, já que o autor pertenceu ao conjunto de intelectuais que problematizaram um modernismo nacionalista, no tocante à (LIRA, ano XIV, n.37, 1994, p. 51):

[...] consideração da arte popular, sua simplicidade plástica e economia na composição tão enfatizados por Mario de Andrade ou Lucio Costa [...] do anseio das oligarquias regionais, de Minas Gerais, Bahia e Pernambuco, em situar em si o Brasil mais prematuro; e, por último, catalisando adeptos do modernismo, do neocolonial e do regionalismo, do projeto hegemônico de estabilização do nacional, do próprio investimento na ideia de povo, trabalho, e família, de integração das raças e classes sociais, de resto, de criminalização de todo gênero considerado menor ou residual [...]

Com sua participação neste processo, Gilberto Freyre levou ao mundo intelectual uma "tradução ou uma refração da arquitetura brasileira" construindo um "léxico que traz o bem arquitetônico para o universo da cultura escrita", tornando-se o "sociólogo dos arquitetos, ou da arquitetura moderna", segundo Silvana Rubino (RUBINO, 1992). O suporte textual fez circular suas interpretações a respeito do ajustamento material das construções à fixação humana no espaço amazônico, a exemplo dos atributos conferidos às casas e pavilhões projetados por Vital Brazil, qualificados como "ecológicos", “econômicos", em "acordo com as condições e possibilidades regionais", valorados nestes termos por Gilberto Freyre no referido artigo jornalístico. A utilização da matéria disponível, do emprego da técnica adequada à sua utilização, atributos estes da nomeada

contra o mocambo" que atuou de 1939 a 1945 contra os mocambos palafíticos, em defesa de sua demolição e da proibição da construção de novos, incentivou diretamente a construção de casas populares. A prefeitura encaminhou uma campanha na qual Gilberto Freyre foi favorável à "higienização dos mocambos por considerá-los, sob certos aspectos, mais saudáveis do que as pequenas casas de vila” (ANDRADE, 2003, p. 226).

${ }^{132}$ Publicado pelo SPHAN em 1937. 
“casa vegetal”, foram também argumentos em defesa ao que eram tornadas tais modalidades construtivas de traço artesanal, abrigos temporários.
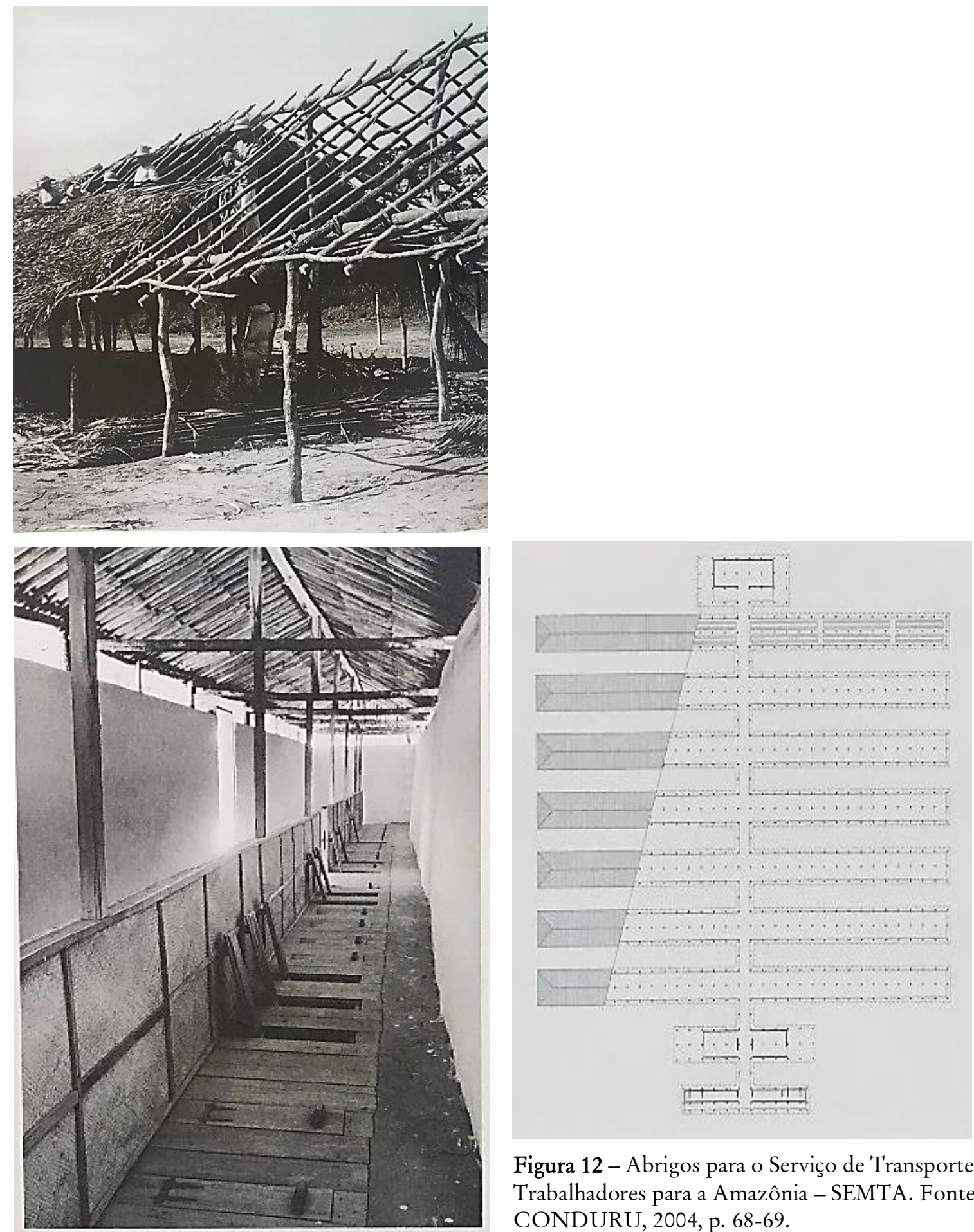

Figura 12 - Abrigos para o Serviço de Transporte de Trabalhadores para a Amazônia - SEMTA. Fonte: CONDURU, 2004, p. 68-69.

O sentido de adequabilidade construtiva à paisagem, absorvida como natureza e condição ambiental da vida regional, foi analisado junto ao procedimento ético adotado por Vital Brazil, nas pontes diretas com a resultante material e visualidade de seu projeto. 
Sobretudo a idealização da fala de Gilberto Freyre centrou a análise do ajustamento dos abrigos àquela leitura de uma Amazônia paisagem. Aquelas construções serviriam à instalação provisória de trabalhadores recrutados pelo Estado, principalmente advindos da região nordeste, quando dispostos ao enfrentamento do trabalho no isolamento dos seringais na Amazônia. Para eles que os abrigos foram destinados, numa tentativa de reativação dos seringais como núcleos produtores, em adequação aos imperativos dos Acordos de Washington, firmados da cooperação entre o Brasil e os Estados Unidos em 1942, especialmente para o fornecimento de matéria prima brasileira àquele país. A medida estimulou o deslocamento e o encaminhamento de trabalhadores para a Amazônia, por meio do Serviço e da Comissão destinados a este fim (SEMTA e CAETA).

Manuel Correia de Andrade trata dos enfoques dados ao espaço geográfico nos escritos de Gilberto Freyre, atentando especialmente para a ênfase que o autor confere à categoria "paisagem", na relação determinante entre fatores ambientais e desenvolvimento de modos de vida. O componente geográfico, para Gilberto Freyre, aparece entrelaçado às práticas culturais, como um ambiente ideado, ao qual se ajustariam as manifestações dos processos de miscigenação, a exemplo do Brasil. Da "generalização de usos como o da rede, o da utilização de animais de caça e de peixes dos rios na alimentação, o da coleta de frutos da floresta, como o sapoti”, a conformação da etnicidade, como questão antropológica, seria fator determinante na "formação de paisagens" habitadas, assim como o foi preponderante para a colonização portuguesa. A noção de "tropicologia”, deste modo, seria explicativa de um condicionamento do ambiente sobre as práticas, consideradas um conjunto comportamental de determinados tipos humanos, bem como suas sociabilidades num dado ambiente climático, que em conjunto seriam conformadores da paisagem (ANDRADE, 2003).

Num paralelo aos "marcos de silêncio", como Roberto Conduru nomeou as obras de Vital Brazil quando situadas no contexto urbano, os abrigos dos soldados da borracha foram também marcos silenciosos, na internalidade do espaço amazônico, sem localização, tanto os abrigos quanto os soldados da borracha, experimentaram da invisibilidade histórica. Roberto Conduru, aos abrigos, os qualifica como experimentos de racionalidade, uma “imagem ideal da razão - a configuração purista de formas desenhadas e moduladas com geometria rígida", uma construção feita em acordo com as "condições locais”, com as 
madeiras disponíveis e mão de obra, pertencente à uma linhagem (CONDURU, 2000, p. 22):

Esses abrigos constituem uma realização contemporânea, porém bastante diversa, da experimentação de Lúcio Costa com estrutura em madeira no Park Hotel, em Nova Friburgo, de 1944, cujo romantismo nostálgico e pitoresco abriu uma linhagem de obras que inclui a casa de fim de semana em Nova Frigurgo projetada por Carlos Frederico Ferreira em 1949 e a residência Hidelbrando Accioly, em Petrópolis, projeto de Francisco Bologna de 1950, passa pelos trabalhos posteriores de José Zanine Caldas e alcança as experiências recentes de construção em madeira na Amazônia, de Severiano Mário Porto e Otacílio Teixeira. Comparados a esse conjunto de obras, os abrigos para o SEMTA, com seu purismo prático e antirepresentativo, revelam o sentido formalista e pragmático, absolutamente contemporâneo, que orientava o racionalismo de Vital Brazil.

A madeira viria a ser o recurso que Lúcio Costa priorizou nos riscos que fez em resposta à encomenda de Thiago de Mello para suas casas, desde a primeira, em 1978, estabelecendo uma síntese, como expressou Hugo Segawa (PROJETO N.125, 1989):

Arquitetura que Lúcio Costa formulou para a Amazônia: compatível com os recursos materiais disponíveis e a singeleza da mão-de-obra local e de seu empreiteiro - o próprio Thiago de Mello.

$[\ldots]$

Trabalhar com a madeira, na Amazônia, é, sobretudo, uma questão de sobrevivência: com ela o caboclo constrói moradias, faz barcos, utensílios. A arquitetura naval é um conhecimento que passa de geração em geração. Como o pai de mestre Chiquinho, carpinteiro civil e naval. Madeira e água são vocações do amazônico.

Embora o governo tenha justificado a realização do investimento como esforço de guerra contra os alemães, para a finalidade de desenvolvimento da economia regional, após a segunda guerra mundial o projeto foi totalmente fracassado. Aos abrigos projetados por Vital Brazil, quando lidos junto ao seu contexto ambiental e político de realização, podem ser acrescidos os atributos de estruturas contingentes, efêmeras, artesanais, diante do parco investimento destinado por parte do Estado ao suporte daqueles migrantes.

Do ponto de vista da atividade projetual de Vital Brazil, sua atenção à elaboração de construções para o Nordeste e o Norte do país aspirava atender a duplo viés, em específico, “construtivo e climatológico”, em seus termos, entendendo o primeiro também, em equivalência ao financeiramente viável. Em seu relato publicado junto ao projeto da estação aeroviária de Belém-PA [figura 13], na Revista Municipal de Engenharia, o arquiteto revelou 
que a partir de sua experiência nas respectivas regiões, sua própria perspectiva da prática projetual fora alterada, quando da busca por "tipos construtivos bem mais elevados" a partir do uso de tecnologias mistas. Isto em razão das dificuldades em acessar materiais industrializados e a farta disponibilidade de outros não beneficiados. De um lado o "atrazo industrial destas zonas", por outro, a fartura de madeira, o que determinaria quase obrigatoriamente sua utilização. Sua experiência também trazia à tona uma conclusão precisa (REV. MUN. DE ENG. N.1, janeiro de 1945, Vol.XII, p. 15):

Cada zona do Norte brasileiro necessita ser estudada sob este aspecto e naturalmente o que previmos para Belém do Pará não é válido para S. Luís do Maranhão ou Fortaleza no Ceará. Mas é fora de dúvida que quem projeta para essas zonas erra profundamente se não tem elementos para estudo das condições locais sob o ponto de vista que focalizamos.

Ainda que como em qualquer outra “zona” a estratégia técnica não prescindisse da conciliação entre limitações e soluções projetivas, ao menos que fosse opção desviar da racionalidade projetual, muito improvável ao engenheiro arquiteto, a novidade das condições que encontrou em Belém, como as "fortes chuvas que lhe dão uma humidade relativamente elevada", ou sua localização, "praticamente sob a linha equatorial”, "sua elevada temperatura", somente "atenuada pelas chuvas e pelos ventos que percorrem a bacia amazônica na direção Leste Oeste do grande rio”, basearam sua formulação explicativa, justamente pela sua distinção frente às condições projetuais mais usuais ao arquiteto. Em planta, a Estação aeroviária de passageiros em Belém do Pará resultou em um vão central com os serviços localizados em recintos fechados nas suas extremidades. A solução que Vital Brazil produziu com a estrutura de madeira, material também previsto para a forração curva do interior da edificação, encerrando um colchão de ar entre esta e a cobertura de fibrocimento, foi também como uma resposta pragmática, assim como a adoção de venezianas nas extremidades norte-sul, sob os beirais, para possibilitar a ventilação no intervalo entre forro e cobertura. Jussara Derenji fez uma ressalva particular a este projeto, quanto à orientação norte-sul em razão das incidências solares diretas e por este motivo indesejadas. A autora também observou a cobertura em cimento amianto, "pouco adequada ao clima local” (DERENJI, dezembro de 1995, p. 75).

Neste momento que antecedeu o término da Segunda Guerra é possível identificar nas revistas uma postura cada vez mais diretiva sobre a Amazônia em paralelo à política 
governamental do Estado, o que vai de encontro ao que afirma Celma Chaves de Souza Pont Vidal a respeito de Belém-PA. Nesta cidade ficaram perceptíveis os impactos advindos dos Acordos de Whashington, quando "a cidade recebe novos investimentos, contrói-se a base aérea de Val de Cans, novas vias são abertas no caminho entre o centro da cidade e o aeroporto e a presença constante de militares norte-americanos movimentam o comércio, apesar da crise das infraestruturas públicas”. Como efeito das expectativas de modernização relacionadas aos Acordos, foi desenvolvido o Plano de Urbanização de Belém, ainda que não tenha sido realizado efetivamente (VIDAL, 2016). A partir da década de 1950 foi registrada nos periódicos uma distinção discursiva, em relação ao que até agora havia sido publicado.

Em retrospecto, a Amazônia apareceu nas revistas até este momento a partir de dois vieses. Um primeiro, em representações nas quais foi associada ao primitivo ou como em referência às raízes culturais do país, no curso da formulação intelectual de uma arte e arquitetura nacionais. Neste caso, a Amazônia foi referenciada muito diretamente entre as décadas de 1930 e 1940, ao arquipélago de Marajó-PA. Outro caminho foi absorvido pela centralidade de Belém-PA em praticamente todas as fontes até os primeiros anos da década de 1940. A referida capital foi o ambiente urbano da prática profissional de engenheiros e outros projetistas, num contexto submetido à premissa da modernização, no qual os referenciais da modernidade eram culturalmente absorvidos (CHAVES, abril de 2016):

[...] nessas produções arquitetônicas periféricas, se registra a adoção de ideais e aspirações de racionalidade e funcionalidade, próprias de uma sociedade que se quer moderna. As particularidades locais, caracterizadas na ausência de um cenário industrial, não foram impedimento para a assimilação de elementos de uma cultura arquitetônica moderna.

Desde a década de 1950, todavia, um "neocolonial sem expressão dos anos 40, foi substituído por uma linha construtiva, na qual princípios estéticos da vanguarda modernista buscam referência nas tradições construtivas regionais”, conforme atestou Jussara Derenji. Os projetistas tinham passado a atuar em duas linhas, absorvendo referenciais externos, observando dados referenciais da realidade local. No primeiro procedimento, passaram a incorporar novas referências vindas de fora, especialmente abstraídas das formulações de Lúcio Costa, na fase em que "maneja os códigos formais do colonial brasileiro" (DERENJI, dezembro de 1995). No segundo caso, os projetistas reelaboraram práticas construtivas 
interpretadas como usuais na Amazônia, ou as recriaram, como novos componentes de projeto.

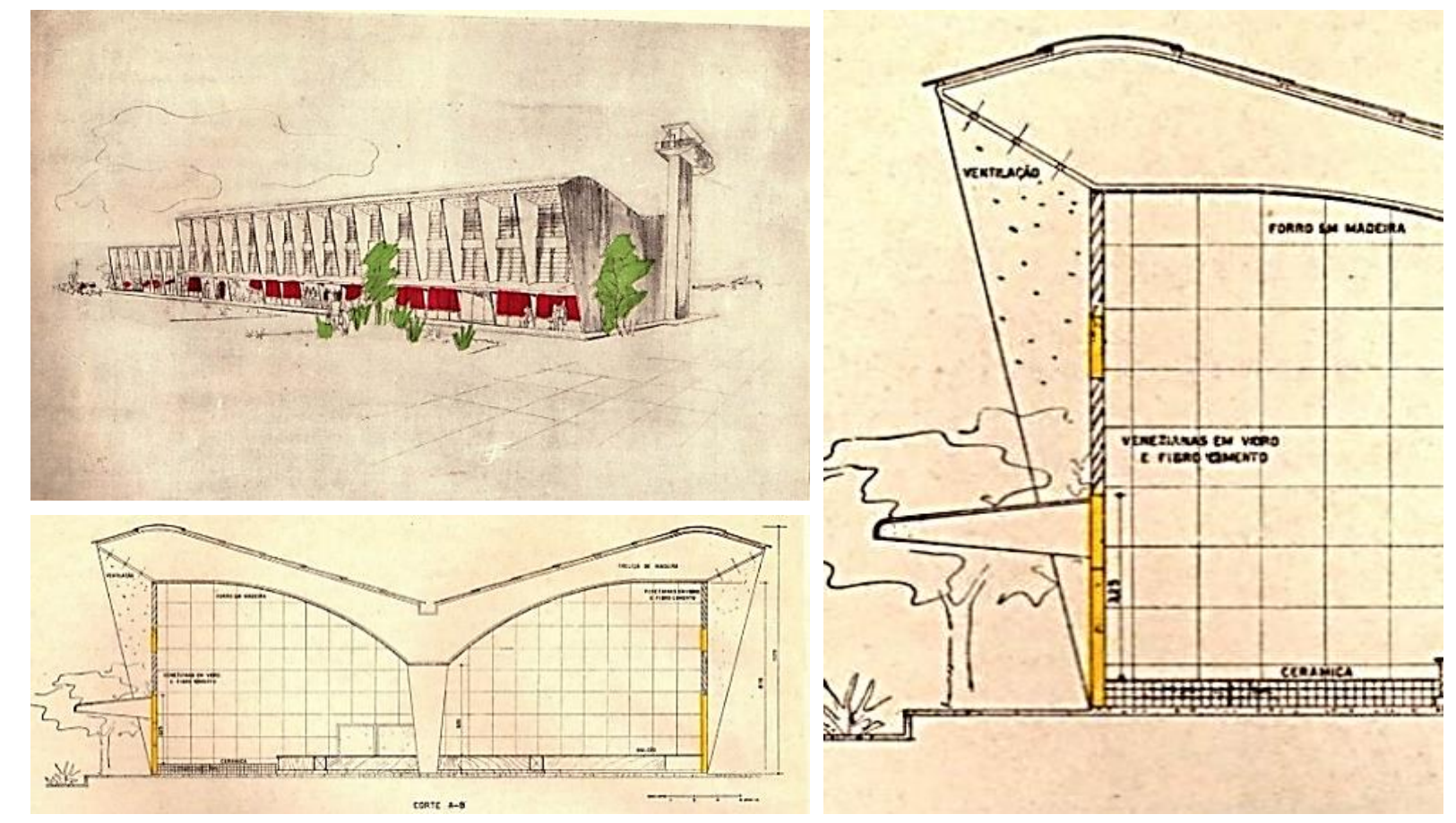

Figura 13 - Estação aeroviária de passageiros em Belém do Pará, projeto do arquiteto engenheiro Vital Brazil. Fonte: REV. MUN. DE ENG. n.1, 1945, Vol.XII, p. 18.

Espacialmente, a representação da Amazônia como vazio verde desabitado, a exemplo do apontamento de Philip Goodwin, ou como vazio à expectativa de ocupação, na conjugação aos significados sociais proferidos por Gilberto Freyre, foi o primeiro quadro revelado pelas fontes, junto à materialidade dos projetos de Vital Brazil, deslocados de quaisquer contextos de inserção reconhecíveis A respeito deste último, Maria Beatriz Camargo Cappello revelou que foi publicado em um número especial da revista The Arquitectural Review, em março de 1944. Na recepção e difusão da arquitetura do "NorteNordeste” em revistas estrangeiras, francesas, inglesas e italianas entre 1940 e 1960, além do projeto de Vital Brazil, do Norte brasileiro, o outro projeto situado na Amazônia publicado foi o do Hotel Amazonas, de Paulo Antunes Ribeiro (CAPPELLO, 2007).

Estes dois projetos sinalizam as pontes construídas entre a região e o restante do país, especialmente dadas sob efeitos das ingerências governamentais e seus incipientes investimentos, fosse à atividade turística ou à infraestrutura. No período após a Segunda Guerra, os planos estatais de ocupação e reestruturação territorial da Amazônia, criaram 
uma série de organismos de estímulo à implantação de atividades econômicas que substituíssem aquelas vinculadas à cultura extrativista e a importação regional, ainda que este aparato estatal tenha sido limitado e contraditório, quando avistado o desenvolvimento regional. O planejamento regional, desde o governo de Getúlio Vargas, teria sido um "subproduto" desta mentalidade planejadora central em que o desenvolvimento seria alcançado por meios materiais infraestruturais implantados regionalmente no país, especialmente no Nordeste, Amazônia e Vale do São Francisco (D'ARAÚJO, 1992). Noutro curso, os projetos de Oswaldo Bratke para cidades empresa no estado do Amapá começaram a ser implantados no fim dos anos de 1950, mas eram representativos dos efeitos das determinações da política de incentivo à mineração estrangeira na Amazônia na década de 1930, especializada no Amapá, em área concedida para esta finalidade pelo Estado, até o ano de 2003.

A ideia planejadora do Estado brasileiro teve como pauta desde os anos de 1930, a ideia de superação do estado de atraso e subdesenvolvimento do país pensado em sua condição periférica, que deveria ser tornado autônomo do ponto de vista econômico internacional. Esta compreensão pautou programas varguistas e alcançou o governo desenvolvimentista de Juscelino Kubitschek. A criação da Superintendência do Plano de Valorização Econômica da Amazônia - SPVEA de 1953 objetivou a elaboração e implantação de um plano de desenvolvimento regional, mais como uma formalidade do que em concordância efetiva ao que discursivamente era veiculado. Em termos formais, aquele seria um meio pensado para o ampliado desenvolvimento regional, a partir da integração do espaço amazônico à economia nacional, de sua ocupação e da promoção de sua "autosuficiência" produtiva, para o consumo regional, já que a industrialização estava concentrada no centro-sul do país (MARQUES, 2013, p. 175):

as primeiras políticas elaboradas pela SPVEA demonstraram a tentativa de reestruturar significativamente a economia regional, superando $\mathrm{O}$ extrativismo. Elas se apoiariam: (a) numa complementaridade à economia nacional (produzindo matérias primas); (b) mercado interno regional (produzindo produtos para seu próprio consumo, substituindo informações); e (c) numa nova complementaridade entre o rural (agora agrícola) e o urbano (centro industrial e comercial). 
Este aparato institucional influiria nos rumos tomados com a implantação da Zona Franca de Manaus em $1957^{133}$ durante o governo de Juscelino Kubitschek, especialmente com a mudança do paradigma com que até então vinha sendo pensada a atividade extrativista regional, substituída em ideação, pelo desenvolvimento industrial, também da agricultura, voltado ao mercado interno. Em seu artigo $1^{\circ}$, o texto da lei enunciava que a Zona Franca serviria ao "armazenamento ou depósito, guarda, conservação beneficiamento e retirada de mercadorias, artigos e produtos de qualquer natureza, provenientes do estrangeiro e destinados ao consumo interno da Amazônia”. Essa mudança foi dada em um período de expectativa ao desenvolvimento, marcado pelo incentivo à industrial, à movimentação do mercado interno, ao investimento de empresas estrangeiras, junto à atuação governamental que buscava o maior crescimento possível com a "expansão tanto do setor público como no setor privado", que explicariam elevados índices de crescimento do país (SKIDMORE, 2010, p. 203).

No entanto, o processo de industrialização das cidades brasileiras entre os anos de 1940 e 1950, para além das atividades industriais, esteve relacionado aos fenômenos de formação de mercados, de expansão do consumo, da própria urbanização, segundo Milton Santos, para quem “os índices de urbanização, ficam estagnados ou evoluem lentamente no Norte, onde devemos esperar os anos 1960" para a transformação de tal situação (SANTOS, 2009, p. 66). Os anos de 1960 foram um divisor, especialmente a partir de 1966, quando foi dado início à fase de implantação de programas de desenvolvimento para a Amazônia pelo governo militar, numa modernização conservadora que Bertha Becker nomeou de "ciclo de devassamento" uma “modernização acelerada” do território (BECKER, 2009, p. 25-26), como já observado no primeiro capítulo.

Várias das medidas desenvolvidas durante o governo militar sobre a Amazônia já haviam sido idealizadas em tempos pregressos, mas adquiriram novas formas de aplicação. A atividade planejadora iniciada nos anos de 1930, os Acordos de Washington em 1942, a

\footnotetext{
${ }^{133}$ A lei no 3.173, em 06 de junho de 1957 instituiu a Zona Franca de Manaus como estratégia para produzir a lucratividade estatal com poucos investimentos, estímulo à absorção de mão de obra barata e de um sistema de incentivos fiscais e isenções, como "um instrumento integracionista, num momento de ascendência do comércio internacional de hegemonia dos Estados Unidos sobre outras nações capitalistas", de modo que por meio da Zona Franca de Manaus, "com sua estratégia ligada às multinacionais, ao comércio de importação e ao modelo agropecuário, abre ainda mais a região ao exterior, promovendo uma economia dependente, altamente espoliadora e prejudicial” (SOUZA, 1978, p. 157).
} 
criação da Superintendência do Plano de Valorização Econômica da Amazônia - SPVEA, a transformação do Banco de Crédito da Borracha em Banco de Crédito da Amazônia em 1951, a criação do Instituto Nacional de Pesquisas da Amazônia em 1952, foram medidas que pouco alteraram os moldes do planejamento para a Amazônia, mesmo na década de 1950. Sua retomada, quando nos anos de 1960, a despeito de "crivo de um Legislativo forte" e dos vários projetos que foram implantados na região pelas vias do autoritarismo, moldaram uma modernização conservadora (D'ARAÚJO, 1992).

A recondução das abordagens sobre a região nas revistas guarda relação especial com os efeitos emergidos das medidas estatais que passaram a transformar mais substancialmente o espaço regional. As formas de contato oferecidas ao leitor com a Amazônia nas revistas especializadas foram alteradas na medida em que a intensificação dos projetos de porte sob o incentivo estatal, mobilizavam as fronteiras regionais, aprofundando a diferenciação entre campo e cidade e artificialmente ou idealmente os aproximando, no plano discursivo. Além de novas imagens, em fotografias panorâmicas e aéreas, novos temas e abordagens reelaboraram a Amazônia. Certo deslocamento do foco de Belém-PA a Manaus-AM e a veiculação de projetos realizados no Mato Grosso na década de 1950, construíram novas centralidades, contextos em urbanização que estavam sendo referenciais às transformações em curso.

Do ambiente urbano, nessas novas centralidades, figuraram edifícios em consonância à moderna arquitetura no Brasil e distinção ao conhecimento vernáculo identificado em imagens veiculadas de palafitas e flutuantes, igualmente presentes nas cidades onde prática de arquitetos foi mais visibilizada nas revistas. Ainda que perturbadoras a algum sentido de ordem que a modernização, quando discursivamente defendida, pudesse almejar, as moradias pobres urbanas foram apresentadas em contraste à atualidade arquitetônica, como cultura material, como fruto da pobreza urbana, na modernidade. As interpretações das moradias, sob a pauta das leituras culturais, oscilaram entre o "popular” e o "vernáculo” ou o “primitivo”. Em relação a estas leituras, os estudos etnográficos foram recorrentes, especialmente na revista Habitat, revista na qual a moradia popular foi apresentada como a síntese de uma tradição regional do construir. Especialmente o indígena, em formas unitárias de designação do nativo, foi associado à um certo ambiente físico, e ambos, sintetizados em uma paisagem homogênea de Amazônia. 
$\mathrm{Na}$ década de 1950, poucos projetos situados na Amazônia brasileira foram identificados na documentação consultada. Sintomático do próprio encaminhamento da atividade editorial nesses anos no Brasil, se em comparação ao número de matérias com temáticas centradas na Amazônia brasileira. Foram cerca de trinta, frente a quantidade de revistas consultadas da década de 1950. Pormenorizando, foram ao todo 118 números da Revista Acrópole, 58 números da Revista Habitat, 16 números da Revista Módulo, 11 números da Revista Brasil Arquitetura Contemporânea, 24 números da revista $A$ Casa, estes, somando 227 exemplares dentre as revistas em circulação. ${ }^{134}$ Os projetos identificados neste grupo de revistas, destinados a diversos contextos e abordagens, seguiam o caminho de uma moderna arquitetura, sob distintos vieses.

Ao todo, dois projetos residenciais foram publicados, um em Belém-PA e outro, uma "casa grande", conforme nomeada, em fazenda no Mato Grosso, respectivamente dos arquitetos A.P. de Albuquerque e Carlos Lemos. Além destes, o Projeto do Banco de Crédito da Amazônia, de Francisco Bolonha em Belém-PA e outros dois projetos, eminentemente urbanos, são de mesma autoria, do Arquiteto Paulo Antunes Ribeiro. ${ }^{135}$ Estes últimos três enunciavam a verticalização em Belém-PA e Manaus-AM. Os de Paulo Antunes Ribeiro, foram um projeto para a sucursal do Banco do Brasil em Belém-PA, identificado em uma única publicação, e o projeto do Hotel Amazonas, a princípio edifício Ajuricaba, publicado em inúmeras revistas, inclusive variados anúncios propagandísticos. A nenhum destes projetos foram acrescidos textos explicativos nem tampouco críticos quando de sua publicação. As publicações lhes conferiram atualidade e os naturalizaram ao tempo de sua realização.

\footnotetext{
${ }^{134}$ Não constam nesta listagem os exemplares da revista "Brasília" em razão da temática restrita desta publicação.

${ }^{135}$ Formado na Escola Nacional de Belas Artes - RJ em 1926, um dos arquitetos que nos anos de 1930 "realizam obras de qualidade onde estão presentes as referências mais gerais da produção da vanguarda internacional” (MARTINS, 2002, p. 376).
} 

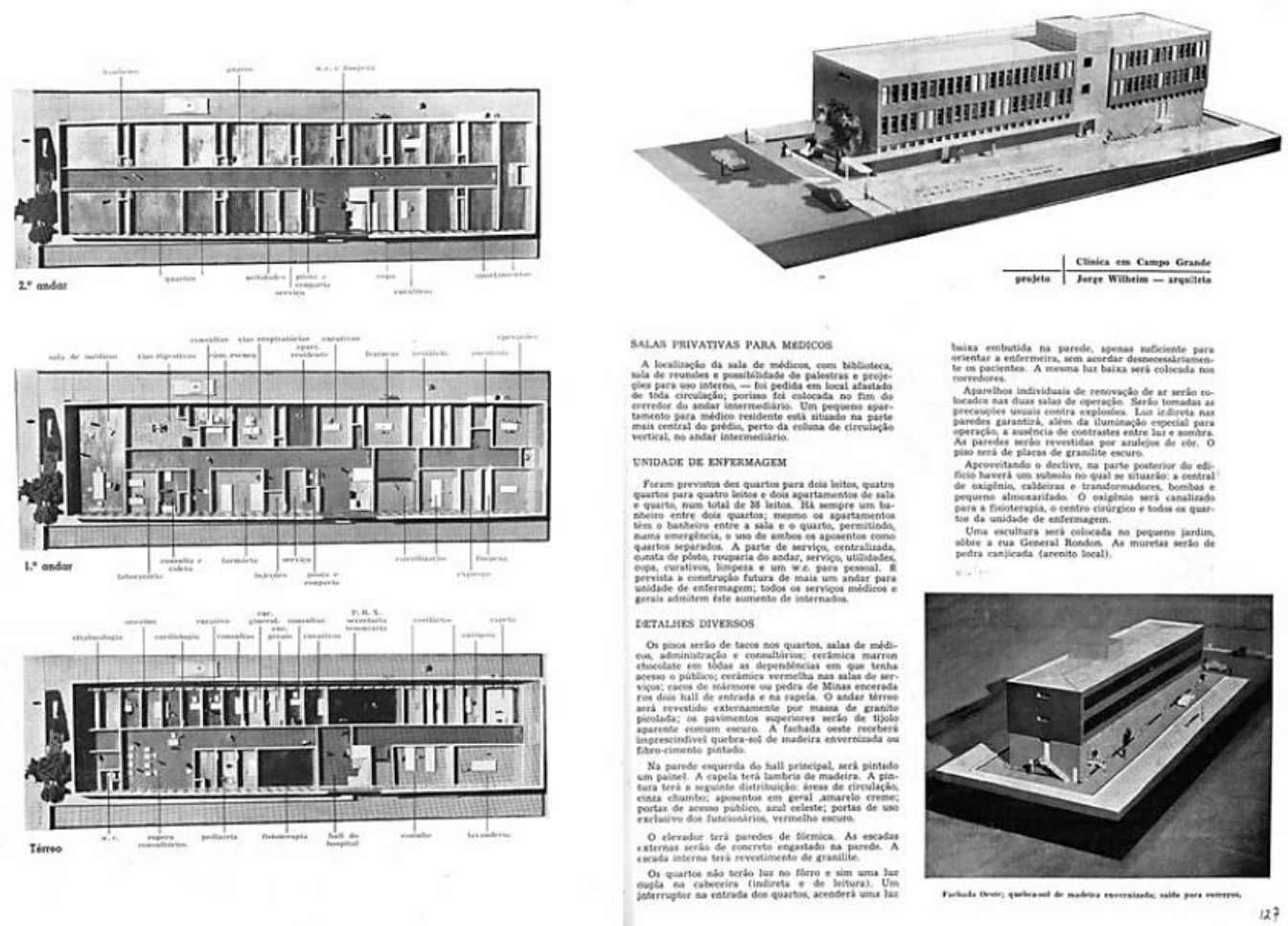

(1)

EXPOSIḈO DE ARQUITETURA (MATO CBOsso)
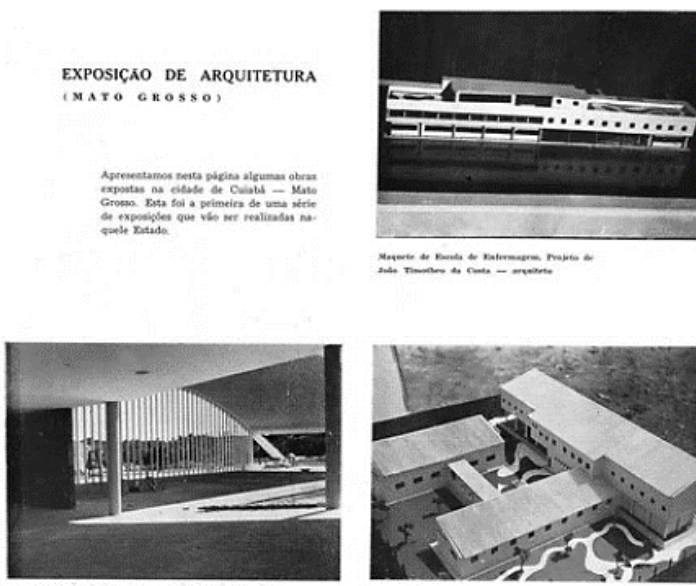

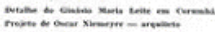

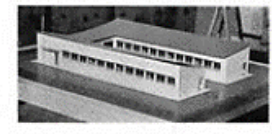

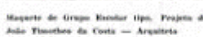

4

(2)

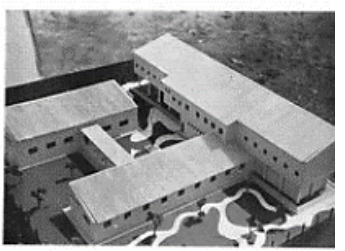

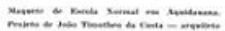

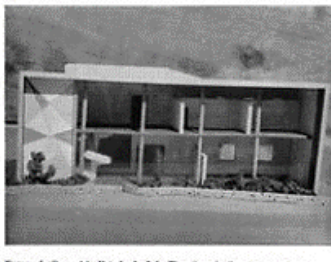

Figura 14 - Projeto de Jorge Wilheim em Campo Grande -MT (1). Fonte: ACRÓPOLE n.195, 1954, p. 125-127); (2) Exposição de projetos em Cuiabá-MT. Fonte: ACRÓPOLE n.201, 1955, p. 412.

Além destes, uma página da revista Acrópole (ACRÓPOLE N.201, junho de 1955) foi dedicada ao registro de uma exposição ocorrida em Cuiabá-MT, com maquetes e fotografia de projetos desenvolvidos para aquela cidade [figura 14]. Foram estes, maquetes da escola de enfermagem, da escola normal em Aquidauana, do fórum de Corumbá, de um 
grupo escolar tipo, todos de autoria do arquiteto João Timótheo da Costa. Junto a estes, uma fotografia do ginásio Maria Leite, em Corumbá, de autoria de Oscar Niemeyer (ACRÓPOLE N.201, junho de 1955, p. 412). Por fim, uma clínica, de autoria de Jorge Wilheim para Campo Grande (ACRÓPOLE N.195, dezembro de 1954, p. 125-127), também foi projeto publicado [figura 14]. Destes, o de Jorge Wilheim foi acompanhado de memória descritiva e apresentação, onde o arquiteto detalhou os materiais utilizados, a adequação espacial e distributiva à função restritiva da arquitetura hospitalar, a quais procurou responder com pragmatismo, como expôs. À volumetria rígida do edifício, de base retangular, foram acrescidas venezianas em madeira, nos dois vãos de abertura em fita, que junto à divisão de base e corpo, acentuada pelo contraste material das superfícies, demarcou em horizontalidade a edificação.

Elementos de uma moderna arquitetura brasileira, em sua vertente carioca, estavam presentes nos dois projetos residenciais, o de Antônio Paul de Albuquerque, ${ }^{136}$ uma residência para F. Flexa Ribeiro, inscrita em lote urbano [figura 15], e o de Carlos Lemos, ${ }^{137}$ projetado para Henrique Roberto Michelis, para um contexto rural [figura 16]. ${ }^{138} \mathrm{~A}$ primeira, traçada a partir de dois volumes geométricos simples desde a planta em L, modulada, ligeiramente aberta ao exterior pelo espaço frontal avarandado no segundo piso, continha parcela interna do lote aberta, bem como garagem em recinto fechado.

A segunda, contemporânea ao projeto da Casa Cavanelas de Oscar Niemeyer em Petrópolis, trazia algumas das questões daquele projeto, de abertura à paisagem natural, manejada desde o traçado dos jardins orgânicos, cobertura em curva leve, vedação internalizada provocando zonas de sombreamento periféricas na edificação, contraposta a painel vertical estruturador do espaço interno, pilares inclinados em uma das extremidades. Neste caso, um plano horizontal, extremamente recortado, cuja materialidade não se fez nítida, estendia o interior à amplitude do espaço externo, ilimitado, nas imagens apresentadas na revista.

\footnotetext{
${ }^{136}$ Arquiteto formado em 1948 pelo Instituto Politécnico Rensselaer, nos Estados Unidos, de intensa atuação em Belém-PA, como projetista e junto a órgãos públicos, dentre os quais a SUDAM. Foi professor entre 1948 e 1951, no Departamento de Arquitetura da Universidade de Kansas, EUA, como professor de "Achitectural Design", e do curso de Arquitetura e Urbanismo da UFPA, entre os anos de 1964 e 1991, além de representante do IAB na região (MIRANDA, CARVALHO e TUTYIA, 2015, p. 47-48).

${ }^{137}$ Arquiteto pela Faculdade de Arquitetura e Urbanismo Mackenzie - SP, formado em 1950.

${ }^{138} \mathrm{O}$ projeto é publicado no mesmo ano em que é realizado o projeto de Oscar Niemeyer para a casa Cavanelas, em Petrópolis.
} 

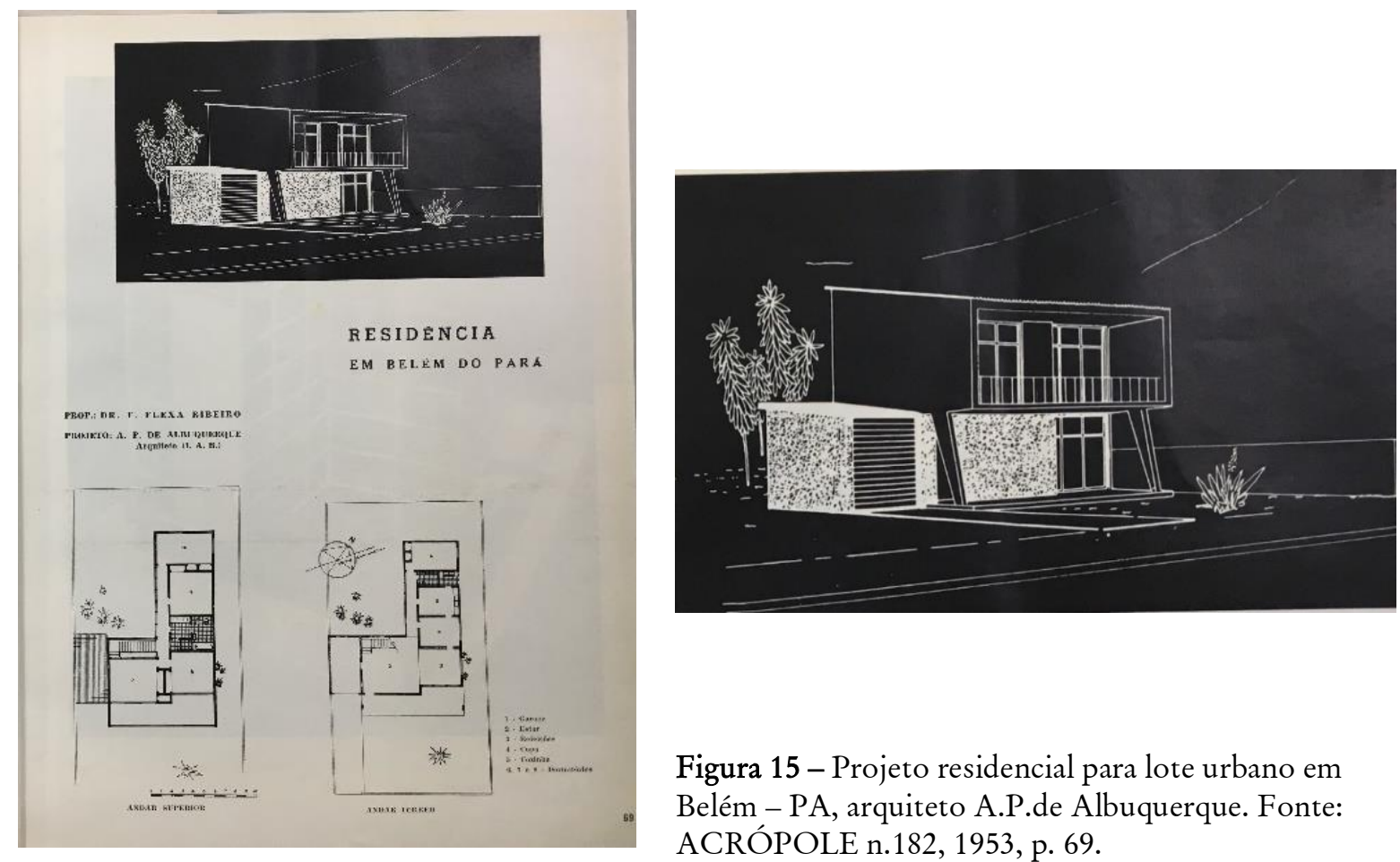

Figura 15 - Projeto residencial para lote urbano em Belém - PA, arquiteto A.P.de Albuquerque. Fonte: ACRÓPOLE n.182, 1953, p. 69.

Outros três projetos, um de autoria de Francisco Bolonha ${ }^{139}$ [figura 18] e outro de Paulo Antunes Ribeiro ${ }^{140}$ [figura 19], ambos em Belém-PA e um deste último em ManausAM [figuras 20-22;24], foram denotativos da presença de uma arquitetura verticalizada e destituída de qualquer apelo memorial. O Banco de Crédito da Amazônia, que havia sido criado em 1942 por Getúlio Vargas para instituir sua política de industrialização a partir dos esforços de guerra (SKIDMORE, 2010), serviria ao financiamento para a retomada das atividades dos seringais. Já com Eurico Gaspar Dutra, em 1950, teve por finalidade incentivar outras atividades produtivas na região, especialmente as industriais e de agricultura na Amazônia, já que desde o fim dos Acordos de Whashington, sua economia, "via-se órfã de políticas de governo federal que permitissem a reprodução local do desenvolvimento experimentado pelo Centro-Sul do país”, as quais miradas pelas elites financeiras e políticas regionais, com vistas articular a economia regional ao processo nacional de industrialização (SERÁFICO e SERÁFICO, 2005).

\footnotetext{
${ }^{139}$ Arquiteto paraense formado em 1945 pela Faculdade Nacional de Arquitetura da Universidade do Brasil (atual Universidade Federal do Rio de Janeiro).

${ }^{140}$ Arquiteto formado na Escola Nacional de Belas Artes - RJ, em 1926, com escritório baseado na Av. Rio Branco - Rio de Janeiro.
} 


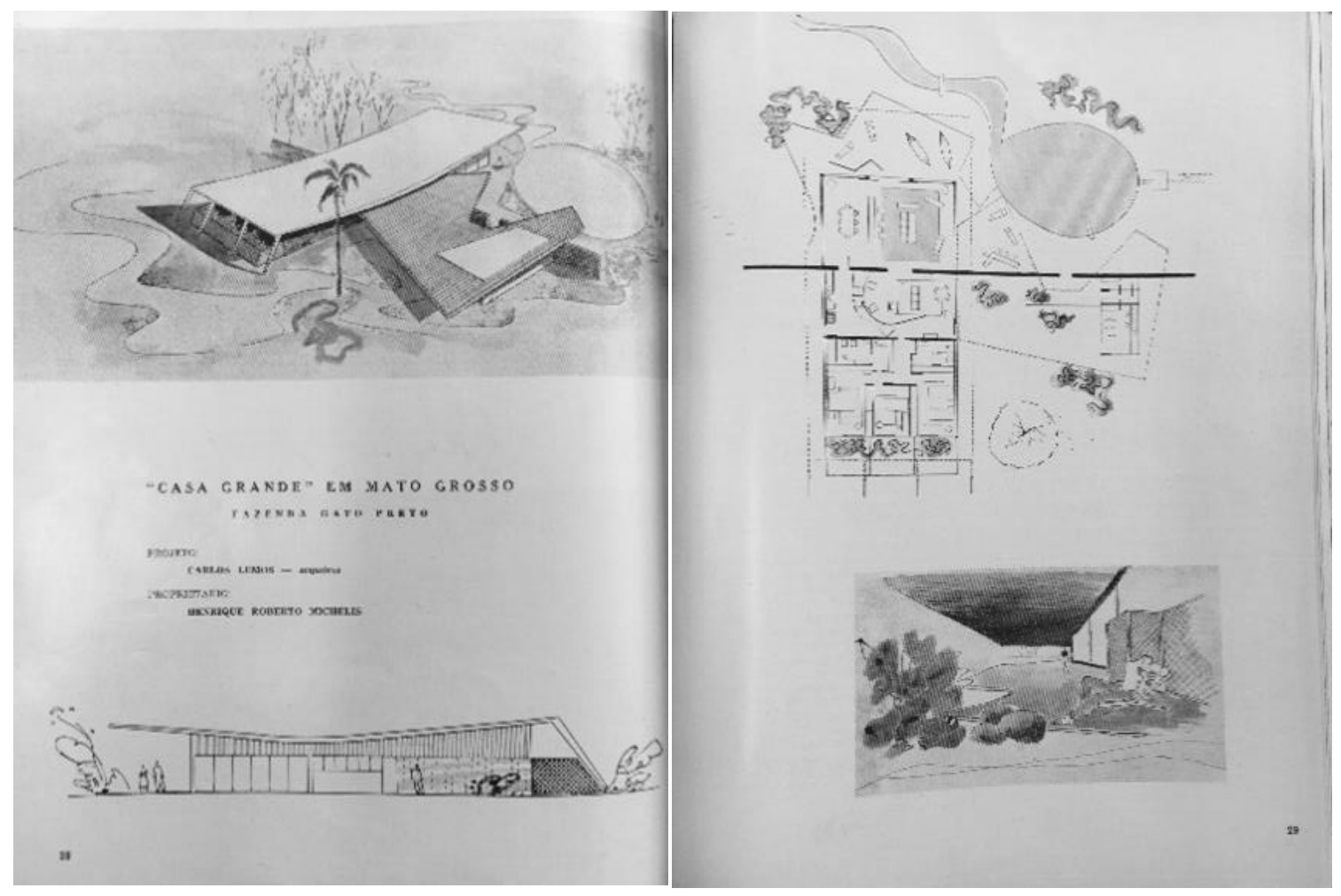

Figura 16 - Projeto de Carlos Lemos para casa de fazenda no Mato Grosso. Fonte: ACRÓPOLE n.193, 1954, ano 17, p. 28.

O projeto de Francisco Bolonha já teria sido proposto em um estágio da ação estatal sobre a Amazônia, sob as aspirações de serem efetivadas novas políticas de crédito para atividades produtivas não mais centradas unicamente na tentativa de restituição do sistema produtivo da borracha, mas visada a industrialização. A realização de Brasília (1957-1960) causou efeito substancial sobre as mentalidades e revigorou amplamente as expectativas nacionais diante do desenvolvimento do país, pelo curso da veloz atividade industrial impulsionada durante o governo de Juscelino Kubitschek, que enfatizava discursivamente o "sentimento de confiança entre os brasileiros", sobre a democracia, o nacionalismo e o desenvolvimento econômico de base industrial.

Sua construção também estava relacionada às estratégias de cooptação de vários segmentos sociais e à resolução indireta de problemas nacionais relativos à reforma agrária, a abertura de novos espaços não explorados pela agricultura, e os impactos positivos, em tese, sobre o abastecimento nacional de alimentos. Brasília foi absorvida e difundida como um símbolo, antes um projeto antevisto pela constituição de 1891, a primeira republicana, tanto caro quanto relativamente utópico para que fosse empreendido em curso apressado, 
agora, uma realização plausível, aceita pelo Congresso em 1956. Sua construção ocorreu (SKIDMORE, 2010, p. 206-211):

[...] gerando expectativa e mobilizando brasileiros de todas as classes, que viam na construção da nova capital no interior abandonado um sinal de maturidade do Brasil. Ela conferiu ao resto do programa econômico de Juscelino, cujos detalhes continuavam desconhecidos da maior parte do grande público, um símbolo de reconhecimento imediato.

A construção de Brasília da noite para o dia, a despeito de seus grandes objetivos, deu ao presidente um inédito poder de barganha diante de adversários suscetíveis aos atrativos de uma participação lucrativa no novo empreendimento. E o programa paralelo de construção de estradas significava que as possibilidades se estendiam muito além dos limites do novo Distrito Industrial.

Para a Amazônia, Brasília e o programa de construção de estradas foram o estopim para a mudança radical do território, que viria a ser aprofundado mais adiante, com a Transamazônica, e todo o planejamento territorial empreendido pelo governo militar. Neste caso, ainda sob a ótica do empreendimento de JK, como informa Bertha Becker (BECKER, 2009, p. 25):

Somente no governo de Juscelino Kubittschek, calcado na "Energia e Transporte" e em "Cinquenta anos em cinco", ações efetivas afetaram a região, através da implantação das rodovias Belém-Brasília e Brasília-Acre, duas grandes pinças contornando a fímbria da floresta. A partir daí, acentuou-se a migração que já se efetuava em direção à Amazônia, crescendo a população regional de 1 para 5 milhões entre 1950 e 1960, e de modo acelerado a partir de então.

Brasília, além de um traçado urbano, alterou sobremaneira as estruturas espaciais regionais amazônicas, a começar pela implantação da Rodovia Belém-Brasília, trecho da BR153, a Transbasiliana, de ligação de Marabá-PA a Aceguá-RS, com $3.585 \mathrm{~km}$ de extensão. O gesto da cruz, traçado primaz de Lúcio Costa, demarcou a interseção de dois eixos direcionados a oeste para Porto Velho, a norte, a Belém, e as rodovias advieram justamente dos eixos, traçados para a ocupação e modernização de espaços até então considerados selvagens e localizados no interior do território nacional, para a articulação estratégica, desde o planalto central, do restante do território nacional (TAVARES, 2013). A rodovia que ligou Belém a Brasília, num fragmento da Transbrasiliana, como ideia de um percurso que atravessaria o país, foi meio para a efetivação do projeto de integração nacional, que no início da década de 1960 (BECKER, 1977): 
[...]por injunções do processo de crescimento econômico nacional, modifica-se a sua percepção, cuja imagem passa a ser a de uma fronteira de recursos, capaz de favorecer tanto o equilíbrio geopolítico interno como o externo", e que tal "percepção" foi traduzida em ações políticas, como "a reorganização de um órgão do desenvolvimento regional - SUDAM - um instrumento de incentivos fiscais para investimentos na área, e a construção de grandes rodovias que circundam e atravessam a região; a primeira delas, ligando a nova Capital Federal, Brasília, à Capital da Amazônia, Belém, implantada em 1960, representou o primeiro passo para a integração da região, estando a exigir uma avaliação dos seus efeitos no desenvolvimento regional.

Bertha Becker apresentou em 1977, alguns impactos decorrentes da implantação da Belém-Brasília. Ela foi um marco do distanciamento que estabeleceu o plano governamental ao desenvolvimento social da região sob o paradigma da modernização do país. A rodovia participou da integração dos estados, conectando aquela “fronteira de recursos" por meio de uma "colonização em lento crescimento". O desenvolvimento disforme com forte diferenciação interna, e a rápida urbanização ao longo da rodovia foram "fator negativo para as cidades tradicionais vinculadas à circulação fluvial”, com parciais mudanças nas condições de vida da população e "positivo principalmente para os polos regionais" de desenvolvimento (BECKER, 1977).
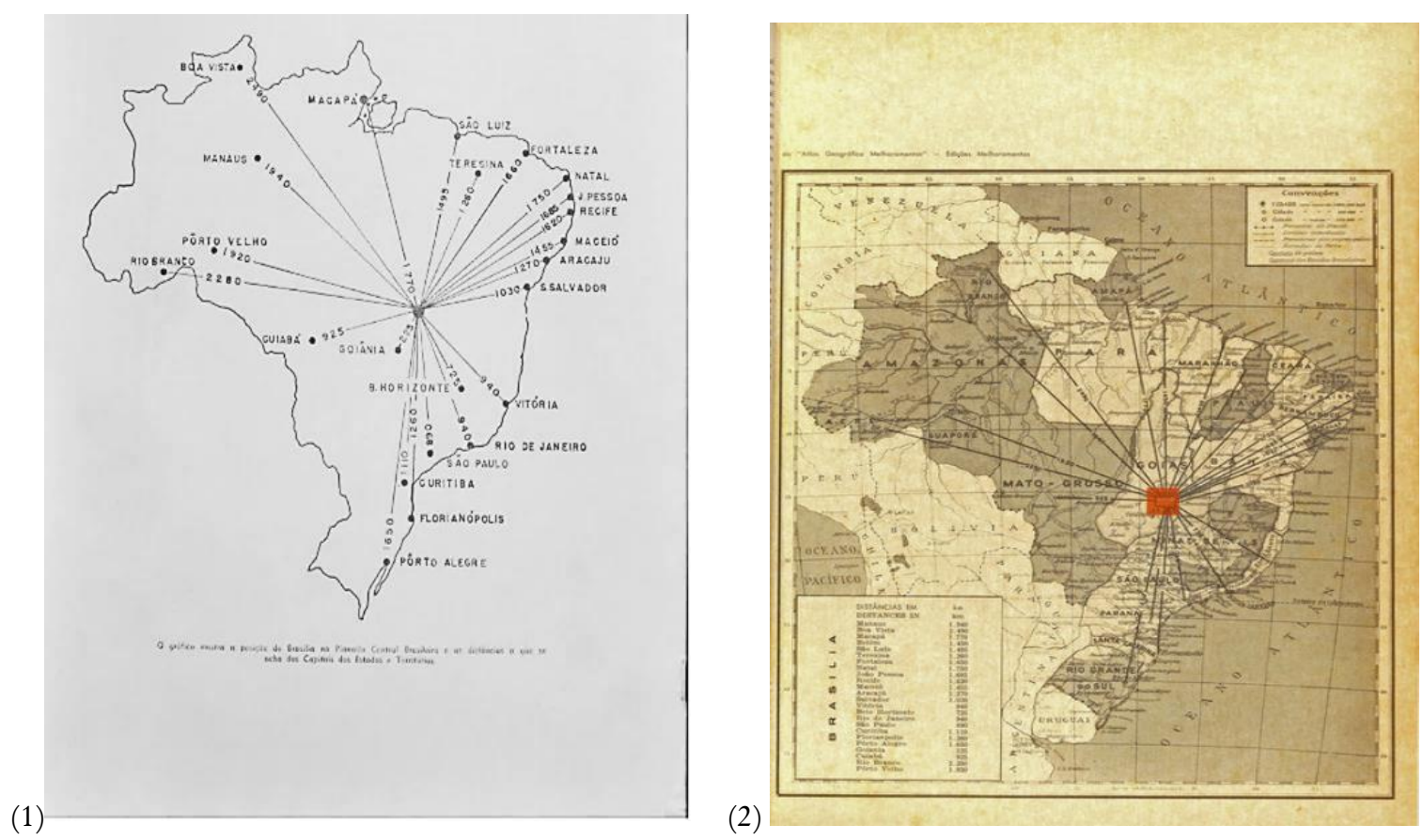

Figura 17 - Gráfico com a posição de Brasília no planalto central e as distâncias das capitais dos estados e territórios e a desconsideração do espaço do território nacional (1). Fonte: BRASÍLIA, n.2, 1957. Mapa da configuração do território e a mesma lógica das distâncias em linha reta (2).

Fonte: Revista ACRÓPOLE n.256, 1960, p. 17. 
Para a escrita da Arquitetura e Urbanismo, Brasília foi constituída como um marco significativo da disciplina, especialmente à periodização, marco explicativo do apogeu de um projeto moderno de arquitetura para o país. A construção da nova capital significou um feito de proporções internacionais. Foi a concretização do projeto moderno de cidade e arquitetura no século XX, com base no Urbanismo funcionalista. A imagem de Brasília e sua concretização serviram de impulso às discussões e práticas dadas a partir de sua realização, pautadas nas melhorias e no desenvolvimento de estratégias de transformação do espaço urbano por parte dos arquitetos, em detrimento da tônica sobre o edifício moderno que centralizaram a atenção profissional até a década de 1950 (ZEIN e BASTOS, 2010).

Mas como projeto moderno da arquitetura no Brasil, Brasília não foi um esgotamento, ainda que demarcatória de determinado segmento do pensamento da arquitetura nacional, aquele referenciado em Lúcio Costa e Oscar Niemeyer. Várias das vertentes que antes mesmo de sua realização já estavam em atividade, prosseguiram em trilhas distintas àquelas da escola carioca, ainda que para tanto não tivessem incorrido em formulações arbitrárias, nem tampouco em completa independência à cultura arquitetônica no país (ANELLI, 2008). Esta afirmativa pode acrescer à produção que passou a ser publicada desde os anos de 1960, situada na Amazônia. Não totalmente desamarrada dos referenciais da arquitetura no Brasil, mas quando observadas pela lente da história, tem uma base explicativa conformada a partir de certas dinâmicas locais e relacionadas a determinados agentes vinculados ao contexto.

Alguns artigos relacionados à Amazônia foram publicados na revista Brasília, sobre os quais deve ser feita breve menção. No de autoria de Carlos Xavier Paes Barreto, intitulado Brasília e a Amazônia, (BRASÍlLIA N.20, agosto de 1959, p. 1), o autor apresentou a partir de relato da história, uma justificativa "geográfica” para a implantação de Brasília, defendendo que “mesmo para os descrentes da operação 'Brasília”, ele deveria produzir progresso “para toda a planície Amazônica”, já que a "Transbrasiliana” espalharia a "civilização de norte a sul”. No de Euryalo Cannabrava, Brasília e a economia nacional, o autor mencionou a construção da Rodovia Belém-Brasília, no curso da obra (BRASÍLIA N.21, setembro de 1958, p. 1-3) e o artigo sem autoria, deputados paràenses opinam, a 
respeito de Brasília (BRASÍLIA N.35, novembro de 1959, p. 15), trouxe um conjunto de relatos de políticos regionais, no qual falaram das doses de “sacrifício" necessárias à coletividade para a construção da cidade, incorporando a Amazônia na discussão a respeito da construção da nova capital do país, como "plenitude arquitetônica e urbanística”, a “verdadeira civilização brasileira”.

Também favorável à construção de Brasília foi Knessee de Mello, observador da interioridade do território do país, conforme expôs no artigo porque Brasília?, publicado em 1960 (ACRÓPOLE N.256, 1960, p. 4-17). Em justificativa à construção da capital, o arquiteto construiu a defesa de uma colonização interna, ideia não inovadora, do espaço amazônico. Defendeu Brasília como forma de ocupação, ainda que tardia, do território nacional. Bem como defendeu a exploração das potencialidades até aquele momento desconhecidas do território, com vistas o desenvolvimento do país. As representações da Amazônia em justificativa à construção da capital foram as recorrentes, as imagens do vazio demográfico, da riqueza potencial à exploração pela "nação". Sua fala registrou um observador distanciado, que afirmava desconhecer a outra realidade, ainda que estivesse defendendo sua exploração. A concepção de uma Amazônia em condição periférica, se fez presente nos termos apresentados pelo arquiteto:

Desconhecemos o Brasil. E porque desconhecemos nossa terra, desconhecemos as razões de Brasília.

Nascemos e vivemos, nós brasileiros, no $3^{\circ}$ país do mundo em área territorial. Oito e meio milhões de quilômetros quadrados. Somente dois outros países têm área superior à nossa.

Mas, quando examinamos como se distribui a nossa população por esses 8 $1 / 2$ milhões de quilômetros quadrados, constatamos horrorizados que dez unidades da Federação, (Rondônia, Amazonas, Rio Branco, Acre, Pará, Mato Grosso, Goiás, Maranhão, Piauí e Amapá) que ocupam mais de 70\% da área total do território brasileiro, têm índice médio de somente um habitante por $\mathrm{Km} 2$, metade do mínimo determinado em geografia humana (dois), para que uma zona seja considerada habitada.

E é aí, exatamente, nessa imensa área desabitada que se encontra a maior reserva petrolífera do mundo, na bacia amazônica, estimada em 1.500.000 quilômetros quadrados. É nessa mesma área abandonada por nós, que se acham os campos de Mato Grosso e Goiás, considerados como a melhor região do mundo para o desenvolvimento da pecuária. E é aí, também, que estão incalculáveis riquezas minerais: o ferro, o manganês, o urânio, os cristais os diamantes, o ouro, etc. E é nessa região que se encontram os 4 milhões de $\mathrm{km}^{2}$ onde a seringueira é nativa.

Quando o Congresso Nacional, no dia 23 de agôsto de 1956, aprovou por unanimidade a Lei 2.874, não aprovou simplesmente a transferência do Govêrno do Palácio das Laranjeiras para o Palácio da Alvorada. Autorizou 
sim, a arrancada definitiva e decisiva da marcha para o Oeste. Autorizou a tomada de posse de $2 / 3$ do nosso território. Autorizou a integração da Amazônia na unidade nacional. Autorizou a transformação mágica do Brasil semi-colonial, sub-desenvolvido, litorâneo, pobre e devedor, numa potência farta e forte, independente, senhora absoluta ade seus próprios destinos.

O projeto da sede do banco projetado por Francisco Bolonha para Belém-PA, dada sua publicação na revista Habitat em 1959, pertenceu a este fluxo desenvolvimentista nacional quando a ação interventora de reordenamento do território nacional centrava esforços à realização da nova capital no período de uma "extraordinária ampliação da produção industrial” no país sob o governo de Juscelino Kubitschek (SKIDMORE, 2010). Este fluxo recaía na Amazônia pelas vias de uma colonização regional cujos efeitos mais diretos seriam sentidos nesse momento com a construção da rodovia Belém-Brasília. Complementar ao projeto, o editorial apresentado na revista, sob o título de Mentalidade de planejamento, sintetizou as ideias norteadoras da revista. O texto foi situado em página contígua ao projeto de Francisco Bolonha, alinhado às pautas urbanas e sociais que ganhavam espaço nos periódicos dos anos de 1950 no Brasil (HABITAT N.55, 1959, p. 1):

De fato, o planejamento urbano bem pouca coisa seria sem o planejamento regional, e êste implica relações mais amplas do planejamento nacional. Então, se sobram automóveis e jipes para exportar e falta feijão, culpe-se a mentalidade que não planejou, que não foi capaz de envolver $o$ desenvolvimento industrial com um planejamento adequado.

Por onde, realmente, começar?

Arquitetos e urbanistas são os que melhor podem trabalhar num sentido de propagação da mentalidade de planejamento que nos falta - embora até no próprio meio técnico, onde não deverá ignorar-se a sua necessidade, ela se torna uma ideia remota...Há muitos técnicos que não acreditam no planejamento nem admitem a mentalidade de planejamento, esta a triste verdade.

No dia em que a mentalidade de planejamento entrar em vigência, teremos, certamente, eliminado a maior parte - a quase totalidade - das causas de nossas crises, da falta de habitação à deficiência da mão de obra qualificada.

Esta já seria uma crítica das que encaminharam muitos dos artigos publicados nas revistas da década de 1960, especialmente dentre as consultadas, a Arquitetura-IAB. Neste caso, o texto que acompanhou o projeto, trouxe elementos referenciais e propositivos expressos, daquele que seria um "monumental projeto", “audacioso e inovador". Seus quinze andares envidraçados para o exterior, seria totalmente destinado às atividades cotidianas da sede bancária, as voltadas ao público no embasamento, já que nos dois 
primeiros pavimentos seria abrigada uma agência, e nos demais, as atividades internas da instituição recém criada. As fachadas em alumínio e vidro, cada um pensado a partir de tratamento específico, "ray-ban”, "termoluz” e "comum”, foi apresentadas como solução de apelo tecnológico da modernidade, para alcançar o efeito "surpreendentemente aproximado” de Mies Van Der Rhoe na Quinta Avenida novaiorquina. ${ }^{141}$
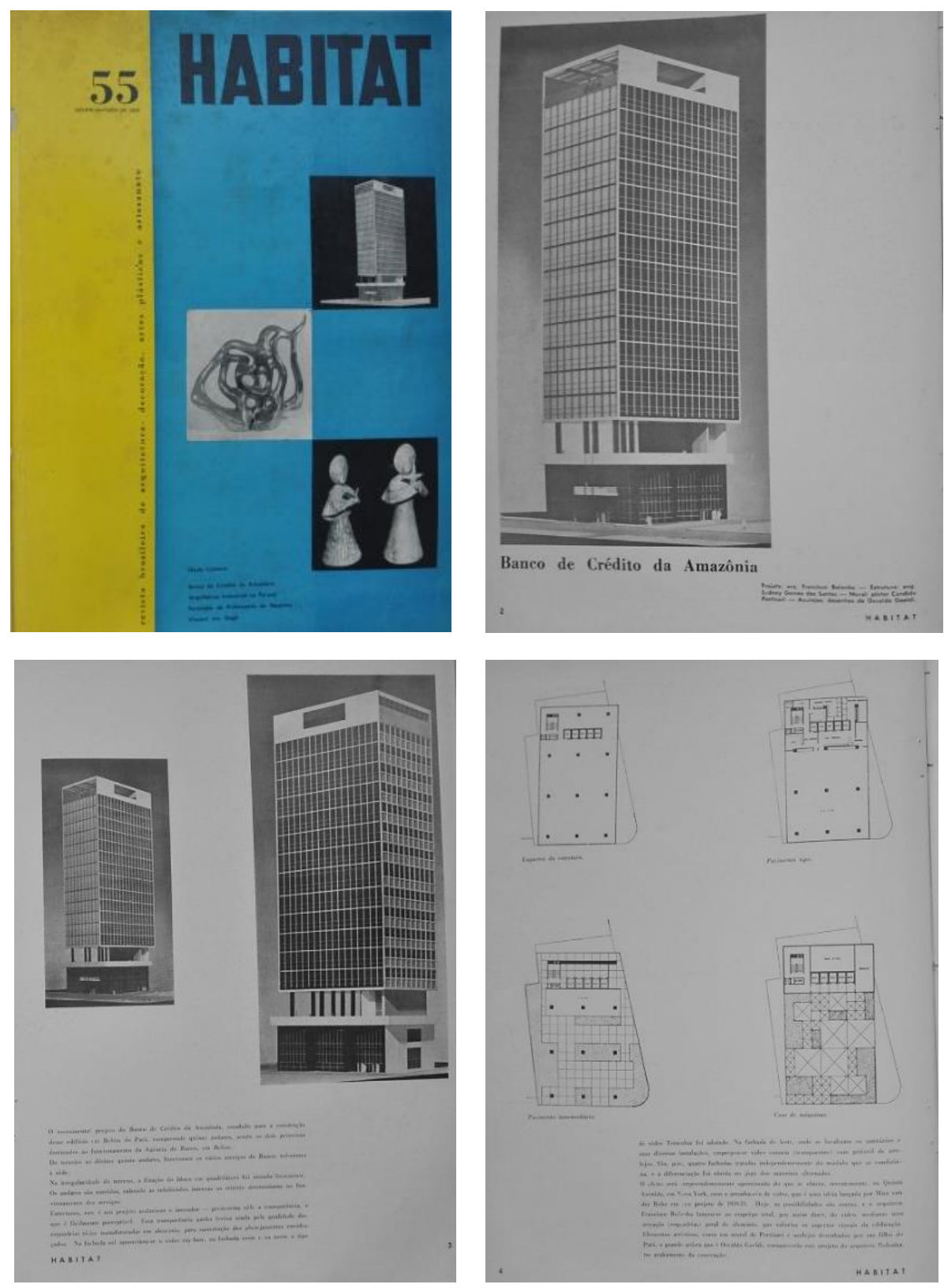

Figura 18 - Projeto do Banco de Crédito da Amazônia, de Francisco Bolonha em Belém-PA. Fonte: HABITAT n.55, 1959, p. 2-4.

\footnotetext{
${ }^{141}$ Ainda que tenha sido publicado posteriormente, o projeto de Francisco Bolonha foi inserido em inversão cronológica para que fossem agrupados os edifícios verticais e para que em sequência fosse concentrada a discussão a respeito da arquitetura "popular", em prosseguimento a este tópico. Em 1942, o governo federal criou o Banco de Crédito da Borracha, vislumbrando um mercado internacional potencial. A respeito do Banco, ele foi transformado em 1951 no Banco de Crédito da Amazônia S.A., com o intuito de estimular novas atividades produtivas, tanto agrícolas, pecuárias, quanto industriais na região (SOUZA, 2010).
} 
Os dois projetos publicados de atoria de Paulo Antunes foram o Hotel Amazonas, a princípio, edifício Ajuricaba, localizado em Manaus-AM e um edifício sucursal do Banco do Brasil, em Belém-PA. ${ }^{142}$ Do que foi possível abstrair dos desenhos publicados, em ambos os projetos, Paulo Antunes adotou o terraço jardim e a planta livre com estrutura de pilares lançados a partir de modulação regular, destinando ao volume que constituiu a planta típica da edificação, geometria simples retangular. Aos serviços, usos excepcionais e à circulação vertical foram acrescidos a tal volume, outros componentes volumétricos, tornados distintos na configuração externa de ambos os edifícios. O térreo livre, ainda que estrategicamente utilizado nos dois projetos como forma continuada do espaço urbano, foi relevado na externalidade, no caso do hotel, configurando um embasamento distinto do corpo da edificação. Nele, foram evidenciados os pilares de seção circular, atravessando três pavimentos e conferindo ao edifício de baixa estatura, certa monumentalidade, ainda mais, frente a feição do entorno de predominante ecletismo. Uma distinção expressiva entre os dois projetos, diz respeito à vedação das superfícies compreendidas como aquelas voltadas desde o interior e exterior, aos eixos de interesse de observação, fosse ao Rio Negro, no caso do hotel, fosse à Avenida 15 de agosto, em Belém. Em artigo recente, Celma Chaves de Souza Pont Vidal faz menção a esta publicação, ao discutir os efeitos do Plano de Urbanização de Belém de 1943, no "marco das intenções do governo nacional e local de planificar o crescimento da cidade”, sobre as diretrizes voltadas à implantação de construções modernas à avenida 15 de agosto, na capital, a partir de 1945, explicando que “com as novas expressões da modernidade, aliando sentido político e econômico que a incluiria definitivamente no circuito imobiliário da cidade, ao mesmo tempo em que demarcaria a expansão das construções verticalizadas modernas nas áreas centrais de Belém” (VIDAL, 2019, p. 147).

\footnotetext{
${ }^{142}$ Em artigo recente, Celma Chaves de Souza Pont Vidal faz menção a esta publicação, ao discutir os efeitos do Plano de Urbanização de Belém de 1943, no "marco das intenções do governo nacional e local de planificar o crescimento da cidade", sobre as diretrizes voltadas à implantação de construções modernas à avenida 15 de agosto, na capital, a partir de 1945, "com as novas expressões da modernidade, aliando sentido político e econômico que a incluiria definitivamente no circuito imobiliário da cidade, ao mesmo tempo em que demarcaria a expansão das construções verticalizadas modernas nas áreas centrais de Belém” (VIDAL, 2019, p. 147).
} 


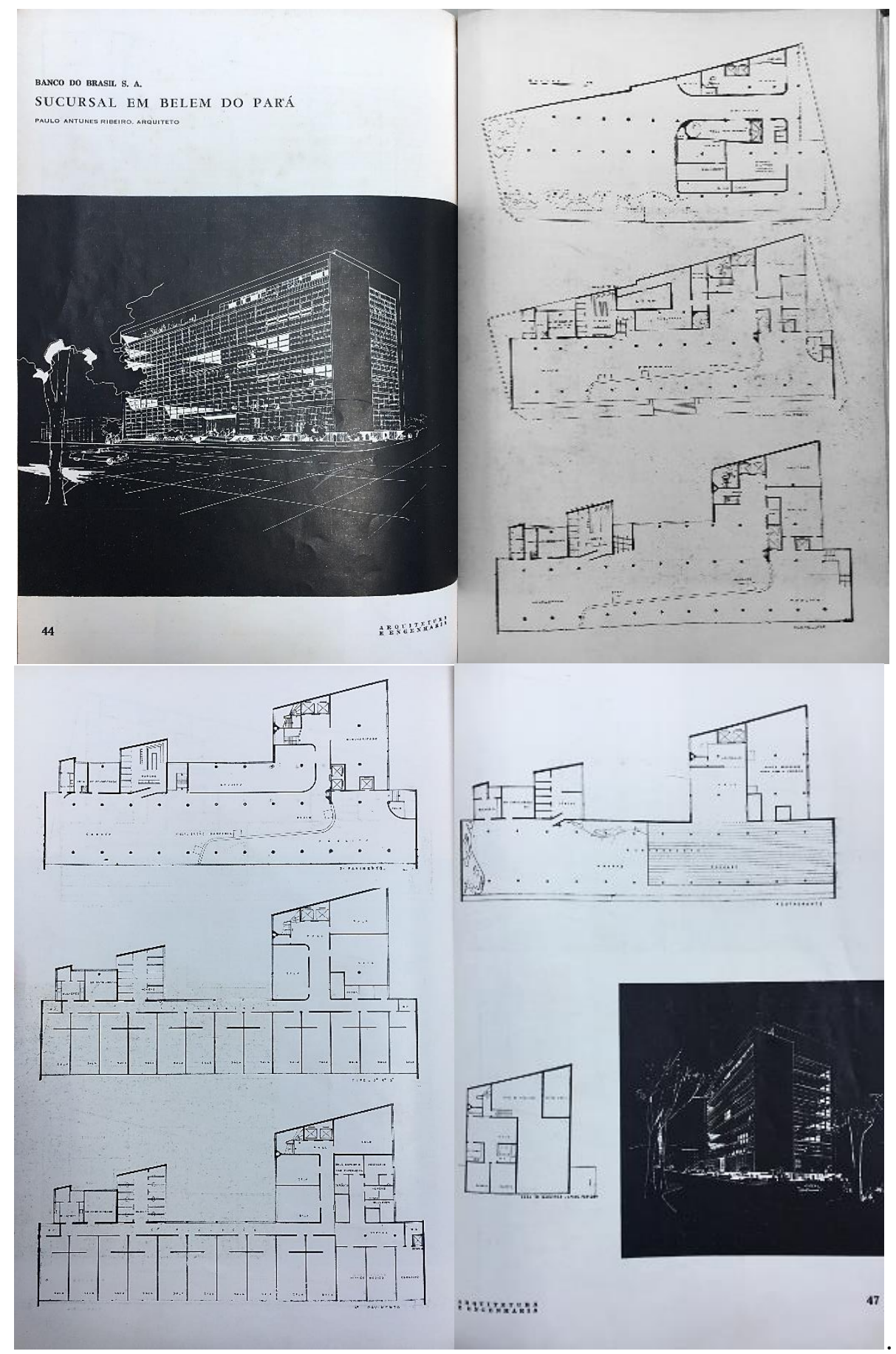

Figura 19 - Projeto de Paulo Antunes Ribeiro para o Banco do Brasil em Belém-PA. Fonte: ARQUITETURA E ENGENHARIA n.28, 1953, ano V, p. 44-47.

Neste primeiro caso, a solução projetual foi a de recuar a parede, mantendo um espaço de intervalo para o exterior, modo de dotar os apartamentos do hotel de varandas individuais. No caso do edifício cuja finalidade foi a de abrigar atividades de escritórios, Paulo Antunes utilizou a superfície envidraçada levemente recuada em relação às empenas 
laterais. Nos dois pavimentos tipo, a circulação horizontal foi internalizada, de modo a tornar tais superfícies distintas, enfatizadas no conjunto.

Diferentemente do projeto para o Banco do Brasil em Belém-PA, o Hotel Amazonas foi edifício muito presente nas fontes documentais, fosse em projeto, obra em andamento ou obra construída. O Ajuricaba, ${ }^{143}$ onde foi instalado o Hotel Amazonas projetado por Paulo Antunes Ribeiro, e os jardins, por Roberto Burle Marx, foi construído entre os anos de 1947 e 1951 em Manaus-AM pelo engenheiro Luiz J. da Costa Leite, e seguiu, como já observado, a constituição alinhada à escola carioca de arquitetura em sua vertente corbusiana. O programa da edificação respondeu, em projeto, tema e programa, aos incentivos governamentais destinados à atividade turística na região amazônica, a partir dos quais investimentos foram alocados em uma incipiente infraestrutura turística.

Esses investimentos ainda que pontuais, num período de relativa estagnação econômica da cidade, no caso do novo edifício, causaram efeitos de transformação na paisagem urbana, marcada pela arquitetura de feição contrastante ao centro antigo urbano, situado ao sul da cidade onde foi implantado. Ainda que outros exemplares em distinção ao casario também estivessem sendo construídos sincronicamente, foi o Hotel que adquiriu projeção nas revistas, além das especializadas, as populares, e nos jornais locais.
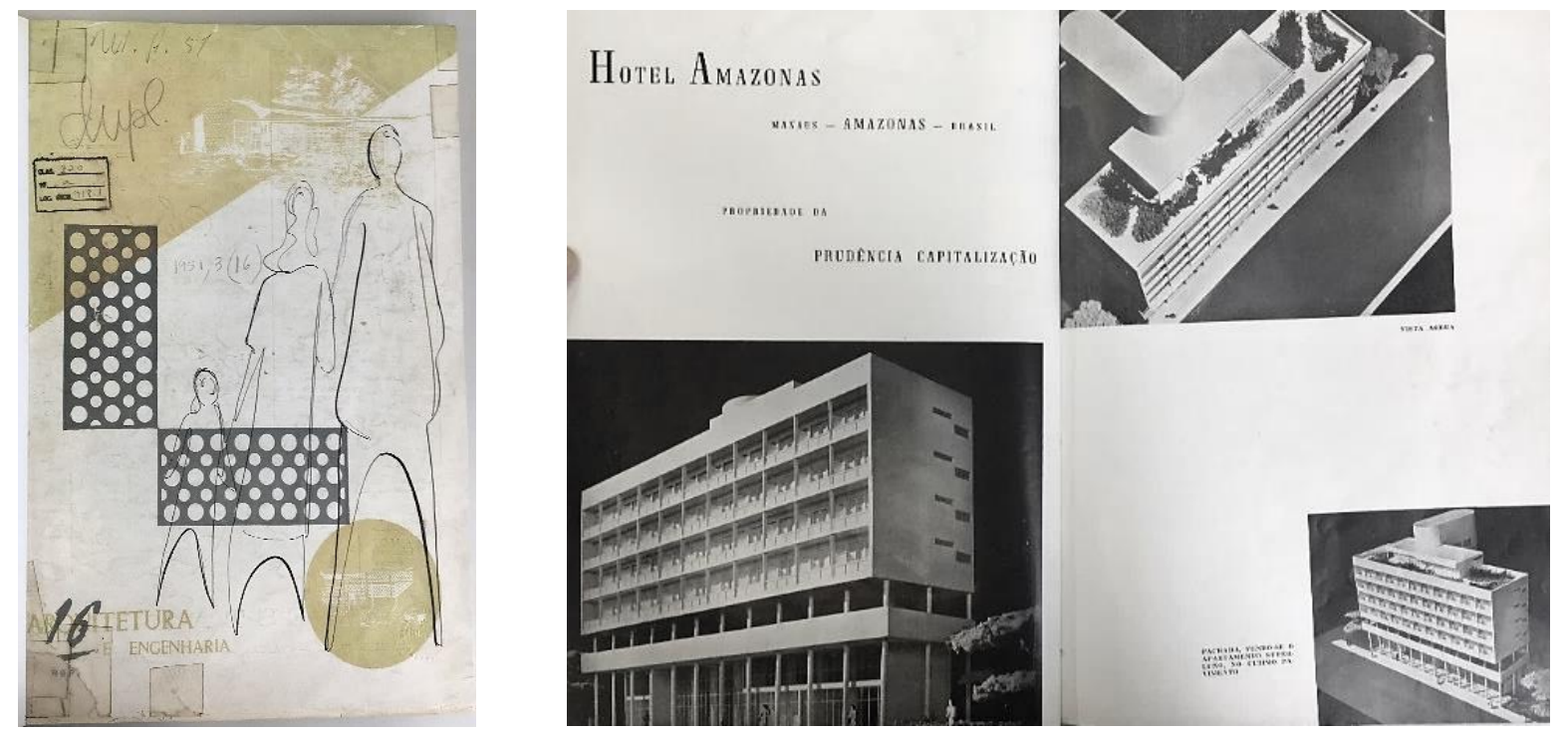

Figura 20 - Hotel Amazonas. Projeto de Paulo Antunes Ribeiro. Manaus - AM. Fonte: ARQUITETURA E ENGENHARIA, n.16, 1951.

${ }^{143}$ Os jornais traziam referência ao "Edifício Ajuricaba", também ao "Hotel Ajuricaba" que viria a ser nomeado "Hotel Amazonas". No Jornal do Comércio de 01 de setembro de 1949 constou a nota referente à presença de Paulo Antunes Ribeiro na cidade para inspecionar as obras do "Hotel Ajuricaba" (JC, 1949). 
O projeto do hotel também foi publicado em diversos números da revista $O$ Cruzeiro, em maior parte, em anúncios publicitários. Neles, o edifício foi situado em contraste à região representada em exotismo, a partir de montagens metaforicamente elaboradas. Nas imagens foram correntes a afirmação do contraste entre o luxo e o conforto do edifício e o contexto de atraso regional referenciado pelo passado de riqueza do período da borracha (O CRUZEIRO, 1950, p. 67):

$\mathrm{Na}$ capital do Amazonas, além do presente que constrói - e aqui merece destaque especialíssimo o Hotel Amazonas que a "Prudência Capitalização" está construindo, prédio que é uma esplêndida afirmação de nossa arquitetura do sol, com terraços, jardins e pilotis sustentando uma estrutura aberta à paisagem - vale recordar a sua eufórica prosperidade "fin de siécle", de que há reminiscências extremamente pitorescas, como, por exemplo, os clássicos prédios residenciais naquele estilo ao gôsto de uma arquitetura sempre "neo" e o Teatro enorme de Manaus.

O material propagandístico foi utilizado para dar publicidade ao empreendimento hoteleiro a partir de sua arquitetura, ainda que qualificada pelo seu oposto. Sua arquitetura foi afirmada pelo confronto com a natureza inóspita e exuberante, conforme inscrita nos anúncios em referência à Amazônia. A imagem da urbanidade foi posta em tensão àquele ambiente regional, rural, que estava em transformação (O CRUZEIRO, 1951):

No coração da selva amazonense existia até agora uma única maravilha que não faltava nunca nos álbuns de fotografias dos turistas que seguiam rio acima: O Teatro Amazonas.

[...] para riscar o projeto o arquiteto carioca Paulo Antunes Ribeiro que se notabilizara pelo projeto só edifício da própria Prudência na Bahia e tinha já em sua bagagem a experiência do magnífico Hotel da Bahia. E entregou a decoração e o desenho dos jardins ao paisagista Roberto Burle Marx.

O resultado foi esse magnífico palácio de 25 milhões de cruzeiros, cujas esquadrias vieram prontas da Inglaterra, cujo ar condicionado veio da América, para confôrto dos turistas que, de avião ou navio, saltarem em Manaus.

[...] jardins exteriores em que Burle Marx domesticou plantas e pássaros selvagens.

O que êsse refrigério de hotel representa para o turismo no norte do Brasil só pode saber quem já esteve em Manaus. E Manaus agradecerá o idealismo dêsse homem que, além do mais, teve o bom senso de entregar a realização do Hotel Amazonas a dois artistas do risco que souberam torná-lo uma obra de arte, conforto e bom gosto.

Quando mediado pela imprensa especializada, o projeto o foi como exemplar portador de técnica das mais atualizadas, ou ainda em agrupamentos de projetos ao tempo de sua realização, no conjunto da moderna arquitetura do país. Fora do circuito 
especializado, foi propagado como antagônico ao mitificado exotismo da Amazônia. A região, sintetizada em imagens de efeito, foi remetida a significados tipificados, como em várias outras publicações. Se esta obra esteve ausente das compilações de viés histórico, nas revistas de arquitetura e engenharia está registrada cerca de uma dezena de vezes, sem contar as não especializadas e imprensa. Em particular, na revista Habitat de n. $4^{144}$ (HABITAT, 1951), foi produzida uma mediação singular do Hotel, junto a imagens e textos, em uma paisagem, dando a ver, insinuado, o contexto de inscrição do projeto.
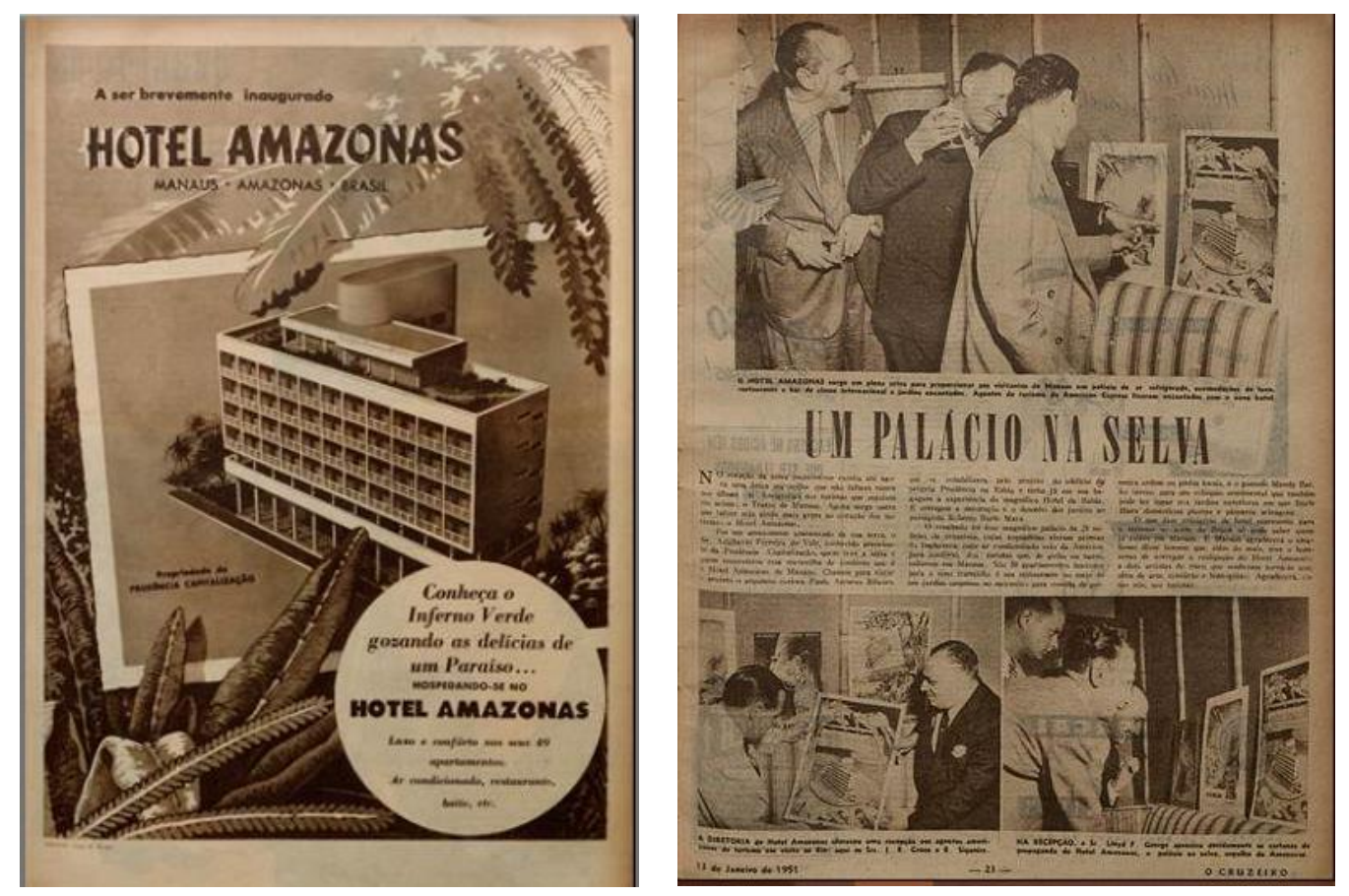

Figura 21 - Hotel Amazonas em páginas da revista O Cruzeiro - RJ. O edifício, como agente da modernização local é representado em contexto de figurações remetidas à paisagem amazônica como "Inferno Verde", referenciada em Alberto Rangel e "Selva", em Ferreira de Castro. Fonte: O CRUZEIRO ed. 51, 1950, p.67; O CRUZEIRO, ed.13, 1951, p.21.

Em geral, quando publicado, o projeto de Paulo Antunes o foi em isolado, sem outros dados de contexto, assim como na Habitat, quando abordou o Amazonas e por extensão, a Amazônia. Outras sínteses que guardam relação com a apresentada nesta Habitat [figura 22], são igualmente consideradas como de construção de uma "paisagem" da Amazônia, situada no trânsito entre o real e o ficcional. Exemplo significativo de síntese similar foi a revista ABA - Arquitetura Brasileira do Ano, em seu primeiro número, de 1967-68, quando dedicada ao Amazonas. Ainda que tenha apresentado projetos

\footnotetext{
${ }^{144} \mathrm{~A}$ revista esteve sob a direção de Lina Bo Bardi até o décimo número, depois no décimo quarto e décimo quinto, até que a arquiteta não participou mais da editoração deste periódico.
} 
desenvolvidos neste estado, uma "paisagem ficcional” foi elaborada a partir do ordenamento de imagens evocativas do real, e de sua articulação aos textos, na construção de uma síntese do lugar representado, a Amazônia.

As imagens prevalentes sobre os escritos, narraram um percurso iniciado com a presença de novos referenciais urbanos no período de riqueza propiciado pela economia da borracha no séc. XIX, revertido em intervenções modernizadoras no centro da cidade. Nas imagens, foram apresentados objetos representativos desta primeira modernização, a ponte de ferro na Av. Eduardo Ribeito, o Teatro Amazonas, o mobiliário em ferro fundido. Além deles, também em síntese, aparecem traços da geografia física, especificamente os igarapés urbanos, e também a arquitetura da habitação sem autoria identificada, tipificada e nomeada como tapiri ${ }^{145}$.

A “novidade”, como informado na legenda junto às fotografias do Hotel Amazonas, era a nova edificação. Além da autoria, foram identificados o engenheiro da obra e também seu financiador. No conjunto das sete páginas da matéria, o narrador é distanciado e se utiliza de atributos descritivos, críticos, ou ainda pautados pelas suas próprias expectativas de futuro, para a cidade e região como um todo. Alguns termos são denotativos dessa forma de observação, e de designações já naturalizadas, entre o real e o mítico, como o "atraso natural”, “teatro do sertão verde”, “deveria começar um trabalho de exploração”, “zona que nos esconde". Os escritos, embora tenham sido dispostos em separado na revista, foram condensados na sequência com que foram publicados, e destacados como a seguir (HABITAT, 1951, p. 62-68):

Quando havia as lendas sôbre a borracha, nos românces falava-se em seringueiras e eram êles conhecidos na Europa toda, persava-se em Manaus como uma nova São Francisco. E as lendas todas eram ligadas ao teatro da nova cidade, às mulheres guerreiras que talvez existiram somente na fantasia dos viajantes.

O teatro de Manaus pode ser também colocado naquela atmosfera de culturalismo que se reflete no Brasil, aliás como em todos os países do mundo, com atraso natural. O teatro do sertão verde, famoso por ter coincidido com o momento de fulgor da borracha naquela região, representa uma das obras mais elaboradas da arquitetura, do ponto de vista da reunião hábil dos mais variados estilos e de suas particularidades. $\mathrm{O}$ conubio entre elementos variados forma às vezes representações de forma estranha e híbridas.

\footnotetext{
${ }^{145}$ A habitação será tema retomado no último capítulo da tese.
} 
Desde o nosso primeiro número, nosso interêsse tem se dirigido à Amazonas, porque quanto mais pensamos naquela região no que há de ser feito, mais achamos que se deveria começar um trabalho de exploração daquela zona que nos esconde ainda quem sabe quais surprêsas: é a Amazonas por enquanto rica demais de propósitos e não de fatos, de futuro antes que de presente. Esperamos que as propostas feitas no Congresso do Unesco em 1947 tornem-se em breve realidade. ${ }^{146}$

Estas cidades características do Brasil, e especialmente aquélas construídas no Norte em épocas a nós mais próximas, como Manaus ligada a acontecimentos tão extraordinários da nossa historia, deveriam ser consideradas num plano de conservação da arquitetura tradicional. A iniciativa particular deve pensar no direito da história, que é o direito do homem moderno. A história e o que nós substancia, e nós fazemos sua síntese. O respeito para o antigo deve ser para nós um fato concreto, uma aspiração moral.

O novo Hotel Amazonas, construído graças à iniciativa tenaz e ampla do sr. Adalberto Ferreira do Valle. Iniciativas como esta levam de novo o Amazonas aos esplendores dos tempos em que as ruas eram pavimentadas com o precioso leite da seringueira.

Além das imagens das águas na cena urbana capturada nas fotografias, contornadas nas bordas junto à terra firme pelas casas de madeira, cabe destacar a imagem do tapiri. A “casa de sapé na baixada do Amazonas” foi a presença de uma arquitetura sem autoria e sem lugar, um exemplar de um dos temas caros à Lina Bo Bardi, a cultura popular, na Amazônia. Seu interesse sobre este universo, bem como seu trânsito entre a arte, a arquitetura, o design foram resultado de um "aprofundamento" da "radicalização política" vivenciada no ambiente paulista após os anos de 1950, como afirma Renato Anelli. Isto porque a “retomada dos compromissos sociais iniciais das vanguardas modernas” à época, pautavam a posição política contundente de Vilanova Artigas, no sentido de pensar arquitetura a partir de suas premissas sociais, numa São Paulo sob efeitos perversos da industrialização. Nesse ambiente reativo, fosse à arquitetura brasileira sob os holofotes da crítica, fosse diante de busca afirmativa por outra perspectiva de modernidade, Lina Bo Bardi fez seu trânsito (ANELLI, 2008).

\footnotetext{
${ }^{146} \mathrm{O}$ escrito se refere à criação do Instituto Hileia Amazônica, no contexto do pós-guerra, proposta como uma instituição internacional mediada pela recém-criada UNESCO, que seria voltada à produção de conhecimento científico sobre a Amazônia, para sua modernização. A ideia foi controversa, em razão das possíveis implicações sobre a soberania nacional, diante da abertura de informações importantes a respeito das reservas naturais, especialmente as petrolíferas. Conforme Maria Celina D’Araújo, "houve aqueles que defenderam a importância da cooperação internacional para a região, e, de outro, os que viram no projeto uma forma de controle do imperialismo econômico, não apenas sobre a Amazônia, mas também sobre o país" (D'ARAÚJO, 1992).
} 


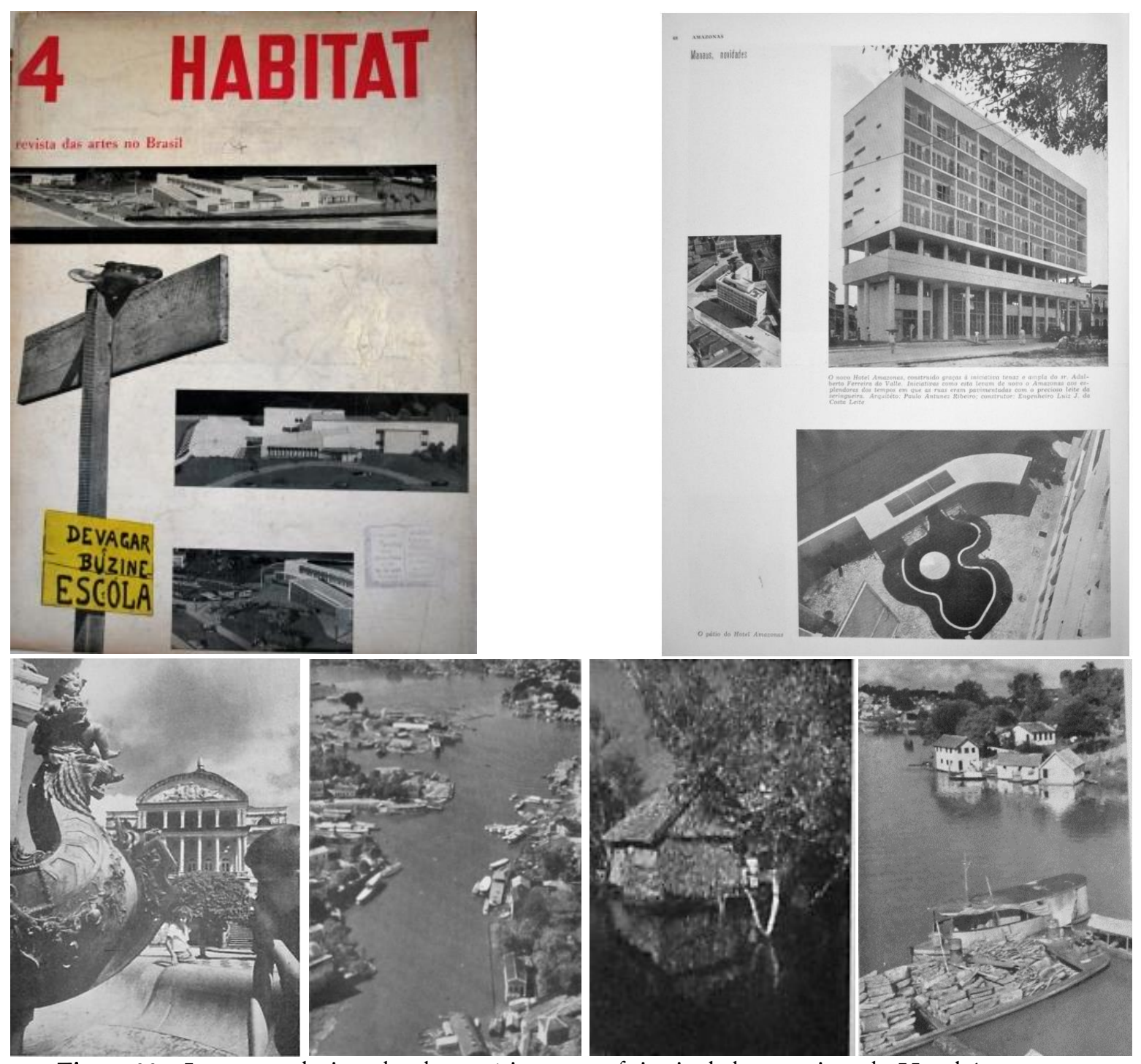

Figura 22 - Imagens selecionadas de matéria em que foi veiculado o projeto do Hotel Amazonas. Fonte: HABITAT, n.4, 1951.

O parco número de projetos publicados em detrimento da quantidade de matérias nas quais foram feitas abordagens sobre a Amazônia na década de 1950, evidenciou o foco das revistas, especialmente Habitat e Módulo. As matérias, dirigidas menos aos feitos dos arquitetos, quando em atenção à Amazônia, registraram um conjunto específico de construções palafíticas, flutuantes, além de artefatos indígenas, modos de vida tradicionais, imagens de ambientes naturais. Deram a ver fragmentos interpretados da paisagem, recortados e recompostos como a Amazônia. Em cada uma das revistas, a arquitetura sob a mesma designação do "popular", foi lida de modo particular e em complementaridade. As duas perspectivas, fosse em associações à valoração do conhecimento do homem comum e dos modos de vida, dos saberes ancestrais, como no caso da Habitat, fosse à exiguidade e à carência, suscitadas pelas moradias pobres às margens urbanas, eram sintomáticas de um 
juízo partilhado, nos anos de 1950, entre segmentos de arquitetos e críticos, da necessidade de iluminação de novos temas e leituras no campo. ${ }^{147}$

Desviados da órbita da arquitetura moderna, especialmente a já consagrada dentro e fora do país, os enfoques apresentados nas revistas aos temas sintonizados às dinâmicas urbanas, foram gradativamente acentuados. Eles acompanhavam uma crítica internacional ${ }^{148}$ que "acendeu um debate polarizado entre a admiração pela originalidade da arquitetura brasileira e a crítica feroz a seu suposto abandono das premissas sociais da ortodoxia moderna” (MARTINS, 2002, p. 374). Não unânime, nem uniforme (ZEIN e BASTOS, 2010) a arquitetura que circulava nas revistas como a Acrópole, que demonstrava os feitos mais significativos da modernização nacional pela arquitetura no ambiente desenvolvimentista nacional, ${ }^{149}$ era na maioria de exemplares situados nos centros mais industrializados do país, como São Paulo e Rio de Janeiro. A Habitat seguia, noutro sentido, uma linha editorial pautada em outros significados atribuídos à modernidade, especialmente na perspectiva de Lina Bo Bardi.

A revista Habitat (1951-1865) fez parte de uma tríade que compôs com as atividades do Museu de Arte Moderna de São Paulo, sob a coordenação de Pietro Maria Bardi e o Instituto de Arte Contemporânea, e a escola de Design fundada no mesmo ano da revista, em 1951. A atividade formativa de novos designers, em adequação à industrialização paulista, foi pensada por ambos, Lina Bo Bardi e Pietro Maria Bardi, junto à formação de

\footnotetext{
${ }^{147}$ Levando em conta que no quadro da Arquitetura internacional este foi um período de dissolução dos Congressos Internacionais de Arquitetura Moderna e abalo das aspirações de desenvolvimento social e material pelas vias de uma Arquitetura Moderna, dentre tantos fatores, pelos efeitos da guerra sobre a Europa. ${ }^{148}$ Carlos Martins trata do momento específico com que se deu essa "ruptura na unanimidade" da arquitetura brasileira frente a crítica internacional, quando críticos atraídos pelas primeiras exposições internacionais de arquitetura no Brasil, depararam, desde a experiência, com a concretude das cidades brasileiras, e quando no Brasil, um conjunto da produção da arquitetura, "cujas características essenciais deixavam de ser atributo exclusivo de individualidades de exceção, para se plasmar numa produção extensiva de alta qualidade média", sendo deslocada do campo estritamente erudito, para influenciar o gosto social (MARTINS, 2002, p. 374).

${ }^{149} \mathrm{Na}$ década de 1950, uma política nacional desenvolvimentista ia sendo trilhada nas bases do poder político de Getúlio Vargas, que tinha "percebido, corretamente, que o nacionalismo, em especial em questões econômicas, tinha grande apelo para vastos setores da opinião pública”, políticos, classe média, ainda que receosa, populares, de modo que o "nacionalismo econômico, portanto, poderia ser muito útil como meio de construir o consenso da opinião pública", mesmo que viesse a acentuar a já profunda "divisão política do país". Desde 1953, em meio a instabilidades internas e pressões de grupos econômicos e políticos de peso nos Estados Unidos, contrários à plena industrialização do Brasil, assim como segmentos nacionais, políticos e militares, em descontentamento às medidas de cunho popular empreendidas por Vargas, especialmente do aumento do salário mínimo, avançava a instabilidade econômica e política no país, bem como a vulnerabilidade de Vargas no poder, e a da efetivação de um mercado interno autônomo e sólido (SKIDMORE, 2010, p. 144173).
} 
público consumidor que seria atingido pela cultura de vanguarda que estavam a difundir, por meio da própria revista e do museu ${ }^{150}$. Sua posição crítica se estendia à arquitetura moderna referenciada em Oscar Niemeyer e Lúcio Costa, uma “invenção estatal da nacionalidade como uma ferramenta radical para consolidar sua agenda política no país e no exterior que acabaria levando à construção do projeto de Niemeyer para a primeira cidade modernista do continente, Brasília”, pela aceitação de sua condição de país colonizado, como fala Jane Hall ${ }^{151}$ (HALL, 2019). O “sertão", dado a ver aos paulistas como os confins do Brasil, foi significado na revista, assim como temas e objetos tornados modernos pela nova perspectiva que apresentou Lina Bo Bardi. O primitivismo foi compreendido como o enraizamento de uma cultura, em conhecimentos e formas materiais. O exotismo era uma categoria formulada pela incompreensão de determinado fenômeno aos olhos do estrangeiro.

Ainda que propositada a empreender um projeto ampliado, fosse pedagógico, mercadológico, cultural, sob diversas facetas, Lina Bo Bardi estava, como num dado momento fizera Mário de Andrade ${ }^{152}$ construindo sua própria compreensão sobre o Brasil, a parte ausente de suas experiências. ${ }^{153}$ Ainda que sob distintas motivações, foi movida à descoberta de paisagens e modos de vida deslocados dos seus próprios referenciais culturais.

\footnotetext{
150 Jane Hall definiu a atuação de Lina Bo Bardi como a do intelectual voltado a "transformar as mentalidades", como forma política de posicionamento crítico, em contrariedade às hegemonias, o que fez, ao enaltecer e dar total visibilidade à cultura compreendida como forma manifesta, desde as suas bases populares, compreendida também, como espaço possível de ação destas mesmas, pela arte e cultura renovadas (HALL, 2019).

${ }^{151}$ Neste artigo, embora recente, são confundidas designações como "sertão", "norte", "nordeste", "remotas regiões", "casa do seringueiro" como espaço homogêneo ao qual Lina Bo Bardi teria dirigido sua atenção.

${ }^{152}$ Telê A. Lopez e Tatiana L. Figueiredo, em artigo publicado na reedição da obra "O turista aprendiz", resgataram de documentação a respeito das viagens de Mário de Andrade à Amazônia. Na captura dos "longínquos brasis", ele compôs anotações, fotografias e narrativas. Foi a partir do trabalho da reescrita, do apelo à memória e à invenção, que Andrade produziu entre 1927 e 1945, em múltiplas versões, a revisão dos atributos de significado que cedeu às viagens, construindo modernamente, um amálgama composto pela vivência e de imaginação, "no complexo jogo das versões ao longo do tempo", onde "a obra domina o scriptor como um "sistema em formação que vai ganhando suas próprias leis", e no qual "o diário da viagem à Amazônia", é composto por "narrativas de viagem e crônicas, na pena de um modernista; por sua estrutura fragmentária, tornam-se uma obra aberta. Fundem-se aos diários do fotógrafo [...] e das legendas subsequentes, experiência de alta modernidade, no decorrer dos roteiros trilhados em 1927" (ANDRADE, 2015 , p. 23-33).

${ }^{153}$ Não foram identificadas nas revistas menções ao fato de que a própria Lina Bo Bardi empreendeu as viagens à Amazônia ou se construiu a partir de outros olhares sua própria interpretação daquele espaço. Este é um ponto a ser desenvolvido em futura pesquisa, foi mantido por ora, em aberto. A respeito das reportagens sobre os Karajá, Paulo Tavares se refere a Mario Baldi, fotojornalista austríaco como o autor dos artigos publicados na Habitat a partir da segunda metade da década de 1950. A partir de sua localização na história da confecção do escritor, desenvolve uma outra narrativa, elucidativa sobre o interior dos processos de colonização empreendidos desde os anos de 1930 em territórios indígenas. (TAVARES, 2013).
} 
Mário de Andrade havia feito de suas percepções e experiências de viagem, conteúdo para formulações artísticas de vanguarda, pela vontade de modernizar a cultura nacional. Com a conjugação do que lhe fosse contemporâneo, a uma determinada ideia de tradição, o intelectual identificava paisagens e práticas culturais na Amazônia, sob a ideia de uma natureza primordial. ${ }^{154}$

Interessado em iluminar as histórias das populações tradicionais e formas de controle sobre o território amazônico empreendido pelo Estado, Paulo Tavares se referiu às revistas, mencionando Habitat e Módulo, como um meio modernista pedagógico e de comunicação. O Estado Nacional, utilizou referências manejadas do primitivo e presentes no imaginário, como forma de sua validação e de suas práticas, bem como pelos projetos que referenciais ao campo da Arquitetura e Urbanismo, produziram novos territórios colonizados na Amazônia, uma fronteira de expansão e exploração. ${ }^{155}$ Componentes da cultura nativa, especialmente a indígena, foram objeto de apropriação por parte das elites culturais e reelaboradas para os diversos “projetos estéticos” e finalidades, mas se utilizando do mesmo ferramental de apoio aos registros capturados a partir de uma "sensibilidade vernacular modernista”, que teria contribuído para construir o discurso de validação das práticas estatais sobre o espaço amazônico (TAVARES, 2013):

A "descoberta do território" foi mobilizada por projetos estéticos que ocupavam diferentes posições no espectro ideológico, servindo tanto a perspectivas críticas em direção a estruturas políticas e culturais herdados do período colonial quanto para posições privilegiadas que simultaneamente os redefiniram e reforçaram.

$[\ldots]$

Enquanto a modernização era diretamente identificada com a ocupação do interior, a própria imagem da fronteira adquiriu um significado simbólico próprio. Humanitária na intenção, mas governamental de fato, a política de pacificação e confinamento voltadas para comunidades indígenas permitiram a domesticação de suas imagens, inscrevendo o primitivo como

\footnotetext{
${ }^{154}$ A viagem à Amazônia foi também ação inacabada do viajante criador, pela incompletude da versão final da narrativa na qual trabalhou até o fim da vida. No recurso ficcional, foi acomodada a inventividade, neste caso, para a vazão do desnorteamento e da emoção provocados pela paisagem inédita, desde o confronto inevitável com suas expectativas prévias. No registro da partida de São Paulo, deixou transparecer uma impressão sobre a Amazônia, quando expressou a "tolice" em ter comprado uma bengala de cana-da-índia para a viagem, parecia "ter sido algum receio vago de índio...". Ciente de que não se tratava de "aventura nem perigo", constatou que para além de sua razão, detinha uma "consciência poética", nas quais "reminiscências" o levavam "mais que a verdade, tribos selvagens, jacarés e formigões", acrescendo que sua "alminha santa imaginou: canhão, revólver, bengala, canivete." Chegou mesmo a ouvir um "Traga um jacaré", denotando não ser o único com aquela imaginação (ANDRADE, 2015, p. 50).

${ }^{155}$ Paulo Tavares exemplifica a análise que desenvolve incluindo os projetos de Oswaldo Bratke para as Vilas Serra do Navio e Vila Amazonas em sua leitura. Tais projetos serão retomados neste e no quarto capítulos.
} 
parte do imaginário moderno nacional, enquanto isolando-os de qualquer forma de ação política.

O ocultamento de populações tradicionais da Amazônia, ou ainda, o manejo das imagens do primitivo para a construção simbólica das fronteiras regionais, serviram ao encobrimento dos efeitos da atuação estatal sobre espaços impactados mais diretamente no território. Noutro sentido, conformaram a Amazônia como paisagem de ocultamento que, no entanto, foi ressignificada gradativamente, a cada nova temporalidade de seu curso histórico, quando consideradas as revistas. As imagens associadas à mitificação ou à atenuação dos processos agressivos de transformação do espaço amazônico, foram tensionadas em novas leituras geográficas, pela manifestação dos grupos sociais afetados mais profundamente pela intervenção estatal, em novas formulações, produzidas por atividades de pesquisa e de reconhecimento do território especialmente a partir da década de 1970. O caráter simbólico disseminado sobre a região foi atenuado pela gradativa aproximação ao território e cada vez mais, pelo aprofundamento da diferenciação entre o campo e a cidade. A retração do nacional em detrimento do regional foi também o produto da presença de arquitetos na Amazônia, mesmo que em sua atuação tenham absorvido, por diálogo, as imagens simbólicas da Amazônia, como paisagem, e suas representações de ocultamento.

As revistas, quando tematizaram a Amazônia, além de reportarem sobre a atividade profissional, influíram sobre a mesma, na medida em que veicularam significados ancorados em concepções sobre o território, constitutivos de uma narrativa de síntese que baseou uma série de projetos e foi reproduzida nesses meios. A inventariação dos textos que tematizaram a Amazônia nas revistas serve à compreensão no presente, de como ela foi significada ao tempo das publicações, junto à veiculação de obras e dos projetos. O resgate de textos e obras capturados das revistas, em articulação, é destinado à reconstituição do percurso histórico da Amazônia no campo da Arquitetura e Urbanismo a partir das ideias em circulação que serviram de base, inclusive, à atividade projetual. Um acervo referencial de projetos e imagens que circularam no conjunto das publicações analisadas, foi também repertório à novas ideações projetuais, e por extensão, a reinterpretações da Amazônia paisagem. Diante de um conjunto de possibilidades apresentadas aos projetistas, ela constituiu seus discursos e subjetivamente, suas criações. 
Deste modo, as revistas reproduziram um imaginário sobre a Amazônia, que foi apropriado à construção discursiva da ação interventora do Estado, como meio de ocultamento da colonização do território amazônico. Sem relativizar os processos, posto que foram tornadas concretudes históricas inegáveis, como a devastação ambiental e a dizimação de populações tradicionais, cabe referenciar os textos em distintas temporalidades. Eles foram redirecionados, no recorte deste tópico, da mitificação do primitivo à qualificação do saber popular. E neste caso, esse deslocamento também produziu efeitos na prática projetual, como quando da influência em processos de produção alternativos à moradia de pobres.

Na revista Habitat, em seu primeiro número, em 1951, uma série de pequenos artigos foram apresentados com imagens que compuseram uma Amazônia paisagem de habitações de madeira revestidas de palha, cenários naturais e águas doces, representativas de um modo de vida associado ao ambiente designado como “do norte do país”. Com maior suporte da etnografia e da apropriação moderna dos saberes, aqueles relacionados ao espaço amazônico e em modos de vida regionais, o morar amazônico foi apresentado no artigo “Amazônas: o povo arquiteto" no qual foi expresso (HABITAT N.1, 1951, p. 68):

Quando se fala em sociedade, pensa-se sempre, sem saber porque, num cocktail ou numa daquelas festas onde as mulheres vão com as costas despidas e os homens com os sapados laqueados.

Mas a sociedade é outra coisa: é o conjunto dos cidadãos, e compreende todas as classes, sem distinções.

[...] O conceito verdadeiro do Brasil trabalhador, país de cimento, espaços e riquezas, sua atividade generosa - esse conceito dizia, deveria ser baseado inicialmente nas camadas sociais do interior, ao longo de rios fabulosos, nos cafezais, nas fazendas de algodão, e nos seringais, nas pontes e oficinas. $[\cdots]$

Reproduzimos aqui o habitat de nossa gente no Amazônas, com sua casa de uma arquitetura extremamente funcional e muito estética, agradável, com cenas da vida cotidiana, que se manifestam através das alegrias do homem simples.

A representação de modos de vida típicos estão apresentados ainda nas imagens selecionadas da primeira revista Habitat [figura 23] onde foi focalizada a temática da moradia, ${ }^{156}$ ainda que nesta mesma publicação outras seguintes, tenham sido veiculadas

\footnotetext{
${ }^{156}$ Um único projeto de residência foi identificado no conjunto da revista consultado, de autoria do engenheiro Leônidas Albuquerque, destinado a si próprio, publicado em matéria intitulada uma "Arquitetura do litoral". Nesta mesma revista está publicado o artigo do engenheiro A. P. de Albuquerque, sobre o arquiteto Antonio José Landi e sua atuação em Belém-PA (HABITAT N.12, 1953).
} 
imagens da cultura material indígena, de homens e mulheres, especialmente de modos de vida como que referenciados nos seringais. Além desta matéria, uma série de outras foram publicadas ao menos até 1956, com prevalência da temática da cultura material indígena.

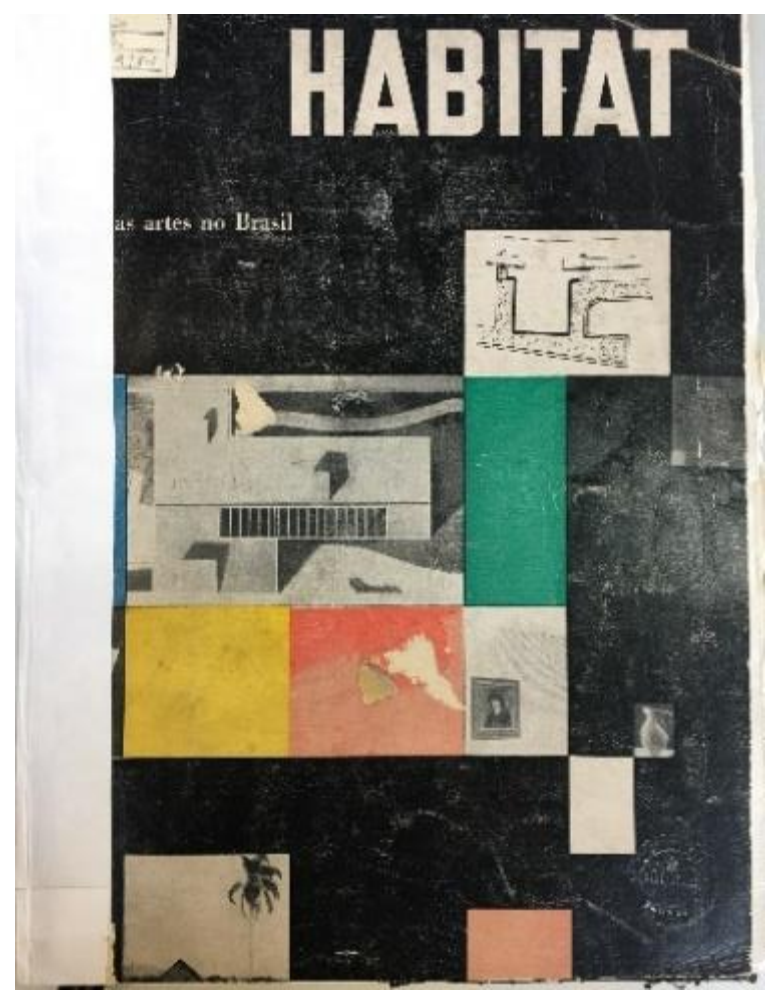

(01)

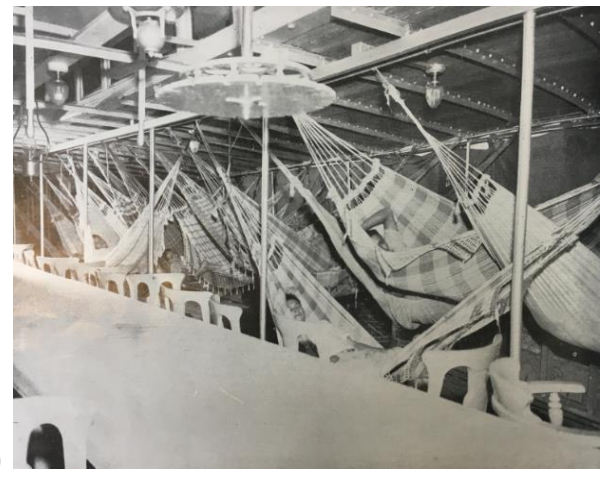

(02)

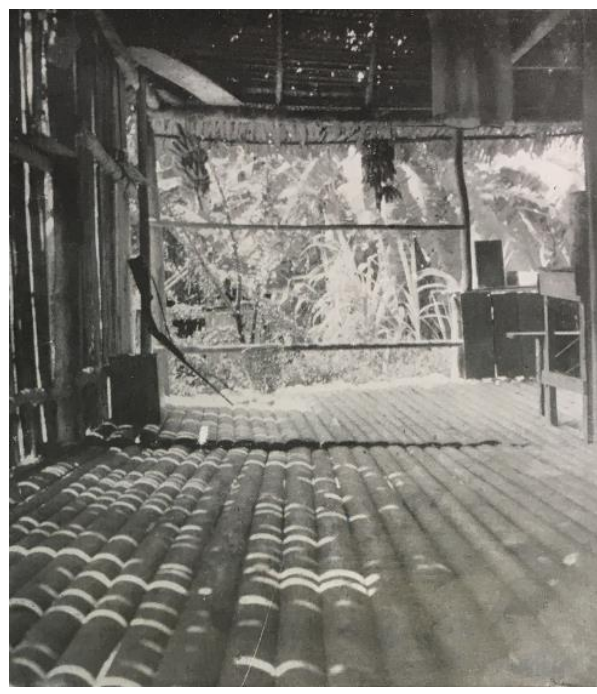

(03)
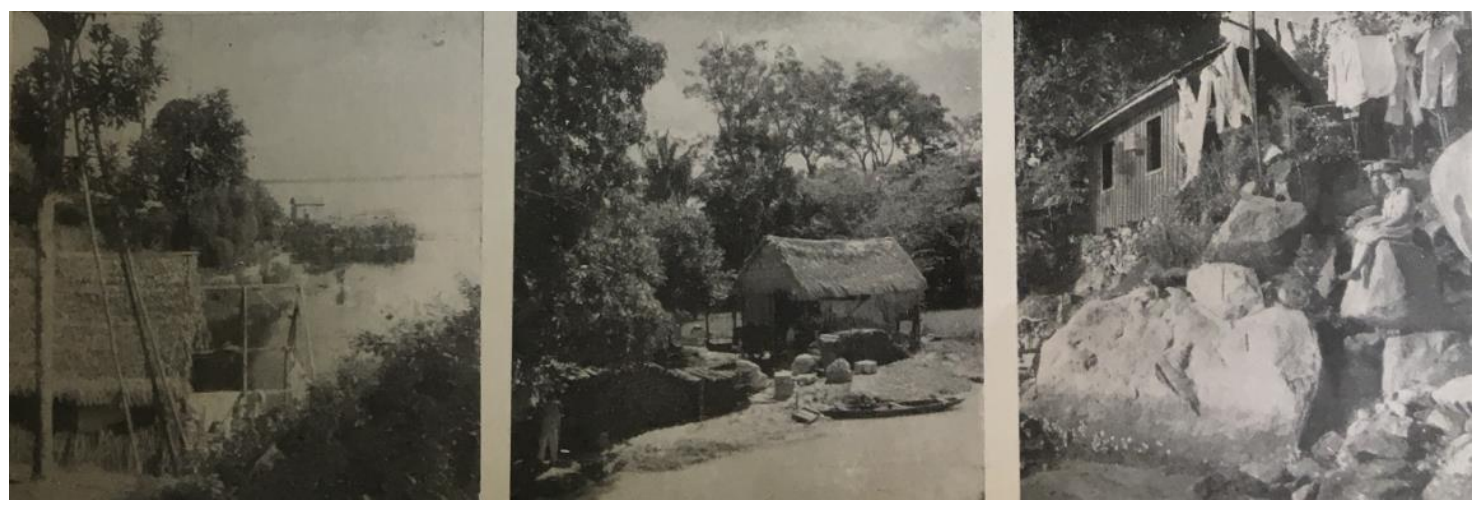

Figura 23 - Imagens da Amazônia na primeira Habitat. Nas legendas, os "navios gaiola que navegam os rios do norte do país” (1); o "interior de uma casa de seringueiro no Acre” (2); em sequência da esquerda para a direita, casas no rio Negro, casa de seringueiro no rio Purús, “casa de operário em Espírito Santo”, um igarapé em Manaus- AM (3). Fonte: HABITAT n.1, 1951, p.54; 68-71. 
No curto artigo que escreveu Joaquim Cardozo ${ }^{157}$ [figura 24] para o primeiro número da revista Módulo, ${ }^{158}$ o engenheiro qualificou as estruturas palafíticas reproduzidas nas fotografias veiculadas junto ao escrito, como fruto da engenhosidade e da adaptação, uma "arquitetura do povo", feita de material o mais adequado e disponível, "sempre realizada com espontaneidade singular", como outros exemplos de arquitetura popular no Brasil, “os mocambos do Nordeste, as favelas do Rio de Janeiro, as casas de tábuas do Paraná e Rio Grande do Sul”. Cardozo valorou o saber popular em adaptação às contingências, defendendo ser esta uma “das mais vivas arquiteturas”, especialmente diante da oscilação das águas do Rio Negro, em Manaus. O cuidado com as madeiras dos avarandados, o ajustamento espacial a vários usos, prontos para a adequação de "rêdes e outros petrechos igualmente simples e rústicos”, a engenhosidade do entalhe da madeira para adaptá-la à escada, todas essas soluções foram resumidas em sua qualidade de "manifestações artísticas populares do Brasil”, fruto do “espírito empreendedor” dos populares (MÓDULO N.1, março de 1955).

Em outro artigo publicado um ano após este, no qual abordou o mesmo tema, a arquitetura palafítica na Amazônia, Joaquim Cardozo expressou seu juízo a respeito (MÓDULO N.5, setembro de 1956, ano 2, p. 20-23):

O que se chama, geralmente, arte popular, não é, como se poderia pensar, a arte do povo, mas a arte das camadas mais pobres e portanto menos cultas da sociedade; pelo menos é essa a acepção corrente para as artes populares mais desenvolvidas: música popular é a música dos compositores pobres dos morros, pintura popular, a pintura ingênua e "primitiva" de artistas pouco instruídos.

Poder-se-ia pensar numa arte popular que não estivesse condicionada a êsses fatores de pobreza e de falta de instrução? Deixo a quem o queira êste tema atraente.

O objetivo dêste trabalho não é a especulação em têrmos de arquitetura de um tal problema, mas somente a revelação de alguns aspectos de arquitetura dos barracos, mocambos, casas sôbre palafitas e outros tipos de casas construídas pela população menos favorecida das cidades. E a novidade dêsse assunto consiste, apenas, em que nunca se deu a devida atenção - excluindo certamente os aspectos antropológicos e etnográficos da questão - ao fenômeno puramente arquitetônico dessa atividade construtiva.

\footnotetext{
${ }^{157}$ Engenheiro Civil, profissional do cálculo estrutural, escritor e à época, coordenador da revista modulo. Foi notabilizado como engenheiro calculista de Oscar Niemeyer. Antes, trabalhou com Luís Nunes em Recife, entre 1935 e 1937.

${ }^{158}$ Nesta mesma revista foi também publicado um artigo sobre os índios Carajá.
} 

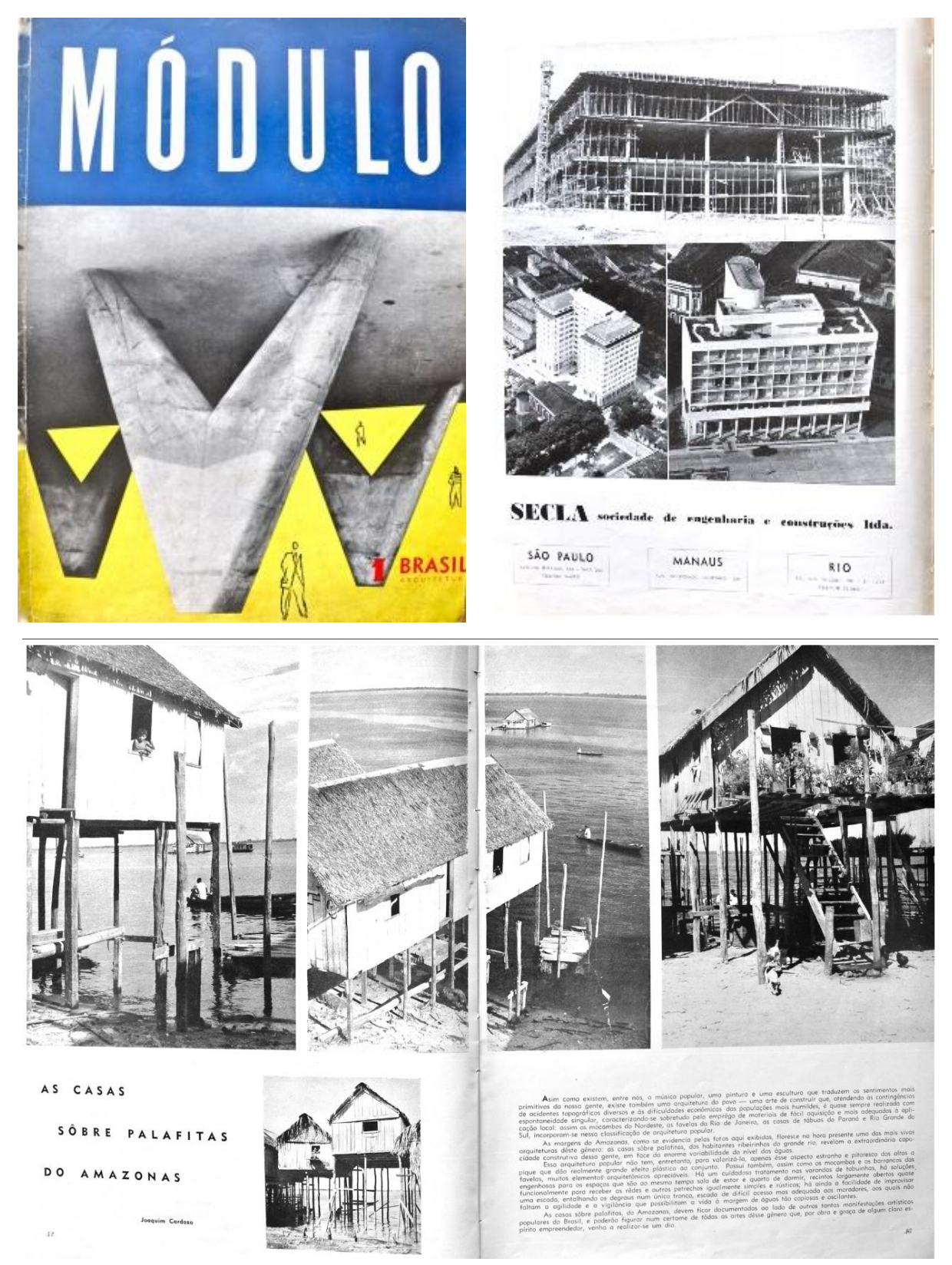

Figura 24 - As casas sobre palafitas no Amazonas. Fonte: MÓDULO n.1, 1955, p. 42-43.

Associadas pela imprensa à "favelas aquáticas”, as moradias eram "construídas sôbre toros de cedros de grande tamanho, os moradores desses flutuantes vão ocupando toda a faixa fluvial de Manaus-AM, criando um problema crescente para as pequenas embarcações atracarem nas redondezas da cidade", muito estigmatizadas pela "sujeira e promiscuidade que vão impregnando na entrada do nosso porto", dito assim, como em forma de intromissão dos migrantes em lugar com outro dono (COMÉRCIO, 16 de janeiro de 1959). Conformavam o que veio a ser nomeada de "cidade flutuante". De tal modo que uma das primeiras medidas interventivas do governo do estado para a construção de 
habitações populares foi a consolidada nos conjuntos de Flores e Raiz a partir de 1965, local para onde seriam destinados os moradores da cidade flutuante quando estivesse extinta. Com o intuito de sanear a beira rio ao sul da capital, área de centralidade comercial dada a localização do porto flutuante, onde as moradias eram em maior parte concentradas, a medida seria antecipatória à instalação da Zona Franca de Manaus, junto a iniciativas visando à atração de recursos de investimentos à capital Manaus [figura25].

Este tema foi retomado pelos arquitetos contratados pelo governo de Arthur Reis, o primeiro a partir do golpe militar de 1964. Estes profissionais foram encarregados de vários projetos sob a solicitação do governo, dentre os quais, projetos de conjuntos de habitação seriada e instalação das Cooperativa de Habitação do Amazonas. As transformações operadas no espaço urbano ocorreram, durante a ditadura militar, sob a justificativa do desenvolvimento da região, a partir de uma medida que "atraísse para ela força de trabalho e o capital, nacional e estrangeiro, vistos como imprescindíveis para a dinamização das forças produtivas locais” (SERÁFICO e SERÁFICO, 2005).

De acordo com o Decreto Lei n ${ }^{\circ} .288$, de 28 de fevereiro de 1967, durante o governo de Castelo Branco, que alterou a Lei de 1957 que regulava a Zona Franca de Manaus, esta seria uma área de livre comércio de importação e exportação e de incentivos fiscais, para criação de um centro industrial, comercial e agropecuário no interior da Amazônia. Além de reestruturar a ZFM, também criou uma Superintendência - SUFRAMA para administrála, vinculada ao Ministério do interior, com vistas a atração de indústrias para a cidade.

O estabelecimento da Amazônia Legal, uma área com aproximadamente 5 milhões de $\mathrm{Km}^{2}$ abarcando os estados de Acre, Amapá, Amazonas, Maranhão, Mato Grosso, Pará, Roraima, Rondônia, Tocantins, equivalente a mais da metade do território nacional, e a criação de um novo órgão, a Superintendência de Desenvolvimento da Amazônia SUDAM159, foram as medidas adotadas pelo Estado para "mostrar a habilidade do novo sistema político em levar adiante o desenvolvimento como uma potência-líder do "terceiro mundo" por meio de novas estratégias para explorar o seu potencial econômico mesmo em regiões com condições naturais adversas e sérios problemas logísticos”. No âmbito governamental, a Amazônia era vista como um espaço passível à colonização, meio

\footnotetext{
${ }^{159}$ Esta nova Superintendência deveria, como fim, substituir a Superintendência do Plano de Valorização Econômica da Amazônia - SPVEA, criada durante o governo de Juscelino Kubitschek.
} 
alternativo para a resolução dos conflitos decorrido das secas no Nordeste e potencial aos “objetivos econômicos do governo militar, fixados no modelo de desenvolvimento orientado para o crescimento econômico" (KOHLHEPP, 2002).

(1)

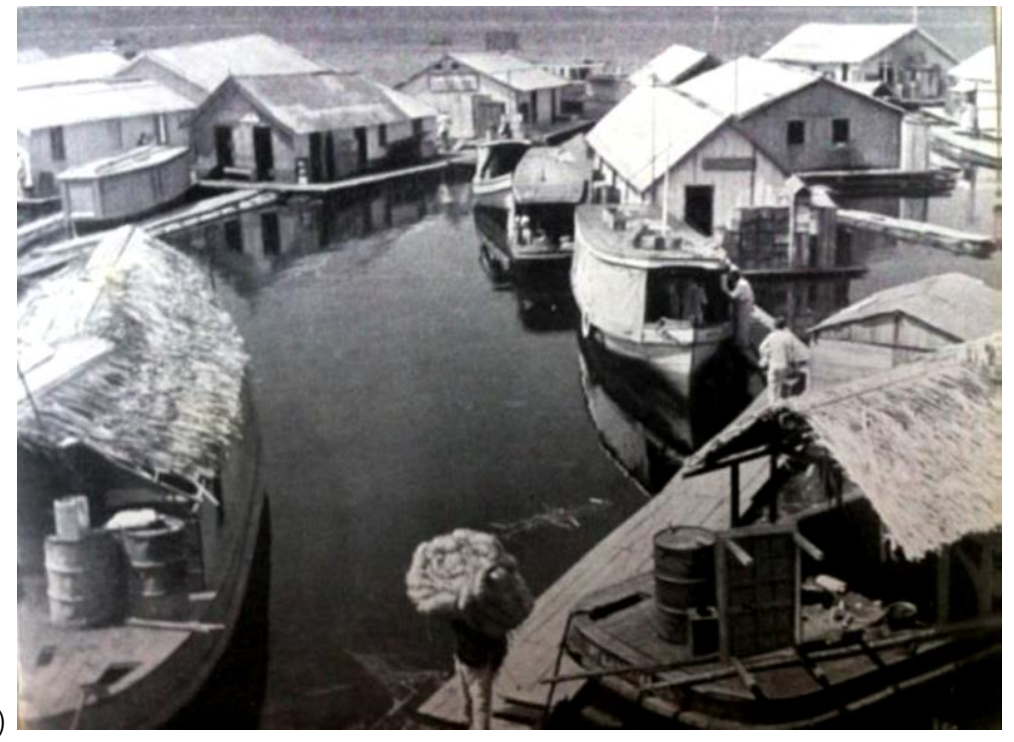

(2)

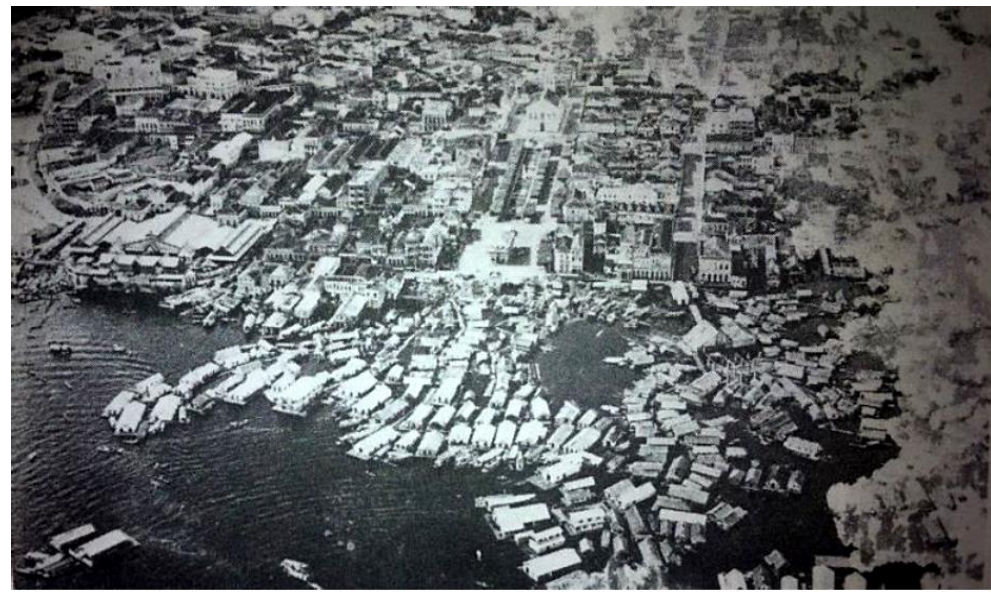

Figura 25 - (1) A cidade flutuante desde seu interior (SCHULTZ, 1964) e (2) em panorama (ANDRADE, 1984).

Assim, a ocupação da Amazônia, desde 1966, foi questão central ao Estado militar, junto a grupos empresariais e políticos. Além das finalidades exploratórias e para amenizar as tensões sociais do nordeste, os motivos para a projeção de uma malha de conexão rodoviária, de telecomunicações, urbana, em velocidade, visavam atenuar focos revolucionários e estruturar uma estratégia de controle ampliado das fronteiras nacionais, por meio de (BECKER, 2009, p. 26-27):

[...] subsídios ao fluxo de capitais através de incentivos fiscais e crédito a baixos juros, indução de fluxos migratórios para povoamento e formação de um mercado de trabalho regional, inclusive com projetos de 
colonização, e superposição de territórios federais sobre os estaduais, compuseram a malha tecno-política.

O privilégio atribuído aos grandes grupos e a violência da implantação acelerada da malha tecno-política, que tratou o espaço como isotrópico e homogêneo, com profundo desrespeito pelas diferenças sociais e ecológicas, tiveram efeitos extremamente perversos, destruindo, inclusive, gêneros de vida e saberes locais historicamente construídos.

Cabe destacar, como aponta Danilo Araújo Fernandes, a participação de grupos intelectuais e políticos regionais na formulação do projeto de desenvolvimento nacional, quando em relação ao “desenvolvimento regional amazônico". Eles se afetaram mutuamente, acabando por "se interpenetrar na dimensão institucional e local do pensamento econômico e social amazônico. Alimentando, e sendo alimentados, ao mesmo tempo, pelos discursos 'modernizadores' e os interesses econômicos e políticos de parcela das elites regionais”. Para Danilo Araújo Fernandes, um conjunto complexo de relações sociais, políticas, culturais, forjaram desde a República, a Amazônia, a partir de noções da “identidade cultural” relacionadas à "ideologia do progresso", construindo um discurso tornado historicamente regular, sobre o desenvolvimento regional amazônico, levado à prática social em inúmeras frentes, particularmente junto ao "pensamento regionalista brasileiro" entre os anos de 1930 e 1960 e do "nacional-desenvolvimentismo" dos anos 1950 (FERNANDES, 2011, p. 49).

Uma geração de intelectuais, deste modo, centrou o "pensamento desenvolvimentista-amazônico", constituindo sua matriz nas décadas de 50 e 60, sob a influência de autores como Euclides da Cunha e Gilberto Freyre, interessada em compreender o ajustamento humano ao meio amazônico com vistas seu desenvolvimento e da própria região. Dentre eles, "Djalma Batista, Arthur Cezar Ferreira Reis e Leandro Tocantins”, que no auge do desenvolvimentismo nacional, debateram e delinearam o pensamento regionalista amazônico, moldando discursivamente um "homem amazônico", uma "identidade regional amazônica”, ponte direta entre a política estatal e regional, a partir de um “discurso culturalista”, travestido em estratégia modernizadora, que quando interventiva, apelou aos significados subjetivos de uma adaptação ao ambiente ecológico regional. Portanto, uma das pautas dessa formulação discursiva era possibilitar a conciliação aos poderes nacionais, garantir de certo modo a autonomia das elites regionais, junto ao 
projeto de modernização e integração nacional do qual a região seria diretamente partícipe. Deste modo, em síntese (FERNANDES, 2011, p. 23-24;53):

[...] o discurso nacional-autoritário que se tornaria cada vez mais importante a partir do regime militar, em 1964, parece encontrar no discurso regionalista amazônico (durante o período pós Segunda Guerra Mundial) um importante componente mediador e um pano de fundo institucional, que acabaria, por fim, por facilitar seu processo de aceitação social do projeto de modernização nacional em escala regional. No período de amadurecimento e auge do nacional-desenvolvimentismo no Brasil (de 1946 a 1964), portanto, o que se verificou na Amazônia foi uma situação de conflito de interesses federalistas mediado de modo implícito por um discurso regionalista e desenvolvimentista moderado que se mantinha em defesa da preservação dos valores culturais amazônicos. Uma tentativa de defesa de um projeto de modernização mediada, portanto, por uma estratégia de desenvolvimento em bases culturalmente mais flexíveis, e voltadas para a preservação dos interesses de amplos segmentos das elites regionais. Uma estratégia que, por fim, sucumbirá a partir da década de 70, demonstrando toda sua fragilidade e alto nível de idealização, sucumbindo em favor de uma estratégia econômica homogeneizadora que imporá um sentido geopolítico muito mais austero e explícito em relação ao processo de modernização autoritária da nação brasileira em relação à Amazônia.

A tese de Danilo Araújo Fernandes foi de importância para esclarecer pormenorizadamente o que empiricamente havia sido constatado nas revistas de Arquitetura, especialmente a publicação do Instituto de Arquitetos do Brasil, da presença dos intelectuais locais a partir da publicação de seus escritos a partir da década de 1960. Ressaltando que a participação de Luiz de Miranda Corrêa, ainda que não seja abordado na tese de Danilo Fernandes, foi significativa, em sua atuação direta na administração do governador Arthur César Ferreira Reis, de 1964 a 1967, implementando atividades no segmento de turismo. Luiz Corrêa publicou uma série de artigos que tematizaram a arquitetura e a paisagem amazônicos e sua história, em síntese, nas revistas. Deste modo, o aporte de Danilo Fernandes, que produziu uma interpretação do encadeamento discursivo, com base na análise documental dos autores principais que formularam o discurso culturalista sobre a Amazônia e empreenderam sua efetivação como força discursiva voltada à modernização regional, elucidou os meandros discursivos de uma articulação de ideias que visavam, ao tempo, sob a ótica econômica, também espacial, a integração da região ao país.

A notabilidade da atividade intervencionista estatal na Amazônia mobilizava, na década de 1960, a imprensa em geral. Com a ditadura, foi apresentado o elo entre uma dimensão mais conjuntural de atuação estatal e a Amazônia, conforme enunciada nas 
revistas especializadas de Arquitetura e Urbanismo. Nos anos de 1950 e 1960, a considerar a atividade intensificada da editoração de periódicos e a variedade de revistas no Brasil, “a circulação de quase uma dezena de periódicos especializados” (SEGAWA, 1998, p. 130), as formas de observação dadas a ver nessas publicações, se aproximaram gradativamente da Amazônia, em novas temáticas ou em sua complexificação. A observação de Philip Goodwin encontrava agora seu contraponto. Intelectuais atuantes, pertencentes às elites regionais, demarcaram suas ideias e sua presença no ambiente regional e nas revistas de arquitetura, com a publicação de alguns textos chaves. A prática de projeto, a ressalvar a primeira escola de Arquitetura e Urbanismo implantada em Belém-PA ${ }^{160}$ em 1964, por outro lado, produziu a rearticulação da prática da Arquitetura a formulações discursivas, como as da história e crítica, na Amazônia.

Durante quase vinte anos, a capital Belém-PA concentrou as escolas de Arquitetura na Amazônia Legal, consolidando uma trajetória acadêmica e centrando a formação de profissionais arquitetos ${ }^{161}$ no âmbito regional. Do ponto de vista da formação disciplinar e acadêmica, até a década de 1980 havia três cursos de Arquitetura e Urbanismo na Amazônia, dois em Belém e um em Campo Grande, ${ }^{162}$ de modo que muitos dos projetos realizados eram provenientes de escritórios situados em outras localidades, como os textos em circulação a respeito desse campo, fossem críticos, jornalísticos, ou de divulgação de projetos e obras realizados na região. Escolas de Arquitetura e Urbanismo foram implantadas a partir de 1964, tendo como marco o curso de AU da Universidade Federal do Pará, criado justamente pela "falta de profissionais da área”, pela “desordem urbana”, pela "política desenvolvimentista” em curso e em função da construção dos "primeiros conjuntos habitacionais” (MIRANDA, CARVALHO, TUTYIA, 2015, p.20).

Jussara Derenji já afirmou ter sido “outra peculiaridade regional [...] a tardia criação de escolas de arquitetura no norte brasileiro”, e detendo-se ao panorama de Belém, onde atuavam engenheiros projetistas que cursaram Arquitetura para terem sua atividade

\footnotetext{
${ }^{160}$ A presença mais expressiva, em termos de projetos publicados, da nova geração de arquitetos belenenses será percebida nas revistas a partir da década de 1970, como será abordado no tópico a seguir deste mesmo capítulo.

${ }^{161} \mathrm{O}$ que pode ter angariado a baixa da publicação de projetos.

${ }^{162}$ Levantamento feito no site emec.mec.gov.br, acessado em 12 de março de 2017. Observa-se que o primeiro curso de Arquitetura e Urbanismo foi implantado em Belém-PA no ano de 1964, na Universidade Federal do Pará e em Manaus no ano de 1992, pela entidade privada Universidade Luterana do Brasil.
} 
reconhecida, além de "poucos profissionais vindos de fora, destacando-se pontuais atuações do arquiteto alemão Oswald Massler e de Álvaro Vital Brasil” nos anos de 1940 e 1960, definiram um quadro da prática profissional na região (DERENJI, 1995). A seguir é apresentado um quando-síntese das escolas implantadas entre os anos de 1964 e 1999 na Amazônia.

Quadro 1 - Ano de implantação dos cursos de Arquitetura e Urbanismo entre as décadas de 1960 e 1990 na Amazônia brasileira.

\begin{tabular}{|c|c|c|c|c|}
\hline $\begin{array}{l}\text { ANO DE } \\
\text { CRIAÇÃO }\end{array}$ & $\begin{array}{l}\text { CIDADE/ } \\
\text { ESTADO }\end{array}$ & INSTITUIÇÃO & Pública & Privada \\
\hline 1964 & \multirow{2}{*}{ BELÉM/ PA } & Universidade Federal do Pará & o & \\
\hline 1980 & & Universidade da Amazônia & & 0 \\
\hline 1981 & $\begin{array}{l}\text { CAMPO } \\
\text { GRANDE/ MS }\end{array}$ & Anhanguera Uniderp & & o \\
\hline 1992 & MANAUS/ AM & Centro Universitário Luterano de Manaus & & o \\
\hline 1993 & DOURADOS/MS & Centro Universitário da Grande Dourados & & $\mathrm{O}$ \\
\hline 1993 & SÃO LUÍS/ MA & Universidade Estadual do Maranhão & o & \\
\hline 1994 & PALMAS/ TO & $\begin{array}{l}\text { Fundação Universidade Federal do } \\
\text { Tocantins }\end{array}$ & o & \\
\hline 1994 & CUIABÁ-MT & Universidade Federal de Mato Grosso & o & \\
\hline 1999 & MANAUS/ AM* & Centro Universitário do Norte & & o \\
\hline
\end{tabular}

Fonte: Elaborado pela autora a partir de dados disponíveis no site www.emec.gov.br, acessado em março de 2017. "Em Manaus a Universidade Federal do Amazonas implantou o curso de Arquitetura e Urbanismo em 2010, o primeiro em Universidade pública no Estado e único até o presente.

A participação direta daqueles escritores, intelectuais da região, com seus textos publicados nos periódicos especializados, já com a presença de uma escola de Arquitetura e Urbanismo em Belém-PA, alcançou em 1967, como aqui defendido, seu ápice, com uma revista chave, a Arquitetura Brasileira do Ano (ABA N.1, 1967-68). A partir dela é estabelecido o recorte final deste tópico. Com a revista, uma determinada concepção de paisagem, de síntese, adquiriu forma e estrutura discursiva. A partir de princípios referidos à uma moderna arquitetura, intelectuais, políticos e arquitetos relacionados mais diretamente à Amazônia, a vislumbraram e à sua arquitetura, sob as premissas de um aporte regional, culturalista.

Esta teria sido uma estratégia conciliatória ao fluxo modernizador, naquele momento, empreendido violentamente pelo estado ditatorial e a mediação mais influente nos discursos regionalistas que ganhariam peso na década de 1980. Um juízo ético associado à prática, foi formulado pela condição elementar de arraigamento e interdependência entre 
arquitetura e ambiente. Este foi construído discursivamente e simbolicamente a partir do paradigma de uma paisagem, e em relação, as formas elaboradas pela arquitetura, a reelaboraram no âmbito do projeto. Estas eram as expectativas dos autores, de civilização na Amazônia, ressaltando o fato de que alguns deles, compunham as prestigiadas elites intelectuais e políticas regionais.

Dos artigos identificados nas revistas até 1968, quando foi publicada a Arquitetura Brasileira do Ano - ABA 1, intitulada Amazonas (ABA N.1, 1967-68), a maior parte deles esteve centrada numa publicação, a Revista Arquitetura $I A B-R J$. O editorial da Revista Arquitetura n.6, de 1962, do Instituto de Arquitetos do Brasil, apresentou muito claramente os propósitos da publicação, de reforçar o valor do planejamento urbano, sem o qual a arquitetura não poderia ser mesmo concebida, de registrar as contradições do espaço urbano no Brasil, de posicionar o arquiteto frente o fluxo de deterioração social nas cidades visibilizando a dilatação de sua atuação profisional. ${ }^{163} \mathrm{O}$ texto apontou aos sinais de esgotamento do prestígio profissional adquirido pela consagração de determinados arquitetos de referência e suas obras, pela monumentalidade destas, mais do que pelos seus “aspectos humanos”.

A revista seria mais um veículo de cultura à profissionais de arquitetura e a todos que “se empenham nas soluções de nossos problemas sociais e culturais", do que o suporte à divulgação de obras de referência. Assim, a habitação pobre não foi apresentada na condição de objeto estético, mas como produto vida urbana, que demandava medidas efetivas de planejamento $^{164}$ (ARQUITETURA IAB N.6, dezembro de 1962). Em continuidade, o artigo Arquitetura, publicidade e literatura especializada, um editorial de Álvaro Pacheco publicado na revista Arquitetura de abril 1964, defendia a importância das revistas especializadas para a difusão da arquitetura, mas também o fazia a partir da crítica à parca publicação no segmento e a falta de qualidade. Para ele, "o movimento editorial do país no âmbito da literatura principalmente quanto às matérias de que nos ocupamos, é praticamente nulo", dada a desvalorização generalizada do trabalho intelectual, e a falta de

\footnotetext{
${ }^{163}$ A própria atividade de serviço das revistas, estabeleceu pontes com a indústria, fornecendo informações técnicas aos projetistas a partir de subsídio publicitário (ARQUITETURA-IAB N.68, fevereiro de 1968, p. 2).

${ }^{164}$ A revista apresentou o relatório conclusivo da I Jornada Nacional de Habitação, bem como a proposição do IAB para ajustes no decreto de criação do Conselho Federal de Habitação, de 1962.
} 
recursos, refletidos muito diretamente da defasagem da indústria da construção nacional. Seu nexo explicativo para a inadequação da arquitetura realizada no país às suas "reais condições sociais, econômicas e humanas", num quadro social instável à atividade profissional dos arquitetos, levantou questões relacionadas ao crescimento urbano como de urgente resolução. As revistas, portanto, seriam suportes propícios à circulação de debates acerca da atividade profissional, sobretudo, quando ampliada pelos desafios apresentados no espaço urbano impactado pela industrialização, sendo a cidade, uma construção da “síntese dos anseios humanos de atingir com harmonia a integração comunitária e consequentemente o bem estar coletivo” (ARQUITETURA-IAB N.29, abril de 1964, p. 2).

A temática do espaço urbano passou à centralidade das revistas, bem como o debate que iria ser acentuado na década seguinte, ao qual a Amazônia seria diretamente relacionada, o do "meio ambiente". Este mesmo tema pautou o VI Congresso Brasileiro de Arquitetos, a Arquitetura e o Meio Ambiente, ocorrido em Salvador de 19 a 24 de setembro de 1966, sob os ecos do que havia sido proposto pela UIA para IX Congresso Internacional de Arquitetos que seria realizado em Praga no ano seguinte ao brasileiro (ARQUITETURAIAB N.52, outubro de 1966, p. 4). Esta temática estava concebida a partir de seis vertentes, a "estrutura residencial”, o "patrimônio histórico", o "meio habitável”, a "produção e o meio ambiente", o "homem e a paisagem", "profissão em função da arquitetura e do meio ambiente" para a integração do arquiteto à atividade de planejamento no desenvolvimento do país, além da "revisão e atualização do ensino" e sua integração às práticas de planejamento $^{165}$ (ARQUITETURA-IAB N.47, maio de 1966). O relatório final do Congresso Brasileiro assim concluía (ARQUITETURA-IAB N.52, outubro de 1966, p. 4):

Até recentemente limitavam-se os arquitetos brasileiros ao tratamento artístico dos edifícios e à elaboração de projetos para a indústria da construção civil; com o avanço tecnológico do mundo contemporâneo, ampliou-se profundamente o campo de atuação profissional, com nítidos reflexos no comportamento dos arquitetos de todo o mundo, mormente naqueles atuantes em regiões em vias de desenvolvimento, onde a complecidade dos problemas evidenciados contrasta com a escassez de

\footnotetext{
${ }^{165}$ As discussões acerca do que viria a ser configurada como Reforma Urbana, foi frequente nas revistas Arquitetura-IAB. Cabe mencionar que os anos de 1960 foram marcados, no âmbito disciplinar, pela crítica às doutrinas apregoadas pelo movimento moderno. Foram difundidos outros focos de interesse, como a importância das centralidades históricas e dos lugares tradicionais, a despeito da crítica empreendida por Janes Jacobs, em seu livro "Morte e vida nas grandes cidades", crítico ao urbanismo moderno e seus efeitos sobre o espaço das cidades.
} 
recursos de tôda a natureza, ensejando uma ação em prol da utilização do planejamento, em tôdos os níveis de aplicação.

De fato, nos anos de 1960, os movimentos ambientalistas tinham absorvido a "demanda ambiental", como um "elemento integrante de uma crítica maior, de base civilizacional". Os ativismos foram a partida para o desenvolvimento de outros movimentos ambientalistas de atuação mais ampla, críticos à modernidade produzida pelo capitalismo industrial (RIBEIRO, 2012). Para os debates dados na Arquitetura-IAB durante a década de 1960, a esta crítica, foi somada a necessidade de incorporação de significados socialmente partilhados à arquitetura. Os anseios advindos da sociedade, populares, poderiam apresentar mais que a monumentalidade estatal, sensibilizar as mentes pelo seu estreitamento aos valores culturais sociais, de modo a cumprir com "as finalidades humanas da arquitetura" em superação ao "formalismo"166 (ARQUITETURA IAB N.6, dezembro de 1962, p. 23). Os editoriais confirmavam um processo de autocrítica disciplinar, mantendo sobretudo a posição da atividade profissional, como aquela necessária às cidades, da qual dependia a melhoria do espaço urbano, especialmente com o planejamento (ARQUITETURA IAB N.12, junho de 1963).

Foram múltiplos os rebatimentos temáticos dessas discussões que cercaram a busca pela qualidade do espaço urbano habitado. Outros temas foram incorporados à problematização do projeto e à técnica planejadora, como as relativas ao ambiente, estensivamente, à paisagem, as técnicas construtivas, quando foram interpretadas a partir das determinantes locais à sua aplicação. São exemplo os artigos de Miran de Barros Latif Ventilação nos trópicos (ARQUITETURA-IAB N.51, setembro de 1966, p. 9-11) ${ }^{167}$, Aeração no trópico (ARQUITETURA-IAB N.58, abril de 1967, p. 23-24) ${ }^{168}$, de Shyam

\footnotetext{
${ }^{166}$ Marcello Accioly Fragelli se referiu ao formalismo resultante do distanciamento gradativo da arquitetura no Brasil aos preceitos de Le Corbusier. Se a brasilidade da arquitetura moderna lhe possibilitou garantir projeção internacional, sua exacerbação produzia o formalismo distanciado dos valores humanos essenciais à arquitetura.

${ }^{167}$ Neste número da revista foi mencionado o contato do "Instituto Regional de Desenvolvimento do Amapá" com a revista, que tinha por finalidade prestar serviços de "assistência técnica e extensão agrícola assim como a elaboração de projetos que tenham por finalidade a promoção do bem estar social da comunidade amapaense e o programa econômico do território" (ARQUITETURA-IAB N.51, setembro de 1966, p. 30).

${ }^{168}$ Neste número da revista foi publicado o projeto da primeira residência de Severiano Mario Porto em Manaus (ARQUITETURA-IAB N.58, abril de 1967, p. 33).
} 
Janveja, Consideraçôes sôbre a arquitetura tropical ${ }^{169}$ (ARQUITETURA-IAB N.48, junho de 1966, p. 9-13), Urbanismo e paisagem, de Jean Chalett (ARQUITETURA-IAB N.52, outubro de 1966, p. 17-19), Carta de vegetação e planejamento, de Luiz Guimarães de Azevedo (ARQUITETURA-IAB N.59, maio de 1967), A arquitetura e o meio ambiente (ARQUITETURA-IAB N.61, junho de 1967), ou toda sorte de estudos sociais, econômicos, geográficos, ecológicos, biológicos articulados prevalentemente às atividades de planejamento urbano e ao território. $\mathrm{O}$ ambiental foi gradativamente, sendo associado primeiro ao que fosse regional, depois ao climático, agora, ao tropical, modo este de como foi universalizado.

Um dos rebatimentos associados ao interesse pela industrialização da construção, como meio de resposta a demandas de ajustamento da racionalidade construtiva, produziu experiências múltiplas entre os anos de 1950 e 1960 (ZEIN e BASTOS, 2010, p. 96-100), frente à problemática ausência de técnicos na atividade da construção civil no país, à época. Dentre estas experiência, foram publicadas as "Escolas pré-fabricadas de madeira", projetadas por Severiano Mario Porto, ${ }^{170}$ sob a encomenda do governo estadual. As escolas seriam fabricadas em madeira, na capital, e transportadas para o interior do estado. Para tanto, o arquiteto previu uma trama tridimensional modulada, em madeira, cujo piso seria elevado do solo e a vedação com venezianas para as salas de aula, fixadas a partir de fundações em concreto, junto a parte edificada em alvenaria, para abrigar instalaçóes sanitárias (ARQUITETURA-IAB N.40, outubro de 1965, p. 16).

Além do projeto para escolas pré-fabricadas, alguns outros de autoria de Severiano Mario Porto foram publicados esparsamente nas revista Arquitetura. A primeira casa que fez para si em Manaus-AM (ARQUITETURA-IAB N.58, abril de 1967) serviu à habitação provisória do arquiteto na cidade, por isso foi também pensada pragmaticamente, para ser construída com certa velocidade. Para tanto a ergueu com material que era abundante, a madeira, assim como em várias de suas obras apresentadas nesta década nas revistas. $\mathrm{O}$ cimento era, conforme sua memória publicada na revista, material relativamente caro, bem

\footnotetext{
${ }^{169}$ Neste mesmo exemplar da revista Arquitetura-IAB foi publicada uma reportagem intitulada "Arquitetura e meio ambiente", relativa ao Congresso UIA, curiosamente ilustrada com uma imagem da praça de Sebastião, em Manaus-AM, veiculada no artigo de Luiz de Miranda Correa publicado havia dois anos, na revista de número 30, (ARQUITETURA-IAB N.48, junho de 1966).

170 Arquiteto formado em 1954 pela Faculdade Nacional de Arquitetura da Universidade do Brasil (atual Universidade Federal do Rio de Janeiro).
} 
como outros que também chegavam à cidade por vias fluvias, razão pela qual oscilavam de preço. Para o arquiteto, a pedra não apresentava "boas características para emprêgo no concreto" e a única alvenaria da casa foi a já existente, aproveitada e acrescida de novos elementos construídos em madeira de acabamento rústico, prioritariamente, maçaranduba, louro, cedro, em fundações, vedações, pisos, armários divisórios (ARQUITETURA-IAB N.58, abril de 1967, p. 33).

$\mathrm{O}$ artigo apresentou duas fotografias da obra erguida e uma planta baixa na publicação do projeto, além de toda a descrição dos materiais, especialmente dos tipos de madeira utilizada com tratamento rústico, as soluções de adaptação da casa à orientação que se apresentava desfavorável, como uso de beirais alongados, venezianas, arranjos de ventilação cruzada. Uma revelação do escrito foi a de que na interpretação de Severiano Porto, a madeira não era "bem aceita como padrão decente de moradia", de que "lá ela é considerada como típica das camadas sociais de menor nível de renda e as exceções observadas dizem respeito exclusivamente a residências de veraneio ou de campo”. Mesmo o Banco Nacional da Habitação não previa o material para habitações populares, de modo que o arquiteto tentou "desfazer o falso conceito que cerca êsse material em Manaus”, diminuindo em sua residência, $25 \%$ do custo da construção frente a base de preço da COHAB-AM no período (ARQUITETURA-IAB N.58, abril de 1967, p. 33).

Dois dos projetos do arquiteto que foram premiados apresentaram, cada um, questões distintas, justamente pelas soluções adotadas. $\mathrm{O}$ projeto que desenvolveu para o Estádio Vivaldo Lima junto a Paulo Emílio Ribeiro [figura 26] foi o que motivou o deslocamento de Severiano Mario Porto a Manaus, a convite do então governador Arthur Cesar Ferreira Reis. O referido projeto recebeu a Menção Honrosa na categoria de "edifício para fins esportivos e recreativos”, na III Premiação Anual do IAB-GB, em 1965. Como destacado do parecer do júri, esta foi "solução simples e inteligente, conduzida corretamente, integrada ao sítio e bem de acordo com a escala do problema”, numa argumentação técnica de teor universalizante. Nenhuma menção à aspectos da cultura do lugar de implantação ou à tradição construtiva. Tratou, nesses termos, de uma solução tida como racionalmente ajustada ao sítio. (ARQUITETURA-IAB N.44, fevereiro de 1966, p. 24). 

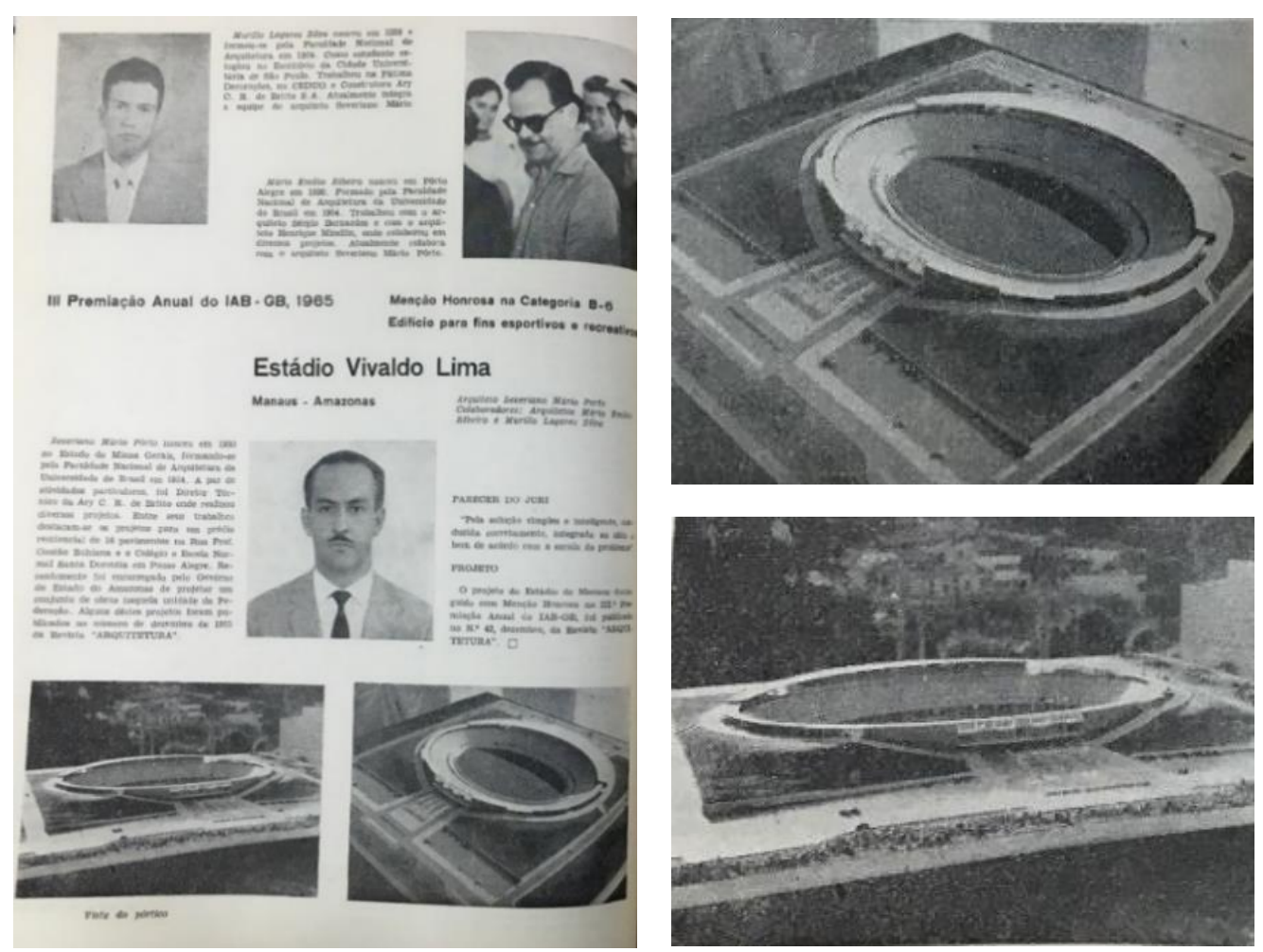

Figura 26 - Projeto do Estádio Vivaldo Lima, de Severiano Mário Porto e Paulo Emílio Ribeiro, III Premiação Anual do IAB-GB. Fonte: ARQUITETURA-IAB n.44, 1966, p. 24.

$\mathrm{Na}$ revista Arquitetura-IAB n.42, o projeto foi justificado pela adaptação às condições existentes, "norteando-se a mesma simplicidade", a partir dos recursos locais, e para o qual foi visada uma "certa monumentalidade e dignidade julgadas convenientes neste estádio", de projeção regional. A revista abordou o ajustamento ao terreno, com o aproveitamento de talude interno existente, como uma qualidade daquele projeto previsto para 47 mil pessoas, executado "com elementos padronizados, pré-moldados em concreto, que se acomodam diretamente sôbre o talude devidamente preparado e compactado, dispensando-se outro tipo de infraestrutura". Além desta solução, foram descritas em conciliação, as relativas às estruturas e à distribuição espacial, acessos, assim como as de ordem técnica, como de drenagem e escoamento de águas pluviais, em memorial de certo modo descritivo (ARQUITETURA-IAB N.42, dezembro de 1965, p. 55-56). 

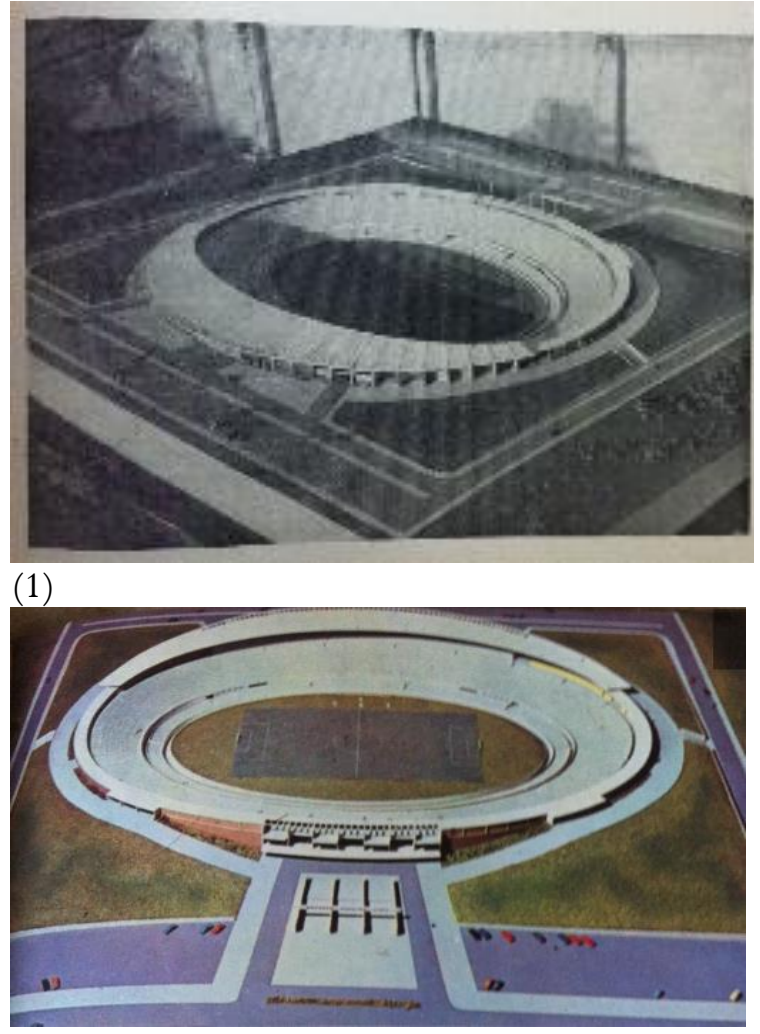

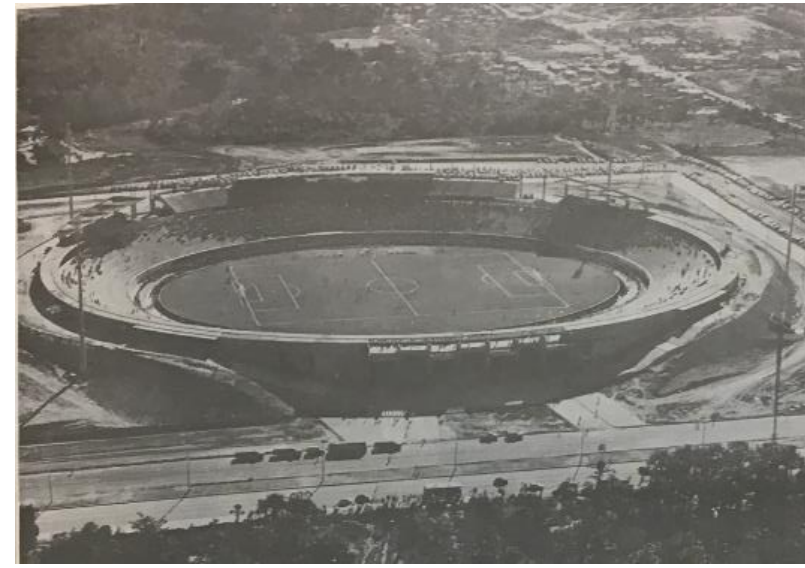

$(2)$

(3)

Figura 27 - Projeto de Severiano Mario Porto para o Estádio Vivaldo Lima em três publicações da década de 1960. Fonte: (1) ARQUITETURA-IAB n.42, 1965, p. 55; (2) ARQUITETURA - IAB n.44, 1966, p.24; (3) AMAZÔNIA É BRASIL, 1967, s/p.

O estádio, conforme identificado nas revistas, seria publicado mais cinco vezes em revistas nacionais, entre 1966 e 2005 [figura 27], sem incluir publicações de outro caráter, como acadêmicas ou as internacionais. Nesta década, além da revista citada, a $A B A-1$ também o publicou, em projeto. O segundo projeto, o do restaurante "chapéu de palha”, foi avaliado pelo juri que o conferiu a premiação como "um projeto que pela simplicidade bem sugere as origens e tradições locais” [figura 28]. Em atenção à pequena memória apresentada na revista junto à publicação do projeto, foi mencionado, provavelmente como informação do próprio autor, o "uso de materiais típicos na região tais como madeira e palha", bem como descrita a ambiência de sua localização, em bairro "tranquilo de clima privilegiado e fora do centro urbano”. Uma combinação de materiais usuais à arquitetura, como fundação de concreto, estrutura de madeira, vedação em tijolo aparente, estrutura em madeira, neste caso a "aquariquara", a outros de menor utilização pela arquitetura erudita, como cobertura em palha de palmeira, confeririam uma figuratividade reforçada pela "utilização de cadeiras de vime, abajour em forma de chapéu" (ARQUITETURA-IAB N.68, fevereiro de 1968, p. 7). 
Estes projetos estavam sendo publicados conforme sua realização, sob justificativas mais objetivas, conciliados à certa racionalidade projetual que lhes viabilizassem em obra, mesmo por se tratarem de encargos públicos na maioria. No contexto era ao tempo, difundida a atividade profissional da Arquitetura e Urbanismo, absorvida com maior projeção pela participação estatal no delineamento dos encargos. No entanto, a proposta para o chapéu de palha, noutra linha programática, no que é possível absorver das poucas informações obtidas na própria revista, resultava de interesse outro por parte do arquiteto, de conferir pela construção e pela combinação desta a outros elementos de ambientacão, um caráter pitoresco e evocativo.

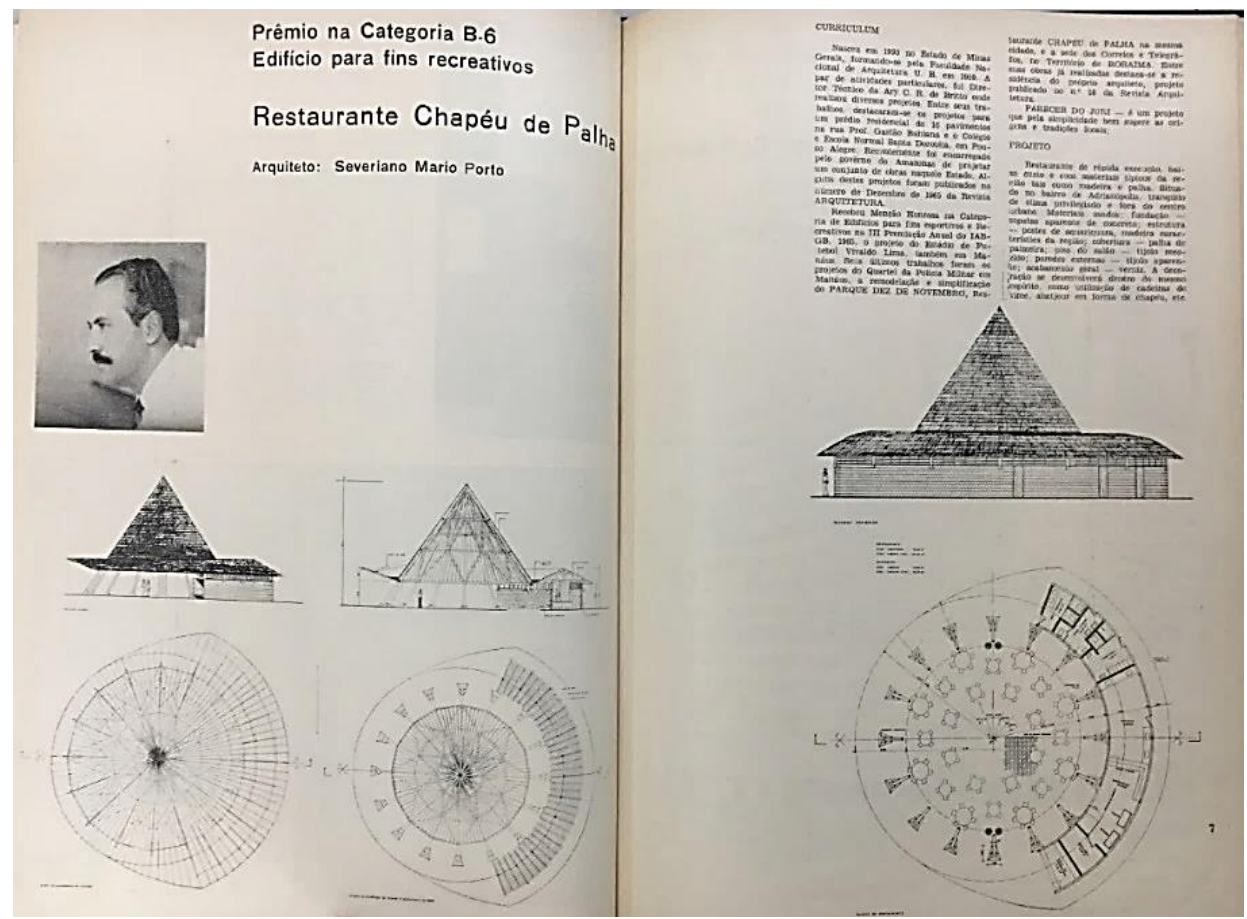

Figura 28 - Projeto de Severiano Mario Porto para restaurante premiado na categoria de "edifícios para fins recreativos”, na V Premiação Anual do IAB - GB, de 1967. Fonte: ARQUITETURA-IAB n.68, 1968.

O uso da madeira em sua própria residência, como mesmo enunciou Severiano Porto, seria além de fruto de raciocínio objetivo, para gerar economia nos custos da obra, uma iniciativa pioneira que a seu ver poderia influir noutras, realizadas entre os abastados locais, informados pela presença de sua arquitetura na capital. A postura de Severiano Mário Porto, guardava deste modo, certa pretensão de colonizar as ideias locais com os preceitos disciplinares da arquitetura, a partir, inclusive, da conciliação e crítica que propôs. As mentalidades locais, formativas dos juízos acerca do segmento da construção civil, deveriam 
absorver as ideias que ali o arquiteto desenvolvia e propagava, em um período no qual na cidade era experimentada certa transformação sob os impactos da implantação da Zona Franca de Manaus-AM e no setor da construção os encargos tanto públicos quanto privados seriam ampliadamente requeridos.
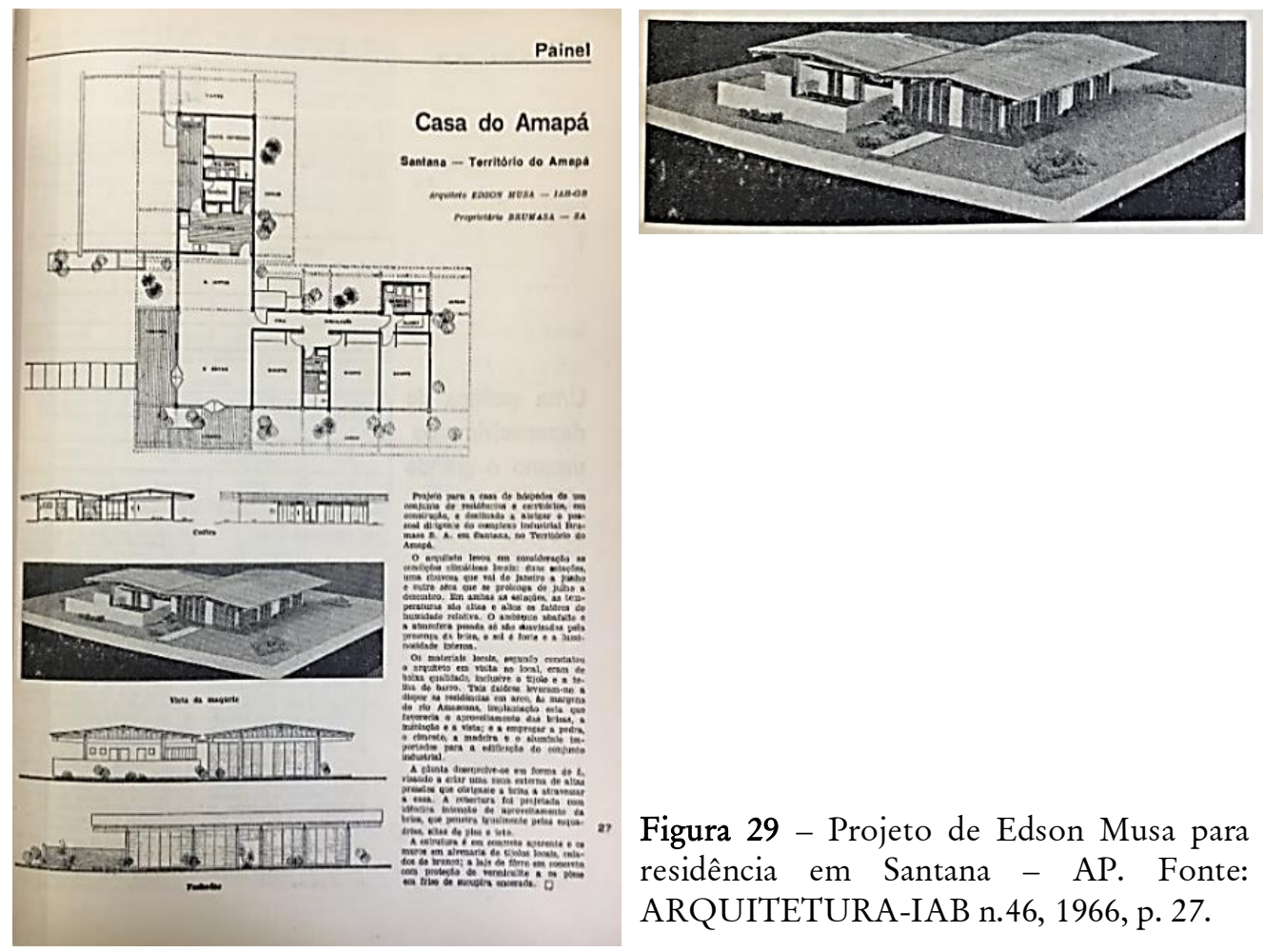

Figura 29 - Projeto de Edson Musa para residência em Santana - AP. Fonte: ARQUITETURA-IAB n.46, 1966, p. 27.

Outro projeto publicado, se amparou discursivamente na adequação ao clima, o de uma residência projetada para os "dirigentes do complexo industrial Brumasa SA", em Santana-AP [figura 29]. Ela foi justificada pela adaptação às duas estações, seca e chuvosa, aos "fatôres de humidade relativa", ao "ambiente abafado", à "atmosfera pesada", ao "sol forte”, à "luminosidade intensa”, somente atenuadas pela presença de brisa. Estes foram os precedentes à justificativa das soluções do pé direito, cobertura e organização em $L$, adotados no projeto. Os materiais "de baixa qualidade”, inclusive o tijolo e a telha de barro", condicionaram o arquiteto à disposição das casas em “arco", às margens do rio Amazonas, para aproveitamento das brisas, da insolação, da vista, também condicionando a adoção de materiais importados, como pedra, madeira, cimento, alumínio (ARQUITETURA-IAB N.46, abril de 1966, p. 27).

Em 1965, 34 páginas de uma Revista-IAB (ARQUITETURA-IAB N.42, dezembro de 1965) foram dedicadas a matérias relativas a obras realizadas ou em curso no estado do Amazonas, também a textos de teor histórico, crítico, numa fusão de temporalidades em 
representações da Amazônia. Dos escritos de cunho histórico ou referenciados em aportes locais, nomeadamente Arquitetura e Urbanismo no Amazonas, figuraram os de Leandro Tocantins, Aspectos da Arquitetura tradicional de Manaus, ${ }^{171}$ Luiz de Miranda Corrêa, Arquitetura contemporânea de Manaus e Pôrto de Manaus, Sheila Freitas Martins, Teatro Amazonas, José dos Santos Lins, Aspectos da Arquitetura do Amazonas no ano de 1900. Fizeram parte deste primeiro conjunto, três artigos tematizados no Urbanismo, o do arquiteto Cesar Oiticica Impressóes sôbre o urbanismo de Manaus, o dos arquitetos Luiz Carlos Antony e Fernando Pereira da Cunha, Bairro da Raiz - Manaus - Urbanismo e Arquitetura, e o de José Lins que supostamente seria José dos Santos Lins, Estrada ManausItacoatiara.

Os demais artigos foram associados mais diretamente a projetos agrupados em um "PaineP”, todos eles de autoria de Severiano Mário Porto: o Estádio Vivaldo Lima, a sede da CAMTEL, a Assembleia Legislativa do Amazonas, o Palácio do Governo, a Secretaria de Produção, situados em Manaus-AM. Além destes, foi publicado o "Plano Habitacional BNH" e um artigo e encerramento, de Elson Farias, intitulado Algumas impressóes de paisagens e homens dos rios do Amazonas (ARQUITETURA-IAB N.42, dezembro de 1965). O nome de Luiz de Miranda Corrêa figurava, mesmo antes, como colaborador da revista Arquitetura-IAB. Ele foi identificado a partir do número 14 desta revista, de agosto de 1963. O de Leandro Tocantins aparece a partir do número 23, de maio de 1964. Conologicamente, um primeiro artigo, A Arquitetura na Amazônia, de Luiz de Miranda Corrêa, teria demarcado o início dessa participação nas revistas de arquitetura, deste grupo de intelectuais. No escrito, o autor defendeu o desenvolvimento de uma arquitetura adequada ao clima amazônico, sob a premissa de uma continuidade histórica dada desde uma origem colonial, reproduzindo uma narrativa, com base numa visualidade, numa estética transposta à arquitetura que estava sendo questionada em outros contextos intelectuais (ARQUITETURA-IAB N.17, novembro de 1963, p. 4):

Nos últimos anos do govêrno ditatorial de Getúlio Vargas, uma construção no Rio de Janeiro, viria a mudar as normas da arquitetura brasileira. Nos referimos ao edifício do Ministério de Educação e Cultura. Descobria-se o grande arquiteto francês, Le Corbusier, que com êste risco e com sua rápida passagem por estas terras, emularia profissionais brasileiros e lançaria os alicerces da moderna arquitetura brasileira, tendo a frente Lúcio Costa e

\footnotetext{
${ }^{171}$ Uma publicação similar, nomeada Manaus: aspectos de sua arquitetura, foi atribuída à Luiz de Miranda Corrêa.
} 
Oscar Niemeyer. Êste movimento iria influenciar, embora palidamente, engenheiros e construtores das cidades amazônicas. Mas naqueles dias, as comunicações entre o sul e o norte do país se faziam de maneira precária. Longas viagens de navios e pouca frequência de aeronaves.

Não existiam revistas especializadas. Total ausência de arquitetos na região. Carência de engenheiros. E poucos foram os que ousaram construir dentro das ideias renovadoras, e os que o fizeram, limitaram-se a transportar o que se fazia no sul, sem a maior preocupação pelas condições locais. O que era bom no sul, poderia não sê-lo no norte.

Informado sobre a moderna arquitetura brasileira, Luiz de Miranda Corrêa reclamava a atualização da arquitetura local, ao menos nas capitais, que foram as cidades por ele citadas. Retratou o produto construído da recém verticalizada Belém-PA e Manaus-AM como a cidade onde eram ausentes as obras de arquitetos, salvo exceções. Ressaltou a inadequação de um conjunto edilício de referências importadas e “inadequadas" à Amazônia, aqueles “absurdos” construídos, que não atenderiam às “necessidades regionais” ainda que já fizessem parte em grande quantidade, do conjunto urbano das "duas capitais da Amazônia brasileira”. Luiz de Miranda Corrêa se refere ao projeto de Paulo Antunes Ribeiro para o Hotel Amazonas como “a mais elegante construção moderna em toda região amazônica”, mas que funcionava em Manaus, "da mesma maneira que uma palhoça de caboclo funcionaria na Groelândia”. Quem “ousaria” projetar e construir, em Belém ou em Manaus, um "hotel ecológico, entre gramados e mangueiras, com amplas janelas, grande varanda, ladeando igarapés?” (ARQUITETURA-IAB N.17, novembro de 1963, p. 5).

Luiz de Miranda Corrêa se referia mais ao discurso da moderna arquitetura brasileira, referenciado em seus primórdio ao neocolonial, ou nos rumos trilhados por obras como o Park Hotel de Nova Friburgo de Lúcio Costa, de 1944-45, cuja espacialidade moderna, numa constituição material atrelada a um “falso anacronismo romântico” (WISNIK, 2001), seria recortado como referência de um determinado modo operativo na obra de Lúcio Costa, quando submetida à integração com uma ideia de paisagem brasileira. Utilizando imagens de formas tipificadas do morar na Amazônia ${ }^{172}$, num agenciamento moderno de imagens domesticadas, as fundiu aos referenciais de uma arquitetura brasileira, a da vertente

\footnotetext{
${ }^{172}$ Não foi identificada nenhuma relação objetivamente apresentada nos textos desse período com os escritos de Bernard Rudofsky e à exposição que realizou no Moma em 1964. De todo modo ele apresentou na exposição, as múltiplas designações da "Arquitetura sem arquitetos", que foi o título da exposição. Esta arquitetura seria aquela produzida por autodidatas, caracterizada como uma arquitetura anônima, rural, espontânea e fruto do conhecimento vernáculo.
} 
carioca, para defender uma regionalidade levada ao construir. Reclamou o uso de varandas, pátios, jardins, "mais madeira e menos concreto", "mais ventilação e menos ornamentos”, “menos Paris, mais árvores, menos Rio de Janeiro, mais Amazônia!”. Ele foi, dos intelectuais, o que convocou os arquitetos e engenheiros da Amazônia a (ARQUITETURA-IAB N.17, novembro de 1963, p. 5):

Criarem uma arquitetura identificada com a terra, com o clima, com o homem, usando matéria prima local. Região com tradição histórica, com traços de cultura definida, como exemplo na alimentação, no 'folclore', na literatura, não pode continuar a ser, por mais anos, copista de habitações que não funcionam em seu território equatorial.

Para a tese, esta foi a formulação primordial do discurso de uma arquitetura adequada à Amazônia e que seria amplamente reproduzido, incorporado à uma estética particularizada em algumas obras icônicas, a exemplo das desenvolvidas por Severiano Mário Porto. Sua arquitetura, inclusive, teria absorvido este discurso e em parte formulada a partir desta diretriz, informada pelas ideias desenvolvidas por intelectuais da própria região, aproximados de uma vertente do pensamento social sobre a Amazônia. No entanto, foi inegável o impacto da obra de Oswaldo Bratke sobre suas formulações, como foi possível identificar em publicações subsequentes a esta. A arquitetura de Severiano Mário Porto foi inclusive frutificada materialmente sob a influência dessas mesmas bases discursivas. Este fato estabelece o paralelo do início do capítulo, deste texto de Luiz de Miranda Corrêa, proferido de um lugar interiorizado, foi pautada uma interpretação da arquitetura para a Amazônia e foi formulada em termos discursivos. No ano seguinte, em outro artigo Problemas habitacionais no trópico brasileiro, o mesmo autor, Luiz de Miranda Corrêa, a partir de paralelos com vários outros países, dentre os quais o Japão, onde havia a “moradia ecológica sonhada por Gilberto Freyre”, “fácil de construir e fácil de usar”, defendeu um "tipo de moradia adequado ao trópico brasileiro. Moradia popular e média pelo menos” (ARQUITETURA-IAB N.30, dezembro de 1964, p. 33).

$\mathrm{Na}$ imagem veiculada junto ao artigo, a moradia solitária, espelhada nas águas, avistada ao longe e envolvida quase poeticamente pela abundante natureza em distinção, conformava uma paisagem ideal, dada pela essencialidade espacial sintetizada naquela imagem de representação da Amazônia (SANTOS, 2010). Uma imagem sintética e homogênea da ambiência tipificada da Amazônia foi subordinada às expectativas elaboradas 
por Luiz de Miranda Corrêa diante da possibilidade que avistou para a Amazônia, o que incluía a arquitetura contemporânea, recurso para tornar a região civilizada. $O$ autor baseava-se em uma concepção interpretada do ambiente amazônico capturado em unidade, tipificando e mediando os modos de vida ali desenrolados. Diante do debate corrente acerca da habitação, o autor acresceu à problemática urbana, a questão da capacidade de significação da arquitetura habitacional, quando realizada na Amazônia (ARQUITETURA-IAB N.30, dezembro de 1964, p. 33):

$\mathrm{Na}$ região amazônica o problema de simples torna-se complexo. Quando os primeiros homens brancos chegaram na região encontraram apenas selvagens em estado primitivo. Nenhuma civilização que apresentasse soluções para a moradia nos trópicos.

Apenas, talvez, na alimentação, o primitivismo dos habitantes tivesse, por intuição ou pelas circunstâncias, chegado a um ponto interessante.

$[\cdots]$

Para os problemas da moradia encontramos atualmente certa receptividade no país, talvez pelos ecos que nos chegam de outras nações, e sem dúvida pela luta empreendida por um pequeno grupo de pioneiros, em que se destaca Gilberto Freyre, Arthur Cesar Ferreira Reis e Leandro Tocantins, entre outros. Luta que deveria ser comandada por arquitetos ilustres como Lúcio Costa, Oscar Niemeyer, Mindlin e tantos outros. Luta que deverá ser a ambição maior da nova Faculdade de Arquitetura da Universidade do Pará.

Esta expectativa diante da implantação da nova escola de arquitetura de Belém-PA, do ponto de vista do intelectual, a colocava o desafio de pensar a habitação sob as premissas de sua adaptação ao "trópico brasileiro". Esta adaptação perpassava o uso da madeira, material tão constantemente usado em "casas populares, médias e até mansões, no campo, na praia e na cidade", em diversas condições climáticas, na "Europa e principalmente nos Estados Unidos”, considerado nesses locais, “de qualidade inferior da Amazônia”. Luis de Miranda Correia propunha a modernização da arquitetura nessas bases, viabilizada pelo investimento de recursos materiais e intelectuais, num "programa de pesquisa e construção de conjuntos residenciais ecológicos, de alvenarias e de madeira, em amplos espaços arborizados”, como solução para a moradia do trópico brasileiro (ARQUITETURA-IAB N.30, dezembro de 1964, p. 32-33).

A realidade com a qual este grupo que passou a ocupar a administração do governo do Amazonas a partir de 1964 se defrontou em Manaus-AM, os condicionou à atuar muito diretamente com o tema da habitação. O governo estadual dirigiu especial atenção à 
dissolução da cidade flutuante, um conjunto articulado de moradias, palafitas e flutuantes, situado sobre as águas do Rio Negro ao sul da cidade, às margens urbanas da capital, no centro antigo de Manaus-AM. Os primeiros conjuntos habitacionais implantados na cidade por meio da $C O H A B-A M^{173}$ acomodaram parcialmente tais moradores, já que muitos outros se asjustaram ao espaço da cidade, em contextos destituídos de qualquer infraestrura urbana (HEIMBECKER, 2014). O artigo de Cesar Oiticica, que foi o primeiro Presidente da Companhia de Habitação do Amazonas, abordou particularidades da urbanização em Manaus, em correspondência a todos os demais artigos que abordaram a habitação, imbuídos do intento de conformá-la às premissas apontadas não unicamente por Luis de Miranda Correa, mas em sintonia com o raciocínio projetual pautado na razão construtiva e na razão planejadora (ARQUITETURA-IAB N.42, dezembro de 1965, p. 35):

[...] o presente govêrno, a grande aglomeração flutuante da entrada do pôrto já foi remoida e que a política habitacional finalmente uma realidade em Manaus, visa a construção de novas casas para essa população, prioritariamente.

Como vimos, Manaus apresenta, já alguns problemas urbanísticos notáveis. A aglomeração de flutuantes e construções palafíticas às margens dos igarapés, cuja expressão máxima, a cidade flutuante, chegou a ser uma atração turística, é o mais flagrante. Hoje, da cidade flutuante só se vê ruínas; alguns flutuantes em demolição ainda são encontrados; mas as casas "pernaltas", na beira dos igarapés, utilizando como terreno suas encostas, despejando nêles seus esgotos, usando-os como áreas de recreação para crianças, retirando de seus leitos o abastecimento de água, permanecem. Belas, muitas vêzes inventivas e por vêzes geniais, como arquitetura popular, estão fadadas, pela sua situação, a serem removidas.

Outros problemas destacados por Oiticica, com texto de acento propagandístico, disseram respeito ao "desleixo a que foi relegada a cidade e seu urbanismo" à ocupação irregular das margens pela indústria local, à uma "zona industrial” que se instalava profundamente no centro da cidade. Oiticica também abordou o crescimento "anárquico" dos bairros, o que prenunciava o "Plano Diretor para Manaus", o primeiro para a capital, acenando que “a Região Amazônica, num futuro não muito distante” poderia "tirar real partido de suas enormes riquezas potenciais" o que tornava pertinente pensar numa

\footnotetext{
${ }^{173}$ Neste mesmo número da revista, o editorial afirmava que no segmento da habitação, não se poderia "infelizmente, contar, neste campo, com muitos sucessos", para o qual o ano de 1966 se apresentava com perspectivas mais ampliadas, em função da adesão mais significativa ao vínculo dos programas de habitação ao planejamento urbano, o que de todo foi criticado pelo caráter especulativo com que, constatou o editor, vinha transcorrendo a produção da habitação no país.
} 
“expansão rápida de Manaus”. Os projetos apresentados na revista davam visibilidade à atividade governamental em curso, em articulação à dos arquitetos recém-contratados pela administração de Arthur Reis, especialmente de novos edifícios institucionais e habitações. Também era construída uma paisagem urbana, transformada pela presença de uma arquitetura modernizada, "contemporânea” [figura 30]. A temática urbana, na publicação de número 42 da revista Arquitetura-IAB, perpassava essa discussão da habitação amazônica como técnica projetual, que ia sendo articulada discursivamente a uma ideia de paisagem amazônica.
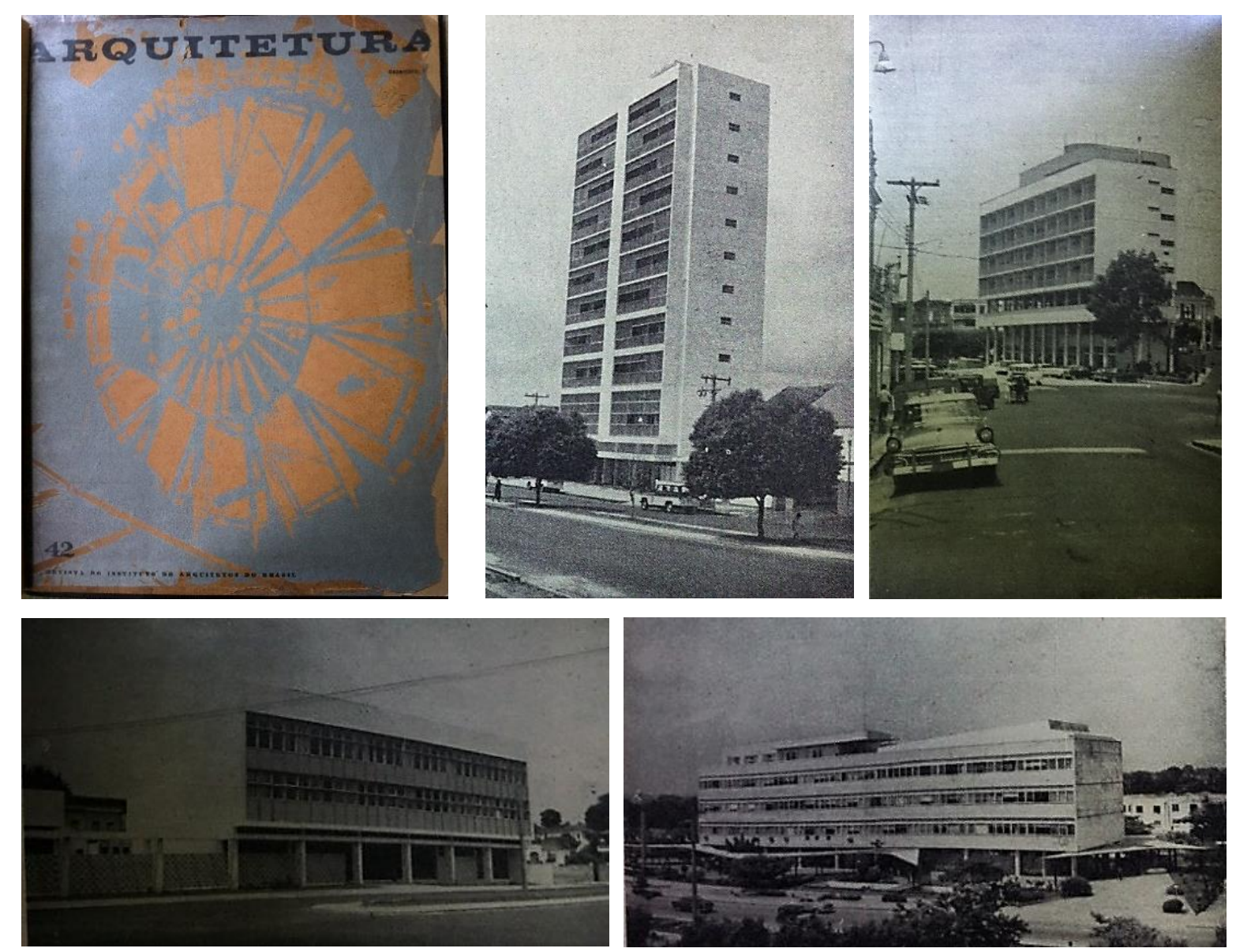

Figura 30 - Imagens publicadas no artigo Arquitetura contemporânea de Manaus. Dentre os edifícios publicados, figurou o de Paulo Antunes Ribeiro. Fonte: ARQUITETURA-IAB n.42, 1965.

Em prosseguimento à narrativa, a revista apresentou um quadro sintético da articulação proposta pelos arquitetos entre planejamento urbano, projeto de conjunto habitacional, projeto da habitação, considerados desde a premissa da ênfase à adaptação de soluções construtivas e espaciais. O raciocínio de projeto, especialmente para as moradias que seriam implantadas pela COHAB-AM, argumentou em razão da modificação dos 
projetos típicos do Serviço Federal de Habitação e Urbanismo - SERFHAU, especificamente na ampliação dos quartos para a incorporação de redes, uso de madeira nas vedações externas, padronização de esquadrias de janela com remoção de vidro e diminuição de ferragens com o uso de madeira. No memorial, o argumento era ratificado pela "pesquisa, iniciada segundo uma urgência máxima, procurando ampliar, baseado em pesquisas cientificamente orientadas, o confôrto gerado por condições ecológicas ideais” (ARQUITETURA-IAB N.42, dezembro de 1965, p. 66).

“Os homens são como os rios”. Assim Elson Farias iniciou seu escrito, sob o título de Algumas impressões de paisagens e homens dos rios do Amazonas. As águas, os rios do Amazonas foram para o autor, os componentes da memória regional, presença para o “alívio" dos olhos, as "grandes estradas”, fonte do alimento do homem. Também foram forma de dar a conhecer, sobre o pescar e os peixes, o transitar, o habitar, sobre o regime condicional de oscilação das águas, flutuando entre os mitos e a realidade. O rio foi apresentado como detentor do verdadeiro e do fantástico, mas eminentemente como componente permanente da paisagem amazônica, junto à floresta, ambos, presença absoluta nas práticas sociais e nas memórias que o autor reconstruiu desde as suas. No conjunto, entre textos e projetos, se fazia notar uma interpretação do que fosse a modernidade, todavia não completamente desgarrada das memórias daqueles próprios escritores, intelectuais nativos, que possivelmente, a não ser pela convergência das ideias absorvidas dos registros nas fontes documentais, alinhavam suas formulações às de determinados arquitetos quando estes, experimentavam a Amazônia, atraídos por aquelas ideias em movimento e pelas oportunidades de trabalho.

Uma paisagem foi apresentada como síntese da Amazônia, em alguns artigos publicados, tanto como premissa ao desenvolvimento de uma arquitetura que em tese fosse nela inscrita e a ela adaptada, conforme apontado por Elson Farias e Luiz de Miranda Corrêa, quanto para basear a validação dos projetos que vinham sendo empreendidos na região, em falas consonantes às que circulavam nas revistas. No artigo de Leandro Tocantins, Arquitetura e paisagismo na Amazônia, o escritor deixava muito evidentes os significados que elaborava para a paisagem amazônica (ARQUITETURA-IAB N.41, novembro de 1965, p. 31-34):

Venho, há tempo, insistindo na criação de uma arquitetura amazônica ecologicamente amazônica, assustado com a proliferação, em Belém e 
Manaus, e outras cidades do Vale, de casas inadaptáveis ao clima tropical, verdadeiras arrogâncias de mau senso, a causarem problemas de higiene, de saúde, de bem-estar, nem sempre percebidos pelos moradores ou proprietários, muito anchos em desfrutar uma casa "moderna" ou "funcional", como erroneamente julgam, porque o moderno nem sempre se casa com o funcional e nem o funcional se expressa daquela maneira no clima quente e úmido do Equador.

Quanto à arquitetura da habitação na Amazônia, Leandro Tocantins apresentou todo repúdio ao uso indiscriminado das "vastas superfícies de vidro", se referindo àquelas fixas, das placas de "cimento armado", utilizando-se de todo repertório higienista para defender não unicamente a arquitetura bem pensada para a Amazônia, que não as tornasse de "interior sufocante”, “casas-estufa”, “fornalhas”, “fonte de tuberculose”, “caixões de tijolo e cal”, “pé direito baixo”, sem janelas em número suficiente, fruto de engenho "disforme dos princípios de higiene e de ecologia”, “ modelos do que não deve ser uma arquitetura tropical", de "estilo modernoso". Em contraste, Tocantins apresentava um contraponto, o da "primitividade", não apenas desde a perspectiva de uma "curiosidade etnográfica", ou em estreito "ultrapassado romântico" como afirmou, mas em sua qualidade, desde uma ótica racional moderna, que a compreendia em sua ótima adaptação (ARQUITETURA-IAB N.41, novembro de 1965, p. 31-33):

[...] vejam-se as barracas da população pobre, herança do taperi indígena. Muito embora elas aparentem falta de conforto, às vezes até falta de asseio, detalhes creditados às falhas do sistema social, jamais agridem a natureza, sempre se harmonizam com os ventos, com a vegetação, com a água, com o tipo de solo.

E se as barracas tomam aspecto de favelas nas cidades de Manaus e Belém é porque, torno a insistir, entra o fator da distorção social, com todas as más consequências estéticas e higiênicas.

A barraca, em seu estado de pureza, demonstra uma visível harmonização com o meio tropical amazônico. É um valor regional em que o homem utiliza e valoriza ao máximo a paxiúba, a madeira, a palha, o cipó, facilmente encontrados na mata. Uma habitação ecológica do começo ao fim.

É lamentável que na Amazônia se esteja tão atrasado no problema da moradia ecológica.

Mas a perspectiva de Leandro Tocantins era da arquitetura entendida como um "fenômeno global", um conjunto de valores empreendidos socialmente, pela arte, na "harmonização ecológica”, sendo a moradia o cerne, lida como um fenômeno social, moral, psicológico. Daí a necessidade de sua integração "ao meio ambiente”, a partir de "raízes culturais e naturais mais profundas”, tarefa esta apropriada ao conhecimento especializado, 
do arquiteto, inclusive. ${ }^{174} \mathrm{O}$ Estado, em seu papel de conduzir a política habitacional do país, deveria a seu ver, desde os bancos de habitação, absorver as premissas norteadoras do projeto habitacional amparado na "realidade geográfica, humana, social e ecológica do Brasil”, em crítica à autonomia que se fazia notar, de casas populares construídas em regime de padronização generalizada, sob o estímulo dos próprios bancos.

Leandro Tocantins se referia a Antônio Lemos, no Pará, como um misto de "Agache e Burle Marx", em virtude de sua atuação na criação de parques e jardins públicos em BelémPA, cidade que reverenciou em detrimento de Manaus, pela maior quantidade de tradições, monumentos históricos e artísticos e em termos urbanísticos. Manaus seria "menos feliz”, em função de não ter adquirido, depois de Eduardo Ribeiro, "uma expressão ecológica na arte dos parques e jardins públicos". Também demonstrou toda expectativa pela implantação da faculdade de Arquitetura e Urbanismo da UFPA, prevendo um "movimento de solidariedade a essa riqueza arquitetônica, e de melhor compreensão do que significa em cultura e tradição".

Leandro Tocantins fazia ecoar das ideias de Lúcio Costa, também referenciando-se numa herança colonial lusa, o sentido de sua adaptação à Amazônia. Dos componentes que haviam sido adequados "inteligentemente ao meio amazônico", estavam os "pátios", "alpendres”, "beirais salientes”, “fontes de água”, "postais largos”, "venezianas, "gelosias”, e outros tantos. Seu ensaio crítico, sobretudo, foi inspirado, ganhava materialidade e visualidade com a referência que fazia ao projeto de Oswaldo Bratke para as Vilas do Amapá, Vila Serra do Navio e Vila Amazonas, uma "experiência vitoriosa de casa ecológica", uma "formulação ecológica muito clara". Ali sim, teriam sido construídas as verdadeiras habitações tropicais, já que o arquiteto tinha absorvido e transposto ao projeto, fatores de “terra, vento, vegetação, luz”, por sinal elementares à arquitetura realizada no país nos anos de 1950, quando parametrizada pelo julgo do racional. Para Tocantins, a arquitetura, junto ao paisagismo, seriam os norteadores de uma "estabilização psicossocial", sob a função de criar harmonia "para uma vida mais feliz, mais rica de produção". Ou seja, a arquitetura da adequação sintetizava o vislumbre do desenvolvimento.

\footnotetext{
${ }^{174} \mathrm{O}$ escritor apresenta as referências do pensamento social brasileiro desenvolvido em Pernambuco, na pessoa de Mauro Mota, também de George Patrix, sobre a arte destituída da restrição institucionalizada dos museus, mas como produto a consumo geral.
} 
Mas aquela arquitetura refletia simbolicamente para Leandro Tocantins, as múltiplas temporalidades regionais da cultura na Amazônia, a "simplicidade da arquitetura primitiva do índio", os "valores europeus e extra-europeus”, além dos regionais, e suas formas, quando transpostas à uma cultura material, numa "mesclagem de formas e estilos adaptáveis ao meio amazônico", "formas de simplicidade e de clareza estrutural”. O projeto de Bratke, enfim, seria um marco, um "ponto de partida para a criação da reclamável casa ecológica na Amazônia”. As soluções às quais se referiu Tocantins, as que considerou dignas de reprodução, foram as que dotaram as casas de ventilação permanente e cruzada, garantida pelas grandes aberturas teladas e persianas de madeira, pelo colchão de ar projetado para entre o forro e o telhado. Ou seja, tratava-se de uma arquitetura que almejava alcançar uma linguagem universal e estava mito ancorada em ideais adaptativos, como pareceu a Lúcio Costa. E Leandro Tocantins tinha esta questão em perpectiva, ao enunciar o "progresso social e econômico da Amazônia” pelo "especificamente regional ao abstratamente universal”, numa retomada de Gilberto Freyre (ARQUITETURA-IAB N.41, novembro de 1965, p. 31-33).

A noção de adaptabilidade na arquitetura, capturada como que em exclusividade num “monopólio modernista” que vem sendo reafirmado pela historiografia, tem, no entanto, sua própria historicidade, como aponta Telma de Barros Corrêa. A partir da década de 1930, a ideia da adaptabilidade foi um conceito assimilado ao discurso dos arquitetos brasileiros e convertido em atributo da produção de uma moderna arquitetura no país desde então. Todavia o conceito, como também foi possível identificar ao longo da feitura da tese, já circulava entre "homens letrados vinculados a vários campos do conhecimento" desde o século XIX. A autora rememora inclusive que a adaptação era tema corrente no início do século XX, a exemplo de artigos das décadas de 1920 e 1930, de autores como médicos e engenheiros, em todo o país. A ideia da qualidade da adaptação era muito relacionada ao ajustamento da arquitetura ao clima. Revigorados por Gilberto Freyre, que exerceu influência direta sobre o pensamento de Lúcio Costa, os atributos de adequação passaram a ser "sistematicamente celebradas", nesses termos, como qualidade de adequação em termos climáticos. Também como uma "plasticidade”, equivalente à qualidade da adaptação física da edificação ao sítio, e a fusão do novo ao tradicional, especialmente quanto a técnicas construtivas. Como forma em continuidade, dois “caminhos básicos” foram adotados por 
arquitetos brasileiros, os que seguiam "na busca de soluções inovadoras de adequação ao clima”, e os que pensavam "o uso de técnicas construtivas tradicionais de forma inovadora", ou de "soluções construtivas inovadoras por meio de meios técnicos disponíveis", como nas Vilas projetadas por Oswaldo Bratke no Amapá (CORREIA, 2009).

Naquele ano de 1965, no Salão Hors Concours da $8^{a}$ Bienal de São Paulo, centro das "mais expressivas manifestações do avanço da arte moderna" (ARQUITETURA-IAB N.41, novembro de 1965, p. 35) foram feitas três homenagens, aos arquitetos Oswaldo Bratke, Carlos Millan e Vilanova Artigas. Do primeiro, a obra destacada foi justamente a relacionada aos projetos que realizou para as cidades empresa da ICOMI, Vilas Serra do Navio e Amazonas [figura 34]. Apresentados pelo arquiteto Lauro Bastos Birkholz na exposição, os projetos foram valorados pela "concepção arquitetônica diretamente ligada às condições de solo e de clima, existentes na região", em localidade isolada dos grandes centros, sem tradição construtiva, constituindo um primeiro "empreendimento realizado racionalmente nessa zona", e que por se tratarem de núcleos urbanos, deveriam orientar o desenvolvimento do lugar dali por diante (ARQUITETURA-IAB N.41, novembro de 1965, p. 24).

Intitulada Casa ecológica da Amazônia consagrada na Bienal de São Paulo, ${ }^{175}$ [figura 32] uma matéria publicada logo após a de Leandro Tocantins na revista Arqutetura-IAB n.41, revelou detalhes dos projetos em um dos "stands mais concorridos na Bienal de Arquitetura, positivando o enorme interesse despertado pelo empreendimento que implantou a civilização na zona tropical brasileira" (ARQUITETURA-IAB N.41, novembro de 1965, p. 35).

\footnotetext{
${ }^{175}$ A exposição dos projetos para o Amapá, segundo informado na revista, seguiria para o Rio de Janeiro, depois para o Norte, e em seguida, para outros países da América e Europa.
} 

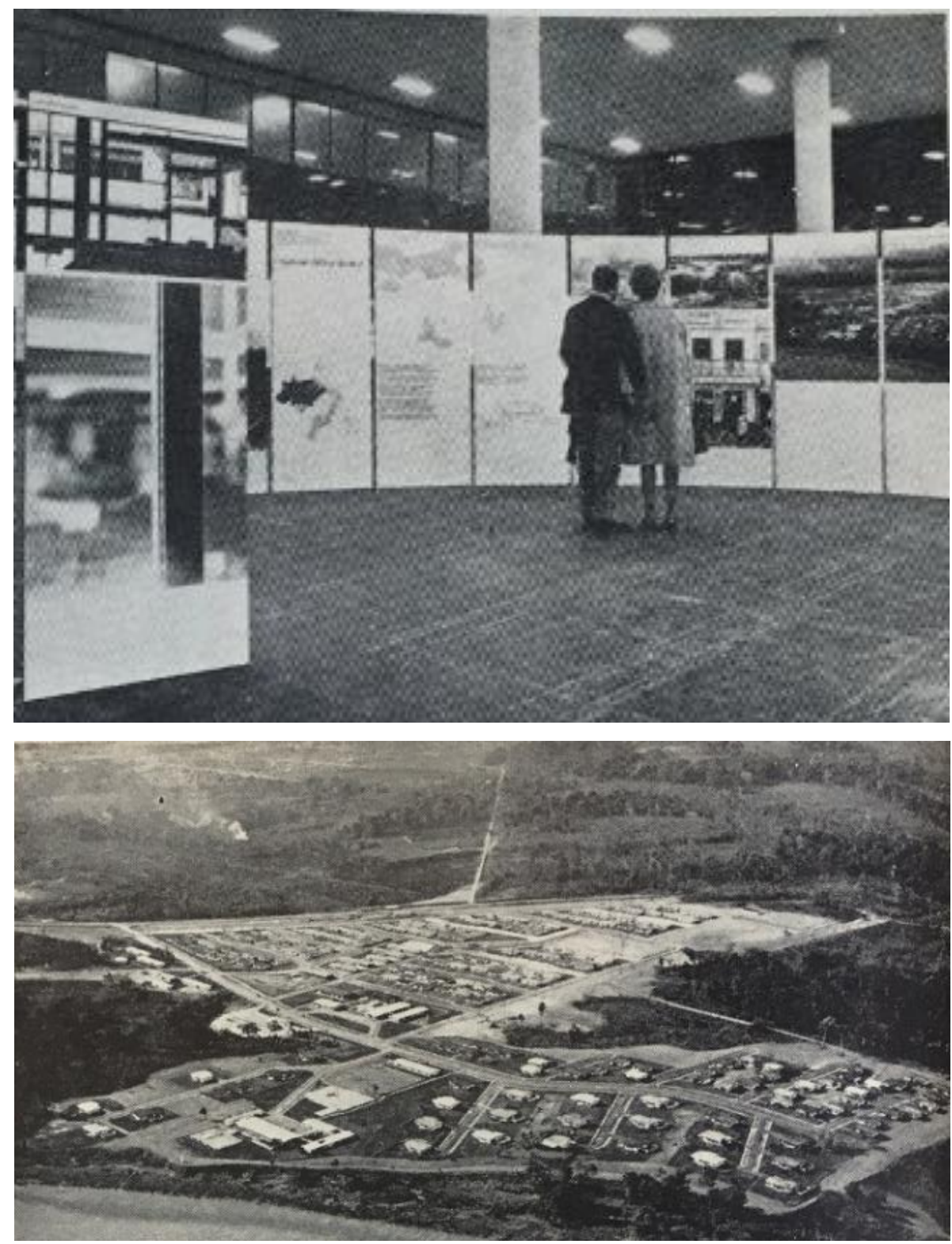

Figura 31 - Imagens veiculadas no artigo Casa ecológica da Amazônia consagrada na Bienal de São Paulo. Fonte: ARQUITETURA-IAB n.41, 1965, p. 35-38.

A sintonia com os escritos de Leandro Tocantins sugere que o texto que acompanhou a matéria a respeito da exposição dos projetos de Oswaldo Bratke na Bienal, que não foi assinado, tenha sido redigido por ele também, pela similaridade entre os textos, no segmento que aborda "A casa ecológica". Os projetos das Vilas Serra do Navio e Amazonas, desenvolvidos por Oswaldo Bratke para serem implantados no Amapá entre os anos de 1955 e 1959, foram produto da contratação do arquiteto pela empresa ICOMI Indústria e Comércio de Minérios S/A, que realizaria atividades exploratórias de jazidas 
minerais na região amazônica, ${ }^{176}$ mais especialmente no que era o Território Federal do Amapá, por meio de concessão pública, ${ }^{177}$ entre os anos de 1953 e 2003 . O texto enfatizou as qualidades do projeto, sua importância para a região, muito aos moldes da crítica feita por Leandro Tocantins. Outra revista publicada no ano seguinte, apresentou matéria mais completa, com desenhos e imagens dos espaços projetados pelo arquiteto em pleno uso, habitados e em funcionamento. Nela foi narrado o transcurso, da motivação original do projeto à obra finalizada, com a objetividade apropriada a dar visibilidade ao projeto desde o ponto de vista de sua formulação, como feito estritamente técnico, revelado como agente da modernização regional e do processo civilizador quando atingindo àquela região (ACRÓPOLE N.326, março de 1966).

Em janeiro de 1964, Leandro Tocantins havia estado na Vila Serra do Navio, onde proferiu a palestra Amazônia: fundamentos de paisagem, vida e história, que seria publicada no mesmo ano pela SPVEA, com apresentação de Luiz de Miranda Corrêa. O texto definiu a paisagem em equivalência aos "cenários" do local. Também falou das "diferentes Amazônias”, em distinções geográficas que iriam “dos campos do Amapá e do Rio Branco às terras cobertas pela floresta equatorial, ou ao litoral paraense”, enaltecendo da fala de Leandro Tocantins, esta perspectiva múltipla da região, de suas fronteiras, e da "vocação lusotropicalista” daquele escritor paraense, que havia sido "anunciada por Gilberto Freyre, em conferência que pronunciou na Universidade de Recife, sôbre uma possível lusotropicologia na Amazônia”, sobretudo na visão de uma paisagem porvir, demarcada pela colonização modernizadora, pela ocupação que até então não havia sido realizada. As

\footnotetext{
${ }^{176}$ Josalfredo Borges, engenheiro do Departamento Nacional de Produção Mineral, constatou a existência de minério de manganês no vale do Rio Amapari em 1934 e em 1945 foram descobertas jazidas de minério de ferro no vale do rio Vila Nova, ambas de grande relevância econômica (RIBEIRO, 1992, p. 11). A atuação da empresa ICOMI na região foi dada desde os anos de 1940, e o ingresso do capital estrangeiro para a realização das atividades de extração e beneficiamento primário do manganês foi dado pela sua fusão à americana Bethlehem Steel Co em 1949, numa "primeira experiência de mineração industrial na Amazônia que conviveu historicamente com a fragilidade da organização da sociedade civil local”. 1997 foi o ano do encerramento das atividades de lavra naquele sítio (MONTEIRO e COELHO, 2003, p. 4-5).

177 De propriedade do engenheiro paulista Augusto Trajano de Azevedo Antunes, a ICOMI, venceu a concorrência pública internacional para o arrendamento das jazidas de manganês no Amapá, assinando vários contratos de concessão com o Governo local. Em 1947 e 1950 para concessão mineral, em 1953 para construção de embarcadouro de minério no Porto Macapá (ou Santana), no estuário do rio Amazonas, no mesmo ano, para construção de estrada de ferro voltada à logística do minério extraído. Antecedendo a realização de suas atividades fins, a empresa deveria construir acampamentos provisórios nas frentes de trabalho, um porto uma estrada de ferro, instalações industriais e duas vilas residenciais para os trabalhadores e suas famílias (RIBEIRO, 1992, p. 13).
} 
expectativas diante desta possibilidade de civilização da Amazônia, compreendida como o contraponto mais direto ao ambiente miticamente selvagem, circulava entre os intelectuais locais. Para Miranda Corrêa, esta condição de desenvolvimento também decorreria da industrialização e diversificação econômica que vislumbravam naquele momento de “euforia econômica” para a região (TOCANTINS, janeiro de 1964, p. 4).
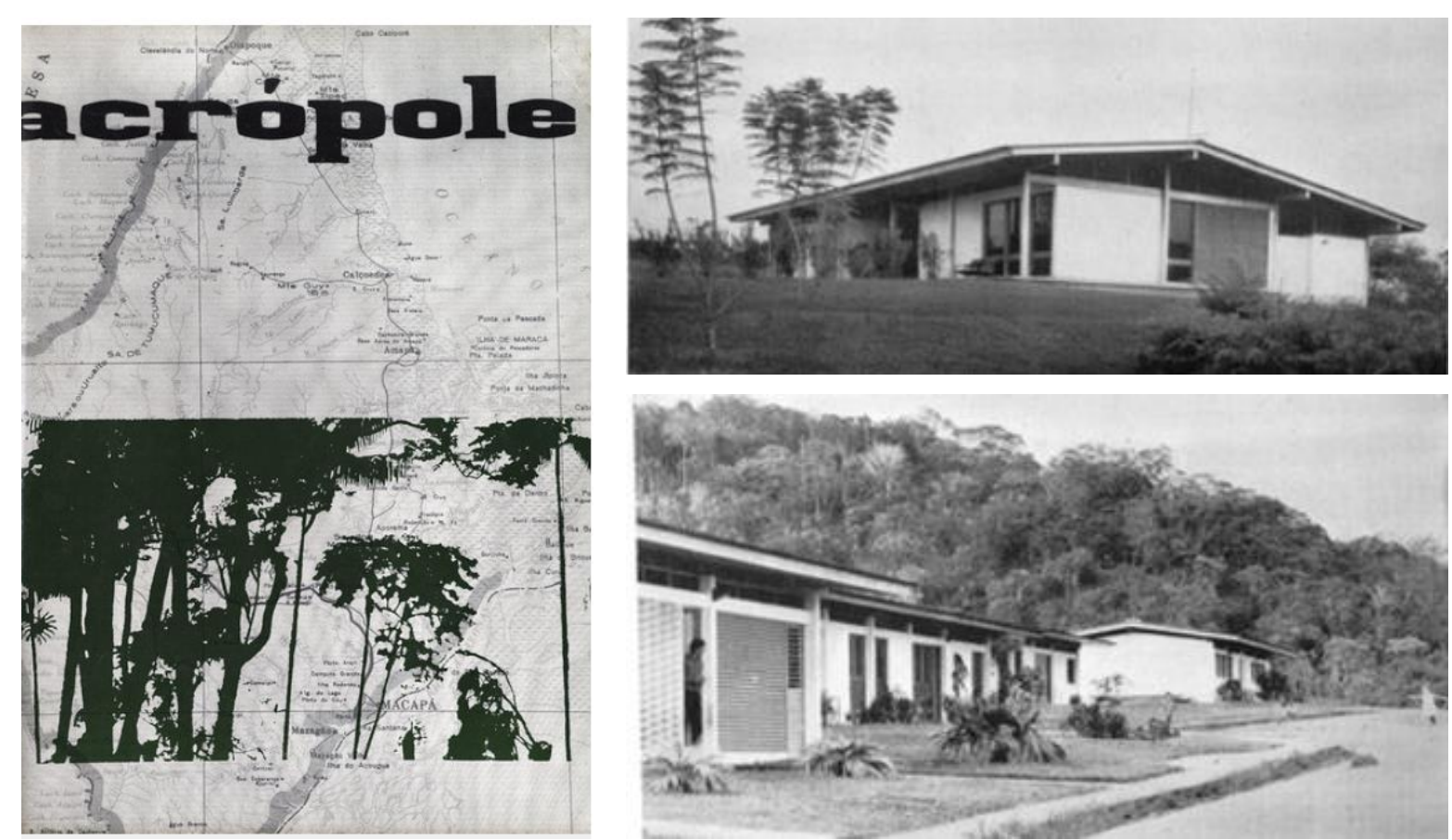

Figura 32 - Habitações projetadas pelo arquiteto Oswaldo Bratke e capa da revista em que foram publicadas, em artigo intitulado Núcleos Habitacionais no Amapá.

Fonte: ACRÓPOLE n.326, 1966, p. 17-38.

Leandro Tocantins, por sua vez, reforçava no discurso que foi registrado por escrito, o pioneirismo daqueles moradores de Serra do Navio, de "humanizar” o Amapá, “com um sentido regional e ao mesmo tempo universal de vida”. Os inscrevia no transcurso histórico, que narrou desde a colonização até aquele estágio da Amazônia, retomando todos os matizes ficcionais consagrados sobre a região, atestando que a "região amazônica, espetacularmente, não se traduz como um todo harmônico” em seus aspectos físicos, e nesse ponto, seria uma unidade que apresentava desigualdades, já que “o lago, o igapó, a várzea, o têso, a terra firme, a floresta, o campo, o rio, a baía, o mangue, a cachoeira, vocabulário comum na Amazônia, tôdas estas denominações possuem um sentido de definição variada". Das amazônias, coube a Leandro Tocantins falar quanto às "vocações regionais", de uma Amazônia entendida como uma "ilha ecológica”, cuja trajetória histórica 
que expôs em detalhe, a levou a ser tornada Amazônia Legal pela Lei 1.806, como foi estabelecida em termos político administrativos (TOCANTINS, janeiro de 1964). Sua abordagem esteve muito centrada na atuação do Estado sobre a Amazônia, norteado pela expectativa de modernização do país pelas vias da integração regional ao território nacional. $\mathrm{Na}$ oportunidade, abordou a questão da "arquitetura regional”, a "casa ecológica amazônica tanto a urbana como a rural", para a qual observou aos presentes (TOCANTINS, janeiro de 1964, p. 22):

É tempo de nos preocuparmos em criar para a Amazônia o seu tipo ideal de habitação, valendo-nos da experiência regional, da matéria prima local, das condições de clima, de vegetação, de luz, de ventilação, e não copiarmos servilmente a arquitetura do Rio e São Paulo, como se observa em Belém do Pará.

Uma arquitetura que também reabilite o azulejo, na paisagem amazônica, onde êle sempre desempenhou função estética, higiênica, funcional e sentimental.

O outro texto de autoria de Leandro Tocantins já mencionado, presente na revista Arquitetura-IAB n. 41, foi publicado pelo governo do estado do Amazonas um ano depois daquela revista, no ano de 1966. Nele, a aproximação às ideias de Arthur Ferreira Reis foram registradas de partida na apresentação que o então governador do Amazonas fez ao escrito de Leandro Tocantins, na qual expressou uma definição precisa para a "paisagem material da Amazônia”, elaborada em seu julgo havia trezentos anos, no qual considerou a paisagem. Sua referência de datação era, como para Lúcio Costa e mesmo Gilberto Freyre, a referenciada no contato luso com o Brasil em geral e com a Amazônia, em particular (TOCANTINS, 1966, p. 3):

\begin{abstract}
A paisagem material da Amazônia, isto é, aquela em que o homem interfere para criá-la, disciplinando a natureza, utilizando-a e transformando-a para ajustá-la aos seus desejos e ao seu sentido estético, não foi objeto de análise do sociólogo nem do urbanista. Vem constituindo capítulo por propor a exame para as conclusões sôbre seus acertos ou a conveniência de sua transformação.
\end{abstract}

Essa conveniência foi centrada na habitação primordial, a que Arthur Reis condicionou, como premissa de uma "resposta justa" ao clima, aos materiais, desde um raciocínio que poderia servir de base inclusive à "política de estado", "visando a casa ecológica, o bairro ecológico, a estrutura dos edifícios de maior porte arquitetônico dentro de exigências ecológicas. E com a casa, a rua, a praça pública, o jardim, tudo enfim, que 
significasse integração humana no ambiente tropical que nos define”. A defesa desta integração total, na qual subjazia certa afetação de senso urbanístico, constituía a “problemática da existência regional” dos trópicos, para Arthur Reis (TOCANTINS, 1966, p. 3).

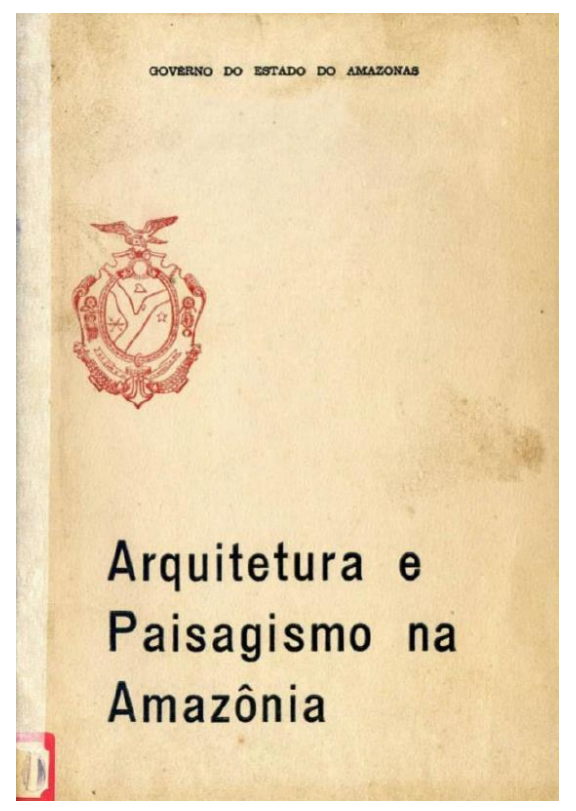

Figura 33 - Arquitetura e Paisagismo na Amazônia, de Leandro Tocantins (TOCANTINS, 1966).

Essas formulações foram marcadamente sintetizadas numa revista, a que finaliza este presente recorte. A Amazônia brasileira foi representada em uma edição impressa em 196768, o número 1 da revista Arquitetura Brasileira do Ano, sob o título de Amazonas [figura 34]. Elas apareceram articuladas à veiculação do que seria o intento de modernização urbana neste estado, partilhado por parte de arquitetos, intelectuais, políticos. A revista realçou o empreendimento estatal levado à região com a administração de Arthur César Ferreira Reis. As referidas formulações foram demarcadas na publicação, meio propagador do discurso oficial desenvolvimentista e conservador desses anos, em sua constituição narrativa e editorial, entrelaçadas diretamente à produção material descrita e ilustrada na revista, oriunda do campo da Arquitetura e Urbanismo, para o qual ela foi a princípio dirigida.

Compôs o conjunto concatenado de conteúdos da primeira $\mathrm{ABA}$, em edição bilíngue, marcada pelo visível esforço de estabelecimento de demarcações temporais da modernização regional, além dos desenhos e memórias dos projetos e obras construídas, formulações de significados a respeito da Amazônia brasileira, elaborada como uma unidade 
cultural, ambiental, social, material, geográfica, histórica e para a presente tese, sobretudo, como unidade de paisagem. A estruturação das referências visuais e dos escritos, de projetos e temas de Arquitetura e Urbanismo, basearam o discurso de um processo apresentado como inevitável, o do desenvolvimento regional. A revista foi também suporte propagador das transformações empreendidas pelo Estado Nacional na Amazônia brasileira durante o governo militar, de domínio e colonização territorial, junto ao programa de sua integração à nação.

As imagens domesticadas de mulheres e homens indígenas e seringueiros anônimos, das habitações tipificadas, fossem tapiris ou palafitas, da paisagem natural genérica, foram iniciais na revista, compondo um sentido de ancestralidade e origem, que forneceu argumento às intervenções modernizadoras e aos projetos desenvolvidos por arquitetos recém-contratados pelo Estado. Os projetistas foram incumbidos de diversos encargos, dentre os quais o Plano Diretor de Manaus, as habitações da Companhia de Habitação do Amazonas, hotéis e aparato institucional novo, como as sedes da Camtel, Portobrás e Dera. Os projetos e seus programas, as imagens veiculadas, os escritos, dentre os quais figuraram um do próprio Arthur Reis, e ao fim, a editoração, compuseram aquele conjunto sintético de uma narrativa da paisagem. Dos projetos publicados na revista, quatro foram de autoria de Luiz Antony e Pereira da Cunha, ${ }^{178}$ dois de Cesar Oiticica, ${ }^{179}$ oito de Severiano Mario Porto, ${ }^{180}$ um referenciado nas atividades da COHAB-AM. Os artigos na revista foram assinados pelo Marechal Joaquim Justino Alves Bastos, pelo governador Arthur Cezar Ferreira Reis, pelo próprio Leandro Tocantins, por Luiz de Miranda Correa, com dois artigos, Maurício Joppert da Silva, ${ }^{181}$ Eudes Prado Lopes, ${ }^{182}$ Alberto Rocha, o geógrafo Orlando Valverde, sem que tenha sido identificado nomeadamente o autor do editorial da revista.

\footnotetext{
${ }^{178}$ Foram estes, o Plano Diretor de Manaus, o Plano de Urbanização do Bairro da Raiz, o Palácio da Cultura Lôbo D’Almada, o Departamneto de Estradas de Rodagem.

${ }^{179}$ Nomeadamente "Experiência do clima e materiais na habitação popular" e Secretaria de Coordenação e Planejamento e CODEAMA.

${ }^{180}$ Companhia Amazonense de telecomunicações - CAMTEL, Polícia Militar do Amazonas, Secretaria da Produção do Amazonas, Estudo para Remodelação do Parque 10 de Novembro, Hotel de 10 quartos para região de caça e pesca, restaurante chapéu de palha, Escolas pré-fabricadas, Residência do Arquiteto.

${ }^{181}$ Registro de uma conferência que proferiu no clube de engenharia em 19 de abril de 1968.

${ }^{182}$ Registro de uma conferência que proferiu no clube de engenharia em 16 de abril de 1968.
} 

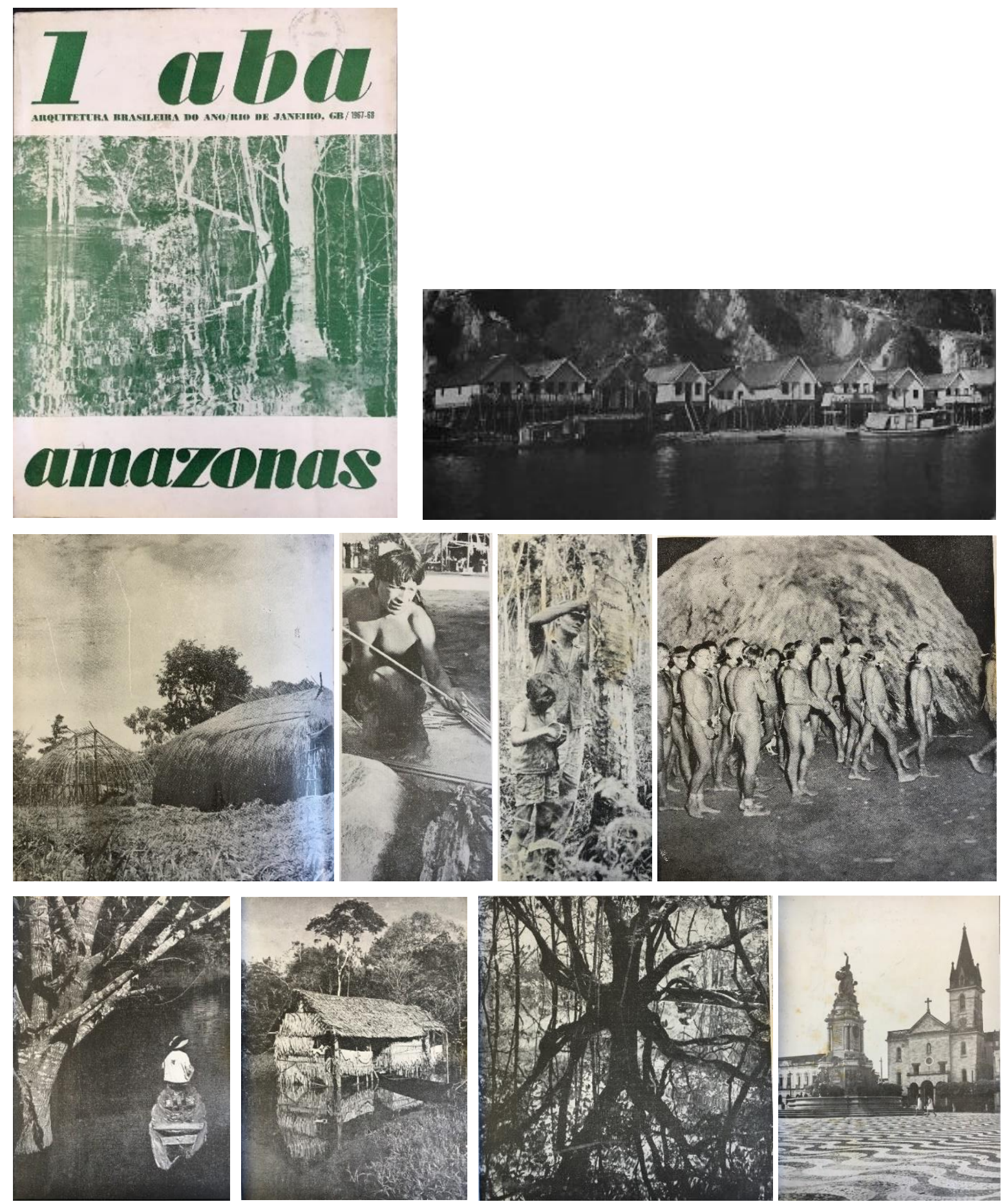

Figura 34 - Imagens localizadas antes da publicação dos projetos na revista Arquitetura Brasileira do Ano. Fonte: ABA n.1, 1967-68.

Ainda que tematizada no Amazonas, os recortes na publicação oscilaram entre o regional e o local, sendo os textos, em geral, voltados à formulações explicativas totalizantes da região. A narrativa em síntese, quando historicizada, foi composta pela chegada dos conquistadores ibéricos à Amazônia Ocidental, para "conquistar e ocupar o espaço", que se 
depararam com "tribos nômades vivendo em pleno mundo pré-histórico". Manaus teria que “esperar o militar Lobo D’Almada”, um militar português, para no século XVIII adquirir uma feição própria de arquitetura. No Império, quando o Amazonas não era mais dependente do Grão-Pará, foram construídos seus principais prédios, em "neoclássico abrasileirado e simplificado". Com a economia da borracha, no século XIX, Manaus e Belém seriam tornadas centros de modernização da "América do Sul", o que possibilitou a existência "em plena selva tropical, da mais moderna cidade de língua portuguesa", neste caso, Manaus-AM. Várias narrativas levantadas ao longo desta pesquisa, as quais não será possível enumerar, deslocam essa centralidade a Belém-PA (ABA N.1, 1967-68, p. 13).

Retomando a narrativa, a sociedade local teria sido formada a partir do dinamismo conferido pela economia da borracha, quando passou a haver umas sociedade nova e plural. Eram feitas fortunas, "às custas dos seringais", o que possibilitou o alcance da modernidade referenciada na França e Inglaterra, fosse nos serviços, fosse nos hábitos, ou nos modos de "construir à europeia", de gosto importado. Esta teria sido, na narrativa, uma primeira modernidade. Depois, veio a decadência econômica. Pouco foi construído entre 1920 e 1950 e o que era feito, era de mau gosto, com poucos recursos e eram produzidos os piores resultados em termos construtivos. Até que os feitos de Lúcio Costa e Oscar Niemeyer, inspirados em Le Cobursier, teriam repercutido "na distante e decadente cidade amazônica". Os "monstruosos edifícios" feitos até 1964 eram "pobres imitações” do que se fazia no centro-sul brasileiro, sob a terminologia de um "funcionalismo". Então, o ano de 1964 teria sido de uma revolução, porque com o "sociólogo Arthur Cezar Ferreira Reis", "toda uma mentalidade e maneia de viver” foram alteradas, já que até então a sociedade local estaria "mergulhada em um imenso conformismo" (ABA N.1, 1967-68, p. 15).

De fato, Arthur Ferreira Reis convocou uma equipe de arquitetos do Rio de Janeiro, São Paulo e mesmo estrangeiros, que quiseram "viver a aventura amazônica", e que no Amazonas, segundo ele próprio, vinham atuando na busca da "arquitetura tropical brasileira". Dentre eles estiveram Severiano Mário Porto, Luiz Carlos Antony, César Oiticca, Fernando Pereira da Cunha, Leon Shastri e Ivan Pimentel. Em suas obras, eram aplicados articuladamente:

os componentes amazônicos integrados à linha mestra da arquitetura brasileira, filha legítima da arquitetura de Le Corbusier. Componentes identificados com a ecologia regional, como sejam águas cruzadas, espaços 
permitindo a utilização de rêdes para dormir, material de construção aconselhável pelo clima do trópico úmido, pisos elevados, lagos, espaços abertos à ventilação, venezianas, utilização de madeiras regionais, em larga escala, ausência de lajes de cimento, etc. isto tudo foi utilizado numa arquitetura que se harmoniza pelo seu próprio traço e pelo material que utiliza.

$[\ldots]$

a evolução do arquiteto Severiano Pôrto, que, à medida que aumentava sua vivência amazônica, e, mais particularmente, amazonense, se identificava com os hábitos locais, ultrapassando sua fase de arquiteto puramente brasileiro, como se evidencia nos projetos da CAMTEL e Assembleia Estadual, passando pelos já amazônicos projetos de Grupos Escolares e Ginásios, onde a preocupação com as peculiaridades regionais é evidente, até atingir a sua fase de arquiteto amazonense, no Projeto da Secretaria de Produção, e, mais definitivamente, no essencialmente amazônico Chapéu de Palha. Neste último a ecologia regional foi respeitada em todos os sentidos e os materiais de construção utilizados são os locais, desde a palha de palmeira até as vigas de aquariquara, esta, madeira regional de grande resistência ao tempo.

Severiano Porto estaria se "transformando" assim, no “inventor da arquitetura amazônica", como no argumento na revista, pela assimilação de "valores regionais" experimentados principalmente a partir de sua vivência em Manaus. Seria este o encontro mais decisivo, frente às expectativas a uma dada materialidade que quase naturalmente ele estava a desenvolver, em resposta, evocando uma memória daqueles que discursivamente elaboravam algum sentido de unidade ética para aquela arquitetura. Severiano Porto, aos olhos de Arthur Reis, estaria iniciando uma verdadeira revolução, a que estava sendo reclamada tanto por ele quanto por Leandro Tocantins, Gilberto Freyre, em vários meios, fossem suas palestras, livros, ou "artigos de revistas especializadas", das que foram identificadas. Seus projetos de modo geral, responderiam àquelas expectativas partilhadas de respeito à “ecologia regional”, em ambiguidade e tensão, dada a crescente transformação territorial e nos centros urbanos amazônicos. Sua mobilização à busca pela forma conciliatória a esses processos mais agressivos de transformação do espaço amazônico, era compreendida ao tempo por esse grupo, como de uma nova "escola tropical" da Arquitetura brasileira (ABA N.1, 1967-68, p. 16).

Os projetos adquiriram feições bem diversas, nas soluções técnicas, nas configurações formais, temas e questões que apresentaram do ponto de vista construtivo. Seu alinhamento, no âmbito da revista, foi dado pela narrativa, não por terem tido correspondência mais direta na conformação de um traço projetual comum, ou mesmo 
absolutamente distinto de vertentes da arquitetura brasileira em curso, constituindo uma tradição ou uma linha de projeto detentora de feição própria e inédita, cujas diretrizes pudessem ser mais claramente reveladas como de uma "arquitetura tropical". Questões correntes, relativas à pré-fabricação, à racionalidade construtiva, às soluções técnicas de conforto, privilegiada a aeração natural, foram uma preocupação em comum entre aqueles arquitetos. Assim como uma dose de pragmatistmo que lhes conferiu rigor técnico, na escolha de materiais disponíveis, dada a necessária exequibilidade dos projetos. A exceção ficou por conta do projeto de Sérgio Bernardes, uma estrutura cupular climatizada, de grandes dimensões, para abrigar um hotel que não chegou a ser construído.
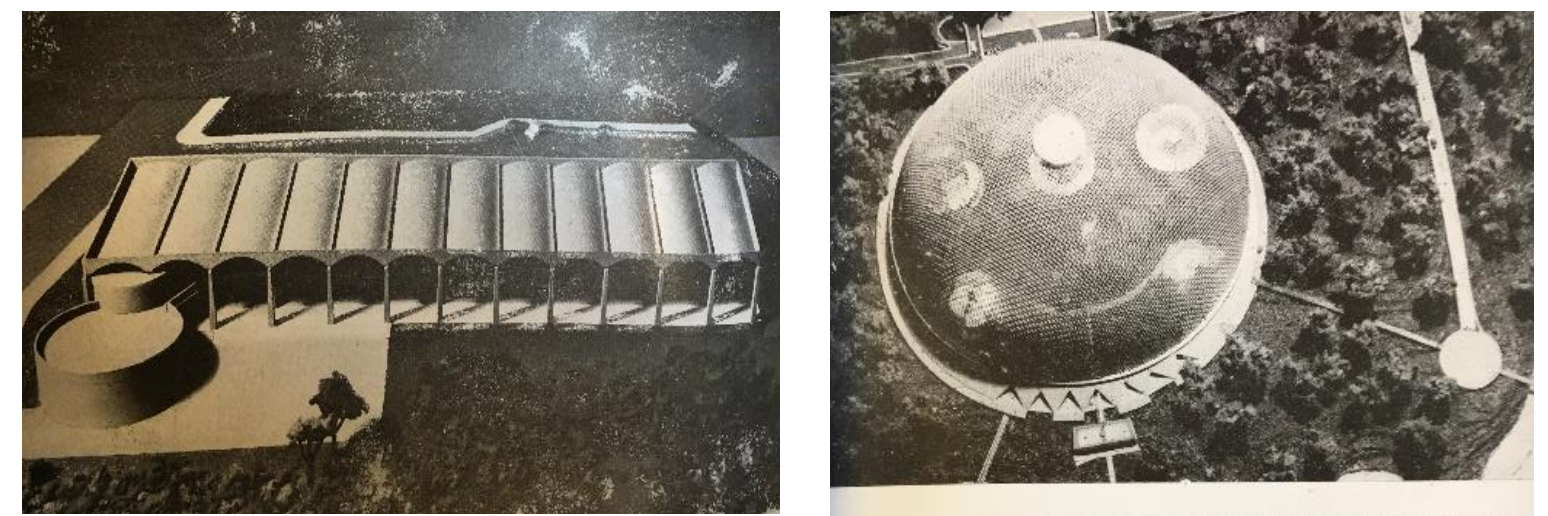

01
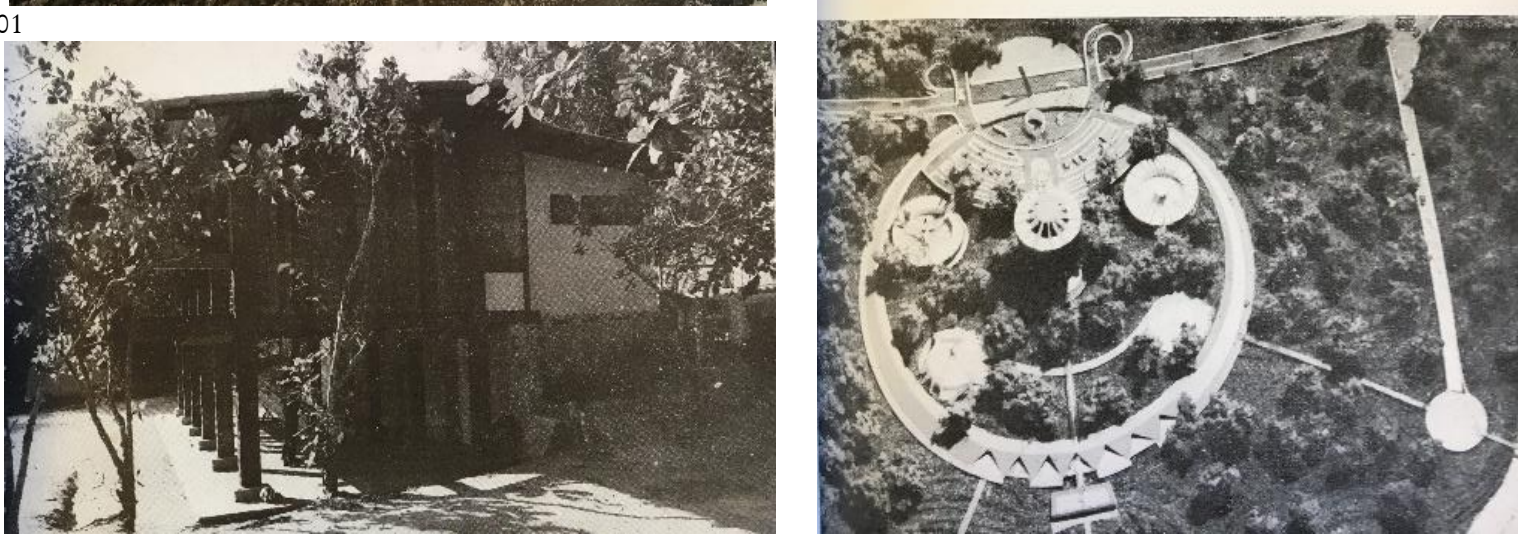

03

Figura 35 - Três projetos de edifícios publicados isolados de contextualidade urbana, na revista ABA-1, em Manaus-AM. Departamento de Estradas de Rodagem-DRM, de Luiz Antony e Pereira da Cunha (1), primeira casa do arquiteto Severiano Porto (2) e Projeto de Sérgio Bernardes para hotel (3). Fonte: ABA n.1, 1967-68, p. 70, 125, 133.

Todavia, a maior tentativa de conciliação dos projetos foi com a paisagem narrada em transformação, fruto da memória, da elaboração e da enunciação do lugar de inscrição desses projetos. Os superlativos do "mundo amazônico", "tôda imensa gleba desdobrada ao norte e ao sul do Rio Amazonas, desde as cabeceiras de sues caudalosos afluentes 
meridionais até os limites do Brasil", "mundo gigantesco onde a presença humana se vem realizando com certa lentidão", em seu recém ingresso na "rotina da vida moderna" especialmente nos "pólos de civilização", Belém-PA e Manaus-AM, pelas “grandes estradas de rodagem, as largas e revestidas de asfalto ou de cimento, a rasgarem a solidão dos campos" (ABA N.1, 1967-68, p. 20-26). Por um lado, os projetos publicados [figura 35] estavam estreitamente relacionados aos debates a seu tempo, sobre a participação profissional na atividade planejadora, no desenvolvimento de planos diretores, na projetação de habitações populares, com vistas a ampliação da prática e seu fortalecimento em novas frentes junto à sociedade. Por outro, os projetos estabeleciam a ponte com o discurso intelectualizado sobre a Amazônia, trazendo à materialidade da arquitetura mais contundentemente, uma paisagem narrada, em consonância as premissas intelectualizadas e os interesses tanto dos profissionais quanto dos agentes políticos, com a projeção regional do lugar, sua integração com o país, e das novas obras, agentes do desenvolvimento regional e de sua modernização material.

A tensão identitária, entre uma Amazônia idealizada e uma Amazônia como concretude, se fundiam na elaboração intelectual e estensivamente, na materialidade dos projetos em curso. De um lado, a evocação da Hinterlândia, compreendida como o espaço utópico, elaborado, desde o qual emerge um modo de vida arraigado ao ambiente, de outro sua associação à habitação ecológica da formulação discursiva de Leandro Tocantins, em uma modernidade aspirada. De um lado, os modos de vida transcorridos na Amazônia, perdurados até o presente, por outro, os efeitos mais expressivos, jamais experimentados até então, da transformação do espaço amazônico. As mediações realizadas pela imprensa, as fotografias das revistas populares, as chamadas de grande efeito, mesmo a própria atividade interventora do Estado ditatorial, mobilizaria as mentes à velocidade de ação sobre o meio natural e espaços interiorizados na Amazônia, desde os anos de 1960. Esta seria a dualidade, tornada uma tentativa conciliatória pelos arquitetos, que permearia uma série de outras experiências projetuais com a Amazônia, ainda que transcorridas em contextos urbanos.

Se observada a perspectiva de que a atuação do Estado sobre a Amazônia foi mais agressiva a partir da década de 1960, é possível que seja identificado traços do dilema tradição/modernidade apontado por Adrian Gorelik, todavia, neste caso, apresentado 
simultaneamente sob duas premissas as quais o autor aproxima recortes temporais. Primeiro, a ideia de que no Brasil, como em outros países da América Latina, o Estado participou diretamente da efetivação de uma arquitetura moderna, desde os anos de 1930, na qual esteve investida a construção de uma identidade comum nacional (GORELIK, 2005, p. 31). No caso brasileiro, o passado deveria de antemão, passar por um processo de construção, inclusive estética, na qual a arquitetura foi importante meio para materializar a modernização e difundir uma ideia de futuro nela pautada.

A outra premissa comportaria dois fenômenos históricos específicos, datados. Um relacionado aos efeitos do pós-guerra, desde quando todo um movimento europeu de questionamento aos paradigmas da modernização como pauta de futuro, a ressignificou em negação, o que na arquitetura viria a ser constituído como um movimento, em termos gerais, de resgate da cidade real e de suas manifestações sob múltiplas acepções, em um “pós-modernismo". Se na Europa e nos Estados Unidos, esse movimento foi baseado em formas de resgate da história, também da cultura popular, ou da cultura de massa, na América Latina foi dada como uma negação da cidade, em um debate "antimetropolitano", por razões relacionadas aos limites sociais de alcance da modernização, para aos movimentos interessados na superação do subdesenvolvimento, como os da reforma agrária e urbana (GORELIK, junho de 2005). Concomitantemente, os efeitos da realização de Brasília sobre a disciplina, teriam aberto campo à outras realizações, fosse na própria prática disciplinar de projeto, fosse junto a novos temas de interesse profissional, calcados na cidade real.

No Brasil, as diferenças sociais urbanas mobilizariam os arquitetos a enveredarem pelas ciências sociais e estudos políticos, ainda que não paralisada a atividade projetual, para uma localização mais precisa, entre os anos de 1960 e 1980. Em acréscimo, o popular e o mundo rural foram evocados como portadores de raízes culturais e forma de valoração de novas arquiteturas. $O$ aporte cultural de uma cultura tipificada na narrativa da amazonicidade serviu aos intentos daqueles intelectuais movidos pelos ideais modernizadores e pelo próprio posto que ocuparam na atividade política, mais especificamente junto ao governo militar, mas não foram perpetuados integralmente como tais. Havia certo romantismo, todavia, entre os mesmos intelectuais, como se absorvidos pelos “arquétipos reconfortantes do passado" (COHEN, 2013, p. 11). Se sua participação 
mais efetiva possibilitou o engajamento de determinados arquitetos na formulação de uma arquitetura atrelada ao seu discurso, materializando-o a partir de códigos da disciplina arquitetônica, e em diálogo com seus próprios referenciais culturais, esta mesma participação se utilizou de modo independente ao mesmo discurso, transitando mesmo vinte anos depois, nas revistas de arquitetura, sob outras designações e justificativas para sua materialidade, a exemplo das culturalistas regionalistas ou ambientalistas.

\subsection{Amazônia, a questão ambiental e a alternativa à Arquitetura brasileira, 1968 a 1989}

Apresentar projetos “do Amazonas ao Rio Grande do Sul”, "sem qualquer cunho regionalista”. Esta foi a proposta apresentada na Revista CJ Arquitetura n.7, de "arquitetura, planejamento e construção”, em circulação nove anos após a publicação da que teria sido, a última dedicada a projetos na Amazônia. ${ }^{183}$ Marcadamente, o editorial esclareceu que esperava contar com a colaboração, provavelmente o envio de documentos de projeto pelos arquitetos, para que continuasse a fazer aquela "revista sem qualquer cunho regionalista, voltada exclusivamente para o interesse da Arquitetura Brasileira”. A partir da temática “obras públicas”, seria então fornecida unidade à linha editorial deste número. Nele constaram projetos no Rio de Janeiro, São Paulo, Minas Gerais, Brasília, Bahia, também outros situados nas capitais dos estados do Pará e Amazonas (CJ ARQUITETURA N.7, 1975).

Estes projetos foram os primeiros identificados na década de 1970, conforme publicados nas revistas de arquitetura consultadas na pesquisa. Os edifícios públicos foram apresentados em exemplos da arquitetura institucional nas duas capitais. O primeiro deles, a partir da imagem da obra pronta e respectivos desenhos, foi de uma equipe de arquitetos do Rio de Janeiro, um edifício situado em contexto urbano, de 16 pavimentos, destinado à sede do Ministério da Fazenda [figura 36].

\footnotetext{
${ }^{183}$ Considerando que as fontes documentais foram restritas às revistas produzidas em âmbito nacional. Hugo Segawa informa sobre os anos de 1970, que a Acrópole deixou de circular em 1971, e não houve outro periódico regular até o ano de 1973, com o lançamento da CJ Arquitetura. A revista Módulo foi relançada em 1975, ainda que "sem a pluralidade de posições" (SEGAWA, 1998, p. 191).
} 


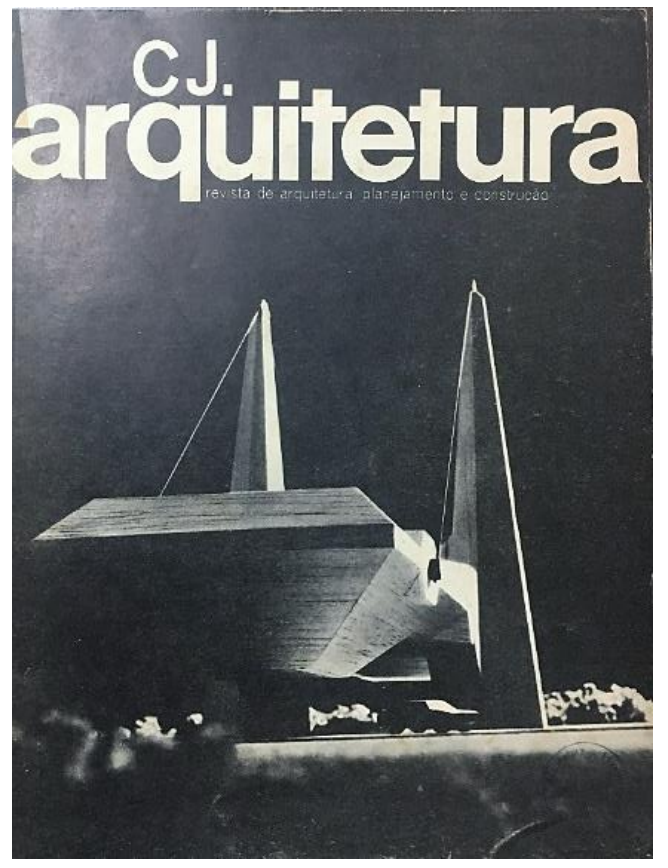

Figura 36 - Capa da revista CJ n.7 e projeto do edifício sede do Ministério da Fazenda em Belém - PA, de autoria de Maria Laura Pinheiro, Eurico Calvente, Luiz Augusto dos Santos Braga, Arima Diehl Pereira Travassos. Fonte: CJ ARQUITETURA n.7, 1975, p. 24-27.

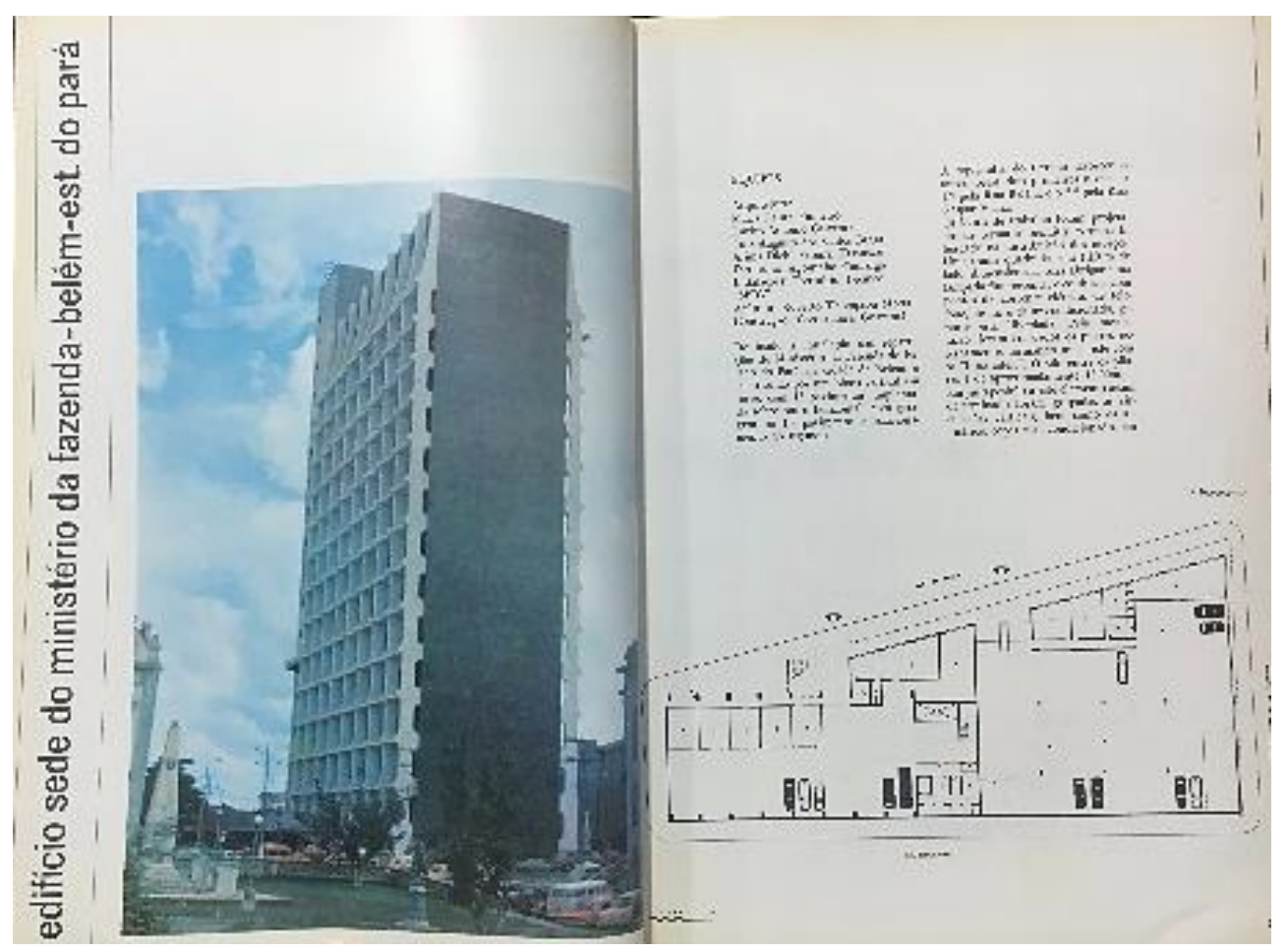

O projeto de $15000 \mathrm{~m}^{2}$ foi pensado a partir de uma trama estrutural em concreto articulada às instalações prediais, com pilares externalizados conformando brises verticais revestidos de mármore, assim como as empenas laterais, em granito, conformando um volume ao qual foi acrescido um bloco monolítico para os serviços e heliporto. A edificação seguiu um código formal da arquitetura de concreto que vigorou na década de 1970. O embasamento do conjunto comportou garagens e jardins. O tratamento das superfícies 
envidraçadas, "de tonalidade bronze", bem como os equipamentos de comunicação, PABX, telex, alarme, ar condicionado, elevadores, circuito de tv fechado no auditório para 200 pessoas, foram informações que no memorial publicado na revista, sugeriram tratar-se de um objeto pensado em atualidade tecnológica, filiado mais diretamente às experiências de estruturas em concreto aparente e em sua industrial.

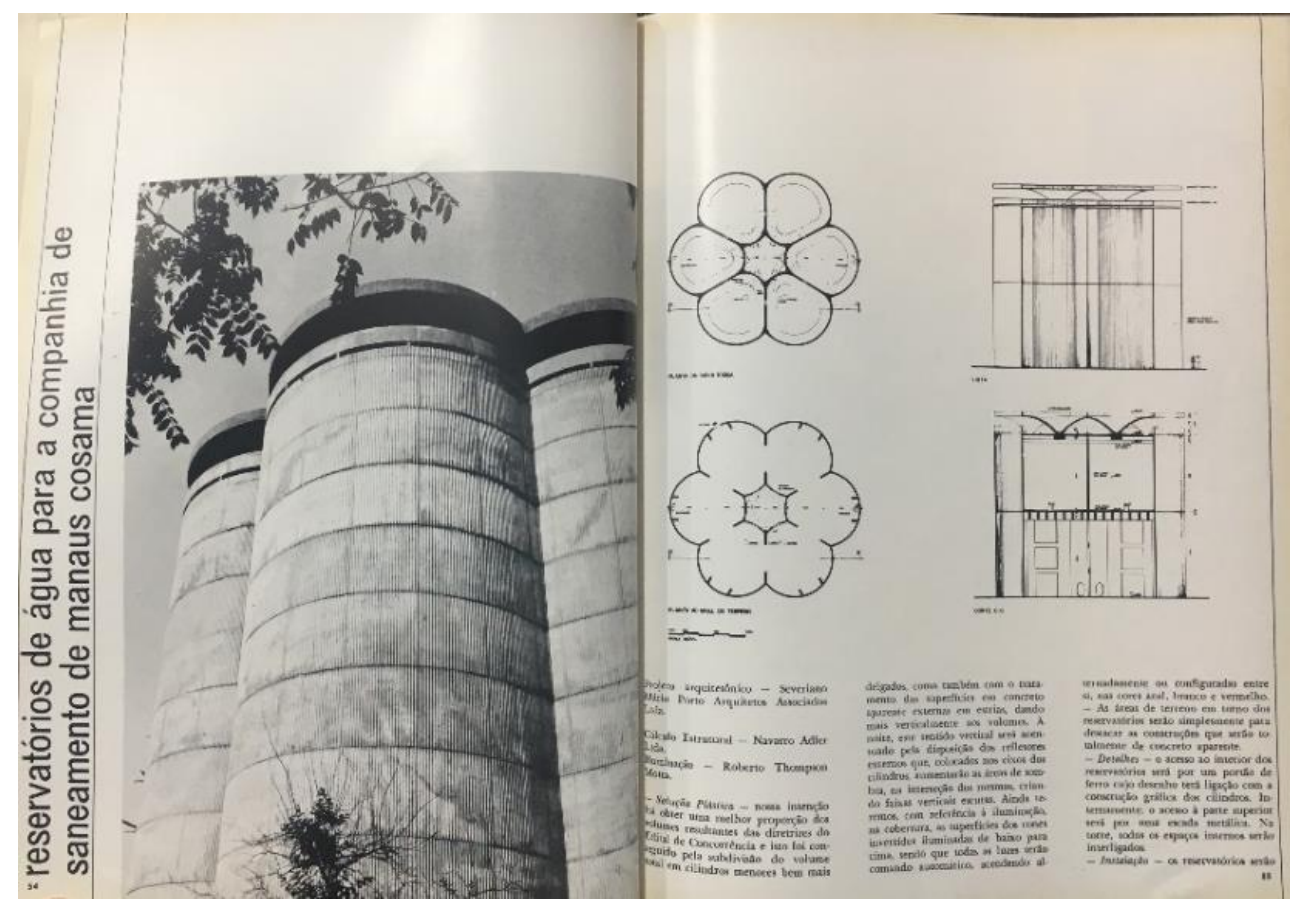

Figura 37 - Projeto tipo para os reservatórios de água de Manaus de autoria de Severiano Mário Porto. Fonte: CJ ARQUITETURA n.7, 1975, p. 54-56.

O outro projeto publicado nesse primeiro momento serviria como tipo à construção de reservatórios públicos da Companhia de saneamento de Manaus-AM [figura 37] e foi de autoria de Severiano Porto. Também foi descrito a partir de princípios racionais e compositivos, previstos como "uma melhor proporção dos volumes" em acordo com as diretrizes demandadas pelo solicitante à sua concepção. Os seis volumes menores combinados em organização centróide, o tornaria mais delgado estruturalmente, e o tratamento em concreto aparente, estriado, obtido com uso de telhas plásticas onduladas, suavizaria as superfícies externas, já que se tratava de grande volume a ser replicado em cinco unidades, na paisagem urbana de Manaus-AM. A cobertura, também pensada como produto do raciocínio estrutural e construtivo, foi concebida em "cone invertido", para delineamento do topo do volume com uma zona de sombreamento. Completando o conjunto, à melhor implantação deveria ser garantido o isolamento dos reservatórios, nos 
lotes onde fossem ser erguidos, para os quais foram previstos ajardinamento de modo a torná-los “símbolo da nova Manaus” (CJ ARQUITETURA N.7, 1975).

Um outro projeto de Severiano Porto também foi publicado na referida revista, a de edificação que serviu à acomodação da sede do Departamento Nacional de Portos e Vias Navegáveis - DNPVN. Sua localização permitiria, em período de cheia das águas do rio, que embarcações atracassem em torno da edificação, ou então, que surgissem "belas praias”, possivelmente "utilizadas pelos usuários do conjunto", conforme afirmado pelo próprio arquiteto na memória que seguiu na revista. Em planta circular, organizada a partir de um pátio interno, a edificação foi construída em concreto aparente, além de ter sido utilizado um tipo de arenito avermelhado, disponível na cidade, na feitura de seus muros de arrimo. A madeira envernizada foi aplicada em acabamentos de esquadrias e venezianas. A edificação, implantada numa ponta de terra firme [figura 39], de fronte à margem esquerda do rio Negro, em território militar em Manaus-AM, foi veiculada em imagem bastante replicada nas publicações de arquitetura desde então, quando avistada em meio à paisagem natural, como em isolado, ainda que se tratasse de contexto urbanizado e acessado por via terrestre (CJ ARQUITETURA N.7, 1975).

A posição claramente reativa ao "cunho regionalista" que pudesse nortear os projetos apresentados na revista, como no editorial, inscrevia a CJ Arquitetura em posição de distinção às manifestações projetuais tidas como arraigadas a contextualidades, explicadas em tradições culturais, ou referenciadas no exotismo relacionado à distinção e no localismo das obras. Nos anos de 1970, o pós-modernismo internacional influía, ainda que não profundamente, nos debates nacionais a respeito da arquitetura brasileira, especialmente pelos aportes de Keneth Frampton a respeito de um "regionalismo crítico". ${ }^{184}$ Sua significação seria balisada pela postura projetual, de resistência à cultura construtiva universalizante. Levada à arquitetura, esta crítica seria revelada pela forma de operação do projeto, ancorado numa cultura localizada, no sítio, e na reinterpretação da tradição, como afirmam Mirian Keiko Ito Rovo e Beatriz Santos Oliveira (ROVO e OLIVEIRA, 2004):

\footnotetext{
${ }^{184}$ A proposta de Keneth Frampton para um Regionalismo Crítico, especialmente a expressa no artigo "seis pontos por uma arquitetura da resistência", de 1983 e em seu livro "História crítica da arquitetura moderna", de 1997 foi dada em associação às ideias de Paul Ricoeur, no livro "Universalization and National Cultures" de 1961, referenciada no termo de Alex Tzonis e Liane Lefaivre. Na América Latina o conceito de "modernidade apropriada" de Cristián Fernandez Cox, deu encaminhamento à esta discussão (SARQUIS, 2012).
} 
a noção de regionalismo presente nos discursos das várias áreas de conhecimento, arquitetura inclusive, assenta-se na crença, por si só problemática, da existência de tradições locais "autênticas" que devem ser preservadas. Isto Implica, portanto, em que possamos avaliar a legitimidade dos signos representativos de uma cultura. Ora, esta tarefa está fadada ao fracasso pois, como demonstrou Alan Colquhoun em seu texto já antológico sobre o conceito de regionalismo, tais signos decorrem de histórias alternativas e revisionistas que foram forjadas pela vontade política dos movimentos nacionalistas do século XIX. De maneira que devemos entender a opção pelo regionalismo não como uma atitude de fé no valor dos códigos arquitetônicos ligados aos costumes de regiões culturais, mas sim como busca de procedimentos contextualizados.
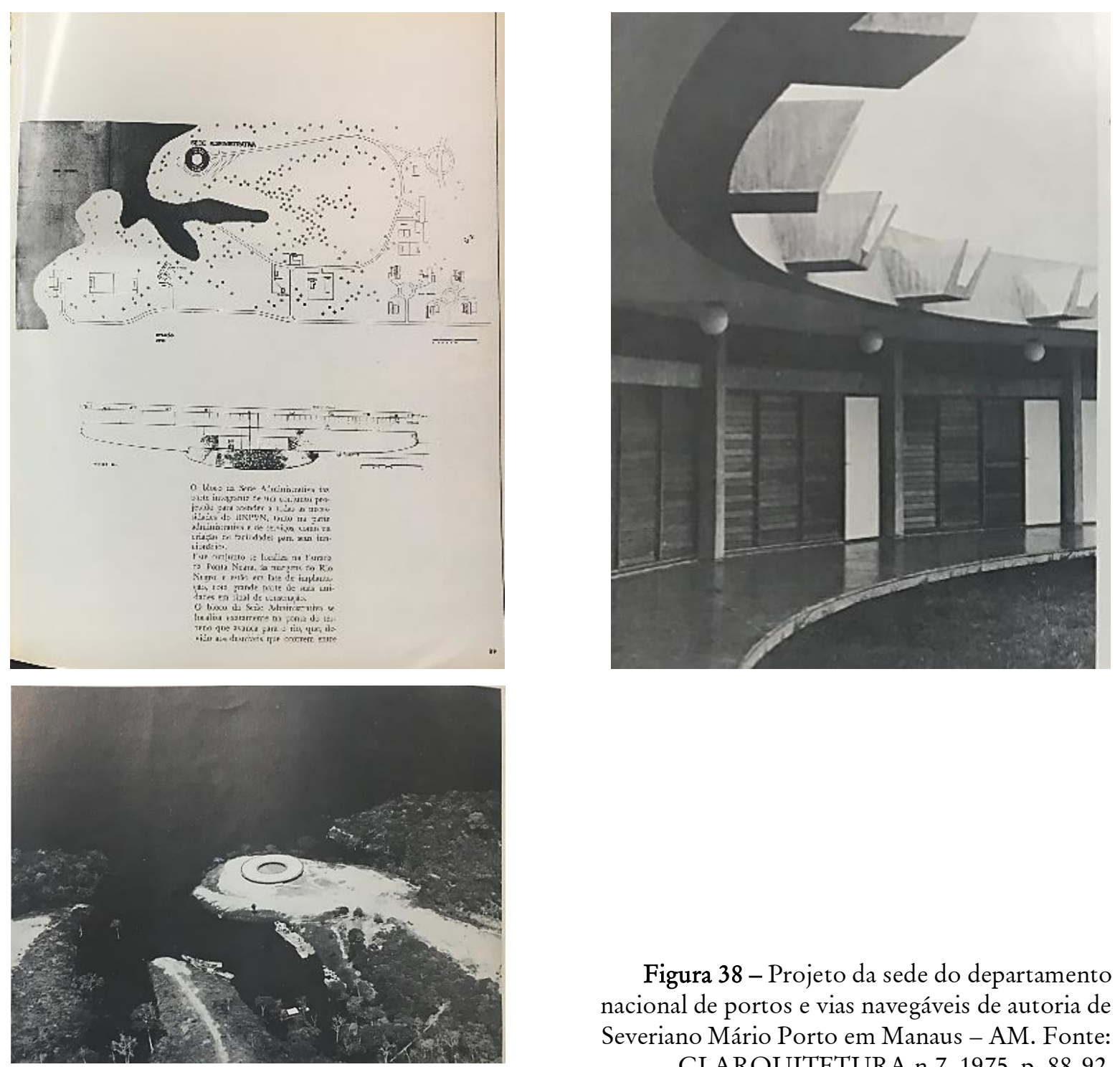

Figura 38 - Projeto da sede do departamento nacional de portos e vias navegáveis de autoria de Severiano Mário Porto em Manaus - AM. Fonte: CJ ARQUITETURA n.7, 1975, p. 88-92.

Deste modo, a posição do editorial da revista foi contrária à admissão de um regionalismo, afirmativa da arquitetura compreendida como unidade disciplinar, universal. 
Com o encerramento das revistas Arquitetura-IAB (1961-1968), Acrópole (1931-1971) e

Habitat (1950-1965), que pautaram os períodos anteriormente tratados neste capítulo, uma quantidade específica de artigos foram publicados sobre a arquitetura na Amazônia, em novas linhas editoriais correspondentes à análise situada neste último recorte. A intensidade das publicações foi ampliada a partir dos anos de 1980, levando em conta a atividade da revista Projeto (1979), ${ }^{185}$ com o maior número delas, 29 dos 45 artigos identificados ao total, considerando unicamente a publicação de projetos. ${ }^{186}$ Para esta amostragem, foram consideradas as revistas CJ Arquitetura (1973-1980), Módulo (1955-1986) ${ }^{187}$ e Arquitetura e Urbanismo-AU (1985-), que, ao tempo, estavam em circulação. Mesmo porque estas novas revistas passaram a ser dominantes no campo editorial. ${ }^{188}$ Além da Módulo, que continuou suas atividades até 1985, a mesma revista CJ Arquitetura (1973-1978), a revista Projeto a partir de 1978, e posteriormente, Arquitetura e Urbanismo-AU ${ }^{189}$ a partir de 1985, balizaram a atividade da imprensa especializada no país. Estas revistas não seriam equivalentes às anteriores, a reportarem as tendências da arquitetura, mas sim, apresentariam as "incertezas de um país no limiar da redemocratização, o atordoamento pós-moderno e a concordata da modernidade brasileira", as quais tinham em comum posturas críticas à arquitetura moderna, e certa "abertura em relação às temáticas e poéticas arquitetônicas contemporâneas” (GUERRA, 2010, p. 14).

\footnotetext{
${ }^{185}$ As revistas Projeto e Arquitetura e Urbanismo - AU, "iniciam um processo de profissionalização do jornalismo em arquitetura, com destaque para Ruth Verde Zein, Cecília Rodrigues dos Santos” e Hugo Segawa, três arquitetos que "migraram depois para a academia" (GUERRA, 2010, p. 14, 21).

186 Isto porque no levantamento também foram consideradas temáticas relacionadas à Amazônia, independentemente da publicação de projetos.

${ }^{187}$ A revista Módulo, ainda que em um momento de divergências disciplinares, se manteve discursivamente filiada à vertente que defendeu, mesmo nos anos de 1980, uma arquitetura brasileira "oficial", "vinculada à tecnologia do concreto e ao discurso do arquiteto Oscar Niemeyer" (BASTOS, 2007, p. 55).

${ }^{188}$ Para Abílio Guerra, o campo editorial no Brasil foi marcado pelo "fenecimento da imprensa de arquitetura no início dos anos 1970", de modo que o surgimento de publicações com este perfil seriam regularmente retomadas a partir dos anos de 1980. Ainda assim, na mesma década de 1970, as revistas CJ Arquitetura e Módulo, publicaram importantes matérias, ainda que parcas, sobre a Arquitetura na Amazônia. Cabe menção à premiação do projeto de autoria de Severiano Porto para a Superintendência da Zona Franca de Manaus publicada pela CJ Arquitetura em seu n.7, de 1975 (CJ ARQUITETURA N.7, 1975), revista esta que reuniu uma série de artigos de distintos campos no n.20, publicado em 1979, sob a temática Amazônia (CJ ARQUITETURA N.20, 1978). Além destas, os números 43 e 53 da revista Módulo, também publicaram a respeito da arquitetura na Amazônia, tenha sido para abordar a temática da habitação popular urbana, como na primeira, ou para centrar atenção à casa projetada por Severiano Porto para Robert Schuster na segunda (MÓDULO N.43, junho a agosto de 1976) (MÓDULO N.53, março e abril de 1979). A própria revista Projeto, entre 1977 e 1979, nos números 2, 11 e 15, fez menção à obras na Amazônia (PROJETO N.2, abril/maio de 1977) (PROJETO N.11, junho de 1979) (PROJETO N.15, setembro/outubro de 1979).

${ }^{189}$ Além da revista Construção São Paulo, do mesmo grupo editorial, que também publicou matérias sobre a Amazônia.
} 
Nesse período outros suportes textuais a respeito da temática desta tese passaram a circular exatamente a partir desta década, que denotam o teor das discussões em vigor a respeito da arquitetura realizada na Amazônia, mesmo no Brasil. Destes documentos, é possível destacar a tese de Eduardo Yázigi, Études preliminares em vue d’um urbanisme tropical pour l'Amazonie brésilienne (YAZIGI, 1972), como demarcatória da pesquisa acadêmica sobre a arquitetura e urbanismo na Amazônia e a dissertação de João Pinto de Castro Filho, Estudo sobre exemplos de Arquitetura Tropical, erudita e suas adequações à Amazônia brasileira (FILHO, 1984), focalizada no projeto de arquitetura, já dos anos de 1980, a partir de quando as publicações periódicas foram intensificadas. A tese de Fleury de Oliveira, Amazônia: Proposta para uma ecoarquitetura, para "estruturas ambientais urbanas” de 1989, ano demarcatório do final do período estudado, foi ancorada na compreensão dos processos sociais locais, sobre assentamentos planejados na Amazônia.

Além desses trabalhos acadêmicos, o livro de Marlene Milan Acayaba e Silva Ficher (FICHER e ACAYABA, 1982), apresentou a arquitetura desenvolvida no norte brasileiro, em específico, a partir de obras de Severiano Mário Porto, no panorama investigado pelas autoras, composto pela produção de arquitetura no país após a realização de Brasília. Como as revistas, catálogos foram publicados e incluíram em suas perspectivas, a arquitetura na Amazônia, como os Arquitetura Brasileira Atual (WISSENBACH, 1983), Cadernos Brasileiros de Arquitetura (WISSENBACH, 1983), Arquiteturas no Brasil/Anos 80 (WISSENBACH, 1988), todos da linha editorial da Projeto.

Uma vertente de textos consumava investigações sobre as condições sociais e geográficas amazônicas, de modo aprofundado. Elas foram meio para a elaboração de recursos intelectuais voltados ao embasamento da formulação consciente do projeto e do planejamento na Amazônia, muito à luz da busca pela compreensão dos efeitos das transformações espaciais conflitivas dadas no território amazônico, como efeitos dos grandes projetos estatais transcorridos desde os anos de 1960 na região. ${ }^{190}$ Por outro lado, parte desses textos publicados a respeito da arquitetura na Amazônia foi decorrente do

\footnotetext{
${ }^{190}$ Neste caso, tanto as revistas institucionais da própria imprensa militar, quanto a imprensa de um modo geral, como as revistas populares, fizeram circular os feitos do Estado na região. Já nas revistas voltadas à publicidade das atividades governamentais, a arquitetura foi utilizada para dar visibilidade às realizações estatais, representadas pela modernização urbana. As revistas populares, do mesmo modo, deram notabilidade à arquitetura, muitas das vezes, pelas vias da propaganda institucional.
} 
interesse de determinados segmentos, de instaurar a atividade crítica regular, apreender, discutir e dar vazão à leituras integrais da prática disciplinar quando realizada profissionalmente no país. O desconhecimento sistêmico daquela produção, conforme explicitado desde os Inquéritos Nacionais de Arquitetura, e as compilações do Instuituto dos Arquitetos do Brasil, após Brasília/Depoimentos, demonstraram um movimento de retorno da escrita de cunho histórico sobre a arquitetura no Brasil, a partir da crítica e da revisão historiográfica. Estes seriam contributo à reconstrução da memória disciplinar, também de abertura do campo à prática, não mais necessariamente em continuidade à narrativa dominante ou centrada em referenciais canônicos consagrados.

Desde a Revista Arquitetura Brasileira do Ano n.1 (ABA N.1, 1967-68), outras revistas compilatórias sob a temática da Amazônia foram publicadas, conciliando disciplinas distintas e construindo cenários para a arquitetura na Amazônia em perspectivas ampliadas, ainda que na maior parte, tenham apresentado como objeto de apreciação em concretude, experiências em Manaus-AM. Além destas revistas, os catálogos das exposições de arquitetura conformaram também fonte documental para a iluminação de arquitetos atuantes e suas produções na Amazônia. Algumas revistas foram dedicadas quase integralmente ao tema da Amazônia, outras construíram debates transdisciplinares com cientistas de outros campos, como da Geografia e Ciências sociais, em matérias aprofundadas, sob distintas matrizes de interpretação. As publicações a respeito da Amazônia, deste modo, compuseram um cenário marcado pela pesquisa acadêmica e pela atividade projetual que era enraizada, especialmente pela presença de arquitetos formados pela Faculdade de Arquitetura da Universidade Federal do Pará e arquitetos de outras procedências que absorveram a oportunidade de trabalho na Amazônia. Também, pela própria ampliação da atividade editorial a partir de meados dos anos de 1970, período no qual a arquitetura na Amazônia foi reportada como nunca antes.

Um dos projetos mais publicados a partir de 1975 foi sem dúvida o edifício de autoria de Severiano Mário Porto para a Superintendência da Zona Franca de Manaus - AM. Uma primeira publicação registrou sua premiação no XII evento do Instituto dos Arquitetos do Brasil. O edifício em concreto aparente conformou a paisagem do recém implantado Distrito Industrial de Manaus-AM, com uma estrutura modulada de $15 \mathrm{~m} \times 15 \mathrm{~m}$, desenvolvida sob a lógica da possibilidade de expansão futura, em malha horizontal regular 
e ocupações alternadas dos módulos, destinados a jardins internos e intervalos espaciais. Em corte, a unidade modular foi pensada a partir da solução de ventilação em "troncos de pirâmides ôcos, com arestas arqueadas" como "coifas distribuidas em toda a extensão da área coberta”, tendo sido evitada a cobertura planar única (CJ ARQUITETURA N.8, 1975, p. 18-23).

Em três revistas publicadas respectivamente em 1976, 1977 e 1978, foram apresentados enfoques distintos sobre a ocupação da Amazônia. Módulo ${ }^{191}$ (MÓDULO N.43, junho a agosto de 1976) e Projeto (PROJETO N.2, abril/maio de 1977) em comentários breves, CJ Arquitetura (CJ ARQUITETURA N.20, 1978) em um número dedicado totalmente à Amazônia. Na Módulo, a habitação foi apresentada como um "velho drama brasileiro", num texto crítico acerca da habitação no Brasil, referenciado no "caos” e no "deficit" habitacional, que apresentou o problemático acesso de populações pobres à propriedade e à habitação no contexto urbano. A comparação entre os mocambos de Recife e as "casas tipo palafitas coberta de sapê", encontradas também "nas vastidões da Amazônia”, moldou a interpretação cruzada do meio urbano amazônico com o rural. A argumentação pautada nas informações dos dados sensitários, de que dos 7 milhões e 200 mil habitantes, 5 milhões integariam o mundo rural, "vivendo em choupanas e palafitas, à beira dos rios e igarapés” se deslocou da perspectiva antropológica de um morar amazônico, como publicado havia vinte anos pela mesma revista, para uma avaliação territorial sob a pauta da urbanização.

Deste modo, a "Transamazônica”, a “célebre e tão promovida estrada” estava destinada ao esquecimento, já havia sido um projeto fracassado, ainda que proposto para a abertura de frentes de trabalho e para "solucionar o problema” dos "retirantes” nordestinos, quando dirigidos às cidades em alternativa à seca no campo, no que havia sido um grande projeto de indução da colonização regional. O editorial da revista Projeto seguiu a mesma linha, porém destacando a presença de arquitetos no "planejamento de agrovilas no norte e nordeste do país". Eles estariam levando ao mundo rural, "sua experiência de organizador do espaço". O editorial reforçava, sob o título de "arquitetura no campo", de fundo, a

\footnotetext{
${ }^{191}$ A revista foi apresentada como publicação independente, uma obra "didática e elucidativa" e do que foi relacionado à Amazônia, duas matérias compuseram este quarto número após a retomada das atividades do periódico, um primeiro a respeito da "residência particular no Brasil", que repercutiria no exemplar número 76, de 1979, e o artigo de Ivan Alves, "a habitação".
} 
atividade profissional que vinha sendo incorporada a outras áreas, tanto no projeto de novas cidades na Amazônia, quanto no segmento do desenho industrial, o outro abordado na revista. A última, CJ Arquitetura, foi a fundo na questão, aproximadamente um ano após a publicação do editorial da Projeto, no período em que a distinção entre cidade e campo ficava cada vez mais evidente e aprofundada.

Aparentemente similares, a capa de um catálogo da exposição organizada por Arthur Cezar Ferreira Reis, intitulada Amazônia brasileira em 1969, ano inicial dos trabalhos de abertura da Transamazônica e a de uma revista que há pouco teria voltado a circular, do ano de 1978, a CJ Arquitetura [figura 39], tinham em comum a imagem de partida, mas continham íntima diferenciação, mesmo porque publicadas em intervalo de quase dez anos. A primeira fornecia base à continuação de um imaginário atrelado à paisagem amazônica, recurso discursivo de cunho desenvolvimentista e conservador à defesa da intervenção militar na região. Na lista de publicações referenciadas no catálogo para a exposição organizada por Arthur Reis constava a revista Arquitetura Brasileira do Ano n.1.

A exposição foi inaugurada em 2 de dezembro de 1969, apresentando um conjunto de publicações acerca da Amazônia, além de dados sintéticos e diversos sobre a região, como "Sociologia, Economia e Política”, "Geografia, Viagens, História”, "Fauna e Flora”, “Música, Literatura”, além de um trecho dedicado à literatura dos viajantes, e de ilustrações de paisagem. Organizada por Arthur Reis, que ocupava à época o cargo de Presidente do Conselho Federal de Cultura e assinava a apresentação da exposição, recorrendo às assertivas da civilização brasileira contraposta à "natureza agressiva exterior”, em defesa da conquista que não fosse "passageira”, reproduziu a questão de Djalma Batista, perguntou (AMAZÔNIA BRASILEIRA, 1969):

A Amazônia permitirá a habitabilidade que não se restrinja a fugidio trânsito do ser humano, incapaz, pelos rigores locais, daquela permanência, necessária para o sucesso que se deseja? Enfim, logro, mera expressão exótica de geografia ou ainda mesmo vazio onde promover-se a demonstração de nosso potencial de cultura e fundamento da grandeza nacional?

A segunda publicação, a ser tratada mais detidamente, foi construída por múltiplos olhares e apresentava os efeitos daquele empreendimento propagado até então, massissamente, em equivalência ao progresso nacional e dominação da floresta, para a integração da Amazônia ao país. Esta teria sido uma primeira publicação, das especializadas 
em Arquitetura e Urbanismo, a veicular uma análise crítica ao projeto estatal sobre a Amazônia. O próprio editorial revelou que embora o tema fosse dos mais discutidos na década de 1970, o campo da Arquitetura e Urbanismo havia estado ausente de debate tão importante para o país, motivo pelo qual a edição respondia ao intento de "preencher tal lacuna”, “sem pretensões de esgotar assunto - mesmo porque ainda há muita coisa a se pesquisar" diante de tema vasto e de inúmeras áreas inexploradas.

(1)

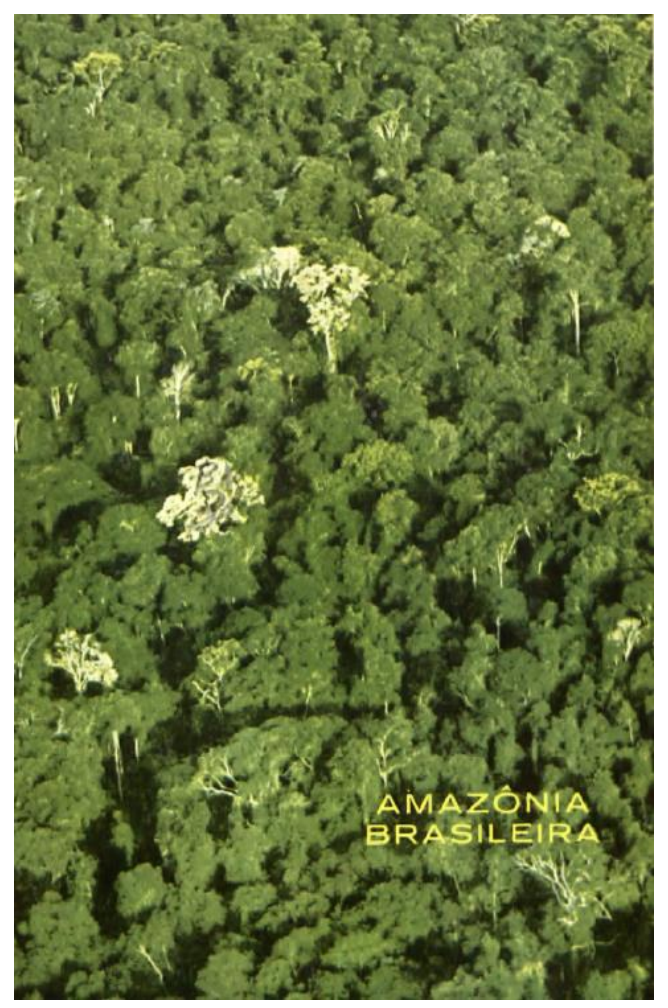

(2)

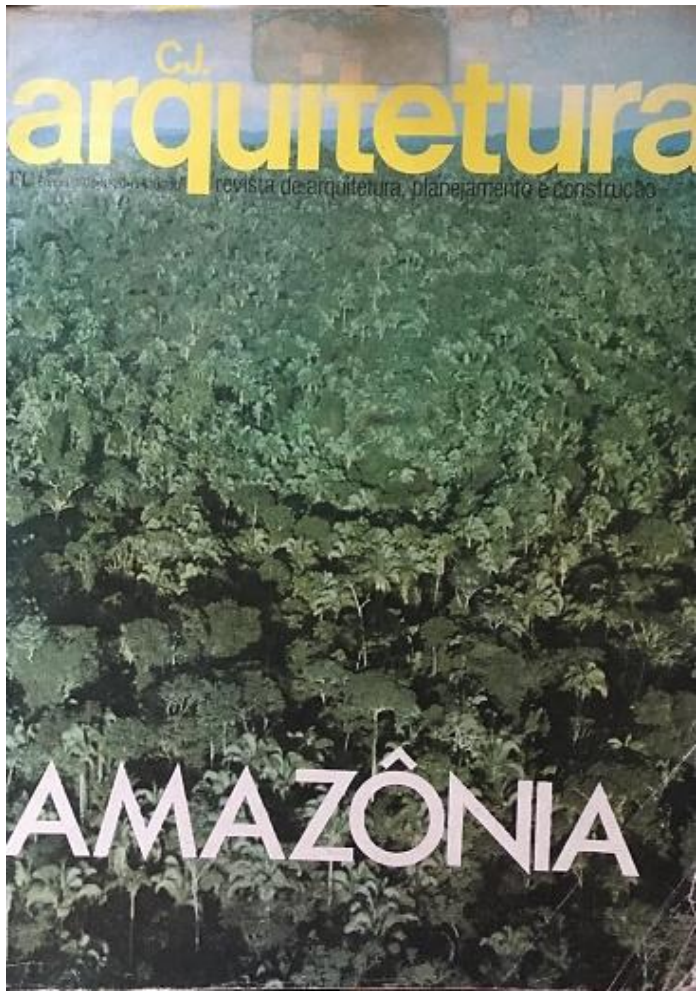

Figura 39 - (1) Capa da exposição de 1969, Amazônia brasileira (AMAZÔNIA BRASILEIRA, 1969); (2) Capa da revista CJ Arquitetura (CJ ARQUITETURA n.20, 1978).

No editorial que ressaltou o interesse da revista em encaminhar uma "discussão eminentemente brasileira", ficava clara a relação entre a publicação e outro protagonista da literatura regional, Márcio Souza. Ele havia publicado pela primeira vez em 1977 o livro $A$ expressão amazonense - do colonialismo ao neocolonialismo, portanto um ano antes da referida revista, que resgatou sua posição de que "falar da Amazônia neste momento, seja em que campo for, será falar de ruínas. Ruínas das culturas originárias, assaltadas e massacradas; ruínas das impossibilidades da civilização ocidental; ruínas da natureza mal compreendida, uma paisagem de destroços” (CJ ARQUITETURA N.20, 1978, p. 3). Ou seja, a pauta crítica não advinha unicamente do campo, mas de entrelaçamentos deste a 
outros olhares como o do escritor Márcio Souza, que haviam de ser apresentados naquele que seria o número da revista dedicado à discussão mais atualizada sobre a Amazônia.

Lúcio Flávio Pinto, assim como Márcio Souza, um escritor amazônida, se referiu ao empobrecimento regional ao explicá-lo pelo déficit das relações comerciais com outras regiões brasileiras e a baixa nas atividades econômicas entre as décadas de 1950 e 1970. Referiu-se à concentração de riqueza dada pela prevalência de indústrias no Amazonas e o expressivo desnivelamento $\mathrm{da}$ renda da população regional frente à média brasileira, apontando o Pará como o estado “de melhores perspectivas na Amazônia”, dada a implantação de projetos industriais incentivados pela recente Superintendência do Desenvolvimento da Amazônia - SUDAM, de 1966. Além destes, enfatizou os investimentos em agropecuária e os projetos de mineração, destacando "Carajás”, “Trombetas” e “Albrás/Alunorte”, que passariam a exportar respectivamente, minério de ferro, bauxita e alumínio, representando "investimento de cinco bilhões de dólares” à época. Frente a tantos investimentos, pouco haveria sido revertido ao desenvolvimento regional, especialmente na renda dos habitantes locais.

Se até final dos anos de 1960 o pensamento técnico e político para o desenvolvimento regional seria dado pelo incentivo à industrialização das matérias primas locais, ${ }^{192}$ a partir dos 1970, com Médici, houve a urgência de integrar a região ao país, o que seria mais tarde expresso no II Plano de Desenvolvimento da Amazônia, que a caracterizou como uma “fronteira tropical”, uma região vocacionada ao fornecimento de matérias-primas para a “região moderna do país” ou para exportação de produtos para o mercado internacional. O investimento, via $S U D A M$, em projetos agropecuários e industriais provocou, especialmente no caso do primeiro, a compra de terras por parte de grandes grupos empresariais, principalmente no Pará e Mato Grosso, algumas em milhões de hectares, como no caso do americano Daniel Keith Ludwig, ${ }^{193}$ não necessariamente a convertendo em terras produtivas, mas em práticas de especulação na região, concentração de grandes

192 O autor se referiu à Getúlio Vargas, quando da criação da SPVEA (Superintendência do Plano de Valorização Econômica da Amazônia) e por ter iniciado as bases do planejamento regional. Para Médici, segundo Lucio Flávio Pinto, "a Amazônia precisaria ser transformada em mercado consumidor com efetivo poder de compra para que assim: 1) participasse [...] do mercado interno[...] 2) contribuísse para a diluição dos custos de produção industrial; (3) incrementasse a sua produtividade a fim de fornecer matérias-primas necessárias à indústria do Centro-Sul”.

${ }^{193}$ Que foi o empresário americano que iniciou a implantação do projeto Jari, em terras situadas entre o Pará e o Amapá. 
propriedades, subutilização da terra e dificuldade de instalação de novos pequenos agricultores. A dificuldade de sua fixação no meio rural os conduzia às capitais, produzindo a intensificação do fluxo de migração interna que provocou nas cidades, como Belém-PA e Manaus-AM, “grandes favelas, formadas predominantemente por imigrantes rurais”. A respeito da transformação do meio natural (CJ ARQUITETURA N.20, 1978, p. 5-8):

Nos últimos 10 anos foram desmatados na Amazônia pelo menos 12 milhões de hectares de florestas - correspondendo quase a toda a área do Amapá - para a implantação de fazendas, estradas extração de madeiras ou projetos de colonização. Nessa área havia sete milhões de metros cúbicos de madeira, que, se exportados, produziriam uma renda próxima de 4,5 bilhões de dólares. Só as derrubadas realizadas pelos projetos agropecuários aprovados pela Sudam atingiram quatro milhões de hectares, tornando-os mais vorazes a cada ano.

$[\ldots]$

As modificações causadas pela ação humana poderão criar problemas imperceptíveis no primeiro momento, mas desastrosos a longo prazo.

$[\cdots]$

Se já é difícil medir a alteração do equilíbrio ecológico, muito mais problemático tornou-se o estudo das repercussões causadas no homem pelas bruscas transformações que ocorrem na Amazônia.

Claramente uma "questão ecológica" estava sendo apresentada, não unicamente observada no âmbito nacional, mas pela comunidade internacional atenta e estarrecida diante dos efeitos devastadores e perceptíveis da transformação do meio natural, a contar a replicação das falas de cientistas estrangeiros que a revista apresentou. Para a Amazônia, passaram a ser feitas projeções tão superlativas quanto as constatações advindas da devastação propagada pela mídia impressa e atestada por observadores internacionais. A questão do desequilíbrio entre meio físico, fauna e flora, passou a cercar a temática da Amazônia, bem como foram constatadas as dificuldades de realização de estudos mais aprofundados que produzissem dados palpáveis de argumentação contrária ao empreendimento estatal. Vários escritos ali reportados não unicamente desde a fala de arquitetos e urbanistas, mas costurados a estas, especialmente à tese de Eduardo Yázigi, crítica aos modelos exógenos introduzidos na ocupação daquela "região tropical", forneciam base ao vislumbre de outros paradigmas para conformação de certa "arquitetura e um urbanismo próprios da Amazônia”, uma “esperança” ali associada diretamente à uma vertente da obra que vinha realizando Severiano Mário Porto, prevalentemente em Manaus, havia mais de uma década. 
Dentre os artigos não relacionados mais diretamente ao campo da arquitetura, foi publicado o Selva Amazônica: do Inferno Verde ao Deserto Vermelho?, em páginas que "misteriosamente" haviam sido suprimidas de seus originais, e naquele momento estariam sendo primeiramente reveladas, de autoria de dois estadounidenses, o ecólogo J.A.Goodland e o diretor do Jardim botânico de Nova Iorque, Howard S. Irwin, com a apresentação do ecólogo gaúcho José Lutzenberger. Outro artigo de Lúcio Flávio Pinto, sociólogo e jornalista com atuação centrada na Amazônia desde a década de 1960, nomeou a região como “um imenso almoxarifado nacional”. A esta altura devem ser observadas duas interpretações suscitadas por esta publicação. Uma primeira, a de que ficou explícita a condição com a qual os arquitetos, quando referenciados na Amazônia, para além de seus contextos estritos de atuação, estavam a lidar. Ainda que tenha permeado suas práticas desde tempos pregressos, a especificidade dada pela designação mais precisa de uma pauta ecológica trazia às consciências o estágio avançado da transformação do espaço natural amazônico. As revistas populares davam vazão a uma formulação estatal pautada no desbravamento e na posse, num processo de colonialismo interno [figura 40,41]. Esta condição, sem precedentes, evidenciava as implicações deste processo sobre o meio local, sobretudo sob a perspectiva de sua interferência mais direta no desequilíbrio ambiental global. Os rebatimentos da Amazônia na condição de frente de expansão, abriam o território à oportunidade da participação direta de arquitetos urbanistas no processo de transformação do espaço regional, fosse na elaboração de novas paisagens, no projeto de edifícios em contextos não urbanizados e novas cidades, na atuação em contextos urbanizados.

Ainda em relação ao primeiro ponto, outro dado no âmbito disciplinar comportou o que será notado desde então nas publicações. Aportes discursivos pregressos foram acrescidos de novas designações, especialmente acerca da necessária adaptação material da arquitetura a premissas que fossem tidas ao tempo, como estritamente amazônicas. Este significado, mais afeito às vertentes preservacionistas do meio natural envolveu o enlace inevitável do raciocínio projetual ao campo disciplinar a um ambiente intelectual permissivo às pluralidades, portanto, não fundamentado unicamente nas pautas de uma arquitetura nacional, mas aberto às múltiplas brasilidades que poderiam vir a ser produzidas em arquitetura. Deste modo, o atributo do regionalismo esteve associado ao produto de uma 
prática da arquitetura conciliatória do projeto ao controverso fluxo de transformação incentivado pelo Estado para a Amazônia. Ainda que possa ter sido atravessado por posicionamentos políticos resistentes à transformação sob os efeitos da intervenção estatal, a prática projetual foi inscrita neste processo quando tornada possível.
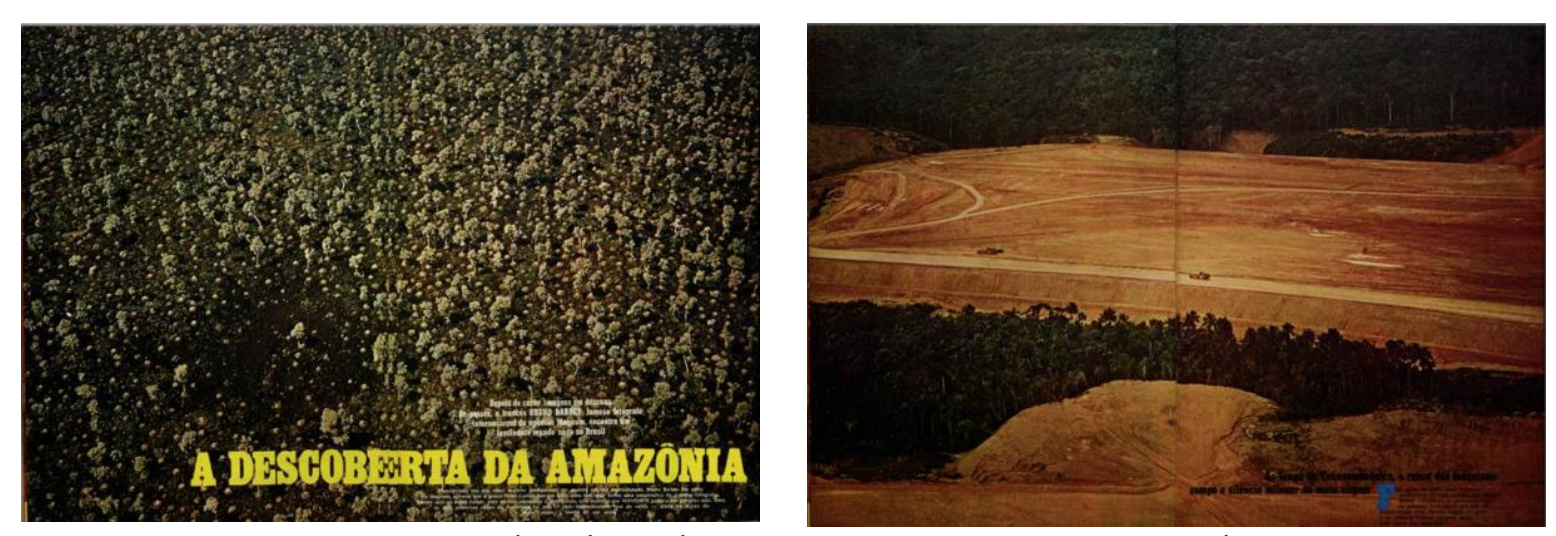

Figura 40 - Matéria A descoberta da Amazônia. Fonte: MANCHETE ed. 1102, 1973.

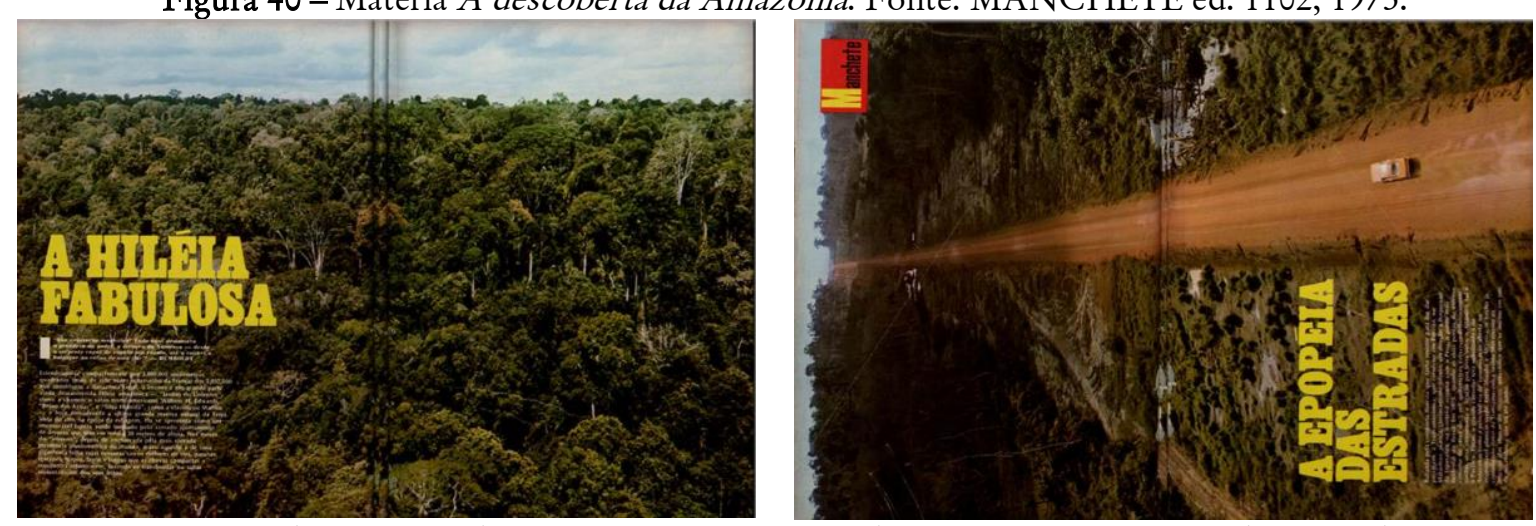

Figura 41 - Edição Especial Amazônia um novo Brasil. Fonte: MANCHETE ed. Especial, 1973.

Uma segunda interpretação está relacionada ao contexto no qual está situado a obra de Severiano Mário Porto. Ela foi de certo modo ressignificada à categoria de arquitetura de potencial adequabilidade ambiental, por meio do argumento textual, nos escritos. A tese de Eduardo Yázigi ${ }^{194}$ havia sido desenvolvida no ano de 1972, fato pelo qual é considerada pioneira em função de ter sido o primeiro estudo acadêmico identificado com igual teor, dentre a documentação levantada. Eduardo Yázigi se aprofundou no processo de urbanização da Amazônia, do Brasil, Colômbia e da Guiana Francesa, como "região subpovoada e subdesenvolvida”, a partir de contextos urbanos referenciais, para desenvolver a proposição de um “urbanismo tropical". Sua proposta intencionada a

\footnotetext{
${ }^{194}$ A revista apresentou o currículo de Eduardo Yázigi, formado em História, Urbanismo, Estudos Políticos
} e Sociais, com doutorado em Urbanismo. Professor de Arquitetura e Urbanismo da FAU-USP. 
“domesticar um espaço selvagem”, um “inferno inadequado para tornar-se a moradia do homem”, onde muitas experiências de ocupação fracassaram e para o qual deveria ser pensada uma "outra forma de vida”, “adaptada” ao que Yázigi chamou de "ecossistema amazônico", como resposta ao estágio de sua irreversível urbanização e industrialização, a partir da qual lançou seu pressuposto:

Toda aglomeração urbana situada em região de floresta equatorial deveria possuir uma organização espacial, uma composição e disposição plástica, assim como um regime de vida originais. Trata-se, portanto, de demonstrar que os embaraços amazônicos exigem soluções especiais, mais desejáveis para seu meio.

A Amazônia nada conheceu de original em matéria de urbanismo; porque, através da história e mesmo hoje, ela recebeu implantações, primeiro copiadas de um quadro europeu e depois do sul do Brasil.

Assim foi delineada a problemática de inscrição do "urbanismo tropical”, de orientação "estritamente ecológica”, fruto da atenção despendida à questões globais e também regionais, como das riquezas minerais do território, das formas manifestas das cidades amazônicas desde as quais poderia realizar sua crítica e construir outros modelos ideais, pensados para aquele "meio natural” e "meio econômico e social”. Destas, novamente Belém-PA e Manaus-AM figuravam como as mais significativas experiências, além dos exemplares de "pequenas cidades espontâneas" e de "new towns", a exemplo de Vila Serra do Navio. Além das cidades, sua arquitetura foi levantada e tipificada em conjuntos de interpretação, junto à transformação urbana de cada sítio em detalhe. Como proposta, o autor evidenciou as "exigências ecológicas" de adequação da arquitetura, em meio urbano ou rural qualquer, mas que ali se colocavam como "certos princípios fundamentais" associados ao conforto e à construção, que determinariam, pela arquitetura, sua influência no espaço urbano.

O autor identificou os exemplos de arquitetura tropical, sem, no entanto, reconhecêlos em “contexto de interrelações”. A conjugação da boa aplicação dos materiais em adaptação às condições de clima, junto à arborização e a "técnicas urbanísticas” pensado a partir dos componentes físicos típicos que identificou na região, para o planejamento de cidades na Amazônia. Ainda na mesma revista, foram registrados dois projetos de autoria de Severiano Mário Porto já publicados anteriormente, o da Superintendência da Zona Franca de Manaus - SUFRAMA, e o da Sede Administrativa da Portobrás em Manaus, “uma perfeita adaptação ao sítio, explorando ainda a beleza do rio Negro que, em certas 
épocas, envolve quase toda a construção principal”. Além destes, outros dois projetos foram registrados, sua casa em Manaus- AM e o Campus da Universidade do Amazonas em Manaus-AM, todos estes, à exceção da residência, foram edifícios ou conjuntos edificados em meio a entornos urbanos não urbanizados, de prevalência natural quando de sua implantação, como a Suframa, situada no novo distrito industrial, a sede da Portobrás, em área militar, e o último, o Campus em área igualmente de entorno natural preservado [figura 42]. Em nenhum dos casos a revista tratou da inserção urbana das edificações, elas aparecem em meio à paisagem natural, o que de fato era ao tempo de sua implantação uma condição dada, de modo que os mesmos edifícios foram também componentes de uma paisagem artificial que eles próprios estavam a estruturar.

Considerado o sentido apontado por Abílio Guerra (GUERRA, 2010), tratava-se de uma ideação projetual entre a vida rural e urbana, da harmonização entre arquitetura e floresta tropical, também construída em abstração, como uma natureza interpretada e constitutiva do espírito nacional, base de formulação de uma moderna arquitetura brasileira. Mas neste caso, como exposto, os projetos são considerados de modo mais pragmático, como acréscimo ou em distinção ao meio contextual, como objetos que constituíram a nova paisagem urbana de uma cidade expandida pela industrialização induzida pelo Estado. Seus temas e sítios de inserção possibilitaram formas de implantação libertas da estrutura urbana tradicional, e conformaram, pela forma com que foram inseridos espacialmente, estruturas particulares de configuração do urbano, mesmo porque foram, à exceção da casa de Severiano Porto inscrita em lote, edifícios institucionais implantados em glebas públicas em eixos de expansão urbana.

Em finais da década de 1970, duas foram as tônicas das revistas. Uma primeira, sob a pauta da questão ecológica, como expresso na nota de divulgação das atividades da Comissão Nacional de Defesa e pelo Desenvolvimento da Amazônia, entidade civil mobilizada à "luta global pelas liberdades democráticas", que tratou dos efeitos do capitalismo contemporâneo sobre a Amazônia, da atuação exploratória de grupos econômicos estrangeiros sobre o território (MÓDULO N.55, setembro de 1979, p. 10). O Conselho Superior do Instituto de Arquitetos do Brasil - IAB também havia se manifestado, na aprovação da "moção condenando o projeto governamental de exploração da Amazônia”, interpretado como parte de um processo de “desrespeito à opinião pública 
e aos legítimos interesses nacionais”, exigindo um debate ampliado junto à sociedade, de vários setores da comunidade "em defesa da Amazônia”, já que aquele projeto estatal subordinava o país de seu "patrimônio", ao capital estrangeiro (PROJETO N.9, junho de 1979).
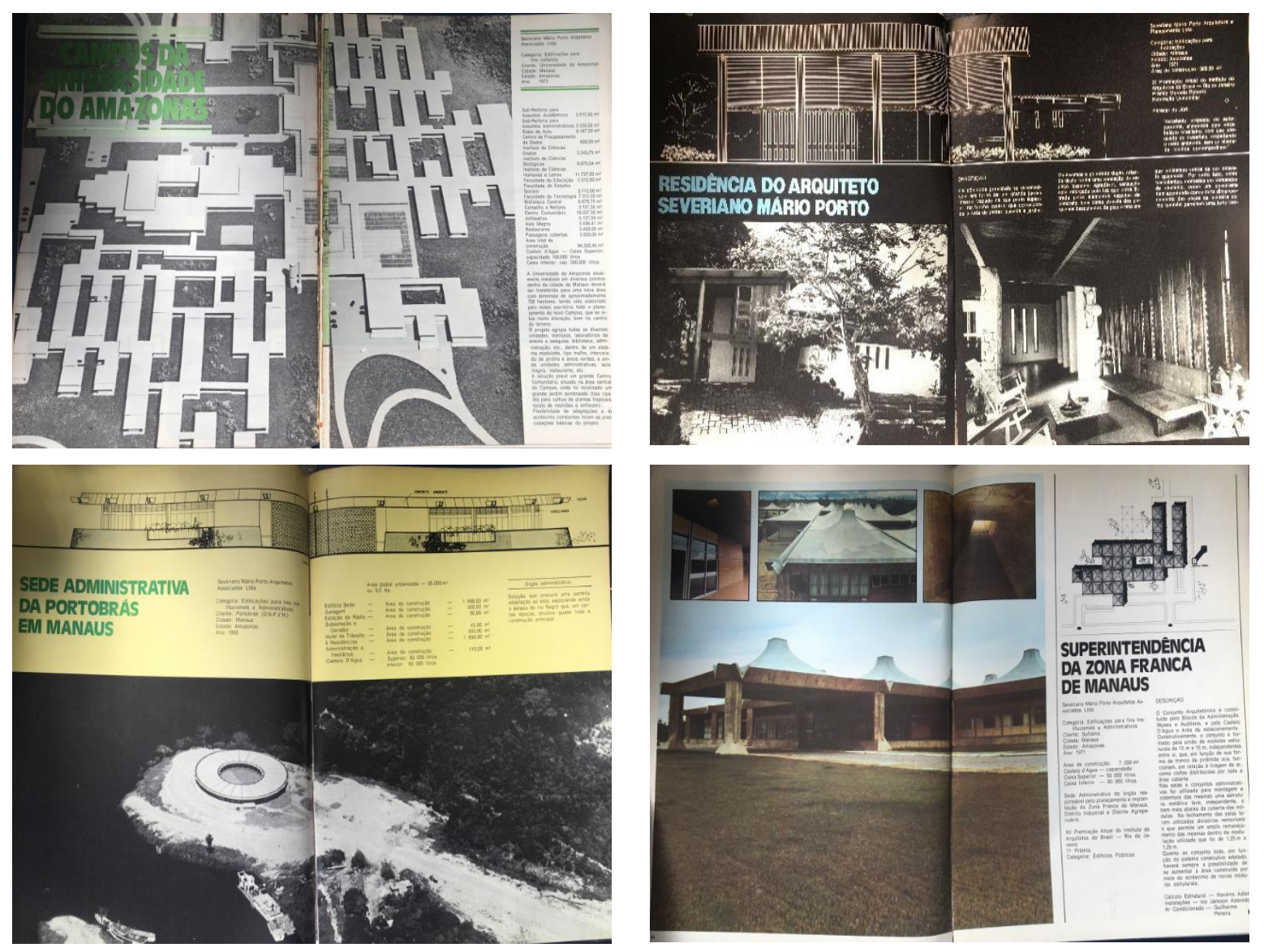

Figura 42 - Projetos na estrutura de novas paisagens e espacialidades urbanas em Manaus-AM. Fonte: CJ ARQUITETURA n.20, 1978.

A nota intitulada arquitetos contra a devastação da Amazônia apresentava a Amazônia como um bem comum, nacional, tendo sido a primeira publicação a designá-la como "patrimônio". $\mathrm{Na}$ nota presente na publicação seguinte, na mesma revista Projeto, intitulada Contratos de risco na Amazônia são ameaça à sabedoria nacional, o IAB divulgou o ato público organizado pelo Comitê de Defesa da Amazônia como forma convocatória da sociedade em defesa "do seu maior patrimônio cultural: a Amazônia”. Aqui o sentido patrimonialista, de um bem de interesse nacional sobre o qual deveriam incidir medidas de preservação, ficou mais demarcado, como meio discursivo para a confrontação aos “contratos de risco” que o Estado vinha realizando na concessão de grandes glebas a grupos 
empresariais estrangeiros, o que para o IAB representava "um atentado à soberania nacional” ${ }^{195}$ (PROJETO N.12, junho de 1979).

Outra tônica das revistas em finais da década de 1970 foi a associação recorrente de projetos de Severiano Mário Porto como possibilidade de atuação profissional em meio ao processo de transformação do território amazônico. Ainda nessa década, dois de seus projetos foram publicados, figurando do mesmo modo, em contextos não urbanizados e sítios naturais, ilustrados pelo traço do desenho particular do arquiteto, transposto às obras em contextos indicativos de uma espacialidade amazônica tipificada. A casa projetada para Robert Schuster no bairro do Tarumã em Manaus-AM [figura 43] centrou a atenção das revistas nesse final de década, especialmente pela premiação naquele ano, pelo IAB, na categoria de "habitação unifamiliar" (PROJETO N.11, junho de 1979, p. 4). Algumas das obras do arquiteto corresponderam à Amazônia no debate profissional e foram intervenções referenciais à atividade profissional na região, sob a recente condição de patrimônio nacional.

A atenção do arquiteto ao "ambiente e com a paisagem" foi um atributo de valoração da obra de Severiano, especialmente quando foi sintetizada no projeto da casa de Robert Schuster, onde prevaleceu a "preocupação de tornar a construção parte da natureza onde esta domina o homem e usufrui, respeitando-a e preservando-a”. Na casa implantada no loteamento rural de grandes terrenos, em área de expansão urbana, o arquiteto trabalhou a madeira a partir de diversos tratamentos, lavrada na estrutura, tabuada no piso e vedações, em venezianas móveis, como cavaco na cobertura, se utilizando de processos artesanais de construção, alguns dos quais conhecidos por artesãos locais ou desenvolvidos em conjunto com eles. Para o júri que lhe concedeu a premiação, o projeto foi fruto de um raciocínio adaptativo da arquitetura, já que foi “adequado às características do ambiente, à mão-deobra e cultura locais, funcionamento simples, espaços ricos, de fácil execução por se basear na técnica regional, possibilitando execução a baixo custo" (PROJETO N.15, setembro/outubro de 1979, p. 19-20).

\footnotetext{
${ }^{195} \mathrm{Na}$ mesma revista, o tema do X Congresso Brasileiro de Arquitetos era divulgado, "Arquitetura Brasileira após Brasília", fortalecendo, como tratado no capítulo anterior, Brasília como o marco da história da arquitetura brasileira. Os subtemas do encontro envolviam além de reflexões mais detidas à prática profissional, as relativas à interferência do ambiente político institucional sobre o espaço habitado e a situação da arquitetura brasileira (PROJETO N.12, junho de 1979).
} 

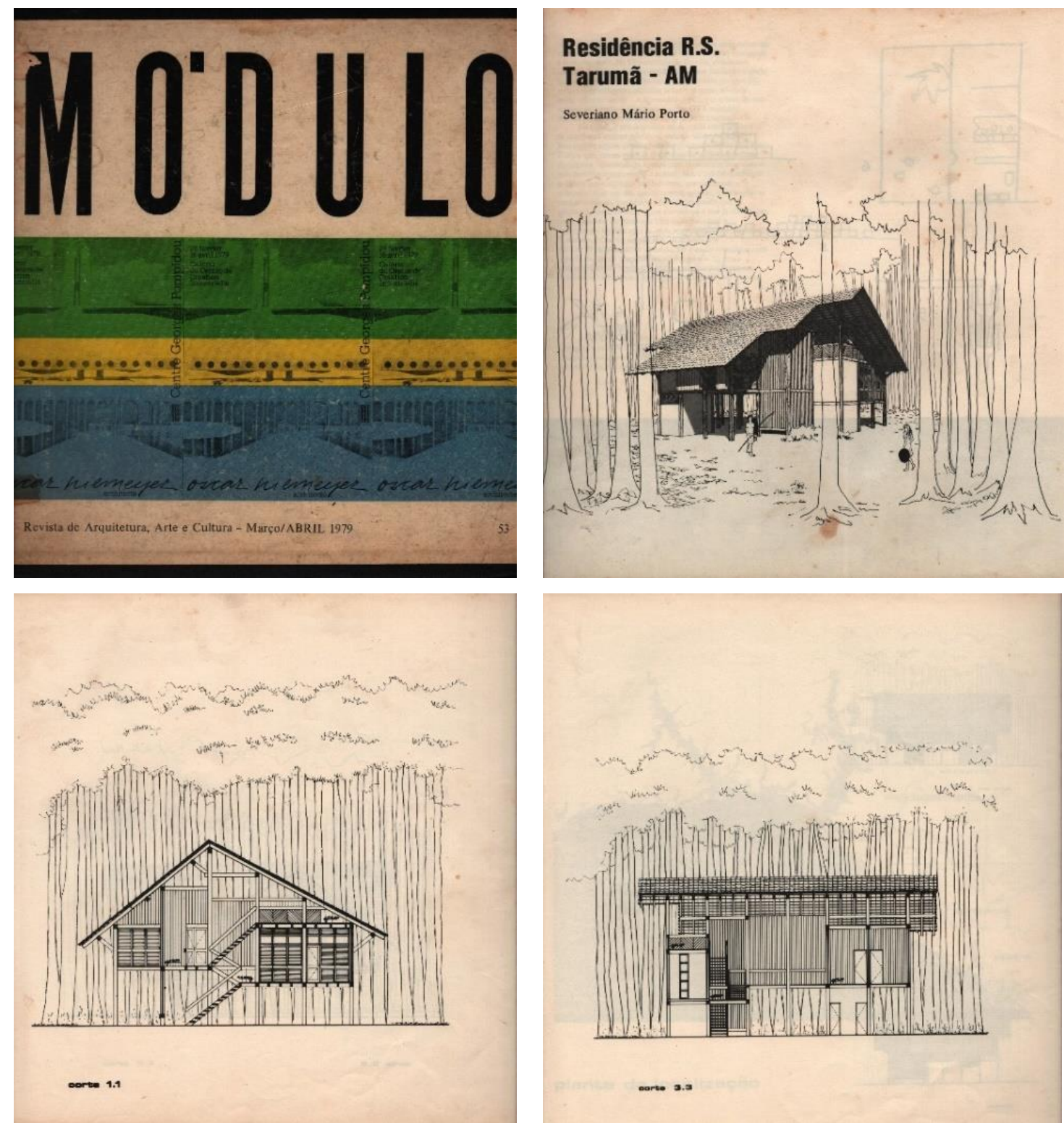

Figura 43 - Projeto de Severiano Porto para residência de Robert Schuster. Fonte: MÓDULO n.53, 1979, p. 60-67.

O atributo de uma "arquitetura tropical" o qual foi associada a produção de Severiano Porto também reapareceu no início da década de $1980,{ }^{196}$ junto à compilação de outros projetos residenciais que forneceram o sentido do que poderia ser "a residência particular no Brasil”, em continuidade histórica, numa narrativa genealógica que alcançou

\footnotetext{
${ }^{196}$ Reapareceu no sentido de que esta significação estava presente na década de 1960, especialmente em falas como as de Arthur Reis a respeito das obras que realizou por intermédio do governo do Amazonas.
} 
as "tendências" de projetos no início dos anos de 1980197 (MÓDULO N.70, 1982). E essa mesma genealogia seria o plano de fundo à representação de projetos desenvolvidos por Severiano Porto com esta mesma temática, explicados pelo paralelo com uma lógica quase natural de sua adequação ao meio, subordinada ao saber fazer do “caboclo", fosse na escolha do sítio, na orientação da habitação, na sua própria feitura. A adequação ao meio amazônico, ao qual se referia Severiano Porto era neste estágio, basilar ao desenvolvimento da ideia de uma "habitação regional”, a partir da evocação de um lugar amazônico tipificado e referenciado no mundo rural da hinterlândia. O próprio arquiteto negou a cidade, quando enalteceu o conhecimento nativo, ou mesmo justificou a inviabilidade de sua aplicação em moradias em contexto urbano, pela escassês dos meios materiais, pelas restrições normativas urbanas, pela prevalência de disponibilidade de material industrializado. Assim avaliou as habitações em Manaus, a seu ver, na maior parte mal construída e situada em áreas invadidas.

A designação de "arquitetura tropical” à obra de Severiano foi frequentemente uma forma valorativa a alguns projetos específicos, dentre os quais os de habitação. O projeto que desenvolveu para sua moradia, inscrita em um loteamento urbano em Manaus-AM em 1971, premiado na IX Premiação anual do Instituto de Arquitetos do Brasil na categoria de habitação unifamiliar, figurou como exemplar das estratégias projetuais do arquiteto para projetos de moradia [figura 44]. Segundo o júri, foi aquela uma "excelente proposta do autor, coerente, elaborada com vocabulário brasileiro, com uso adequado de materiais, respeitando o meio ambiente, sem se alinear da técnica contemporânea" (PROJETO N.40, maio de 1982).

O projeto foi publicado pelas imagens que acentuaram a inscrição da casa imersa no meio natural, conformando a paisagem junto a este. Internamente, como descrito na revista, a espacialidade foi desenvolvida ao redor de um espaço central destinado a usos distintos e continuados, com pé direito duplo, no qual incidia uma luz filtrada por "elementos vazados de concreto", bem como "basculantes de piso a teto" com vidro amarelo. A estrutura de madeira foi determinante ao projeto, só excetuada sua aplicação nas áreas de instalações

\footnotetext{
${ }^{197}$ A considerar nesta linha interpretativa da adaptação, os projetos publicados na referida compilação, de Cydno de Silveira e Amélia Gama, "Arquitetura de Taipa”, e a casa de praia de autoria de Acácio Gil Borsói, com "emprego de materiais simples e locais como a madeira, a telha de barro, as alvenarias de tijolos e pisos de pedra”.
} 
hidrosanitárias. Para Ruth Verde Zein, Severiano Porto trilhou caminhos alternativos às soluções de projeto, produzindo em múltiplas frentes, ainda que "tributários da herança moderna” (ZEIN, 2001, p. 193-194):

Sua postura relembra uma das mais interessantes características da arquitetura moderna brasileira: a adaptação de postulados genéricos, advindos dos mesres europeus, ao sítio, clima, materiais e até ao jeito nossos. Pertence a uma tradição que produziu obras como o Hotel de Friburgo, de Lúcio Costa, a casa de Oswald de Andrade, de Oscar Niemeyer, a caixa d'água de Olinda, de Luis Nunes, para citar os mais conhecidos.
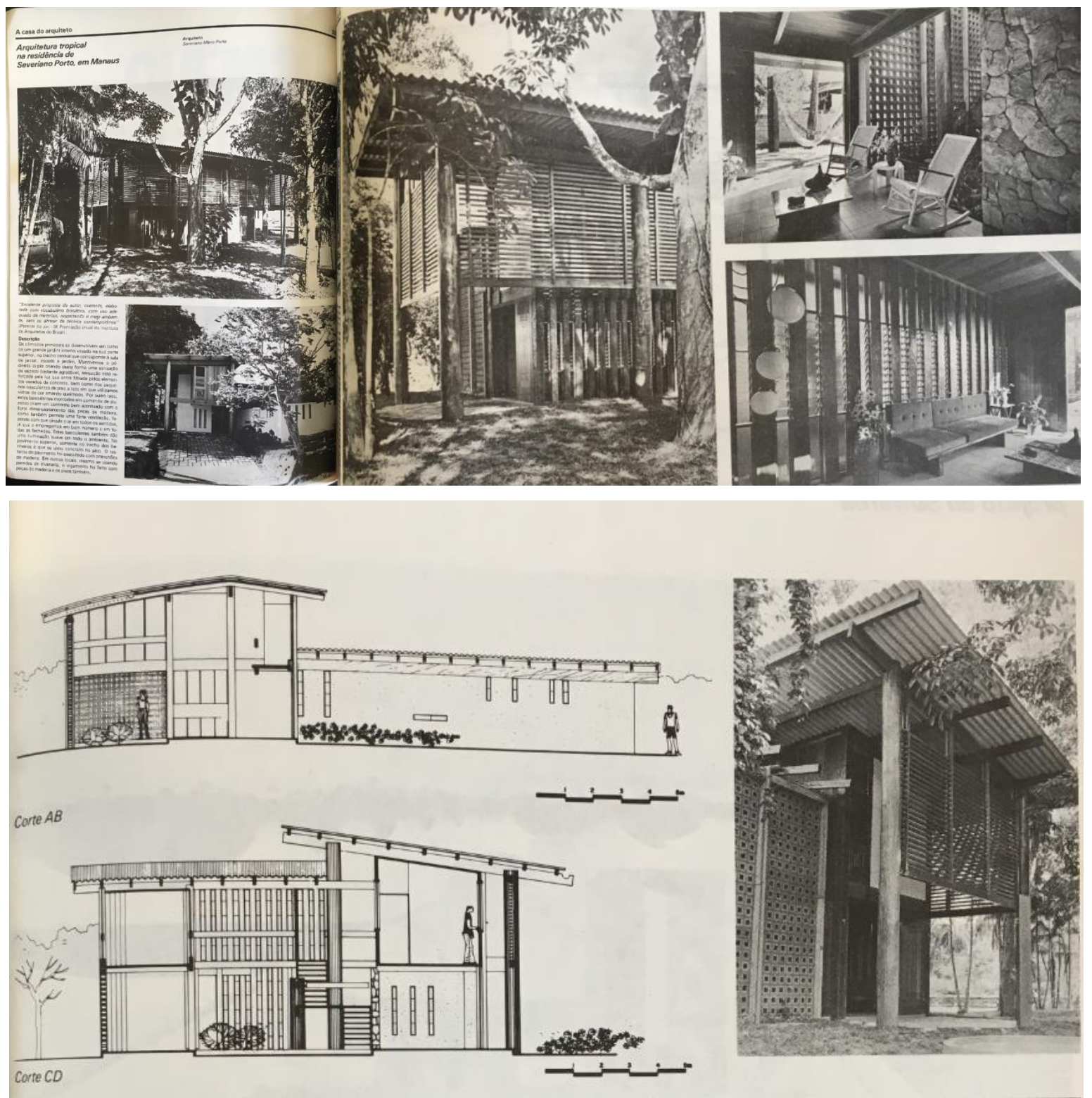

Figura 44 - Casa de Severiano Mário Porto, Manaus - AM. Fonte: PROJETO n.40, 1982, p. 22-25. 
Sua perspectiva de desenvolvimento de projetos junto ao meio natural, partia da aplicação do conhecimento técnico e construtivo indiscriminado. No caso da Amazônia, o meio se mantinha "inexplorado", tanto que o arquiteto especulava sobre a qualidade adaptativa do projeto arquitetônico junto à presença de uma infraestrutura urbana, como fizera Eduardo Yázigi. Determinante à implantação da moradia, condicionada às dimensões dos lotes, no desenvolvimento de suas ideias de arquitetura não dispensava uma concepção de "urbanização em geral”, inclusas áreas verdes, as soluções de sombreamento e o planejamento de áreas destinadas aos demais usos na cidade. A respeito do conhecimento erudito na arquitetura atestou que (MÓDULO N.70, 1982, p. 66):

As Universidades, em geral, não atentam para o aprendizado de técnicas primitivas e simples, afastando-se mesmo, de uma maneira geral, do ensino de técnicas construtivas, esquecendo-se que a atividade final do arquiteto não é o projeto, e sim a obra, a construção.

É difícil encontrarmos laboratórios, canteiros de obra, oficinas, dentro das Faculdades de Arquitetura, o que torna limitados e inseguros na área de construção os profissionais já formados.

No início da década de 1980 a questão da "crise ambiental” era vista pelo IAB como reflexo direto da crise do capitalismo, fruto de um desequilíbrio global que vinha sendo manifesto nos ecosistemas planetários e na "comunidade humana”, avistado em fenômenos como "o descontrolado crescimento demográfico, a desigual distribuição de riquezas, a ênfase no desenvolvimento de tecnologia predatória e concentradora de poder e de capital, e o processo de achatamento do nível cultural da população”, além do crescente consumo estimulado pela publicidade. Estas seriam as razões para o distanciamento do homem de um “equilíbrio natural” ideal. Estas razões demandariam do arquiteto outras formas de posicionamento e crítica, dada sua inevitável interferência quando da criação de estruturas artificiais para o meio (PROJETO N.28, março/abril de 1981). ${ }^{198}$ Todavia, na prática, esta posição era imprecisa, era mais uma pauta de discussão do IAB, assim como no próprio campo disciplinar e junto à sociedade de modo ampliado, incluso às comunidades organizadas, nessa década. ${ }^{199}$

\footnotetext{
${ }^{198}$ No editorial desta revista, Vicente Wissenbach já demonstrava o seu interesse em montar uma "mostra latino-americana de arquitetura".

${ }^{199}$ Em debate realizado em São Paulo, sobre cidades novas e cidades existentes, organizado pelo "Instituto Brasileiro de Planejamento", Joaquim Guedes narrou de sua experiência no projeto de Caraíba-BA, uma cidade para servir de suporte à mineração, e o quanto havia raciocinado a partir do clima, do ambiente, da observação de cidades vizinhas existentes, dos "hábitos e formas próprias da região", e sobre a ilusão de
} 
Grandes intervenções estavam em curso e a atividade profissional de arquitetos se expandia a frentes como as que Hugo Segawa associou a "um Brasil grande e moderno”, num intervalo entre as décadas de 1950 e 1980, marcado em 1964, pela “capacitação do Estado para intervir na economia, apesar da retórica liberal”, com incentivador à formação de grandes conglomerados que atuaram em áreas estratégicas, como energia, setor bancário, transporte, comércio. A indústria foi constituída em setores produtivos de atuação, especialmente em “infraestrutura, transporte, comunicação, estradas e outros, num projeto político econômico de integracão nacional”, de dinamização e concentração da economia em determinados segmentos. Neste fluxo, arquitetos encontraram trabalho junto a grandes projetos desenvolvimentistas, inclusive em empresas de engenharia, num transcurso crescente até a "crise do petróleo" (SEGAWA, 1998).

Alguns projetos publicados no início da década de 1980 foram exemplos da atividade projetual de arquitetos à equipamentos asssociados à infraestrutura da modernização conservadora na Amazônia, bem como às redes de integração nacional implantadas pelo Estado. Foram estes, a usina hidrelétrica de Tucuruí (PROJETO N.44, outubro de 1982), o terminal rodoviário de Cuiabá-MT (PROJETO N.26, janeiro de 1981), projetos de cidade, como para Matupá-MT ${ }^{200}$, a cargo da Fronteira Norte Engenharia de Desenvolvimento, especializada em projetos de colonização (PROJETO N.45, novembro de 1982), as empresas de telecomunicações (PROJETO N.45, novembro de 1982).

A usina de Tucuruí, no rio Tocantins-PA, [figura 45, 46] que custaria cerca de dois bilhões de dólares, foi fruto de um consórcio de empresas japonesas Nippon Amazônia Aluminium, formado em sociedade com a Companhia Vale do Rio Doce, que detinha 51\% do capital investido, e que formavam a empresa Alumínio do Brasil (Albrás), que começou a funcionar em 1985. O governo tinha interesse na "autossuficiência em energia na região" e as empresas japonesas, em obter "alumínio a preços mais competitivos para as suas indústrias”, motivo pelo qual fizeram o investimento. Em detrimento do aumento dos custos, saíram do acordo e a eletronorte custeou o restante da obra com endividamento junto a bancos internacionais, especialmente franceses, sendo submetida, para tanto, a uma

projetar uma "cidade sem classes". Tais questões portanto, relativas à adequabilidade do urbanismo ao ambiente estavam em amplo debate nos anos de 1980 (MÓDULO N.71, 1982).

${ }^{200} \mathrm{O}$ planejamento arquitetônico e acompanhamento das obras seria de Ricardo Julião e o desenvolvimento e execução do projeto de urbanização seria de autoria de Cândido Malta Campos Filho. 
série de condições. A obra inaugurada teria custado ao fim, mais de cinco bilhões de dólares, sem contar os juros dos empréstimos e os subsídios das tarifas à Albrás, que provocaram dificuldades de operação por parte da eletronorte, "fazendo com que a tarifa venha a ser majorada para outros consumidores" (BRITO, 2001, p. 195).

A obra em si, iniciada em 1975, cuja execução principal ficou a cargo da empresa Camargo Corrêa $S / A$, demandou um grande canteiro industrial, envolveu a construção de uma barragem para a formação de um reservatório de $2.160 \mathrm{~km} 2$, implantação de rodovias, porto, aeroportos, além de cidade para cerca de 40 mil pessoas, para a instalação de funcionários da hidrelétrica, com vilas residenciais e centros comunitários, além do sistema de transmissão de energia a partir de projetos desenvolvidos pelo Consórcio EngevixThermag. Na revista que a publicou, a obra aparece como um "marco do desenvolvimento das regiões Norte e Nordeste do país" e nela foi informado que a energia gerada seria praticamente utilizada pelos "complexos industriais para beneficiamenteo de minérios provenientes do interior amazônico", sendo que "outra parcela" serviria aos "núcleos urbanos da região" (PROJETO N.44, outubro de 1982, p. 59-69).
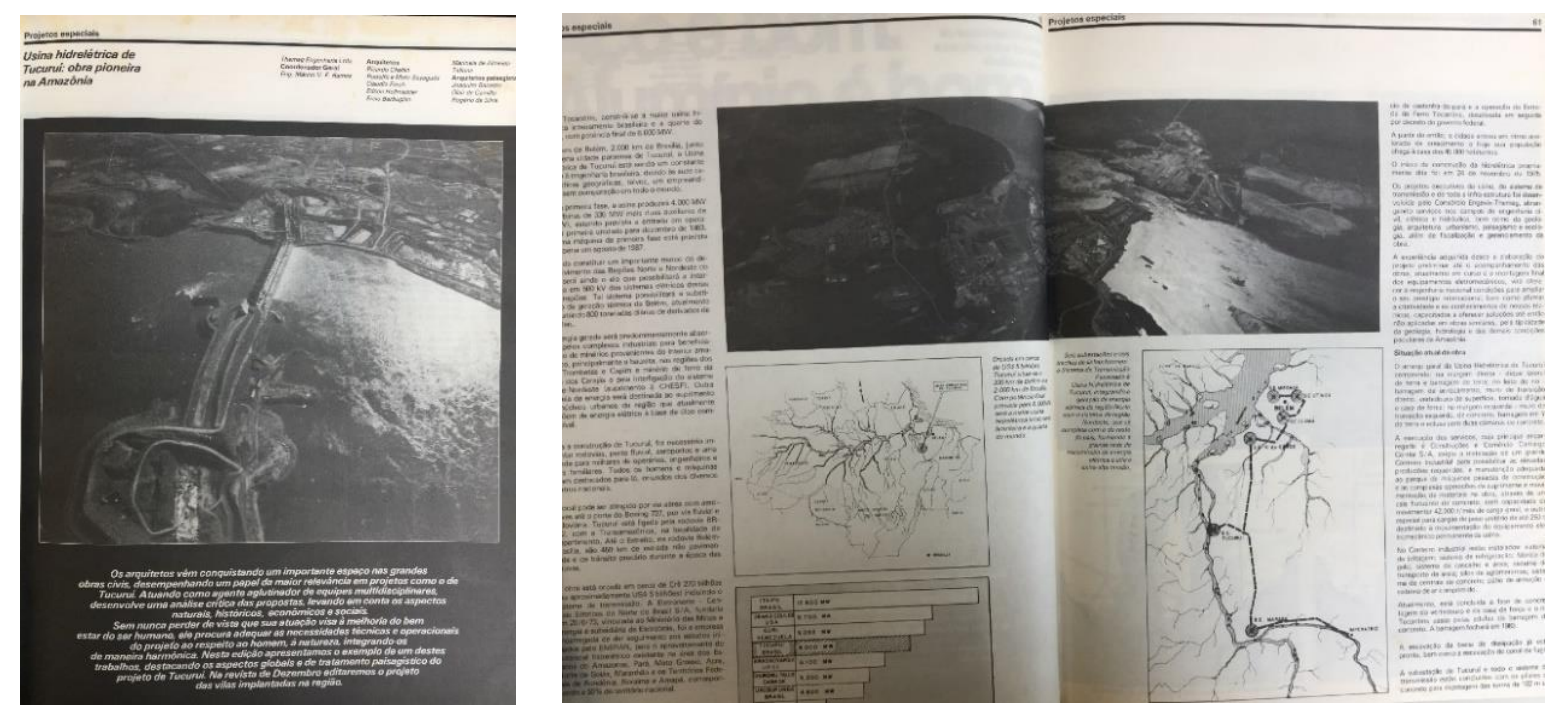

Figura 45 - Usina hidrelétrica de Tucuruí. Fonte: PROJETO n.44, 1982, p. 59-69.

No ano seguinte, a "selva tropical" foi apresentada como um "desafio para os projetistas", apresentada como empecilho para a realização da cidade que serviria de base às atividades da usina, uma "experiência sui generis no Brasil", frente a "necessidade de desenvolvimento socioeconômico da região amazônica”. A proposta integraria as novas vilas projetadas ao núcleo anteriormente existente em Tucuruí onde até então eram 
prevalentes as atividades de extração de castanha e madeira, e de pesca, em uma única estrutura urbana. Do ponto de vista dos projetos, a argumentação foi pautada pela adaptação das vilas às condições geofísicas, também favorecendo a "drenagem natural", recomendando-se a "preservação de áreas verdes remanescentes" e aproveitamento das espécies nativas para o paisagismo, com vistas a "preservação da floresta do entorno".
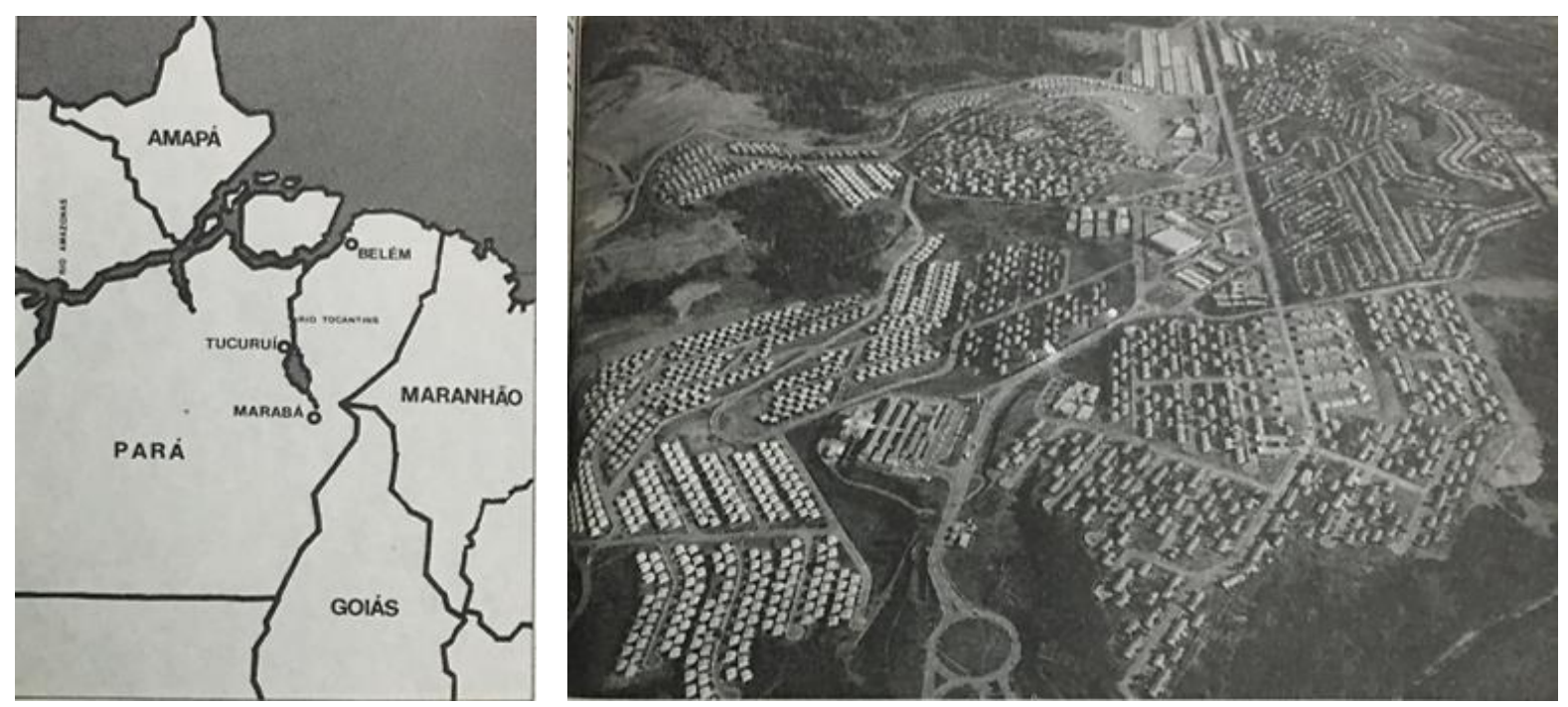

Figura 46 - Vila permanente da Usina de Tucuruí. Fonte: PROJETO n.56, 1983.

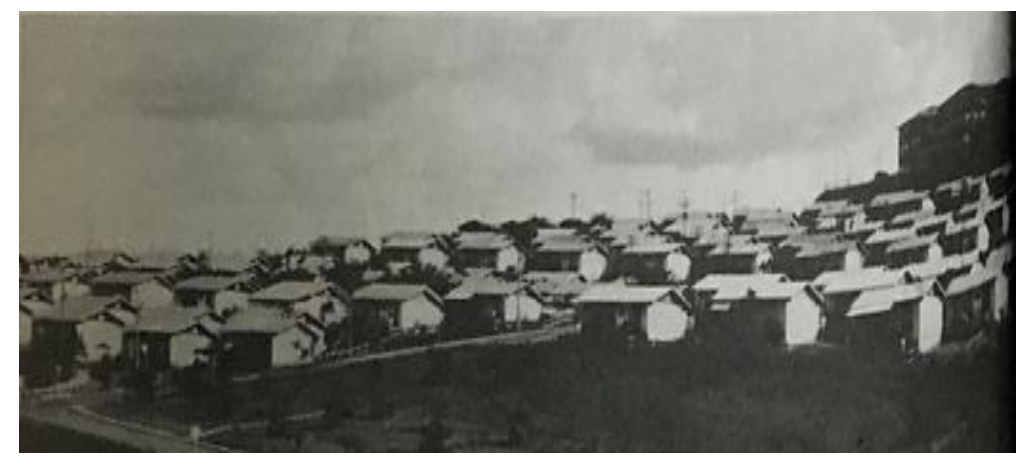

Para as moradias, a utilização de "materiais regionais", visou as melhores condições de conforto, junto à "criação de microclimas e áreas sombreadas" e a adoção de soluções como beirais alongados e uso de venezianas, recursos estes, já há tempos conhecidos. Das conclusões acerca da obra, o texto registrou a "série de distorções sociais, resultado da metamorfose provocada rapidamente na região, tanto pela grande injeção de recursos, como pelas fortes correntes migratórias”, que se concentraram no núcleo antigo, já que as vilas haviam sido geridos como espaços controlados, quando projetadas para famílias de funcionários da Eletronorte, numa "situação contrastante", pois a "qualidade de vida de seus habitantes atinge níveis quase ideais". Por fim, estavam em curso, um plano de implantação 
de um núcleo industrial e de outro, de "suporte ao campo e à exploração nacional da floresta" (PROJETO N.56, outubro de 1983, p. 56-67).
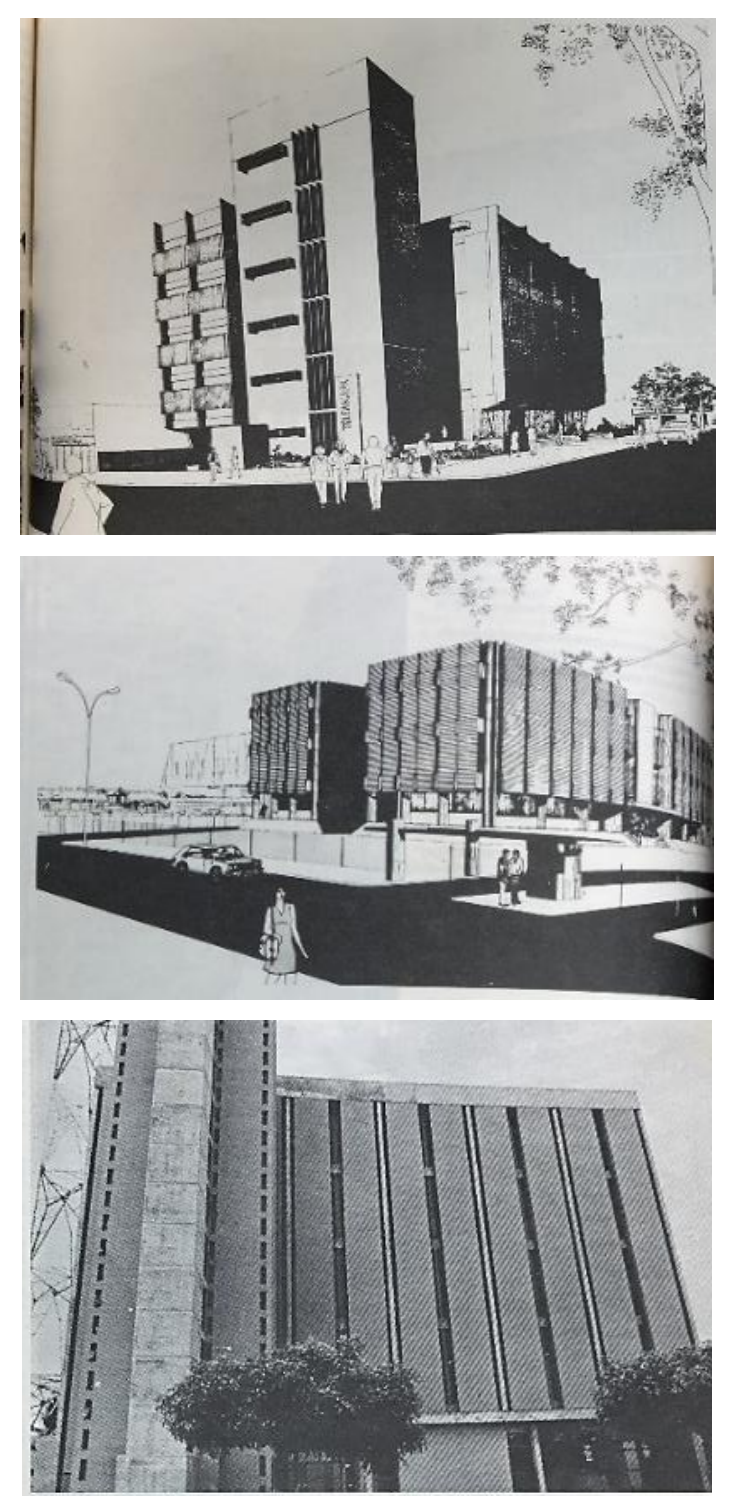
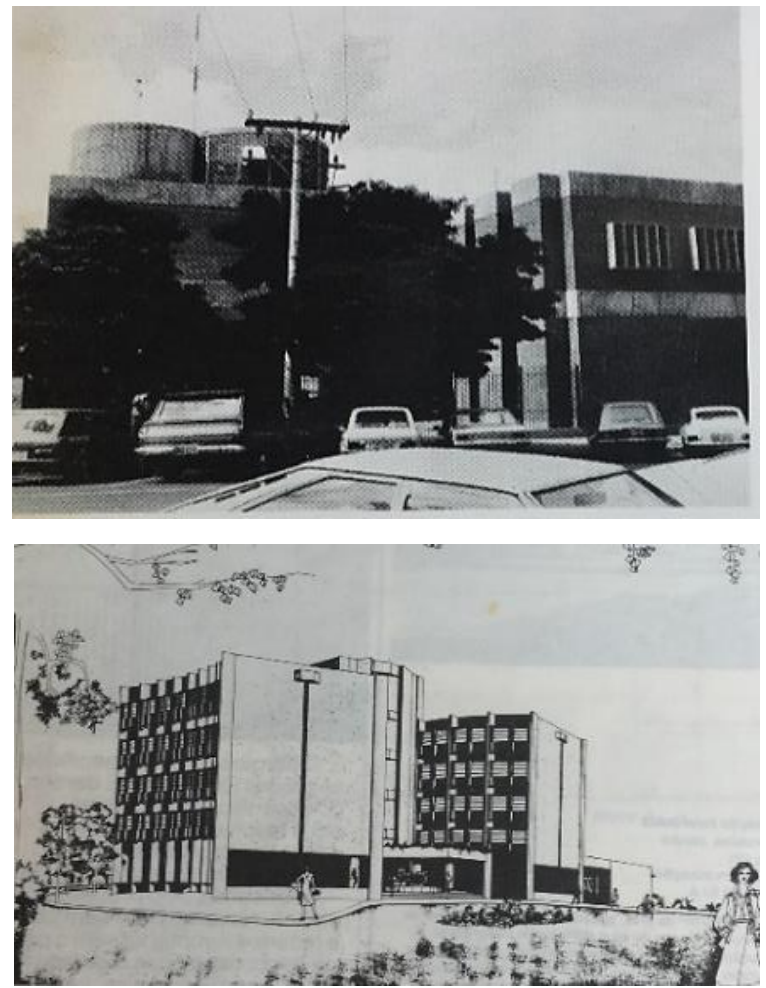

Figura 47 - Projetos desenvolvidos por Sérgio Teperman para o setor de telecomunicações, dentre os quais a sede no Amapá, Mato Grosso, Pará, Acre e Maranhão. Fonte: PROJETO n.45, 1982, p. 57-67.

Segundo Sérgio Teperman, que havia desenvolvido mais de cem trabalhos para o segmento de telecomunicações [figura 47], os projetos para essas empresas incluíam além "das estações telefônicas", os "centros de manutenção e operação, áreas de lazer, centros administrativos, edifícios sede, centros de treinamento, almoxarifados, postos de serviços, postos comerciais, levantamentos de requisitos de programas", dentre outras espécies de trabalhos às quais seu escritório já vinha se dedicando havia cerca de dez anos. O trabalho, portanto, envolvia tanto a atividade projetual especificamente, como a elaboração de 
diagnósticos diversificados, demandados inclusive pela especificidade do local de implantação dos projetos, em suas necessidades técnicas particulares.

Para tanto, Teperman considerava não uma "padronização de projetos”, mas a “sistematização de soluções arquitetônicas e construtivas”, como da adoção da distinção entre zonas de circulação e infraestruturas e para equipamentos, a criação de "dutos externos” para as instalações, a atenuação da massa edificada e a qualidade do espaço de trabalho no interior das edificações a partir do uso estratégico de aberturas, replicação de detalhes construtivos, a coordenação de projetos. Dos elencados na longa listagem que apresentou o arquiteto na revista, foi possível destacar aqueles desenvolvidos para contextos urbanizados das capitais do Amapá, Mato Grosso, Pará, Acre e Marahão (PROJETO N.45, novembro de 1982, p. 51-56).

O edifício projetado para o terminal rodoviário em Cuiabá-MT detinha uma complexidade prioritariamente conferida pela inscrição no território e foi pensado a partir da articulação regional que produziria, tendo sido objetivado como um aparato construído para o espaço urbano da capital [figura 48]. Em concreto, o edifício foi desenvolvido em três níveis, adaptado muito diretamente às condições topográficas do sítio e à facilitação dos fluxos, temática central do raciocínio levado à intervenção. Esta foi uma tipologia que segundo Hugo Segawa ainda não havia sido desenvolvida até a década de 1970, quando o Departamemto de Estradas e Rodagens e respectivos departamentos estaduais "formularam normas para a implantação de terminais rodoviários”, considerados uma série de requisitos de qualidade da implantação e da espacialidade de equipamentos para tal finalidade (SEGAWA, 1998, p. 168). Foi durante o período de 1968 a 1974 que o Estado implantou ainda que parcialmente, uma malha de redes de circulação viária estendida à Amazônia, o que veio a demandar equipamentos desse tipo, considerando que entre 1970 e 1976, foi implantada a ligação entre Cuiabá - MT e Santarém - PA, ainda sob ideais integracionistas, expansionistas, de colonização e valorização da terra.

Nos anos de 1980, o projeto desenvolvimentista dos governos militares estavam demonstrando “sinais de esgotamento", em função da abertura do regime, do aumento da pobreza regional na Amazônia, dos graves impactos sobre o meio advindos de seus projetos, especialmente o da rede rodoviarista, dos efeitos excludentes da modernização empreendida pelo Estado na região, todos estes fatores motivadores de ampliadas pressões e conflitos 
sociais internos e externos. ${ }^{201} \mathrm{E}$ essa dualidade, demonstrada pela representação de uma Amazônia modernizada e integrada à nação, a partir dos projetos de desenvolvimento, e outra, uma Amazônia devastada, acompanhou no início da década as publicações, prevalentemente quando foi tema das revistas Projeto e Arquitetura e Urbanismo.
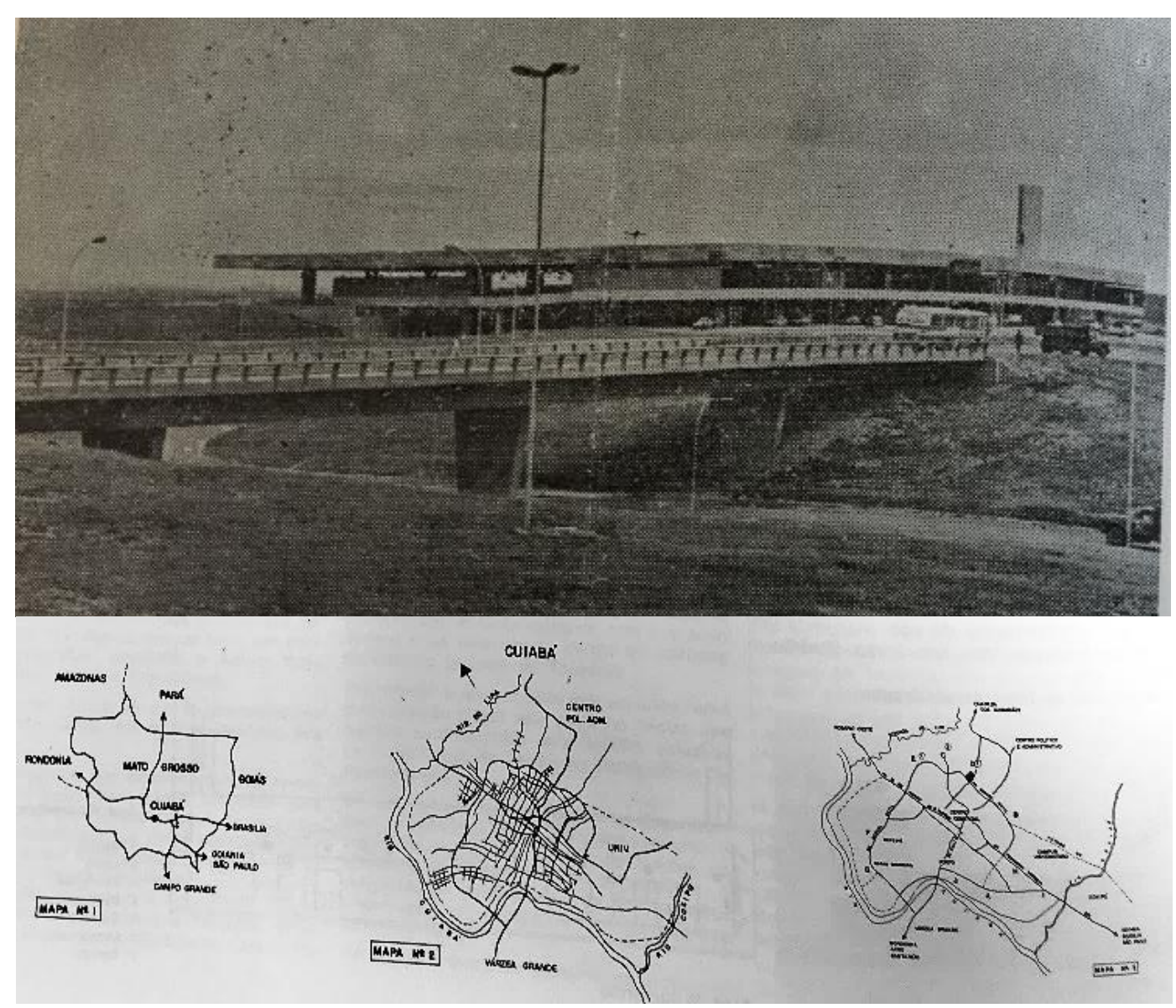

Figura 48 - Projeto de terminal rodoviário de Cuiabá-MT, de autoria de Moacir Freitas, Ercílio G. de Souza, Paulo A. Mendes da Rocha, Newton Arakawa. Fonte: PROJETO n.26, 1981, p. 16-18.

Também outra temática passou a circular nos periódicos, relativa às condições do espaço urbano das cidades na Amazônia, tanto a partir de experiências de projeto concretizados quanto os que foram eminentemente utópicos. A respeito da Amazônia, o Conselho Superior do IAB divulgava o documento final da reunião ocorrida em janeiro de 1982 na cidade de Belém-PA (PROJETO N.38, março de 1982, p. 8-9):

${ }^{201}$ Daniel Chaves Brito desenvolveu estudo detalhado a respeito do caráter paradoxal da modernização empreendida pelo Estado na Amazônia, considerando espectro ampliado dos efeitos dos planos e programas empreendidos, inclusive os ambientais e sociais. Mais precisamente, pelo fato de que quando realizados os grandes projetos estatais para a Amazônia, o foram "mergulhados em um mar de irracionalidades" (BRITO, 2001, p. 196). 
foi aprovada moção que torna público o "profundo temor pelo futuro e destino das riquezas amazônicas, ao mesmo tempo em que repudiam a forma autoritária como se decidem os projetos que se implantam nesta região, conclamando os demais segmentos da sociedade brasileira, na luta pela conquista dos instrumentos democráticos de decisão sobre nossos destinos.

$[\ldots]$

Defesa da Amazônia - Entendendo que a Amazônia, um dos mais importantes ecossistemas ainda preservados da terra - encontra-se profundamente ameaçada pelo avanço acelerado da fronteira de exploração que se alastra a partir dos grandes Projetos Oficiais e Privados e da ação gananciosa e predatória de especuladores internacionais, propõe-se a todos os segmentos da sociedade brasileira que se lancem, unidos ao IAB, numa ampla frente de defesa ecológica da Região.

Uma obra publicada neste ínterim, no início da década de 1980, ainda que em 1967/68 já estivesse sido publicada na revista ABA, em projeto, foi a pousada na ilha de Silves-AM projetada por Severiano Mário Porto, Mário Emílio Ribeiro e equipe, premiada em 1982 na categoria de obra construída. A obra foi tida pelo júri como "uma arquitetura tão bem realizada, com tal integração de material/linguagem/criatividade/resultados” que mereceu a premiação. O juri chamava atenção para o "didatismo das fotografias da fase de construção, onde se vê o domínio dos arquitetos sobre o material e uma linguagem coerente com a Amazônia, desvinculada de estereótipos” [figura 49].

O projeto foi voltado à atividade turística na região e vinha sendo estudado desde 1966, ainda que sua implantação tenha ocorrido em 1979. Terence Keller Andrade e Maria Goretti Tavares atribuem às iniciativas governamentais entre os anos de 1964 a 1985, o processo que nomearam de "turistificação" dos lugares amazônicos. As iniciativas de turistificação foram articuladas às estratégias geopolíticas de governos militares sob o mote discursivo da integração nacional, já que sua "abertura ao mundo se fortalecia com o fenômeno turístico, possibilitando a mobilidade de pessoas e capitais” na região. Estruturas governamentais foram estruturadas para promoção do desenvolvimento regional por meio da atividade turística, de modo intensificado a partir da década de 1970, pela SUDAM, tendo sido lançado um primeiro "Plano de Turismo da Amazônia", no qual a Amazônia foi concebida como uma "fronteira tropical" de exploração pela atividade econômica turística, no início da década de 1980 (ANDRADE e TAVARES, 2012).

Foram previstos outros equipamentos para o complexo projetado em Silves-AM, não unicamente a pousada, como cabanas, mirantes, porto flutuante, garagem de barcos, 
área para plantio, granja, na ilha de poucos moradores que viviam da pesca e do trabalho em pequenas fazendas de gado próximas. No texto apresentado junto ao projeto, no qual a madeira foi utilizada com diversas técnicas e em distintos componentes construtivos, foi emitido o juízo acerca da Amazônia, como meio para a fundamentação e justificativa do projeto em questão (MÓDULO N.75, 1983, p. 58-59):

A natureza simples, num estágio primitivo, os lugarejos, a beleza e a suntuosidade da Amazônia em seus vários recantos, onde o silêncio só é comparável às suas proporções, torna o homem pequeno, muito pequeno mesmo, diante daquele cenário.

Ambientar o turista nessas regiões, para que ele comece a se preparar emocionalmente para poder sentir e viver esses momentos, foi a preocupação inicial, quando da elaboração em 1966, dos primeiros estudos.
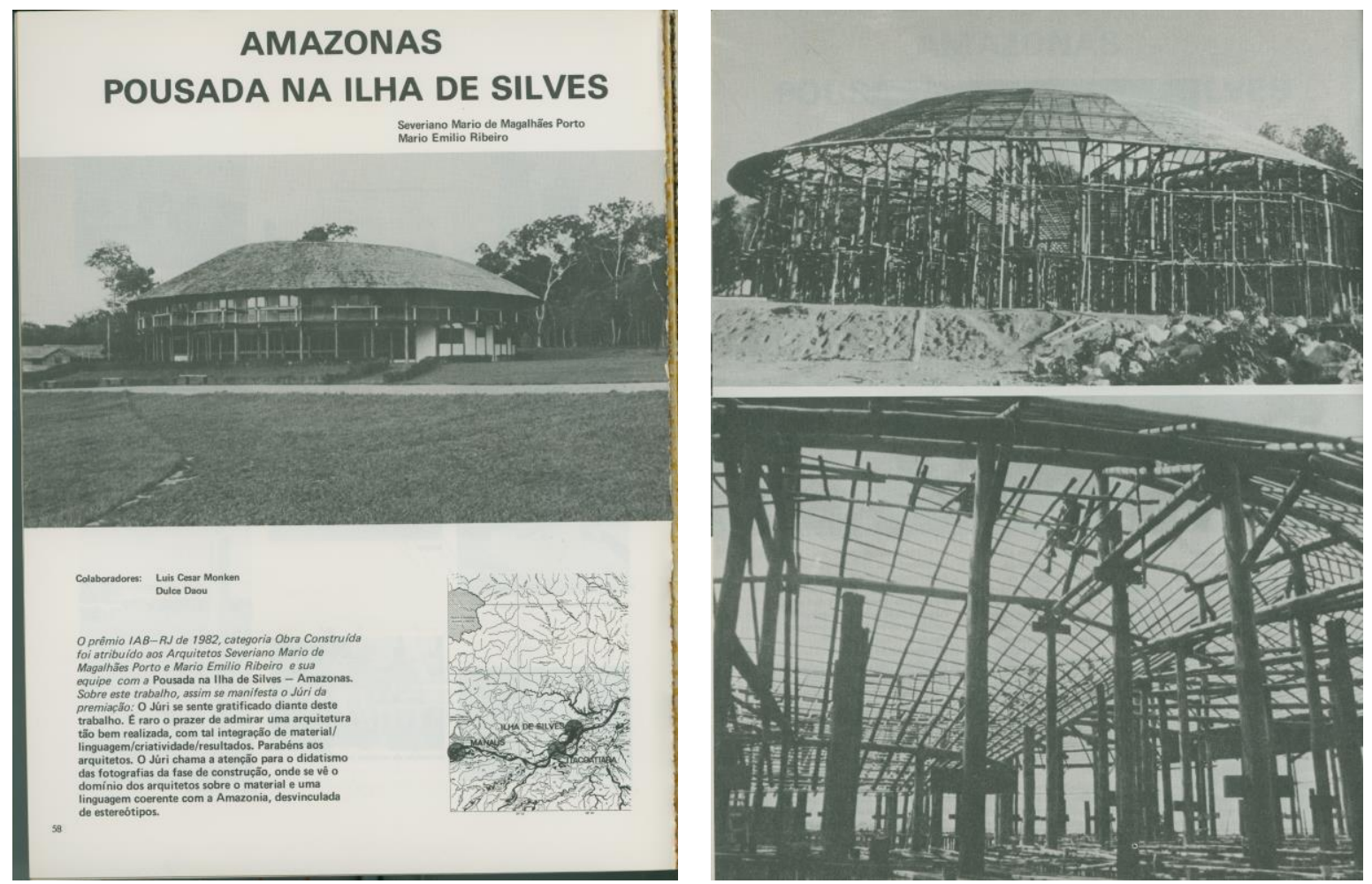

Figura 49 - Projeto de pousada na ilha de Silves-AM, de Severiano Mário Porto, Mário Emílio Ribeiro e equipe. Fonte: MÓDULO, n. 75, 1983, p.58-61.

Três outras publicações da revista Projeto registraram nesse mesmo ano, o projeto da pousada para a ilha de Silves-AM (PROJETO N.49, março de 1983) (PROJETO N.53, julho de 1983) (PROJETO N.57, novembro de 1983). A primeira correspondeu ao artigo de Ruth Verde Zein acerca da temática do projeto de hotéis, intitulada Projeto de Hotéis: adequação entre arquitetura e economia de custos [figura 50], tendo por base a discussão 
da viabilidade do empreendimento neste ramo, frente às soluções projetuais demandadas aos arquitetos. A pousada de Silves-AM, neste caso, publicada separadamente, foi apresentada em fotografias da obra pronta e em construção, também, a partir do próprio projeto (PROJETO N.49, março de 1983, p. 36-46). Quanto ao texto que acompanhou o projeto, ao ser publicado em separado, foi similar ao publicado na revista Módulo (MÓDULO N.75, 1983), provavelmente de autoria do próprio arquiteto autor da obra.
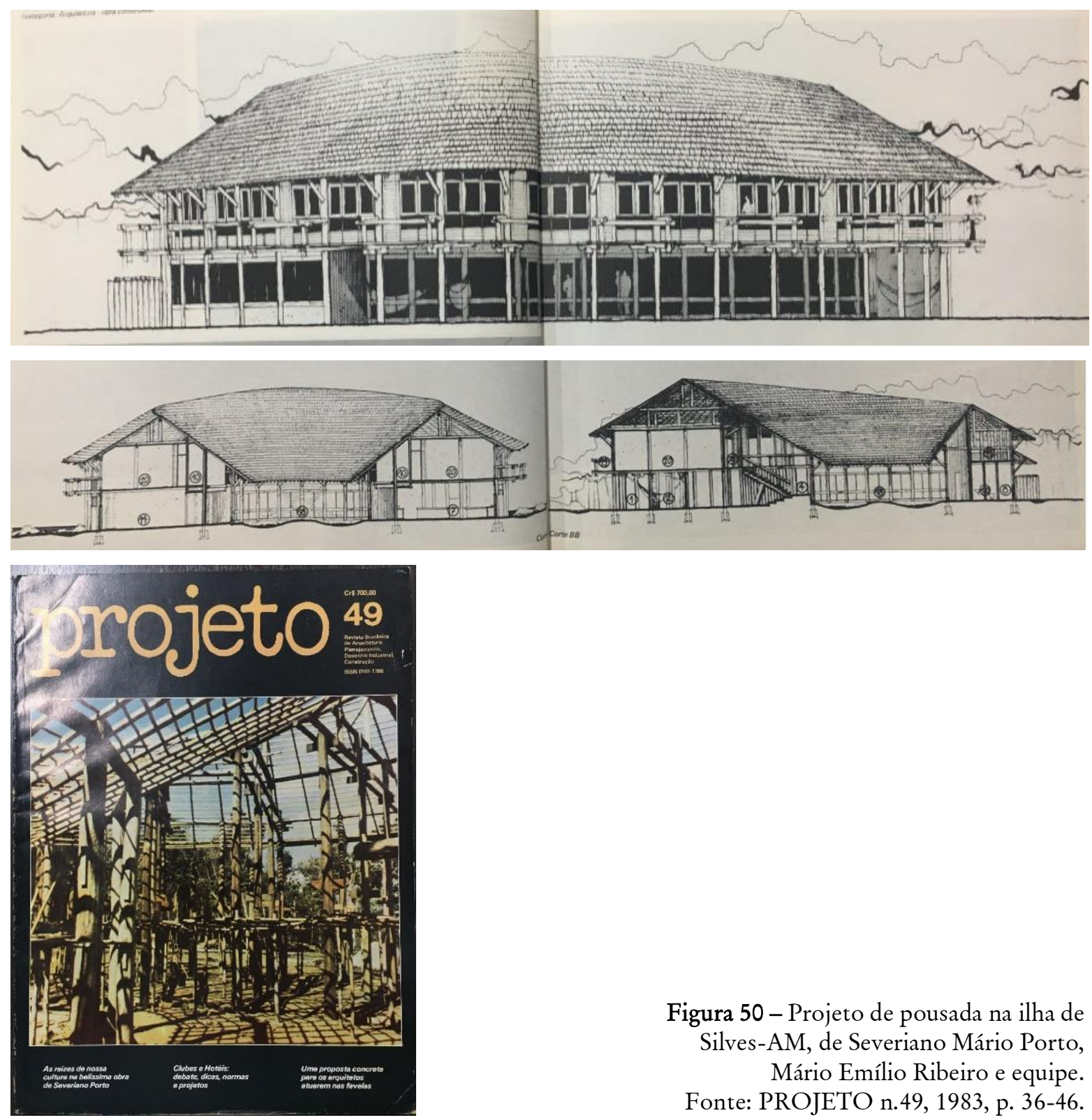

Figura 50 - Projeto de pousada na ilha de Silves-AM, de Severiano Mário Porto, Mário Emílio Ribeiro e equipe. Fonte: PROJETO n.49, 1983, p. 36-46.

O projeto da pousada também foi incluído no Panorama Pós-Brasília, em um "esforço necessário para se compreender as características do momento de transição" 
daqueles anos de 1980. Em nota sobre o tema da tecnologia, o hotel foi considerado "alternativo" em comparação ao concreto, já que seria este "o material por excelência da arquitetura brasileira, com exceções notáveis de madeira e metal que apenas confirmam a regra”. A imagem do projeto foi utilizada como exemplo dos que, naqueles anos, tendiam à utilização de "materiais com nível tecnológico relativamente mais simples", também à "simplificação dos processos construtivos, seja usando tecnologias alternativas, seja valorizando o conhecimento vernacular regional, numa proposta de adequação às condições econômicas locais, sem envolver uma dependência maior com tecnologias de ponta" (PROJETO N.53, julho de 1983, p. 83).

Uma breve menção foi feita sobre a relação que o projeto estabelecia com o saber local, o que pôs em pauta a questão da existência de uma cultura construtiva tradicional, amazônica. A casa de Severiano Mário Porto à rua Recife em Manaus-AM ${ }^{202}$ também foi publicada nesta mesma matéria a partir de uma fotografia, em abordagem sobre a "valorização de materiais e técnicas de uso local" e sobre a apropriação que o arquiteto produzia em sua obra, de um "vocabulário regional e o respeito pelo meio ambiente". Ele teria adotado este procedimento de modo associado à "técnica contemporânea e aos espaços necessários para o uso atual”. Deste modo, a técnica se ajustava ao programa e o uso da madeira foi justificado pela sua adequação, já que o arquiteto sofreu a influência do que seria a "experiência do homem local, que domina a técnica desse material". O projeto da pousada para Silves-AM, sob a categoria de hoteis de "lazer", produzia uma "linguagem coerente com a região, despreocupada de esteriótipos e modas” (PROJETO N.53, julho de 1983, p. 89;97;115-116) e o procedimento de projeto, de "valorização" da cultura vernácula, passou a ser componente explicativo da pousada de Silves-AM.

O interesse pela arquitetura indígena na mesma publicação foi demonstrado por dois artigos, uma pesquisa, Formas e símbolos em aldeias indígenas brasileiras, de Cristina Sá, arquiteta, e outra de Renato Delarole, fotógrafo e jornalista, A casa tupi-assurini: significado e construção. Ambas evidenciaram, pelo aprofundamento com que analisaram aquelas sociedades, suas particularidades sociais e culturais, bem como a relação destas com a cultura material que produziam, a arquitetura e o espaço de sua vivência. A primeira, voltava-se à "área cultural do Tocantins-Xingu", no ambinete do "cerrado do Brasil

\footnotetext{
${ }^{202}$ Além do projeto para a Suframa.
} 
Central”, e a segunda, ao grupo remanescente dos tupi-guarani, os “assurinis”, localizados junto ao rio Ipiaçava, afluente do Xingu, no Pará (PROJETO N.57, novembro de 1983, p. 51-61). Nesta mesma revista, além de ter sido apresentado o projeto de Severiano Porto para o Departamento Nacional de Portos e Vias Navegáveis - DNPVN (PROJETO N.57, novembro de 1983, p. 64), foi publicado o de Silves-AM, representada como um "paraíso ecológico", onde havia sido construída aquela arquitetura "respeitando a exuberância da natureza", na valoração do texto ao lugar de implantação do hotel (PROJETO N.57, novembro de 1983, p. 80-81).

Outra produção ganhou notabilidade nesse início dos anos de 1980, em contraponto àquela desenvolvida para novas áreas de expansão ou em contextos rurais, como o caso de Silves-AM. Uma arquitetura urbana, com destaque à produção de Severiano Mário Porto, foi publicada nas revistas e evidenciou, além dos próprios artefatos construídos, paisagens recém transformadas pelos novos programas e formas de ocupação que o arquiteto propunha. Em plena atividade em Manaus-AM nesses anos, Severiano Porto estruturou escritório e carreira, projetando na capital e na região de um modo geral, para os mais variados encargos, fossem públicos ou privados, tão diversos quanto os contextos aos quais se destinaram seus obras ou mesmo as soluções que adotou para cada uma.

Em artigo de 1986, Ruth Verde Zein já observava a inconsistência da designação pósmoderna para a produção de Severiano Porto, bem como uma unidade [figura 51]. Se referiu às críticas que a apontavam como obra "exótica”, ainda que à época se referisse à ela como uma "outra modernidade”, citando Enrique Browne ao falar, em relação ao arquiteto, dos “caminhos alternativos que não deixam de ser tributários da herança moderna” (PROJETO N.83, janeiro de 1986, p. 45). Um panorama da obra de Severiano Mário Porto foi publicado em 1986 na revista Projeto, cuja atuação estava a produzir uma "arquitetura moderna brasileira no Amazonas, usando madeira, concreto, aço sem nenhum preconceito" (PROJETO N.83, janeiro de 1986, p. 45). A publicação forneceu uma leitura da trajetória de mais de vinte anos do arquiteto, apresentou vários de seus projetos na Amazônia, sobretudo, a abrangência de sua atividade na região. Na revista foram destacados projetos implantados em novas frentes de espansão urbana em Manaus - AM, em áreas consolidadas desta cidade, bem como em outros contextos urbanos em transformação, como Porto Velho - RO, Cuiabá - MT e Campo Grande - MS. 

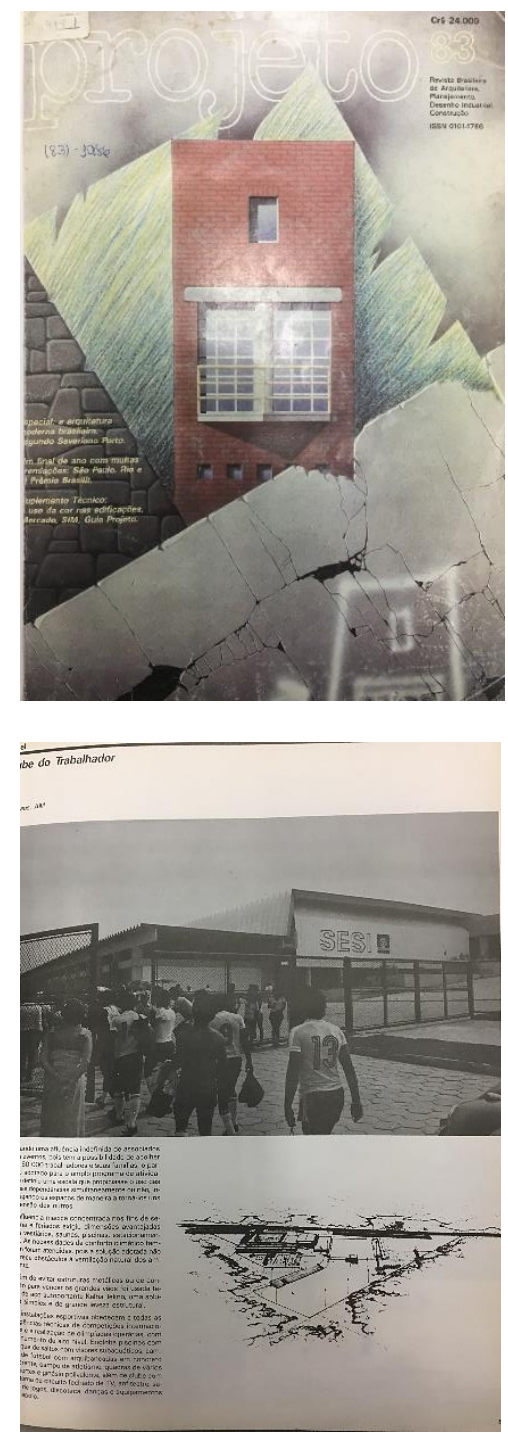

(3)

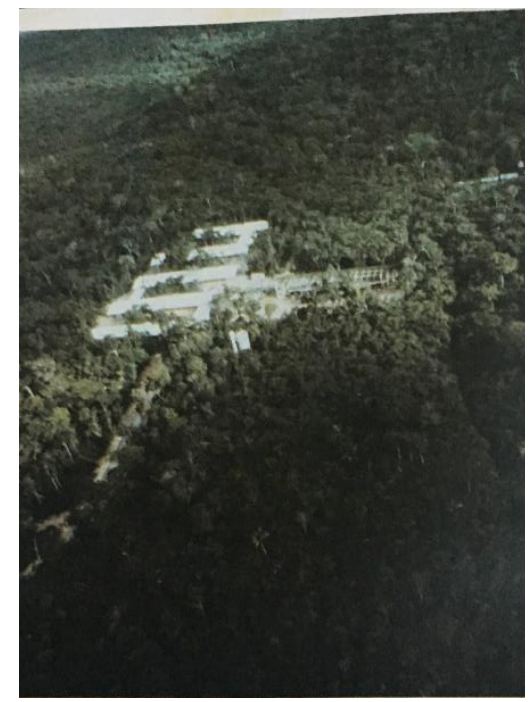

(1)

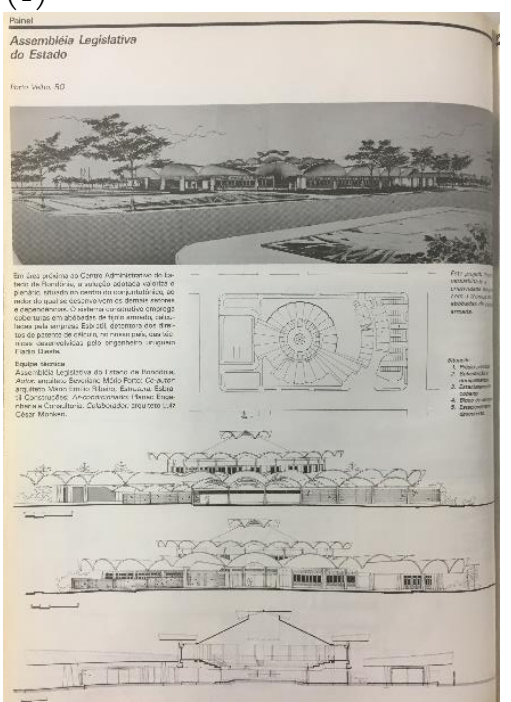

(4)

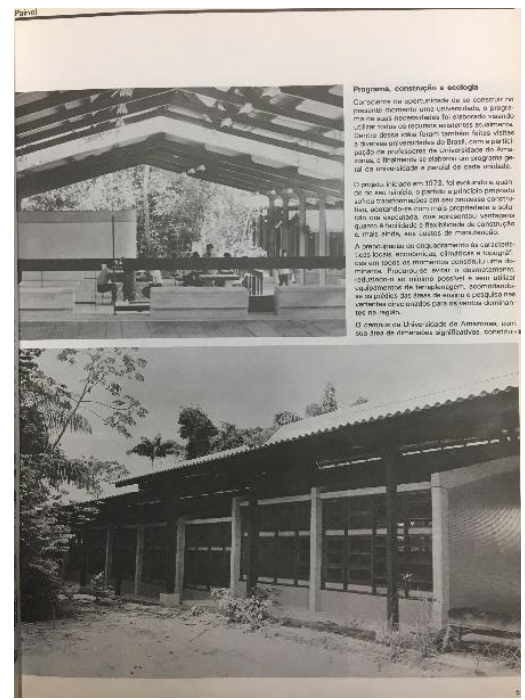

(2)

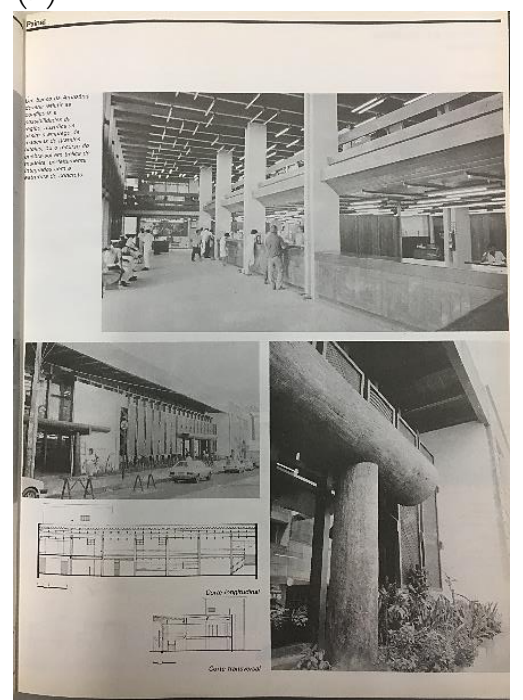

(5)

Figura 51 - Capa da revista; Universidade do Amazonas em Manaus (1;2);

Clube do Trabalhador - SESI em Manaus (3); Assembleia Legislativa do Estado em Porto Velho - RO (4); Banco da Amazônia em Manaus - AM (5).

Fonte: (PROJETO N.83, janeiro de 1986).

Duas imagens de ilustrações de Paulo Caruso [figura 52] apresentaram enfaticamente uma crítica aos projetos estatais na Amazônia e nas revistas onde as ilustrações serviram de capa, eram veiculados outros projetos, que sustentavam respostas àqueles modelos de intervenção. Na primeira revista, um projeto tematizou a Amazônia a partir da reconfiguração do paradigma urbanizador, adaptando o traçado ideal de cidades ao contexto amazônico, em desconexão a qualquer outra estrutura urbana prévia. Outro projeto desenvolvido para Manaus-AM, foi registrado enquanto estava sendo implantado 
ao norte da cidade, em área de expansão, um “projeto voltado para a realidade” (PROJETO N.38, março de 1982). A proposta de urbanização da Amazônia de Spencer de Morais Pupo Nogueira [figura 54], intitulada “Ocupação climática da Amazônia”, consistiu numa "malha agrourbana interflorestal”, partida de uma geometria regular.
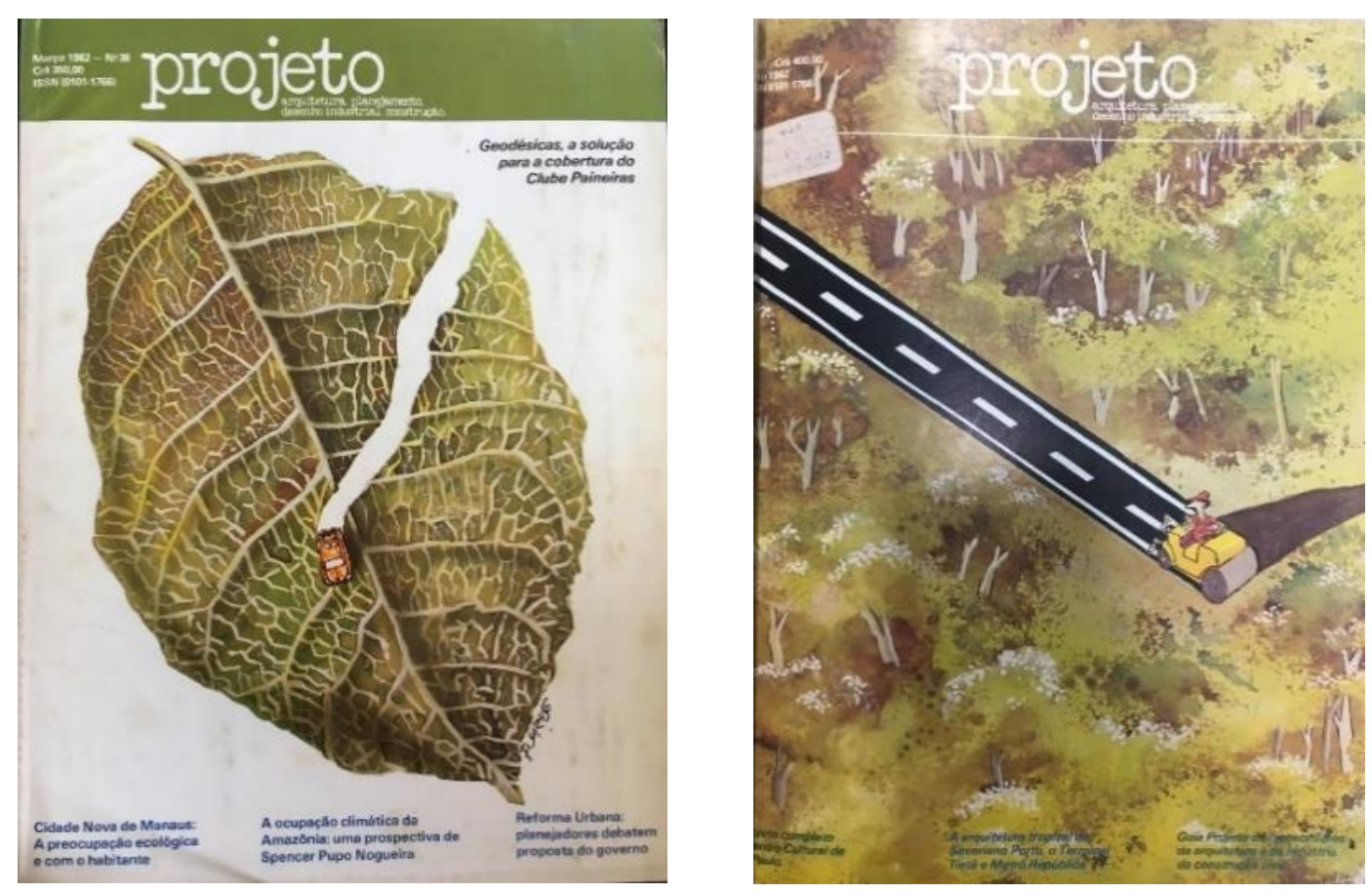

Figura 52 - Revistas com denúncia e crítica à devastação ambiental na Amazônia, com capas de Paulo Caruso. Fonte: PROJETO n.38, 1982; PROJETO n.40, 1982.

Foi produto da reinterpretação do arquiteto do tema da fronteira agrícola na Amazônia, na implantação de assentamentos rurais projetados com vistas a colonização interna e ocupação daquele espaço que historicamente vinha sendo pensado como um vazio demográfico, por meio do seu povoamento. Uma "malha amazônica" foi então pensada pela interligação de módulos produtivos de 3200 ha cada um, com 64 lotes de 50 ha, para que fossem destinados a 55 comunidades cada, entremeados de floresta preservada. A proposta do arquiteto incluiu sistema de transporte e de geração de energia alternativos, pela conciliação de diversas tecnologias. $\mathrm{O}$ arquiteto resgatou a modalidade das moradias palafíticas, sob a justificativa de sua “significação prática e arquetípica”, já que no projeto elas fariam parte do "repertório vernacular das técnicas regionais", podendo ser erguidas pelos próprios "usuários", como edificações nos centros urbanos segundo os moldes do projeto (PROJETO N.38, março de 1982, p. 30-34). 
Fruto de pesquisas que o arquiteto realizou no mestrado e doutorado, a proposta, de teor utópico, deveria consistir um modelo ideal para a urbanização do território amazônico, motivo pelo qual o arquiteto se utilizou de estudos bioclimáticos para desenvolver sua proposição. Ainda assim, ele desconsiderou os particularismos sociais e as variadas formas de ocupação do espaço já existentes na Amazônia, tomando o território em tipificação, tanto em relação aos modos de vida quanto a própria geografia.
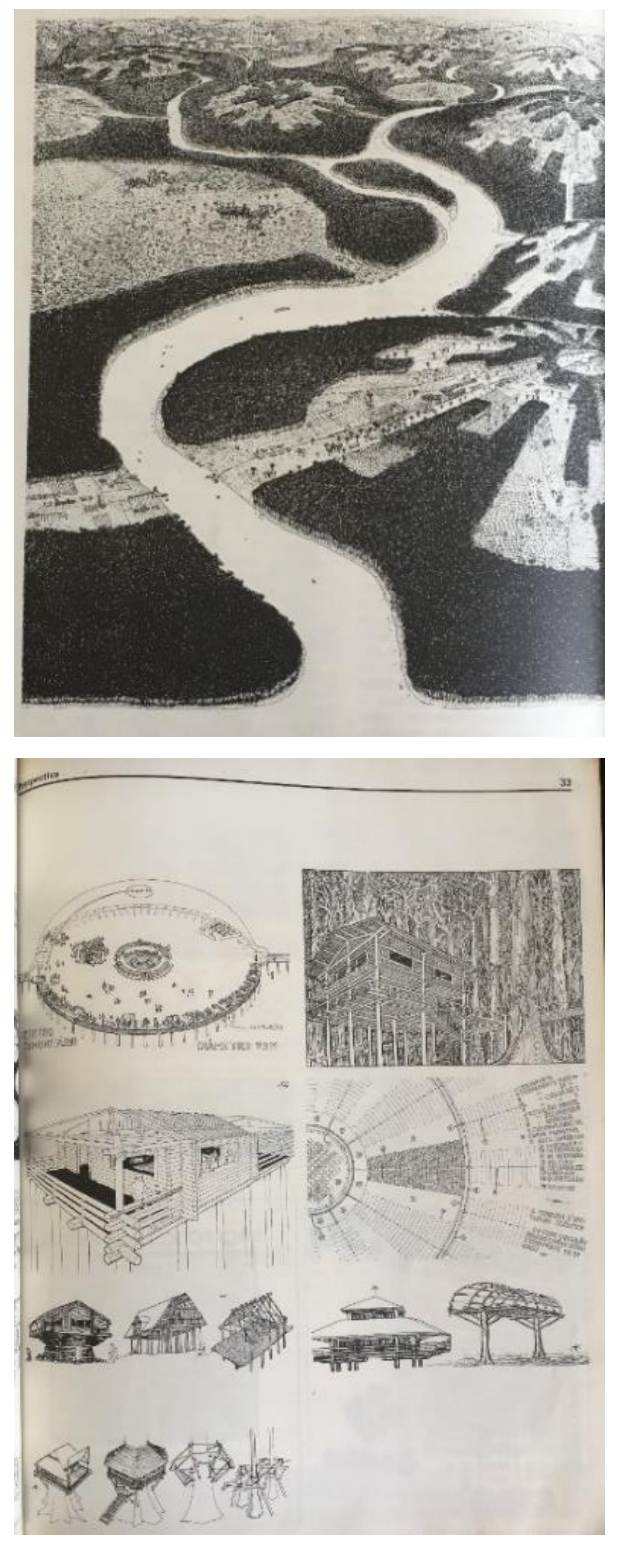
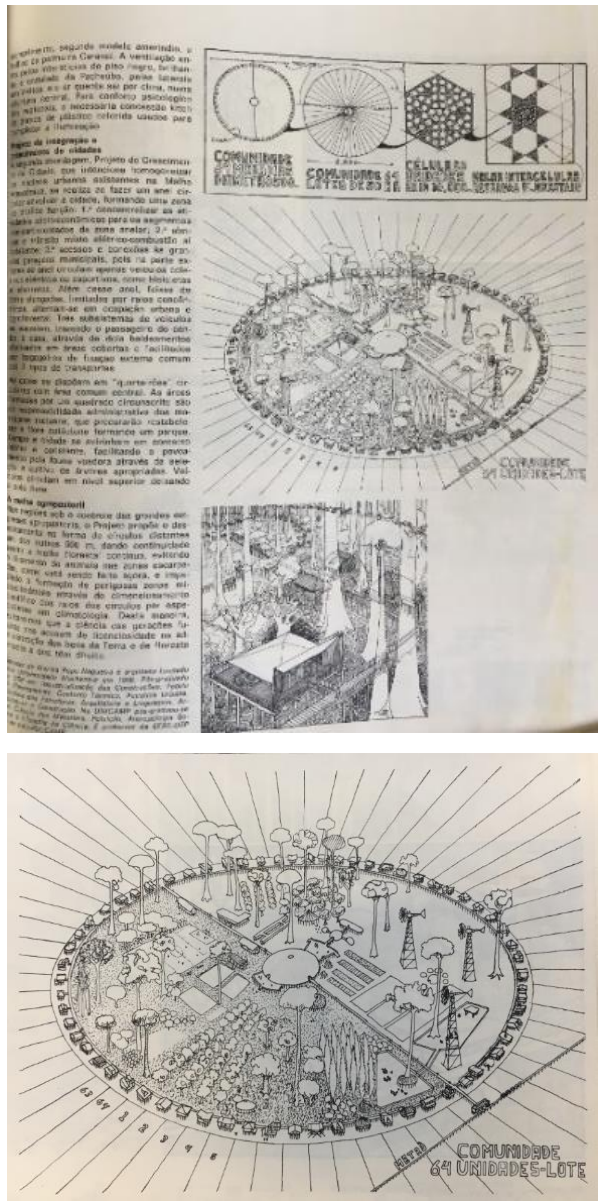

Figura 53 - Projeto de urbanização da Amazônia, de Spencer de Morais Pupo Nogueira. Fonte: PROJETO n.38, 1982, p. 30-34.

$\mathrm{Na}$ mesma revista foi publicado um outro projeto, implantado em Manaus-AM. Situado na zona norte da cidade, foi o tema da matéria Cidade Nova de Manaus: um projeto 
voltado para a realidade, de autoria de Ricardo Julião, ${ }^{203}$ Edson Musa e Edith de Oliveira, dimensionado para 75 mil habitantes, podendo alcançar os 100 mil, à época [figura 54]. A Zona Franca de Manaus havia atraído à capital, mais expressivamente desde os anos de 1970, um contingente de trabalhadores que fez aumentar desde então a população local em mais de $100 \%$. Este era o motivo pelo qual esse projeto estava sendo realizado, sob o financiamento do $\mathrm{BNH}$ e do governo estadual. Os arquitetos se mobilizaram de início, a conhecer o "complexo ecológico amazônico, o homem que o habita, com seu modo de vida característico”.

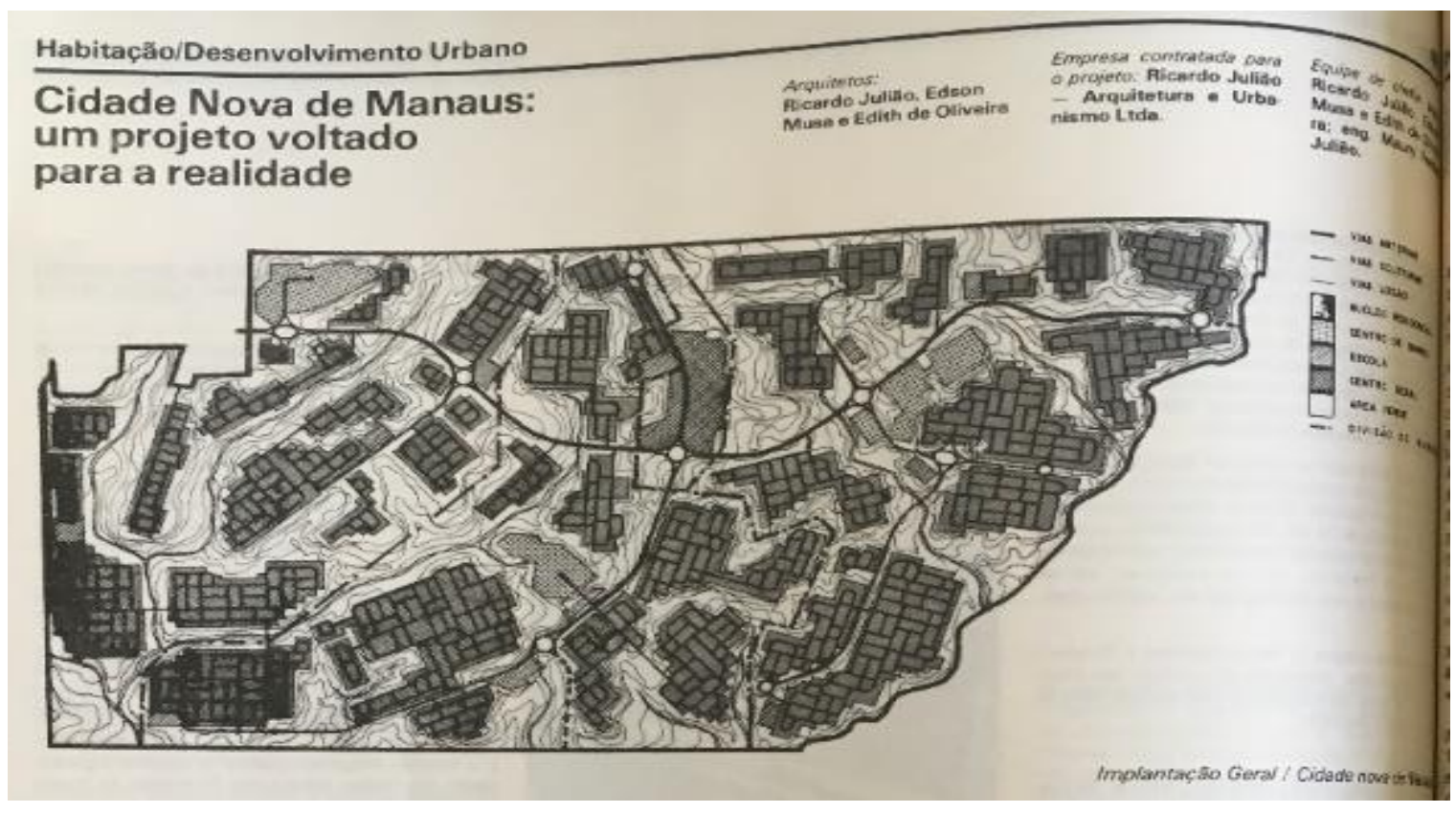

Figura 54 - Implantação geral do conjunto habitacional Cidade Nova em Manaus-AM, de autoria de Ricardo Julião, Edson Musa e Edith de Oliveira. Fonte: PROJETO n.38, 1982, p. 40-48.

Esta evocação de um outro lugar, não apenas da cidade em expansão, em virtude do fluxo conduzido de industrialização e as demandas por habitação decorrentes deste processo, foram presentes no texto da matéria publicada, na qual foi exposto o interesse de criar algum elo entre as dimensões imaterial e territorial da Amazônia, considerada como um objeto em inteireza. A defesa do projeto, perpassou falas relativas à elaboração de uma “Amazônia paisagem”, de um modo de vida e de um nativo tipificado, também à premissa

\footnotetext{
${ }^{203} \mathrm{O}$ arquiteto foi também o responsável pelo projeto da agrovila da "Companhia Real Agroindustrial (CRA II)" a $140 \mathrm{~km}$ de Belém próximo a Acará-PA, com 280 casas, que seria implantada em 1990. Seria este o terceiro projeto do arquiteto, além da Cidade Nova de Manaus-AM e o centro em Cuiabá-MT (PROJETO N.83, janeiro de 1986).
} 
projetual da adequabilidade da intervenção, quando realizada na Amazônia, todas estas, perpassadas pelo ideário ambientalista (PROJETO N.38, março de 1982, p. 40-41):

Isto porque o nativo da Amazônia, perfeitamente adaptado a esse complexo, não se deixa vencer pela pujança do rio ou da mata. Mas também não os agride de maneira irreversível. Utiliza-se de seus recursos com parcimônia, procurando tirar o máximo de conforto e de alimentação com o mínimo de dispêndio de energia e de material. Na realidade, a ecologia amazônica apresenta aspectos em que uma incrível exuberância se alia a uma surpreendente fragilidade. Deste modo, todas as ações humanas na região, principalmente as de maior amplitude, deveriam realizar-se com o máximo de prudência. Para impedir a desintegração do ambiente, e em consequência, a desnaturação do homem.

O raciocínio sobre o ambiente, condicionaria as decisões de projeto, em sua face conservacionista, a exemplo das intenções de "preservar a cobertura vegetal nativa”, manter “estabilidade física e química do solo", compatibilizar as edificações ao clima, desde o uso de materiais locais. Mesmo no início da atuação da COHAB-AM (ABA N.1, 1967-68), os arquitetos que estavam envolvidos com a formulação de projetos de habitação já se interessavam pela adoção destas mesmas premissas e realizavam experimentos construtivos de adaptação à Amazônia, para produzir conforto. Tais soluções projetuais já haviam sido publicadas na década de 1960, o que também foi enfatizado por Severiano Porto neste mesmo ano de 1982 (MÓDULO N.70, 1982).

No caso do loteamento da cidade nova, em Manaus-AM, os arquitetos dirigiam sua atenção à preservação, a partir da previsão de áreas verdes nos projetos, para produção de um “microclima mais favorável ao habitante da cidade”, já que na Amazônia a vegetação absorveria até " $50 \%$ da grande quantidade de energia radiante que atinge a superífie da terra na região equatorial”. Àquele contexto seria adaptada “uma cidade racional”, harmonizada “com a paisagem circundante” a partir de estratégias de hierarquização viária e da previsão de equipamentos e infraestrutura urbana compatíveis a cada bairro, cada um com cerca de 25 mil pessoas, contendo unidade de vizinhança e núcleo habitacional.

No texto foi revelado o interesse não unicamente adaptativo, de promover conforto, mas deste ser aliado à lógica preservacionista, de "respeito à natureza a que o amazonense está habituado", respeito ao "sistema ecológico", também como ajustamento técnico ao meio, ou mais detidamente à topografia natural. A ideia de um enraizamento cultural, desde o delineamento de uma interpretação da Amazônia em sua "grandiosidade paisagística”, foi 
transposta a algumas decisões de projeto, como a manutenção de $20 \%$ da área total da área de implantação do conjunto, destinadas à preservação, como “áreas verdes”. Também, desde a qual os arquitetos produziram conhecimento sobre uma cultura junto à natureza, especialmente a respeito do solo, chuvas, espécies típicas, formas de plantio típicas, inclusive "praticada pelo índio", além das formas de habitar. A questão da habitação foi considerada em particular, como a moradia do trabalhador da indústria, aquele migrante vindo do interior. Os arquitetos à busca de uma "moradia mais adequada”, motivo pelo qual analisaram "exaustivamente o homem e seu modus vivendi na região", retomaram a tipificação do mundo rural, para explicar o projeto horizontal, inclusive da própria moradia, com estruturas, esquadrias, venezianas de madeira, cobertura de fibrocimento, tijolos aparentes, beirais alongados e às soluções da adoção do colchão de ar entre teto e forro, e ventilação cruzada (PROJETO N.38, março de 1982, p. 41-44):

Considerou então ser inadmissível que o amazonense fosse transferido de sua casa de palha, da sombra de sua floresta e da proximidade do rio, para ser "acondicionado" em cubículos de cimento e ferro, em espaços monótonos e restritos, caracterizados pelos descampados e pelo alinhamento retilíneo e uniforme...

Concluiu-se, ainda, que a "casa-padrão" e as cidadezinhas "de cimento" construídas no gênero "uniforme e sem graça das habitações populares" desfigurariam o ambiente. Por não acompanharem a topografia natural, o espaço ilimitado, e o clima rude, além de serem antieconômicos.

Daí que, levando-se em conta esses elementos, o projeto das construções procurou adequá-las às condições ambientais, mas também à tecnologia local e aos materiais em disponibilidade imediata no mercado.

[...] a implantação de um sistema artificial de vida na região amazônica deve ser precedida de cuidadosas ponderações a respeito desse relacionamento homem/ meio ambiente com o propósito de evitar a transformação do ajuste natural e perfeito em contraste conflitante, o que resultaria a degenerescência do ambiente e a consequente desnaturação do homem. $[\ldots]$

o INPA - com longa tradição na pesquisa de materiais adequados, de medidas de proteção do solo e da vegetação e, mesmo, de tipos de construção que, pelo seu dimensionamento, materiais empregados, orientação em relação à insolação etc. constituem a moradia ideal em termos de conforto e economia, ao homem da Amazônia. Os resultados de tais estudos, orientados pelo arquiteto Severiano Porto, têm sido aplicados já, de longa data e com absoluto sucesso, nas próprias construções realizadas na área do INPA, seja para fins de moradia, seja de ambientes de trabalho.

Aspectos relativos à exequibilidade do projeto, em se tratando de um loteamento de elevada densidade, foram detalhadamente expostos como em consonância com as 
características geofísicas locais, muitas vezes no texto, tidas como da "Amazônia". Os fundamentos geológicos foram utilizados para a adoção de medidas adaptativas do projeto, das redes infraestruturais e também das soluções de implantação dos edifícios projetados, para a garantia da presença de áreas verdes, um dos componentes principais do conjunto. Considerada a problemática do projeto de ocupação da Amazônia, esse deslocamento da unidade edilícia para o conjunto urbano, de modo relacionado aos pressupostos de ajustamento da arquitetura ao lugar, resultou da transformação urbana das cidades, com suas novas demandas por moradia, também da crítica fortalecida, aos efeitos devastadores dos grande projetos estatais sobre o meio natural. A voz do geógrafo Aziz Ab’Saber foi notada em várias fontes, dentre as quais uma revista destinada à construção civil, público diverso do estrito de arquitetos [figura 55].

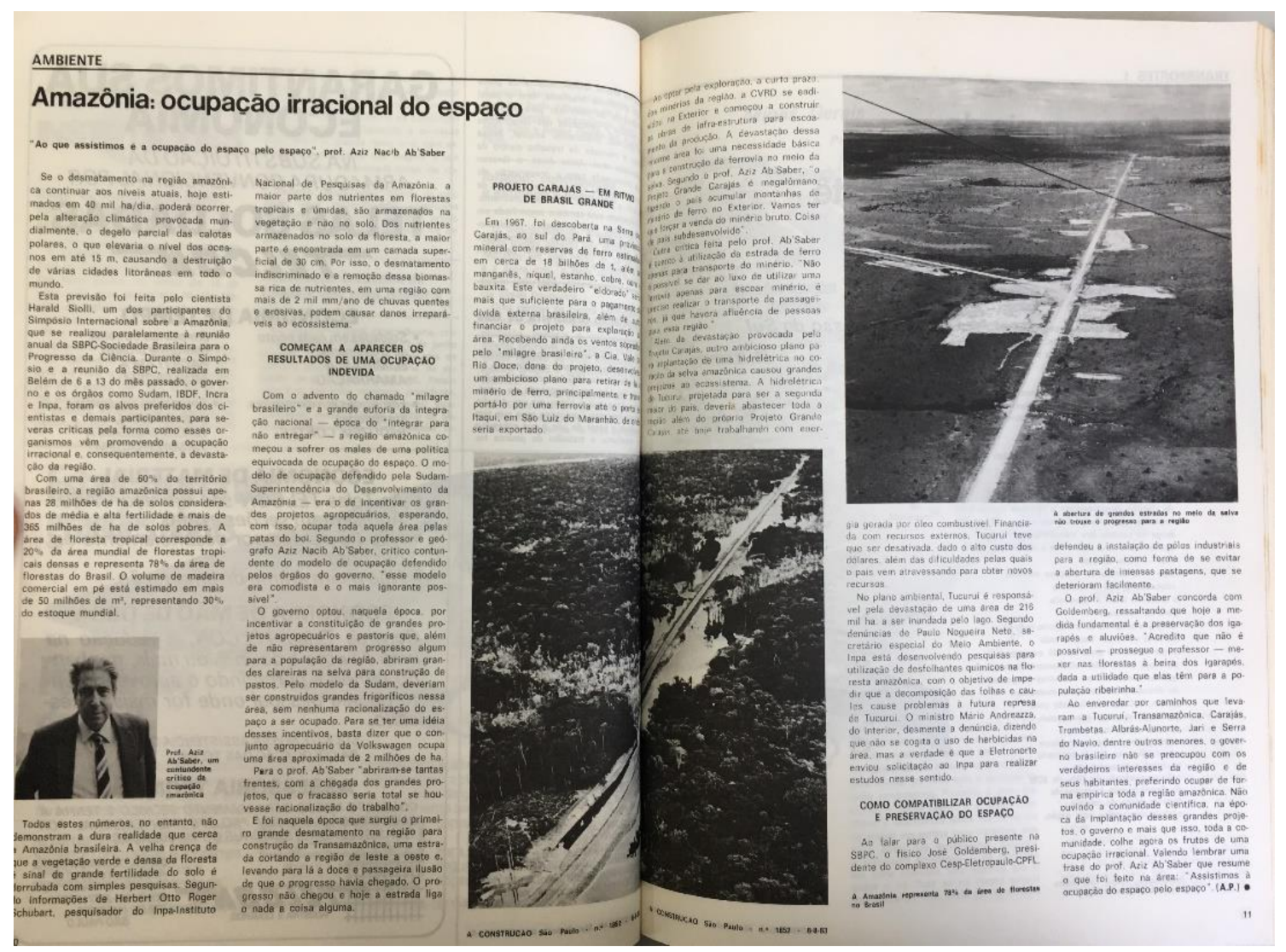

Figura 55 - Artigo Amazônia: ocupação irracional do espaço.

Fonte: A CONSTRUÇÃO SÃO PAULO n.1852, 1983, p. 10-11.

A matéria decorreu da realização do Simpósio Internacional sobre a Amazônia ocorrido junto à reunião da Sociedade Brasileira para o Progresso da Ciência - SBPC, 
realizada em Belém-PA. As perspectivas, como registradas, eram de prevalentes críticas à “ocupação irracional e consequente devastação da região”, que representava à época, 78\% das florestas do Brasil, $20 \%$ da área mundial em florestas tropicais, "um volume de madeira comercial em pé estimado em mais de 50 milhões de $\mathrm{m}^{3 \%}$, de um solo tido como pobre, sendo a maior parte de nutrientes em florestas do tipo tropical úmido, "armazenados na vegetação e não no solo”. Quando no solo, a maior parte estaria concentrada em uma camada superficial de $30 \mathrm{~cm}$. Na oportunidade, grande parte da comunidade científica havia se colocado contrária ao estímulo viabilizado pela SUDAM aos grandes projetos agropecuários, "esperando, com isso, ocupar toda aquela área pelas patas do boi”, um modelo "comodista e ignorante", que abriu enclaves na Amazônia e não promoveu o desenvolvimento de populações locais, segundo o geógrafo Aziz Ab’Saber CONSTRUÇÃO SÃO PAULO N.1852, agosto de 1983):

Ao enveredar por caminhos que levaram a Tucuruí, Transamazônica, Carajás, Trombetas, Albrás-Alunorte, Jari e Serra do Navio, dentre outros menores, o governo brasileiro não se preocupou com os verdadeiros interesses da região e de seus habitantes, preferindo ocupar de forma empírica toda a região amazônica. Não ouvindo a comunidade científica, na época da implantação desses grandes projetos, o governo e mais que isso, toda a comunidade, colhe agora os frutos de uma ocupação irracional.

A Transamazônica foi a intervenção de grande impacto, inicial de um processo cujo resultado foi desastroso, de um progresso que não chegou já que "hoje a estrada liga o nada a coisa alguma”, já que não chegou a ser finalizada. Com a descoberta de cerca de 18 bilhões de toneladas de reservas minerais em Carajás em 1967, um “verdadeiro eldorado”, segundo Ab’Saber, foi desenvolvido o projeto de sua exploração e exportação em curtíssimo prazo, motivo da construção de uma ferrovia desde o Pará ao Maranhão apenas para a exportação do minério em seu estado bruto, "coisa de país subdesenvolvido", com grande devastação onde foi implantada. ${ }^{204}$ As soluções aventadas à época da reunião foram partilhadas entre o geógrafo e o físico José Goldemberg quando ambos defenderam a instalação de polos industriais na região. Para Ab’Saber, não seria possível “mexer nas florestas à beira dos igarapés, dada a utilidade que elas têm para a população ribeirinha” (A CONSTRUÇÃO SÃO PAULO N.1852, agosto de 1983, p. 10-11).

\footnotetext{
${ }^{204} \mathrm{O}$ geógrafo também tratou na matéria dos prejuízos ambientais e materiais acarretados pela Usina de Tucuruí.
} 
A centralidade interventiva por parte de arquitetos nas cidades, como as que foram prevalentemente centradas em Manaus-AM nas revistas, em virtude dos efeitos da industrialização mais intensificada na capital a partir da década de 1970, era demarcada por obras já publicadas nesse início da década de 1980. Dentre elas, o edifício da Superintendência da Zona Franca de Manaus - SUFRAMA, projetado em 1971, representava uma modernização urbana transposta ao edifício destituído daquelas características mais dirigidas aos projetos habitacionais, prevalentemente referenciadas no que foi reconhecido como um saber local ou uma tradição construtiva associados ao modo de vida na Amazônia. O projeto do edifício sede da Suframa foi publicado em periódicos nacionais cerca de dez vezes, entre 1975 e 1990. Em 1982, sob o título Harmonia entre formas e funcionalidade do projeto da Suframa, um artigo replicou, praticamente, as mesmas informações já publicadas anteriormente, assim como as fotografias. Mas de certo modo, a incorporação dos projetos da residência de Severiano Mário Porto e da SUFRAMA ao editorial crítico, os endossava como obras das mais importantes sob a preocupação de adequação, "de ambientá-las, bem como ao clima tropical” (PROJETO N.40, maio de 1982, p. $3 ; 26-28)$.

A revista Projeto $^{205}$ centrava, no início da década de 1970, debates ampliados sobre a arquitetura no Brasil, aqueles registrados ou mesmo estimulados pela imprensa especializada. Vários artigos de convocação à retomada da atividade crítica, mesmo da jornalística, revigoravam discussões no campo, tanto as reflexivas quanto as prospectivas, da prática profissional contemporânea e pregressa, a exemplo do número comemorativo dos dez anos de atividade da revista (PROJETO N.42, maio de 1982). A publicação cercou o processo de restabelecimento das atividades da imprensa especializada em Arquitetura e Urbanismo no país, já que na década de 1970, “os meios de comunicação e intercâmbio na área de arquitetura - as revistas - haviam desaparecido”, especialmente pela pressão do regime, conforme expressou Miguel Alves Pereira. Nesse movimento de retomada das discussões acerca da arquitetura, o projeto da Suframa, o de Revitalização do Centro Urbano de Belém-PA e o dos Reservatórios de Água da Cosama em Manaus-AM, foram

\footnotetext{
${ }^{205}$ Neste número, Miguel A. Pereira fez um retrospecto da atividade editorial de Vicente Wissenbah, desde o jornal da década de 1970 que publicava junto ao IAB, passando pela editora do Arquiteto, a publicação dos Cadernos Brasileiros de Arquitetura, até a revista Projeto, em 1977. Este viria a ser o veículo de circulação nacional com mais projetos publicados, dos realizados na Amazônia, dentre as fontes consultadas (PROJETO N.42, maio de 1982).
} 
localizados em um conjunto de obras levantadas a partir da pesquisa realizada por Ruth Verde Zein no ano de 1979, compondo nesse número da revista Projeto um quadro da Arquitetura Brasileira Atual [figura 56].
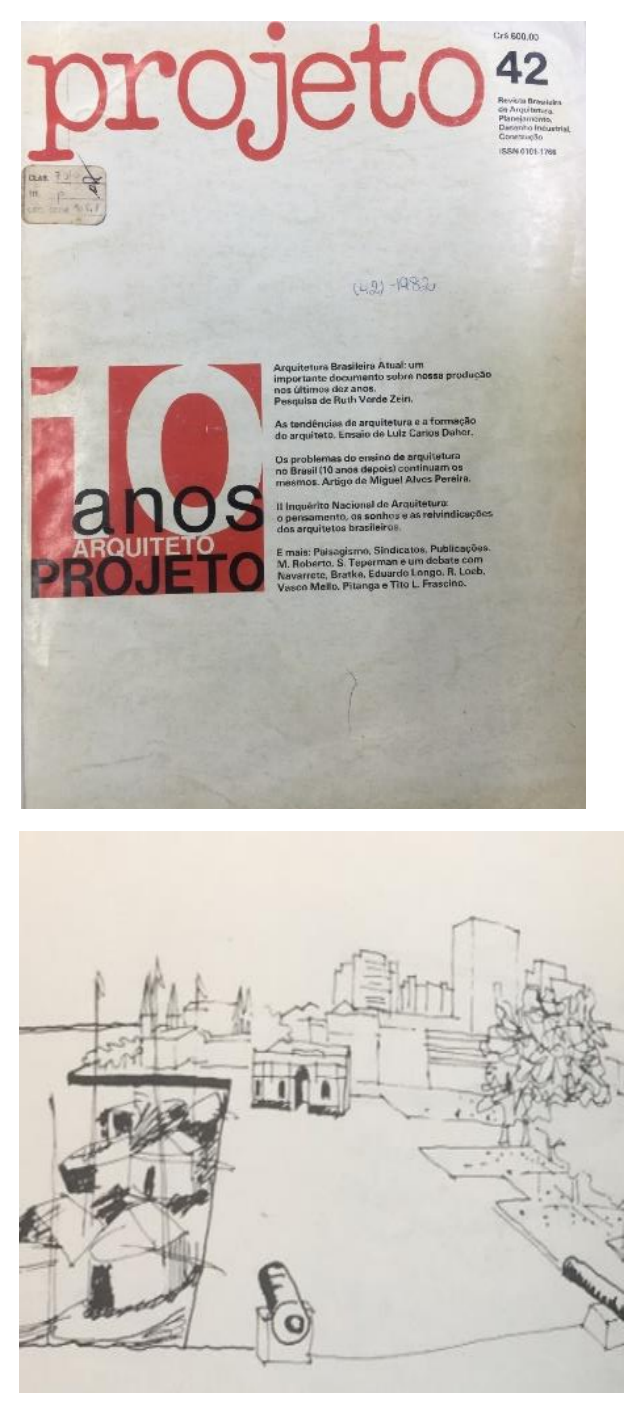

Figura 56 - Imagens dos projetos publicados no artigo Arquitetura Brasileira Atual, no segmento da revista Projeto Os anos 70/Tendências. Fonte: PROJETO n.42, 1982, p. 133;154;155.
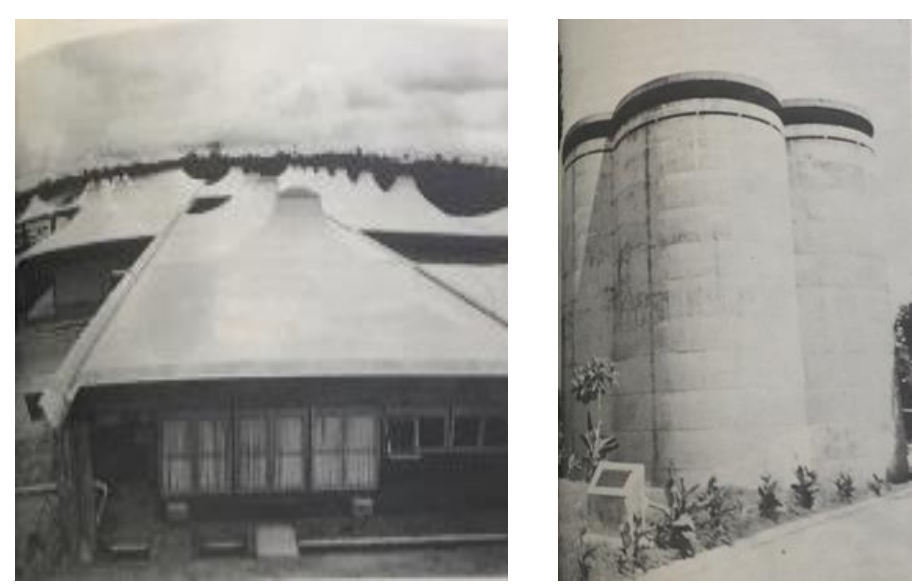

A atualidade dessas obras, especialmente os projetos de Severiano Mário Porto, que de fato foram os mais publicados no período, as colocou em condição de representantes da produção referencial da arquitetura na região norte do país, já que a matéria se propunha a produzir "um levantamento das principais obras e projetos de arquitetura nos últimos quinze anos, procurar analisar suas características, linhas de pensamento de projetação". Justamente foi esta a maneira de fomentar o "debate crítico e estético da produção arquitetônica recente, e para seu estudo e documentação", a partir de determinados temas que tornassem possível a sistematização daquela empreitada que estava sendo retomada, 
frente a "defasagem” da divulgação pela imprensa da atividade profissional no país. As obras foram enquadradas nas categorias de edifícios educacionais, culturais, esportivos e institucionais, centros médicos, de habitação coletiva, edifícios industrais, terminais, intervenções relacionadas ao patrimônio. Em duas delas, projetos de desenho urbano e edifícios cívicos e administrativos, figuraram três projetos na região, sendo dois realizados em Manaus-AM e um em Belém-PA (PROJETO N.42, maio de 1982, p. 106).

Foi justamente a temática urbana que concentrou as três obras referenciais à arquitetura no Brasil situadas na região norte sem que, no entanto, estivessem associadas à Amazônia, ou aos efeitos da condicional localização das obras nos projetos, ou ainda, como pertencentes àquele recorte do país. As obras foram inscritas em um quadro referencial do conjunto de realizações da disciplina e integraram junto a outras, um conjunto de base às discussões recém retomadas nas revistas. O projeto de "Revitalização do Centro Urbano de Belém-PA”, foi um projeto complexo voltado à preservação do patrimônio cultural, a memória urbana, todavia a partir da sua adequação ao sistema viário e à valorização do pedestre composto por oito proposições, como descrito em síntese na legenda apresentada junto a um único croqui da proposta.

A publicação de Silvia Ficher e Marlene Acayaba [figura 57] foi referencial de uma escrita de teor histórico que abarcou a arquitetura na Amazônia, neste caso, apresentando obras já publicadas anteriormente, especialmente as de autoria de Severiano Mário Porto. Ao prefaciar o livro, Miguel Alves Pereira revelou o interesse das autoras pela realização da "montagem de um mapa do movimento brasileiro de arquitetura moderna nos últimos cinquenta anos" (FICHER e ACAYABA, 1982, p. 4), composto pelo "acervo de um conjunto de objetos arquitetônicos e ideias, cuja interação sugere uma leitura a partir do lugar, da região do país, onde essas obras foram produzidas” (FICHER e ACAYABA, 1982, p. 5). Explicitou também o método historiográfico relacionado ao que o objeto da pesquisa pareceu lhes sugerir. Isto implicaria o entendimento do "prelúdio da ideia do mapa da ideia de região” para a compreensão do fenômeno. Também, uma fixação analítica, na materialidade das obras realizadas, compreendidas em relação ao seu local de implantação.

O livro foi estruturado segundo uma periodização estabelecida pelo contato de arquitetos brasileiros com a vanguarda europeia, até a realização de Brasília, com acréscimo das duas últimas décadas de produção de arquitetura no país. As autoras buscaram um 
“sentido de unidade” nas obras, a partir da identificação das influências de Lucio Costa, Oscar Niemeyer e Vilanova Artigas e se propuseram a analisar as influências externas, "vínculos com a produção da arquitetura europeia e americana”, absorvidas por arquitetos brasileiros. Esta foi a distinção fundamental daquela compilação elaborada por Ruth Verde, já que aqui as autoras procuraram alinhavar as realizações pregressas da arquitetura, uma memória disciplinar com a afirmação da demarcação realizada por Brasília.

O Brasil foi elaborado a partir da constatação de que nos últimos vinte anos houve no "discurso da arquitetura brasileira” a constância de debates de cunho ideológico pela incorporação de determinados conceitos explicativos de arquiteturas dos "países de terceiro mundo", como "cultura brasileira, subdesenvolvimento, dependência cultural, dominação ideológica”. Deste modo, ainda que em continuidade, afirmaram a autonomia da atividade de projeto no âmbito nacional em independência, caracterizando essa nuance do perfil revisionista proposto pela publicação, ressignificando a produção no país, frente o temor ao “chamado pós-modernismo” em iminência (FICHER e ACAYABA, 1982, p. 7). Silvia Ficher e Marlene Acayaba situaram as "Origens da Arquitetura Modena Brasileira” junto às vanguardas artísticas do Rio de Janeiro e São Paulo dos anos de 1920. Reforçaram o marco da construção em São Paulo, da "primeira obra moderna”, bem como a contribuição da liderança de Lúcio Costa no Rio de Janeiro, para o ensino e para a divulgação ampla do ideário moderno no Brasil, ao qual imprimiu “orientação racionalista”. A Lúcio Costa foi também atribuído o esforço contínuo de "desenvolver uma arquitetura que ao mesmo tempo refletisse as características nacionais e fosse atualizada em relação às tendências europeias mais avançadas”, o que equivaleu ao uso de materiais tradicionais junto a outros “elementos da arquitetura moderna”, como pilotis e brises, como já mencionado nesta tese.

As autoras atribuíram o surgimento de uma "linguagem arquitetura mais livre" no Rio de Janeiro a essa “reconciliação” entre "princípios do Movimento Moderno europeu” e “a herança nativa”, confirmando as constatações anteriores de que o brise-soleil, em suas diversas modalidades e nomeações, foi um componente que afirmou a conjugação de “elementos da tradição colonial” à técnica moderna da arquitetura no Brasil. O uso de painéis de azulejo foi exemplo de como a "tradição foi reaproveitada", ressaltada a importância da integração entre interior e exterior para o "clima brasileiro". As distinções nos contextos de realização das obras a partir dos anos 1950, foram explicadas pelo 
deslocamento dos arquitetos formados na Escola de Belas Artes do Rio de Janeiro para outras cidades brasileiras, o que "estimulou a difusão" daquele repertório. Em cada região foram circunscritos olhares críticos, ainda que baseados na premissa da unidade de uma arquitetura moderna no Brasil. A escolha das obras selecionadas para o livro decorreu de sua relação com os contextos de sua implantação.

$\mathrm{Na}$ busca pelas realizações ancoradas numa determinada cultura arquitetônica, moderna, Ficher e Acayaba desenvolveram sua explicação a respeito das "Tendências regionais após-1960". A região, compreendida como meio junto ao qual foram culturalmente geradas as distintas obras de arquitetura, a partir da dissolução da unidade arquitetônica moderna no Brasil. A esta "unidade", equivaleu uma "linguagem arquitetônica única", aquela que sob a influência de Le Corbusier, esteve aliada ao "nacionalismo político da época". Brasília teria sido a "afirmação plena do Movimento Moderno" e com a concretização deste ideário, como evento, ultrapassou "o interesse regional". A partir daí, o regional ou a "regionalização" passaram a ser compreendidos como fenômenos sóciohistóricos. Contrariamente ao juízo unitário apresentado a priori o texto foi levado para a atenção às diferenças regionais, econômicas, climáticas, tecnológicas, aos programas, que teriam sido potencializados devido à industrialização estendida a todo o país, acarretando "um processo de regionalização".

A partir da interpretação de especificidades, foram apontadas as categorias de enquadramento da produção brasileira a partir de 1960, articuladas a perfis simplificados das regiões de sua localização. O próprio agrupamento regional decorreu não da estrutura administrativa regional, mas da avaliação de realizações segundo nexos de interpretação das autoras. Uma "arquitetura tropical" seria extensiva do "Rio de Janeiro a Fortaleza e Manaus". O sul industrializado (numa perspectiva econômica) seria posto em contraste com o nordeste rural e pobre. A arquitetura perdeu seu perfil monumental, por todo o país e os arquitetos passaram a se dedicar ao planejamento, o "papel demiúrgico do arquiteto carioca" desapareceu, ou seja, o texto foi conduzido para representação do declínio daquela fase reconhecida da arquitetura centrada no Rio de Janeiro. Com isso, desenvolveram uma lógica que o validou como evento findo, a existência de uma "expressão dominante para a arquitetura brasileira". 


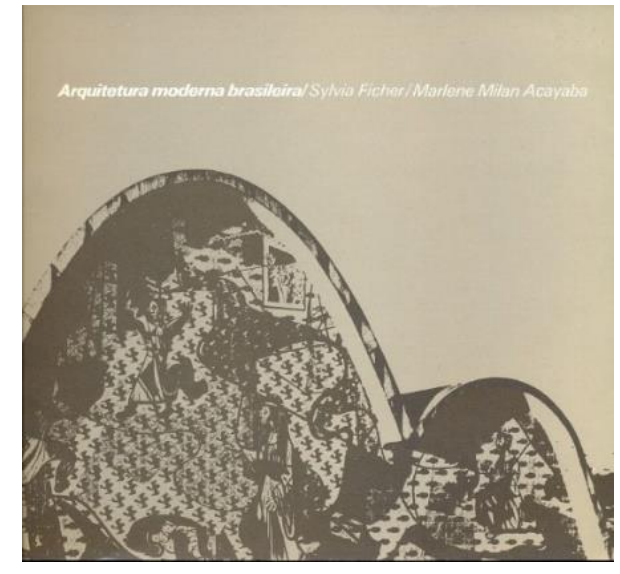

(1)

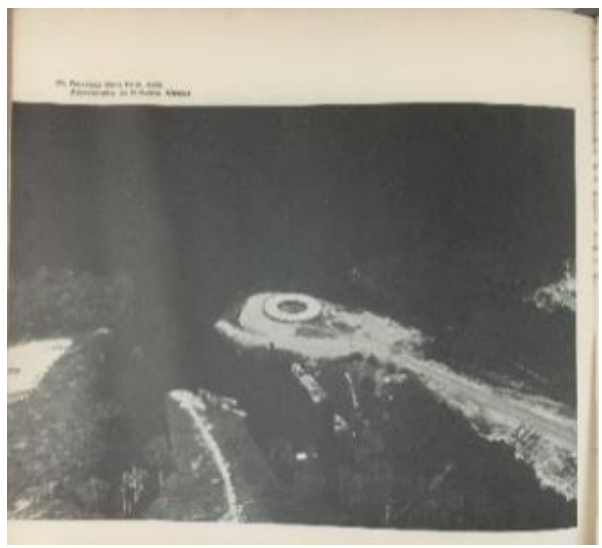

(3)

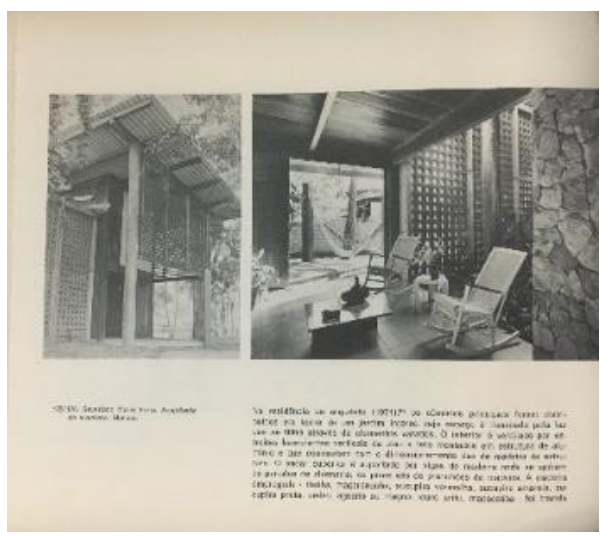

Figura 57 - Imagens de projetos em páginas dedicadas à Arquitetura no Norte do país no livro Arquitetura Moderna Brasileira. Em sequência, Sede da Portobrás (1), Superintendência da Zona Franca de Manaus (2), Residência do Arquiteto Severiano Porto (3) e Residência de Robert Schuster (4), todas as obras em Manaus - AM. Fonte: FICHER \& ACAYABA, 1982, p.106-111.

(2)

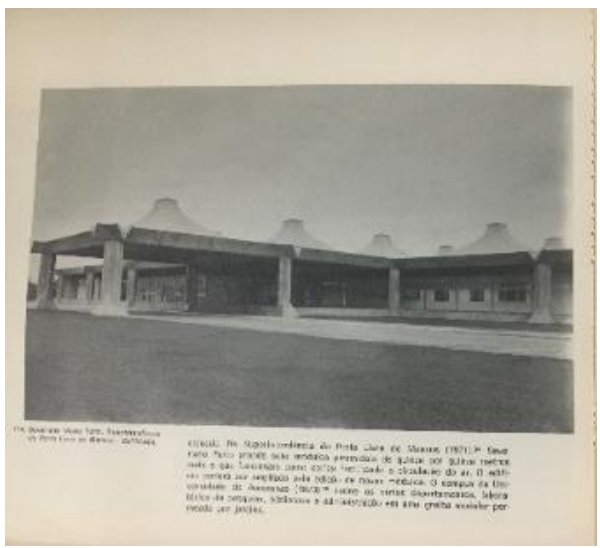

(4)

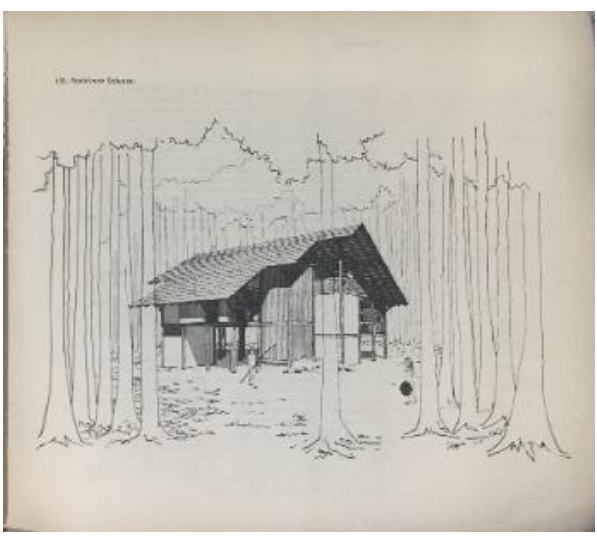

Assim, a lógica da arquitetura após os anos de 1960, deveria ser "procurada em cada região" mesmo que a leitura tenha buscado traços de unificação da linguagem entre os projetos. Da região sul foi destacada uma “estética própria”, já dos exemplares realizados em São Paulo, foi destacado o emprego extensivo do concreto armado aparente em volumes compactos e a preocupação com o entorno urbano (FICHER e ACAYABA, 1982, p. 4869). Em Recife, reforçaram o ajustamento da arquitetura a localidades com clima bastante distinto daquelas do sudeste, a adoção de "soluções novas", reinterpretações, decorrentes das implicações do calor, da umidade, da necessidade de aeração constante, sobre a prática projetual (FICHER e ACAYABA, 1982, p. 94-96). Na região Norte, o livro foi detido a 
Manaus-AM, como o local em que se fazia “mais urgente a determinação de princípios” que pudessem orientar a adaptação das construções ao "meio ambiente", termo este utilizado pela primeira vez no livro.

Foram apresentadas quatro das obras de Severiano Mário Porto, ilustrativas da atuação do arquiteto de formação no Rio de Janeiro. Interessado na pesquisa de elementos construtivos que amenizassem os efeitos do clima nas construções, fez arquitetura em adaptação às condições naturais locais, por vezes incorporando o conhecimento popular a partir da adoção do artesanal como processo produtivo (FICHER e ACAYABA, 1982, p. 107-110). Ao tratar das dimensões regionais nas quais a arquitetura foi realizada, as autoras averiguaram a extensão e abrangência dessa realização, nuançada quando levada a outras realidades sociais, materiais, ambientais, distintas daquelas dos locais de sua formulação. Sem negar a influência do ideário inicial dos intelectuais relacionados à arquitetura moderna brasileira, falaram do impasse teórico vivenciado no campo frente incertezas disciplinares e sociais, construindo uma análise que considerou a "variedade de dialetos plásticos" no território nacional (FICHER e ACAYABA, 1982, p. 117).

A exposição “Arquitetura Brasileira Atual” [figura 58], apresentada também na revista Projeto, foi transposta a um catálogo no qual figuraram obras de Sérgio Teperman e Paulo Lepage, em especial a Estação telefônica em Santarém-PA, e de Severiano Mário Porto e Paulo Emílio Ribeiro, especificamente, a Pousada na ilha de Silves, de 1979, a residência do arquiteto Severiano Porto e a sede da SUFRAMA, ambas de 1971. A exposição foi o produto de um movimento voltado a "olhar” para o país e sua produção variada, imersa nas "contradições do espaço brasileiro", econômica, social e politicamente, mas também em sua condição de país latino-americano, partilhando com os demais, do passado colonial e da condição cultural entrelaçada por parte de determinados segmentos de arquitetos latino-americanos interessados no debate acerca da arquitetura, a partir dos anos de 1980 (ZEIN e BASTOS, 2010, p. 242). 

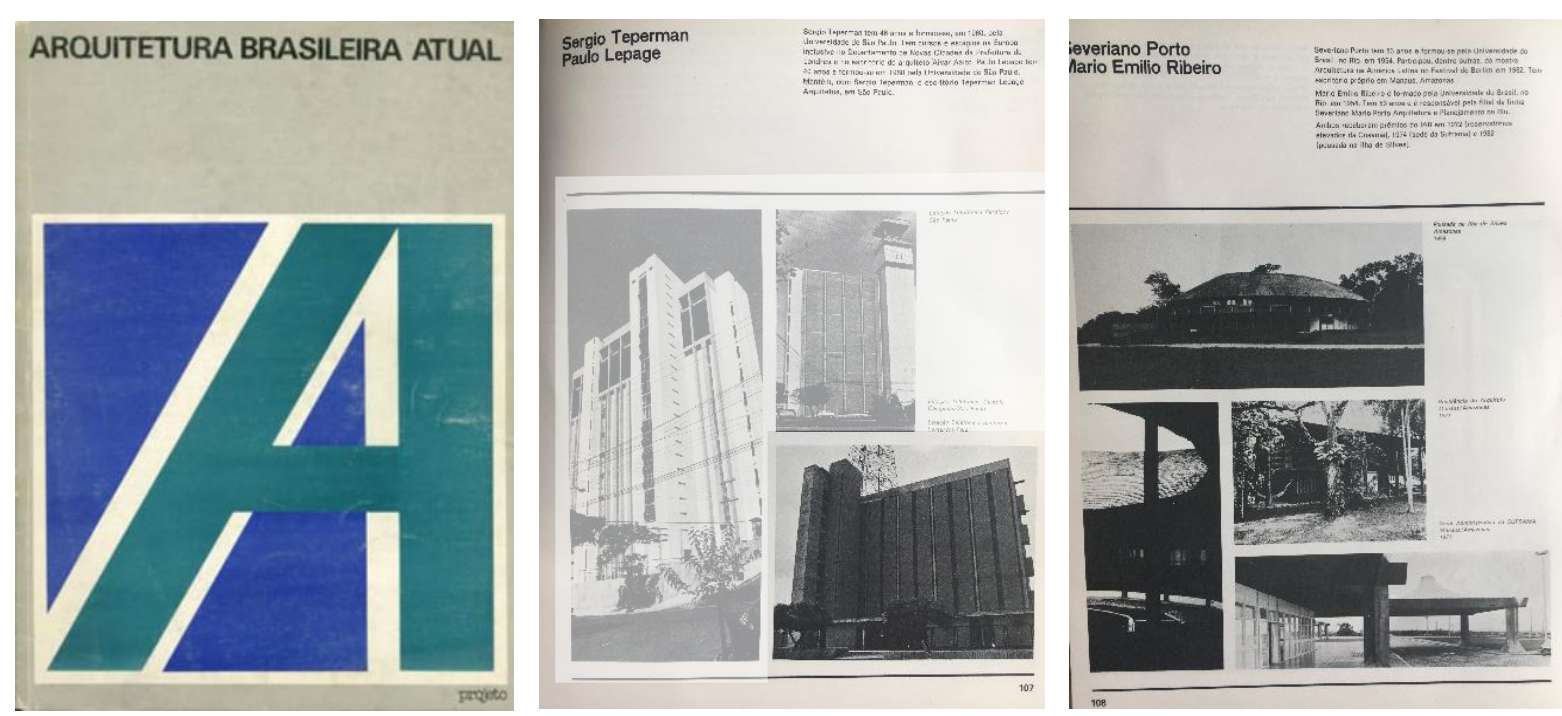

Figura 58 - Capa do catálogo da exposição Arquitetura Brasileira Atual e projetos publicados, de Sergio Teperman, Paulo Lepage, Severiano Porto e Mário Emílio Ribeiro, atuantes na Amazônia. Fonte: MOSTRA DA ARQUITETURA BRASILEIRA ATUAL, catálogo, 1983, p.107-108.

A referida exposição, organizada pela revista Projeto junto ao Centro de Artes y Comunicación de Buenos Aires, representados respectivamente por Vicente Eissenbach e Jorge Glusberg, apresentou projetos de 97 arquitetos. Foi inaugurada em Buenos Aires e foi montada em São Paulo, Brasília, Rio de Janeiro, como evento de retomada das discussões mais detidas à Arquitetura e Urbanismo no Brasil, fomentando a crítica num período de parco debate no campo. Em um outro recorte, o da América Latina, também estava sendo inscrita a obra de Severiano Porto, correspondendo à intelecção de seus projetos à espectro ampliado da crítica e dos feitos do campo. Para Hugo Segawa (SEGAWA, 1998, p. 193194):

[...] a arquitetura amazônica [...] surge mais por uma percepção de contexto que por uma vontade de tipificar alguma manifestação arquitetônica. São manifestações que coincidem com alguma preocupação pós-moderna, mas não tem origem nesse fenômeno internacional tampouco voltam-se a uma busca específica de identidade. Se há alguma preocupação nesse sentido, trata-se se um esforco da crítica de arquitetura. E é a partir da apreensão dessa diversidade, do aprofundamento das diferenças que se permite estabelecer a condição mais precisa do regionalismo: caracterizar uma singularidade no interior de uma totalidade. A prática de uma especificidade que se articula e interage numa dimensão mais ampla.

Da assertiva de Hugo Segawa, quando se refere à "percepção de contexto”, ou ao “esforço da crítica”, compreende-se o papel ativo da teorização sobre a inscrição no campo, das obras associadas à Amazônia. Em acréscimo, é necessário ratificar a importância desta 
associação das obras ao contexto, quando localizadas na Amazônia, dada a impossibilidade de que sejam alienadas do conjunto de questões que historicamente a região tem concentrado, tenha sido na formatividade do território, tenha sido como pensamento social, por exemplo. Se lidas em isolado ao campo, as obras tidas como "amazônicas” não são de fato uma resposta regionalista à uma pretensa identidade que porventura estaria sendo buscada pelos arquitetos. No entanto, lidas em interdependência ao contexto, diante dos motivos que as tornaram possíveis, e por isso também revelam de seu valor, as obras, incluindo sua materialidade, esclarecem sobre o tensionamento identitário emergido do processo mais ampliado da controversa modernização regional da Amazônia. Também, quando postas em relação à Amazônia, a compreensão das obras desnaturaliza algumas categorias que quando associadas ao movimento pós-modernista na arquitetura, são destituídas de sentido, mas que vista sob a perspectiva de ser pensada a Amazônia, em sua trajetória histórica, são capturadas desde outros significados. Assim que a compreensão da Amazônia, como construção intelectual e material, é determinante para o entendimento das obras de arquitetura quando a ela relacionadas, na modernidade.

A partir de 1985, os Seminários de Arquitetura Latino-americana passaram a ser organizados com o objetivo do estabelecimento de um campo de trocas e debates entre os representantes dos países participantes, bem como a identificação de "uma base comum de uma possível identidade arquitetônica latino-americana”, de uma arquitetura que fosse moderna, adequada ao ambiente, plural, sem uma referência material que mobilizasse àquela produção a alguma vertente em comum. Desses encontros, Cristián Fernández Cox desenvolveu uma categoria a partir da qual poderiam ser dadas formas distintas de expressão da modernidade na América Latina, a modernidade apropriada. O conceito, que não comportava "um estilo, mas uma atitude" previa desde uma tríade, a pauta de debates entre os críticos e arquitetos: o ajustamento ao lugar de realização da obra, a assimilação e legitimação da crítica, a resposta projetual segundo “situação específica”, esta, em detrimento da reprodução automatizada referenciada em soluções inadequadas aos lugares de realização dos projetos de arquitetura (ZEIN e BASTOS, 2010, p. 244-245).

Para Ruth Verde Zein e Maria Alice Junqueira Bastos, aquela categoria facilitou a evidenciação de algumas experiências de arquitetura em "situações extremas, como a Patagônia ou a floresta amazônica" tidas como regionais, ou apropriadas, como um "efeito 
demonstração", ainda que de fato a "situação geográfica” não fosse a diretriz para a realização dos debates e da própria atividade crítica naqueles termos, de uma modernidade apropriada (ZEIN e BASTOS, 2010, p. 244-245). Para Marlene Acayaba, tratou-se de uma “formulação", portanto, advinda do desejo de conhecer alguma "tradição viva”, por meio da recuperação do passado e construção do presente, pois, “ao buscar as tradições, termina-se por reinventá-las” (PROJETO N.77, julho de 1985, p. 52).

No âmbito local, era realizada um ano depois, a Primeira Mostra de Trabalhos de Arquitetos de Manaus, promovida pelo IAB/AM [figura 59], com o objetivo de "informar a comunidade de Manaus sobre as atividades dos profissionais arquitetos ali residentes”, junto a qual foi feita toda uma programação de conferências proferidas por Jorge Derenji, ${ }^{206}$ Carlos Maximiliano Fayet e Severiano Mário Porto. O intercâmbio entre esses profissionais e a escola de arquitetura da UFPA se fazia evidenciada pela presença, também, de Severiano Porto, ${ }^{207}$ mais tarde, como professor do Curso de Especialização em Arquitetura nos Trópicos realizado na Universidade Federal do Pará, entre os anos de 1986 e 1987.

$\mathrm{Na}$ exposição ocorrida em Manaus-AM, os arquitetos expositores foram Agesilau Souza de Araújo, David Rodney Lionel Pennington, Edunyra Assef, Ivanete Cintra Machado, José Henrique Bento Rodrigues, Roger de Souza Abrahim, Severiano Mário Porto, Mário Emílio Ribeiro, Mário Alvise Tedesco, Ana Lúcia Nascentes da Silva, Antônio Carlos Bonetti, Lauro Yoshimura e Marçal Lemos Pereira, os quatro últimos, atuantes junto a Secretaria Municipal de Planejamento Urbano de Manaus (PROJETO N.72, fevereiro de 1985, p. 12). A proposta do evento era também a de "discutir e avaliar a participação do arquiteto" na condução dos problemas identificados na "população urbana do Brasil, que vive uma crise sem precedentes na história recente do país” (MOSTRA DE ARQUITETOS DE MANAUS, outubro de 1984). Havia, portanto, certo eco das discussões dadas em âmbito nacional, mesmo pelas dinâmicas encaminhadas pelo IAB regional, que se fazia notar neste evento.

\footnotetext{
${ }^{206}$ O arquiteto Jorge Derenji havia sido contratado para o Departamento de Projeto do Curso de Arquitetura em Belém, "recém-egresso" da Faculdade de Arquitetura da UFGRS. Chegou à capital no ano de implantação do curso na Universidade Federal do Pará, em 1964 (MIRANDA, CARVALHO e TUTYIA, 2015, p. 49). ${ }^{207}$ Sob a coordenação de João Pinto de Castro Filho e José de Andrade Rayol, e os “ministrantes" Mácio Villas Boas, Edgar Albuquerque Graeff, Luiz Carlos Chichierchio, Azael Rangel Camargo, além de Severiano Porto.
} 
Capítulo 3 - Dentro e fora da História:

centralidade da Amazônia brasileira nos textos e prática de A.U. no Brasil, 1934 a 1989

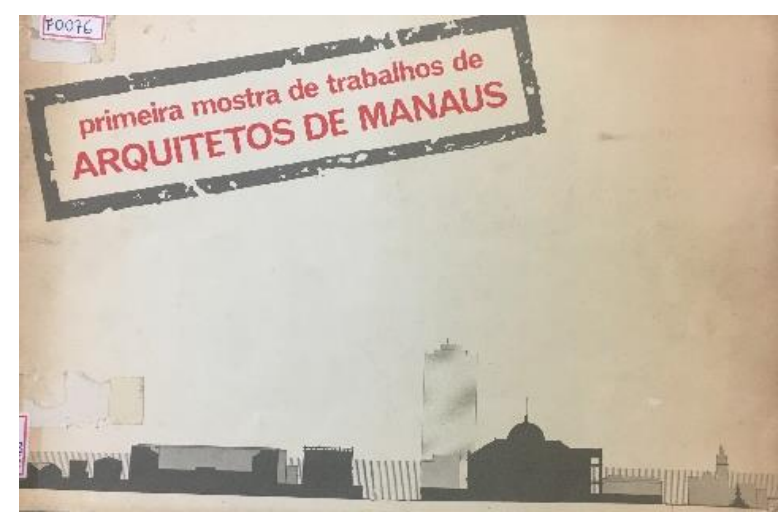

(1)

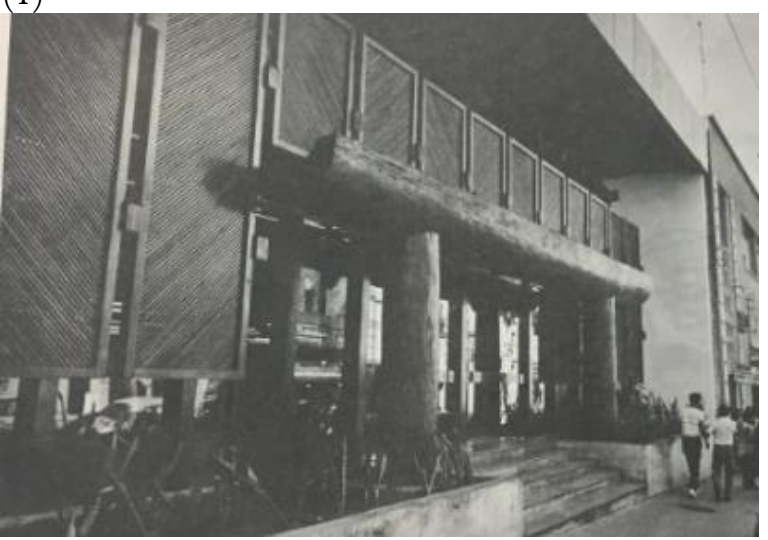

(3)

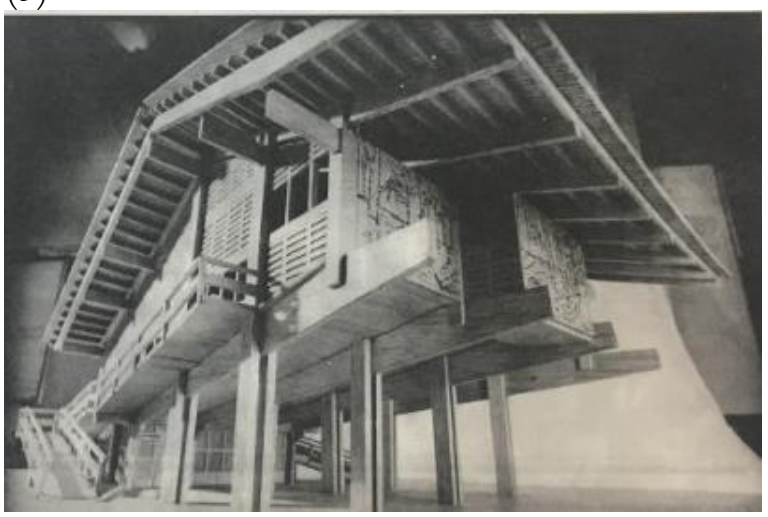

(5)

Figura 59 - Projetos expostos na primeira mostra de arquitetos de Manaus. Capa do catálogo (1); conjunto parque Ayapuá de Mario Alvise Tedesco de 1981 (2); projeto do banco da Amazônia de Severiano Mário porto e Mário Emílio Ribeiro, 1974 (3); projeto para sede da Justiça Federal do Amazonas de 1978, de Agesilau Souza de Araújo (4); projeto do auditório do Campus do INPA, 1983, de

David Rodney Lionel Pennington (5); projeto para o Banco do Estado do Amazonas, 1984, de José Henriques Bento Rodrigues (6).

Fonte: MOSTRA DE ARQUITETOS DE MANAUS, catálogo, 1984.

A atenção dos arquitetos às questões ambientais e relativas ao conforto na arquitetura ultrapassava, à época, qualquer motivação mais específica de enraizamento à tradição, do ponto de vista constitutivo de uma figuratividade. Mesmo que uma arquitetura pudesse fazer aflorar formas construtivas as quais os processos artesanais de construção se fizessem presentes, ou mesmo determinados modos de vida e formas sociais fossem 
evocados por arquitetos mais experimentalistas, como Milton Monte, os debates acerca de uma arquitetura para a Amazônia centralizados na escola de arquitetura da UFPA ${ }^{208}$, eram refletidos da preocupação a aspectos relativos à adequação moderna do projeto e obra. $\mathrm{O}$ enfoque era centrado na produção "voltada ao uso de materiais regionais como a telha de barro e a madeira, em coberturas com amplos beirais, estruturas, fechamentos e revestimentos”, onde cobertas marcadas, beirais quebrados, formas libertas do solo, foram artifícios dados num processo racional de adaptação da técnica construtiva ao local de sua inscrição (MIRANDA, CARVALHO e TUTYIA, 2015, p. 73).

O aperfeiçoamento do projeto era uma busca, fosse através dos cursos de especialização ou mostras de arquitetura ${ }^{209}$ e o intercâmbio entre arquitetos foi constante nesse período. Severiano Porto participou em 1985 das Jornadas de Bioclimatismo y Ecotecnicas Aplicadas a la Arquitectura, organizadas pelo Colégio de Arquitetos da Costa Rica, onde fez conferências e participou de exposição de trabalhos. A questão ambiental foi fortalecida como recurso técnico à projetação e como argumento valorativo acrescido à arquitetura (PROJETO N.81, novembro de 1985).

Giovanni Blanco Sarquis afirma ter havido nos anos de 1980, em Belém-PA, uma certa vertente de pensamento na qual o sentido de adequação constituía um “engajamento” a uma arquitetura "regionalizada" como aspiração, desde um agenciamento que Sarquis definiu como de conversão de elementos universais à composição de linguagem própria e ajustada a condições dadas pelo contexto amazônico (SARQUIS, 2012, p. 89), retomando a questão do contexto em sua análise, lido sob nova linha interpretativa, como uma postura de aspiração, uma intenção partilhada entre os arquitetos:

$\mathrm{Na}$ transição para a década de 1980, a leitura que se fazia de uma arquitetura regional na Grande Belém se identificava com projetos nos quais eram utilizados materiais tradicionais como a madeira e a cerâmica; aplicadas estruturas (especialmente) em madeira, segundo técnicas tradicionais e com ênfase à valorização formal; desenvolvidas amplas coberturas destinadas à proteção contra a radiação solar e as chuvas constantes; e adotados recursos construtivos que favoreciam a circulação interna do ar, como persianas e brises. Nesta senda, surgiram edifícios cujas soluções arquitetônicas relacionaram-se ao conhecimento das especificidades do sítio na tentativa de reinterpretá-lo, expondo certo engajamento quanto à valorização da ideia de regionalismo.

\footnotetext{
${ }^{208}$ Destacadamente pela realização do Curso de Especialização em Arquitetura nos Trópicos na Universidade Federal do Pará, entre 1986 e 1987.

${ }^{209} \mathrm{O} 1^{\circ}$ Salão Amazônico de Arquitetura aconteceu em 1980, em Belém-PA.
} 
Para o arquiteto João Pinto de Castro Filho, a eficiência da arquitetura seria um atributo adquirido, justamente, pela adequação de desdobramentos em diversas disciplinas. Seu estudo, mais detidamente, foi voltado à compreensão ds meios de adequação da arquitetura quanto ao aspecto do conforto ambiental, referenciado no conhecimento cultivado por arquitetos atuantes na Amazônia, cujas obras serviram à sua base de investigação. Castro Filho estava a construir uma linha interpretativa, uma elaboração acerca da cultura construtiva amazônica, em estudo pioneiro realizado por arquiteto atuante na região, especificamente no Pará. Para tanto, realizou viagens de reconhecimento do panorama da arquitetura na região, com vistas à construção de um inventário documental de obras, as quais poderia reconhecer in loco.

Em sua dissertação [figura 60], Castro Filho abordou conjunturalmente a Amazônia, seus aspectos sociopolíticos e também o meio físico. A questão climática foi central ao seu trabalho, já que se aprofundou no tema ao tratá-lo na Amazônia, onde desenvolveu estudos recortados de suas "ambiências". Identificou parâmetros que seriam necessários ao conforto térmico ideal na Amazônia e como recorte empírico, analisou obras de arquitetura segundo os parâmetros de adequação que elaborou a partir do conhecimento aprofundado acerca das características ambientais que mapeou na região. Em 1988, João Castro Filho enunciava a Amazônia a partir da perspectiva de um tropicamazonismo arquitetural, na "busca de uma arquitetura aberta e genuinamente amazônica”, “arejada e confortável”, pesquisa esta, que desenvolvia havia dez anos. O arquiteto foi o que retomou explicitamente as construções discursivas de Leandro Tocantins, reformulando-as materialmente a partir de um paradigma para a habitação, diante da possibilidade de tornarse Belém, seu contexto atuação, uma “ilha de calor”. 

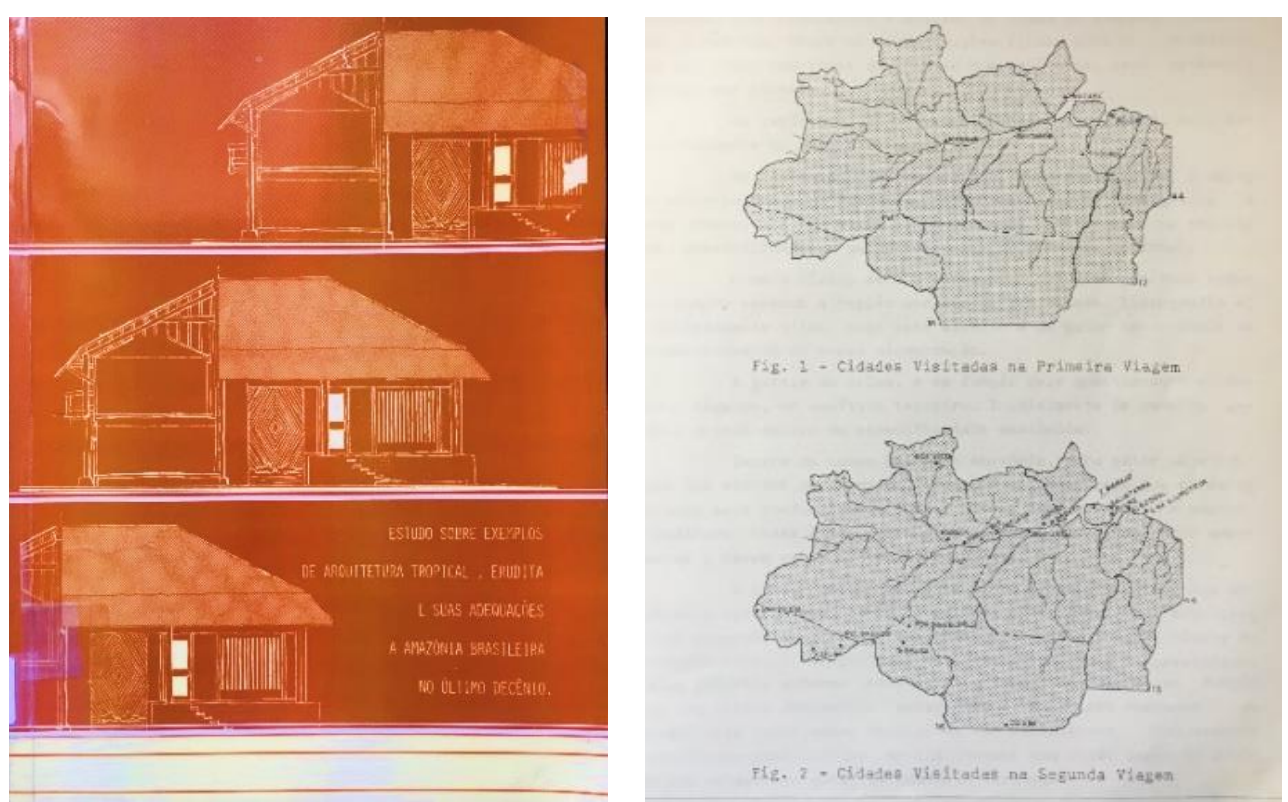

Figura 60 - Dissertação Estudo sobre exemplos de arquitetura tropical, erudita e suas adequaçóes a Amazônia Brasileira no último decênio defendida na Escola de Engenharia de São Carlos, Universidade de São Paulo. Capa e mapa das viagens. Fonte: FILHO, 1984.

Em termos ideais, ao arquiteto, seria coerente "morar numa casa como se fosse embaixo de uma árvore frondosa”. Esta habitação ideal ao clima quente e úmido da Amazônia, trazia a tona novamente, como pressuposto, uma paisagem antiurbana memorialmente evocada, um sítio natural idealizado, inversamente, adaptado à implantação de sua arquitetura. Esta, foi pensada em termos construtivos e técnicos a partir do raciocínio objetivo sobre o funcionamento da construção, primordialmente, pelo traço artesanal e soluções de conforto e pela aplicação de "elementos que sejam amazoniáveis", inclusive novos materiais. A Amazônia narrada como paisagem, e em poética, no argumento de projeto pelo texto de João Castro Filho, serviu de base discursiva à sua produção, também, como sustentação das soluções adotadas, explicadas a partir de se enraizamento no lugar. No projeto para o retiro Tragraste, o arquiteto teve toda uma "oportunidade de aplicar toda a teoria" desenvolvida sobre "a arquitetura mais adequada à região amazônica" (PROJETO N.115, setembro de 1988, p. s/p):

O telhado de cada unidade funciona como um chapéu protetor ou a copa de uma árvore, deixando que o sol só bata nas paredes até as 9 h30 e depois das $16 \mathrm{~h} 30$. Os beirais generosos são complementados por quebra-chuvas, o que permite deixar as janelas abertas, mesmo ao chover.

$[\ldots]$ a temperatura se situa em torno de 25 graus durante o dia, caindo para vinte à noite. Em termos de Amazônia, esse é o conforto térmico ideal, sem uso de ventilador ou ar-condicionado. 
O arquiteto, formado pela Universidade Federal do Pará em 1976 concluiu o mestrado na USP de São Carlos - SP e voltou à Belém em 1984, desde quando realizou um "trabalho voltado para a Amazônia". Em 1988, o Centro Tecnológico da Universidade Federal do Pará desenvolvia "o segundo curso de especialização em arquitetura tropicap", tendo sido planejado em longo prazo, com o objetivo de criação de um "grande núcleo de estudos da arquitetura tropical" na UFPA (PROJETO N.115, setembro de 1988).
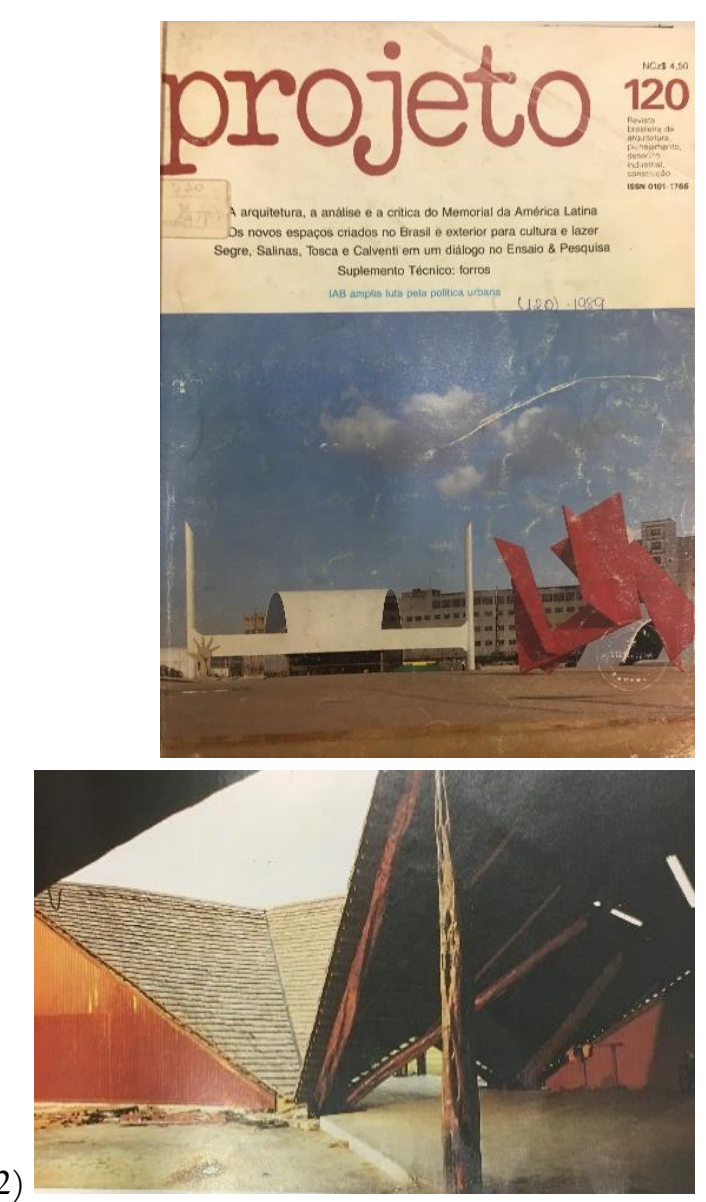

(1)

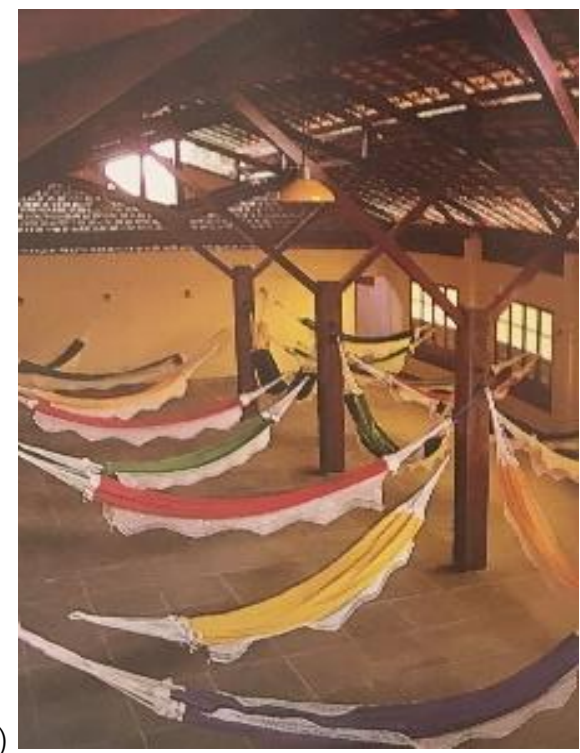

(1)

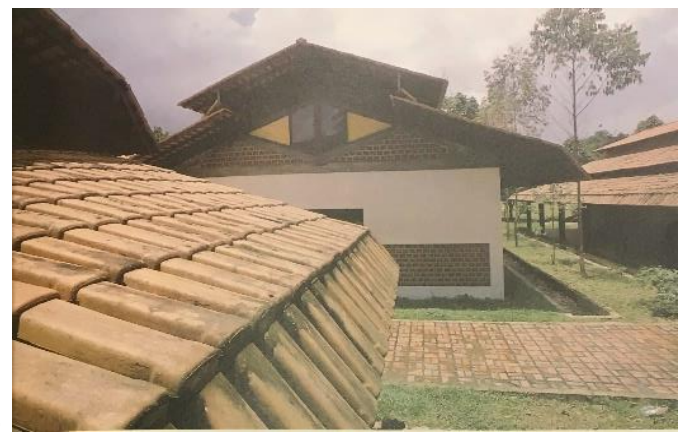

Figura 61 - Capa e imagens do projeto de João Castro Filho para o Retiro Tagaste, em Ananindeua - PA (1) e projeto para o Parque Anauá, de Otacílio Teixeira Lima Neto, em Boa Visa - RR (2). Fonte: PROJETO n.120, 1989.

O arquiteto adotou uma postura crítica diante da colonização cultural a arquitetura na Amazônia e o "Retiro Tagaste" seria um exemplar típico, onde aplicou toda a teoria "sobre a arquitetura mais adequada à região amazônica" (PROJETO N.120, abril de 1989). Quatro pontos são centrais ao fim deste recorte proposto, também para a compreensão do estágio no qual a arquitetura na Amazônia foi significada nas revistas no final da década de 1980. O acento ao pluralismo, ao meio ambiente, às referências identitárias, à busca pela 
autodesignação cultural, foram pautas postas em relação, absorvidas nas discussões sobre a arquitetura no Brasil. O primeiro, diz respeito à condição admitida desde os textos, pela crítica e história, da pluralidade com que a arquitetura no Brasil vinha sendo desenvolvida e passou a ser reconhecida, especialmente após Brasília. Outra chave de leitura, diz respeito, como já observado, à atenção despendida à questão ambiental e sua amplitude, na qual a Amazônia foi tornada central, no âmbito interno ou mesmo transnacional, igualmente sob ótica disciplinar. E em relação a este ponto, outras questões correlatas contribuíram para endossar esta discussão no campo, a exemplo da emergência das manifestações sociais organizadas na conjuntura da redemocratização do país. Paulo Tavares faz uma síntese da posição da Amazônia no cenário internacional de discussão acerca do meio ambiente e de sua conservação (TAVARES, 2013):

Em 1989, quando o discurso ambiental já havia sido infiltrado junto à sensibilidade pública e o Brasil estava correndo suas primeiras eleições democráticas em vinte e cinco anos, a Amazônia emergiu como uma arena multi dimensional de conflitos políticos, em que reinvindicações éticas em nome da humanidade e da natureza foram intimamente articuladas com as contingências locais sócio-históricas, afetadas pelas forças da modernização global. Em todo o terceiro mundo, espaços que forneciam matéria-prima para a industrialização militarizada experimentada durante a guerra fria foram convertidos em linhas transnacionais de disputa em torno $\mathrm{da}$ qual as comunidades locais e uma rede internacional de defesa ambiental e ativismo em expansão reuniram-se em defesa de modos dissidentes de gestão dos recursos naturais. $\mathrm{Na}$ Amazônia, às margens da fronteira moderno-colonial, articulações hegemônicas entre imaginários nacionais, o Estado e território foram contestados e reformuladas no momento em que a democracia foi redefinida.

O que foi designado como "identidade" abarca um conjunto de significados, internos ao campo da arquitetura, mas não unicamente, concorrentes à admissão dos regionalismos, ainda que associados aos movimentos de aspiração às distinções e particularismos como modo de inserção na modernidade, como mobilização política à autodesignação e à afirmação cultural, desde uma dada regionalidade. O próprio pluralismo como condição identificada na arquitetura nos anos 1980, daquela trajetória após Brasília, sinalizava a obra de Severiano como um caminho alternativo à arquitetura no Brasil, e todo um conjunto de realizações associadas aos seus feitos referenciais, propagados mais intensamente nessa década. Sob o acento do regional, um conjunto de projetos de Severiano Mário Porto foi publicado na revista A Construção São Paulo, em artigo de Hayfa Y. Sabbag 
[figura 62]. Os projetos destacados foram qualificados a partir da atenção do arquiteto à "preservação da identidade regional, com uso de técnicas e materiais apropriados ao clima e ao ambiente locais", como "caminho para uma possível arquitetura genuinamente brasileira" ${ }^{210}$ (A CONSTRUÇÃO SÃO PAULO N.1972, novembro de 1985, p. 15-19).

Hayfa Sabbag escreveu vários dos artigos acerca da obra de Severiano, dentre os quais aquele no qual falou de sua arquitetura como "feita de pequenos e simples elementos, mais próximos do homem e de seu universo, desvinculada de conceitos internacionais", num processo de recuperação da relação "do homem com o seu habitat - atitude fundamental no procedimento arquitetônico" no processo de projeto. Uma das preocupações fundamentais de sua obra seria justamente a "preservação da identidade regional e a revalorização do uso da madeira e das técnicas caboclas, mais adequadas às circunstâncias locais, bastante específicas". Seriam as suas obras "bastante singulares", de "linguagem, muito coerente com o clima da Amazônia". Em toda sua trajetória desde que chegou a Manaus em 1965, "para executar a reforma do Palácio Rio Negro e projetar outros edifícios públicos”, quando "tomou contato com um universo totalmente diferente do Rio de Janeiro", inclusive com moradias qualificadas como "simples abrigo e morada, contrapunha-se à ideia de residências duradouras e permanentes, já cristalizada nos centros urbanos", com a adoção de "respostas regionais", ainda que com variação no uso dos materiais e técnicas construtivas.

A partir de entrevista concedida pelo arquiteto, publicada em outro artigo de Hayfa Sabbag, a sua casa foi apresentada como que atrelada intimamente aos saberes regionais, capturados por Severiano Porto a partir de sua chegada a Manaus, em 1965, já que "em suas andanças pela Amazônia surpreendia-se com a coragem e o conhecimento dos homens que habitam a mata, dela tiram sua subsistência e remédios que necessitam”. Esta leitura seria particularmente transposta aos projetos de habitação. No texto, uma síntese do que havia sido publicado no mesmo ano, Hayfa Sabbag reforçou que somente com o reconhecimento nacional e internacional, os projetos de Severiano passaram a ser absorvidos em âmbito local, considerando que a madeira era até então, material prevalente em habitações pobres,

${ }^{210}$ Conforme apontado no Congresso Nacional de Arquitetos em Belo Horizonte e do reconhecimento internacional, na Bienal de Buenos Aires. No artigo foi abordada a atividade docente do arquiteto no curso de Engenharia Civil da Universidade Federal do Amazonas, que priorizava a regularidade do "fazer" arquitetura, e o conhecimento embasado na própria construção, distanciando-se dos "projetos de exceção, para consumo da elite e não para as necessidades verdadeiras do povo" (A CONSTRUÇÃO SÃO PAULO N.1972, novembro de 1985, p. 19). 
como ele havia constatado e constantemente afirmado. A respeito do caráter regional, Severiano Porto foi crítico ao ensino corrente de arquitetura, que criava "estruturas impostas" como forma de limitação à adoção de soluções construtivas com maior propriedade (AU N.3, novembro de 1985, p. 38), provavelmente aquelas tidas como populares e por isso estigmatizadas, como referido no texto.

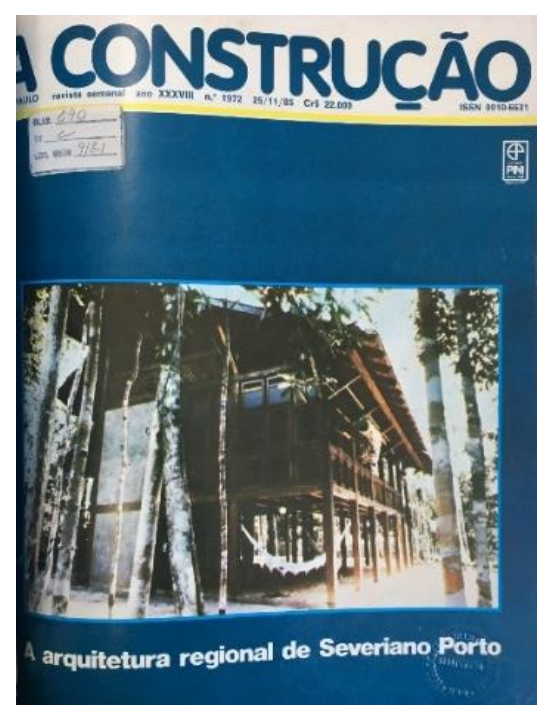

Figura 62 - Matéria da revista $\mathrm{A}$ Construção São Paulo sobre a obra de Severiano Mário Porto. Fonte: A CONSTRUÇÃO SÃO PAULO n.1972, 1985.

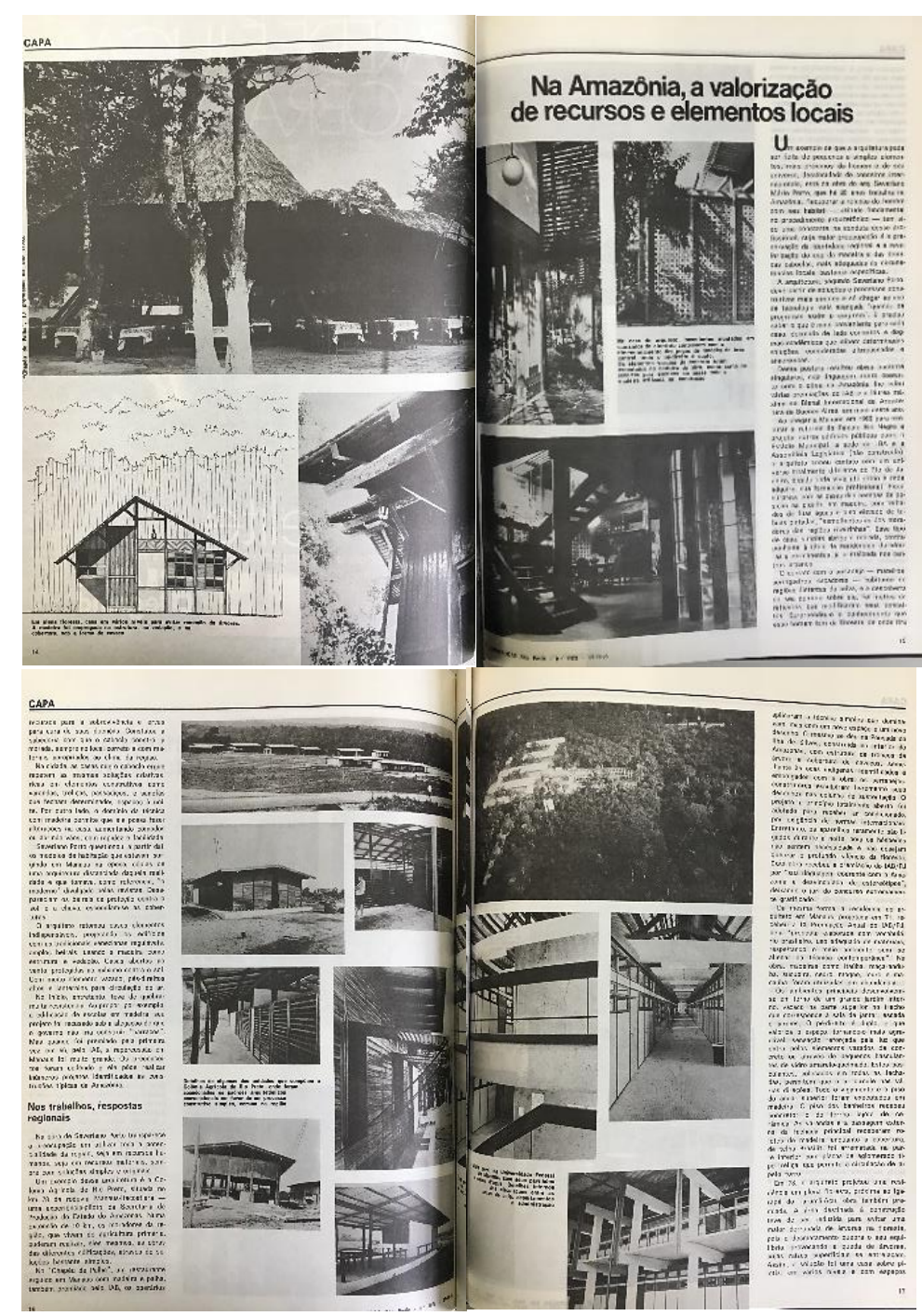

Outros artigos trataram da projeção arquitetura de Severiano Porto, inclusive internacional. $\mathrm{Na}$ Bienal de Arquitetura de Buenos Aires de 1985 foi premiado pela atualidade e modernidade do caráter regional de sua obra, como forma de "identidade cultural”, central, e não periférica, da arquitetura latino-americana, além de socialmente efetiva, como expresso por Ruth Verde Zein. Na anotação de Marlene Milan Acayaba, a Amazônia foi apresentada como o lugar do "exílio" de Severiano e onde foi possível que 
criasse uma arquitetura "vinculada à ecologia, ao ambiente, a situações naturais e sócioculturais próprias”, ao tratar da mesma premiação (PROJETO N.77, julho de 1985).

Um artigo de autoria de Ruth Verde Zein, Um arquiteto brasileiro: Severiano Mário Porto, viria a firmá-lo como um profissional de obra múltipla e abrangente, um arquiteto brasileiro que vinha realizando há vinte anos projetos no país, e havia sido recentemente premiado na Bienal de Arquitetura de Buenos Aires, em 1985. A autora se localizou frente à dualidade, talvez mais oriunda dos escritos críticos do que da obra do arquiteto, na avaliação sobre a referida mostra. $O$ reconhecimento de sua qualidade adaptativa de um lado e o desvalor relacionado ao catáter exótico de outro, a fez reconhecer, no texto de amplo panorama da obra de Severiano Porto, seu "pertencimento à tradição brasileira de adaptação de postulados modernos ao sítio, clima, materiais e ao jeito brasileiro". O “caráter correto" dos edifícios, a ausência de limites para a absorção de boas referências e meios, não eram esgotados em seu projeto, onde nenhuma fórmula poderia ser encerrada (PROJETO N.83, janeiro de 1986, p. 43-86):

a adaptação de postulados genéricos advindos dos mestres europeus, ao sítio, clima, materiais e até ao jeito nossos. Pertence a uma tradição que produziu obras como o hotel de Friburgo, de Lúcio Costa, a casa de Oswald de Andrade, de Oscar Niemeyer, a caixa-d'água de Olinda, de Luis Nunes, para citar os mais conhecidos.

O apropriado enlace de certa arquitetura de Severiano Porto à tradição disciplinar no Brasil, não foi para a autora um meio de enquadrá-lo em uma linha referencial de projeto, ao contrário, serviu para que atestasse sua "abertura às possibilidades” em situações diferentes, encargos e sítios, que em sua perspectiva como projetista demandaram soluções igualmente distintas. A “integração das arquiteturas regionais" foi o propósito da publicação “Arquiteturas no Brasil/Anos 80" [figura 63], organizada a partir de cada uma das regiões do país desde as quais foi destacada um conjunto seleto de projetos, numa época de uma "cultura marcada pela multiplicidade de alternativas". Uma leitura mais abrangente foi a apresentada neste catálogo, incluindo obras e projetos em cidades como Boa Vista, Mosqueiro, Paritins, além das capitais Belém e Manaus.

O texto de Hugo Segawa que relevou o fenômeno da revalorização das técnicas tradicionais de construção, identificado como o resultado da consciência ambientalista da década de 1970, guardou relação com as obras apresentadas quando situadas no norte do 
país (SEGAWA, 1988). De certo modo, acentuando a pluralidade e admitindo a diversidade das produções, a seleção das obras apresentadas seguiram prevalentemente uma linha em comum, da inserção em entorno não urbanizado ou não enunciado na publicação.
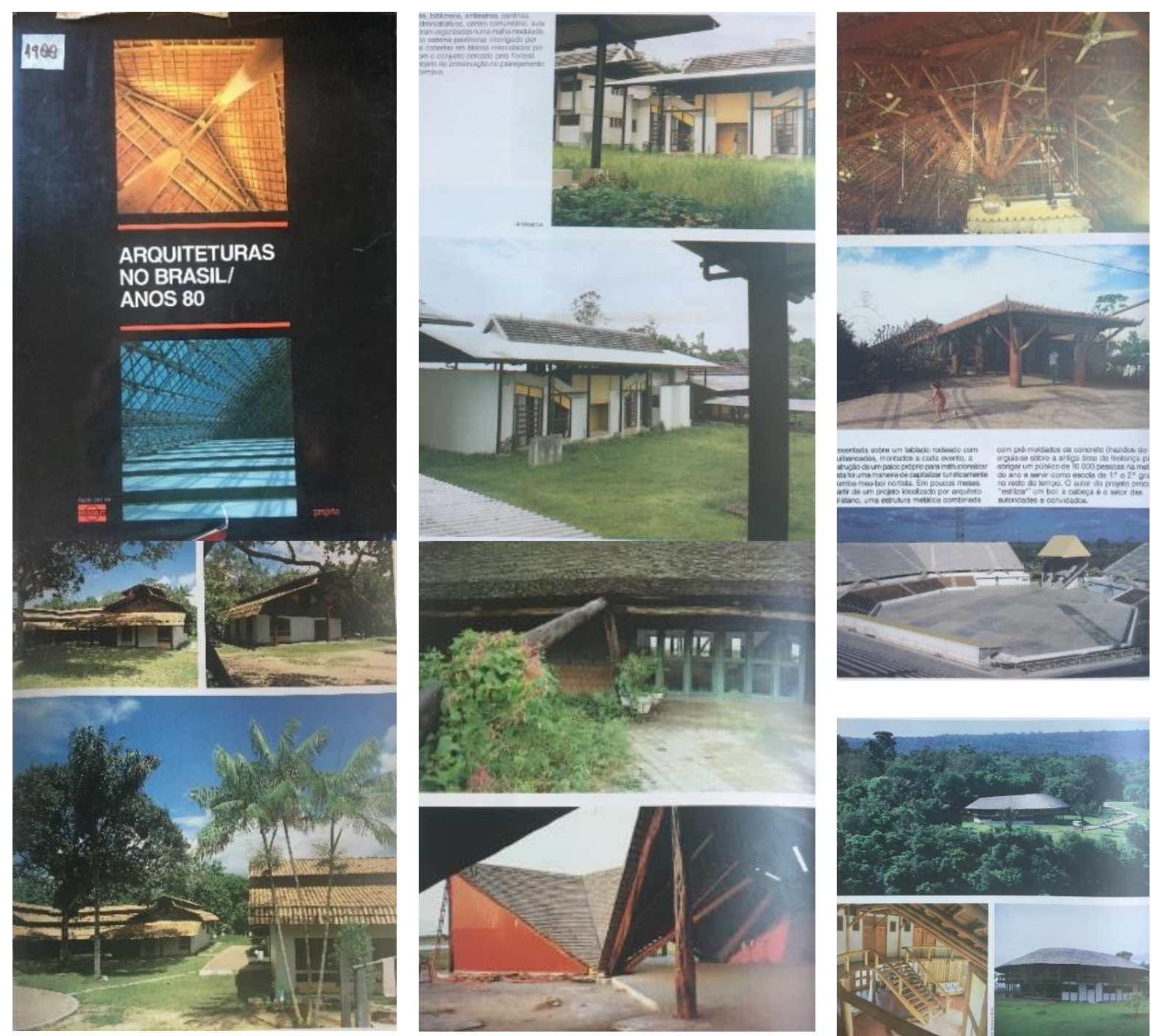

Figura 63 - Arquiteturas no Brasil: Anos 80. Fonte: SEGAWA (org.), 1988; PROJETO n. 114, 1988.

O enfoque transdisciplinar da publicação "planeta Amazônia" [figura 65] apresentado pela revista AU de número (AU N.10, 1987), ainda que sob a marca de arquitetos e temas referidos diretamente a Manaus-AM, trouxe a tona um debate acerca da Amazônia. O próprio editorial, abordou a Amazônia, sob o aspecto da preservação ambiental, ao tempo do resgate das técnicas tradicionais, dos aportes culturais nos debates que cercaram a Arquitetura e Ubanismo em finais da década. A imagem genérica da capa evocou algum lugar na Amazônia, desde uma construção flutuante de madeira e palha, para 
o início dos olhares variados que foram apresentados pela revista acerca da Amazônia (AU N.10, 1987, p. 3):

Por sua escala e importância ecológica a Amazônia é objeto constitucional. Certamente a letra de lei é limitada para defender uma ocupação ecológica, tese exemplar do prof. Aziz Ab’Saber, que não deixa dúvidas quanto a ser uma das possivilidades concretas para o futuro daquela imensa área, mais da metade do território nacional. É preciso também despertar a consciência. O que ainda resta do índio e do caboclo, as intensidades do sol, da chuva, da umidade e do cento, os muitos Amazonas e a grandeza da floresta e a infinidade de insetos, peixes e animais é que fornecem as lições para um projeto de convívio na Amazônia. Nâo é possíve, pensarmos em abrir novas estradas para uma região que conta com uma rede urbana de base estritamente fluvial, com 80 mil km de rios navegáveis. Da mesma forma é ingênuo pensá-la intocada, frente aos extraordinários potenciais energéticos e minerais em fase crescente de exploração. Essa contradição reforça teses que precisam da química institucional e política para transformar-se em permanentes ações de interesse coletivo.

O título da revista reforçou o caráter internacional do debate acerca da preservação ambiental quando abordado desde a Amazônia, um "planeta Amazônia”, título que abarcou justamente as múltiplas perspectivas a respeito da região que estavam sendo apresentadas na revista, já que além do próprio fenômeno “Amazônia” no âmbito da arquitetura e urbanismo, foram apresentadas outras camadas de interpretação. Ainda que o tema ambiental tenha percorrido a revista, seu enfoque foi voltado ao fenômeno urbano na Amazônia, o que a tornou uma publicação referencial, posto que apresentou uma leitura aproximada, do que fossem as pautas além de pertinentes e observadas em aproximação: o crescimento das cidades na Amazônia, a partir de Manaus, mais especialmente sob os efeitos da industrialização transcorrida mais decisivamente desde o início da década de 1970 . O resgate do trabalho de Spencer Nogueira foi de partida uma problematização das formas de ocupação do território frente a questão ambiental [figura 64]. Ele foi representativo justamente por se tratar de um projeto sem localização específica, uma ideia conciliatória entre mundo rural e urbano, uma formulação utópica e questionadora da modernização na Amazônia.

O debate acerca de soluções à ocupação em adequação ao fenômeno urbano na Amazônia conduziu a linha editorial da revista, trazendo a interpretação da região em grandezas distintas, escalares e temáticas, postas em diálogo. $\mathrm{Na}$ estrutura da revista, a Amazônia foi situada na modernidade, em sua condicional importância ambiental ao 
planeta. Noutro sentido, centrou temas relativos às condições espaciais e urbanas aferidas em aproximações ao fenômeno do espaço regional. O diálogo entre as duas escalas de observação decorreu mais diretamente da variedade espaço social que compunha a Amazônia, das metrópoles, cidades projetadas, aos espaços dos “povos testemunha”, os que “ficaram nos bolsões da Amazônia”. O fenômeno do espaço amazônico, como abordado na revista, não ficou retido às fronteiras de expansão, mas foi abordado em recortes bastante diferenciados, quando relacionados à transformação do espaço amazônico, como o relativo ao direito à terra, o consumo mundial ou à tecnologia.

A perspectiva urbana de Manaus-AM foi apresentada em sua caracterização mais aproximada ao real, como uma "capital sitiada pela floresta”, sobretudo quando identificado o modo de pensar do "profissional que vive na região amazônica”. Esta leitura, desde o interior, registrou os olhares de Severiano Porto, Ivanete Cintra, Roger Abrahim, César Oiticica, Alfredo Marques, Carlos Rodrigues Siva, José Henriques Rodrigues e Ana Cláudia de Aguiar. Alguns atuantes no serviço público, no órgão do planejamento urbano da prefeitura e do patrimônio histórico - Sphan. A ênfase das falas, se é que é possível homogenizá-las, recaiu sobre os particularismos, a especificidade urbana de Manaus, “encravada no coração da Amazônia”, desde a trajetória histórica de sua fromação urbana, dos processos econômicos, as fases demarcatórias da modernização, até o alcance da industrialização induzida e seus efeitos não absorvidos pela atividade planejadora. Severiano Porto, atento àqueles particularismos, referenciava suas observações sintetizando-as numa necessidade de regionalização da arquitetura, nestes termos (AU N.10, 1987, p. 32;37):

"Vivemos numa região completamente diferente", desabafa Severiano Porto. Uma região, diz o arquiteto, muito mais importante tanto no plano da natureza quanto no aspecto turístico. "Deveria haver, portanto, uma preocupação maior com o regionalismo, nem que fosse para consolidar uma intenção turística".

Sem excluir as influências e tendências que vêm de fora, Severiano Porto reconhece que os profissionais podem até incluir em seus projetos elementos e linguagens do colonial ao pós-moderno, desde que sejam observadas as condições climáticas.

É dessa forma que espera conjugar o regionalismo com intercâmbios e influências da evolução dos costumes, da tecnologia ou dos meios de comunicação. Defende, assim, um regionalismo capaz de reunir todas essas influências com a preocupação de preservar o comportamento e costumes ocais. Um regionalismo, enfim, consciente - conclui. 

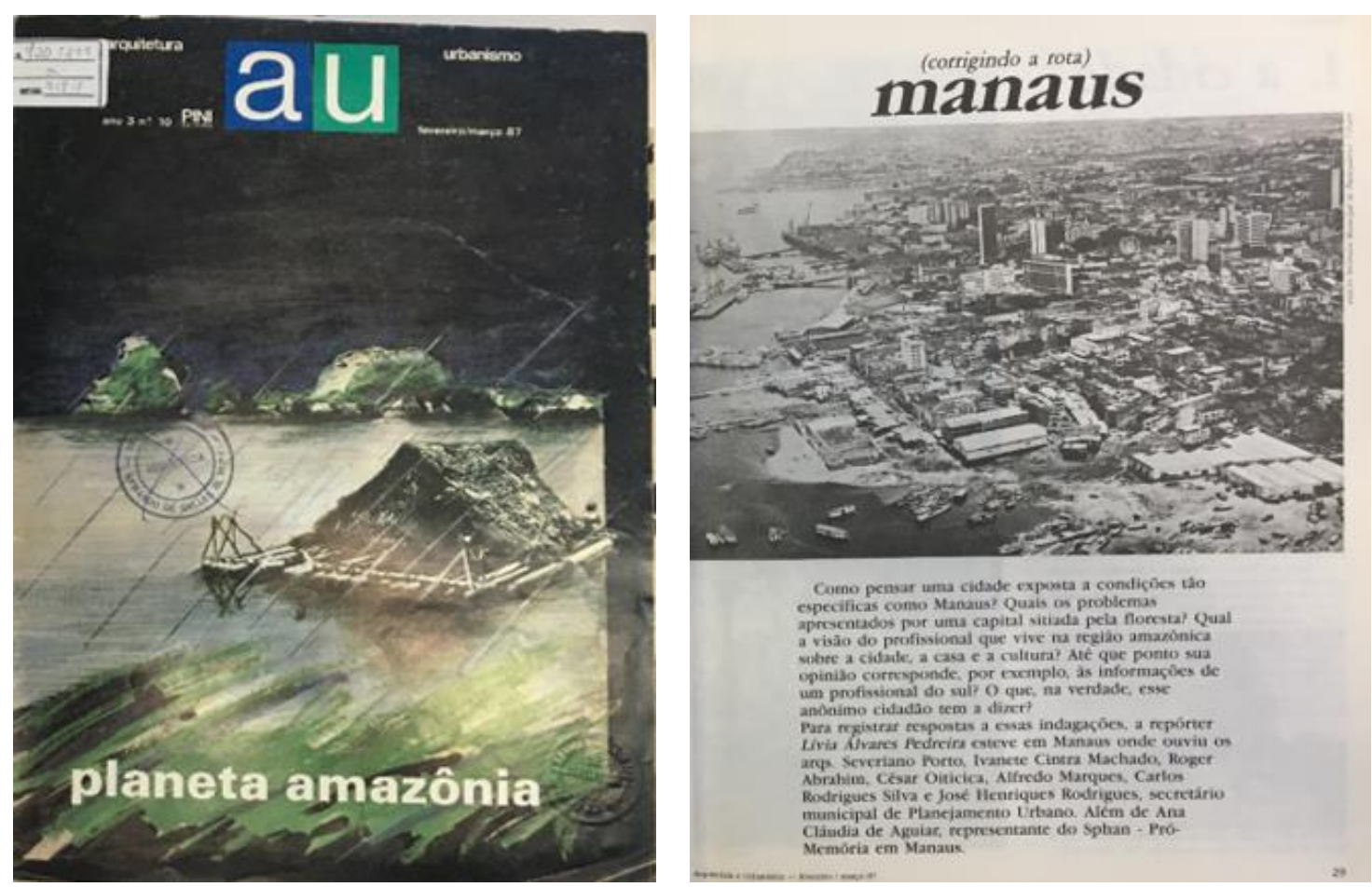

Figura 64 - Planeta Amazônia. Fonte: AU n.10, 1987.

A esta altura, o delineamento do que fosse a arquitetura regional, centrada em parte da obra de Severiano Porto, quando esta pauta foi deslocada ao contexto urbanizado de Manaus-AM, já impactado pela recente industrialização, adquiriu contornos diferentes, em 1987. Mesmo acionados pela memória, os saberes construtivos tradicionais e o elo entre a arquitetura com o mundo rural, se esmaeciam diante das demandas urbanas da capital. Não se tratava unicamente de uma formulação da crítica, mas da constatação que uma arquitetura urbana estava sendo delineada, a partir de temas contundentes, como o da habitação, apresentado na revista junto à “questões urbanas urgentes”. Não mais sob a dimensão utópica do morar típico e afins, mas desde a exposição das ocupações favelizadas, das beiras sem saneamento e das demandas sociais por moradia. Severiano Porto, por outro lado, reiterava no tema da habitação, a necessidade de uma "arquitetura adequada à região", ressaltando as críticas aos conjuntos habitacionais. Era sem dúvida um outro momento da atividade profissional do arquiteto na capital. Os efeitos da industrialização traziam à tona problemas de ordem geral, de modo que a questão da adequação cultural soou como pouco atual, como causa passada, frente o rol de novas questões apresentadas pelo espaço na Amazônia.

Os projetos de Oswaldo Bratke para as Vilas da Icomi, por outro lado, foram retomados como ícones, em associação ao discurso ambientalista que permeou a revista, 
apresentados, inclusive sob a máxima de "nada se destroi”. A ideia mesma de uma arquitetura respeitosa para com o lugar "distante da civilização", "uma aventura inesquecível”, com os mesmos desenhos e argumentos de projeto já bastante publicados, voltava à tona. A questão é que a cidade empresa, projetada por Bratke, como fenômeno urbano na Amazônia, trazia consigo uma gama de contrariedades, dentre estas, a mais elementar, de se tratar de um projeto de base à exploração mineral. A tonalidade do texto referenciado nos projetos de Bratke, foi de uma narrativa memorial, fundida ao tempo presente da revista. Acerca da Amazônia, Joaquim Guedes também se posicionou em depoimento a Haifa Y. Sabbag, na temática das novas cidades amazônicas, as "cidades na Amazônia”, como tratado no primeiro capítulo, por Saint Clair Trindade. Ou seja, as cidades “criadas em função dos grandes complexos hidrelétricos, da exploração de minérios e dos negócios de terras”. “Adeus ás ilusões”, assim foi intitulado o artigo de registro da entrevista de Guedes, no qual fez uma leitura dos projetos de Marabá-PA e Carajás-PA, até então não identificado nas publicações (AU N.10, 1987, p. 49-50):

Ao ser indagado sobre o que significa a Amazônia para um urbanista paulista, Guedes pára um momento para refletir. A pergunta soa meio surrealista [...] Ele confessa então que, no início, quando projetou Marabá e Carajás, a imagem da Amazônia era algo de dificílima compreensão, "quase inatingível devido aos mitos que a cercam". Chama a atenção para a fragilidade do sistema amazônico, argumentando, em função do progresso de conhecimento que viveu a região, que ela representa tanto quanto qualquer parte do território brasileiro com problemas específicos. "Apenas ela é a Amazônia”, enfatiza.

$[\ldots]$

O importante é olhar a Amazônia como algo real, embora precioso, porque ela indiscutivelmente contém elementos cuja integridade é fundamental para o país, cujo conhecimento é fundamental para nós. Mas a inclinação é colocar de lado toda a fantasia, até para poder se trabalhar de forma útil e correta. Especialmente se estas fantasias não coincidem com os interesses do homem.

O pragmatismo da fala de Joaquim Guedes, em narrar objetivamente o enfrentamento dos problemas com os quais se deparou ao projetar cidades na Amazônia, trouxe à tona um processo de aproximação que estava em curso, de reconhecimento por parte de projetistas e de críticos, da variedade espacial e cultural constitutiva da Amazônia. Os olhares cruzados sobre a Amazônia e a tonalidade retrospectiva das falas, acenou na revista o momento reflexivo pelo qual a disciplina passava ao tratar da temática Amazônia. As experiências resgatadas e as interpretações mais ancoradas nos efeitos concretos da 
transformação do espaço e do território pautaram várias das abordagens: Aziz Ab’Saber, desde a geografia, tratou objetivamente dos efeitos dos grandes projetos estatais na região; José Ribamar Bessa, retomou a questão da cidade, na Amazônia sob a ótica das Ciências Sociais; a análise científica dos pesquisadores do Instituto Brasileiro de Análises Sociais e Econômicas do Rio de Janeiro, especialmente sobre as consequências do processo de colonização sem planejamento, defendeu de que "a própria ideia de região amazônica entrou em crise e cabe, portanto, repensar esse processo novamente" (AU N.10, 1987, p. 74).

Diante da referida "crise" o cruzamento de olhares sobre a Amazônia, a iluminação a partir de distintos campos de compreensão e conhecimento, posto que se trata de uma formulação que antecede, em muito, qualquer elaboração que possa estar contida nas reflexões mais restritas da Arquitetura e Urbanismo, conferiram à revista um caráter transdisciplinar. Foi acrescida ao debate, a argumentação de Fleury de Oliveira, que viria a defender sua tese Amazônia: Proposta para uma ecoarquitetura [figura 66], no ano de 1989, sobre a proposta de estruturas ambientais urbanas em assentamentos planejados na Amazônia, pressupondo seu "planejamento econômico e ecológico".
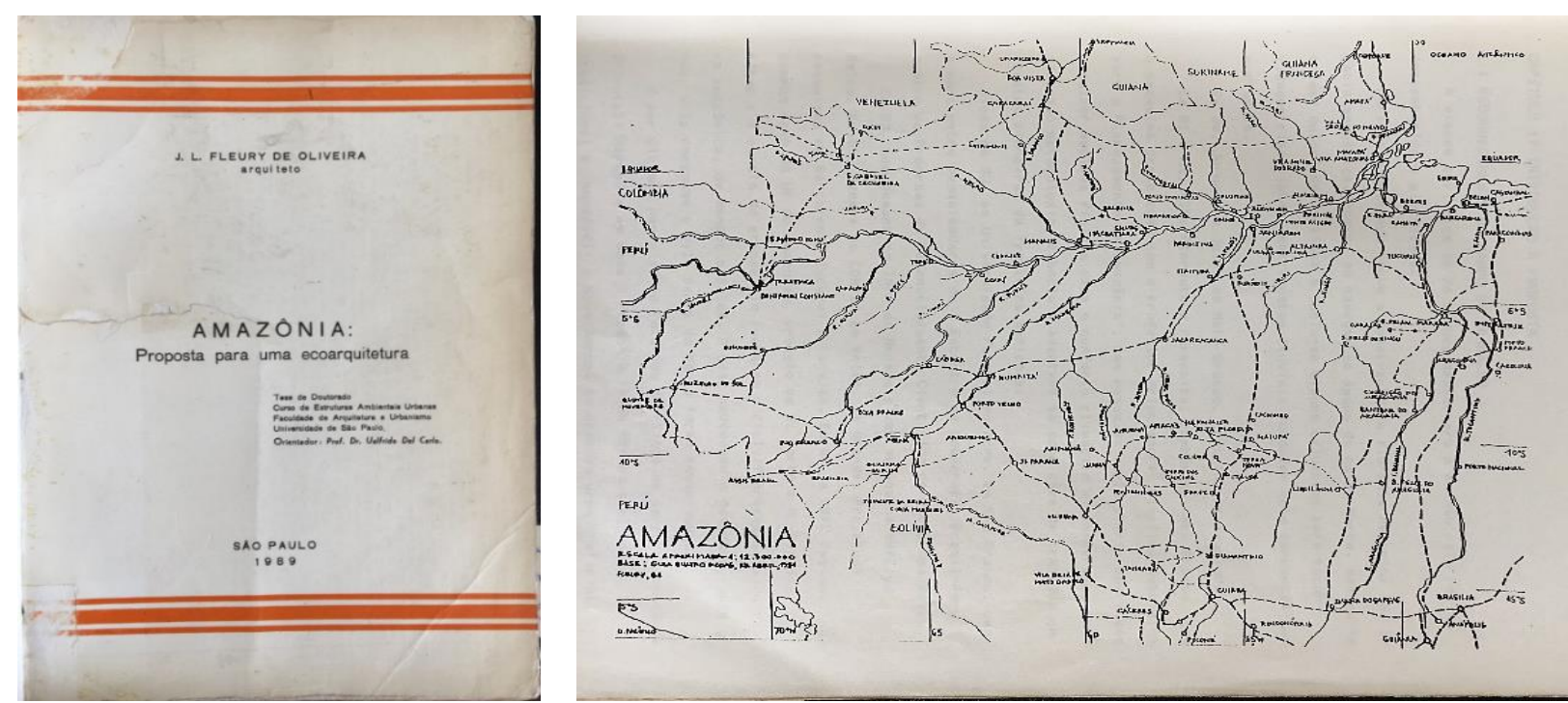

Figura 65 - Leitura territorial de Fleury de Oliveira, para proposta em adequação ao território, de uma ecoarquitetura para a Amazônia (OLIVEIRA, 1989).

O arremate da narrativa da revista foi dado pelo enfoque conferido à Amazônia pelos Seminários de Arquitetura Latinoamericana - SAL, também em tom retrospectivo, especialmente pela rememoração do Seminário ocorrido em 1985, quando da premiação de Severiano Porto em Buenos Aires, do "impacto pela grandiosidade e pela imagem de 
vitalidade da Amazônia ali exibida”. A busca por formas de identificação e conciliação das experiências na arquitetura, era então dada em conjunto com o estabelecimento de novas fronteiras de interpretação da Amazônia e da própria atividade projetual. Identidade, ambiente e autodesignação foram pautas cruzadas neste final da década de 1980. Em sua atividade, os arquitetos no Pará aspiravam à autodesignação, diante de um cenário bastante plural no campo da arquitetura. Tanto Milton Monte quanto João Castro Pinto Filho tiveram suas obras publicadas e apresentaram desde suas próprias falas, sua motivação as razões para realizá-las.

A realização da primeira Bienal de Arquitetura Tropical de Manaus em 1988 e do XII Enea em Belém, que debateu as "diferenças regionais” da arquitetura, foram sinais da assimilação de um paradigma da arquitetura na Amazônia desde o interior do fenômeno, por parte de arquitetos ali atuantes, que a esta altura haviam se enraizado ou formado sua carreira na região. A respeito da Bienal de Arquitetura tropical que seria realizada em Manaus (PROJETO N. 108, 1988, p. 24):

Desenha-se no mapa das preocupações dos arquitetos da região amazônica e de outras regiões do país a importância da I Bienal de Arquitetura Tropical de Manaus [...]

Sâo compreensíveis as preocupações. Essa Bienal será um canal de comunicação direto e eficiente em favor do maior conhecimento da arquitetura praticada em uma região que tem mexido com a consciência e principalmente com a inconsciência dos mais diversos grupos econômicos nacionais e transnacionais.

Os projetos apresentados na mostra serão analisados e discutidos dentro do contexto do ambiente de sua concepção. Em resumo: levando-se em conta suas vinculações, tendências, ideias: as raízes a partir das quais eles afloraram e se desenvolveram. E sabemos o quanto as raízes regionais da Amazônia têm sido gradativamente solapadas, sacrificadas, ao longo do tempo. E o quanto grupos empresariais radicados em outras regiões do Brasil e de outras nações têm se empenhado em impor a esse universo produtos e técnicas que ele, pela sua própria natureza, repele como impraticáveis, antieconômicos e até antiestéticos.

Os projetos foram apresentados em diálogo com as "raízes regionais da Amazônia”, contribuir para o aperfeiçoamento da técnica e de sua aplicação para "tornar mais consistente a relação do homem com o meio ambiente tropical”. Aqui, o "meio tropical" em sentido mais ampliado, se apresentava como um novo rebatimento do que fosse o paradigma ambiental para a atividade projetual, não regional unicamente, não climático, mas “tropical”. A qualidade do projeto estava associada à sua adequação a um ambiente que se 
tornava cada vez mais desnudado e compreendido, como lugar de atuação prática dos arquitetos. Nesta mesma matéria foi feita menção à obra premiada de João de Castro Pinto Filho, na IV Bienal Mundial de Arquitetura em Sófia, Bulgária, um "título da maior significação, que passa a ser atribuído não ao arquiteto, mas à arquitetura tropical", entendida a partir de um paradigma construtivo, ainda que estético quando em referência mais direta ao que fosse uma paisagem antiurbana.

De geração anterior à de João Castro Filho, Milton Monte, já adotava desde o início de sua atuação em Belém - PA, uma postura crítica, à defesa de uma arquitetura regionalizada e em adequação, especialmente climática, partilhada com Severiano Mário Porto. Ela foi formativa de princípios que percorreram as carreiras de ambos, desde os anos iniciais de sua atividade como arquitetos na região, na década de 1960. A crítica de Severiano Porto, neste caso, também respondia aos espaços em transformação e à prática da construção em contextos urbanizados, recém urbanizados, quando da disseminação de novos materiais e arquiteturas sob impulso da industrialização e processos especulativos no espaço urbano desde a segunda metade do século XX. No caso particular de Manaus, na cidade eram experimentados os efeitos da implantação da Zona Franca e a crítica à arquitetura não se restringiu à proferida pelos especialistas, mas pelos intelectuais e demais observadores das mais recentes mudanças na paisagem urbana da capital. Márcio Souza, na leitura que fez, explicitou assim suas impressões (SOUZA, 1978, p. 162):

Fala-se muito no problema urbano de Manaus e há um plano de reforma urbana em andamento. Mas a natureza e a ecologia da cidade exigem mais do que a abertura de avenidas e a racionalização do escoamento do trânsito. Os aspectos paisagísticos e arquitetônicos estão abandonados e entregues à rapina da especulação imobiliária. $\mathrm{O}$ que torna a cidade numa anarquia onde o mau gosto é o nível menos grave, e o mau gosto arquitetônico de Manaus é um caso único.

O aprofundamento da distância entre a ruralidade e a urbanidade dada a notabilidade das transformações das cidades, trazia a tona, no ambiente profissional, as discussões acerca do desajuste das novas construções às condições climáticas tropicais, dada a incorporação de modelos exógenos à região. A circulação que fez Severiano Mário Porto pelo interior da Amazônia, especialmente quando do acompanhamento de encargos públicos, o aproximou também das implicações da vastidão territorial e dos meios de transporte. Além das questões mais objetivas relativas aos meios e recursos, a "arquitetura amazônica" como ele 
próprio atestou, "não foi um processo deliberado, mas um comportamento natural", a partir da observação do "pessoal nativo - os seringueiros, para mim gigantes", com quem teria aprendido sobre um "fazer regional" (PROJETO N.83, janeiro de 1986).

A notabilidade do processo de transformação do espaço amazônico, exposto em suas mais profundas contradições, foi visibilizada iconicamente pela projeção do projeto do Centro de Proteção Ambiental de Balbina - CPA em Balbina - AM, sobre o que representou como encargo público, pelas questões relativas ao programa e pelas respostas projetuais de Severiano Mário Porto. Em um momento de esgotamento da política nacional desenvolvimentista, no qual a Amazônia é constituída como "vetor tecnoecológico na dinâmica regional", uma "fronteira socioambiental" (BECKER, 2009), o projeto adensou algumas importantes contradições que acompanharam a controversa modernização regional, motivo pelo qual será feita uma abordagem particular a respeito deste projeto no próximo capítulo. A construção do Centro de Proteção Ambiental de Balbina revelou o virtuosismo de Severiano Mário Porto, o aperfeiçoamento de seu trabalho sob a temática que o pautou quando em relação à paisagem regional, a absorção dos saberes locais e da mão de obra artesanal no espaço interiorizado na Amazônia. Por outro lado, a fragilidade de seu caráter ecológico em afirmação à preservação ambiental na Amazônia. 


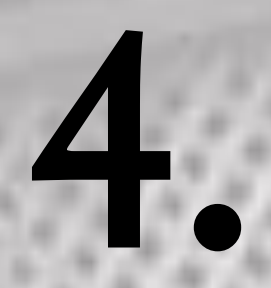

Narrativas de Paisagem, argumentos de Projeto 
Neste capítulo são apresentados projetos que transformaram o espaço na Amazônia brasileira, contatando pautas desenroladas ao longo dos três períodos propostos no capítulo anterior a este, delineados pela alternação dos atributos localizados nas fontes no recorte da tese, entre 1934 e 1989, conferidos à arquitetura na Amazônia e ao território. Na parte final desse intervalo, 1955 a 1989, tais pautas situaram a transformação do espaço amazônico e adensaram a Amazônia em condição de paisagem, como pontes à atividade projetual de arquitetos na região. Em continuidade, os projetos selecionados sintetizam um curso narrativo cujo conteúdo foi capturado das publicaçóes. Nelas, a paisagem foi recurso à leitura do território, precedente ao projeto, seu conteúdo discursivo e de valoração da obra de arquitetura, como componente estruturante de sua ideação. Localizada entre a depuração de uma longa construção cultural e a atitude propositiva de arquitetos, foi sustentação à elaboração de novas paisagens, que iam sendo alteradas pelas vias do projeto de arquitetura a partir de diferentes posturas projetuais. Assim, os arquitetos ao conceberem a obra de arquitetura junto à paisagem, como depuração e prospecção, ressignificaram o território o reordenando materialmente, com a implantação de artefatos pioneiros. Estes princípios justificam a seleção dos projetos sobre os quais foram elaborados os comentários deste capítulo. Os projetos selecionados foram relevados no conjunto das publicaçóes e sua escolha decorreu justamente do fato de que amparam a presente análise, produto da costura dos textos das fontes. Eles demarcaram cortes significativos da transformação do espaço regional, junto a significados que iam sendo proferidos sobre o próprio território. O primeiro dos projetos levanta a questão das moradias como componentes da paisagem tipificada da Amazônia, sob a evocação da hinterlândia, do mundo rural. O segundo, a arquitetura de Oswaldo Bratke para as duas Vilas da ICOMI no Amapá, é representativo de uma paisagem civilizatória, na conjuntura do início do processo de exploração mineral da Amazônia. O arquiteto levou a cabo um projeto racional às cidades empresa que projetou, adotando soluçóes construtivas que iriam influenciar geraçóes de arquitetos, em especial quando atuantes na Amazônia. Seu projeto foi absorvido pelo campo discursivo das elites intelectuais e de estruturas de governo regionais, mediado pela forma como sua materialidade adequou-se à modernização conservadora estatal e à uma modalidade construtiva difundida como de cunho regional. O terceiro projeto, situado em uma área de expansão urbana, o Distrito Industrial em Manaus-AM, foi a sede da Superintendência da Zona Franca na capital. O edifício demarcou a fase de início da constituição da paisagem do novo setor industrial deslocado do centro urbano na década de 1970 e representativo da presença do Estado na cidade. A lógica expansiva dos projetos que, como este, a exemplo do campus da Universidade do Amazonas, foram espalhados em sítios de prevalência natural, foi tanto possibilitada por terem sido implantados em terras públicas, quanto em razão da inexistência de precedência significativa que os contivesse em estrutura urbana prévia. Essas arquiteturas foram artifícios à estruturação do próprio tecido urbano. O quarto projeto, o Centro de Proteção Ambiental de Balbina-AM compôs o espaço transformado pela implantação de uma Usina Hidrelétrica, Balbina-AM, um desastre ambiental. A paisagem memorializada decorreu da presença do artefato projetado por Severiano Porto, que serviria ao monitoramento ambiental após a instalação da usina. Ele foi a própria evidenciação do desastre natural ali transcorrido. Oúltimo projeto, de Milton Monte para o Interpass em Mosqueiro - PA é revelador da paisagem identitária, fruto de um processo de experimentação e vivência do engenheiro e arquiteto Milton Monte na Amazônia. A vida do arquiteto e sua obra construíram em conjunto o significado da sua produção, absorvida pela crítica em associação à regionalidade. A paisagem identitária foi fruto da experiência do amazônida Milton Monte, no seu trânsito pelo espaço amazônico e junto às suas obras. Aos significados afetivos, posto que enraizados no próprio arquiteto, foram acrescidos os intentos de construção de uma forma arquitetônica expressiva e demarcatória da Amazônia, o que encerra tanto o capítulo quanto o período abordado na tese.

Imagem: Projeto de Milton Monte para o Interpass Clube. Fonte: PROJETO n.156, 1992. 


\subsection{O projeto como um fato de paisagem na Amazônia}

No âmbito da Arquitetura e Urbanismo, a paisagem na Amazônia é uma resultante material, manejada em condições específicas e esporádicas, pela implantação de projetos que foram a cada tempo, reestruturadores do espaço e do território regional, em contextos de distintas urbanidades. No entanto, a Amazônia, como uma construção cultural que tem sido reelaborada ao longo da história, foi forjada junto à formulações de uma identidade regional, que acarretou quando levada à prática do projeto, uma constante tensão: sem a objetivação de uma tradição autêntica, homogênea e particular, a prática evocou a memória, revivificou determinados modos de vida, saberes e fazeres relacionados ao ambiente amazônico e ao imaginário.

Determinados elementos da paisagem cultural foram narrados dispersamente em textos publicados nas revistas desde a década de 1930, tendo sido delineados mais precisamente a partir das revistas do $I A B$ na década de 1960. Algumas de suas edições notabilizaram a Amazônia e a modernização regional em interpretações modernas atinentes à complementaridade entre o vernáculo e a modernidade, entre a memória e a modernização. Elas emergiram do fluxo de transformação do território e das expectativas diante da dissolução de estruturas social e culturalmente assentadas. Habitat e Módulo, por sua vez, desde a década de 1950, miraram os saberes desenvolvidos junto ao ambiente amazônico, ao veicularem a experiência primitiva e universal dada entre natureza e modos de vida, bastante efatizados em alguns de seus textos. Nas décadas seguintes, a paisagem foi narrada, subjascente aos projetos de arquitetura. Associados à Amazônia, à paisagem narrada da região, os projetos foram veiculados a contextos rurais, não urbanizados ou em áreas de recente expansão urbana. A Amazônia foi igualmente referenciada no interior e em urbanidades afinadas ao meio natural, ao modo de vida fixo e perene, quando em estado de expectativa pela modernização.

Um exemplo deste agenciamento entre memória e modernidade, foi o projeto de autoria de Francisco Bolonha do Banco de Crédito da Amazônia para Belém-PA. Ele seria “audacioso e inovador”, desenvolvido sob a referência de Mies Van Der Rhoe. No mesmo edifício, um mural de Portinari intitulado $O$ seringal e a azulejaria de Osvaldo Goeldi revelariam uma síntese moderna das artes, a presença de uma estética atrelada à ideia de brasilidade, mas sobretudo o passado regional memorializado (HABITAT N.55, 1959, p. 
2-4). No agenciamento moderno da memória, o passado foi evocado, ainda que ausente na obra que seria implantada em um dos dois “pólo de civilização” na Amazônia, Belém-PA (ABA N.1, 1967-68, p. 20-26), como exemplo. Assim como projetos implantados em áreas urbanizadas das duas capitais mais referenciadas nas revistas, Manaus-AM e Belém-PA, em geral, os grandes projetos sob incentivo estatal não foram referenciados numa ideia de Amazônia como paisagem.

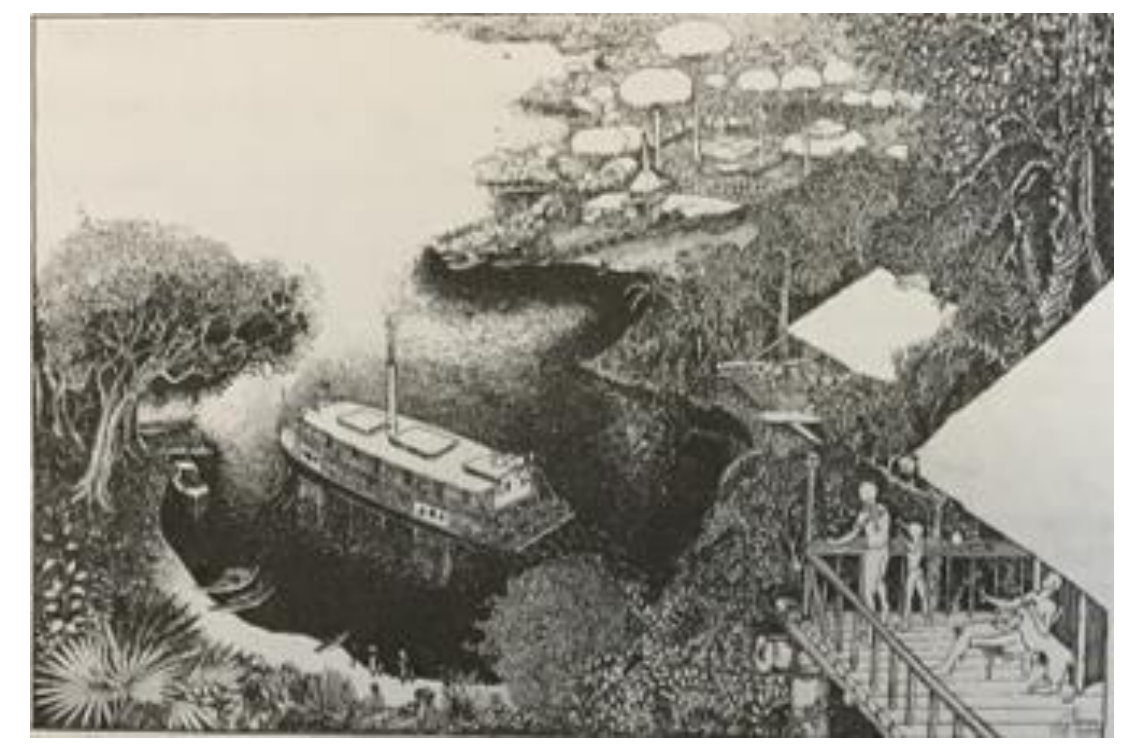

Figura 66 - Realidade amazônica. Fonte: AU n.10, 1987, p. 3.

Diferentemente, esta discussão da Amazônia como paisagem cabe aos projetos desenvolvidos em frentes de expansão na Amazônia e está, mesmo no presente, relacionada a deteminados programas e escalas que abarcam reflexões acerca da relação da pertinência do artifício à natureza. Esta postura ética condiciona a paisagem à uma aspiração, desde a qual se quer responder sobre a intervenção ideal. Sendo a Amazônia um espaço de possibilidade de expansão, guardadas os limites desta síntese, nas novas frentes de ocupação, qual intervenção na paisagem é perfeitamente ajustada à Amazônia? Se as perdas com a modernização são postas em causa, e neste caso os movimentos sociais e ambientalistas desde finais dos anos de 1960 acenaram para a necessidade de atualização dos paradigmas da modernização, a Amazônia paisagem vem à tona, é revelada em sua complexidade social, cultural, ambiental, presentificada para além do julgo estritamente simbólico. O projeto então, se aproxima do temor diante da inevitável transformação do meio natural, referenciado na Amazônia. 
Esta abordagem guarda certo paralelo à leitura que realiza Abílio Guerra no tocante à arquitetura no Brasil e a relação entre os significados conferidos à natureza pelos seus agentes mais diretos, bem como por intelectuais atuantes na formulação da modernização das artes nacionais. O autor sintetizou na exposição "viver na floresta" 211 uma análise partida desses termos, sendo que seu texto e a própria exposição, compuseram o argumento de que na arquitetura brasileira, a natureza interpretada por Lúcio Costa como "floresta tropical" foi componente da elaboração de uma cultura nacional construtiva migrada a múltiplos aportes discursivos, especialmente do cultural, ao ambiental e ao ecológico. Em sua interpretação, a adaptação de "princípios modernos europeus às condições civilizacionais, culturais e climáticas locais" consistiu em um "verdadeiro projeto de estabelecimento do homem brasileiro no território tropical", numa genealogia que tomou como ponto de partida, o projeto de Lúcio Costa para a Vila Monlevade ${ }^{212}$ (GUERRA, 2010). Neste caso, a paisagem é considerada como uma elaboração cultural pelas vias do projeto, a qual é levada à materialidade, que passa desde si, a representar e construir uma nova concepção do lugar.

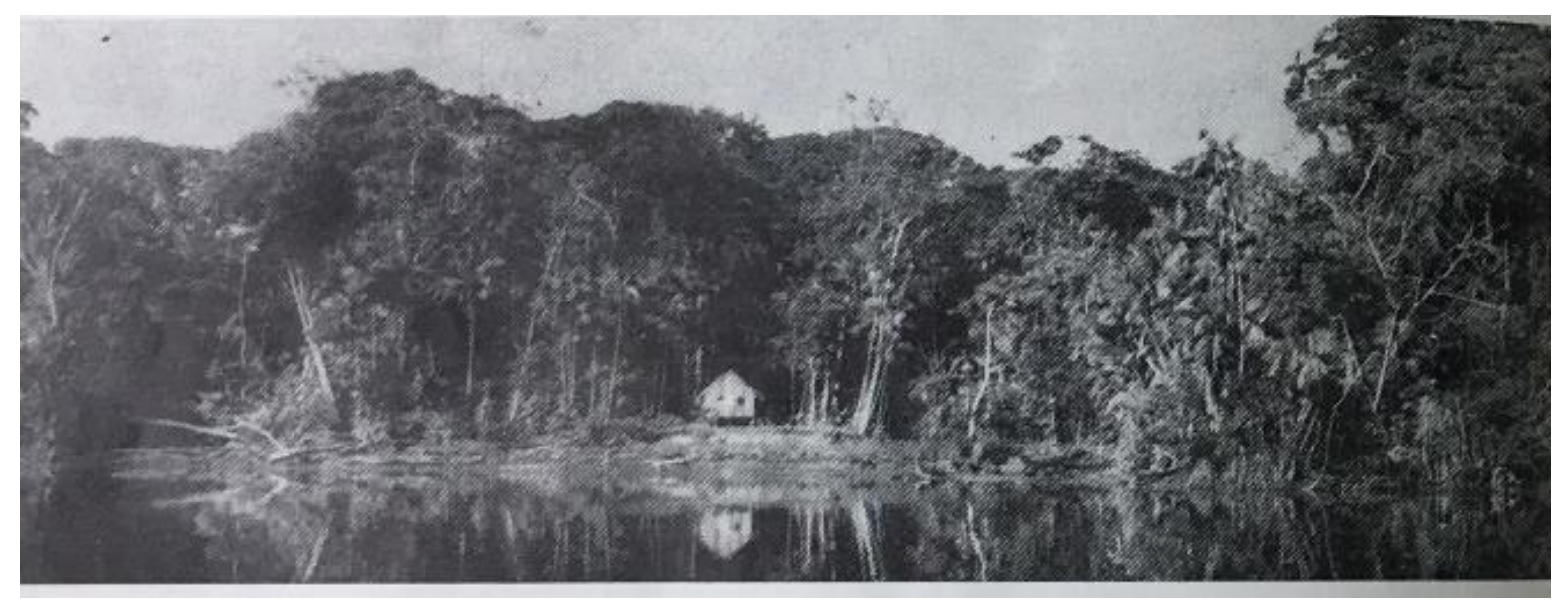

Figura 67- Uma síntese da paisagem, em ilustração do artigo de Luiz de Miranda Corrêa, "Problemas habitacionais no trópico brasileiro". Fonte: ARQUITETURA-IAB n.30, 1964, p. 32.

\footnotetext{
${ }^{211}$ As obras de Severiano Mário Porto que foram apresentadas na exposição, o Campus da Universidade do Amazonas, de 1973, o condomínio Praia da Lua, de 1979, o Centro de Proteção Ambiental de Balbina, de 1988, foram associados a um "escopo da arquitetura ecológica" (GUERRA, 2010, p. 31).

${ }^{212} \mathrm{O}$ projeto não construído de Lúcio Costa para a Vila Monlevade, foi um projeto destinado a um concurso para a Companhia Siderúrgica Belgo-Mineira, no qual o arquiteto elabora tanto o conjunto edificado no plano da vila quanto formula um modo de vida que ali seria acomodado e desenvolve discursivamente o projeto.
} 
Neste sentido, a paisagem tem antecedido e sucedido o ato projetual quando tematizada a Amazônia, mesmo que a partir de distintas posturas projetuais, como as apresentadas neste último capítulo. Tem antecedido, quando o projeto é dado em referência à depuração de uma geografia simbólica, produto da construção histórica da Amazônia junto a determinados elementos de significação e síntese, sejam naturais, humanos, sociais. Tem sucedido, quando extensivamente à prospecção desenvolvida pela formulação projetual, tanto contatanto tais premissas memoriais, quanto aspirando abarcar simbolicamente o território em síntese. São obtidas deste processo, outras camadas constitutivas da paisagem: uma camada equivalente à paisagem como construção material, posto que o projeto é ato pioneiro de arquitetura no sítio de inscrição, afetado pelas reflexões atualizadas da disciplina; outra, diz respeito à construção subjetiva que mobiliza a Amazônia como memória e a seus referentes, neste caso, objetificados na hinterlândia; outra camada, uma construção discursiva, decorre dos significados e razões do projeto em síntese argumentativa e interessada. Uma proposo material e também discursiva de suas ideações.

Os textos, além de tratarem muito diretamente dos eventos relativos à arquitetura, fizeram circular representações sobre a Amazônia, quando a ela foram relacionados os encargos dos projetos, as soluções projetuais e suas bases argumentativas, cruzadas pelas ideias de uma Amazônia como paisagem. Esta categoria, revigorada mais fortemente pelos estudos geográficos a partir dos anos de 1970, pareceu muito apropriada à tese, pela limitação em significar uma dada totalidade espacial e abarcar uma completude, neste caso, um território geografado. Também, pela paisagem absorver significados atribuídos ao campo do simbólico e da subjetivação individual. Noutro curso, a paisagem tem sido entrelaçada muito intimamente à cultura disciplinar da arquitetura no Brasil, especialmente quando ela foi elaborada a partir das alegações da possibilidade de uma cultura construtiva em comum, nacional. Extensivamente, o território amazônico, compreendido como paisagem, foi absorvido não apenas como substância à concepção da arquitetura, mas como meio de unificação e homogenização de uma região culturalmente complexa, sob a pretensa modernização regional.

A paisagem é tomada como uma categoria que ativa reflexões sobre a condição física do território, sua duração e transitoriedade e às representações e elaborações simbólicas. 
Ela expõe a dinâmica de produção e representação do espaço e nela opera muito profundamente a cultura. Em contraposição à compreensão da paisagem unicamente como “manifestação física da formação socioeconômica”, explicada pelos fenômenos conjunturais imanentes da modernidade, da economia e das formas sociais de poder, a geografia francesa da década de 1970, retomou a paisagem em sua dimensão cultural, conforme explica Leo Name (2010). À paisagem foram acrescidas novas interpretações, passando de uma resultante das "marcas” humanas sobre o espaço, o que até então vigorava na geografia, ao “valor simbólico, artístico ou moral” incidente sobre o espaço. Sob o julgo de uma "pósmodernidade”, à paisagem foram acrescidos outros significados entre os anos de 1980 e 1990, no movimento da "Nova Geografia Cultural", tornada uma "maneira de ver o mundo" ou um "produto permanentemente inacabado", incompleto, ou uma "maneira de se produzir, manipular e contemplar o espaço", admitida a complementaridade da representação e da realidade, nas práticas sociais. A própria paisagem, considerada no âmbito da cultura como um produto da ação humana foi convertida em "um texto, dada sua condição de espaço que é ao mesmo tempo produzido, contemplado, interpretado e muitas vezes consumido, necessariamente precisando da interação com um ou mais sujeitos individuais ou coletivos para sua existência” (NAME, 2010, p. 178).

A paisagem como uma elaboração, portanto, é fruto da apropriação de certos referentes do contexto o qual, a partir dela, é pretendido concebê-la, reelaborá-la. Por outro lado, uma leitura centrada na paisagem é possível também a partir de distintos recortes de observação: políticos, culturais, físicos, sociais, quando voltados a propósitos de compreensão de uma dada unidade física e espacial, eminentemente cultural. No âmbito da prática projetual, esta elaboração comportou uma construção da ordem material e do artifício, junto aos referenciais disciplinares, mas também da captura dos referentes do contexto amazônico, elaborados e reelaborados no tempo. Os atributos textualmente elaborados sobre a Amazônia, nos escritos e imagens de arquitetura, também influíram a construção de uma paisagem ideada.

A cultura arquitetônica, considerada desde seus componentes teórico práticos, adensou os significados do que fosse a paisagem amazônica, em reelaborações materiais e simbólicas. Textos e projetos, no desenvolvimento da arquitetura na Amazônia, cumpriram 
papeis interdependentes, em mútua influência e fundamentação, em atendimento à prospecção da paisagem. O adensamento de representações acerca da Amazônia como paisagem foi concomitante à concretização de determinados artefatos tornados icônicos, constituindo um processo de mão dupla, pelas vias textuais e em relação à prática de projeto. A própria arquitetura é portanto tornada um fato de paisagem, num paralelo à arquitetura como um "fato urbano" de Aldo Rossi, para quem a obra de arquitetura constitui prática de criação, no trânsito entre a memória individual e coletiva, em seu caso, para a redefinição da cidade e da transformação de sua imagem. O artefato é compreendido como componente de partida à ordenação e significação do território, e desde onde a própria paisagem é considerada um “artefato cultural” (NESBITT, 2006, p. 20).

As interpretações, portanto, devem articular os textos aos projetos, ressignificando a ambos em nova narrativa. Aqui é defendida a hipótese de que para a arquitetura na Amazônia, na conjuntura a qual se tratada na tese, ou seja, no período de transformação mais radical do território e dos espaços urbanos amazônicos, as narrativas de paisagem foram base aos argumentos de projeto. A Amazônia como paisagem foi reformulada nos escritos e junto à implantação de arquiteturas que lhe materializaram novos e ressignificaram velhos sentidos, moldando novos lugares.

Especialmente em frentes de expansão, arquitetos elaboraram artefatos pioneiros para os espaços que estavam a reordenar. Os projetos aqui apresentados, são justamente, demarcatórios de estágios da transformação do espaço na Amazônia brasileira e contataram pautas desenroladas ao longo dos três períodos propostos no capítulo anterior a este, delineados pela alternação dos atributos conferidos à arquitetura na Amazônia e ao próprio território, entre 1934 e 1989. Na segunda metade deste intervalo, de 1951 a 1989, as pautas adensaram a Amazônia em condição de paisagem, e conforme foi intensificada a atividade profissional na região, a Amazônia foi mais reportada nas revistas.

Além de pertencerem aos estágios distintos da transformação do espaço amazônico, em continuidade, os projetos selecionados demarcam estágios de um fluxo também narrativo, cujo conteúdo foi capturado das publicações. Nelas, a paisagem foi recurso à leitura do território, precedente ao projeto, conteúdo discursivo e meio de valoração da obra de arquitetura, como componente estruturante de sua ideação. Localizada entre a depuração de uma longa construção cultural e a atitude propositiva de arquitetos, foi 
sustentação à elaboração de novas paisagens, recém alteradas pelo projeto de arquitetura. Assim, os arquitetos ao conceberem a obra de arquitetura junto à paisagem, como depuração e prospecção, ressignificaram o próprio território. Os projetos selecionados foram relevados no conjunto das publicações e amparam a presente análise, junto aos sentidos que iam sendo produzidos sobre e no próprio território.

O primeiro dos projetos põe em relevo a questão das habitações amazônicas, em sua condicional presença nas paisagens culturais tipificadas, especialmente de beiras ou clareiras. Estas moradias guardam relação direta com o projeto de Severiano Mário Porto para a casa de Robert Schuster, na qual o arquiteto transpôs ao projeto um ideal romantizado de modo de vida dado junto ao meio eminentemente natural, é a casa icônica. O segundo, o projeto de Oswaldo Bratke para as arquiteturas das Vilas Serra do Navio e Amazonas, no Amapá, é representativo de uma paisagem civilizatória, na conjuntura do processo inicial de intensificação da exploração mineral da Amazônia. O arquiteto levou a cabo um projeto racionalizado às cidades empresa que projetou, adotando soluções construtivas que iriam influenciar gerações de arquitetos, não unicamente os atuantes na Amazônia. A materialidade de sua proposta foi absorvida no campo discursivo das elites intelectuais e governamentais regionais, como em adequação ao seu projeto desenvolvimentista, pelo que seria um modelo de intervenção em perfeito ajustamento à região.

O terceiro projeto, situado em uma área de expansão de Manaus-AM quando recém industrializada, o Distrito Industrial da cidade, foi o edifício para a sede da Superintendência da Zona Franca, inaugural da paisagem do novo setor industrial deslocado do centro urbano da cidade na década de 1970 e representativo da presença do Estado na capital. A lógica expansiva dos projetos que, como este, a exemplo do campus da Universidade do Amazonas, foram dispersos em sítios de prevalência natural, foi tanto possibilitada pelo fato de serem implantados em terras públicas, quanto pela inexistência de precedência urbana significativa que os contivesse em malha regular. Essas arquiteturas foram artifícios da estruturação do próprio território.

O quarto projeto, do Centro de Proteção Ambiental de Balbina-AM, compôs uma paisagem memorializada. Construído como suporte à realização da atividade 
monitoramento ambiental da Usina Hidrelétrica recém instalada, o edifício foi a própria evidenciação do desastre natural ali transcorrido, para o qual foi uma compensação contraditória e desproporcional. Ao fim, o projeto de Milton Monte para o clube Interpass, em Mosqueiro - PA, revela uma paisagem identitária, fruto de um processo de experimentação e vivência do engenheiro e arquiteto Milton Monte na Amazônia. A vida do arquiteto e sua obra construíram em conjunto o significado da sua produção quando associada à sua proposição de regionalidade, a partir de uma intenção eminentemente estética.

Os escritos dos quais foram abstraídas as interpretações que seguem pertencem todavia ao conjunto das fontes documentais já apresentadas, não baseadas necessariamente nas falas autorais, mas decodificadas pelo entrelaçamento a outros textos, sendo que, a esta altura, cabe articulá-las e organizá-las sem a linearidade implicada pela sequencialidade do curso dos acontecimentos com que foram apresentadas até então. Os saltos temporais, deste modo, são intencionais, e mais do que conectar as experiências de projeto apresentada a seguir, é pretendido que sejam valoradas em recortes mais restritos, tanto de observação, quanto em relação às questões que destes temas e obras puderam ser abstraídas. Como consequência, no conjunto, são apresentadas para esse arremate do texto da tese, uma nova narrativa, revigorando do tempo da produção dos artefatos selecionados, dentro do limite apresentado pelas fontes documentais, as circunstâncias com que foram realizados, ainda que sob os olhos do presente.

A Amazônia, como paisagem prospectiva, foi questão frequentemente tematizada nos projetos de arquitetura, prevalentente publicados nas revistas até o fim dos anos de 1980, pelas quais adquiriram projeção e visibilidade. Em um ambiente criticamente interessado nas novas experiências que abrissem o campo à multiplicidade de vertentes projetuais que vinham sendo delineadas desde os anos de 1950 no país, a Amazônia, e a arquitetura ali desenvolvida, foram oportunidade ao preenchimento de uma lacuna disciplinar. Em conjuntura, um fluxo de transformação do espaço amazônico estava em curso a partir da atividade interventora estatal desde a década de 1960. Ele foi elaborado junto à arquitetura, pela intelectualidade regional que se viu diante de um quadro de possibilidade de ação, participando ativamente das revistas do Instituto de Arquitetos do Brasil. 
Estes intelectuais acresceram discursivamente aos sentidos do que seria uma arquitetura prospectada às áreas de expansão ou fora dos centros urbanos, alcançando distintas designações e atributos. Dentre estes, "ecológica”, "tropical” e como afirmou Hugo Segawa, “a arquitetura amazônica”, teria portanto emergido "mais por uma percepção de contexto que por uma vontade de tipificar alguma manifestação arquitetônica” (SEGAWA, 1998, p. 193), se referindo à negativa dos arquitetos atuantes na Amazônia na adoção de posturas engajadas ao regionalismo crítico. Noutro sentido interpretativo, ainda que desligados de uma premissa de autenticidade requerida pelo posicoinamento afeito a um regionalismo crítico, ou da adoção de posturas políticas de resistência à uma pretensa arquitetura global, é necessário a consideração das intenções adaptativas da arquitetura especialmente quando transpostas ao desenvolvimento de uma estética significada junto à Amazônia paisagem. Deste modo, as leituras apresentadas a seguir, feitas a partir dos textos consultados e em relação às obras, consideram em específico, sentidos atribuídos à paisagem desde intervenções tornadas referenciais ao campo da arquitetura no Brasil, onde escritos, imagens e ideias formularam, a cada momento, distintas camadas de leitura do espaço amazônico.

\subsection{A paisagem tipificada pela habitação}

Para Josep Maria Montaner, na América Latina, onde "habitar é uma atividade de construção social”, dadas as demandas urgentes e ampliadas por habitação, a casa é como um "microcosmo", mesmo as simples, quando é convertida em "pequenos mundos autônomos”. Ao carcaterizar esta imagem, ainda que reconheça o autor ser bastante geral, ele a elabora para colocar a questão da casa como objeto à crítica de arquitetura latinoamericana. Todavia, ao ser considerada a moradia amazônica nas representações nos textos de arquitetura, há algo que de certo modo se relaciona ao que Montaner nomeia da "capacidade especial de criar mundos" de cada latino-americano, em "culturas que se abrem à paisagem”, especialmente. ${ }^{213}$ Essa especialidade é ilustrada pelos “exemplos de casas como microcosmos, integradas ao entorno"que o autor menciona. As casas publicadas da

${ }^{213}$ Os exemplos de arquitetos no Brasil que Montaner se utilizou para tratar da moradia foram Oscar Niemeyer, Lina Bo Bardi, Lúcio Costa, Paulo Mendes da Rocha. 
Amazônia nas revistas, e os textos as revelam de certo modo desde esses dois parâmetros, como microcosmo, como cultura junto à paisagem.

Estes sentidos apontados por Montaner podem ser deslocados à Amazônia paisagem, sob a perspectiva de que determinados modos de vida arraigados ao ambiente frutificados da experiência com que o espaço da Amazônia tem sido experimentado, transcorreram em dependência direta ao meio. O modo de vida, tomado em geral, e o exterior, em paisagem, neste caso, comporta o espaço ao qual se abre a casa, estão na Amazônia, intimamente relacionados. O delineamento de um modo de vida e a inscrição da casa na paisagem amazônica fornecem pelos textos, à casa, um significado completo do morar amazônico. A integração ao entorno, frente a possibilidades múltiplas de escolha, mas sobretudo como ato limitado pelos meios e pela ação quase natural de erguer e habitar a casa, do homem amazônico "primitivo”, "nativo”, “caboclo”, em múltiplas designações, elabora seu microcosmo, convertido em modo de vida padrão nas interpretações que tipificam os modos de morar. A casas tipicamente amazônicas, como representado nas revistas de arquitetura, são perfeitamente ajustadas ao modo de vida referenciado no mundo rural e em categorias segundo as quais são inseridas na condicional geografia física, de áreas alagáveis de várzea a áreas de terra firme, sob o traço comum da construção em madeira coberta de palha, absorvida pela natureza. Luiz de Miranda Corrêa as expôs em 1963, em homogenização, revelando principalmente a ideia de haver uma determinada forma de habitar a Amazônia, e esta forma advinha do sentido mais primitivo que se pudesse identificar, na materialidade exteriorizada das residências registradas nas fotografias que publicou junto a seu artigo, em 1963, A Arquitetura na Amazônia [figura 68].

Ainda que enunciada em determinadas particularidades, especialmente pela condição física do sítio de sua implantação, a casa foi apresentada diversamente nas publicações, em especial, como "tapiri”, "palafita”, "flutuante”. Sua materialidade e a forma com que foi representada, qualificaram a extensividade que as habitações tipificadas estabeleciam junto ao meio, pela utilização estrita de recursos disponíveis, especialmente a madeira. Em razão da abundância do material, do ciclo de perecimento, reposição dos materiais em coberturas e revestimentos e retorno ao meio, a casa seria um objeto continuamente renovado pela substituição do material. Mas esses tipos, deslocados a contextos urbanos, foram percebidas como em desconformidade. Mais afeitas ao ambiente rural, as casas da Amazônia como 
paisagem, quando implantadas nas grandes cidades, confrontam os códigos urbanos, sendo associadas à pobreza, inadequação e a comportamentos inapropriados e distúrbios morais. ${ }^{214}$
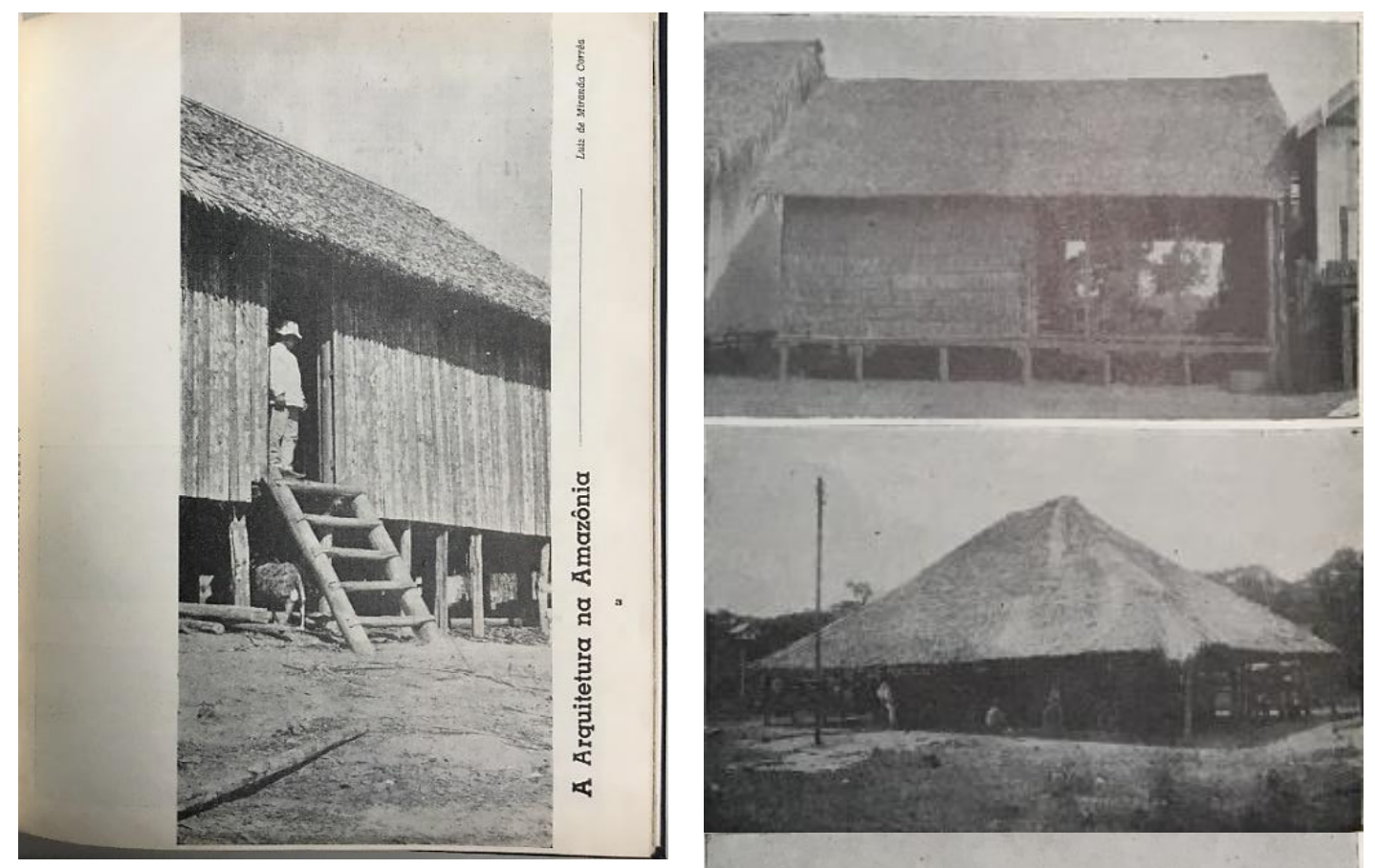

Figura 68 - Imagens de moradias típicas presentes no artigo de Luiz de Miranda Corrêa. Fonte: Arquitetura-IAB n.17, 1963, p. 3-5.

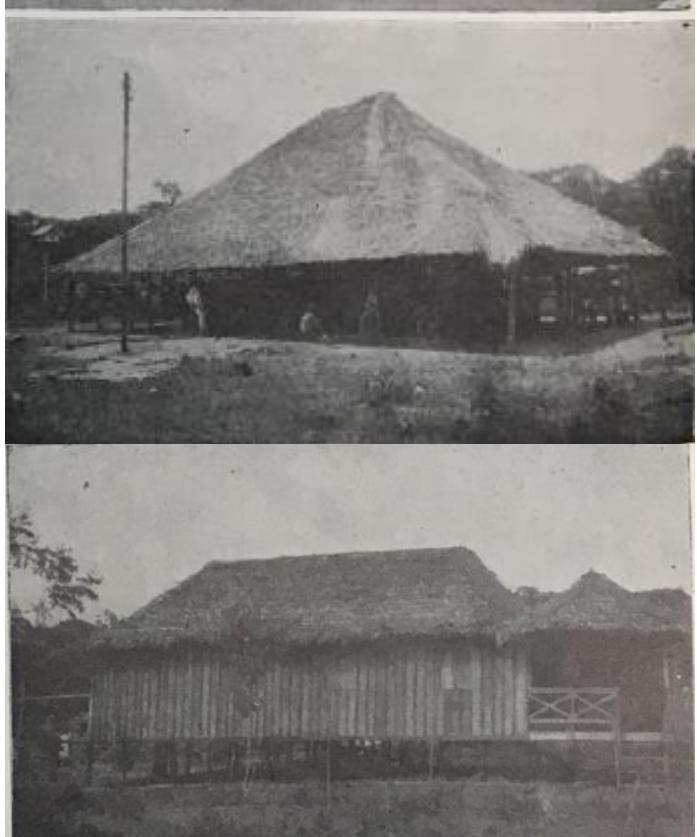

Thiago de Mello interpretou as habitações situadas em Manaus - AM, opondo um tipo enraizado de habitação a outro, dos conjuntos habitacionais, projetados pelos arquitetos contratados a partir da década de 1960. Os novos conjuntos habitacionais causavam estranhamento ao memorialista, no desenho da paisagem urbana da capital. Porém, de suas memórias a respeito da cidade, resgatou uma arquitetura extensiva à

${ }^{214} \mathrm{O}$ caso da dissolução da cidade flutuante em Manaus é particular, no qual a desqualificação da casa e dos moradores foi utilizado como discurso crítico, inclusive moral, como justificativa para sua remoção, diferentemente de quando à casa é conferido um sentido mais etéreo, romântico, cultural (HEIMBECKER, 2014). 
Amazônia, mesmo quando deslocada à cidade. A respeito da "Arquitetura de Manaus", assim se expressou o poeta (MELLO, 1983, p. 77-79):

Mas coisa que Manaus pode realmente se orgulhar, como obra nascida do talento e bom-saber do seu povo, é de sua arquitetura popular. Nos bairros pobres, na periferia da cidade que se espalha, nos barracos de beira de igarapé, é que estão as casas autenticamente amazonenses, feitas para atender a exigências estéticas intuitivas, mas também para que sirvam da melhor maneira às suas funções de moradia urbana, de gente que tem um determinado jeito de viver ainda que mal versados em matéria teórica de ecologia. São casas simples, quase singelas. Na maioria de madeira, chão de itaúba ou sucupira. (...) Os nossos sobradinhos de madeira são um primor de criação arquitetônica (...). É preciso reparar na delicadeza com que descem as linhas das meias ou das duas águas de seus telhados e no esmero da junção das tábuas de suas paredes (Todos sabemos que são um horror, em matéria de arquitetura, as casas que compõem os "conjuntos" habitacionais de agora).

$\mathrm{Na}$ Arquitetura e Urbanismo, a valorização do saber popular, e "homem comum" foi uma pauta emergida do período após os anos de 1950, relacionada à valorização das realidades individuais, imperfeitas, subjetivas. No pós guerra, o existencialismo teria influído na busca pela "diversidade cultural, contextualismo, preexistências ambientais, tradição, linguagem comunicativa, arquitetura anônima, etc”, como contraponto à idealização e universalização dos usuários da arquitetura na sociedade produtiva, segundo as premissas originárias de um movimento moderno europeu (MONTANER, 2001, p. 18). As revistas traduziriam as reflexões renovadas do campo disciplinar, centrando na arte e arquitetura anônimas na Amazônia. A Habitat, mais frequentemente, estabeleceu pontes diretas entre o erudito e o popular, sobretudo, com o reposicionamento da produção sem autor, a partir da crítica e da utilização de seus próprios instrumentos de legitimação.

Em algumas revistas é possível identificar a elaboração de um panorama da história da habitação na Amazônia, como um processo evolutivo e contínuo partido de uma origem imprecisa. A ideia de aperfeiçoamento da habitação percorreu as publicações, como norteamento das interpretações dessa arquitetura e aventamento de novas possibilidades para o tema. Ao serem inscritas em um tempo histórico superado ou quando objetificadas como modelares, síntese de um conhecimento desenvolvido ao longo do tempo e adensado no artefato da casa amazônica, a habitação é delineada como um pressuposto a novos projetos. Estes modelos, os mais adaptados, posto que resultantes das respostas 
naturalizadas às condições impostas pelo meio, seriam a base para o desenvolvimento da habitação regional e ao seu aperfeiçoamento em continuidade.

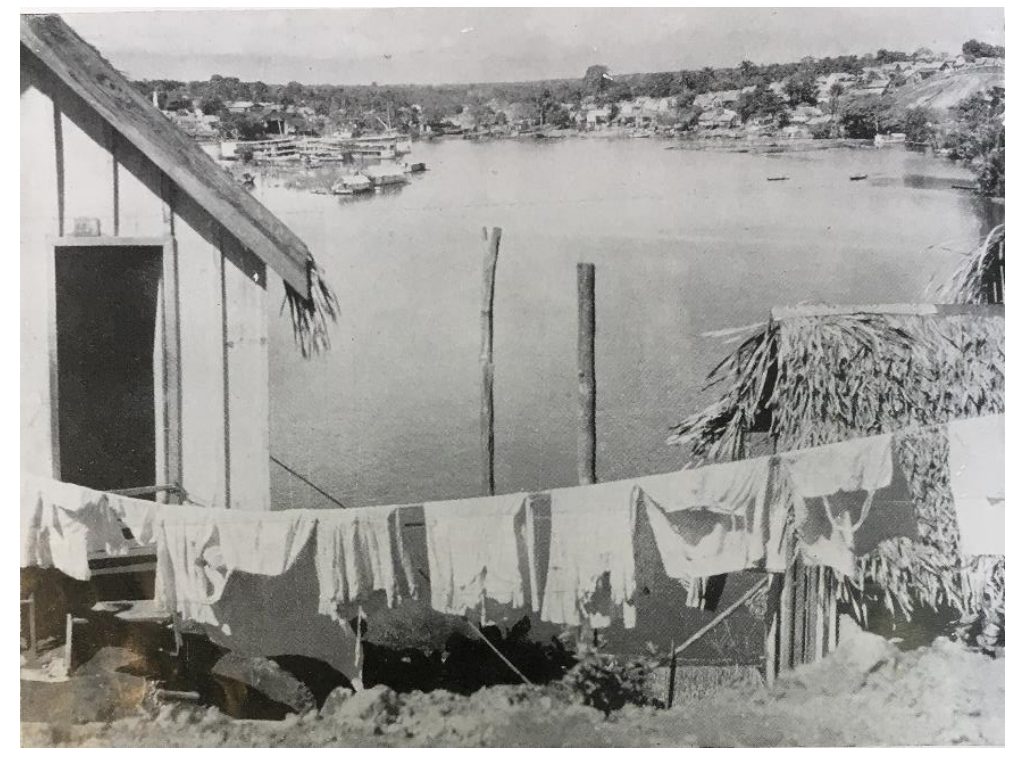

Figura 69 - Exemplo de uma arquitetura "extremamente funcional e muito estética" no artigo

“Amazônas: o povo arquiteto". Fonte: HABITAT n.1, 1951, p.54; 68-71.

Para Luiz de Miranda Corrêa, os habitantes da casa e ela própria, foram elaborados desde uma perspectiva de linearidade histórica evolutiva. Para ele, a superação da condição primitiva da casa só havia ocorrido pela presença do colonizador luso e de seu conhecimento junto àquele ambiente. Avaliou que não haveria até o momento de sua escrita, solução técnica e estética atualizada para a casa na Amazônia, uma questão a seu ver, que deveria ser uma busca de ajustamento construtivo ao meio, todavia, modernizado (ARQUITETURA N.22, abril de 1964, p. 12-45):

O selvagem em seu estado primitivo, tal como foi encontrado pelos descobridores e primeiros colonizadores, se achava em plena época neolítica, no máximo na mesolítica, utilizando palafitas ou choças de barro cobertas de fôlhas ou ramos de palmeira, sem maiores preocupações que o abrigo da chuva, das inundações, dos animais da floresta. Até hoje as populações mais atrasadas ou de menor poder aquisitivo, continuam a usar o mesmo tipo de moradia. A própria madeira encontrada em grande quantidade só foi empregada regularmente quando os europeus se estabeleceram no vale. A moradia amazônica, a nosso ver, deve ser simples, leve, refratária ao calor e resistente à umidade. São problemas técnicos e estéticos aguardando solução. As construções luso-brasileiras se não eram levez pelo menos atendiam às condições de simplicidade, resistência ao calor e à umidade indicada pela região. Não é demais repetir que a arquitetura ibérica já era, na Europa, a mais tropical. A portuguêsa ainda se encontrava mais predisposta a se prolongar no trópico americano pelos 
contactos africanos e asiáticos. Nas casas dos engenheiros e fazendas do Pará, como nas casas grandes do nordeste, é visível a adaptação dos traços às necessidades da vida e do clima.

A revista Habitat, desde seus primeiros números, já havia dedicado espaço à habitação na Amazônia, sob outros aportes, advindos dos estudos culturais, da etnologia e etnografia. Neste caso, a revista veiculava os tipos habitacionais equiparando sua atualidade material e os saberes envolvidos em sua produção, aos desenrolados em contextos urbanizados, como forma valorativa dos saberes populares.

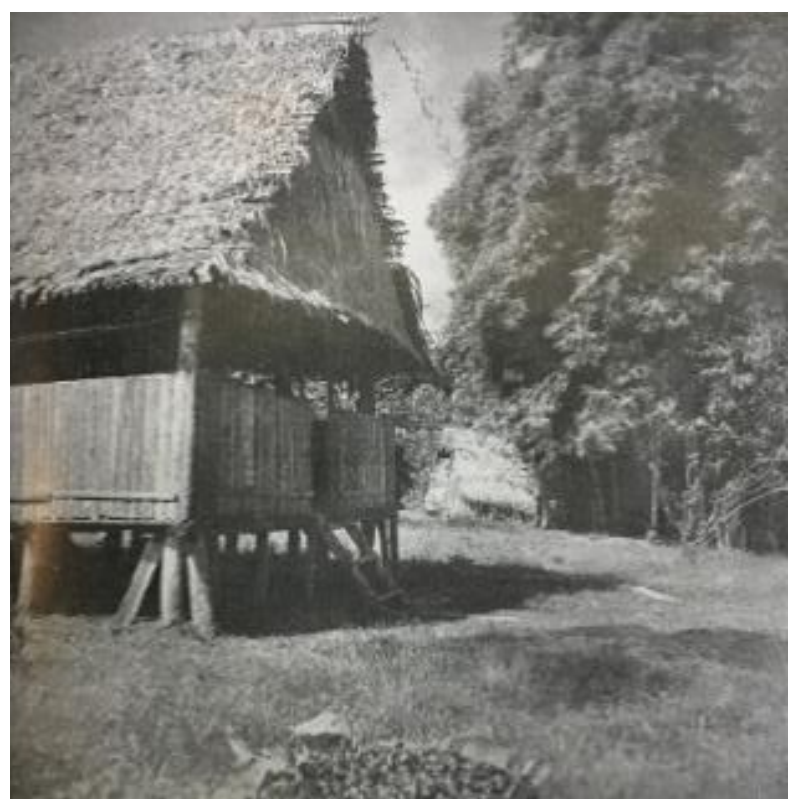

Figura 70 - Imagem da moradia com a legenda fachada da finíssima casa do Sr. José da Silva e Matto, numa localidade do Amazonas.

Fonte: HABITAT n.7, 1952, p. 3-9.

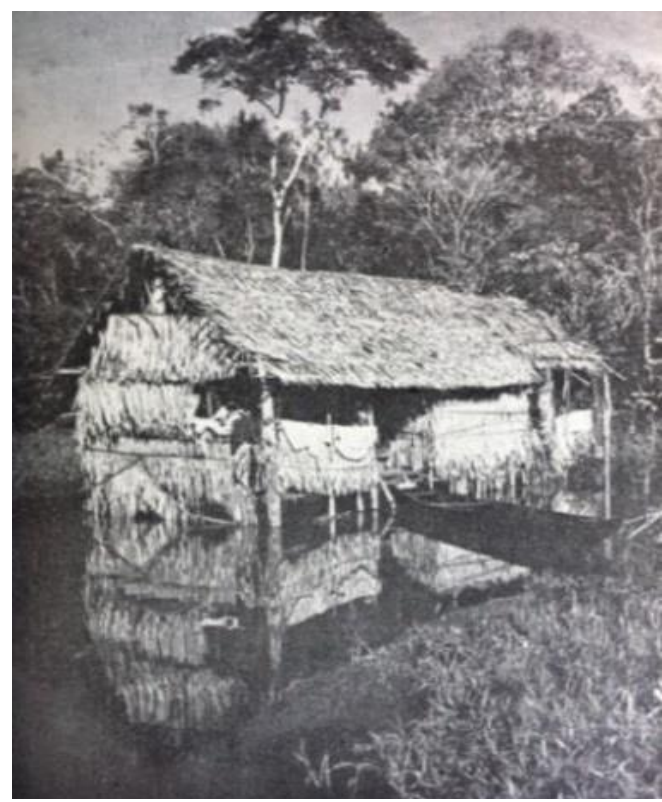

Figura 71 - Imagem do tapiri. Fonte: ABA n.1, 1967-68, p. 23.

Mais pragmaticamente, havia um conhecimento bastante específico sobre a adequação da habitação ao ambiente amazônico quando implantada em contextos rurais ou não urbanizados, como objeto de interesse presente nas falas até então destacadas no trabalho. Nos artigos que havia publicado na década de 1950 na Revista Módulo, também nas referências feitas nos inúmeros artigos sobre a casa na Amazônia publicados na revista Habitat, a arquitetura típica foi tratada pelo engenheiro Joaquim Cardozo como produto desta habilidade do habitante na Amazônia desenvolvida ao longo do tempo, inclusive técnica. Com olhar mais aproximado aos modos de vida e desde o contato mais direto com as memórias pessoais dos habitantes, a definição que apresenta Leno José Barata Souza, historiador interessado na investigação inclusive de formas múltiplas de habitar e transitar 
na região, do habitante da Amazônia, este foi o significado que sintetizou acerca do "tapiri” (SOUZA, 2010, p. 40):

No mundo médio das várzeas vive e trabalha o ribeirinho amazônico, ele sabe que sazonalmente (em média de seis em seis meses) suas terras baixas serão inundadas pelas águas, daí a importância estratégica das suas casas pernaltas, nas quais as palafitas amazônicas são as principais expressões; $\mathrm{da}$ praticidade do tapiri, cuja construção à base de palha e madeira leve, facilita seu deslocamento para as terras mais secas.

Cruzando as formulações do engenheiro à do historiador, a partir da significação de Leno Barata é possível extrair as categorias de análise com que Joaquim Cardozo caracterizou o fenômeno que se propôs observar, o das moradias pobres. Uma primeira, explica a arquitetura popular pela sua associação à pobreza e contingência, o que as conferiu “sentido até pitoresco", em detrimento de atributos geralmente associados ao "abandono e à miséria”. Quanto à tipificação, as associou ao "primitivo", desde um paralelo com as demais artes, quais fossem a pintura, música e escultura, atribuindo à tal construção um enraizamento cultural. ${ }^{215}$ Partiu da identificação dos componentes construtivos cuja técnica e engenhosidade o fez valorar as moradias. Selecionados de seus próprios modelos de observação, leu as formas construtivas e arranjos formais de efeito estético, que demandaram também um observador de olhar treinado (MÓDULO N.5, setembro de 1956, ano 2, p. 20-23):

Constância de proporções e uma insistência uniforme de linhas [...] fachadas principais, definidas pela cobertura em "chalet" [...] instintivo movimento de estandartização; são em geral pequenas aberturas em relação às superfícies das fachadas. O que sobretudo dá certo ritmo a êsse tipo de casas, além da boa proporção das fachadas laterais[...] apesar do aspecto caótico que se tem à primeira vista uma significação e um relevo que exprimem soluções incompletas de qualquer causa mais intimamente desejada e apenas não expressa por falta de recursos materiais. Tanto assim que, qunado êstes recursos existem ainda que escassamente, todos êsses elementos arquitetônicos se apresentam mais cuidadosamente tratados.

\footnotetext{
${ }^{215}$ Diante das teorias acerca do primitivo exploradas por Cláudia Costa Cabral e Helena Bender (CABRAL e BENDER, 2017), conforme exposto por Joaquim Cardozo, sua formulação para o que fosse uma arquitetura primitiva aderiram a dois significados, um primeiro, que o toma em distinção à erudição, portanto em oposição à cultura elevada, e noutra direção, o que aponta para uma vernacularidade, no sentido de produto da contingência e da inventividade com base numa determinada em conhecimento anônimo tipificado no tempo, numa ligação naturalizada com a tradição. Todavia, também conclui, ao qualificar o saber popular, que fatores contingentes implicam a restrição das soluções inventivas quando aplicadas à moradia pobre.
} 

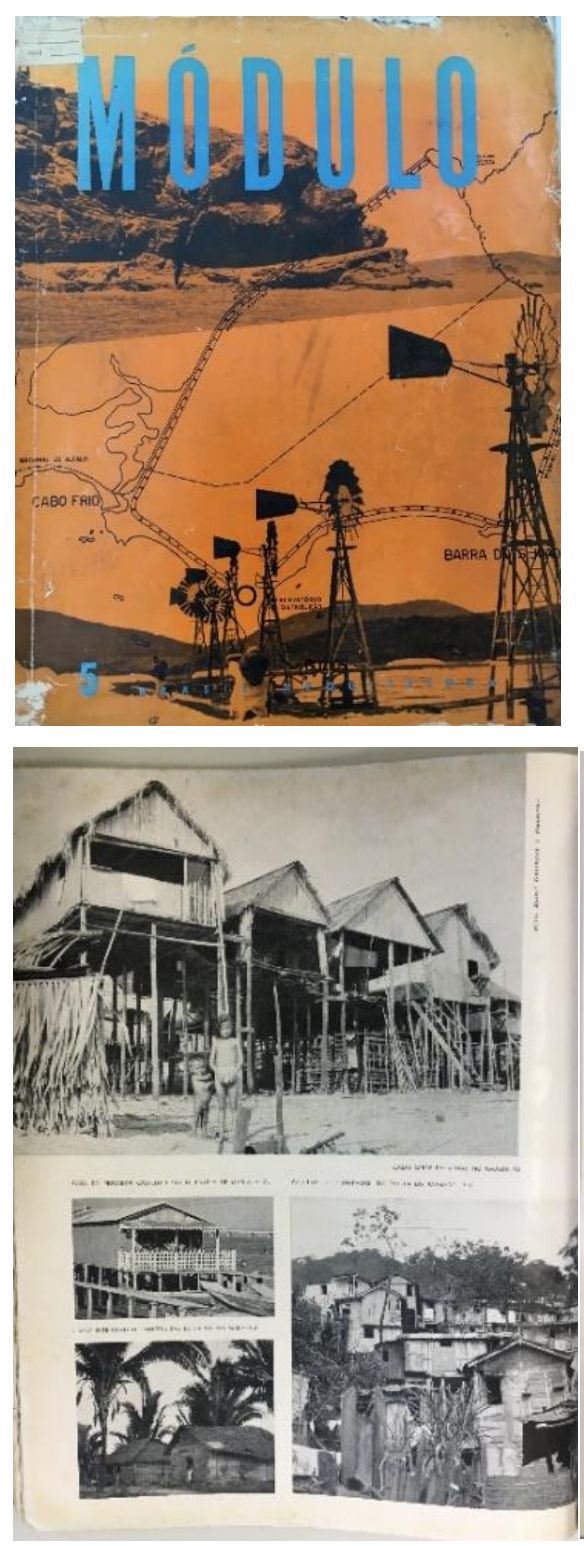

Figura 72 - Artigo do engenheiro Joaquim Cardozo, diretor da revista Módulo. Fonte: MÓDULO n.5, 1956, ano 2, p. 20-23.
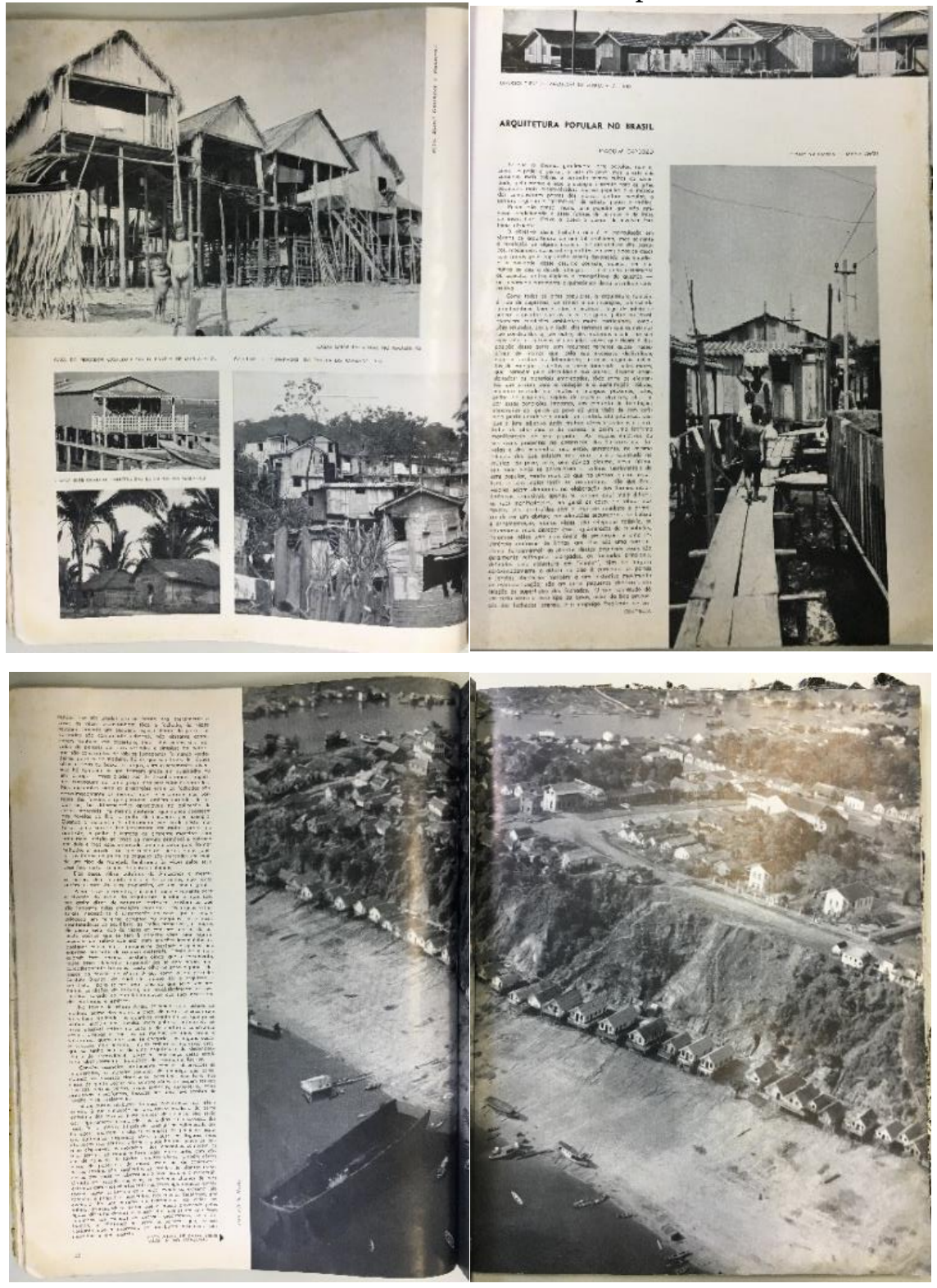
A construção da casa palafítica envolve um conjunto de conhecimentos, a começar pela compreensão plena dos regimes de cheia e vazante na região, dos materiais, dos tipos de madeira, formas específicas de tratamento, secagem, manejo, componentes estes de um saber fazer transmitido no tempo e adquirido da experiência junto ao ambiente geográfico. Em contexto, as habitações flutuantes, como as palafíticas às margens de Manaus-AM, desde a decadência dos seringais na primeira década do século XX, eram uma realidade a qual, com o tempo, foi provocando insatisfação a determinados segmentos sociais locais.

Também ao próprio governo local, as palafitas seriam o retrato do atraso, já que as construções estavam além de descoladas de seu contexto originário rural, determinando a paisagem pela presença de pobres urbanos. Tais moradias foram explicadas pelos dois fluxos migratórios que em específico, haviam ocorrido respectivamente nos anos de 1920, e mais tarde, a partir de meados dos 1940 (HEIMBECKER, 2014). Em contraste à sua condição de objeto exótico ou fruto do saber primitivo, as palafitas e flutuantes conformavam uma manifestação inapta à cidade para segmentos interessados na modernização e na ideia do asseamento urbano, como revelado em inúmeros escritos dos anos de 1950 e 1960 . Na síntese que fez Dorinethe Bentes sobre o aumento dos “subúrbios” pelos trabalhadores dos seringais que foram “abandonados à sorte”, afirmou que "restava-lhes migrar para a capital”, frente ao fracasso da reativação destes nos anos de 1940 (BENTES, 2012, p. 50).

Severiano Mario Porto reconheceu ser este um conhecimento específico, o da produção da habitação na Amazônia, como paisagem. O arquiteto o tomou como referência e como recurso à sua própria compreensão do ambiente com o qual passou a lidar a partir de 1965, quando realizou seus primeiros projetos em Manaus-AM e para onde faria sua mudança no ano seguinte. Um estágio particular de transformação do espaço urbano na Amazônia era então experimentado pelo arquiteto, já que muitos dos encargos profissionais a ele conferidos eram situados em áreas de expansão urbana. ${ }^{216} \mathrm{~A}$ conformação do território amazônico nesses anos, mais intensamente na década de 1970, seria perpassada pela

${ }^{216}$ Entre 1960 e 1980, a população urbana no país cresceu anualmente em 7,85\% e na Amazônia, 10,85\% (GODFREY, 1988). 
intensidade dos conflitos entre o mundo rural e o urbano, concretamente. ${ }^{217}$ Também pela transformação de paisagens urbanas como a de Manaus-AM, uma realidade sobre a qual ele passaria a interferir muito diretamente e cada vez mais.

Ao próprio arquiteto, com quem Robert Schuster havia trabalhado intensamente desde sua chegada à Manaus-AM, ${ }^{218}$ a habitação isolada situada em área de expansão urbana pareceu ser a materialização do que especulara acerca da casa amazônica. ${ }^{219}$ Em uma visão prospectiva de paisagem, a casa e o modo de vida a ela associados mais diretamente replicariam um morar amazônico, resignificado pelo projeto erudito para a habitação que passaria a desenvolver para o topógrafo em 1978.

Ao contrário de Luiz de Miranda Corrêa, no escrito há pouco apresentado, a casa tipificada, amazônica, guardaria em si uma elevada dose de atualidade, motivo pelo qual Severiano Porto a tomou como objeto de sua interpretação e referência. Dadas as possibilidades que aventava para o desenvolvimento de uma ideia de arquitetura mais ajustada ao ambiente amazônico, considerou as habitações tipificadas pela sua compatibilidade, principalmente em relação à adaptação ao clima. No registro que fez de uma apresentação em 1976, ${ }^{220}$ Severiano pormenorizou aqueles elementos referenciais da moradia amazônica, ${ }^{221}$ a qual nomeou de "nativa":

$\mathrm{Na}$ habitação nativa encontramos muitas respostas. A casa bem orientada e dentro de princípios adequados à região. A cobertura permitindo uma aeração permanente. Cobertura de palha. Paredes de palha, ora simples, ora tecidas. Casas elevadas do solo num sentido de defesa contra animais e contra a umidade. Temos também as casas de madeira, as casas cobertas de cavaco, ou de telhas de barro, fibrocimento, chapas galvanizadas ou de alumínio, porém aplicadas dentro do mesmo princípio ecológico. E a casa flutuante? Esta perfeitamente integrada às condições de nossa região, adaptada a oscilação imensa e constante do nivel dos nossos rios, ora subindo, ora descendo e a variação de suas margens que avançam e recuam, as vezes quilômetros de profundidade, e o caboclo, o homem primitivo, o nativo procurou a sua solução. E ela saiu simples e espontânea, perfeita mesmo.

\footnotetext{
${ }^{217}$ Como observado no primeiro capítulo, esses foram os anos de intensificação de conflitos de terra, pelos grupos sociais mais diretamente envolvidos, "populações indígenas, migrantes, grandes empresas, latifundiários, garimpeiros, e outros - resulta numa violência rural frequente na Amazônia, ainda que transcorridas de variadas formas e em várias localizações (GODFREY, 1988).

${ }^{218}$ Inclusive na obra do estádio Vivaldo Lima.

${ }^{219}$ Nesta narrativa são acrescidos os relatos orais de Luzia Schuster, esposa de Robert Schuster e Wolfgang Schuster, um dos filhos do casal.

220 Severiano Mário Porto concedeu uma cópia à Bosco Chamma, dedicando ao arquiteto o escrito em 1976. 221 Vale notar que em 1978 Severiano Porto havia acompanhado as obras das casas projetadas por Lúcio Costa para Thiago de Mello, recém-chegado do exílio.
} 
Não se tratava unicamente de pensar a edificação adaptada, mas de alcançar uma condição ideal de interferência material junto ao meio, na relação entre sítio e arquitetura, entre natureza e artifício. Sua arquitetura deveria possibilitar aquela experiência, do próprio modo de vida ao qual o arquiteto fazia constantemente menção, desde uma "preocupação de tornar a construção parte da natureza onde esta domina e o homem a usufrui, respeitando-a e preservando-a" (PROJETO N.15, setembro/outubro de 1979, p. 19). A casa icônica concretizaria um ideal do habitar amazônico, sob a lógica desenrolada por Severiano Mário Porto, como aqui interpretado.

Certa noite, ao se encontrarem, Robert Schuster e Severiano Porto debateram acerca da casa. O estrangeiro, imigrante austríaco vindo no pós-Segunda Guerra ao Brasil, apreciava o isolamento da cidade pela qual tinha pessoalmente pouco apreço. $\mathrm{Na}$ memória do projeto, publicada junto a este nas revistas de arquitetura, assim foi delineado o perfil do “proprietário” (PROJETO N.15, setembro/outubro de 1979, p. 19):

Robert Schuster, topógrafo austríaco, residente na Amazônia ${ }^{222}$ há cerca de 20 anos, tendo trabalhado em "serviços de campo" por toda a região, através das matas, ao longo dos rios, igarapés e indo muitas vezes 'as suas cabeceiras e cruzando por terra firme até as nascentes de outras bacias. Casado com amazonense também identificada com a vida coltada à natureza.

O delineamento do perfil pelo próprio arquiteto caracterizou Robert Schuster como um desbravador, acentuado o fato de que lhe atraía muito mais a natureza do que a urbanização. Severiano Porto, por outro lado, almejava a concretização de suas ideias da casa cuja imagem se fazia junto ao meio natural, almejava experimentar pelo ato do projeto, o desenho de uma casa referenciada no modo de vida típico. Faltava alguém que as concretizasse, um cliente ideal que estava então sendo contatado. Depois, um sítio ideal. No recente loteamento rural feito em Manaus, o "Tarumã", ${ }^{223}$ num fluxo inicial de especulação das terras periféricas à área urbanizada da cidade, um terreno foi identificado como o sítio ideal.

\footnotetext{
${ }^{222}$ A conotação conferida à Amazônia, na adoção do termo, deixou subentendida sua interpretação do que fosse realizar o projeto ou vivenciar a região. O arquiteto deixava claro sua forma de compreensão daquele espaço, a Amazônia, sob a ótica de uma paisagem.

${ }^{223}$ Situado junto a uma das quatro bacias hidrográficas da cidade de Manaus-AM.
} 
A princípio, o projeto de Severiano Porto que seria realizado no mesmo loteamento onde foi erguida sua própria residência, à Rua Recife (CJ ARQUITETURA N.20, 1978, p. 36-39), foi então transferido para mais longe da área urbana central da capital, onde não havia qualquer infraestrutura ou traço de urbanização na paisagem, um lote acessado por via recém aberta, sem afaltamento, de pissarra. A casa, integralmente projetada para ser construída em madeira, demandaria grandes esforços logísticos, além de custo elevado, já que o material se fazia de difícil acesso em Manaus, à época. A procedência da madeira não foi local. O fluxo de desmatamento era intensificado em virtude da urbanização de Manaus, mas também como procedimento usual na construção civil. Antes de erguer a casa, era comum que fosse feita limpeza completa do terreno, eliminando qualquer vestígio de vegetação, primária ou não, que pudesse ser empecilho à construção.

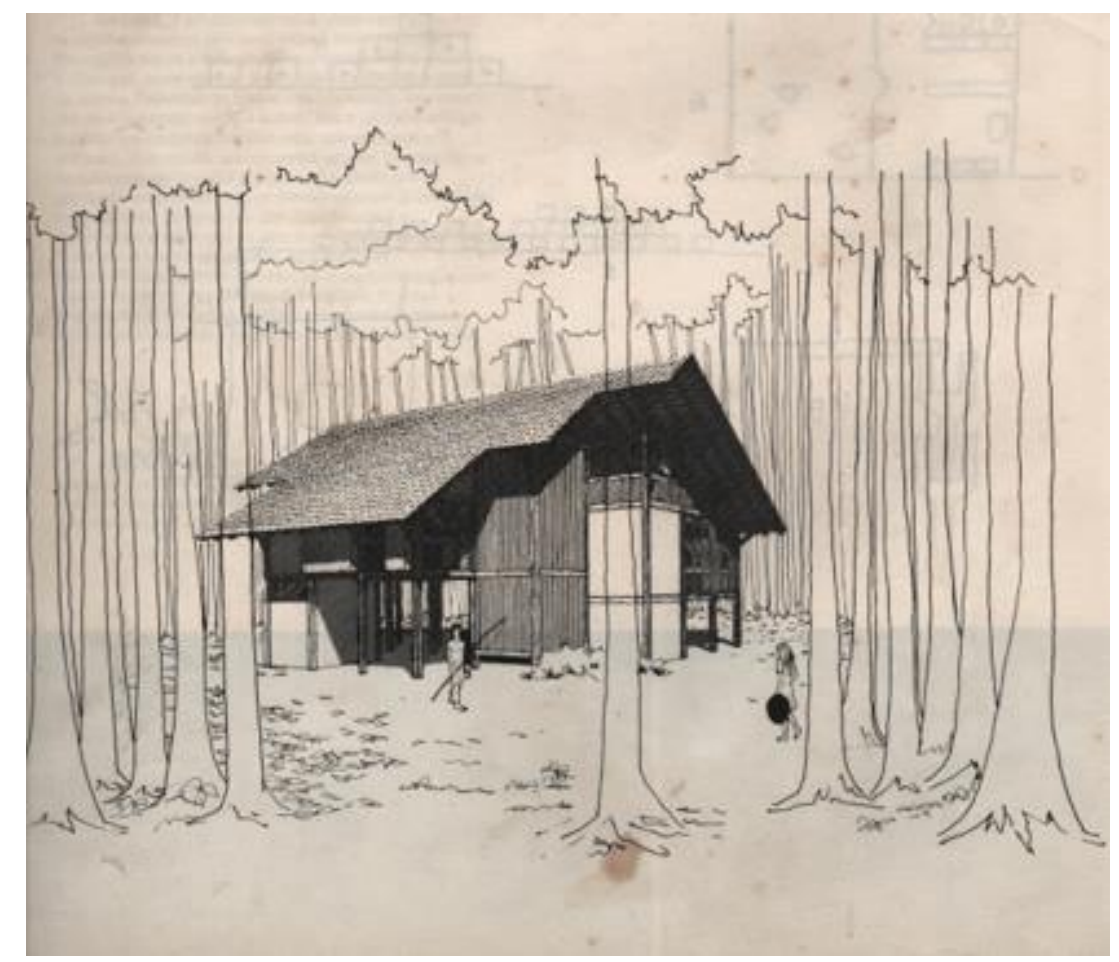

Figura 73 - Desenho mais publicado da casa projetada para Robert Schuster, por Severiano Porto.

Robert Schuster tinha longa experiência no país, tendo vivido no Rio de Janeiro, Belém e Manaus, onde realizou a atividade de topógrafo por longo período, em muitas das obras projetadas por Severiano, desde a do Estádio Vivaldo Lima (ARQUITETURA-IAB N.42, dezembro de 1965). Robert Schuster se empenhou pessoalmente na construção da casa, contratando cerca de 15 trabalhadores para a empreitada, especialmente artesãos hábeis com a madeira, que seria utilizada na construção, a partir de diversas técnicas e 
formas de aplicação, a exemplo dos "pilares árvore, lascados no enchó", a cobertura de cavaco, onde foram aproveitados os resíduos da obra. As madeiras, vindas de barco do interior, foram de tipos variados, aplicadas em assoalhos, vedações, peças estruturais, esquadrias, cobertura, com a inventividade que desprendeu a obra daqueles parâmetros primordiais de projeto "primitivo", ainda que rememorando seus referentes visuais, especialmente quanto à espacialidade, quando da liberação do corpo da casa do solo. Para Miriam Keiko Rovo, o princípio de flexibilidade que Severiano Mário Porto adota nos projetos de moradia, "está diretamente ligado às ideias que defendem a participação do usuário na arquitetura, coincidindo com o movimento ecológico, em evidência nos anos 70", ainda que a autora faça referência à outras linhas de projeto como à "mobilidade das divisões internas" de Gerrit Rietveld no projeto da Casa Schröeder de 1924 ou a proposta de LE Corbusier para o "Museu de crescimento ilimitado" de 1931, onde são enfatizados os conceitos de "crescimento e flexibilidade da arquitetura" (LIMA, 2004, p. 34).

Luzia Schuster revelou em entrevista, a intimidade adquirida com o vocábulo da arquitetura e da construção, além de domínio sobre a dimensão físico-espacial da casa, provavelmente o resultado de anos de vivência junto a Robert Schuster, com quem também partilhou suas memórias pessoais. As suas percepções da casa, mesclaram-se provavelmente às repercutidas pela imprensa e mesmo às falas de Schuster e Porto, considerando toda a repercussão do projeto nos jornais, revistas e entre a comunidade de intelectuais, especialmente da arquitetura e de campos relacionados aos estudos do meio ambiente. Luzia rememora, por exemplo, que os fins de semana eram dedicados aos encontros com visitantes e convidados que frequentavam recorrentemente a casa, cerca de 20, 30 pessoas aos finais de semana, dentre eles estrangeiros e profissionais ligados ao meio ambiente. 
(1)

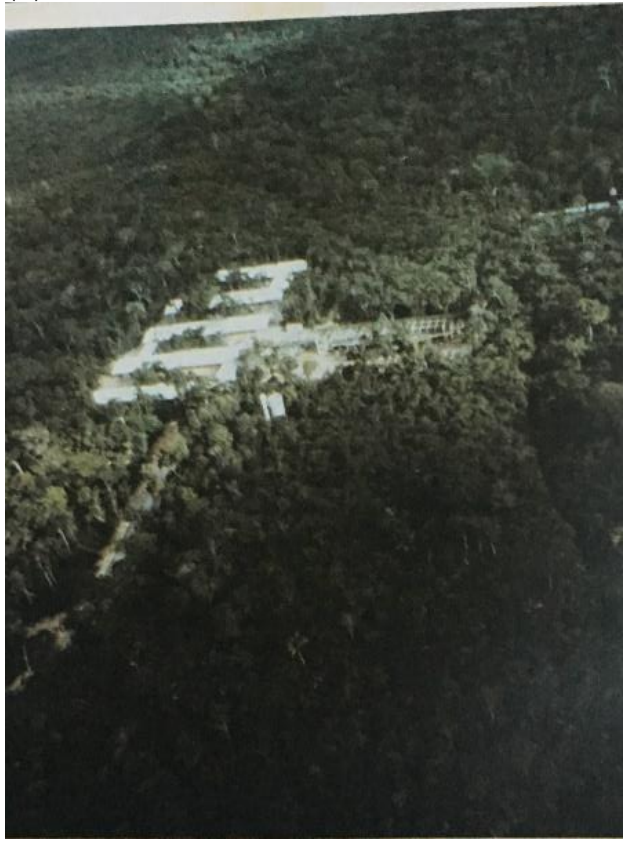

(3)

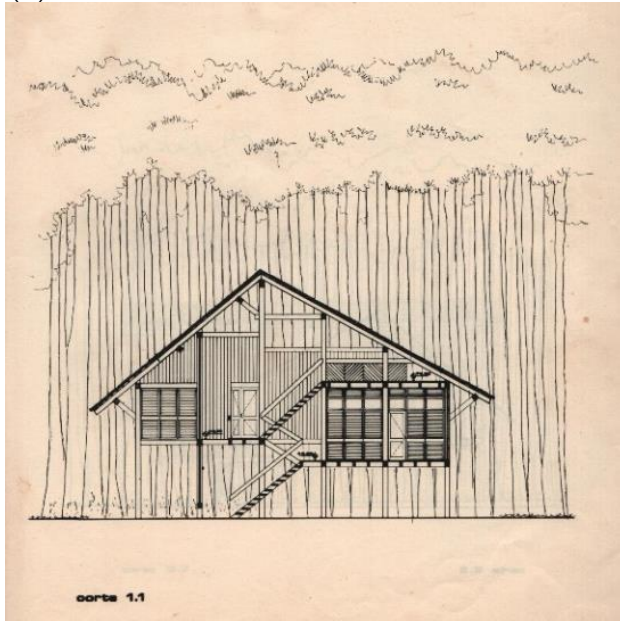

$(2)$

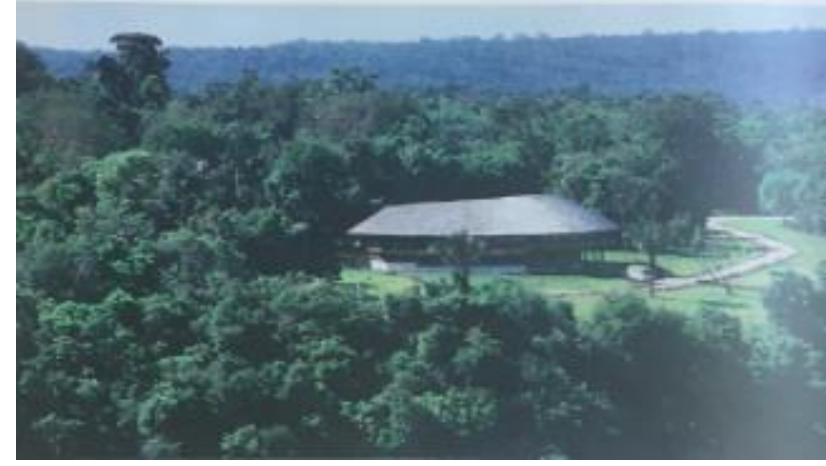

(4)

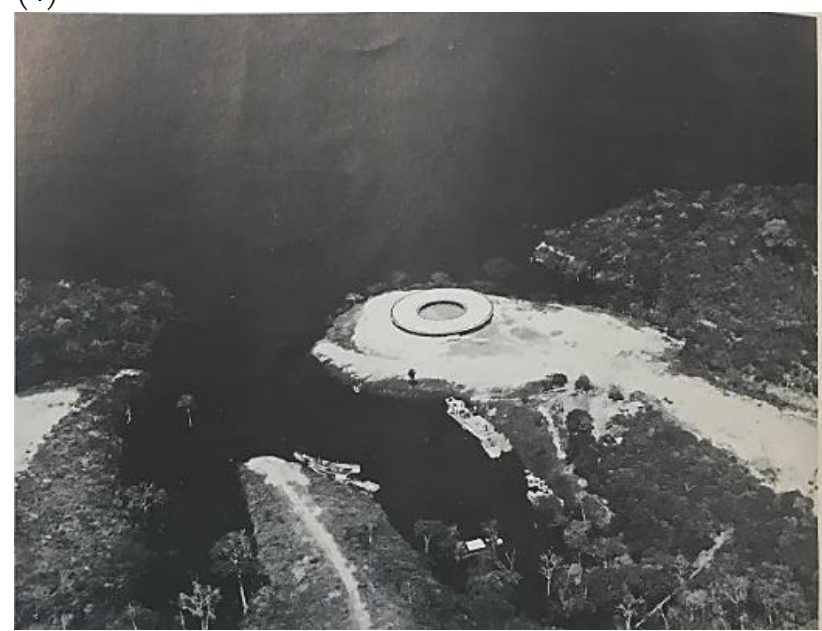

(5)

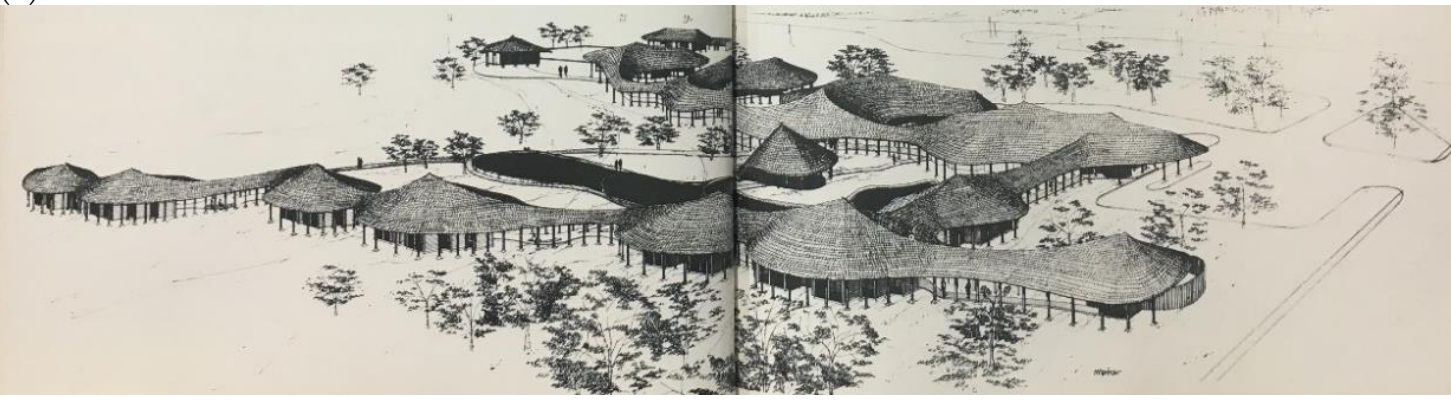

Figura 74 - (1) Universidade do Amazonas, Manaus - AM. Fonte: Revista PROJETO n.83, janeiro de 1986; (2) Pousada, Silves - AM. Fonte: Revista PROJETO n. 114, setembro de 1988; (3) Sede do

Departamento Nacional de Portos e Vias Navegáveis, Manaus - AM. Fonte: Revista CJ ARQUITETURA n.7, 1975; (4) Residência Schuster, Manaus - AM. Fonte: Revista MÓDULO n. 53, março-abril de 1979; (5) Centro de Proteção Ambiental, Balbina - AM. Fonte: Revista PROJETO n.125, 1989.

O desenho que mais fez circular a concepção do projeto da "Casa do Tarumã” ou da “Casa Schuster” foi aquele no qual o arquiteto sugeriu a interação entre obra e natureza na 
conformação da paisagem, a representação da habitação imersa, icônica. Uma imagem total da casa em meio aos alongados troncos de árvores ao seu redor, único traço de inscrição do objeto no território. A vara de pesca nas mãos de um homem caminhando de pés descalços, a mulher carregando uma cestaria, certa calmaria no ambiente, podem ser lidos no registro gráfico do projeto no desenho. No registro gráfico, havendo indicativo do que fosse o seu contexto mais ampliado de locação, Severiano ainda que despropositadamente, deu margem à imaginação inerpretativa sobre o lugar onde estaria implantada a casa. A identificação imediata é a de uma "Amazônia”, uma paisagem sintetizada, onde o projeto adquire sentido justamente pelo modo como é narrada e materializada pela implantação da habitação.

A atividade projetual de Severiano Porto na Amazônia, quando concebida desde uma perspectiva da paisagem, incluiu a referenciação às práticas construtivas capturadas dos saberes e fazeres de populações nativas. Experientes no ambiente amazônico, pela vivência e trânsito naquele espaço, compuseram o repertório do arquiteto, desde quando desenvolveu sua atividade na região. A este contato, ele acresceu os frutos do diálogo com a paisagem memorial culturalmente construída, sobretudo pelo pensamento intelectual, como uma síntese reelaborada e significativa da imagem do território.

A paisagem amazônica não prescindiria do habitante, o amazônida, deslocado à tema nesta obra. Rebatida nas representações gráficas dos projetos e fotografias que circularam nesses anos, a paisagem prospectada na Amazônia, incluía como procedimento, a inserção dos objetos que com ela adquiriram valor, e a ressignificaram. A imersão do edifício em

meio natural, o edifício expansivo em contexto natural, a monumentalização da paisagem natural pela inscrição do edifício, são exemplos das lógicas utilizadas pelo arquiteto e que estão presentes em inúmeras fotografias e desenhos que mediaram os projetos e obras. Ainda que se tratassem em muitos casos, de contextos urbanizados, a problemática do projeto retida na relação entre edificação e meio natural contribuiu para veicular imagens de sítios não explicados, áreas de expansão urbana ou recém transformadas.

\subsection{A paisagem civilizatória, arquitetura das Vilas Serra do Navio e Amazonas, no Amapá}

A instituição do Código de Mineração de 1934, no qual foi estabelecida a distinção entre as propriedades do solo e subsolo nacionais, permitiu que desde então ele fosse posibilitada concessão pública da exploração mineral no país. Era assim demarcado o 
ingresso do capital internacional na região da Amazônia brasileira, pela participação direta de indústrias mais especificamente ligadas à área de mineração. Ainda, após a Segunda Guerra com os "Acordos de Washington" e o alinhamento do governo brasileiro ao dos Estados Unidos, foram instituídas estratégias de exploração de recursos naturais da Amazônia brasileira, das quais participaram governos e grandes estruturas empresariais (OLIVEIRA, 1988, p. p.14-16). Nesse processo ${ }^{224}$ foram implantadas novas cidades, tornadas componentes de uma nova dinâmica territorial, marcada pela modernização heterogênea do espaço regional amazônico (JÚNIOR, 2010 mar./set., p. p.120).

As novas cidades implantadas na Amazônia constituíram processos de modernização da cultura material local e do território, considerando as formulações intentadas por Oswaldo Bratke para as Vilas da Icomi, a partir do que considera Adrián Gorelik, de que "na cidade latino-americana a modernidade foi um caminho para a modernização", se referindo à "vontade ideológica de uma cultura para produzir um determinado tipo de transformação estrutural" (GORELIK, 1999). A modernização regional, nesta linha, compôs um dos propósitos fundantes das ações governamentais dirigidas à Amazônia brasileira nesses anos, quando o vazio como metáfora construiu o discurso de uma necessidade de renovação radical e foi continuamente reafirmado para a efetivação de projetos de novas cidades. Todavia, com efeitos sobre uma modernização pouco efetiva do ponto de vista social, constituindo uma modernização paradoxal e conflituosa, extremamente danosa ao meio natural (BRITO, 2001).

Os projetos de Bratke para a Icomi, são exemplares muito presentes na história escrita da Arquitetura e Urbanismo, em variados estudos e interpretações, seja por suscitarem a qualidade da técnica, seja em adesão ao pensamento desenvolvido da cultura disciplinar da arquitetura no Brasil, ou pelo interesse, oscilante, de agentes centrais no campo - arquitetos e urbanistas, teóricos e críticos - em formas materiais em extensão à moderna cultura construtiva, neste caso, levada a lugares considerados remotos. Também pela perspectiva de articulação engenhosa entre o moderno e primitivo, raciocínio de Lúcio

\footnotetext{
${ }^{224}$ Daniel Brito se refere às cidades empresa para fins exploratórios, como enclaves modernos na Amazônia. Estes, centralizariam todo o "instrumental de domínio da natureza" ao mesmo tempo em que não inclusivos da população local, produzindo gradativamente e expressivamente, mecanismos de sua exclusão (BRITO, 2001).
} 
Costa, deslocado a contextos regionais. Ainda os referidos projetos são objeto de pesquisadores interessados por processos de urbanização realizados em ambientes não afetados pela modernização cultural, bem como pelos impactos sociais, ambientais, decorrentes de sua realização.
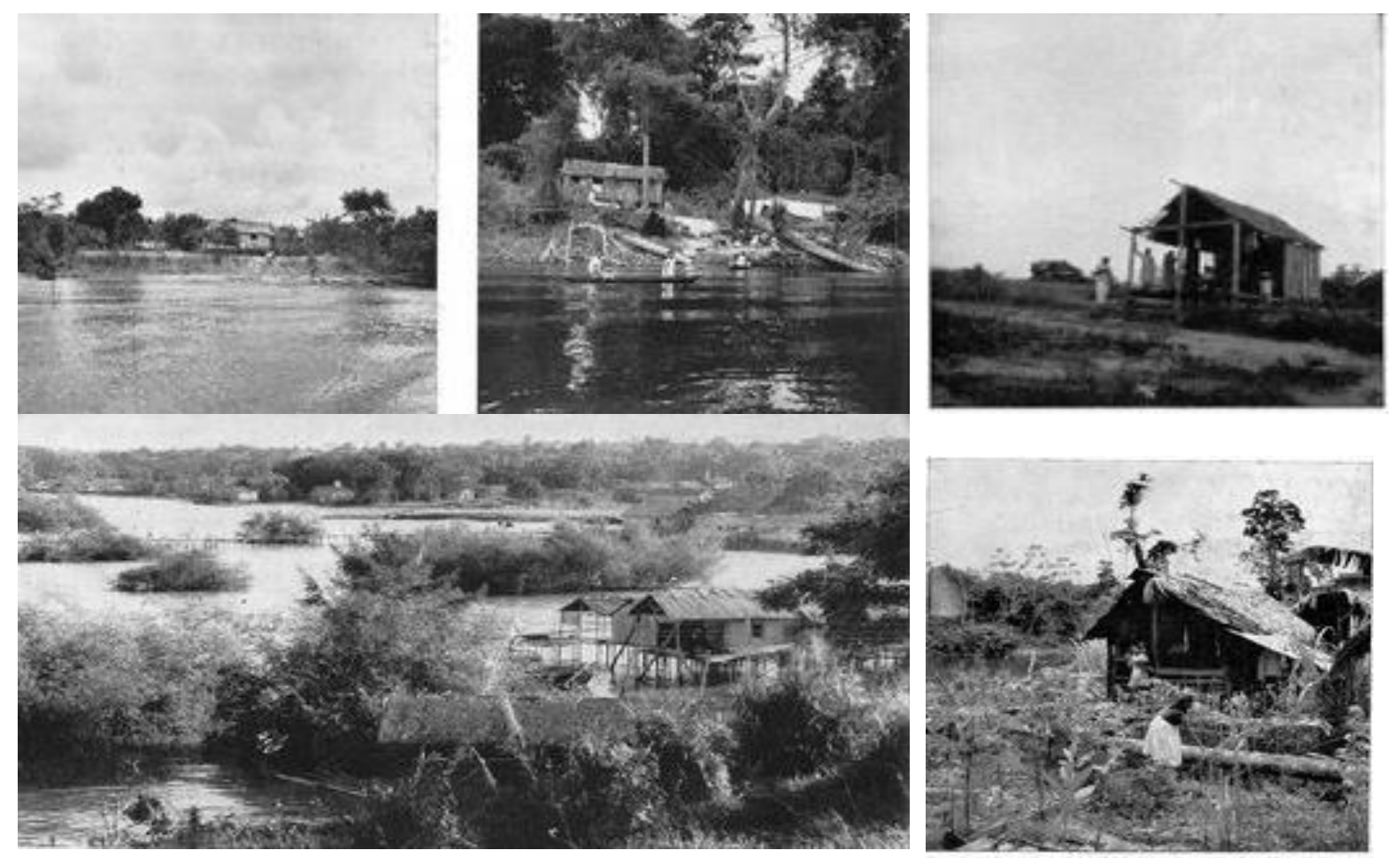

Figura 75 - Imagens referenciais à escolha dos locais de implantação das Vilas no Amapá, comentadas pelas "condições físicas e socioeconômicas locais existentes na região".

Fonte: ACRÓPOLE, n.326, 1966, p. 18-19.

A participação do arquiteto no processo de implantação do complexo industrial ocorreu de 1955 até 1959, até quando os núcleos urbanos por ele projetados para acomodação dos trabalhadores da Icomi estavam construídos e as atividades empresariais, em curso. Bratke foi, nesse período, incumbido de desenvolver o planejamento geral das Vilas, da infraestrutura ao detalhamento (ACRÓPOLE, 1966, p. p.21). O primeiro contato do arquiteto com o local de do projeto foi acessando-o por barco. Lá se deparou com técnicos estrangeiros que "trabalhavam na construção da estrada de ferro e na montagem da planta industrial” (RIBEIRO, 1992, p. p.19,20). Este contato de Bratke com o lugar foi narrado por Benjamin Adiron Ribeiro, como procedimento usual de projetista, "o que todo arquiteto deve fazer antes de sentar à prancheta": conhecer profundamente o ambiente, as formas materiais do habitat, os costumes. Utilizando trechos escritos das memórias de Bratke, Ribeiro reforçou suas afirmativas a respeito da preocupação do arquiteto em 
compreender de antemão, a geografia, o homem, o clima, os meios (RIBEIRO, 1992, p. p.20), uma paisagem pregressa, enfim:

Uma coisa ficou bem clara para Bratke: na Serra do Navio nada existia em termos urbanos; tudo teria que ser previsto, planejado, executado. Não se tratava, apenas, de projetar um grande conjunto residencial, mas de planejar, integralmente, uma pequena cidade.

Para isso, o arquiteto empreendeu pesquisa sobre outros núcleos similares, como os já existentes na Venezuela, e desenvolveu minucioso estudo planejador, a partir de dados pessoalmente coletados ou fornecidos pela empresa contratante, a exemplo dos prazos de execução do trabalho ou do contingente de trabalhadores a considerar para as vilas (RIBEIRO, 1992, p. p.22,23). A representação da Amazônia, mais precisamente desde a localidade analisada por Bratke, constatado em sua desocupação, e do espaço, que narrou como selvagem, compôs o sentido atribuído ao lugar de implantação dos projetos, enfatizados os obstáculos ao acesso, seu isolamento, distanciamento, o completo vazio humano, as dificuldades de abastecimento e trocas comerciais ou culturais, bem como a densidade verde, "de pouca variação de cor, porém com grandes variedades de espécies”, além das chuvas abundantes, da temperatura variante entre $27^{\circ} \mathrm{C}$ e $35^{\circ} \mathrm{C}$, com umidade relativa de $95 \% .{ }^{225}$ Os dois locais para implantação da vila foram articulados às atividades industriais as quais dariam suporte. O núcleo de Vila Serra do Navio seria "encravado em plena floresta”, mais perto das minas, a $200 \mathrm{~km}$ do porto de embarque do minério, e a Vila Amazonas, foi localizada ao lado deste porto, a $20 \mathrm{~km}$ de Macapá, já que a logística da atividade industrial a partir da exploração incluía o transporte do manganês por via férrea até o porto (ACRÓPOLE, 1966, p. p.19).

As dificuldades com a construção das vilas eram notórias, pelas condições de transporte de materiais, pelo desconhecimento geral a respeito dos materiais locais disponíveis (ACRÓPOLE, 1966, p. p.19). A realização daquele projeto, de uma paisagem civilizatória, foi realizado em meio a série de entraves, já que a inadequação da operação

\footnotetext{
${ }^{225}$ A descrição de Benjamin Adiron Ribeiro a este espeito foi a seguinte: “As jazidas de manganês do Amapá estão situadas sob a linha do Equador (ou, mais exatamente, na latitude $\mathrm{N} 1^{\circ} \mathrm{e}$ na longitude W $52^{\circ}, 5$ ), em plena selva amazônica, junto ao rio Amapari. Segue-se que o clima é quente e úmido; a temperatura média, ao longo do ano, é de $27^{\circ} \mathrm{C}$, sendo frequentes temperaturas de até $35^{\circ}$. A umidade relativa do ar é de $95 \%$. As chuvas são abundantes e, às vezes, torrenciais; o índice pluviométrico anual é de $2.000 \mathrm{~mm}$. Os ventos predominantes, fracos, sopram de Leste e Nordeste, com velocidade máxima de $22 \mathrm{Km} /$ hora. No local das jazidas o terreno é acidentado, mas a altitude é modesta: da ordem de 120m” (RIBEIRO, 1992, p. p.24).
} 
exprimia em grande parte o caráter exógeno daquela operação colonizadora. Benjamin Adiron Ribeiro também se deteve à apresentação de antecedentes do lugar (neste caso, o de implantação do projeto de Vila Serra do Navio). Em 1992, na caracterização do que nomeou “meio ambiente”, expressou uma preocupação preservacionista, e a respeito da floresta (RIBEIRO, 1992, p. p.24-26):

Quanto à selva amazônica, suas características ambientais vão se tornando mais conhecidas, na crista da atual onda ecológica. Todos sabem, por exemplo, que a floresta tropical ali é densa e luxuriante, perenemente verde, muito rica em espécies vegetais; que é quase impenetrável. Por baixo do emaranhado das copas, mesmo durante o dia, prevalecem à meia-luz, a penumbra, quase a escuridão. A rede hidrográfica da região é copiosa, com uma infinidade de rios, afluentes, igarapés, que formam extensas lagoas e igapós, nos baixios inundáveis, durante a estação chuvosa; ficando difícil, em algumas áreas, dizer onde começa a terra e termina a água. Ainda assim, ou por isso mesmo, a fauna é pobre em mamíferos de grande porte, quando comparada com a fauna das savanas e florestas tropicais africanas. Para compensar, a Amazônia é o reino dos anfíbios, dos répteis aquáticos em seus rios e alagados deslizam o jacaré-de-papo-amarelo, as cobras peçonhentas, a monstruosa sucuri. Pela galharia das árvores deslocam-se bandos de macacos, cuja algazarra provoca a revoada de pássaros de colorida plumagem. Ao cair da noite, a selva se enche de morcegos; nos igarapés, há abundância de peixe. E, naturalmente, subindo dos remansos, dos igapós de água estagnada, enxameiam nuvens de insetos; entre esses, a temível anófele, transmissor da malária, e o mosquito transmissor da leishmaniose.

O argumento de Bratke para o desmatamento completo na área de implantação das vilas e da inserção de vegetação exótica, decorreu da constatação do arquiteto de que a sustentação das árvores era dada pela interdependência de suas copas, em conjuntos de vegetação, o que seria uma especificidade daquele ambiente. À localidade, "em plena selva amazônica”, se estendia na leitura de Oswaldo Bratke, à cultura de um "homem da região”, assim representado nas formas de vida nos textos da revista Acrópole, e mais tarde, os resgatados por Adiron Ribeiro. Nas leituras do arquiteto, os modos de vida apareceram a partir de algumas designações específicas, como dependentes dos cursos dágua e da floresta, em "regime nômade", de maneira "primitiva”, "vivendo as margens dos rios”, "geralmente descalço, usando somente calção", "protegendo a cabeça com chapéu de palha" (ACRÓPOLE N.326, março de 1966, p. 17).

Os textos de Bratke, quando desenvolveu os projetos de Vila Serra do Navio e Vila Amazonas, resgatados pela historiografia (RIBEIRO, 1992) (SEGAWA e DOURADO, 
1997), ou analisados sob a influência do caráter disciplinador do Urbanismo moderno (CORREIA, 2012) exprimiram a distinção que realizou entre o civilizado e o incivilizado, quando em resposta aos encargos em questão. Os escritos de Benjamin Ribeiro, dos quais é extraído o trecho a seguir, no tópico que o autor nomeou de "meio social”, reproduziram informações veiculadas anteriormente em vasta matéria publicada pela revista Acrópole (ACRÓPOLE N.326, março de 1966), como já observado, reafirmando-as e evidenciando o juízo que fez Bratke a respeito de um conjunto de condições locais quando da realização dos projetos contratados pela Icomi (RIBEIRO, 1992, p. 26):

Difícil falar em meio social, tratando-se da Serra do Navio no ano de 1955. Como o resto da Amazônia, a região era quase desabitada; exceto por raras famílias de caboclos, alojadas em ranchos de madeira erguidos à beira rio, apoiados sobre palafitas e cobertos de sapé. Ou por garimpeiros de ouro, aventureiros que se deslocavam de uma região para outra, acampando aqui e ali. Nem índios havia mais por lá.

É possível identificar a indistinção com que Oswaldo Bratke percebeu aqueles “caboclos da Serra do Navio", que "levavam vida primitiva, subsistindo com a pesca, a caça e pequenas roças de feijão e mandioca” eram “ignorantes, se bem que muitos fossem alfabetizados” que "não estavam afeitos ao trabalho sistemático”. Quanto à paisagem, enunciava ser o rio a principal via de circulação intraregional, o qual era feita muitas vezes com a canoa de madeira a remo, também típica. Nela, a identificação do tipo humano, sobretudo de sua forma de habitar naquele ambiente, foi dado num esforço interpretativo por parte do arquiteto, para a compreensão dos modos de vida locais, sobretudo, para a identificação das construções adaptadas e que por ele foram bem vistas pelas soluções de conforto (RIBEIRO, 1992, p. 26):

Seu rancho, sempre sobre palafitas, obedecia a princípios instintivos de conforto climático: era quase tudo aberto, gozando das brisas, sendo apenas fechado com esteiras de palha o ambiente destinado ao casal, o qual também servia para guardar seus bens; dormiam em redes. Apesar de morar na selva, nunca localizavam seu rancho junto à mata; sempre distante desta, dentro da clareira aberta para a roça, receosos da queda de árvores. Seu fogão era uma espécie de torta de barro endurecido, apoiada sobre uma tábua. 

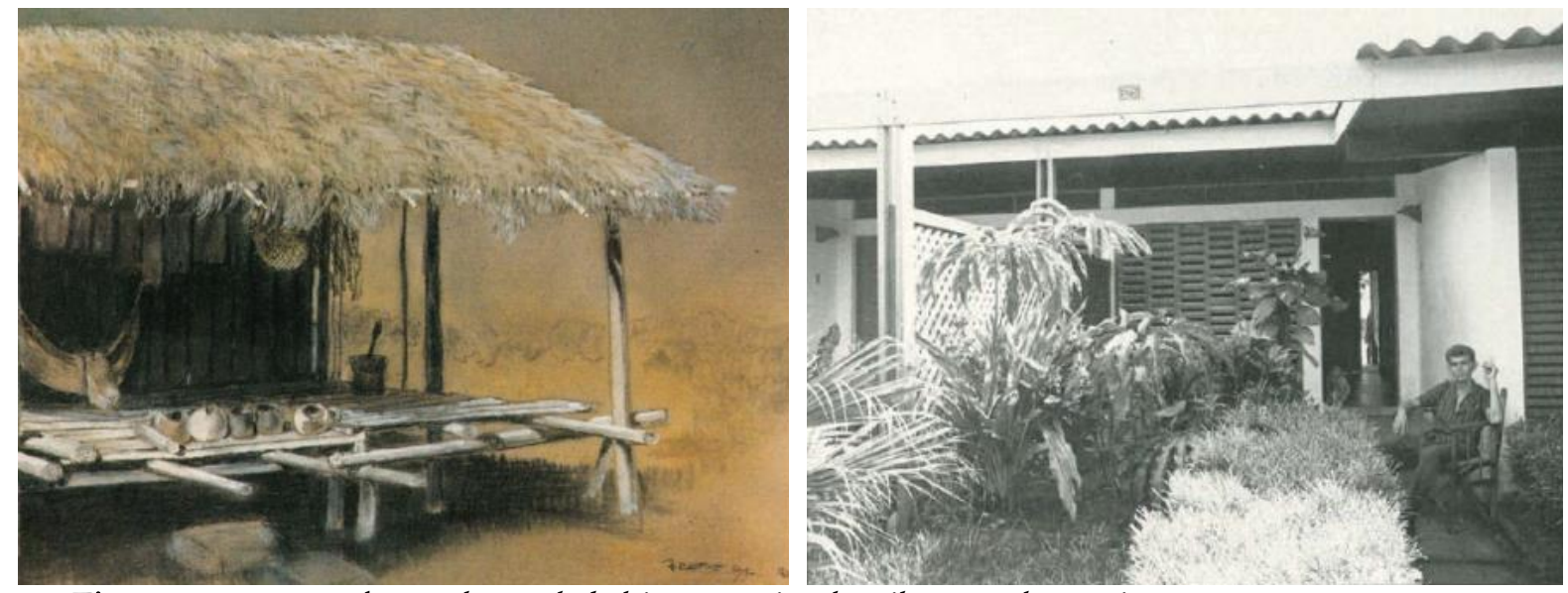

Figura 76 - Síntese da Evolução de habitação típica de Vila Serra do Navio (RIBEIRO, 1992, p. 4).

A formulação de significados frente os recursos de que dispunha e a particularidade das soluções projetuais, denunciaram o zelo com a forma construída, com a pequena escala e o pormenor. Por outro lado, no domínio sobre a conformação do espaço projetado, nas proporções consideradas mais adequadas entre construções e áreas livres, verdes, o arquiteto incorporou ao rol de suas decisões, aquelas relativas à gestão comunitária. Assim, os núcleos habitacionais foram idealizados a partir do princípio da "autossuficiência”, e todas as atividades cotidianas, citadinas, foram antevistas em projeto, garantindo "atração e retenção dos empregados das diversas categorias”, originários da região amazônica ou de outras partes do Brasil (ACRÓPOLE N.326, março de 1966, p. 19) (RIBEIRO, 1992, p. 40).

No projeto urbanístico, com uma “urbanização informal, não retilínea” (RIBEIRO, 1992, p. 56) foram pensadas superquadras circundadas por avenidas de uso restrito, a pedestres e a eventualidades ou emergências. Os edifícios foram dispostos no sentido ideal leste-oeste, tendo sido produzidos recuos nos alinhamentos das unidades habitacionais com vistas à formação de espaços propícios ao encontro de adultos e recreação de crianças. As habitações ganharam cores variadas e não foram feitos cercamentos para delimitação de lotes. Os espaços produzidos pelo desalinhamento das habitações, "pequenas praças”, foram interligados por passagens de pedestres, e estas, aos diversos equipamentos urbanos projetados. Vale ressaltar a espacialidade central da praça referencial do conjunto urbanístico, agregadora de atividades e de simbolismo cívico. Assim, para o conjunto de Vila Serra do Navio e Vila Amazonas construídas para população de 2500 habitantes foram 
adotadas as diretrizes modernas de zoneamento e distribuição de equipamentos (ACRÓPOLE N.326, março de 1966, p. 20-21).

Oswaldo Bratke teve autonomia para decidir a respeito tanto dos arranjos espaciais, das soluções construtivas, desenvolvendo um padrão que decorreu de "técnica e princípios" que viabilizassem a realização do empreendimento, frente às limitações para obtenção de materiais, os fatores climáticos locais, os prazos demandados. Optou pelo uso de blocos de concreto feitos in loco, de madeira em forros, de telhas de fibrocimento, de beirais alongados com mais de um metro e ventilação cruzada, com uso de venezianas e outros elementos vazados telados em substituição ao vidro, para controle de iluminação no interior das edificações (ACRÓPOLE N.326, março de 1966, p. 21). Estas foram soluções encontradas pelo arquiteto visando conforto especialmente em virtude das elevadas taxas de umidade locais. Forros de madeira inclinados acompanhando os telhados de fibrocimento, em geral de duas águas, intervalados por espaço destinado à circulação de ar, foram aplicados para obtenção de melhor isolamento térmico nos espaços interiores das edificações.

Também a respeito das decisões projetuais, quanto aos materiais de construção, após conhecer as condições ambientais, sociais, materiais e logísticas na região, onde atestou não haver à época, uma genuína tradição construtiva, optou pela utilização de determinados tipos de madeira locais e de outros estados (andiroba, louro, sucupira, massaramduba, cedro), também pela fabricação local de componentes construtivos de concreto e telhas de fibrocimento. A produção foi estendida ao mobiliário das casas, completamente equipadas para serem entregues aos moradores, o que demandou a montagem de estrutura de produção e formação de profissionais no próprio local, uma "atividade manufatureira nova, pequena, mas ativa. Seus operários, treinados pela Icomi, tornaram-se bons artesãos e tiveram a possibilidade de começar seus próprios negócios” (RIBEIRO, 1992, p. 53-54).

Quanto às moradias, nas duas vilas, os tipos de habitação e sua localização urbana foram diferenciados segundo gênero, forma familiar e nível profissional dos habitantes. Habitações para solteiros, por exemplo, foram aproximadas aos espaços centrais, concentradores de equipamentos urbanos dos núcleos, nos quais estavam situadas atividades administrativas, de serviços e comércio, espaços cívicos, recreativos, religiosos, hospitalares e educacionais (ACRÓPOLE N.326, março de 1966, p. 31-33). Já as habitações 
operárias, de dois e três dormitórios, geminadas duas a duas, compunham unidades de vizinhança, circundando espaços centrais das vilas. Habitações destinadas a “operários”, seguiram tipo distinto das habitações de "funcionários" ou de "chefes e engenheiros", das quais foram aproximados os edifícios de recepção e hospedagem. Nestas, o arquiteto isolou as unidades, dispersando-as em espaço mais aberto e desalinhando-as em implantação (ACRÓPOLE N.326, março de 1966, p. 23-35).

Precedentes do próprio campo do Urbanismo foram mobilizados ao projeto, especialmente em "soluções projetuais difundidas no âmbito dos CIAMs e das cidades jardins”. A hierarquização do sistema viário e profusão de espaços verdes coletivos, tratados paisagisticamente, foram exemplos destes. As casas foram distinguidas em projeto e disposição, segundo os grupos sociais aos quais foram destinados, pelo cargo exercido na Icomi e estrutura familiar de pertencimento, organização típica de uma cidade empresa, tendo Oswaldo Bratke operado por meio do projeto, uma "divisão social do espaço" (CORREIA, 2012, p. 138-140). Esta faceta conservadora da propositura dos projetos de Bratke, especialmente no ideal disciplinador, civilizatório, o arquiteto além de expressar textualmente, incorporou nos desenhos das cidades, materializando-as a partir da perspectiva de espaço "limpo, disciplinado e seguro". Também, as baixas densidades, a dispersão dos moradores, o interesse na dissolução de concentrações foram aspectos incorporados ao projeto, conservador quando produziu espaços restritivos aos moradores das vilas, em um tipo de formulação consonante ao caráter privado, portanto controlado pela administração da empresa (CORREIA, 2012, p. 141).

A Vila Serra do Navio foi uma experiência "embrenhada” na "inóspita e selvagem Amazônia”, junto aos "perigos provenientes da selva”, os "riscos importantes, apenas dissimulados, da malária e leishmaniose”, um verdadeiro contraste à proposição de cidade que subjazia o projeto e seus efeitos espaciais, como interpretou Luiz Espallargas, numa fala entremeada de representações acerca da Amazônia. Em sua crítica, valorizou o “inquestionável compromisso que esse projeto estabelece com a arquitetura moderna mais eficaz e convincente, quando observados os elementos e decisões que constituem seu desenho, quando se considera que cumpre todo o arco que vai do desenho da cidade ao desenho da colher”, portanto quando se realiza como um projeto total. 


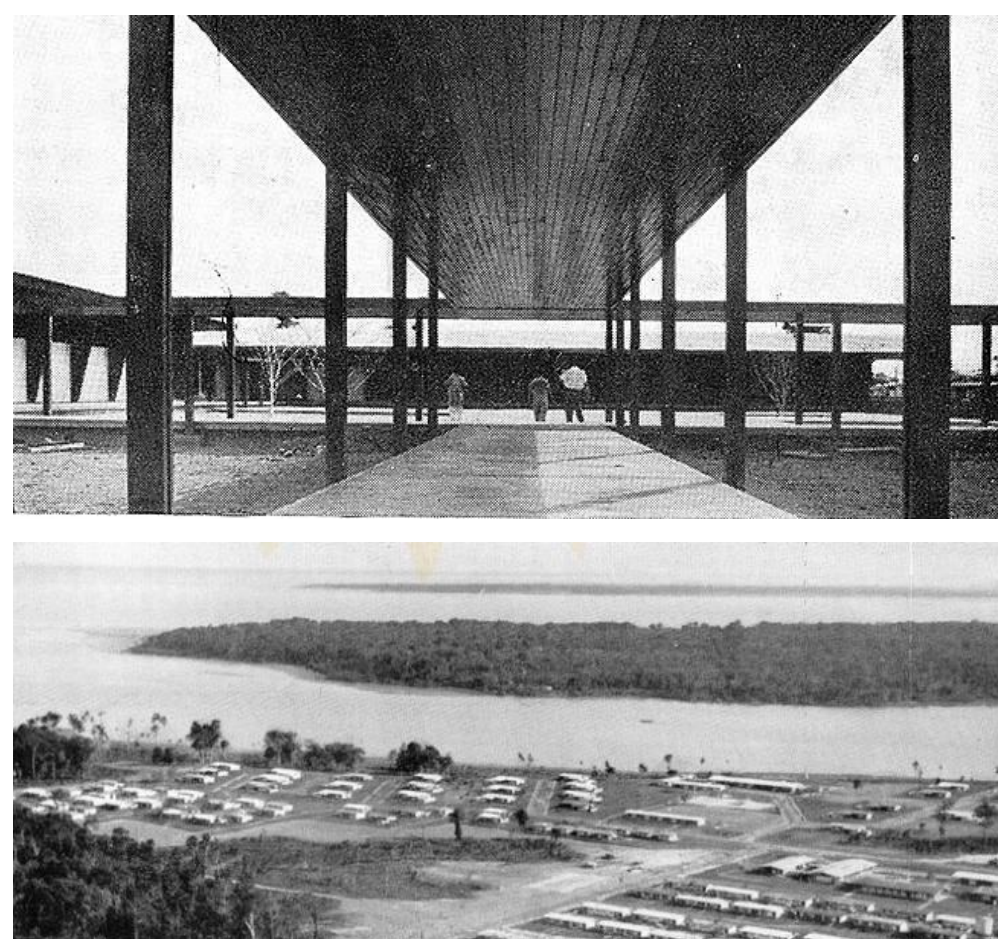

Esquema técnico das construções

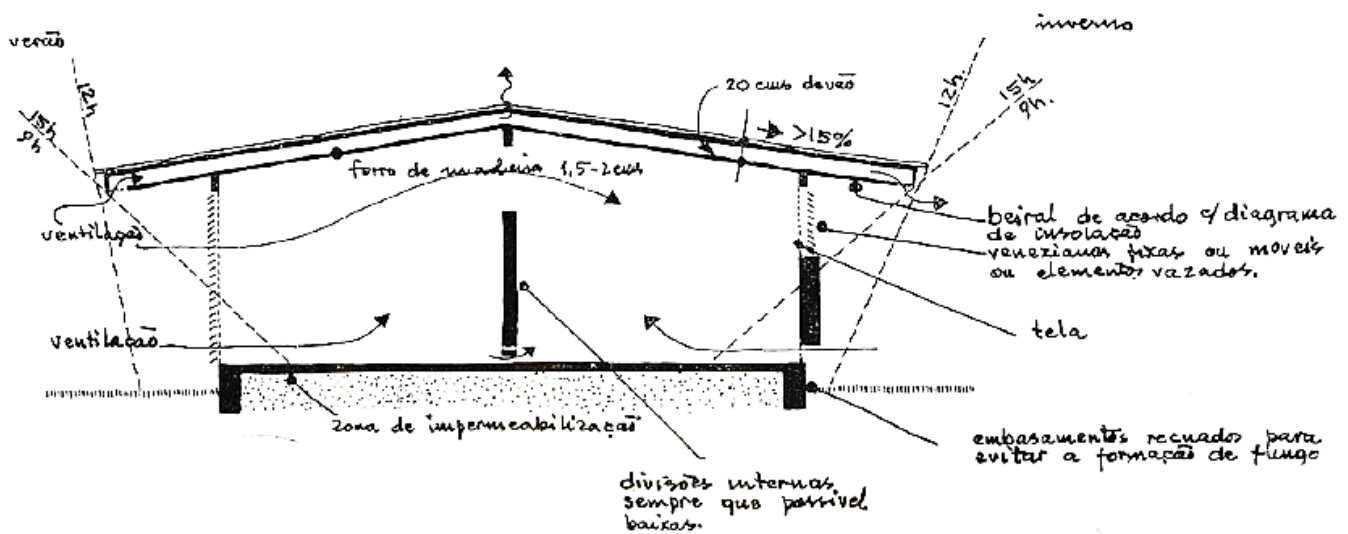

Figura 77 - Espacialidade moderna, construção racionalizada e desenho da paisagem civilizatória na Amazônia, numa tríade sintética do projeto de Bratke em imagens veiculadas na Revista Acrópole. Fonte: ACRÓPOLE n.326, 1966.

Não houve uma tentativa de mimetização da paisagem por parte de Oswaldo Bratke, embora no projeto tenha buscado responder racionalmente à natureza, na espacialidade exterior que envolveu o interior das edificações projetadas, uma "solução moderna e universal” adaptada à floresta amazônica “sem dar margem à dúvida”. A validação do projeto de Bratke foi evidenciada desde esse raciocínio de rebatimento moderno em contexto natural, perpassado pelo "escrúpulo" no ato projetual e o respeito à uma cultura disciplinar do projeto (ESPALLARGAS, 2009, p. 67-69): 
Se essa arquitetura encontra seus artifícios para melhor adaptar-se às condições climáticas tropicais, isso não quer dizer que, para isso, tenha que renunciar à experiência moderna consolidada. Bratke desenha na floresta sem ocupar-se com o folk, o vernáculo ou o regional, sem precisar inventar ou copiar uma arquitetura apta e especial para essas condições adversas, como se o moderno fosse demasiado fino ou delicado para enfrentar a condição rude. Como se o moderno fosse esnobe e refinado demais para essa gente e cultura embrutecidas.

$[\ldots]$

Para defender a solução climática adequada, todos os cronistas deste projeto urbano apressam-se em exibir a série de belos desenhos de Bratke dedicados às palafitas, aos ranchos caboclos, mas não fazem menção à solução do problema por intermédio da simples e competente aplicação da internacional arquitetura moderna, com beiral, ventilação cruzada e paredes rebaixadas entre os cômodos. É importante insistir que a construção da Vila Serra do Navio não é devedora de qualquer tipo de regionalismo em que se interpretam técnicas e materiais locais e convocase toda a sabedoria ancestral e acumulada para construir de maneira adequada e comprovada, no lugar. $\mathrm{O}$ arquiteto propõe e constrói em seu tempo, com o que conhece, e isso deve frustrar aqueles que esperam traços de brasilidade num desenho particular e justificado pela Amazônia.

O projeto de Oswaldo Bratke, nesta perspectiva, foi fruto da racionalidade moderna aplicada à constituição da paisagem civilizatória de determinação do lugar. $\mathrm{Na}$ década seguinte, ela seria capturada pelo discurso governamental e de intelectuais locais, que encontraram nas soluções adotadas pelo arquiteto, ajustamento às suas próprias expectativas de modernização regional construtiva. Das leituras que realiza sobre o ambiente o qual receberia a intervenção colonizadora, são os registros dos relatos de Bratke que possibilitam também a compreensão dos distanciamentos que estabelece entre a precedência e suas propostas. Em distinção ao que a vernacularidade ou a tradição lhe pudesse revelar, sua concepção de paisagem, ajustada à própria temática de uma cidade controlada, a todos os condicionantes materiais e logísticos que lhes foram determinantes ao projeto, perpassada pelo ato projetual racional, foi uma paisagem pensada pelo paradigma da civilização.

Uma paisagem civilizatória, portanto, expressa nas próprias falas e desenhos de Bratke, em oposição ao estágio primitivo com que viviam os nativos. A crítica, em geral, quando releva esta dimensão do projeto de Bratke, o faz a partir do paradigma da dualidade quando de seu “enfrentamento” da Amazônia. Para Hugo Segawa, por exemplo, o projeto foi essencial para a transformação do local "distante", "perdido”, em um lugar concretamente, por meio de atitude desbravadora e até certo ponto inédita, já que não havia 
“nada sistematizado" a respeito daquela região, no tocante às suas características físicas e climáticas, o que o arquiteto investigou em sua "aventura amazônica” (SEGAWA, 1996, p. $675)$.

Diante das consequências ambientais acarretadas pela atuação da Icomi no Amapá e com o tombamento de Vila Serra do Navio no ano de 2010, fica evidente que se por um lado os impactos sociais advindos do empreendimento afetaram sobremaneira a região, sem produzir desenvolvimento regional, o feito arquitetônico e urbanístico extrapolou o caráter estrito do encargo. Os projetos das vilas constituíram a paisagem civilizatória que serviu como referência à disciplina, quando transcorrida na região, pela arquitetura e a modalidade construtiva que ali se realizou, mas por outras experiências que seriam dadas, especialmente no âmbito da arquitetura. O projeto foi referência para uma geração de arquitetos que pensaram a arquitetura na Amazônia, especialmente pelas soluções construtivas racionais ajustadas aos meios construtivos e ao clima.

Entre os intelectuais locais e outros segmentos interessados na produção e promoção de uma arquitetura moderna na Amazônia, esta foi a materialização primordial de um discurso, transposto à solução projetual. Bratke incorporou racional e objetivamente o lugar onde foram implantados os dois projetos que foram enclaves de modernização, concebidos desde uma ideia de paisagem civilizatória à novas cidades na Amazônia. A homenagem que recebeu na $8^{\mathrm{a}}$ Bienal de São Paulo conferiu visibilidade ao projeto naquele ano de 1965, uma "concepção arquitetônica diretamente ligada às condições de solo e de clima, existentes na região", (ARQUITETURA-IAB N.41, novembro de 1965). Transpondo racinoalmente soluções construtivas e espaciais desde a disciplina à ressignificação dos referenciais sociais e culturais locais, e do lugar, o arquiteto concebeu uma paisagem civilizatória à Amazônia.

\subsection{A paisagem industrial, Suframa em Manaus}

Uma das imagens referenciais do edifício sede da Superintendência da Zona Franca de Manaus-AM, assim considerada pelo fato de recorrentemente ter sido publicada nas revistas, é a que o enquadra numa perspectiva alinhada à malha ortogonal que orientou o projeto de Severiano Porto, e põe em primeiro plano os cones de ventilação que idealizou para a cobertura, composta em conjunto por tais unidades modularmente dispostas em 
pauta geométrica horizonal. $\mathrm{Na}$ fotografia, eles são avistados replicadamente, em direção ao segundo plano da imagem [figura 79-2]. Uma elevação vertical do ponto de vista deslocou a observação apreendida pela fotografia, para acima da altura do topo dos cones, o que revelou ao fundo, e em panorama, uma perspectiva ampliada do horizonte unicamente composto pelo maciço vegetal que circundava a edificação recém-construída. Nenhum outro edifício aparece na imagem, apenas este. Tal fotografia referencial, inclusive, está presente na primeira publicação do projeto em 1975, na revista CJ Arquitetura (CJ ARQUITETURA N.8, 1975).

O edifício da Suframa foi um dos objetos pioneiros numa paisagem que estava sendo construída, em significado e materialidade, na conjuntura da intensificação da urbanização da Amazônia, com a direta interferência do Estado na região, com o Plano de Desenvolvimento Nacional e na década de 1970, com a implantação dos planos desencadeados por uma geopolítica militar, relacionados ao Programa de Integração Nacional destinado à ocupação efetiva da Amazônia. Além das várias formas de urbanização espontâneas na Amazônia, a empreendida pelo Estado, com o incentivo ao urbanismo rural, criação de cidades, projetos de colonização em novos eixos de circulação, atração de povoamento para organização do mercado de trabalho, foram as mais efetivas. Elevadas taxas de crescimento urbano, as maiores do país entre os anos de 1970 e 2000, decorreram dessa estratégia interventiva levada à ocupação da Amazônia, na qual a Zona Franca de Manaus teve papel preponderante (BECKER, 2013, p. 33). Esta foi uma área de livre comércio de importação e exportação e de incentivos fiscais, para criação de um centro industrial, comercial e agropecuário no interior da Amazônia, “criada como um instrumento integracionista, num momento de ascendência do comércio internacional de hegemonia dos Estados Unidos sobre outras nações capitalistas” (SOUZA 1978, p.157).

Já no início da década de 1960 era aventada pelo então governador Plínio Coelho a construção de uma cidade industrial nos arredores de Manaus, "um distrito industrial rigorosa e tecnicamente planejado, para a instalação das futuras industrias”, na perspectiva de um "surto desenvolvimentista" para a cidade, sem que no entanto fosse realizado (JORNAL DO COMÉRCIO, 1963). 


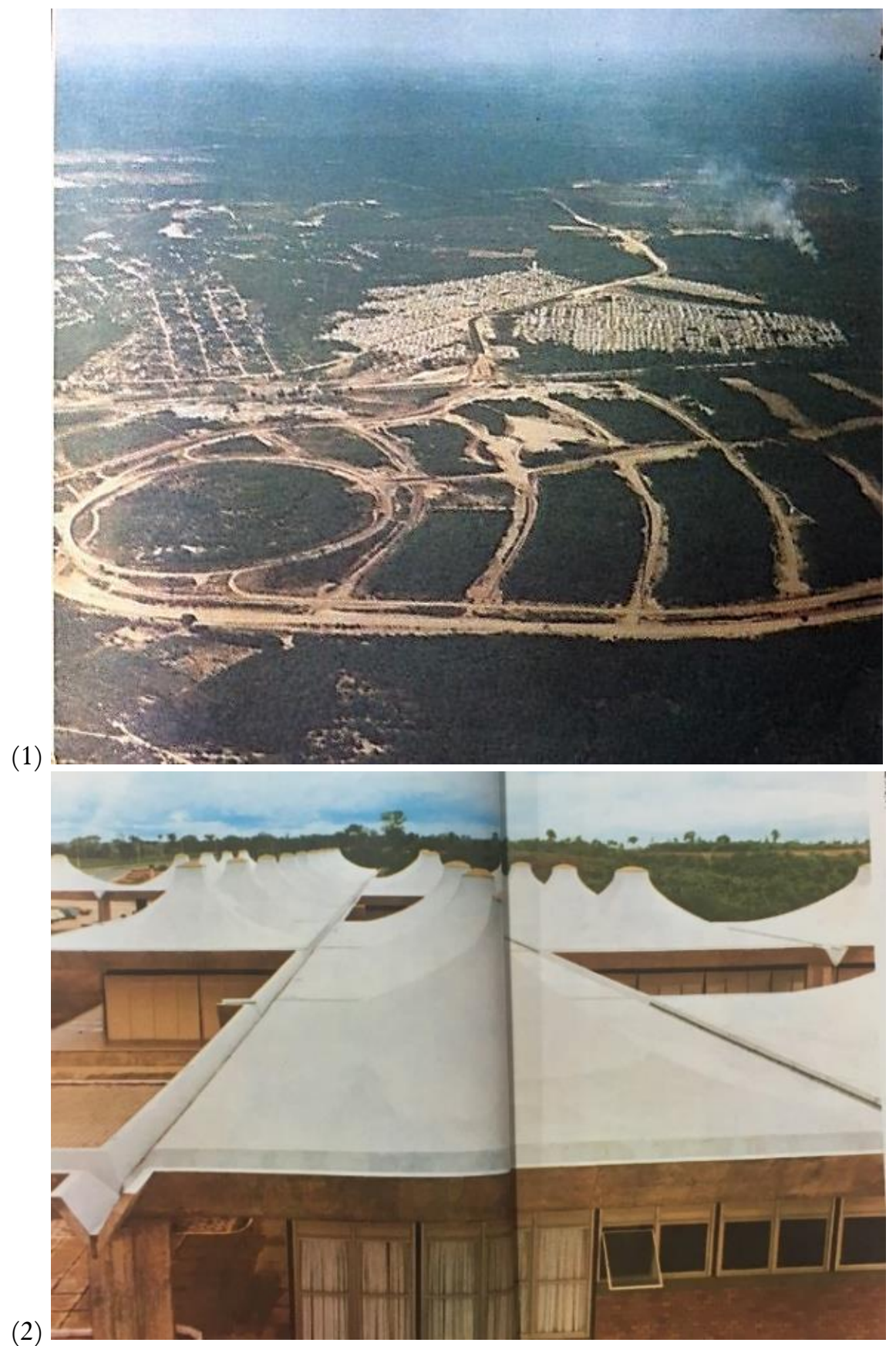

Figura 78 - (1) Perspectiva da implantação do Distrito Industrial em Manaus-AM (SUFRAMA, 1971); (2) Paisagem da recente industrialização em uma perspectiva da sede da Suframa (CJ ARQUITETURA n.8, 1975).

Em 1957, havia sido criada uma "Zona Franca na cidade de Manaus", por Juscelino Kubitschek, por meio da Lei no 3.173. Esta lei foi totalmente alterada em 1967, pelo Decreto-Lei no. 288, de 28 de fevereiro de 1967, que além de reestruturar a Zona Franca de Manaus, também criou uma Superintendência - SUFRAMA para administrá-la e atrair a instalação de indústrias na cidade. Os efeitos da instituição da ZFM no espaço urbano 
ocorreram a partir desse segundo momento, durante a ditadura militar, sob a justificativa de desenvolvimento econômico da região. O Plano Diretor desenvolvido por Luiz Antony e Pereira da Cunha para Manaus, tinha esse propósito inicial, o de alterar o anteriormente desenvolvido para o município, em 1965, justamente pela "necessidade de se criar um Distrito Industrial”. Outros projetos eram conciliados a este, o de conjuntos habitacionais, de arborização urbana, de um palácio cultural (ABA N.1, 1967-68, p. 53-54).

A partir de finais de 1969, foi iniciada a implantação do Distrito Industrial, depois de um processo de negociações junto ao Estado para a captação de investimentos para a capital, período no qual foram realizadas as atividades de planejamento e as obras de infraestrutura para implantação de novas empresas na cidade. O loteamento do novo Distrito foi estabelecido em 1970, à época, sua área equivalia a 3/4 da área urbana da cidade. Neste ano, as redes de abastecimento estavam sendo construídas, bem como o aterramento de áreas alagadas e canalização de esgotos, tendo sido no ano seguinte, concluídas as redes de energia e iluminação pública. Em 1971 o projeto desenvolvido por Severiano Porto estaria concluído, pensado para o novo Distrito, à margem direita da BR-319.226 O Jornal do Comércio assim noticiava a construção da sede da Suframa em 1972, em matéria intitulada "nova sede da Suframa é o progresso do Amazonas" (JORNAL DO COMÉRCIO, 1972, p. 3):

A nova sede da Superintendência da Zona Franca de Manaus, que será erguida no Distrito Industrial, terá 2 mil metros quadrados de área construída. O projeto é do engenheiro arquiteto Severiano Porto e custará aproximadamente 11 milhões de cruzeiros, devendo ficar pronta em dezembro de 1973. O seu projeto é muito original abrigando 48 módulos onde funcionarão todas as divisões e secções da SUFRAMA. A arquitetura será moderna e além da parte administrativa, possuirá anfiteatro, auditório, garage, oficina e outras dependências.

Os lotes do novo DI teriam um tamanho médio de $10 \mathrm{mil} \mathrm{m} 2$ cada. No ano de 1973, três fábricas estavam em construção e os lotes de outras nove estavam sendo preparados para a construção do aparato industrial. Uma segunda e terceira áreas já haviam sido previstas para ampliação do setor industrial da capital. A esta altura haviam sido destinadas concomitantemente, as áreas para construção de diversos equipamentos de porte, a saber, a Universidade do Amazonas e o Departamento de Portos e Hidrovias. A paisagem da

\footnotetext{
${ }^{226}$ Rodovia que ligaria Manaus a Porto Velho, não asfaltada até o presente.
} 
industrialização era extensiva à cidade, ainda que sintetizada na implantação de um novo distrito, do qual a Sede da Suframa constituiu um evento demarcatório, simbólico e material.

(1)

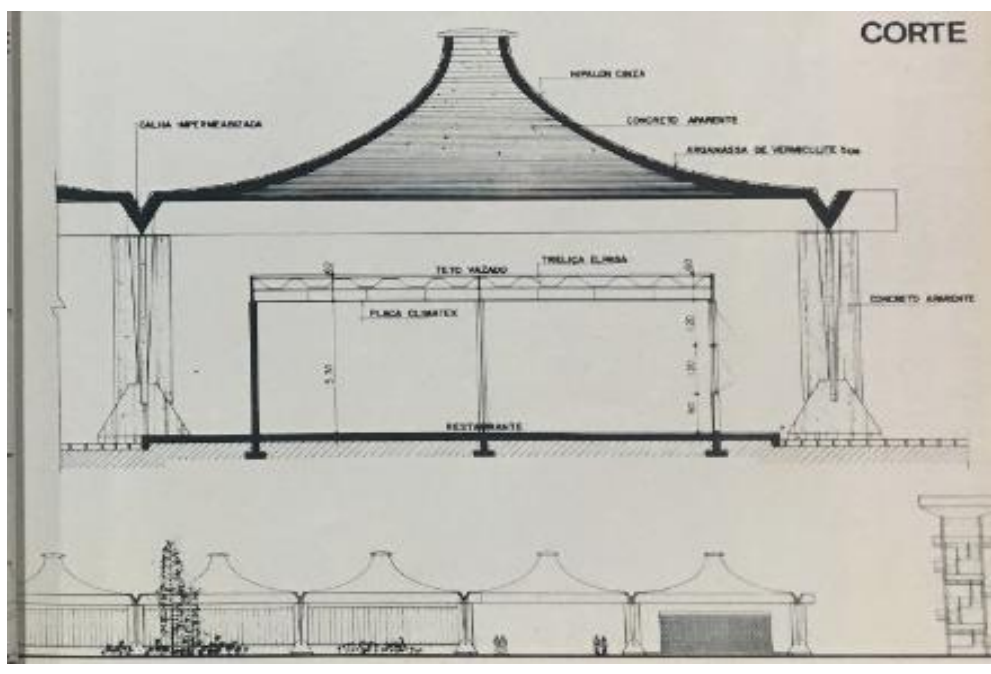

(1)

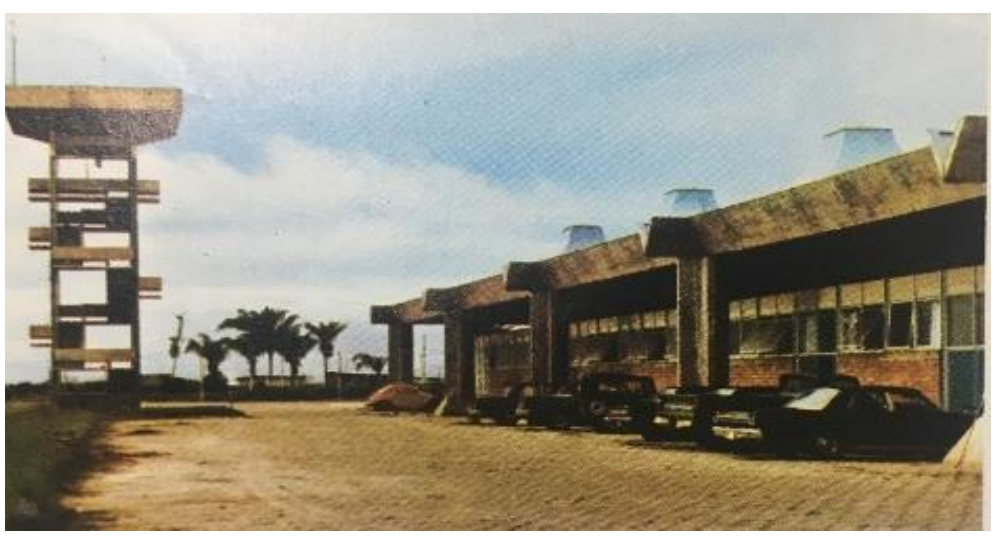

(2)
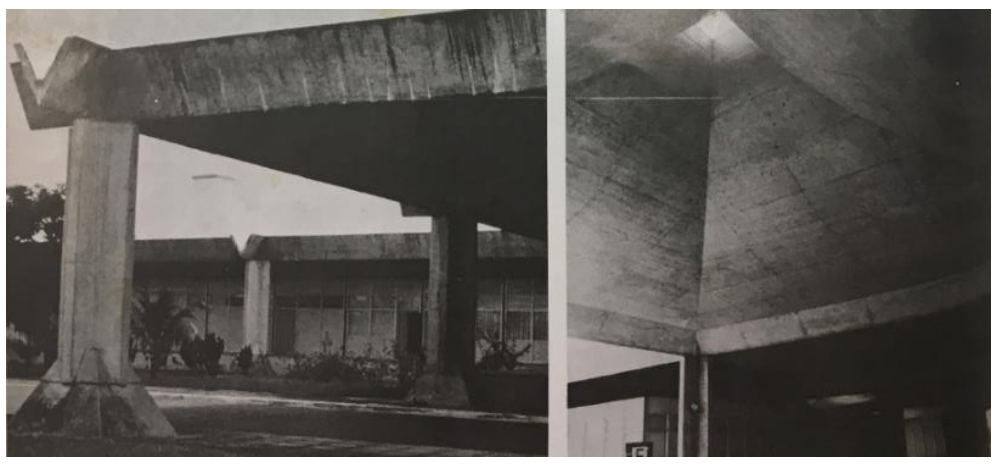

Figura 79 - (1) Suframa, de Severiano Mário Porto, na XII premiação anual do IAB - GB. Fonte: CJ ARQUITETURA n.8, 1975, p. 6-7,18-23); (2) Publicação da mesma obra na revista Projeto. Fonte: PROJETO n.83, 1986, p. 46.

O processo de industrialização que estava sendo induzido em Manaus foi demarcado pelo ritmo de implantação de novos conjuntos habitacionais no período, e a ampliação do contingente populacional local, demandando em 1975, a contratação por parte da Prefeitura, de um Plano de Desenvolvimento Local Integrado, quando passaram a ser estabelecidos os zoneamentos urbanos locais. As novas arquiteturas, dada esse processo de 
transformação urbana, compuseram artifícios da estruturação do próprio território e a implantação do Distrito Industrial nesses anos, em área de expansão urbana da cidade, concorreu diretamente para o ajustamento de limites físicos e espaciais urbanos.
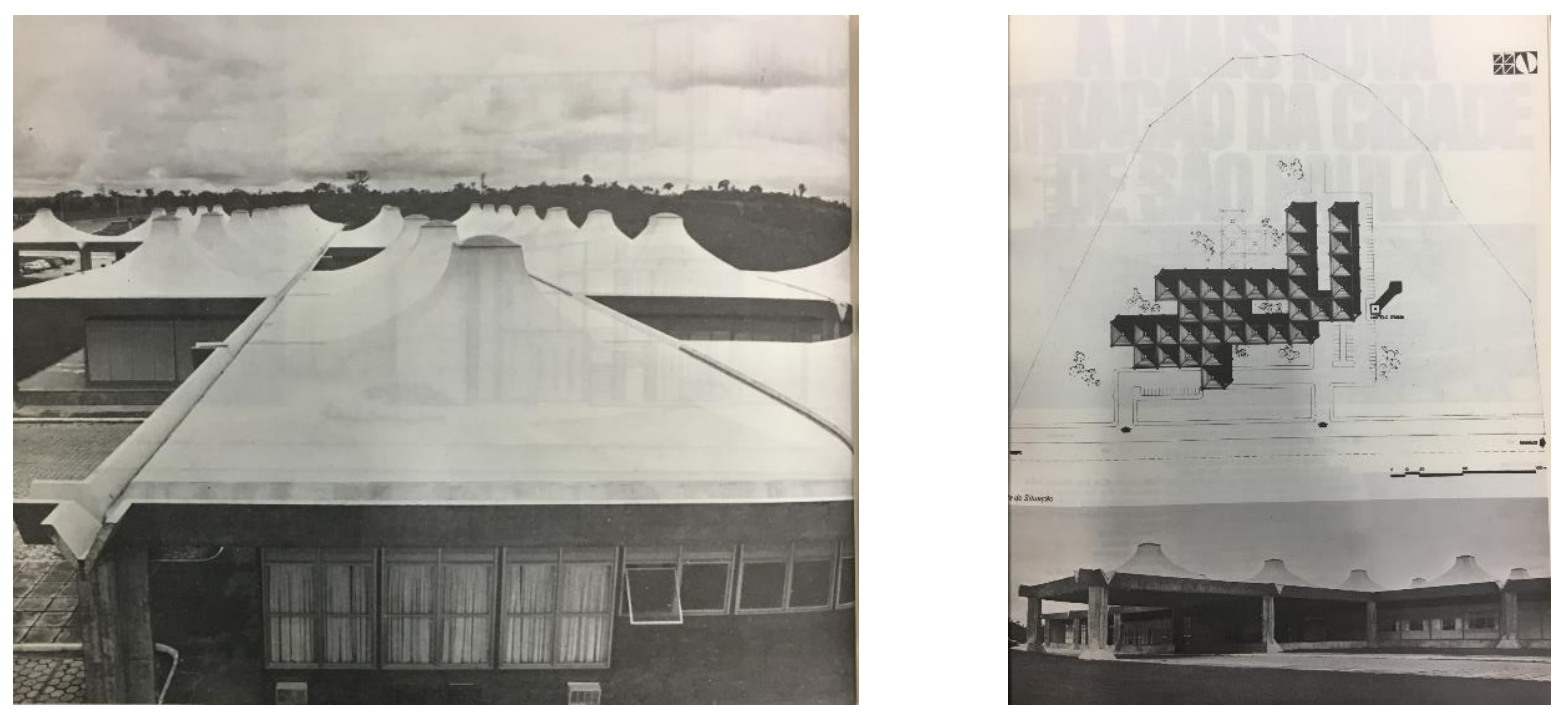

Figura 80 - Suframa e implantação por malha expansiva. Fonte: PROJETO n.40, 1982.

A sede da Suframa não tinha sido finalizada, ainda que sua inauguração estivesse prevista para o ano de 1973 (JORNAL DO COMÉRCIO, 1973, p. 3). Passou a funcionar no ano seguinte, em 1974, tendo sido concluída em 16 meses pela construtora Norberto Odebrecht, com 7.500 mil metros quadrados, concentrando as atividades antes dispersas em duas edificações na área central da cidade. O edifício, constituiria uma "das mais belas obras de arquitetura do norte brasileiro" (JORNAL DO COMÉRCIO, 1974, p. 4), segundo o jornal local, que frequentemente reportava as qualidades do trabalho de Severiano Porto, denotando o reconhecimento social e profissional angariado pelo arquiteto nesse período em Manaus.

Neste projeto, Severiano Porto pôs em diálogo a Amazônia e a prática mais atualizada da disciplina da arquitetura, em particular, a referida numa terceira geração de arquitetos alinhados à moderna arquitetura, porém, situados em vertentes que reformularam o pensamento disciplinar desde os anos de 1950. Em particular, é possível associar a obra em questão, à experiência holandesa, no que tange o distanciamento da tradição estrita da cultura moderna na arquitetura. Esta relação se deve à atenção que arquitetos como Aldo van Eyck despenderam à "recuperação do vigor plástico da arquitetura racionalista", produzindo soluções que influenciaram a prática disciplinar, a exemplo do "uso de malhas geométricas, a busca da flexibilidade, a definição de espaços 
neutrosque facilitem a apropriação por parte dos usuários, a recorrência a formas e volumes arquetípicos” (MONTANER, 2001, p. 54).
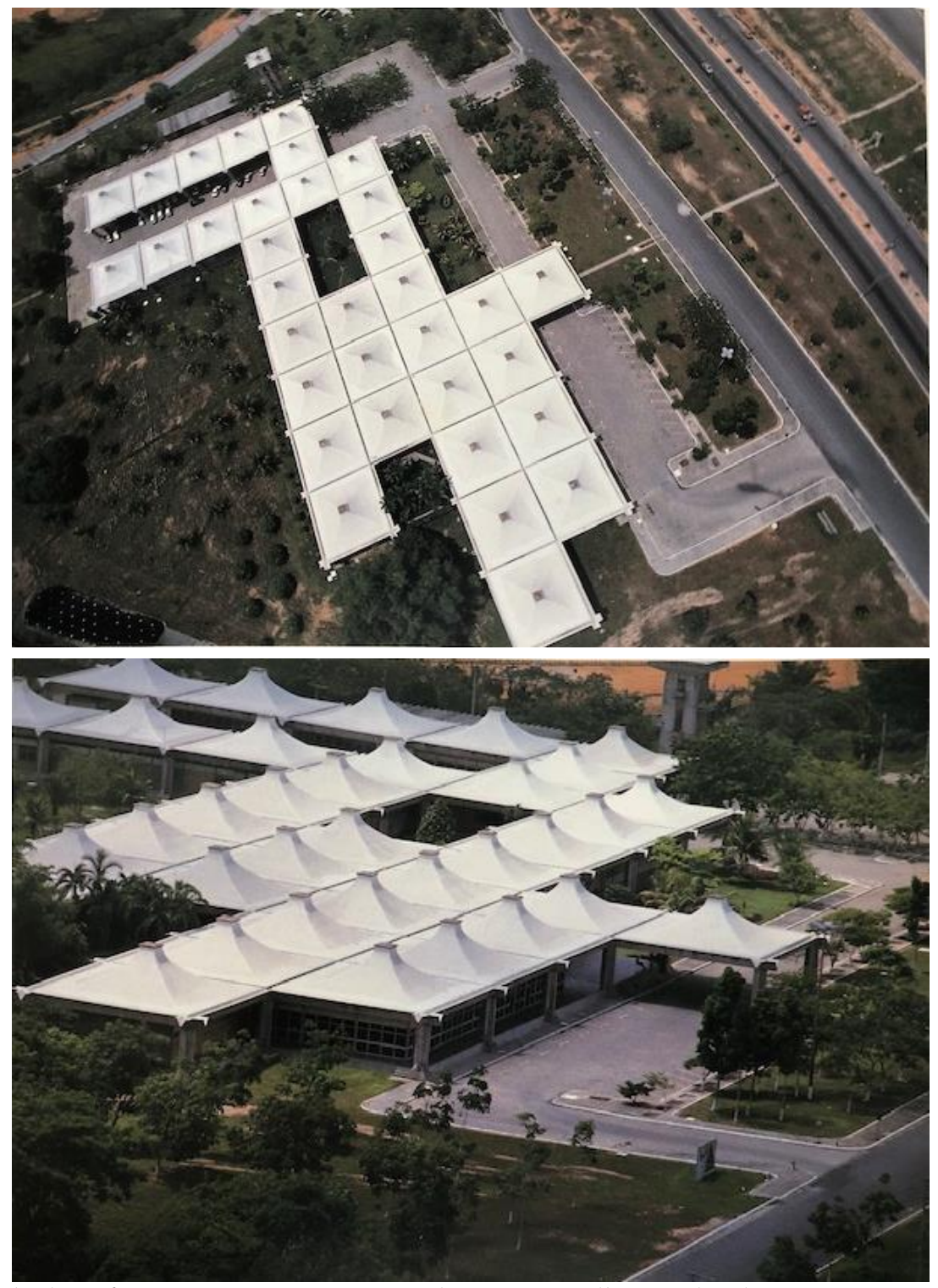

Figura 81 - Sede da Suframa em registros que evidenciam a malha regular do projeto e a ênfase conferida pelo arquiteto à cobertura. Fonte: BENCHIMOL, 1989.

Esses mesmos atributos nortearam a memória relatada na revista CJ Arquitetura, onde foi ressaltada a capacidade de representação do projeto, da "intenção firme e definitiva do Governo Federal de desenvolvimento e industrialização da região”. Deste modo, a arquitetura da sede da Suframa deveria refletir "solidez", "tecnologia atual”, ao mesmo tempo garantir "flexibilidade” em seus espaços. Quando da premiação da obra, o júri se manifestou a respeito das qualidades da sede da Suframa, quando da XII premiação do IAB (CJ ARQUITETURA N.8, 1975, p. 22): 
O prédio pertence a uma agência governamental e a expressão da arquitetura corresponde à sua função, destacada no âmbito local, sem lançar mão de recursos suntuários e de ostensiva monumentalidade. Distribuição planimétrica apoia-se em um elemento celular agrupado de maneira bastante livre, formando pavilhões e pátios. Sugere ainda a possibilidade de futuras expansões do prédio. As circulações seguem uma trama nítida, tornando espontâneo o acesso às diversas funções do programa.

Deste modo, a arquitetura da Suframa também respondeu em termos práticos e como metáfora, às expectativas de expansão das atividades industriais em Manaus - AM. Situada em terreno sem limites urbanos precisos, o projeto composto pela malha horizontal, foi adequado à demanda de ampliação, e conferiu à paisagem, sentido similar. As qualidades projetuais da Suframa, frequentemente enunciadas quando de sua publicação, especialmente a partir da década de 1980, denotaram a notabilidade inventiva do arquiteto. Sua obra passou a ser referenciada como tendência, também como linha alternativa projetual à Arquitetura no Brasil (PROJETO N.53, julho de 1983) (PROJETO N.42, maio de 1982), mas quanto ao edifício, desde sua particular expansividade, Severiano Porto contribuiu à constituição de uma concepção de paisagem industrial na Amazônia, em conformidade com a nova instituição para a qual desenvolveu o referido projeto.

\subsection{A paisagem da memorialização da perda, Centro de Proteção Ambiental em Balbina -} $\mathrm{AM}$

A construção de uma usina de geração de energia para abastecimento da cidade de Manaus - AM vinha sendo aventada desde 1971, quando em 1973 foi contratado pela Eletronorte o “inventário hidrelétrico da região", período em que o governo decide sobre a construção de uma hidrelétrica no rio Uatumã. Em 1978, foi iniciada a construção da estrada de acesso ao local de implantação da Usina, desde a BR-174 (Manaus- Boa Vista), cujas obras foram iniciadas em 1981, e em 1989 viabilizaram seu funcionamento. Segundo o geógrafo José Aldemir de Oliveira (OLIVEIRA, 2000, p. 160-164):

A hidrelétrica de Balbina foi, dos projetos públicos executados recentemente na Amazônia, o mais criticado. As críticas iam da inviabilidade econômica, ao impacto causado ao meio ambiente e ao desrespeito aos direitos das populações atingidas. A sua construção mostrou de forma inequívoca os resultados e os contrastes de um planejamento centralizado, autoritário e excludente que norteou a ação do Estado para a Amazônia. Balbina não se 
explica per se. Embora existam as especificidades, Balbina só se explica quando analisada como parte de um contexto mais amplo que inclui a produção e a reprodução do espaço para atender ao processo de integração nacional que significa enquadrar o território a um único e global modelo capitalista cada vez mais exigente de infraestrutura para fazer frente às necessidades de exploração dos recursos naturais da Amazônia.

Deste modo, para a compreensão da paisagem de Balbina, dada a presença do Centro de Proteção Ambiental - CPA da Vila que serviu de apoio ao funcionamento da Hidrelétrica, há que se considerar a conjuntura e as circunstâncias em que foi realizada. $\mathrm{O}$ $C P A$ não foi fruto de uma ação planejada a priori, mas de uma medida compensatória frente aos danos provocados pela instalação de ambos os aparatos, da Hidrelétrica e da própria Vila. Os estudiosos de Balbina são unânimes a demonstrar, como o fez o geógrafo José Aldemir de Oliveira, a frequente divulgação parcial de informações, seu desencontro ou ocultamento por parte das estruturas governamentais. No planejamento, a hidrelétrica foi pensada para abastecer $80 \%$ do consumo de energia em Manaus, de 1985 a 1994. Este percentual foi reduzido a 65,5\% em 1987 a 1993 e, mais tarde, a 55\%, tendo sido questionada a sua construção amplamente, dada a baixa vazão do rio Uatumã e sua inadequação aos fins de geração de energia. ${ }^{227}$ Nele, os moradores diretamente afetados pela obra, tiveram que desenvolver por si só, seus “próprios meios de sobrevivência”, tamanhos os prejuízos socioambientais acarretados pela construção da Usina e até o presente lutam judicialmente para reaver o que perderam. Quanto ao prédio do $C P A$, José Aldemir de Oliveira apresentou uma posição, estabelecendo sua própria narrativa daquela paisagem (OLIVEIRA, 2000, p. 95):

Chega-se à vila e por um instante tem-se a impressão de uma paisagem que se diferencia da vila de Pitinga e da cidade de Presidente Figueiredo. À frente, no sentido norte, surge uma larga avenida com dupla pista e canteiros centrais ajardinados. $\mathrm{Na}$ primeira construção que se vê, predomina madeira em blocos arredondados com cobertura de cavacos dispostos em círculo, numa tentativa do arquiteto de assemelhar o seu projeto a uma aldeia indígena. Numa região saturada pela mesmice e caracterizada pela despreocupação com a estética, não deixa de surpreender esse tipo de construção que busca os motivos e matérias-primas do lugar para estabelecer um novo padrão arquitetônico, adaptando-o principalmente às condições climáticas. Ao mesmo tempo, esteticamente, busca o equilíbrio recorrente por meio de traços suaves, visando amenizar o impacto visual da construção de uma cidade no meio da floresta. $\mathrm{O}$

\footnotetext{
${ }^{227}$ Mesmo os técnicos que a priori defenderam a construção da Hidrelétrica, passaram a negá-la e questionar de sua implantação.
} 
prédio do (Centro de Pesquisa Ambiental) tem em suas formas uma tentativa de produzir estética e funcionalmente construções adaptadas às condições da Amazônia. $O$ prédio talvez não tenha nenhuma beleza. Olhando-o de perto percebe-se até um excesso de concreto. A avenida, com as suas largas pistas e seus canteiros centrais, não tem qualquer razão de existir.

Sua leitura tonalizada pela crítica, apreendeu o edifício em uma paisagem referenciada no processo de destruição pela construção da usina que o próprio geógrafo acompanhou. A fala de José Aldemir, desde o interior do fenômeno, apresenta uma posição distinta das publicações de arquitetura quando se referem ao CPA como tendo sido fruto da mobilização intencional de compensação pelos danos ambientais da usina, como encargo antevisto de início. A leitura desta obra, quando esvaziada completamente do processo ao qual se refere José Aldemir, demove da perspectiva de compreensão, a arquitetura elaborada para a Amazônia paisagem, pois a distancia tanto dos motivos de sua realização, quanto dos significados capturados pelo arquiteto do processo que chegou ao encargo, reelaborado no ato projetual. Tal esvaziamento remove sentidos conferidos quando da concepção do edifício e de sua interpretação, portanto, parcela importante do conteúdo que o explica e ao seu significado.

A construção do CPA foi ao tempo de sua realização, a própria demarcação da exaustão do processo interventivo do Estado na região, contra o qual a sociedade amplamente se posicionou. A revista AU de número 11 foi a primeira publicação identificada nas fontes, que registrou o CPA de Balbina, como um projeto (AU N.11, fevereiro e março de 1987, p. 53-57). Na descrição, apresentou o CPA com a "finalidade justamente de estudar e acompanhar" aqueles "desequilíbrios" que seriam advindos da implantação da hidrelétrica. Sua importância, como abrigo às atividades continuadas de monitoramento e registro dos "acontecimentos anteriores à construção ocorridos durante o período de sua implantação e os posteriores ao seu término de funcionamento", ou seja, seria um aparato muito dependente do interesse público em garantir a perpetuação dessas práticas no local da Usina. Para tanto, o arquiteto engendrou um complexo estrutural com madeiras "recém-tiradas" das áreas de inundação. Elas foram utilizadas na totalidade do complexo, nas estruturas, na cobertura em cavaco, vedações, coberturas de transição. Passagens e cobertas livres foram organicamente dispostas no sítio, possibilitando 
diferentes trânsitos e formas de circulação. Sob a cobertura principal, foram situados os recintos fechados, ainda que envolvidos pela espacialidade circundante.
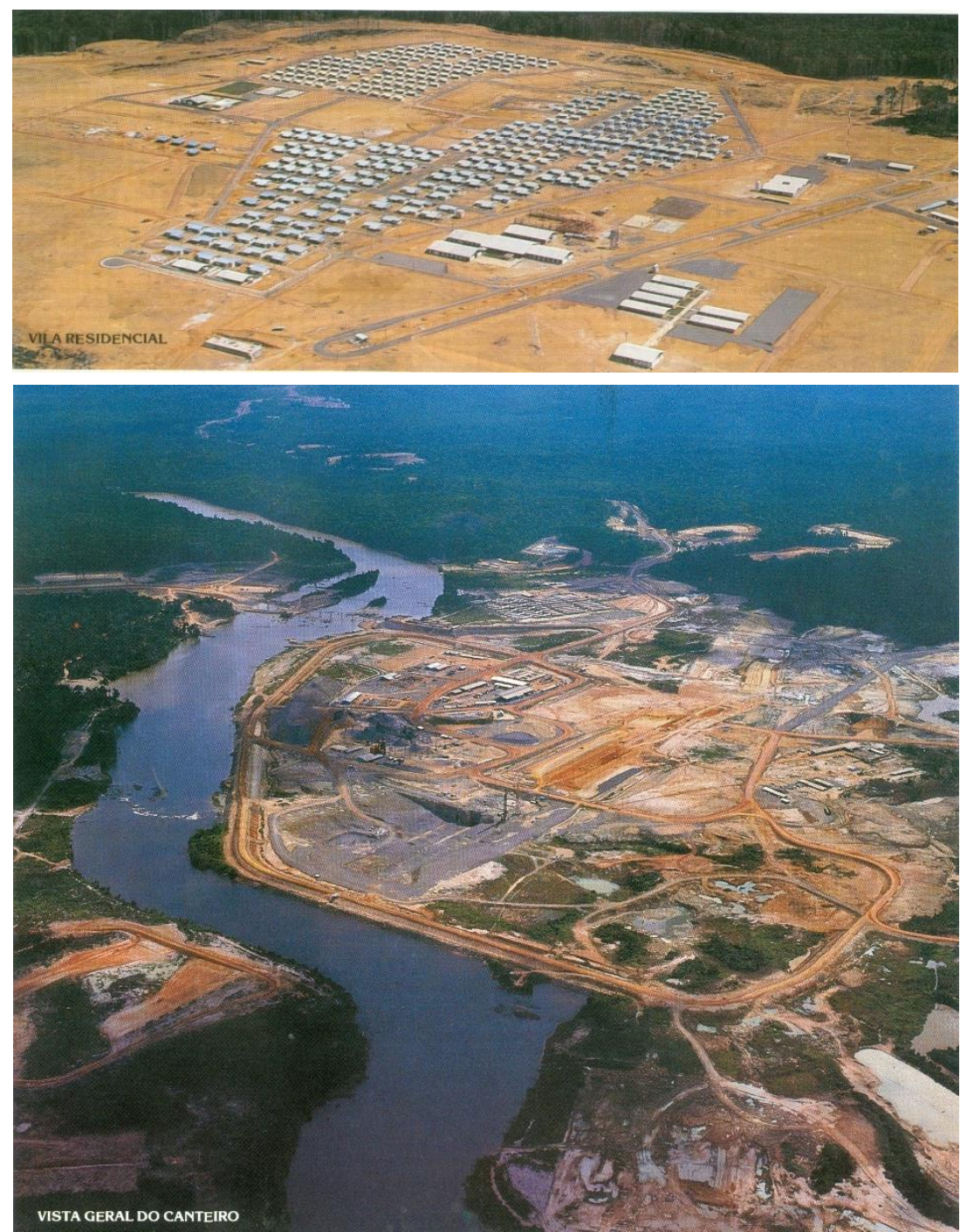

Figura 82 - Vila e vista geral do canteiro de Balbina - AM. Fonte: ELETRONORTE, 1982.

A proposta de Severiano Porto condensou e converteu elementos de uma paisagem amazônica que estava sendo substancialmente impactada, bem como os modos de vida e meio natural pré-existentes ao local de implantação de Balbina - AM, alterados pelo desmatamento, inundação e implantação novo aparato industrial e Vila. O equipamento foi projetado pelo arquiteto para atender ao programa que deveria dar suporte a atividades técnicas, de pesquisa e monitoramento ambiental diante dos impactos da intervenção. A 
paisagem que Severiano propôs, foi demarcada pelo uso da madeira residual daquela devastação (PROJETO N.125, 1989):

O Centro de Proteção Ambiental de Balbina, concebido para estudar e acompanhar os impactos decorrentes da construção e operação da hidrelétrica de Balbina, a primeira de grande porte executada no Estado do Amazonas, levou em conta o fato de que a ampla área seria inundada na fase de formação do lago. A floresta, portanto, seria atingida, e com ela todo o seu ecossistema, com reflexos no clima, temperatura, fauna, flora, etc. Além disso, o registro dos acontecimentos durante a construção da hidrelétrica e a sistematização dos conhecimentos respectivos forneceriam subsídios valiosos e orientação para as demais e futuras intervenções do gênero, na Amazônia, sugerindo providências e caminhos para minimizar os efeitos negativos e prejudiciais de obras dessa natureza na região.
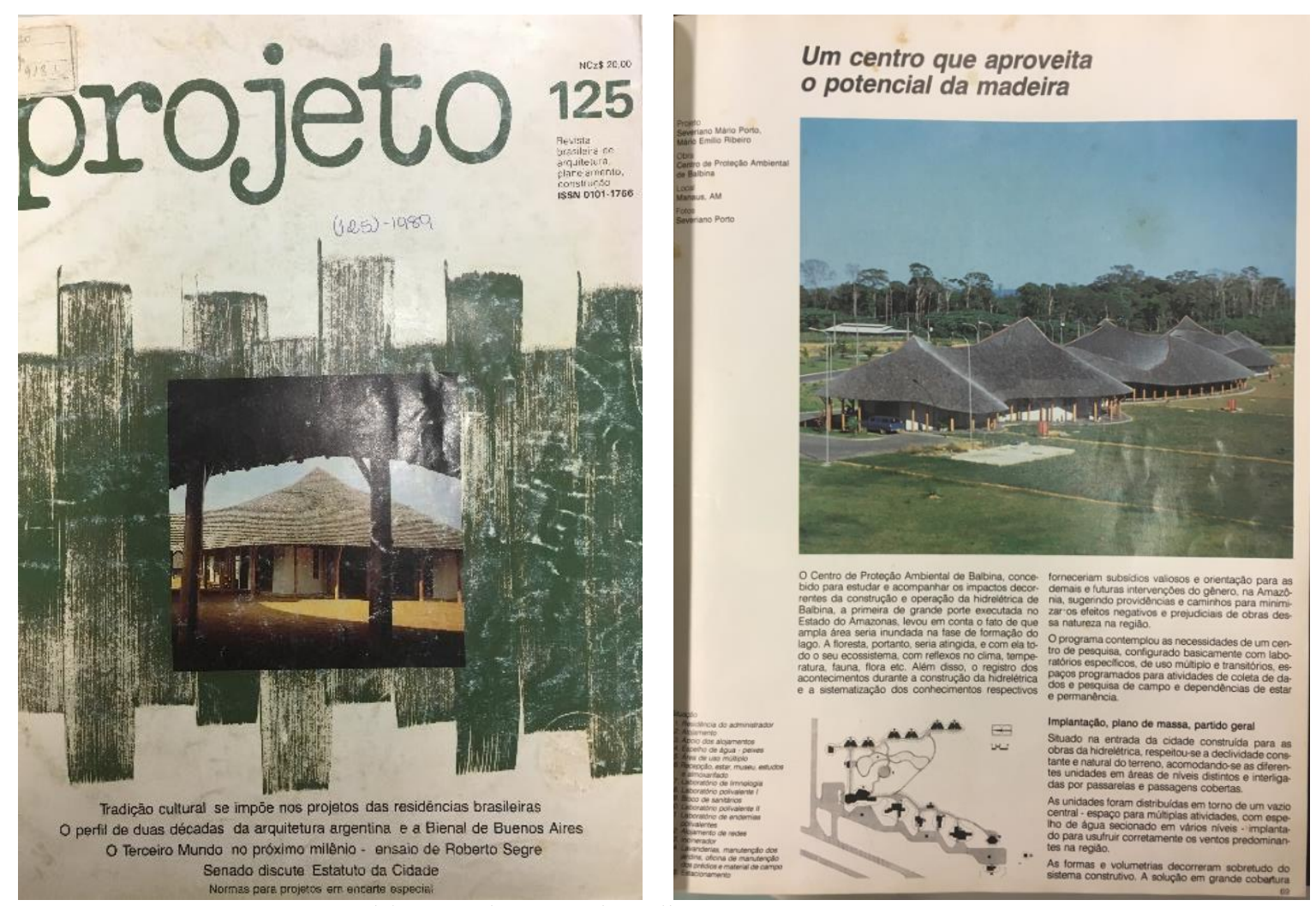

Figura 83 - Publicação do CPA de Balbina. Fonte: PROJETO n.125, 1989.

A localização desta obra junto ao campo disciplinar da Arquitetura, ainda que imprecisa, aponta a algumas questões, tanto pelo processo de sua execução, quanto pela materialidade resultante do projeto implantado. Uma delas diz respeito à defesa da articulação entre antropologia e arquitetura que nos anos de 1960 e 1970 absorveu um relativismo cultural advindo das Ciências Sociais, afetando profundamente a prática do projeto. A prática passou a admitir posturas alternativas, não referenciadas em parâmetros prévios ideais, implicando a adoção de "soluções mais experimentais, atrevidas, versáteis e 
adequadas a cada contexto social, que não imponha modelos senão aprendam de cada lugar" (MONTANER, 2001). Este princípio poderia sugerir uma auto determinação em condição periférica perante a impossibilidade de acesso à recursos tecnológicos avançados, refinados. No entanto esta sugestão não cabe ao projeto em pauta, até mesmo diante de todo o investimento demandado pelo conjunto da obra de Balbina, incluindo grande aparato material ali disposto.

(1)

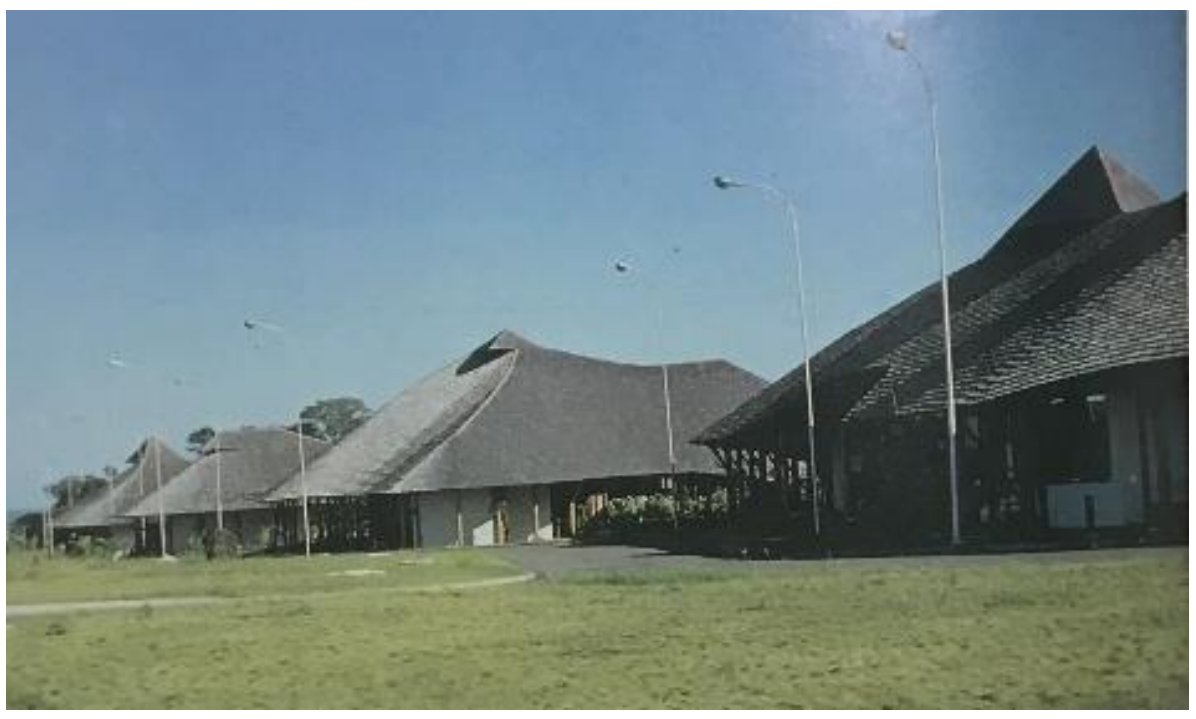

(2)

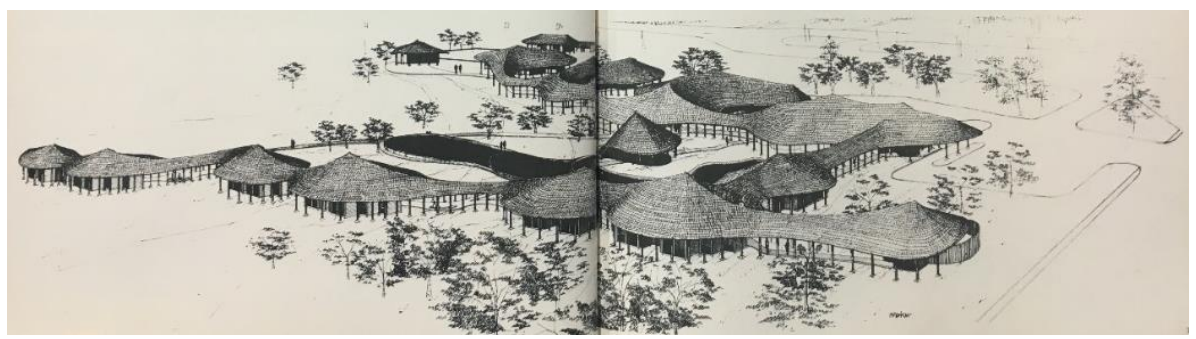

Figura 84 - (1) Centro de Proteção Ambiental de Balbina em imagem do conjunto edificado, enfatizado pela cobertura dominante. (2) Registro em desenho do projeto compondo a paisagem.

Fonte: PROJETO n.125, 1989.

$\mathrm{Na}$ postura projetual que adotou Severiano Porto, a reutilização da madeira residual oriunda do desmatamento da área de implantação da usina e da vila foi um ponto de partida à concepção da obra. Este foi um juízo ambientalmente preservacionista, de certo modo coerente, ainda que de efeitos pouco significativos se interpretados em termos comparativos, quantitativamente, em relação aos danos acarretados pela construção do complexo da usina. Com a utilização do material que seria descartado, o arquiteto presentificou a memória recente, das perdas acarretadas pelo complexo. Por sua vez, ao adensar o projeto com os vestígios materiais do ambiente que precedeu a usina e dada a constituição material da edificação, evocou um conjunto mais ampliado e complexo de 
referências culturais. Um sentido primitivo é presente na obra, quando compreendido como um agenciamento estético da técnica, remetida modernamente ao sentido originário da cultura construtiva a qual se quer relacionar a obra, na elaboração de uma linguagem que the signifique contemporaneamente.

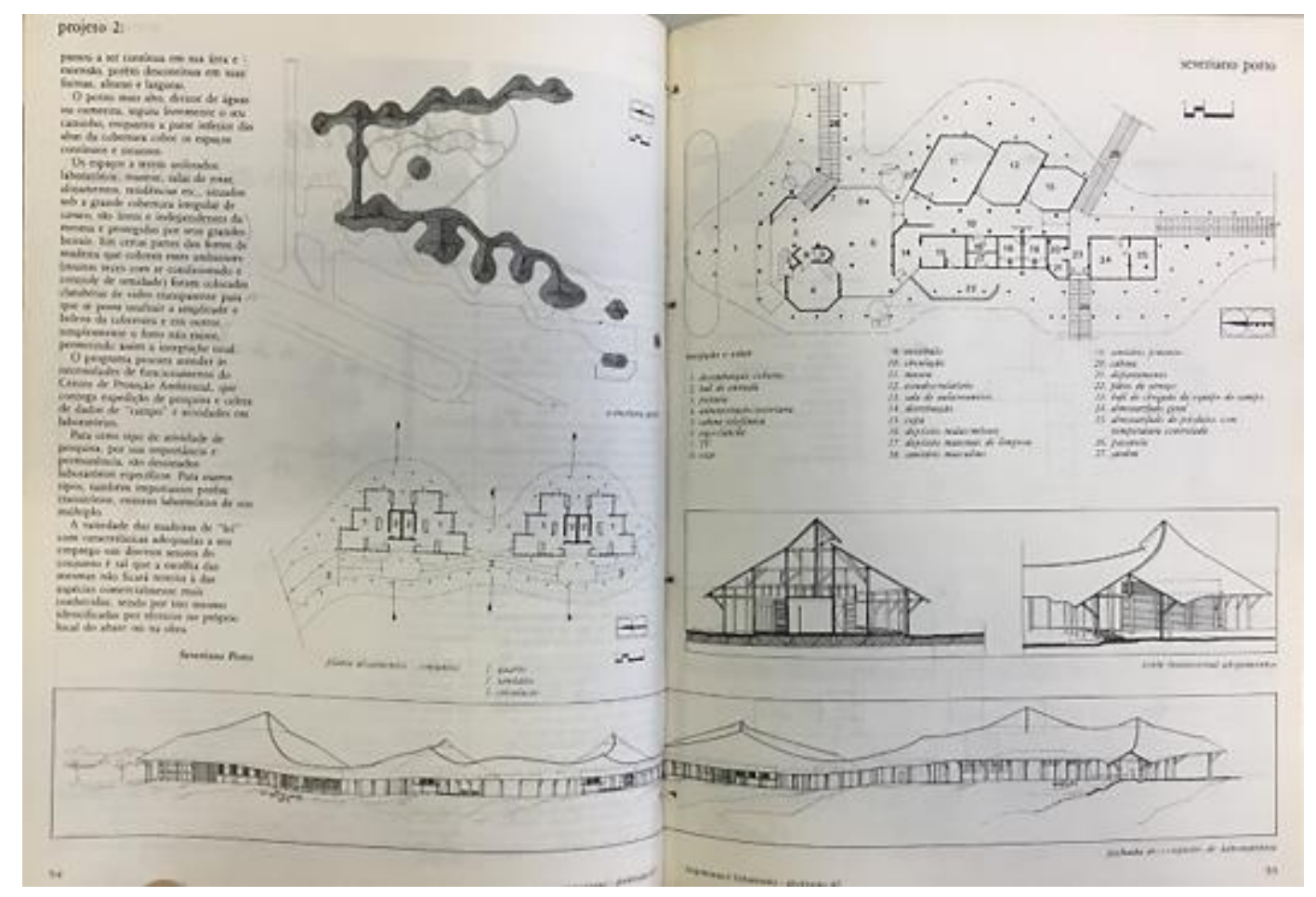

Figura 85 - Projeto com implantação completa do CPA - Balbina, de Severiano Porto. Fonte: AU n.11, 1987.

De certa forma não é colocada em primeiro plano, a questão relativa ao sentido que remete à edificação, se a uma cultura genuína ou autêntica, se originária do contexto ou não. Tal precisão apresenta-se irrelevante diante dos efeitos fenomenológicos da obra junto à paisagem, no contexto desta leitura. A linguagem da edificação comporta um caráter vestigial, remete à condição de precedência, um tempo não precisado, todavia latente. Neste ponto, há uma implicação da sobrevivência da edificação quando relacionada à duração do material. A demanda por reposições seria dada em conformidade com seu ciclo de vida útil, o que acarretou uma série prejuízos, desde a ausência de manutenção, até a desocupação e esvaziamento do $C P A$. O artifício não foi absorvido pelo contexto social e a própria Eletronorte havia sido a responsável por dar prosseguimento às pesquisas e atividades de monitoramento que a edificação abrigaria. Esse descolamento entre a obra e as sociabilidades locais tanto afetou as atividades do CPA quanto sua preservação. A composição social, no âmbito local, tinha um caráter até certo ponto desarraigado e 
dependente da conduta da empresa pública, de técnicos e funcionários que trabalhavam na usina.

Sua preservação tem sido desafiada como à da própria paisagem conformada pelo $C P A$. Trata-se de uma edificação icônica, marcada pela monumentalidade produzida pela interdependência entre meio natural e edificação. $\mathrm{Na}$ distribuição espacial, o arquiteto procedeu o necessário ajustamento da edificação às demandas técnicas, de laboratórios e outros espaços funcionalmente desenhados em estrutura ortogonal de distribuição. A espacialidade contínua sob a cobertura, de caminhos protegidos por passarelas e variações de altura, e a falta de rigidez na determinação dos fluxos, garante a fluidez do espaço coberto ao exterior, espaço que circunda a edificação. Os componentes regulares, recintos fechados dispostos com certo grau de independência, com coberturas próprias, foram situados sob a cobertura orgânica, de extensão significativa, cuja escala faz com que se sobressaia na paisagem, predominante frente aos demais componentes de projeto. A estrutura de sustentação alongada, os cavacos utilizados na cobertura, são elementos construtivos de madeira que mimetizam o ambiente e são reforçados por ele, constituindo uma paisagem reafirmativa da perda, da memorialização, que evoca e monumentaliza o que foi soterrado pela usina.

\subsection{A paisagem identitária, Interpass Clube de Milton Monte em Mosqueiro - PA}

Para o engenheiro e arquiteto Milton Monte, ${ }^{228}$ a natureza era a "fonte de inspiração" ao desenvolvimento de sua arquitetura. A natureza também foi um componente de suas memórias pessoais, de sua "infância amazônida". O arquiteto nascido em um seringal em Xapuri, no Acre, atuou desde 1952 no estado do Pará. Cybelle Miranda, Ronaldo Carvalho e Dinah Tutyia resgataram das memórias de Milton Monte esta relação formação, ao desenvolverem pesquisa e registrarem sua participação na trajetória da Faculdade de Arquitetura da Universidade Federal do Pará, implantada 1964. Milton Monte foi um dos engenheiros civis que atuavam no projeto e na construção em Belém e pertenceram à primeira turma de arquitetos formados em Belém - PA. Os pesquisadores também comportaram no referido trabalho, as referências às quais Milton Monte se aproximou, nos

\footnotetext{
${ }^{228}$ Arquiteto paraense, professor da UFPA, ministrou a disciplina "Desenhando com natureza" em mestrado na Universidade Central de Caracas (MIRANDA, CARVALHO, TUTYIA, 2015, p.74).
} 
anos de formação e prática projetual. Primeiramente, as “casitas californianas” da costa oeste dos Estados Unidos, que adaptou aos seus projetos pela compatibilidade ao clima amazônico, pelo ajustamento dos beirais e telhados que o teriam inspirado. Também, a "Arquitetura e Construçôes", com seus edifícios modernos. Além das revistas (MIRANDA, CARVALHO e TUTYIA, 2015, p. 73-75):

Monte citou como arquitetos que o influenciaram durante o curso de graduação em Arquitetura: Richard Neutra e sua arquitetura social na Costa Rica (década de 30), o organicismo de F.L.Wright; a cidade de Vila Amazonas e Serra do Navio (1962) de Oswald Bratke, pela preocupação com a aeração natural; Lucio Costa com o Parque Guinle e Oscar Niemeyer.

Entre os arquitetos cujas obras lhe serviram de inspiração, havia a particularidade do contato de cada um deles, em momentos e a partir de questões distintas, com a temática da relação entre natureza e artifício, entre clima e arquitetura, bem como o caráter adaptativo da arquitetura ao seu meio de inserção. Para Giovanni Blanco Sarquis, Milton Monte, em contexto paraense, foi precursor na década de 1960 de uma arquitetura "de caráter regional, sendo contemporâneo do arquiteto Severiano Porto”. Além do mais, teria sido um profissional muito "interessado na observação do ambiente e conhecimento de suas especificidades", de modo que "manejou o ofício de construtor articulado com questões de projeto relacionadas a um desenho moderno e inerentes ao contexto amazônico" (SARQUIS, 2012, p.75):

Construída a partir da percepção quanto aos condicionantes climáticos locais e à tradição construtiva regional, a produção arquitetônica desse profissional associa-os a elementos e soluções vinculados ao repertório moderno. Desse modo sua arquitetura materializa-se pela força que as composições volumétricas adquirem na totalidade, com especial destaque para a solução estrutural e autonomia formal conferida à cobertura de seus mais diversos projetos. Estes aspiram a uma adaptação topológica, notadamente quanto à aplicação de elementos vinculados à disponibilidade de materiais da região e a seu domínio pela mão de obra local (madeira, telha e tijolos cerâmicos), conformando forte legibilidade regional ao projeto.

O diálogo entre o "moderno e o regional” sobre o qual fala Giovanni Sarquis, foi fruto de uma interpretação de Milton Monte. Ele voltou-se à compreensão das subjetividades da linguagem arquitetônica a partir da análise restrita de seus objetos. Buscou identificar significados relacionados às formas de inserção dos projetos de arquitetura na Amazônia, do sentido locacional produzido pelo espaço amazônico. Porém, sua 
interpretação não o distanciou do caráter moderno dos seus projetos, nos quais transpôs aspirações universais de um ambiente amazônico constituído idealmente, se referenciando nos princípios que ideava Frank Lloyd Wrigth, especialmente ao tratar da organicidade na arquitetura. As obras de Milton Monte, segundo Sarquis, evidenciam o conhecimento sobre as características dos materiais aplicados que utiliza em processos de síntese que revelam o domínio técnico, numa “atitude projetual”, acima de tudo "pragmática”. Nela são reelaboradas referências eruditas e vernáculas, produzindo espacialidades modernas a partir de agenciamento similar àquele ao qual se refere Severiano Mário Porto em seu relato a respeito de uma “Arquitetura na Amazônia”. Esta arquitetura deveria necessariamente ser pensada em unidade e harmonia com o meio, universal em seu propósito, firmada em valores construídos a partir do enraizamento no contexto (PORTO, 1981, p.215-224):

Arquitetura de ontem e de hoje no Amazonas.

[...] A moda e os padrões eram importados e na arquitetura podemos sentir o reflexo desses fatores.

Em seu preâmbulo, Severiano Mário Porto aborda a arquitetura produzida junto o período correspondente à economia da borracha, descrevendo a incompatibilidade da região à arquitetura eclética, com a qual estabelece parâmetro para abordar o ideal ao seu tempo (idem):

São lembranças do passado. São testemunhos de uma época em que o conhecimento da ecologia não se tornava desesperadamente necessário como nos dias atuais, em face da explosão demográfica, do crescimento urbano e de todos os problemas deles decorrentes.

Mas também seria pedir demais, pois até hoje não só na Amazônia [...] continuamos a não nos preocupar com estes fatos, isto é, da adaptação da edificação às condições regionais e específicas de cada cidade.

[...] a arquitetura espontânea do homem local. Esta sim, a mais rica em subsídios relativos à ecologia, identificação e emprego de materiais regionais, sistema construtivo, escolha do sítio e implantação da edificação.

O protagonismo de Milton Monte no Pará e sua projeção internacional não foram refletidos nas revistas até a década de 1980. Assim como não foi o ineditismo e inventividade com que realizou aprofundadas pesquisas sobre o desempenho de materiais e técnicas pertencentes aos modos de construir tipificados, identificados junto a populações rurais na Amazônia. A leitura moderna destes que foram tornados seus objetos de estudo primordiais e percorreram o conjunto de sua atividade de projeto, foi o meio para que desenvolvesse soluções racionalizadas que compuseram um repertório técnico e estético, sobretudo novas paisagens, inclusive em contextos construídos. Neles, a exemplo de Belém - PA, estabeleceu pontes entre as duas paisagens, rural e urbana, na adoção de juízos éticos 
referenciados nos saberes tradicionais ao mundo rural, somados à postura reativa ao uso indiscriminado e inconsistente de materiais e soluções construtivas inapropriadas à Amazônia. A arquitetura do barracão e o beiral quebrado foram soluções típicas desenvolvidas por Milton Monte, componentes absorvidos pela cultura arquitetônica regional. Em ambos os casos, o arquiteto estabeleceu uma tensão identitária ao associar os modos de fazer, o construir anônimo, e suas próprias criações eruditas, as práticas e saberes atinentes ao mundo rural em contraponto aos contextos urbanizados para os quais projetou.

A obra de Milton Monte passou a ser representativa de sua longa trajetória de reflexão e prática na Amazônia, resultado de sua própria compreensão e vivência na região. Sob o título "arquitetura amazônica", designativo de sua postura projetual, a revista Projeto publicaria pela primeira vez a obra do Interpass Club. Situado na ilha de Mosqueiro - PA, inaugurado havia três anos, o projeto foi fruto do "aperfeiçoamento de uma tecnologia própria e o uso de materiais locais". A composição desenvolvida pelo arquiteto em "barracão" e o "beiral quebrado", ambos enfatizados na revista, foram utilizados neste projeto. Estes foram tipos desenvolvidos pelo arquiteto na década de 1970, sem que tivesse angariado projeção nas publicações consultadas desses anos. As duas soluções não seriam apenas para atender "exigências climáticas da Amazônia", mas também foram justificadas pela precedência e enraizamento, em "suas origens culturais, baseadas no homem do interior e no índio", como ele próprio alegou no registro feito na referida revista (PROJETO N.148, dezembro de 1991).

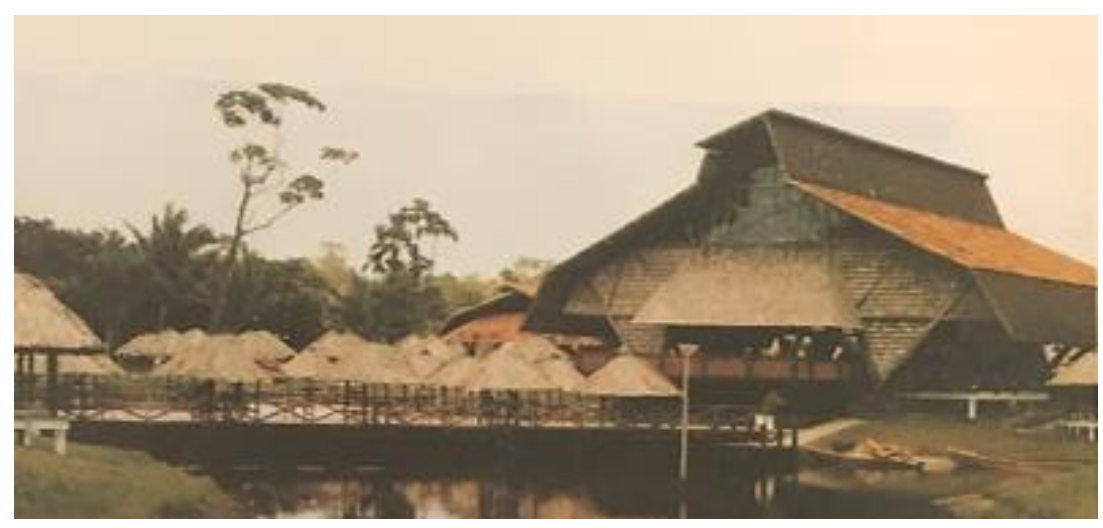

Figura 86 - Projeto de Milton Monte para o clube Interpass. Mosqueiro - PA. Fonte: PROJETO n.148, 1991.

Milton Monte havia sido engenheiro por doze anos, antes de cursar arquitetura na primeira turma da Universidade Federal do Pará. Sua intimidade com a técnica, prática 
construtiva e com os materiais, foi acrescida à atividade de arquiteto, possibilitando que conciliasse os conhecimentos acumulados à formulação da subjetividade estética da arquitetura, em seu caso, referenciada na Amazônia. Em seu raciocínio acerca do processo projetual, aspirava a compreensão da região na qual atuava, cujas características formariam pressupostos à busca por soluções apropriadas de projeto. Esteve atento muito especialmente às soluções adaptadas à condição climática, de "muito mormaço e grande índice pluviométrico”. Sua experiência com a pesquisa e o conhecimento aprofundado acerca dos materiais locais serviu de base às suas formulações projetivas. A paisagem que Milton Monte projetou para a Amazônia, portanto, foi aquela que mesclou a técnica e a subjetividade. A ambas, relacionou sua experiência e a memória sobre aquele ambiente amazônico.

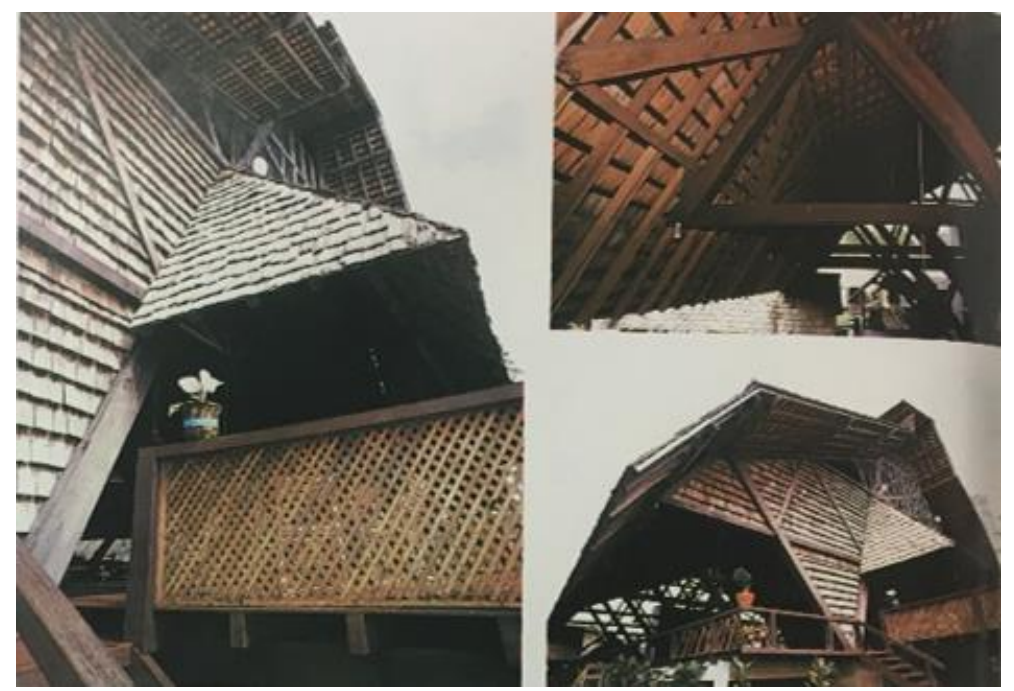

Figura 87 - Projeto de Milton Monte para o clube Interpass. Mosqueiro - PA. Fonte: PROJETO n.156, 1992.

Milton Monte desenvolveu uma tipologia pavilhonar intencionada como linguagem para a arquitetura adequada à Amazônia, aperfeiçoada em síntese na concepção do “barracão”. A construção valorizada pela cobertura dominante, como forma de abrigo, foi aprimorada como "uma cobertura muito generosa, para abrigar do sol e da chuva". O "beiral quebrado” em acréscimo, também compôs a solução tipificada, aperfeiçoada ao longo de sua experiência como projetista. Ambas foram tecnicamente aplicadas a várias obras que desenvolveu Milton Monte, a partir desta tipologia do barracão. Este teria sido o resultado aperfeiçoado de uma série de experiências construtivas e com o ato de projeto, que levaram ao rebaixamento da ponta do beiral como estratégia de proteção à iluminação natural e ao 
mesmo tempo às chuvas, podendo a construção permanecer aberta ao exterior, para a obtenção da melhor aeração possível.
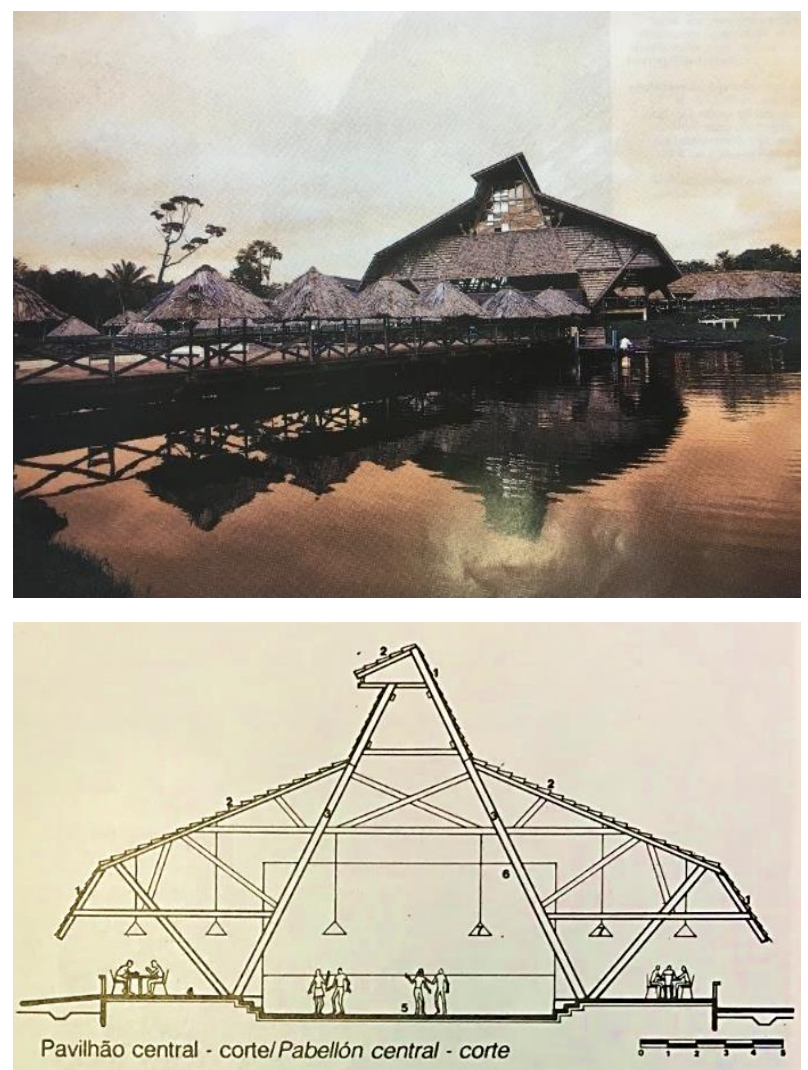

Figura 88 - Fotografia do conjunto e corte do "barracão" do clube Interpass. Mosqueiro - PA. Fonte: PROJETO n.156, 1992.

Interessado no uso da madeira e da cerâmica, justificou sua ampla aplicação, por ser a Amazônia de solo "sílico argiloso" e na região, “em qualquer lugar, encontra-se argila de excelente qualidade para fazer cerâmica vermelha”. Milton Monte justificou a adoção da técnica artesanal à sua obra, na aplicação dos materiais pela incorporação dos saberes locais, como os de carpinteiros. Chegou a afirmar que "se os arquitetos da Amazônia se voltassem para produzir uma arquitetura realmente centrada na região, ela seria uma das mais belas e significativas do mundo". Para o arquiteto, a atividade projetual seria envolvida pela subjetividade, já que "arquitetura é uma coisa ligada à emoção, que só se sente quando se está criando” (PROJETO N.148, dezembro de 1991).

No projeto que realizou para o clube Interpass, especialmente, revelou o interesse pela obra de arte total, incluindo a completa projetação de luminárias, objetos cerâmicos, atrativos ao usuário do clube, assim como Severiano Porto havia feito no projeto do Restaurante Chapéu de Palha, publicado em 1968. A principal construção do complexo do Interpass foi o "pavilhão de recreação", um fato de paisagem, síntese obtida pela 
interpretação moderna da Amazônia e pela concepção construtiva, pragmaticamente ajustada ao projeto (PROJETO N.156, setembro de 1992, p. 90):

Conceitualmente, esse pavilhão retoma a ideia do "grande barracão", edificação tão comum na Amazônia. Na paisagem, o conjunto cobertura/ estrutura do pavilhão sugere um grande pássaro amazônico pousado à beira do lago e espelhado em suas águas, com as asas abertas. O galpão recreativo é uma grande estrutura de madeira coberta com cavacos também de madeira, telhas de barro tipo canal. O desenho da cobertura com grandes beirais "quebrados" protege o interior do sol e das fortes e constantes chuvas; ausência de paredes de fechamento assegura ventilação por sob a cobertura (cujo pé-direito é de $11 \mathrm{~m}$ ) sem obstáculos, resultando em agradável clima e sensação de abrigo. A estrutura aparente de madeira, o contraste da cobertura de cavaco com telhas de barro e o desenho de sugestão zoomórfica [...] são soluções criativas de bom efeito plástico.

O Interpass Clube foi concebido em uma paisagem demarcada pela arquitetura inspirada no ambiente amazônico. $\mathrm{O}$ arquiteto o havia tanto pesquisado, interessado em compreender mais profundamente os modos de adaptação de habitantes anônimos ao meio natural na Amazônia, quanto o experimentado, como um arquiteto amazônida. Restituídas na obra, as soluções capturadas na internalidade da Amazônia, foram transpostas a novos componentes construtivos e à forma expressiva do projeto. Esta arquitetura, ainda que relacionada ao moderno, é tendida ao desprendimento a seus princípios mais ortodoxos, constituindo uma linguagem, de caráter experimental e autônomo, de intencional arraigamento ao contexto amazônico. Deste modo, a obra do Interpass, pode ser situada como resultado aprimorado de um conjunto de experimentações do arquiteto, desenrolados ao longo de sua vivência na Amazônia, possibilitados pela interpretação e reelaboração moderna do saber anônimo situado no mundo rural, e na latente paisagem da desmesura da Amazônia.

Não é possível prescindir do conhecimento adquirido da experiência de determinados habitantes com a Amazônia. Ele foi absorvido e reinterpretado em obras como as de Milton Monte, pesquisador atento às soluções construtivas artesanais, no interior da região. Com essa leitura, junto à sua própria experiência, conhecimento técnico e repertório disciplinar, elaborou uma linguagem renovada para a arquitetura para a Amazônia. A intencional contextualização de sua produção não constitui um procedimento comum ou um movimento ampliado em âmbito regional, ainda que se esvazie de sentido se pensada fora da Amazônia, posto que estreitamente próxima de sua vivência regional. 


\section{Considerações finais}

A presente perspectiva histórica da arquitetura na Amazônia entre 1934 e 1989, foi elaborada a partir de sua identificação em revistas especializadas e na historiografia da Arquitetura e Urbanismo no Brasil. A Amazônia foi avistada na leitura documental das fontes e em seu cruzamento com bibliografia que a considerou a partir dos recortes $\mathrm{da}$ modernização, urbanização e como paisagem. Acompanhando o fluxo da intervenção estatal sobre a região, a atividade de arquitetos foi sendo intensificada e remetida nas revistas, a contextos nos quais o território foi sendo modificado, inclusive pela sua própria produção. Uma concepção de Amazônia como paisagem, depurada e prospectiva, atravessou a atividade projetual e foi absorvida nas mediações efetuadas pelos textos, em representações conferidas às obras e projetos, bem como ao próprio território.

A atividade de projeto na Amazônia dialogou distintamente com a prática disciplinar, sob a influência de construções culturais que, em longa duração, formularam a região como paisagem, especialmente escritos entrelaçados à uma genealogia do pensamento social sobre e na Amazônia. As representações assentadas no pensamento social foram identificadas nos textos de arquitetura, que as absorveram discursivamente. Elas também foram naturalizadas pela cultura arquitetônica, como em reproduções das designações da Amazônia como vazio demográfico, inferno verde, condicionamento ambiental.

A participação de uma elite intelectual e política da região nas revistas de arquitetura na década de 1960, possibilitou a propagação de certas construções culturais de tipificação do homem amazônico, do ambiente, do modo de vida, da paisagem, em paralelo às ideias basilares de Lúcio Costa para a arquitetura brasileira. Estas formulações que defenderam uma cultura genuína amazônica, como norteadora da modernização regional construtiva, foram naturalizadas no campo da Arquitetura e Urbanismo no intervalo em estudo. Conduziram reflexões sobre o projeto de arquitetura reformulando sua base argumentativa, encontrando na obra de Oswaldo Bratke para as vilas do Amapá, uma condensação material. A mediação textual e discursiva deslocou a arquitetura racional de Bratke, à imagem ideada 
de uma modernização de acento regional, em condição de distinção, mas ainda interligada à uma cultura nacional.

Se a princípio as soluções projetuais de Oswaldo Bratke foram modelares ao desenvolvimento de uma arquitetura racionalmente ajustada ao meio, essa aspiração pragmática foi gradativamente sendo deslocada a outro patamar, adquirindo significados novos, como os produzidos pelas discussões acerca do ambientalismo, ou de uma identidade regional, amazônica, na arquitetura. Isto pelo fato de que ela foi travessada pelas transformações disciplinares após a concretização de Brasília, desde quando foi admitida a pluralidade projetual no país, e pelas pautas sociais de movimentos reativos às intervenções empreendidas pelo Estado na região. Também foi afetada pelas reflexões internacionais que desde os anos de 1950 relevavam o resgate de pautas éticas e sociais na arquitetura, especialmente pelo movimento de reconhecimento e incorporação de formas culturais variadas, de modos de vida e saberes populares, pela arquitetura erudita.

As revistas especializadas, fontes importantes para o campo da Arquitetura e Urbanismo no Brasil, reproduziram algumas dessas construções culturais, até mesmo em textos integrais de influentes intelectuais, interessados na arquitetura como meio para a modernização da Amazônia sob o enfoque do desenvolvimento regional. A importância das revistas no recorte temporal analisado é advinda do fato de que fizeram circular ao tempo dos acontecimentos, os eventos demarcatórios da trajetória da disciplina no país, em um significativo volume documental. Ainda que a Amazônia não tenha sido prevalente nesses meios, foi possível capturar desde a frequência com que foi publicada, os sentidos que a cada momento a região e uma certa arquitetura a ela relacionada, foi registrada nessa mídia.

As revistas inscreveram a Amazônia em enfoques e contextos plurais, e a explicaram desde fatores do interior e exterior da disciplina. As obras publicadas foram acompanhadas de textos autorais de projetistas e de escritos críticos, registradas sincronicamente à sua realização, ou em arcos ampliados de tempo, também sustentadas em atualidade. Além dos enfoques disciplinares, foram registrados nas revistas, os oriundos de outros campos, quando atinentes à Amazônia. Geógrafos, historiadores, ambientalistas, políticos, poetas, dentre tantos outros agentes, falaram sobre arquitetura e Amazônia nas revistas especializadas. Estes autores adensaram as discussões sobre a arquitetura na Amazônia sob distintos aportes. 
Do conjunto da documentação, três intervalos foram propostos, pela mudança do teor das mediações acerca da Amazônia, pela presença de publicações demarcatórias e significativas às formulações conceituais acerca do desenvolvimento da arquitetura na região, pelos aspectos conjunturais determinantes do processo de modernização regional conforme apresentado nas publicações. Em cada um desses intervalos, foram reunidas as obras publicadas, 106 ao todo, e os juízos críticos textualizados sobre elas e sobre a Amazônia, presentes nas revistas. Estes dados foram concatenados conforme apresentado no terceiro capítulo da tese, onde compuseram um relato continuado, compondo o registro da atividade profissional na Amazônia em circulação nas revistas nacionais, nos anos estudados.

No recorte em análise, de 1934 a 1989, uma paisagem foi sendo depurada pelo projeto, servindo de base a novas projeções, às paisagens que nesse período foram sendo prospectadas pelos arquitetos junto às suas obras, consonante à transformação do espaço amazônico. As representações sintéticas do território, o formularam desde imagens evocativas, referenciadas no pensamento social sobre a região, especialmente quando sintetizada numa paisagem de modos de vida intimamente relacionados ao ambiente natural na Amazônia ou a este ambiente geografado simbolicamente. A relação entre o lugar de inscrição e a obra de arquitetura como fator de origem, decisivo ao projeto, foi então, como tem sido até o presente, uma estrutura explicativa utilizada para o desenvolvimento e promoção da arquitetura na Amazônia, uma paisagem imanente, para a arquitetura praticada no presente.

A trajetória de arquitetos como Severiano Porto ou Milton Monte, é reveladora de uma experiência com o projeto sob a influência desse processo, que culminou no recorte final, com a projeção de uma arquitetura considerada como amazônica ou em adequação àquele espaço, nas revistas nacionais e estrangeiras. Parte da obra desses arquitetos, especialmente quando situada em áreas de expansão, absorveu a pauta da adequação climática, do ajustamento cultural e da estética regional. Esta formulação naturalizada, foi absorvida no campo e do próprio campo, a partir das elaborações textuais. Sob o discurso da autorreferência, tais obras podem ser explicadas pela imersão na construção histórica que agenciou a memória regional, na conjuntura do desenvolvimentismo conservador, e que migrou para novos suportes discursivos preservacionistas surgidos nos anos de 1960. 
Se o hotel para pescadores publicado em 1967 foi artifício à modernização conservadora com base no desenvolvimento regional pelas vias da turistificação da Amazônia, foi também localizado no fenômeno do após Brasília, em finais dos anos 1970, como exemplo da pluralidade e como solução alternativa à arquitetura no Brasil. Já na década de 1980, foi tido como projeto ecológico, adaptado, ético no respeito ao conhecimento construtivo popular e anônimo, na conjuntura de um esgotamento do desenvolvimentismo. Sob estas múltiplas designações, quase sempre foi mantida a relação entre arquitetura e lugar nas explicações acerca do hotel. As representações, narrativas da Amazônia como paisagem, figuraram como imagens da síntese explicativa do território e foram absorvidas, reconfiguradas, como base conceitual a concepções de novas paisagens prospectivas por arquitetos atuantes na região.

Os sentidos adquiridos pelas obras apresentadas no último capítulo da tese, foram dados pela sua interdependência à paisagem. A implantação desses objetos pioneiros foi determinante à designação do contexto onde foram inseridos, em áreas de expansão. $\mathrm{O}$ caráter dos encargos e a concretização dos projetos em novas paisagens, elaboradas a partir de distintas posturas projetuais, revelaram estágios distintos da transformação do espaço amazônico a assimilação da arquitetura ali desenvolvida, pelo campo disciplinar. Os temas propostos para cada tópico no último capítulo e as obras selecionadas arremataram o trabalho com uma síntese interpretativa do processo relatado no capítulo anterior. Esta síntese foi feita a partir da seleção de obras icônicas, ligadas à ideia de uma Amazônia paisagem, dispostas em sequência para recompor o processo da arquitetura na Amazônia nesses anos.

Partindo de um ideal civilizatório com as Vilas de Oswaldo Bratke, a paisagem imanente foi percorrida pelo habitar amazônico tipificado junto ao ambiente, com a casa Schuster de Severiano Mário Porto. Em sequência, o contraponto apresentado pela Sede da Suframa em Manaus revelou uma nova paisagem industrial nascente, na área de expansão da capital, um estágio significativo da atuação do Estado na região e da própria projeção da carreira do arquiteto. Em revés, o Centro de Proteção Ambiental de Balbina foi disposto em confronto com a atuação do Estado na região. Esta foi uma obra elaborada sobre as bases da destruição, memorializando as perdas ambientais com a monumentalização da paisagem. Ao fim, a obra do arquiteto amazônida, Milton Monte foi indicativa de um 
estágio de consagração da arquitetura amazônica. Nela o arquiteto desenvolveu uma estética identificada com a região e consigo próprio, ao sintetizar na estrutura projetada, toda sua experiência com a Amazônia.

Ao examinar a Amazônia a partir do modo como foi dada a ver nos anos em pauta, nas revistas de arquitetura, a tese revela as formulações dos arquitetos e as mediações destas, nas revistas. Uma ideia de paisagem historicamente construída, foi relacionada aos projetos publicados remetidos à Amazônia. Os projetos situados em contextos urbanizados ou que foram desgarrados da temática contextual, foram as arquiteturas de acento urbano, em geral não referidos à Amazônia, mas aos seus próprios locais de inscrição ou ao pragmatismo de suas soluções.

A Amazônia, como unidade, adquiriu sentido único na história, por ação do artifício da própria cultura. A particularidade da obra dos arquitetos na região também se constitui no plano histórico, determinada pela temporalidade. A produção dos arquitetos não se sustenta, quando lida como em retorno à uma cultura pretensamente única, autêntica amazônica, posto que ela é composta por uma multiplicidade de tradições e grupos sociais. Todavia, são os procedimentos de projeto que fazem do projeto na Amazônia uma prática particularizada, quando formulados junto confrontamento de arquitetos com a Amazônia paisagem, diante das experiências emergidas do contato com o meio natural desmedido da fronteira socioambiental e com as populações tradicionais. A Amazônia como uma paisagem, é a condição que especifica o projeto, onde a tensão à modernização, explicita a dualidade que a própria modernidade produz, entre construção e destruição. Ainda que a tese não encerre tão ampliado assunto e recorte, deve contribuir para a problematização do objeto Amazônia em perspectiva histórica, apresentando uma leitura estrita sobre vasta documentação até então não tratada, que trouxe à tona uma Amazônia como uma elaboração, mas também, no caso da arquitetura, como concretização, ao materializar novas paisagens pelo projeto. 


\section{Referências}

ALIATA, F.; SILVESTRI, G. A paisagem como cifra de harmonia: Relações entre cultura e natureza através do olhar paisagístico. Curitiba: UFPR, 2008.

AMARAL, S.; CÂMARA, G.; MONTEIRO, A. M. V. Relatório Técnico - Análise espacial do processo de urbanização da Amazônia. [S.l.]: INPE, 2001.

ANDRADE, M. Amazônia esfinge do terceiro milênio. Manaus: Metro Cúbico/ Suframa, 1981.

. Manaus: Ruas, fachadas e varandas. Manaus: Humberto Calderaro, 1984.

ANDRADE, M. C. D. O espaço geográfico na obra de Gilberto Freyre. In: KOSMINSKY, E. V.; LÉPINE, C.; PEIXOTO, F. A. (. ). Gilberto Freyre em quatro tempos. Bauru: FAPESP/ UNESP/ EDUSC, 2003. p. 223-233.

ANDRADE, M. D. O turista aprendiz; edição de texto apurado, anotada e acrescida de documentos por Telê Ancona Lopez, Tatiana Longo Figueiredo; Leandro Raniero Fernandes. Brasília: IPHAN, 2015.

ANDRADE, M. O. D. Percursos de reconhecimento: memória da antropologia brasileira através dos diários de campo e de viagem. Política \& Trabalho. Ed. 27 - 30, p. 243-266, 2008.

ANDRADE, R. D. P. A Amazônia vai ressurgir!: saúde e saneamento na Amazônia no primeiro governo Vargas (1930-1945). Rio de Janeiro: Casa de Oswaldo Cruz/ Fiocruz, 2007.

Conquistar a terra, dominar a água, sujeitar a floresta. Getúlio Vargas e a revista "Cultura Política" redescobrem a Amazônia (1940-1941). Belém: Bol. Mus. Para. Emílio Goeldi. Cienc. Hum., p. 453-468, 2010.

ANDRADE, T. K.; TAVARES, M. G. O projeto de integração Amazônica visto pela turistificação dos lugares. Revista Confins n.14, 2012.

ANELLI, R. Architettura contemporanea. Brasile. Milão: Motta Architettura, 2008. 34, 2017.

Para interpretar a arquitetura: curadoria como prática formativa. USJT arq.urb n.20. set-dez, p. 27-

ARAGÓN, L. E. Novos temas regionais para o estudo da Amazônia no atual contexto internacional. In: FELDMAN, S.; ANA, F. (. ). O urbano e o regional no Brasil contemporâneo. Mutações, tensões, desafios. Salvador: EDUFBA, 2007. p. 153-174.

ARANTES, O. Urbanismo em fim de linha. São Paulo: EDUSP, 1998.

ARAÚJO, V. D. S. Notação de um turista aprendiz. Belém: Universidade Federal do Pará, 2008.

AYMARD, M. O homem e o historiador. In: LOPES, M. A. Fernand Braudel. Tempo e História. Rio de Janeiro: FGV, 2003. p. 11-20.

BASTOS, M. A. J. Pós-Brasília. Rumos da Arquitetura brasileira. São Paulo: Perspectiva, 2007.

BECKER, B. K. A urbe amazônida. Rio de Janeiro: Garamond Universitária, 2013.

A implantação da rodovia Belém-Brasília e o desenvolvimento regional. Anuário do Instituto de Geociências v.1, p. 32-46, 1977.

Amazônia Geopolítica na virada do III Milênio. Rio de Janeiro: Garamond, 2009. 
BENTES, D. Manaus: Outras faces da história, 1910 - 1940. Piauí: Reggo, 2012.

BERMAN, M. Tudo que é sólido desmancha no ar. A aventura da modernidade. São Paulo: Companhia das Letras, 1982.

BESSE, J.-M. Ver a terra: seis ensaios sobre a paisagem e a geografia. São Paulo: Perspectiva, 2019.

BLOCH, M. Apologia da História ou o ofício do historiador. Rio de Janeiro: Zahar, 2001.

BOURDIN, A. A questão local. Rio de Janeiro: DP\&A, 2001.

BRAUDEL, F. Escritos sobre a História. São Paulo: Perspectiva, 2013.

BRITO, D. C. D. A Modernização da Superfície: Estado e Desenvolvimento na Amazônia. Belém: UFPA/ NAEA/ PDTU, 2001.

BRITO, R. A semana de 22. O trauma do moderno. In: TOLIPAN, S. Sete ensaios sobre o Modernismo. Rio de Janeiro: Funarte, 1983. p. 13-18.

BRUNA, P. Os primeiros arquitetos modernos. São Paulo: Edusp, 2015.

BUENO, M. F. O imaginário brasileiro sobre a Amazônia: uma leitura por meio dos discursos dos viajantes, dos livros didáticos de Geografia e da mídia impressa. São Paulo: Universidade de São Paulo USP, Dissertação de Mestrado, 2002.

BURKE, P. O que é História Cultural? Rio de Janeiro: Zahar Ed., 2005.

CABRAL, C. C.; BENDER, H. Usos do primitivismo. Pedra, barro e arquitetura moderna. Pós, Rev. Programa Pós-Grad. Arquit. Urban. FAUUSP. São Paulo, v. 24, n. 43, p. 80-97, 2017.

CAPPELLO, M. B. C. Arquitetura em revista: Arquitetura moderna no Brasil e sua recepção nas revistas francesas, inglesas e italianas (1945-1960). São Paulo: Universidade de São Paulo, Tese de Doutorado, 2005.

. Recepção e difusão da arquitetura moderna no Brasil: Norte-Nordeste nas revistas francesas, inglesas e italianas entre 1940 e 1960. In: (ORG), F. D. M. Arquitetura moderna no Norte e Nordeste do Brasil: universalidade e diversidade. Recife: FASA, 2007. p. 129-149.

CAPPELLO, M. B. C.; CAMPELLO, M. D. F. D. M. B. (. ). Palavras e imagens impressas: as publicações periódicas especializadas e sua contribuição para a pesquisa em Arquitetura e Urbanismo. Porto Alegre: IV Enanparq. 2016.

CARDOSO, C. F.; MALERBA, J. O. Representações: Contribuição a um debate transdisciplinar.

Campinas: Papirus, 2000.

CARDOSO, C. F.; VAINFAS, R. O. Domínios da História. Ensaios de teoria e metodologia. Rio de Janeiro: Elsevier, 1997.

CARRANZA, L. E.; LARA, L. F. Modern Architecture in Latin America. Art, technology and utopia. Austin: University of Texas Press, 2014.

CASTRO, E. Urbanização, pluralidade e singularidades das cidades amazônicas. In: CASTRO, E. (. ). Cidades na floresta. São Paulo: Annablume, 2008. p. 13-39.

CAVALCANTI, L. Moderno e brasileiro. Rio de Janeiro: Jorge Zahar Ed., 2006.

CHARTIER, R. A História Cultural entre práticas e representações. Lisboa: Difusão Editorial, 1988. . O mundo como representação. Estudos Avançados 11 (5), p. 173-191, 1991.

CHAVES, C. Documentação e estudo da arquitetura residencial moderna em Belém (1940-1970). Anais do Seminário Nacional do Docomomo Brasil, p. 1-12, abril de 2016. 
CHAVES, C.; SILVA, G. V. D. Antagonismos e afinidades: arte e arquitetura em Belém entre as décadas de 40 e 60. Brasília. junho de 2011.

CHUVA, M. R. R. Os arquitetos da memória. Rio de Janeiro: UFRJ, 2009.

COHEN, J.-L. O futuro da arquitetura desde 1889 - Uma história mundial. São Paulo: Cosac Naify, 2013.

COLOMINA, B. Revistas underground da arquitetura radical. In: SEGRE, R., et al.

Arquitetura+Arte+Cidade. Um debate internacional. Rio de Janeiro: Viana \& Mosley, 2010. p. 89-100.

COMAS, C. E. D. Protótipo e monumento, um ministério, o ministério. In: (ORG.), A. G. Textos fundamentais sobre história da arquitetura moderna brasileira - parte 1. São Paulo: Romano Guerra, 2010. p. $79-108$.

CONDURU, R. Vital Brazil. São Paulo: Cosac\&Naif, 2000.

. Tectônica tropical. In: ANDREOLI, E.; FORTY, A. (. ). ARQUITETURA MODERNA BRASILEIRA. Hong Kong: 2004, 2004. p. 58-105.

CORRÊA, R. L. A periodização da rede urbana da Amazônia. Revista Brasileira de Geografia. Ano 49, n.3, p. 39-68, 1987.

. Formas simbólicas e espaço algumas considerações. GEOgraphia ano IX, n.17, 2007.

CORREIA, T. D. B. Arquitetura e ambiente: a noção de adaptabilidade ao meio no discurso modernista. Revista da Pós v.16 n.25 junho São Paulo, p. 134-150, 2009.

CORREIA, T. D. B. Bratke e o projeto civilizatório da ICOMI. Pós v.19 n.31, junho, p. 132-145, 2012.

COSTA, G. V. Belém, neocolonialismo, história e historiografia da arte contemporânea brasileira. Arte \& Ensaios. Revista do ppgav/eba/ufrj, Rio de Janeiro, p. 76-85, junho 2015. ISSN 29.

COSTA, K. S. Homens e natureza na Amazônia brasileira: dimensões (1616 - 1920). [S.l.]: Universidade de Brasília, 2002.

DALMONTE, E. F. Mídia, fonte \& palanque do pensamento culturalista de Gilberto Freyre. Salvador: Universidade Federal da Bahia, 2009.

D'ARAÚJO, M. C. Amazônia e desenvolvimento à luz das políticas governamentais: a experiência dos anos 50. Revista Brasileira de Ciências Sociais, Ano 7, no 19, p. 40-55, 1992.

DERENJI, J. D. S. Arquitetura eclética no Pará. In: FABRIS, A. (. ). Ecletismo na arquitetura brasileira. São Paulo: Nobel, 1987. p. 146-175.

. Modernismo na Amazônia. Projeto n.192, p. 73-78, dezembro de 1995.

DOSSE, F. A história. Bauru: EDUSC, 2003.

DROULERS, M. Fazer Territó-rios na Amazônia. Confins n.31, 2017.

DUTRA, E. D. F. Cultura. In: SCHWARCZ, L. M. (. ).; GOMES, A. D. C. (. ). História do Brasil nação 1908-2010. Vol.4. Olhando para dentro 1930-1964. Madrid e Rio de Janeiro: Mapfre e Editora Objetiva, 2013. p. 228-274.

ESPALLARGAS, L. Caraíba e Serra do Navio: a construção da cidade brasileira. USJT - arq.urb n.2, p. 5679, 2009.

FALCON, F. J. C. História e representação. In: CARDOSO, C. F.; MALERBA, J. (. ). Representações. Contribuição a um debate transdiciplinar. Campinas: Papirus, 2000. p. 41-79. 
FERNANDES, D. A. A questão regional e a formação do discurso desenvolvimentista na Amazônia. Belém: Programa de Doutorado em Desenvolvimento Sustentável do Trópico Úmido do Núcleo de Altos Estudos Amazônicos, 2011.

FIGUEIREDO, A. M. D. De pinceis e letras: os manifestos literários e visuais no modernismo amazônico na década de 1920. Territórios \& Fronteiras. Cuiabá, v. 9, n.2, dez., p. 130 - 155, 2016.

FIGUEIREDO, A. M. D.; CHAMBOUlEYRON, R.; ALONSO, J. L. R.-P. Dossiê Amazônia e História Global. Apresentação. Tempo, 2017. ISSN 23(3).

FILHO, F. S. T. Tentativas de enraizamento. Arquitetura brasileira e formação nacional. São Carlos: Universidade de São Paulo, Tese de Doutorado, Departamento de Arquitetura e Urbanismo, 2010.

GIMENEZ, L. E. Pós-modernismo, arquitetura e tropicália. Revista Projeto n.65, julho 1984. p. 87-99.

GODFREY, B. J. Frentes de expansão na Amazônia: uma perspectiva geográfico-histórica. Geosul v.3, n.6, p. 7-19, 1988.

GONÇALVES, C. W. P. Amazônia, Amazônias. São Paulo: Contexto, 2008.

GONDIM, N. A invenção da Amazônia. Manaus: Valer, 2007.

GORELIK, A. O moderno em debate: cidade, modernidade, modernização. In: MIRANDA, W. M. Narrativas da Modernização. Belo Horizonte: Autêntica, 1999.

2005.

. Das vanguardas à Brasília. Cultura urbana e arquitetura na América Latina. Belo Horizonte: UFMG, 2005.

Das vanguardas à Brasília. Cultura urbana e arquitetura na América Latina. Belo Horizonte: UFMG,

A produção da "cidade latino-americana". Tempo social, revista de sociologia da USP v.17 n.1, p. 111-133, junho de 2005.

GORELIK, A.; LIERNUR, J. F. La sombra de la vanguarda: Hannes Meyer en México, 1930 - 1949. Buenos Aires: Proyecto editorial, 1993.

GUERRA, A. A construção de um campo historiográfico. In: GUERRA, A. (. ). Textos fundamentais sobre hist;oria da arquitetura moderna brasileira - parte 1. São Paulo: Romano Guerra, 2010. p. 11-22.

Arquitetura brasileira, viver na floresta. São Paulo: Instituto Tomie Ohtake, 2010.

Arquitetura e natureza. São Paulo: Romano Guerra Editora, 2017.

GUTMAN, M. Teaching Marshall/Marshall Teaching: Encounters with Berman. In: CORBY, J. (. ). Adventures in Modernism: Thinking with Marshall Berman. New York: UR/ Terreform, 2015. p. 52-61.

HALL, J. Lina Bo Bardi, o intelectual orgânico e a revista Habitat. In: PEDROSA, A. Lina Bo Bardi: Habitat. São Paulo: MASP, 2019. p. 72-79.

HEIMBECKER, V. P. C. Habitar na cidade: Provisão estatal da moradia em Manaus, de 1943 a 1975. Manaus: Universidade Federal do Amazonas, Dissertação de Mestrado, 2014.

JOLY, F. D. O Mediterrâneo antigo. In: LOPES, M. A. Fernand Braudel. Tempo e História. Rio de Janeiro: FGV, 2003. p. 143-150.

JÚNIOR, A. D. D. C. A revolta dos primeiros índios cristãos: guerra e conflitos na construção da Amazônia portuguesa - século XVII. Fronteiras \& Debates. Macapá, v.2, n.1, p. 21-49, jan/jun de 2015. 
JÚNIOR, A. D. O. Amazônia: paisagem e região na obra de Eidorfe Moreira. Bol. Mus. Pará. Emílio Goeldi. Cien. Hum., Belém, v. 10 n.3, p. 569-581, set-dez 2015.

JÚNIOR, S.-C. C. D. T. Cidades na floresta: os "grandes objetos" como expressões do meio técnicocientifico informacional no espaço amazônico. IEB, p. 113-137, 2010 mar./set.

KOHLHEPP, G. Conflitos de interesse no ordenamento territorial da Amazônia brasileira. Estudos Avançados 16 (45) maio/agosto, São Paulo, p. 37-61, 2002.

LARA, F. L. C. Modernismo popular: elogio ou imitação? Cadernos de Arquitetura e Urbanismo, Belo Horizonte, v.12, n.13, dez. 2005, p. 171-184, 2005.

LASSANCE, G. et al. Leituras em teoria da arquitetura 2. Textos. Rio de Janeiro: Viana \& Mosley, 2010. p. 21-23.

LE GOFF, J.; NORA, P. História. Novos objetos. Rio de Janeiro: Francisco Alves, 1995.

LIMA, D. A. E. O mundo da hinterlândia e os avanços da fronteira no espaço tocantinense. Textos e debates, Boa Vista, n.26, p. 99-112, 2014.

LIMA, M. K. L. I. R. D. S. O lugar da adequação em Severiano Porto: Aldeia SOS do Amazonas, Rio de Janeiro: Universidade Federal do Rio de Janeiro, Dissertação de Mestrado, 2004.

LIRA, J. T. C. D. Naufrágio e galanteio: viagem, cultura e cidades em Mário de Andrade e Gilberto Freyre. n.57. ed. São Paulo: Revista Brasileira de Ciências Sociais, v. 20, 2005.

- A romantização e a erradicação do mocambo, ou de como a casa popular ganha nome. Recife, década de 30. Espaço \& Debates, p. 47-60, ano XIV, n.37, 1994.

LOPES, M. A. Fernand Braudel. Tempo e História. Rio de Janeiro: FGV, 2003.

LOPES, V. F. D. M. Processos socioartísticos em Moacir Andrade: Estilo e artes plásticas na Amazônia. Manaus: Universidade Federal do Amazonas, 2018.

MACIEL, C. A. A. A retórica da paisagem: um instrumento de interpretação geográfica. Espaço e Cultura, UERJ n.26, jul/dez, p. 32-48, 2009.

MAIA, J. M. E. Estado, território e imaginação espacial. O caso da Fundação Brasil Central. Rio de Janeiro: FGV, 2011.

MARQUES, G. S. SPVEA: o Estado na crise do desenvolvimento regional amazônico (1953 - 1966).

Revista Soc. Bras. Economia Política, São Paulo, p. 123-162, fevereiro 2013. ISSN 34.

MARTINS, C. A. F. Arquitetura e Estado no Brasil. Elementos para uma investigação sobre a constituição do discurso moderno no Brasil, a obra de Lúcio Costa 1924/ 1952. São Paulo: Universidade de São Paulo, Dissertação de Mestrado, 1987.

MARTINS, C. A. F. Construir uma arquitetura, construir um país. In: SCHWARTZ, J. Da a. São Paulo: Cosac \& Naif, 2002. p. 373-435.

MARTINS, C. A. F. "Há algo de irracional." Notas sobre historiografia da arquitetura brasileira. In: (ORG.), A. G. Textos fundamentais sobre história da arquitetura moderna brasileira. Parte 2. São Paulo: Romano Guerra, 2010. p. 131-168.

MENEZES, U. B. D. Fontes visuais, cultura visual, História Visual. Balanço provisório, propostas cautelares. São Paulo: Universidade de São Paulo, Revista Brasileira de História n.45, 2003. p. 11-36.

MIRANDA, C. S.; CARVALHO, R. M. D.; TUTYIA, D. R. Uma formação em curso. Esboços da graduação em Arquitetura e Urbanismo da UFPA. Belém: Universidade Federal do Pará, 2015. 
MONTANER, J. M. Depois do movimento moderno. Arquitetura da segunda metade do século XX.

Barcelona: Editorial Gustavo Gili, 2001.

MONTANER, J. M. Arquitetura e crítica na América Latina. São Paulo: Romano Guerra, 2014.

MONTEIRO, M. D. A. A ICOMI no Amapá: meio século de exploração mineral. Novos cadernos NAEA v.6 n.2 dez, p. 113-168, 2003.

MONTEIRO, M. D. A.; COELHO, M. C. A ICOMI no Amapá. Relatório geral de observação.

Florianópolis: Observatório Social, 2003.

NAME, L. O conceito de paisagem na geografia e sua relação com o conceito de cultura. GeoTextos vol.6, n.2 dez, p. 163-186, 2010.

NERY, J. C. Falas e ecos na formação da arquitetura moderna no Brasil. Salvador: Universidade Federal da Bahia, Tese de Doutorado, 2013.

NESBITT, K. (. ). Uma nova agenda para a arquitetura. São Paulo: Cosac \& Naif, 2006.

NEVES, E. G. Arqueologia da Amazônia. Rio de Janeiro: ZAHAR Editor, 2006.

NEVES, M. C. D. O. A colocação e a casa do seringueiro: exemplo de arquitetura vernácula da Amazônia. Rio Branco: Gráfica TJ, 2007.

NUNES, B. F. A interface entre o urbano e o rural na Amazônia brasileira. In: CASTRO, E. (. ). Cidades na floresta. São Paulo: Annablume, 2008. p. 41-58.

OLIVEIRA, A. U. D. Integrar para não entregar. Políticas públicas e Amazônia. Campinas: Papirus, 1988.

OLIVEIRA, F. D. Crítica à razão dualista/ O ornitorrinco. São Paulo: Boitempo, 2003.

OLIVEIRA, J. A. D. Cidades na Selva. Manaus: Valer, 2000.

PACHECO, A. S. et al. Pesquisas em Estudos Culturais na Amazônia. Cartografias, literaturas \& saberes interculturais. Belém: EditAEDI, 2015.

PEREIRA, J. C. M. Os modos de vida na cidade: Belterra, um estudo de caso na Amazônia brasileira. Rio de Janeiro: Universidade do Estado do Rio de Janeiro, 2012.

PESAVENTO, S. J. História \& História Cultural. Belo Horizonte: Autêntica, 2003.

PIÑÓN, H. Teoria do Projeto. Porto Alegre: Livraria do Arquiteto, 2006.

PINTO, R. F. A viagem das idéias. Estudos Avançados 19 (53), p. 97-114, 2005.

PINTO, R. F. Viagem das idéias. Manaus: Valer/ Prefeitura de Manaus, 2006.

PIVA, L. G. Ladrilhadores e semeadores: a modernização brasileira no pensamento político. São Paulo: 34, 2000.

RABELLO, A. C. Amazônia: uma fronteira volátil. Estudos Avançados 27 (78), p. 213-235, 2013.

RANGEL, A. Inferno Verde: cenas e cenários do Amazonas. Manaus: Valer, 2008.

REIS, A. C. F. Súmula de História do Amazonas 3a ed. Manaus: Valer, 2001.

RIBEIRO, B. A. Vila Serra do Navio. Comunidade Urbana na Serra Amazônica. Um projeto do Arquiteto Oswaldo Arthur Bratke. São Paulo: Pini Editora, 1992.

RIBEIRO, F. P. O paradigma ambiental na globalização neoliberal: da condição crítica ao protagonismo de mercado. Soc. \& Nat., ano 24, n.2. Uberlândia, p. 211-226, 2012. 
RIBEIRO, O. D. S. Tradição e modernidade no pensamento de Leandro Tocantins. Manaus: Universidade Federal do Amazonas, 2012.

ROVO, M. K. I.; OLIVEIRA, B. S. Por um regionalismo eco-eficiente: a obra de Severiano Mário Porto no Amazonas, abril 2004. Disponivel em:

<http://www.vitruvius.com.br/revistas/read/arquitextos/04.047/594>.

RUBINO, S. Entre o CIAM e o SPHAN: diálogos entre Lúcio Costa e Gilberto Freyre. In: KOSMINSKY, E. V.; LÉPINE, C.; PEIXOTO, F. A. (. ). Gilberto Freyre em quatro tempos. Bauru:

FAPESP/UNESP/EDUSC, 2003. p. 267-285.

RUBINO, S. B. Gilberto Freyre e Lúcio Costa, ou a boa tradição. Óculum, p. 77-80, 1992.

SANTOS, M. Técnica, espaço, tempo: globalização e meio técnico-sientífico-informacional. São Paulo: EDUSP, 1994.

SANTOS, M. A Urbanização brasileira. São Paulo: EDUSP, 2009.

SANTOS, M. P. A paisagem como imagem e representação do espaço na geografia humana. GEOUSP Espaço e tempo, São Paulo, n.28, p. 151-165, 2010.

SAQUET, M. A. As diferentes abordagens do território e a apreensão do movimento e da (i)materialidade. Geosul, v.22, n.43, p. 55-76, jan./ jun. 2007.

SARQUIS, G. B. Diálogos contemporâneos na arquitetura belenense (1979-2007). São Paulo: Universidade Presbiteriana Mackenzie, Tese de Doutorado, 2012.

SCHOR, T.; COSTA, D. P. D.; OLIVEIRA, J. A. D. Cidades, Rede Urbana e Desenvolvimento na Amazônia dos Grandes Rios. In: TRINDADE JR., S.-C. C., et al. Pequenas e Médias Cidades na Amazônia. Belém: FASE, ICSA - UFPA, 2009. p. 35-57.

SECRETO, M. V. A ocupação dos "espaços vazios" no governo Vargas: do "Discurso do rio Amazonas" à saga dos soldados da borracha. Estudos Históricos, p. 115-135, 2007.

SEGAWA, H. Oswaldo Arthur Bratke: Vila Serra do Navio e Vila Amazonas. IV Seminário de História da Cidade e do Urbanismo, V.4, n.3, p. 673-679, 1996.

. Arquiteturas no Brasil 1900-1990. São Paulo: Edusp, 1998.

SEGAWA, H.; CREMA, A.; GAVA, M. Revistas de arquitetura, urbanismo, paisagismo e design: a divergência de perspectivas. Ci. Inf., Brasília, v. 32, n. 3, São Paulo, p. 120-127, 2003. Disponivel em: <>.

SEGAWA, H.; DOURADO, G. M. Oswaldo Arthur Bratke. São Paulo: ProEditores, 1997.

SERÁFICO, J.; SERÁFICO, M. A Zona Franca de Manaus e o capitalismo no Brasil. Estudos Avançados 19 (54), p. 99-113, 2005.

SEVCENKO, N. O front brasileiro na guerra verde: vegetais, colonialismo e cultura. Revista USP n.30 junho/ agosto , p. 108-119, 1996.

SILVA, H. R. D. A história como "a representação do passado": a nova abordagem da historiografia francesa. In: CARDOSO, C. F.; MALERBA, J. (. ). Representações. Contribuição a um debate transdisciplinar. Campinas: Papirus, 2000. p. 81-99.

SILVA, M. C. D. Metamorfoses da Amazônia. Campinas: Universidade Estadual de Campinas, 1997.

SILVA, V. T. D. C. E. A modernidade nos trópicos. Gilberto Freyre e os debates em torno do nacional. Recife: Carpe Diem, 2009.

SILVESTRI, G. Paisaje y representación. Revista de historia intelectual n.3, p. 231-245, 1999. 

2003.

El color del río: historia cultural del paisaje del Riachuelo. Bernal: Universidad Nacional de Quilmes,

SIMMEL, G. A metrópole e a vida mental. In: VELHO, O. G. (. ). O fenômeno urbano. Rio de Janeiro: Zahar, 1973. p. 11-25.

SKIDMORE, T. E. Brasil: de Getúlio a Castello. São Paulo: Companhia das Letras, 2010.

SOARES, L. D. C. Delimitação da Amazônia para fins de Planejamento Econômico. Revista Brasileira de Geografia, 1948. 165-210.

SOUZA, L. J. B. Cidade flutuante. Uma Manaus sobre as águas (1920-1967). São Paulo: Pontifícia Universidade Católica de São Paulo, 2010.

SOUZA, M. A Expressão Amazonense. São Paulo: Alfa-Omega, 1978.

. Breve História da Amazônia. Rio de Janeiro: Agir, 2001.

SPADONI, F. Dependência e resistência: Transição da arquitetura brasileira nos anos 1970 a 1980. In: GITAHY, M. L. C.; LIRA, J. T. C. D.; (ORGS.) Tempo, cidade e arquitetura. São Paulo: FAU/ Annablume/ FUPAM, 2007. p. 241-266.

TAVARES, P. Modern Frontiers - Beyond Brasília, the Amazon. In: REAL, P. D.; GYPER, H. (. ). Latin American Modern Architectures: Ambigous Territories. New York: Routledge, 2013. p. 191-212.

THIERION, B. Olhares sobre a terra e o homem da Amazônia: Um imaginário em construção. Simpósio Amazonia: Travelers, Writers and Its People. University of California, Davis: [s.n.]. 2014.

TINEM, N. Arquitetura Moderna Brasileira: a imagem como texto. São Paulo 06: [s.n.], 2006. Disponivel em: <http://www.vitruvius.com.br/revistas/read/arquitextos/06.072/352>.

. O alvo do olhar estrangeiro. O Brasil na historiografia da arquitetura moderna. João Pessoa: EDUFPB, 2006.

TRINDADE JR., S.-C. C. D. Uma Floresta Urbanizada? Legado e Desdobramentos de uma Teoria sobre o Significado da Cidade e do Urbano na Amazônia. Espaço Aberto, PPGG - UFRJ, V.3, N.2, p. 89-108, 2013.

Uma leitura da Amazônia a partir da obra de Milton Santos: contribuições da Escola Uspiana de Geografia. Papers do NAEA 366, Belém, Abril 2017.

Cidades na floresta: os grandes "objetos" como expressões do meio técnico-cientifico informacional no espaço amazônico. Revista IEB n.50, p. 113-138, set./ mar.2010.

Das "cidades na floresta" às "cidades da floresta": espaço, ambiente e urbanodiversidade na Amazônia brasileira. Papers do NAEA n.321, 2013.

TUPIASSÚ, A. Amazônia, das travessias lusitanas à literatura de até agora. Estudos Avançados, 2005. p. 299-320.

UGARTE, A. S. O mundo natural e as sociedades indígenas da Amazônia na visão dos cronistas ibéricos (séculos XVI e XVII). São Paulo: Universidade de São Paulo, 2004.

VASCONCELLOS, D. V. Pequenos apontamentos acerca de Roger Bastide e Gilberto Freyre, doi intérpretes do Brasil. n.2. ed. [S.l.]: Revista do IMEA - UNILA, v. 1, 2013.

VENANCIO, G. M. Roger Chartier. In: (ORG.), M. P. Os historiadores clássicos da história. Petrópolis: Vozes; PUC Rio, 2014. p. 291-308.

VICENTINI, Y. Cidade e história na Amazônia. Curitiba: Editora UFPR, 2004. 
VIDAL, C. Experiências do moderno em Belém: construção, recepção e destruição. V!rus n.12, 2016.

VIDAL, C. C. S. P. Arquitetura moderna e Estado na capital do Pará: contribuições para a construção do campo historiográfico. In: (ORG.), J. A. T. Pesquisa em Arquitetura e Urbanismo na Amazônia - Rede Amazônia de pesquisa em Arquitetura e Urbanismo. Macapá: UNIFAP, 2019. p. 133-155.

VILARINHO, C. R. O. O Brasil e o Banco Mundial diante da questão ambiental. Revista de Ciências Sociais-UNESP, v.15, São Paulo, p. 37-57, 1992.

WAISMAN, M.; NASELLI, C. 10 Arquitectos Latinoamericanos. Sevilla: Consejeria de Obras Públicas y Transportes, 1989.

WIMMER, N. Blaise Cendrars e o Brasil: "Brésil, des hommes sont venus". n.1998. ed. [S.l.]: Lettres Françaises, 2013.

WISNIK, G. Lucio Costa. São Paulo: Cosac\&Naif, 2001.

WISNIK, G. Modernidade congênita. In: ANDREOLI, E.; FORTY, A. (. ). Arquitetura moderna brasileira. Hong Kong: Phaidon, 2004. p. 22-55.

ZEIN, R. V. O lugar da crítica. Ensaios oportunos de arquitetura. São Paulo: ProEditores Associados, 2001.

ZEIN, R. V. Quando documentar não é suficiente. In: ZEIN, R. V. Leituras críticas. São Paulo: Romano Guerra, 2018. p. 104-125.

ZEIN, R. V.; BASTOS, M. A. J. Brasil: Arquiteturas após 1950. São Paulo: Perspectiva, 2010.

ZHOURI, A. O ativismo transnacional pela Amazônia: entre a ecologia política e o ambientalismo de resultados. Horizontes Antropológicos. Porto Alegre, ano 12, n.25. jan/jun, p. 139-169, 2006. 


\section{Fontes Documentais}

(ORG.), H. S. Arquiteturas no Brasil: anos 1980. São Paulo: Projeto, 1988.

A CAPITAL N.305, Jornal. Manáos, 23 de maio de 1918 Anno II.

A CASA N. 201-203, Revista. Rio de Janeiro, fevereiro a abril de 1941.

A CASA N.183, Revista. Rio de Janeiro, agosto de 1939.

A CASA N.195-196 Revista. Rio de Janeiro,agosto e setembro de 1940.

A CONSTRUÇÃO SÃO PAULO N.1852, Revista. São Paulo, agosto de 1983.

A CONSTRUÇÃO SÃO PAULO N.1972, Revista. São Paulo, novembro de 1985.

ABA N.1, Revista Arquitetura Brasileira do Ano. Rio de Janeiro, 1967-68.

ACRÓPOLE N.326, Revista. São Paulo, 1966.

ACRÓPOLE N. 48, Revista. São Paulo, abril de 1942.

ACRÓPOLE N.1, Revista. São Paulo, maio de 1938.

ACRÓPOLE N.182, Revista. São Paulo, 1953.

ACRÓPOLE N.193, Revista. São Paulo, outubro de 1954, ano 17.

ACRÓPOLE N.195, Revista. São Paulo, dezembro de 1954.

ACRÓPOLE N.201, Revista. São Paulo, junho de 1955.

ACRÓPOLE N.20-21, Revista. São Paulo, dez/jan de 1939-40.

ACRÓPOLE N.256, Revista. São Paulo, 1960.

ACRÓPOLE N.268, Revista. São Paulo, fevereiro de 1961.

ACRÓPOLE N.326, Revista. São Paulo, março de 1966.

ACRÓPOLE N.48, Revista. São Paulo, abril de 1942.

ACRÓPOLE N.52, Revista. São Paulo, agosto de 1942.

ACRÓPOLE N.6, Revista. São Paulo, outubro de 1938.

ACRÓPOLE N.8, Revista. São Paulo, dezembro de 1938.

AMAZÔNIA BRASILEIRA, C. D. E. Amazônia brasileira. Rio de Janeiro: Biblioteca Nacional. Divisão de publicações e divulgação, 1969.

AMAZÔNIA É BRASIL, Revista. Brasília: Vitória Régia, 1967.

ARQUITETURA E ENGENHARIA N.28, Revista. IAB Minas Gerais. Belo Horizonte, 1953, ano V.

ARQUITETURA E URBANISMO N.4, Revista. Ed. Pini, São Paulo, fevereiro de 1986.

ARQUITETURA IAB N.12, Revista. Rio de Janeiro, junho de 1963. 
ARQUITETURA IAB N.6, Revista. Rio de Janeiro, dezembro de 1962.

ARQUITETURA N.22, Revista. Rio de Janeiro, abril de 1964.

ARQUITETURA-IAB N.17, Revista. Rio de Janeiro, novembro de 1963.

ARQUITETURA-IAB N.29, Revista. Rio de Janeiro, abril de 1964.

ARQUITETURA-IAB N.30, Revista. Rio de Janeiro, dezembro de 1964.

ARQUITETURA-IAB N.40, Revista. Rio de Janeiro, outubro de 1965.

ARQUITETURA-IAB N.41, Revista. Rio de Janeiro, novembro de 1965.

ARQUITETURA-IAB N.42, Revista. Rio de Janeiro, dezembro de 1965.

ARQUITETURA-IAB N.44, Revista. Rio de Janeiro, fevereiro de 1966.

ARQUITETURA-IAB N.46, Revista. Rio de Janeiro, abril de 1966.

ARQUITETURA-IAB N.47, Revista. Rio de Janeiro, maio de 1966.

ARQUITETURA-IAB N.48, Revista. Rio de Janeiro, junho de 1966.

ARQUITETURA-IAB N.51, Revista. Rio de Janeiro, setembro de 1966.

ARQUITETURA-IAB N.52, Revista. Rio de Janeiro, outubro de 1966.

ARQUITETURA-IAB N.58, Revista. Rio de Janeiro, abril de 1967.

ARQUITETURA-IAB N.59, Revista. Rio de Janeiro, maio de 1967.

ARQUITETURA-IAB N.61, Revista. Rio de Janeiro, junho de 1967.

ARQUITETURA-IAB N.63, Revista. Rio de Janeiro, setembro de 1967.

ARQUITETURA-IAB N.68, Revista. Rio de Janeiro, fevereiro de 1968.

ARTHUR REIS, M., 1964.

AU N.10, Revista. São Paulo, 1987.

AU N.11, Revista. São Paulo, fevereiro e março de 1987.

AU N.3, Revista. São Paulo, novembro de 1985.

AU N.4, Revista. São Paulo, 1986.

AU N10, , Revista. São Paulo, Planeta Amazônia, 1987.

BATISTA, D. Da habitabilidade da Amazônia. Manaus: Cadernos da Amazônia n.4, INPA, 1965.

BELÉM-BRASÍLIA, S. R. Amazônia: Uma conquista do nosso tempo. [S.l.]: Observador econômico e financeiro, janeiro de 1960.

BENCHIMOL, S. Zona Franca de Manaus. A conquista da maioridade. São Paulo: Sver \& Boccato, 1989.

BRASÍLIA N.20, Revista. Novacap. Rio de Janeiro, agosto de 1959.

BRASÍLIA N.21, Revista. Novacap. Rio de Janeiro, setembro de 1958.

BRASÍLIA N.35, Revista. Novacap. Rio de Janeiro, novembro de 1959. 
BRASÍLIA, N. 2 , Revista. Novacap. Rio de Janeiro, fevereiro de 1957.

BRUAND, Y. Arquitetura contemporânea no Brasil. São Paulo: Perspectiva, 1981.

CJ ARQUITETURA N.12, Revista. São Paulo, 1976.

CJ ARQUITETURA N.20, Revista. São Paulo, 1978.

CJ ARQUITETURA N.7, Revista. São Paulo, 1975.

CJ ARQUITETURA N.8, Revista. São Paulo, 1975.

CORRÊA, L. D. M. Manaus: Aspectos de sua arquietura. Rio de Janeiro: SPVEA - Agência Guanabara, 1964.

DI MARCO, A. R. (. ). Cadernos Brasileiros de Arquitetura - CBA n.19. São Paulo: Projeto Editores Associados, 1987.

ELETRONORTE. UHE BALBINA. [S.l.]: [s.n.], 1982.

FICHER, S.; ACAYABA, M. M. Arquitetura moderna brasileira. São Paulo: Projeto, 1982.

FILHO, J. P. D. C. Estudo sobre exemplos de arquitetura tropical, erudita e suas adequações à Amazônia brasileira no último decênio. São Carlos: Escola de Engenharia da Universidade de São Paulo, Dissertação de Mestrado, 1984.

FREYRE, G. Em torno da colonização da Amazônia. O Jornal, 19 junho 1943.

GOODWIN, P. Brazil Builds. Nova Iorque: William E. Rudge's Sons para o Museu de Arte Moderna de Nova Iorque, 1943.

HABITAT N.1, Revista. São Paulo, 1951.

HABITAT N.10, Revista. São Paulo, 1952.

HABITAT N.12, Revista. São Paulo, 1953.

HABITAT N.24, Revista. São Paulo, 1955.

HABITAT N.55, Revista. São Paulo, 1959.

HABITAT N.7, Revista. São Paulo, 1952.

HABITAT, N. 4, Revista. São Paulo, 1951.

IBGE. Mapa do Brasil. [S.l.]: [s.n.], 1940.

JORNAL DO COMÉRCIO, Jornal. Manaus, 01 setembro 1949.

JORNAL DO COMÉRCIO, Jornal. Manaus, 16 de janeiro de 1959.

JORNAL DO COMÉRCIO, Jornal. Manaus, 10 junho 1972.

JORNAL DO COMÉRCIO, Jornal. Manaus, 31 janeiro 1973.

JORNAL DO COMÉRCIO, Jornal. Manaus, 24 janeiro 1974.

JORNAL DO COMÉRCIO, Jornal. Manaus, 11 agosto 1963.

MANCHETE ED. ESPECIAL, Revista. Rio de Janeiro, fevereiro de 1973.

MANCHETE ED.1102, Revista. Rio de Janeiro, 1973. 
MELLO, T. D. Manaus: amor e memória. Manaus: [s.n.], 1983.

MILWARD, M. P. Do aparecimento das artes - da arte brasileira - seus criadores e sua aplicação. Revista Municipal de Engenharia n.6 vol.IX, p. 23-29, 1942.

MINDLIN, H. Modern architecture in Brazil. Rio de Janeiro/ Amsterdam: Colibris, 1956.

MÓDULO N.1, Revista, Rio de Janeiro, março de 1955.

MÓDULO N.43, Revista, Rio de Janeiro, junho a agosto de 1976.

MÓDULO N.5, Revista, Rio de Janeiro, setembro de 1956, ano 2.

MÓDULO N.53, Revista, Rio de Janeiro, março e abril de 1979.

MÓDULO N.53, Revista, Rio de Janeiro, março/abril de 1979.

MÓDULO N.55, Revista, Rio de Janeiro, setembro de 1979.

MÓDULO N.63, Revista, Rio de Janeiro, abril/maio de 1981.

MÓDULO N.70, Revista, Rio de Janeiro, 1982.

MÓDULO N.71, Revista, Rio de Janeiro, 1982.

MÓDULO N.75, Revista, Rio de Janeiro, 1983.

MOREIRA, E. Amazônia o conceito e a paisagem. Rio de Janeiro: Agência da SPVEA, 1960.

MOSTRA DA ARQUITETURA BRASILEIRA ATUAL, Catálogo, São Paulo: Projeto Editores Associados Ltda, 1983.

MOSTRA DE ARQUITETOS DE MANAUS, Catálogo, Manaus, outubro de 1984.

O CRUZEIRO ed.1, Revista, p. 67, 1950.

O CRUZEIRO ed.13, Revista, p. 21, 1951.

OLIVEIRA, J. L. F. D. Amazônia: proposta para uma ecoarquitetura. São Paulo: Universidade de São Paulo, Tese de Doutorado, 1989.

PROJETO N. 108, Revista, Sâo Paulo, 1988.

PROJETO N. 114, Revista, São Paulo, setembro de 1988.

PROJETO N.11, Revista, São Paulo, junho de 1979.

PROJETO N.115, Revista, São Paulo, setembro de 1988.

PROJETO N.12, Revista, São Paulo, junho de 1979.

PROJETO N.120, Revista, São Paulo, abril de 1989.

PROJETO N.125, Revista, São Paulo, 1989.

PROJETO N.148, Revista, São Paulo, dezembro de 1991.

PROJETO N.15, Revista, São Paulo, setembro/outubro de 1979.

PROJETO N.15, Revista, São Paulo, setembro/outubro de 1979.

PROJETO N.156, Revista, São Paulo, setembro de 1992. 
PROJETO N.16, Revista, São Paulo, novembro de 1979.

PROJETO N.2, Revista, São Paulo, abril/maio de 1977.

PROJETO N.26, Revista, São Paulo, janeiro de 1981.

PROJETO N.28, Revista, São Paulo, março/abril de 1981.

PROJETO N.38, Revista, São Paulo, março de 1982.

PROJETO N.40, Revista, São Paulo, maio de 1982.

PROJETO N.40, Revista, São Paulo, maio de 1982.

PROJETO N.42, Revista, São Paulo, maio de 1982.

PROJETO N.44, Revista, São Paulo, outubro de 1982.

PROJETO N.45, Revista, São Paulo, novembro de 1982.

PROJETO N.49, Revista, São Paulo, março de 1983.

PROJETO N.53, Revista, São Paulo, julho de 1983.

PROJETO N.56, Revista, São Paulo, outubro de 1983.

PROJETO N.57, Revista, São Paulo, novembro de 1983.

PROJETO N.72, Revista, São Paulo, fevereiro de 1985.

PROJETO N.77, Revista, São Paulo, julho de 1985.

PROJETO N.81, Revista, São Paulo, novembro de 1985.

PROJETO N.83, Revista, São Paulo, janeiro de 1986.

PROJETO N.83, Revista, São Paulo, janeiro de 1986.

PROJETO N.9, Revista, São Paulo, junho de 1979.

REALIDADE N.67, Revista, Amazônia. [S.l.]: [s.n.], 1971.

REV. MUN. DE ENG. N.1, Revista, Rio de Janeiro, janeiro de 1945, Vol.XII.

REV. MUN. DE ENG. N.3, Revista, Rio de Janeiro, julho de 1943, vol.X.

REV. MUN. DE ENG. N.5, Revista, Rio de Janeiro, setembro de 1940.

REV. MUN. DE ENG. N.6, Revista, Rio de Janeiro, novembro de 1942, vol.IX.

REVISTA DE ARQUITETURA N.1, Rio de Janeiro, maio de 1934.

REVISTA DE ARQUITETURA N.2, Rio de Janeiro, junho de 1934.

REVISTA DE ARQUITETURA N.3, Rio de Janeiro, julho de 1934.

REVISTA DE ARQUITETURA N.7, Rio de Janeiro, novembro de 1934.

SANTOS, M. O espaço dividido: os dois circuitos da economia urbana dos países subdesenvolvidos. Rio de Janeiro: Francisco Alves, 1979.

SEGAWA, H. Arquiteturas no Brasil: Anos 80. São Paulo: Projeto, 1988. 
SCHULTZ, H. Isto é a Amazônia. São Paulo: Melhoramentos, 1964.

SUFRAMA. Boletim informativo. Manaus: Superintendência da Zona Franca de Manaus/ Ministério do Interior, 1971.

TOCANTINS, L. Arquitetura e paisagismo na Amazônia. Manaus: Governo do Estado do Amazonas, 1966.

TOCANTINS, L. O rio comanda a vida. Rio de Janeiro: Biblioteca do Exército, 1973.

TOCANTINS, L. Introdução - A bíblia ecológica do padre João Daniel. In: DANIEL, P. J. Tesouro descoberto do rio Amazonas. [S.l.]: Biblioteca Nacional, 1976. p. vol. 1, pp. 7-24.

TOCANTINS, L. Amazônia: Fundamentos de paisagem, vida e história. Palestra pronunciada em Serra do Navio - Amapá: SPVEA - Coleção Araújo Lima, janeiro de 1964.

VENHA investir no Amazonas. São Paulo: Governo do Estado do Amazonas, 1969.

WISSENBACH, V. C. Arquitetura brasileira atual. São Paulo: Projeto Editores Associados, 1983.

WISSENBACH, V. E. Arquiteturas no Brasil/ Anos 80. São Paulo: Projeto, 1988.

XAVIER, A. Depoimento de uma geração. Arquitetura moderna brasileira. São Paulo: Pini Ltda, 1987.

YAZIGI, E. Études preliminares en vue d'un urbanisme tropical pour l'Amazonie brésilienne. Paris:

Universite de Paris, 1972. 
